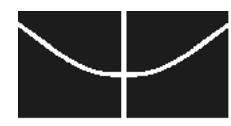

Universidade de Brasília

Faculdade de Direito

Programa de Pós-Graduação em Direito, Estado e Constituição

NOS RASTROS DE UM PROCESSO:

trabalho, conflito e uma experiência de micro-história

Rafael Lamera Cabral

Brasília

2016 



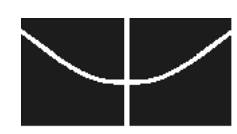

Universidade de Brasília

Faculdade de Direito

Programa de Pós-Graduação em Direito, Estado e Constituição

\author{
Rafael Lamera Cabral
}

NOS RASTROS DE UM PROCESSO:

trabalho, conflito e uma experiência de micro-história

Tese apresentada ao Programa de Pós-Graduação em Direito, Estado e Constituição da Universidade de Brasília (UnB) como parte dos requisitos exigidos para obtenção ao grau de Doutor em Direito.

Orientador: Prof. Dr. Cristiano Paixão.

Linha de Pesquisa: Constituição e Democracia - História Constitucional e Historiografia

Brasília - DF 
Ficha catalográfica elaborada automaticamente, com os dados fornecidos pelo(a) autor(a)

Nos rastros de um processo: trabalho, conflito e uma experiência de micro-história / Rafael Lamera Cabral; orientador Cristiano Paixão. -- Brasília, 2016 .

$422 \mathrm{p}$.

Tese (Doutorado - Doutorado em Direito) -Universidade de Brasília, 2016.

1. História constitucional. 2. Conflito

trabalhista. 3. Greve. 4. Conselho Nacional do

Trabalho. I. Paixão, Cristiano, orient. II. Título. 


\title{
Rafael Lamera Cabral \\ NOS RASTROS DE UM PROCESSO: \\ trabalho, conflito e uma experiência de micro-história
}

\author{
Tese apresentada ao Programa de Pós-Graduação em \\ Direito, Estado e Constituição da Universidade de Brasília \\ (UnB) como parte dos requisitos exigidos para obtenção ao \\ grau de Doutor em Direito. \\ Orientador: Prof. Dr. Cristiano Paixão. \\ Linha de Pesquisa: Constituição e Democracia - História \\ Constitucional e Historiografia
}

Aprovado em

Banca Examinadora:

Prof. Dr. Cristiano Paixão, Orientador (FD/UnB)

Prof. Dr. Airton Lisle Cerqueira Leite Seelaender (FD/UnB)

Prof. Dr. José Otávio Nogueira Guimarães (História/UnB)

Profa. Dra. Magda Barros Biavaschi (IFCH/UNICAMP)

Prof. Dr. Arnaldo Sampaio de Moares Godoy (Direito/UniCEUB)

Prof. Dr. Argemiro Cardoso Moreira Martins (Suplente FD/UnB) 

Para meus pais... 



\section{AGRADECIMENTOS}

Tentar enumerar todos aqueles que contribuíram para a trajetória desta pesquisa é uma tarefa arriscada. Consciente dos riscos, aceito o desafio. Uma tese de doutorado é uma atividade de constante aprimoramento intelectual. Nessa empreitada, a presença de meu orientador, prof. dr. Cristiano Paixão, foi fundamental. Presente nos principais momentos de inquietação, sempre esteve disponível para instigar e apontar alternativas para as dificuldades compartilhadas. Seu rigor, franqueza e brilhantismo intelectual inspiram-me, constantemente.

O apoio da equipe de gestão documental e memória do Tribunal Superior do Trabalho (TST) também se destaca. Luiz, Leonardo, Rosemary, Adan e Wilson sempre se mantiveram receptivos em minhas longas visitas ao tribunal. Sem a completa abertura dos arquivos do TST, esta tese não seria possível. Registro também um agradecimento especial à equipe do TRT da $4^{\text {a }}$ Região, que, além de compartilhar experiências, oportunizou livre acesso à coleção de processos trabalhistas de São Jerônimo/RS do período entre 1938 e 1947.

Ao Museu Estadual do Carvão. A visita a Arroio dos Ratos/RS foi um grato momento de dupla realização: i) constituído como um espaço de memória, o museu foi instituído no antigo escritório da Companhia Estrada de Ferro e Minas de São Jerônimo, ao lado das ruínas da usina termoelétrica da companhia. Estar naquele local me fez retornar a 1934 e permitiu reconstruir dados e informações que apenas as fontes podiam informar; e ii) conhecer o pesquisador Alexsandro Witkowski, pois seu conhecimento e boa vontade com a história carbonífera da região reforçam as ações de resistência para a proteção e defesa do patrimônio histórico e dos espaços de memória.

Ao grupo de trabalho dos Arquivistas Sem Fronteiras, que atuaram na organização do arquivo das companhias carboníferas no Museu do Carvão. Fica o registro de agradecimento aos profissionais Francisco Cougo, Alexandre Veiga, Deise Formolo, Tiago Nuñez, Sílvia Simões e Rejane Ávila. Ao professor Jorge Vivar, um agradecimento especial pela imensa colaboração em todo o processo de acesso às fontes.

À dona Eva, que cedeu gentilmente o livro de memórias de seu pai, Adalberto Thimóteo dos Santos; ao sr. Claudio Rollo; às equipes do cartório de registro civil e de imóveis de São Jerônimo, Arroio dos Ratos e Butiá, pela disposição em colaborar e à Laeticia Jensen Eble, pelo trabalho de revisão da tese.

À Universidade Federal Rural do Semiárido (Ufersa), que, durante 18 meses, concedeu afastamento para minha qualificação.

À Capes, pela concessão da bolsa de pós-graduação do Programa Novo Prodoutoral. 
À Universidade de Brasília (UnB), pelo ambiente de cordialidade, generosidade e pluralidade que promove todos os dias. Nesse ambiente, também foi possível a realização de minha banca de qualificação da tese, oportunidade em que agradeço aos professores José Otávio Nogueira Guimarães e Airton L. C. Seelaender pelas valiosas contribuições.

Aos servidores da secretaria da Pós-Graduação da Faculdade de Direito da UnB. Maria Helena, Lia, João e Euzilene, que, sempre acessíveis, prestaram grandes auxílios nessa caminhada.

Ao grupo de pesquisa Percursos, Narrativas e Fragmentos fica a eterna gratidão. Os amigos Raphael, Rogério, Maria Celina, Maria Pia, Fernando, Cláudia, Mamede, Eneida, Douglas, Ricardo, Noêmia, Matheus, Mariana, Leonardo, Roberto, Thaís, Cristina, José Nunes, entre tantos outros, tornaram minha estadia na UnB mais agradável, regada a discussões acadêmicas de alto nível e lembranças para uma vida toda.

Aos amigos, infinitamente inumeráveis, que sempre estiveram presentes, perseverantes e que me apoiaram desde o início, inclusive, aos que gentilmente se dedicaram à leitura da tese e prestaram auxílio imediato.

Aos amigos Fábio Francisco Esteves, Débora e Suzana Sampaio, pela acolhida fraterna em Brasília desde o início.

Aos meus pais, Gilda e Nilton, pela generosidade e apoio incondicional. À minha irmã, Shaiellen, e a meu cunhado, Marco Aurélio, e aos pequenos sobrinhos do coração, Jorge e Miguel.

Por fim, à minha companheira Lilian Caporlíngua Giesta, pelo apoio, presença e confiança em nosso projeto de futuro. 


\section{RESUMO}

Em um processo judicial ou administrativo, a história de seus participantes pode ser representada, por um lado, por seus desfechos, limites e possibilidades; por outro lado, também pode revelar indicadores sociais, econômicos, políticos e jurídicos de um determinado período. O desenvolvimento desta pesquisa está interligado diretamente aos rastros deixados por um processo trabalhista. Selecionada em um fundo de arquivo no Tribunal Superior do Trabalho (TST), a reclamação trabalhista movida por sete empregados de uma mina de carvão do interior do Rio Grande do Sul foi processada junto ao Conselho Nacional do Trabalho (CNT) a partir de agosto de 1934. O pedido de reintegração ao trabalho baseava-se em uma denúncia de que a Companhia Estrada de Ferro e Minas de São Jerônimo (CEFMSJ) violara as regras do decreto que vinculava a despedida de empregados estáveis à abertura de inquérito administrativo para apurar a ocorrência de falta grave, inexistente naquele caso. Entre 1934 a 1938, período em que o processo teve curso, o CNT determinou a reintegração de quatro trabalhadores, comprovadamente estáveis. Em pouco mais de quatro anos, a trama processual deixou rastros que possibilitaram o levantamento de indícios, provas e vestígios de interesse para a história constitucional. Subsidiada pela metodologia da microhistória italiana, esta pesquisa se construiu como um exercício de redução na escala de observação, devendo ser compreendida como uma experiência que visa explorar uma realidade não acessível de outra forma. As reações dos mineiros e a forma como instrumentalizaram a reclamação trabalhista estavam conectadas com as transformações sociais e constitucionais do período. Os rastros deixados pelo processo permitiram investigar: i) o impacto que a legislação trabalhista no início da década de 1930 assumiu na relação entre empregados e empregadores; ii) a resistência da empresa e os argumentos por ela apresentados para recusar ou se ajustar a nova ordem constitucional; e, em face de tal recusa ou ajuste, iii) como os espaços público e privado, que se constituíam de maneira complexa, alimentavam interpretações incertas sobre o direito de greve, a ordem pública e seu sistema de controle e vigilância.

Palavras-chave: História constitucional. Conflito trabalhista. Greve. Conselho Nacional do Trabalho. 



\begin{abstract}
In a judicial or administrative proceeding, the history of its participants can be represented by its outcomes, limits and possibilities. On the other hand, it can also reveal social, economic, political and legal aspects of a given period. The history of this research is linked directly to the traces left by a labor claim. Selected in an archive of the Superior Labor Court, the labor claim of seven employees of a coal mine in the interior of Rio Grande do Sul has been processed by the National Labour Council, from August 1934. The request for work reinstatement was based on a complaint that the Companhia Estrada de Ferro e Minas de São Jerônimo had violated the rules of the decree that stated that the dismissal of stable employees should have administrative investigation into the occurrence of serious misconduct, nonexistent in this case. Between 1934-1938, duration period of the judicial process, the National Labour Council ordered the reinstatement of four stable workers. In over more than four years, the procedural plot left traces which made it possible to survey evidences and remains that are of interest to the constitutional history. Subsidized by the Italian micro-history methodology, this research was as a reduction on the scale of observation, and should be understood as an experience which exploit a reality not accessible otherwise. The reactions of the miners and how they managed the labor claim were connected with the social and constitutional transformations of the period. The traces left by process allowed to investigate: i) the impact of labor laws in the early 1930s took in the relationship between employees and employers; ii) the company's resistance with their arguments to deny or adjust to new constitutional order; and, as a development of this refusal or adjustment, iii) how public and private spaces, which are constituted in a complex way, contributed to confusing interpretations of the right to strike, public order and its control and surveillance system.
\end{abstract}

Keywords: Constitutional history. Labour conflict. Strike. National Labour Council. 



\section{RIASSUNTO}

In un processo giudiziario o amministrativo la storia dei suoi partecipanti può essere rappresentata dai suoi esiti, limiti e possibilità. D'altra parte, può anche rivelare indicatori sociali, aspetti economici, politici e giuridici di un periodo storico specifico. La storia di questa ricerca è legata direttamente alle tracce ritrovate in un processo giudiziario nell'ambito lavorativo: la richiesta di sette lavoratori di una miniera di carbone all'interno dello stato del Rio Grande do Sul nell'ambito del Consiglio Nazionale del Lavoro, dall'agosto del 1934. I lavoratori argomentavano che la Compagnia Ferroviaria e di Miniere di San Girolamo (RS) aveva violato le norme giuridiche che collegavano le dimissioni dei dipendenti stabili per motivi de colpa grave all'apertura di un'inchiesta amministrativa. Tra 1934-1938, durante il quale il processo era ancora in corso, il Consiglio Nazionale del Lavoro ha ordinato il reintegro di quattro lavoratori stabili. Dopo quattro anni, la trama procedurale ha lasciato tracce che hanno permesso di investigare le prove, gli indizi e i segni che interessano alla storia costituzionale. Con fondamento nella metodologia della micro-storia italiana, questa ricerca è stata costruita come un esercizio di riduzione sulla scala di osservazione, dovendo essere intesa come un'esperienza che sfrutta una realtà altrimenti non accessibile. Le reazioni dei minatori e la forma come la questione giuridica è venuta risolta nell'ambito processuale erano collegate con le trasformazioni sociali e costituzionali del periodo. Le tracce lasciate dal processo hanno permesso investigare: i) l'impatto delle leggi sul lavoro nel 1930 all'interno del rapporto tra lavoratori e datori di lavoro; ii) gli argomenti utilizzati dalla Compagnia Ferroviaria e di Miniere di San Girolamo per non applicare le nuove norme costituzionale; iii) come gli spazi pubblici e privati, che erano costituiti in modo complesso, alimentavano delle interpretazioni incerte sul diritto di sciopero, sull'ordine pubblico e sul loro sistema di controllo e sorveglianza.

Parole chiave: Storia costituzionale. Contenzioso del lavoro. Sciopero. Consiglio Nazionale del Lavoro. 



\section{LISTA DE ABREVIATURAS E SIGLAS}

ANC - Assembleia Nacional Constituinte

Art. - Artigo

Cadem - Consórcio Administrador de Empresas de Mineradoras

CAP - Caixa de Aposentadorias e Pensões

CCMB - Companhia Carbonífera das Minas de Butiá

CCR - Companhia Carbonífera Rio-Grandense

CEFMSJ - Companhia Estrada de Ferro e Minas de São Jerônimo

CGEDM - Coordenadoria de Gestão Documental e Memória do TST

CNT - Conselho Nacional do Trabalho

COC - Círculo Operário Católico

CPOP - Comitê Pró-Organização Proletária

DNT/MTIC - Departamento Nacional do Trabalho

FORGS - Federação Operária do Rio Grande do Sul

FUG - Frente Única Gaúcha

MCAR - Museu Estadual do Carvão

MTIC - Ministério do Trabalho, Indústria e Comércio

NuMEP - Núcleo de Memória, Estudos e Pesquisas do TST

OIT - Organização Internacional do Trabalho

PL - Partido Libertador (RS)

PRL - Partido Republicano Liberal (RS)

PRR - Partido Republicano Rio-Grandense (RS)

SMAR - Sindicato dos Mineiros de Arroio dos Ratos

TRT - Tribunal Regional do Trabalho

TST - Tribunal Superior do Trabalho

UFRGS - Universidade Federal do Rio Grande do Sul 



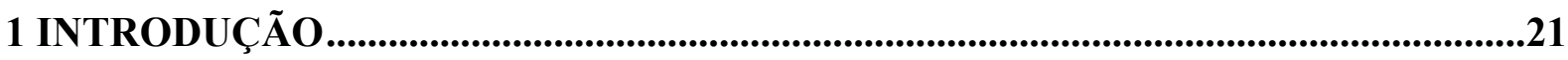

1.1 A micro-história e a organização do trabalho ...................................................28

2 NOS RASTROS DO PROCESSO N 9.582/1934-CNT .....................................................33

2.1 O caso Domingos Mantilha e outros no Conselho Nacional do Trabalho ................34

3 NOS LIMITES DO CONFLITO: OS MINEIROS, O SINDICATO E A COMPANHIA DE MINERAÇÃO EM ARROIO DOS RATOS ........................................................53

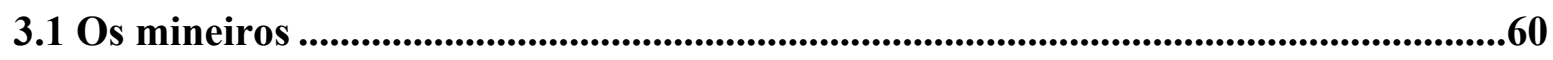

3.2 Sindicato dos mineiros de Arroio dos Ratos ....................................................65

3.3 Companhia Estrada de Ferro e Minas de São Jerônimo .......................................82

4 TRABALHO, CONFLITO E NOVOS DIREITOS: O PROCESSO DE

TRANSFORMAÇÃO SOCIAL A PARTIR DA NOVA ORDEM CONSTITUCIONAL

4.1 Greve, expulsão e abandono de emprego: revisitando os argumentos da companhia

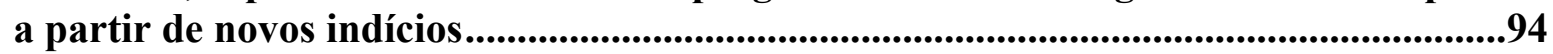

4.1.1 O status de elemento "indesejável" e o direito de greve nos primeiros anos da década de 1930

4.2 A CEFMSJ, os usos da autoridade policial e a institucionalização da violência...121

4.3 O impacto da reclamação trabalhista para a institucionalização de direitos inéditos .131

4.3.1 Nos limites da autoridade policial, o Ministério do Trabalho.....

4.3.2 Entre a lei e a estratégia: a conformação do direito e da política diante do Conselho Nacional do Trabalho

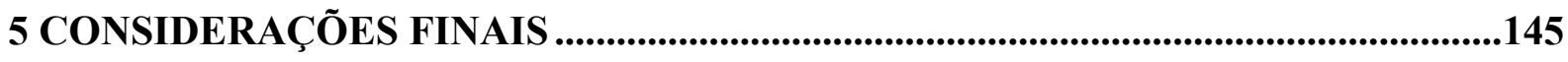

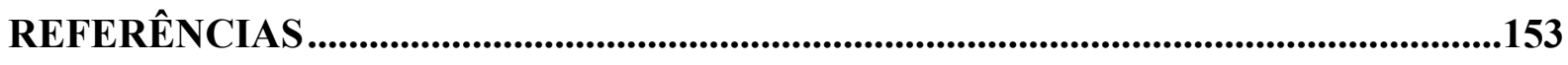

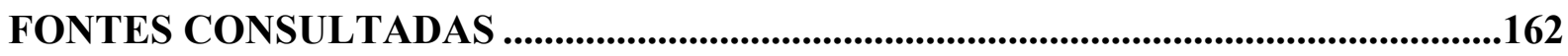

APÊNDICE A - QUADRO SINÓPTICO ....................................................................165

ANEXO A - RECLAMAÇÃO TRABALHISTA N. 9.582/1934 - CNT ...........................169 



\section{INTRODUÇÃO}

Uma cidade, uma campina, de longe são uma cidade e uma campina; mas, à medida que nos aproximamos, são casas, árvores, telhas, folhas, grama, formigas, pernas de formigas, ao infinito. Tudo isso se reveste com o nome de campo.

Blaise Pascal

A partir de 1930, mudanças profundas marcaram o mundo do trabalho no Brasil. O nascimento de uma incipiente regulamentação do direito do trabalho acelerou-se em um contexto político, econômico e social inédito, com forte fragmentação e instabilidade no arranjo de interesses reformulados no pós-Revolução de 1930.

No campo político as transformações empreendidas por Getúlio Vargas e seu staff marcavam os primeiros passos para um possível rompimento com a experiência republicana anterior que, calcada na política dos governadores, fomentava um modelo complexo de federalismo aliado a um regime liberal de grande repercussão na estrutura institucional do país.

No aspecto econômico, as promessas da Revolução envolviam um projeto que fosse capaz de superar as forças do atraso, representadas, naquele momento, pela necessidade de promover uma alteração no modelo agrário-exportador para industrial, com inovações técnicas para transformar o país em uma nação moderna, com integração das forças produtivas (trabalhadores e empresários) e reforma das normas jurídicas.

No centro dessas movimentações políticas e econômicas, a questão social merecia destaque. Identificadas em múltiplas vertentes, as reformas sociais atingiam temas como seguridade social, regulamentação do trabalho, educação e saúde pública. Em pouco mais de 4 anos (1930-1934), o governo provisório estabeleceu uma série de regulamentações sobre a vida dos trabalhadores, que se dirigiram à nacionalização do trabalho, aos marítimos, ferroviários, mineiros, bancários, acidente de trabalho e etc., e desde a criação do Ministério do Trabalho, Indústria e Comércio (MTIC - 1930), um longo processo de repactuação de estratégias e interesses se formalizou até a Constituição de 1934.

A experiência constitucional de 1934 acabou por consolidar na historiografia do direito o primeiro modelo nacional daquilo que, posteriormente, chamou-se de constitucionalismo social. No entanto, associa-se, às rupturas próprias desse período, uma série de modificações ocorridas nas relações desenvolvidas pela política e pelo direito que impactou diretamente na linguagem de novos direitos na década de 1930; nesse aspecto, 
investigar a forma como esses direitos foram institucionalizados e praticados naquela dinâmica social de forte fragmentação constitui-se como um ponto de partida relevante.

As questões atinentes ao trabalho eram arquitetadas em terrenos instáveis. O legado institucional do país era marcado por uma complexa estrutura liberal econômica (com caráter híbrido e, portanto, também interventora) que refletia, nos limites de atuação política do governo, descontentamentos amplos que marcavam vários setores da economia, como latifundiários, empresários, industriais a trabalhadores. A forma como a política trabalhista e, por consequência, social era instrumentalizada pelo governo foi objeto de disputas na década de 1930.

Em parte, a estratégia utilizada pelo governo na tentativa de superar o liberalismo tinha na regulamentação do trabalho um forte componente. A nova regulação foi estabelecida mediante a edição de dezenas de decretos que visava normatizar as profissões, com definição de direitos e deveres aos empregados e empregadores. Ao mesmo tempo, o Estado avançava na criação de instituições responsáveis por fiscalizar e garantir a aplicação dessas regras, como se pode observar com os estabelecimentos das juntas de conciliação, comissões mistas, inspetorias regionais, conselhos regionais e nacional do trabalho.

No bojo dessa complexidade, à ideia de novos direitos misturavam-se em uma realidade concreta que não permitia a construção de um modelo claro ou inequívoco e, talvez, exatamente por isso, ainda foi comum associar as organizações dos trabalhadores, sobretudo após a reforma sindical de 1931, a modelos antagônicos: i) corporativista ${ }^{1}$ e não combativo, ou seja, submisso aos patrões e aliados do MTIC; e ii) independente ou de oposição, vinculado aos movimentos comunistas, anarquistas ou socialistas. No entanto, esse diagnóstico foi objeto de diversas interpretações ao longo do tempo.

Entre as décadas de 1960 e 1980, a "Era Vargas" foi objeto de grandes programas de pesquisa que buscavam revisitar o período e lançar novas interpretações sobre a história do país. Organizadas em amplas diretrizes, as pesquisas sobre a organização do trabalho e questões sociais a ela relacionadas atribuíram ao Estado uma política "populista" que, entre suas consequências, mapeavam nas normas de proteção social ao trabalho a configuração de uma "concessão" de regulação que se aliava à cooptação dos trabalhadores com os ditames do Estado. Nesse aspecto, a matriz corporativista representava o caráter autoritário do poder

\footnotetext{
${ }^{1} \mathrm{O}$ uso do termo corporativismo não é pacífico e, neste trabalho, sua eventual vinculação ao modelo fascista de regulação do trabalho não é indicado.
} 
estatal sobre as classes operárias ${ }^{2}$. Não obstante, ao mesmo tempo em que essas interpretações vinham à tona eram refutadas. Contrárias à tese do "mito da outorga", outras pesquisas buscaram compreender o papel dos trabalhadores no processo de transformação social e normativa da década de 1930, principalmente pelo acompanhamento de suas estratégias e ações organizadas sindicalmente ${ }^{3}$.

Fato é que, durante muito tempo, essas interpretações promoveram modelos que tiveram um peso significativo no debate historiográfico, especialmente por exteriorizarem a dualidade repressão x legislação como marca característica da organização do trabalho no Brasil.

A partir dessas considerações, essa pesquisa procurou investigar situações concretas e representativas dessa tensão que também marcou o processo de constitucionalização dos direitos sociais - regulação do trabalho, com a Constituição de 1934.

Em visita ao fundo de arquivo do Conselho Nacional do Trabalho $\left(\mathrm{CNT}^{4}\right)$ no Tribunal Superior do Trabalho (TST), uma reclamação trabalhista de setembro de 1934 chamou a atenção. Tratava-se de um pedido de reintegração ao trabalho promovido por sete mineiros de uma mina de carvão da Companhia Estrada de Ferro e Minas de São Jerônimo - CEFMSJ, de Arroio dos Ratos, Rio Grande do Sul. A ação foi proposta poucos meses após a promulgação da Constituição de 1934 e a reclamação foi tramitada no próprio CNT, que recebia sua primeira grande reforma sob a nova égide constitucional.

$\mathrm{Na}$ composição entre capital e trabalho, verificou-se o desdobramento do conflito trabalhista em outros níveis de complexidade, permitindo a assunção de novos "lugares de direito" e, com isso, de situações imprevisíveis que colocavam no centro da crise interesses de trabalhadores, empregador e a instituição do CNT para as composições do direito do trabalho e do sistema protetivo estatal.

A partir dos rastros deixados pela reclamação foi possível construir um programa de pesquisa que buscou identificar o impacto que um processo de natureza trabalhista causava

\footnotetext{
${ }^{2}$ Magda Barros Biavaschi (2007) contribui com esse debate ao mapear essas discussões. Para a autora, essa matriz pode ser compreendida a partir de estudos de Francisco Weffort, Aziz Simão, Octavio Ianni e Armando Boito Jr., principalmente quando refletem o controle do Estado sobre as massas e atendimento de suas demandas, por meio de um "sindicalismo de Estado [que] desorganiza os trabalhadores e mantém o movimento social sob a direção política da burguesia, o que evita o questionamento da propriedade privada dos meios de produção e da exploração do trabalho assalariado" (BIAVASCHI, 2007, p. 82).

${ }^{3}$ Nesse sentido, Biavaschi (2007) chama a atenção para os trabalhos de Angela Maria de Castro Gomes, Jorge Ferreira e Evaristo de Moraes Filho.

${ }^{4}$ Sobre o Conselho Nacional do Trabalho, ver Oliveira (1988), Souza (2009) e Untura Neto (2010). O CNT era um órgão administrativo ligado ao poder executivo e responsável pela fiscalização do trabalho e previdência social entre 1923 a 1945.
} 
em contextos de constitucionalização de direitos e instituição de práticas e ações protetivas de longo alcance. Os registros do processo levaram a uma história complexa iniciada em Arroio dos Ratos, um distrito do município de São Jerônimo, berço da exploração de carvão na região do baixo Jacuí, no Rio Grande do Sul. Era uma vila pequena, e os trabalhadores mineiros, ${ }^{5}$ reclamantes na ação, eram pessoas simples, dedicadas ao trabalho insalubre no subsolo das minas, muitas vezes em profundidade superior a 60 metros.

De longe, Arroio dos Ratos era uma comunidade comum: uma igreja, uma praça, um cinema. Diferentemente de como era descrita nos livros e fontes documentais, ao se aproximar daquela realidade, uma nova cidade emergia de seu subterrâneo. Nos poços de exploração de carvão, as galerias e subgalerias se entrecruzavam transportando milhares de trabalhadores mineiros, com desejos, aspirações e interesses, em busca de melhores condições de vida. Na esteira dessas transformações, a comunidade de Arroio dos Ratos congregava uma incipiente organização trabalhista de destaque no cenário das minas de carvão da região.

A exploração de carvão nas minas era árdua, regada por um sistema punitivo, construído em meio a um modelo difuso em que público e privado se conectavam a partir do interesse do empregador. Naquela situação, em que as ambiguidades das regras postas, ausência de informação e necessidade de tomar decisões em tempo de incertezas eram constantes, as histórias de vida dos mineiros importam, principalmente, por permitirem a opção de novas categorias interpretativas para uma melhor compreensão dessa realidade.

O caso relata uma situação não incomum nas minas de carvão do país: o conflito entre empregados e patrões para o cumprimento da legislação social produzida nos últimos anos da Primeira República até o início da década de 1930. A principal legislação para ferroviários e $\operatorname{mineiros}^{6}$ foi demarcada pela introdução da Lei Elói Chaves, de 1923 (e suas alterações, em 1926, 1931 e 1932). Ao estabelecer a obrigatoriedade de Caixas de Aposentadoria e Pensões (CAPs), a legislação incluiu também a garantia de estabilidade decenal aos empregados que comprovassem tempo de serviço mínimo de dez anos dedicados a uma mesma empresa. A estabilidade, desse modo, oferecia garantia de manutenção do vínculo de emprego do trabalhador, tornando a possibilidade de dispensa mais restrita aos casos de falta grave, apurados em inquérito administrativo.

\footnotetext{
${ }^{5}$ Para um aprofundamento sobre o perfil dos mineiros na região do baixo Jacuí, ver: Sulzbach (1989) e Veit (s.d.).

${ }^{6}$ Aos mineiros, a estabilidade decenal seria estendida apenas em 1932. No entanto, desde 1926, a condição de ferroviários envolvia um conceito amplo, abrangendo todos os empregados que exerciam suas funções ligados diretamente ou não às estradas de ferro.
} 
A reclamação trabalhista relatava a dispensa sem justa causa de trabalhadores estáveis e não estáveis, com pedido de reintegração aos seus ofícios. A aposta era por uma intermediação política no Ministério do Trabalho em Porto Alegre, em busca de uma composição célere para o conflito. No fundamento jurídico, a referência era a violação ao decreto que exigia a instauração de inquérito administrativo (inexistente no caso) para apurar falta grave de empregados estáveis. A primeira manifestação da CEFMSJ informava que a substituição dos trabalhadores ocorrera por abandono de emprego, configurada com a expulsão dos mineiros pela polícia local, após denúncia de estarem tramando uma greve geral nas minas em março de 1934 - sendo considerados, então, indesejáveis.

Os fatos que legitimaram as demissões dos empregados têm origem em um possível movimento de greve. Desde o início da Assembleia Nacional Constituinte, em novembro de 1933, o direito à greve estava em disputa na arena política. O conceito "greve dos trabalhadores" foi utilizado sob muitas perspectivas. Com o processo em análise não foi diferente, sobretudo quando se verifica nos autos dois documentos que divergem sobre as datas da expulsão dos mineiros em decorrência da greve. O primeiro, apresentado pela empresa, aponta que a expulsão ocorreu em março de 1934; e o segundo, de lavra do delegado de polícia de São Jerônimo, José Maria de Carvalho, indica a data de 15 de fevereiro de 1934.

A forma como o processo se desenvolveu, atrelado ainda à configuração das defesas apresentadas, refletia, na verdade, o uso de uma racionalidade seletiva e limitada, cuidadosamente construída para não expor as realidades mais ameaçadoras do mundo do trabalho em conflito com a lei, mas de grande referência para a história do direito constitucional brasileiro. ${ }^{7}$ Os acontecimentos locais (em que foram presenciados os conflitos entre polícia, mineiros e companhia) - por mais que representassem uma prática, possivelmente, reiterada da companhia empregadora - estavam interligados a fatos econômicos e políticos que fugiram do controle da companhia. ${ }^{8}$ Nesse contexto, surgem problemas interessantes para a reflexão acerca da história do direito em momentos de

\footnotetext{
${ }^{7}$ Essa referência se ancora nas perspectivas adotadas por Giovanni Levi, em $A$ herança imaterial. Em seu estudo, Levi (2010, p. 46) explica sobre a trajetória de uma comunidade do Piemonte do século XVII: "na verdade, a incoerência entre as normas, a ambiguidade das linguagens, a incompreensão entre grupos sociais ou simples indivíduos, a ampla inércia ditada pela preferência por um estado habitual ou pelos custos que derivam de escolhas feitas em condições de extrema incerteza não são obstáculos que nos impeçam de considerar esta sociedade como sendo ativa e consciente em cada uma das suas partes, nem de vermos seu sistema social como o resultado da interação entre comportamentos e decisões assumidos no âmbito de uma racionalidade plena embora limitada".

${ }^{8}$ A reclamação trabalhista, possivelmente, era uma das primeiras que não foram resolvidas por intermédio do inspetor do MTIC, em Porto Alegre e, ao ultrapassar esse filtro, chegou ao CNT em um momento de grandes redefinições na política e no direito com o retorno da nova ordem constitucional.
} 
aplicação do direito. O que emergia desses conflitos não era apenas uma resistência ou crise no sistema punitivo local, mas a presença de alternativas, de possibilidades históricas que, ao serem ritualizadas mediante o processo, permitiam o registro dos limites e avanços de uma comunidade de trabalhadores que passava a ser mediada pelo direito de maneira inédita.

O processo em análise teve curso há 81 anos. O caminho percorrido pela pesquisa foi, primeiramente, situar o caso que originou as dispensas dos mineiros em seu contexto local. A partir daí, buscou-se reconstituir o ambiente social, político, econômico e jurídico das minas de Arroio dos Ratos, permitindo, assim, identificar elementos constantes e regras gerais que demonstrassem uma circularidade temática que colocava em evidência as tensões entre exercício, reconhecimento e proteção de direitos no mundo do trabalho.

À margem do caso Domingos Mantilha e outros, o conjunto de vestígios, fragmentos de verdade, representações do real, provas documentais e testemunhos levantados pela pesquisa produziu um impacto significativo sobre algumas premissas em que se assentava a investigação. A reconstituição do vivido, a começar pela redução na escala de observação proporcionada pelo universo restrito do processo, permitiu traçar um programa de pesquisa que viabilizou a revogação de algumas certezas. E, a partir das estratégias sindicais, de trabalhadores, empregadores e dos tribunais (ou órgãos administrativos, como o CNT), foi possível demonstrar o longo processo de elaboração e redefinição de espaços institucionais que direito e política reproduziram em um determinado momento constitucional. Desse modo, o processo em apreciação inseriu-se em um universo de novas experiências, em que as inovações da política social, a redefinição de espaços jurídicos e a reorientação do sistema produtivo e econômico assentavam-se em bases diversas e inéditas na configuração nacional promovida desde a Revolução de $1930{ }^{9}$

Entre os trâmites administrativos do processo, verificam-se possibilidades históricas promissoras, por isso, alguns cuidados metodológicos foram fundamentais. Por um lado, Hespanha (2005, p. 30) afirma que, geralmente,

as matérias históricas relevantes são identificadas a partir do leque dos conceitos e problemas jurídicos contemporâneos e isto leva a uma perspectiva deformada do campo histórico, em que os objetos e as questões são recortadas a partir do modo de ver e conceber o direito nos dias de hoje.

Por outro lado, Costa (2010) acentua que a cultura jurídica do presente não pode ser um obstáculo para a reconstrução do passado e, na maioria das vezes, o jogo interpretativo

\footnotetext{
${ }^{9}$ Sobre a revolução de 1930, ver Fausto (1987), Silva (1966), Gomes (1990) e Ferreira e Sá Pinto (2003). Para um maior aprofundamento sobre os reflexos do período para a construção do direito do trabalho, ver Biavaschi (2007).
} 
passa a ser mediado pela linguagem do passado, a linguagem do historiador e a linguagem do presente. ${ }^{10}$ As duas observações são válidas e foram relevantes para o percurso que se pretendeu utilizar nesta pesquisa.

Ao buscar o significado e localizar a "realidade" a partir dos documentos, novas perguntas direcionavam a estruturas que relacionavam as práticas sociais registradas no processo em ambientes mais amplos: os conflitos entre polícia e trabalhadores; a atuação da polícia e poder executório do CNT; e a relação entre público e privado dentro das estruturas econômicas e trabalhistas da época, entre outros. Uma leitura a contrapelo ${ }^{11}$ do caso e a análise do resultado final do processo - isto é, a decisão pela reintegração ou não dos empregados - oportunizaram verificar como os usos das instituições e estratégias dos empregados e empregadores evidenciam outros elementos da realidade e conferem sentido às práticas e comportamentos mais duradouros na relação entre direito e política.

Assim, até que ponto a "judicialização do conflito" dos mineiros em Arroio dos Ratos pode ser exemplificativa para a tensão entre direitos sociais, ordem pública (poder judiciário, polícia) e estado de direito? Ou, ainda, como os conflitos policiais podem ser compreendidos dentro do movimento de ampliação e restrição de direitos de empregados nas regiões carboníferas de São Jerônimo? A partir dessas questões, os objetivos da investigação começaram a se desdobrar, formalizando um duplo movimento que aliava, por um lado, uma compreensão sobre o evento narrado no processo e, por outro, a descrição dessas estruturas de direitos que configuravam a [ex]tensão de direitos sociais e seus limites nas minas de carvão, em Arroio dos Ratos/RS, em 1934.

Por essa perspectiva, a reclamação trabalhista de Domingos Mantilha e outros contra a CEFMSJ permite verificar a ampliação de um espaço político, jurídico e social que estava acessível, aberto. A opacidade, a zona cinzenta que representava a transição da linguagem e da prática sobre direitos transcritos na regulação do trabalho constituiu um jogo em que as regras estavam abertas. Com a redução na escala de observação, por meio desse processo, torna-se possível captar tais transições, que, por sua vez, tinham influência nas mudanças institucionais que a regulação do trabalho propunha.

\footnotetext{
${ }^{10}$ Costa (2010, p. 4) prossegue ao dispor que "o historiador atua a partir de seu presente: ele trabalha ativando as categorias linguísticas e conceituais que lhe são ofertadas por sua cultura. É essa linguagem que ele dispõe para entender a linguagem do passado, para nela decifrar os testemunhos desse passado, para recontá-lo. A linguagem do seu presente, contudo, não é o objeto da sua pesquisa, mas apenas seu (indispensável) instrumento; o objeto da sua pesquisa é a linguagem do passado".

${ }^{11}$ Conforme preceitua Walter Benjamin (1994).
} 
Essas considerações levantadas também permitem refletir, diante dessas possibilidades de espaços abertos no período em que se origina a Constituição de 1934, acerca dos contornos discursivos assumidos pela política e pelo direito quando o foco se direciona para a forma como o CNT interagiu com o caso e o julgou. Os silêncios dos conselheiros sobre a polícia e a prisão podem revelar o ambiente político do período, principalmente diante das fronteiras indefinidas entre o legal e o arbitrário, ante o conflito apresentado pela constitucionalização de determinadas condutas públicas e a violência político-policial.

A seção a seguir contém a exposição da escolha metodológica e da organização do trabalho.

\subsection{A micro-história e a organização do trabalho}

Em termos metodológicos, a perspectiva assumida para essa pesquisa assentou-se nas experiências da micro-história italiana. Nos últimos anos, um conjunto de estudos sobre essas experiências foi inserido no debate historiográfico brasileiro. ${ }^{12}$ A possibilidade de incluí-las também nos estudos sobre história constitucional tem demonstrado bons resultados.

O projeto da micro-história passou por inúmeras modulações particulares ao longo do tempo (REVEL, 1998; ROJAS, 2012). Cada uma dessas configurações representou um momento específico de sua trajetória e não é propósito desta tese deslindá-las. ${ }^{13}$ Entretanto, cabe fazer uma pequena incursão sobre a micro-história, para, sobretudo, explicitar como este trabalho recorreu a ela e dela se beneficiou ao longo de seu desenvolvimento.

A opção pela micro-história está intimamente ligada à redução da escala de observação do objeto a ser analisado. Essa redução, contudo, deve ser compreendida como uma experiência que visa explorar uma realidade não acessível de outra forma ${ }^{14}$.

$\mathrm{O}$ uso do termo micro para se referir à micro-história não pode ser empregado para designar histórias dos pequenos, dos distantes ou dos excluídos (LEVI, 2009), como também não pode ser designado para histórias locais ou de espaços pequenos e reduzidos: a microhistória se colocou como uma nova maneira de enfocar a história, que entre seus “procedimentos principais, reivindica o da 'mudança de escalas' do nível de observação e estudo dos problemas históricos e, por conseguinte, utiliza o acesso aos níveis 'macro-

\footnotetext{
${ }^{12}$ Nesse sentido, ver: Lima (2006; 2009) e Oliveira e Almeida (2009).

${ }^{13}$ Entre as principais referências de estudos sobre a micro-história encontram-se Carlo Ginzburg, Edoardo Grendi, Giovanni Levi, Jacques Revel, Bernard Lepetit, Maurizio Gribaudi e Simona Cerutti.

${ }^{14}$ Para um aprofundamento deste tema, ver Ginzburg (1991a; 1991b; 2006a e 2006b).
} 
históricos' $[\ldots]$, como procedimento metodológico para o enriquecimento da análise histórica" (ROJAS, 2007, p. 99, grifos do autor).

Com a redução na escala de observação, a reconstrução de momentos, como um conflito de greve, ou de situações complexas, como a relação entre público e privado, ou até mesmo entre pessoas, ao serem "investigadas com olho analítico, em âmbito circunscrito, recuperam um peso e uma cor; não como exemplos, na falta de explicações melhores, mas como referência dos fatos à complexidade dos contextos nos quais os homens se movem" (LEVI, 2009, p. 14).

$\mathrm{Na}$ prática, com a redução na escala, há uma mudança no nível de informação disponível sobre o objeto, modificando não apenas o que era ou não perceptível, mas também transformando a configuração da realidade analisada (ROJAS, 2007). Desse modo, o desafio dessa proposta consiste na atividade de recriar as conexões entre os diversos níveis observados, ao mesmo tempo que se leva em conta suas especificidades e diferenças.

A abordagem microanalítica, quando incorporada aos estudos da história constitucional, envolve, antes de tudo, uma determinada interpretação da história. A história constitucional não pode ser compreendida apenas a partir da observação do texto constitucional, com suas características, estilos e conteúdos, tampouco por uma redução ao campo político, como as discussões constituintes. Histórias constitucionais, sob essa perspectiva, enfocam, na maioria das vezes, concepções gerais que "mais ensinam sobre as preferências ideológicas de seus autores que sobre o direito" ${ }^{15}$ e suas experiências propriamente ditas.

Ao confrontar essas experiências de história constitucional, a micro-história, a partir de uma perspectiva reduzida, coloca-se como um modelo que auxilia na identificação do campo constitucional dentro de um panorama real, de um campo em que a luta por direitos e seu desenvolvimento institucional se firmam e se constituem. Desse modo, torna-se possível demonstrar situações que escapariam das análises de macro-história sobre direito, política e Constituição.

Nesse sentido, o estudo do caso Domingos Mantilha e outros, presente na reclamação trabalhista $n^{\circ}$ 9.582/1934-CNT, pode ser elucidativo. Como dizia Ginzburg (2007), analisar de perto uma documentação circunscrita, ligada a um grupo desconhecido em um evento único e singular, é um grande desafio, sobretudo quando os silêncios observados e as lacunas da

\footnotetext{
${ }^{15}$ A referência a esta passagem se origina em Seelaender (2012, p. 423), quando lançou notas sobre a história constitucional brasileira.
} 
documentação tornam-se parte do relato. As alterações na regulamentação do trabalho e a alegada violação dessas regras por parte da companhia colocaram sete trabalhadores em uma situação excepcional. As reações dos mineiros e a forma como as instrumentalizaram estavam conectadas com as transformações sociais e constitucionais do período. No momento em que o movimento dos trabalhadores e a situação de despedida se agrupam, aquele contexto de instabilidade das formas, e peso decisivo das ações do grupo/sindicato, ou até mesmo as referências genéricas que o processo envolveu passam a se constituir como um campo específico que põe em jogo configurações sociais não apenas complexas mas também imprevisíveis. $^{16}$

O trabalho foi construído a partir dessa perspectiva e organizado em três capítulos. No primeiro, apresenta-se o caso a partir dos dados obtidos na reclamação trabalhista, destacando-se cada passo do processo até seu arquivamento definitivo, em 1941. É relevante destacar que na metodologia da micro-história, os obstáculos postos às pesquisas sob a forma de lacunas e distorções documentais, como esclarece Ginzburg (2007), tornam-se parte do relato a partir do momento em que as pistas fragmentárias são acolhidas para explorar implicações gnosiológicas e transformá-las em elementos narrativos.

O segundo capítulo reconstitui o contexto que envolvia os principais personagens do processo. Em regra, toda configuração social reflete interações incontáveis de estratégias individuais que somente uma observação próxima possibilita reconstruir (GINZBURG, 2007). Os mineiros foram identificados a partir de seus registros civis, visando situá-los em um espaço de institucionalidade que envolvia o local de trabalho e as formas de organização política nas quais estavam inseridos. Nesse aspecto, concedeu-se atenção especial à história do Sindicato dos Mineiros de Arroio dos Ratos, a qual colaborou, principalmente, na interpretação acerca das estratégias e contradições às quais os trabalhadores estavam submetidos. A relação microscópica e a dimensão contextual mais ampla tornou-se o princípio organizador da narrativa. Por seu turno, a reconstrução da história da companhia também foi articulada, para contextualizar, na prática, o impacto de uma reclamação trabalhista na relação entre o público e o privado, tal como a estabelecida pela companhia à margem da ordem constitucional.

\footnotetext{
${ }^{16}$ Maurizio Gribaudi (1998, p. 129) entende que a "essa noção de imprevisibilidade é a que me parece esclarecer melhor o nível em que se situa a análise microssocial: o de uma causalidade que é, a cada momento, pensada como abertura. Se um processo evolui de maneira não previsível, isso significa que os fatores que favoreceram a concretização de uma solução de preferência a outra são contextuais; estão ligadas à especificidade de escolha e de dinâmicas que se atualizaram num momento e num lugar particulares".
} 
Por fim, o terceiro capítulo dedica-se à análise do caso, com vistas a compreender os limites e as possibilidades que o conflito lançou para a história do direito, sobretudo ao direito constitucional. Para tanto, a partir da tematização de indícios, provas e evidências que transformaram o caso, demonstra-se como as tensões, enfrentamentos e direitos foram articulados dentro do aparato institucional organizado pela nova ordem. 


\section{NOS RASTROS DO PROCESSO N 9.582/1934-CNT}

Nos últimos anos, o poder judiciário trabalhista tem intensificado ações que buscam aprimorar as políticas de resgate de memória que marcaram sua atuação no tempo. Essas ações envolvem um conjunto de reflexões que tencionam aquilatar a gestão documental e a proteção especial a documentos de arquivos de interesse histórico, consolidando a memória institucional do judiciário, bem como difundir e incentivar pesquisas relacionadas à história, à evolução do direito do trabalho e da Justiça do Trabalho.

A preservação e a divulgação desse acervo histórico pretendem ser instrumentos de apoio à administração, à cultura e ao desenvolvimento científico, bem como elementos de prova e informação, destinados a pesquisadores, gestores e à população em geral, conforme previsto em lei. ${ }^{1}$ Os registros dessas ações revelam ao público objetos e documentos que recuperam e reconstituem momentos relevantes para os tribunais e a sociedade civil, desvelando tradições, costumes, conflitos e, sobretudo, retratos da vida cotidiana, pública e privada, que, reunidas em documentos, cristalizam em um determinado momento histórico narrativas, linguagens, fatos e evidências que subsidiam novas abordagens analíticas para a composição do passado, presente e futuro.

Nesse sentido, o Tribunal Superior do Trabalho (TST), ao ampliar a estrutura da Coordenadoria de Gestão Documental e Memória (CGEDM), ${ }^{2}$ tem oferecido uma contribuição integrada para o resgate, a preservação e a divulgação da história da Justiça do Trabalho. Essas ações avançaram nos anos 2000, com a constituição de um grupo de trabalho para a organização e seleção de documentos históricos que passariam a compor o memorial da Justiça do Trabalho. ${ }^{3}$

Uma das frentes de trabalho da CGEDM ocorreu no âmbito do Núcleo de Memória, Estudos e Pesquisas (NuMEP), que, a partir de 2003, promoveu o tratamento especializado nos documentos que hoje compõem o Fundo CNT. Esse fundo é composto por documentos judiciais e

\footnotetext{
${ }^{1}$ Trata-se da Lei $\mathrm{n}^{\circ} 8.159$, de 9 de janeiro de 1991, que dispõe sobre a Política Nacional de Arquivos Públicos e Privados e, posteriormente, a Lei de Acesso à Informação - Lei no 12.527, de 18 de novembro de 2011. No judiciário trabalhista, é possível identificar, principalmente após a Constituição de 1988, iniciativas isoladas dos tribunais regionais e de seus membros em busca do resgate da memória da Justiça do Trabalho. Para aprofundamento, ver Biavaschi e Droppa (2011). A consolidação dessas iniciativas ocorreu com o provimento da Política Nacional de Resgate à Memória da Justiça do Trabalho (Ato Conjunto no 11/TST.CSJT.GP, de 3 de maio de 2011).

${ }^{2}$ Em 6 de dezembro de 2011, o TST lançou a Resolução Administrativa no 1.485, que criou a seção de memória, estudos e pesquisas, e transferiu para a CGEDM a responsabilidade pela manutenção do espaço cultural denominado "Memorial do TST".

${ }^{3}$ Ato $n^{\circ}$ 580/GDGCA.GP, de 6 de setembro de 2000.
} 
administrativos que registram a história do Conselho Nacional do Trabalho entre 1923, quando foi criado, e 1946, quando se transformou no Tribunal Superior do Trabalho (TST).

Em pouco mais de 20 anos de existência, o CNT produziu um inventário superior a 50 mil decisões, lavradas em acórdãos e decisões monocráticas. Atualmente, o Fundo CNT possui 976 processos preservados. Entre eles, o caso Domingos Mantilha, selecionado para compor as análises desta tese. ${ }^{4}$

\subsection{O caso Domingos Mantilha e outros no Conselho Nacional do Trabalho}

Nos primeiros dias do mês de setembro de 1934, o Conselho Nacional do Trabalho (CNT) autuou uma reclamação trabalhista encaminhada pelo inspetor Evandro Lobão dos Santos, da $11^{\text {a }}$ Inspetoria do CNT em Porto Alegre/RS. Tratava-se do processo dos mineiros Domingos Mantilha, Liberalino Machado de Lima (ou Januário Machado de Lima), Raphael Mezza, Antônio Nunes das Pedras, Adalberto Azambuja dos Santos, João Keenan e Thomaz Gonçalves da Silva ${ }^{5}$ contra a Companhia Estrada de Ferro e Minas de São Jerônimo (CEFMSJ).

$\mathrm{O}$ caso se originou em uma das instalações da CEFMSJ, no distrito de Arroio dos Ratos, município de São Jerônimo/RS. Inicialmente, os autos foram distribuídos ${ }^{6}$ para a $17^{\mathrm{a}}$ Inspetoria Regional ${ }^{7}$ do Ministério do Trabalho, Indústria e Comércio (MTIC), em 16 de agosto de 1934, em Porto Alegre/RS. O inspetor do CNT, responsável pela fiscalização das Caixas de Aposentadorias e Pensões (CAPs), acionou a empresa mediante ofício, em busca de informações sobre os motivos das demissões.

A primeira manifestação oficial da empresa ocorreu em 22 de agosto de 1934. Produzida em lauda única e encaminhada ao inspetor Evandro Lobão dos Santos, esclarecia que os empregados Liberalino Machado de Lima, Raphael Mezza, Antônio Nunes das Pedras e Adalberto Azambuja dos Santos foram expulsos das minas de carvão pelas autoridades policiais em março de 1934, “como indesejáveis, motivo por que nossa Companhia os considerou demitidos por abandono de emprego". ${ }^{8} \mathrm{O}$ empregado Domingos Mantilha foi transferido para lugar diverso de sua ocupação, por conveniência do serviço e "com igual ordenado, deixou de

\footnotetext{
${ }^{4}$ É importante registrar que as frases originais descritas nos autos ou em outras fontes documentais foram atualizadas, quando necessário, para a atual grafia da língua portuguesa, preservando-se o sentido original.

${ }^{5}$ As primeiras petições no processo indicavam apenas o nome de Thomaz Gonçalves. A partir de 1935, a referência a Thomaz Gonçalves da Silva tornou-se comum.

${ }^{6}$ À fl. 04 dos autos, o processo recebeu identificação no $161-34$, em 16 de agosto de 1934.

${ }^{7}$ As inspetorias foram criadas pelo Decreto $\mathrm{n}^{\mathrm{o}} 21.690$, de $1^{\circ}$ de agosto de 1932 . A referência à inspetoria no Rio Grande do Sul consta no Decreto n ${ }^{\mathrm{o}} 23.288$, de 26 de outubro de 1933.

${ }^{8}$ Fl. 03 do processo $n^{\circ} 9.582 / 1934$.
} 
se apresentar no serviço que lhe fora destinado". Os empregados João Keenan e Thomaz Gonçalves da Silva teriam deixado de comparecer ao serviço "por sua livre vontade", o primeiro, em 1929 e o segundo, em dezembro de 1933, sem darem nenhuma satisfação.

Na sequência, seguia o processo na íntegra, com petição inicial ${ }^{9}$ e provas documentais dos empregados reclamantes, todos representados pelo advogado do Sindicato dos Mineiros de Arroio dos Ratos (SMAR). ${ }^{10}$ Dos sete reclamantes, apenas Antônio e Adalberto, segundo dados da petição, possuíam pouco mais de sete anos de vínculo de emprego. Os demais eram empregados estáveis, com tempo superior a dez anos na categoria de mineiros.

$\mathrm{Na}$ petição inicial, os empregados narravam que as demissões foram injustas, visto não terem cometido faltas graves que justificassem a reação da empresa e em função da violação dos procedimentos legais para despedida, ${ }^{11}$ presentes no art. 53, do Decreto $\mathrm{n}^{\mathrm{o}} 20.465$, de $1^{\mathrm{o}}$ de outubro de 1931, que exigia a instauração de inquérito administrativo para apurar a existência de falta grave de empregados com mais de dez anos prestados a uma mesma empresa. ${ }^{12}$ Embora reconhecessem que Antônio e Adalberto poderiam ser demitidos sem

\footnotetext{
${ }^{9}$ Fls. 05 e ss. do processo ${ }^{\circ} 9.582 / 1934$.

${ }^{10} \mathrm{O}$ sindicato dos Mineiros de Arroio dos Ratos foi criado em $1^{\circ}$ de janeiro de 1933 e reconhecido pelo MTIC em junho do mesmo ano.

${ }^{11}$ O Decreto $\mathrm{n}^{\circ}$ 22.096, de 16 de novembro de 1932, estendeu aos serviços de mineração o regime das Caixas de Aposentadoria e Pensão e outros dispositivos de proteção social e previdenciária aos trabalhadores (Decreto $\mathrm{n}^{\circ}$ 20.465 , de $1^{\circ}$ de outubro de 1931, alterado em 24 de fevereiro de 1932).

${ }^{12}$ Com a redação de 1931, o art. 53 dispunha que: "Após dez anos de serviço prestado à mesma empresa, os empregados a que se refere a presente lei só poderão ser demitidos em caso de falta grave, apurada em inquérito, feito pela administração da empresa, ouvido o acusado com a assistência do representante do sindicato da classe, cabendo recurso para o Conselho Nacional do Trabalho. $\S 1^{\circ} \mathrm{O}$ empregado contra o qual for arguida falta grave poderá ser desde logo suspenso de suas funções pela empresa, mas a demissão somente se dará após deliberação do Conselho Nacional do Trabalho, se este reconhecer a falta arguida. $\S 2^{\circ}$ No caso de reconhecer o Conselho Nacional do Trabalho a não existência de falta grave ao empregado, fica a empresa obrigada a readmiti-lo ao serviço e a indenizá-lo dos salários durante o período de sua suspensão. $\S 3^{\circ} \mathrm{O}$ empregado demitido, com mais de 10 anos de serviço, poderá continuar como associado da Caixa, pagando em dobro, até perfazer o período de 30 anos, a contribuição correspondente ao vencimento que recebia ao ser dispensado, se assim o requerer, no prazo máximo de 60 dias da demissão. $\mathrm{O}$ associado nestas condições, a partir de 55 anos de idade, perceberá, uma renda vitalícia equivalente à importância da aposentadoria a que teria direito se continuasse em serviço no cargo que ocupava ao ser exonerado, feita a conveniente habilitação perante a Caixa. $\S 4^{\circ}$ Não se compreendem neste artigo os cargos de diretoria e gerência das empresas e os da confiança imediata dos governos e das administrações superiores das empresas. $\S 5^{\circ}$ Não se compreendem igualmente neste artigo os empregados que se tenham tornado desnecessários por ter sido suprimido o serviço ou departamento das empresas em que trabalhavam em virtude de ter desaparecido o seu objeto ou pela superveniência de novas invenções. Mas, neste caso, os empregados que forem dispensados terão direito de se aposentar, com tantos trinta avos da média dos vencimentos dos últimos três anos quantos forem os anos de serviço de cada um, cabendo às empresas a obrigação de entrar antecipadamente e de uma só vez para as Caixas com a importância global das contribuições dos empregados assim aposentados, bem como manter a sua própria, como se tais empregados continuassem em serviço, sujeitando antecipadamente o processo de aposentadoria, com todas as informações, ao Conselho Nacional do Trabalho". O decreto era uma reforma para as Caixas de Aposentadoria e Pensão, e foi assinado por Getúlio Vargas, Lindolfo Collor, Oswaldo Aranha, José Maria Whitaker e José Américo de Almeida. Em 12 de julho de 1934, o governo provisório lançaria novo dispositivo, o Decreto $\mathrm{n}^{\circ} 24.694$, sobre os sindicatos profissionais. Somente poderiam se sindicalizar os possuidores de carteira de trabalho; os empregados já sindicalizados que não a possuíssem corriam o risco de perderem a filiação.
} 
ofensa a dispositivos de leis por não serem estáveis, "a injustiça de tal ato não deixa de ser chocante, para qualquer pessoa, que se preze de ter um pouco de sentimento de justiça para com o seu semelhante". Acrescentaram que todos os possíveis meios amigáveis e pacíficos foram empregados pelos trabalhadores visando reverter a despedida, mas não obtiveram resultados. Buscando a reintegração dos trabalhadores, o sindicato requereu a intervenção do Ministério do Trabalho.

Com a ausência de inquérito administrativo, os trabalhadores promoveram uma ação de justificação judicial, ${ }^{13}$ em 18 de junho de 1934, no juízo distrital de São Jerônimo/RS. O procedimento objetivava colher depoimento de testemunhas, a fim de esclarecer os seguintes questionamentos: $i$ ) comprovar a estabilidade superior a dez anos dos empregados Domingos, Liberalino (ou Januário), Raphael, João e Thomaz na CEFMSJ; ii) comprovar tempo de serviço superior a sete anos dos empregados Antônio e Adalberto; iii) demonstrar que a despedida ocorreu sem justificativa; $i v$ ) que não cometeram nenhum ato de improbidade; $v$ ) que não eram ébrios habituais; vi) reconhecer ausência de desídia no desempenho de suas funções; vii) atestar ausência de segredo profissional que vinculasse suas atividades na empresa; viii) firmar ausência de ato de indisciplina ou insubordinação; ix) ausência de abandono de emprego sem causa justificada ou autorizada mediante licença médica; e $x$ ) ausência de ato lesivo a honra ou violência física. Em sua maioria, os quesitos apresentados correspondiam às situações em que a falta grave poderia ser reconhecida nos termos do artigo 54, do Decreto $n^{\circ} 20.465 / 1931$.

A justificação judicial era um procedimento previsto nos arts. 808 a 810 do Código de Processo Civil do Estado do Rio Grande do Sul. Seu escopo era instrumentalizar a satisfação de uma pretensão probatória, a fim de demonstrar uma relação jurídica ou a existência de um fato. Instruída por um juiz de direito e com a presença de um promotor público, os autos eram julgados por sentença e entregues aos interessados.

No pedido de justificação judicial apresentado pelo advogado Alcides de Oliveira Carracho, ${ }^{14}$ do SMAR, foram arroladas dez testemunhas, ${ }^{15}$ cujas oitivas ocorreram a partir do

\footnotetext{
${ }^{13}$ No processo no 9.582/1934, a justificação judicial pode ser encontrada entre as fls. 06-23.

${ }^{14}$ À fl. 10 do processo $\mathrm{n}^{\circ}$ 9.582/1934, há uma procuração outorgada por Castor Bispo, presidente do Sindicato dos Mineiros de Arroio dos Ratos.

${ }^{15}$ Nos autos de justificação foram ouvidas apenas oito testemunhas. Francisco Serpa, solteiro, de 21 anos, foi impedido de testemunhar, por não conseguir comprovar sua identidade, já que apresentou nome diverso no momento da oitiva. João Tomaz Miranda, casado, de 65 anos, não compareceu ou foi dispensado pelos interessados.
} 
dia 19 de junho de 1934, sob jurisdição do juiz de direito Alcebíades Pereira e do promotor público Ernani Coelho.

A primeira testemunha, Eduardo Wesbert, era casado, com 58 anos de idade e sem identificação da profissão. Afirmou que conhecia pessoalmente João Keenan como empregado da companhia por mais de 40 anos; acrescentou que Keenan estava em licença de saúde e quando terminou, a companhia negou-lhe retorno. Alegou que João Keenan não havia praticado ato de improbidade; não era ébrio habitual ou teria desempenhado com desídia suas funções; que não lhe fora confiado segredo por força do cargo; não havia cometido ato de indisciplina ou grave insubordinação, abandono de emprego ou ato lesivo da honra e boa fama contra qualquer pessoa, sem ofensa física a seus colegas e superiores.

Felipe Ferreira da Silva, casado, profissional do comércio (tendo atuado como patrão ${ }^{16}$ de galeria na mina de carvão), com 64 anos de idade, informou que conhecia pessoalmente João Keenan há mais de 40 anos como empregado da companhia, quando trabalharam juntos desde 1888; alegou que há alguns anos, Keenan havia solicitado licença do trabalho para tratamento de saúde e quando retornou, seus serviços foram dispensados pela empresa. Acrescentou que Keenan nunca praticou ou fez os atos questionados que justificassem sua demissão.

Horácio Gomes da Rocha, casado, mineiro, com 34 anos de idade, informou que conhecia pessoalmente Domingos Mantilha, Liberalino Machado de Lima, Raphael Mezza, Thomaz Gonçalves, Antônio Nunes das Pedras e Adalberto Azambuja dos Santos. Acrescentou que, quando se empregou na companhia, em 22 de julho de 1921, já trabalhavam na empresa Domingos, Thomaz e Raphael, e que, em 1924, Antônio e Adalberto foram empregados na mesma empresa, tendo sido demitidos sem justificativa alguma. Questionado se tinha conhecimento de terem praticado atos que justificassem suas demissões, alegou que os trabalhadores nunca cometeram tais faltas.

Em 20 de junho de 1934, Pedro Porto Fagundes, solteiro, mineiro, com 29 anos de idade, informou que conhecia pessoalmente Domingos Mantilha, mas conhecia pouco os outros justificantes. Acrescentou que Domingos trabalhava há mais de 15 anos na companhia e foi demitido sem motivo. Alegou que nunca ouviu nada contra os justificantes nas minas de Arroio dos Ratos, tendo-os como bons homens e operários.

\footnotetext{
${ }^{16}$ Segundo Clarice Gontarski Speranza (2012, p. 53), "a figura do patrão relaciona-se estritamente à forma de exploração das minas na época. Mineiros mais experientes e com maior conhecimento técnico, eles coordenavam o trabalho das equipes responsáveis pela extração em cada galeria e recebiam das empresas pelo serviço, pagando aos trabalhadores sob seu comando".
} 
Francisco Neves, espanhol, solteiro, mineiro e com 40 anos de idade, era empregado da companhia desde 1919 e informou conhecer pessoalmente Domingos, Liberalino, Raphael e Thomaz como empregados da companhia por mais de dez anos; e que também conhecia Antônio, tendo este mais de sete anos de emprego na companhia. Acrescentou que não conhecia Adalberto e que tinha conhecimento de que foram demitidos sem motivo algum. Alegou que quanto aos justificantes que conhecia seriam incapazes de praticaram atos que justificassem suas demissões.

Osório Custódio, casado, mineiro, com 28 anos de idade, também era empregado da companhia. Alegou que conhecia todos os justificantes e que tinham mais de dez anos de vínculo na empresa, com exceção de Antônio e Adalberto, com apenas sete anos. Informou que os justificantes eram ordeiros e não haviam cometido faltas graves.

João Pires, casado, mineiro, com 44 anos de idade, declarou que conhecia pessoalmente Domingos, Liberalino, Raphael e Thomaz, todos com mais de dez anos de emprego na companhia; acrescentou que presenciou quando o dr. Mário Pena, representante da companhia, demitiu Liberalino e Thomaz, não sabendo informar os motivos da dispensa. Questionado sobre as faltas graves, informou que os trabalhadores tinham uma conduta de correção, disciplina e que mereciam louvor.

José Pinheiro dos Santos, casado, mineiro, com 25 anos de idade, declarou que era empregado da companhia há 13 anos. Informou que conhecia pessoalmente os justificantes e que trabalhavam por mais de dez anos na companhia, com exceção de Adalberto e Antônio, com tempo superior a sete anos; que por conhecê-los pessoalmente, poderia afirmar que eram bons cidadãos e operários.

No processo administrativo original, logo após a juntada da ação de justificação dos mineiros, registra-se a ausência das folhas 25 a 30, provavelmente, correspondentes a documentos ou outra ação de justificação em nome de Liberalino (ou Januário) Machado de Lima. Nos autos, foi deferida pelo CNT, a pedido do sindicato, a extração de documentos e justificação judicial desse empregado. ${ }^{17}$

Acostadas ainda ao processo, encontravam-se duas declarações relacionadas à condição de Liberalino Machado de Lima ou Januário Machado de Lima. A primeira

\footnotetext{
${ }^{17}$ À fl. 182 do processo $n^{\circ} 9.582 / 1934$, essa informação pode ser comprovada. O pedido refere-se ao reclamante Liberalino, em 29 de novembro de 1940, quando o sindicato dos mineiros (na época, o presidente era Zalmiro Keenan) solicitou o desentranhamento de todas justificações judiciais, certidão de nascimento e atestados de saúde em nome de Liberalino ou Januário Machado de Lima. Autorizado o desentranhamento, os documentos foram recebidos pelo sindicato em 5 de agosto de 1941 (fl. 191).
} 
declaração em destaque foi produzida por Pedro Logue Sobrinho e Adalberto Thimóteo dos Santos, na qual declararam conhecer

o camarada Liberalino Machado de Lima, conhecido também pelo nome de Januário, como empregado, conosco, da Companhia Estrada de Ferro e Minas de São Jerônimo, onde, desde 1914, exerceu várias atividades, sendo ultimamente tocador de carros da qual, há pouco, foi despedido, por intrigas dum tal Cathalã, que, por aqui, andou como operário, mas que, depois, se soube ser um secreta da polícia. ${ }^{18}$

Na segunda declaração um farmacêutico e um enfermeiro alegavam conhecer o

operário Liberalino Machado de Lima, conhecido também pelo nome de Januário, como empregado, conosco, da Companhia Estrada de Ferro e Minas de São Jerônimo, onde exerceu várias atividades, sendo por último tocador de carros, há muitos anos, desde 1914, época em que se empregou. ${ }^{19}$

Após o recebimento dos autos pelo CNT, o diretor da $1^{\mathrm{a}}$ Seção, Theodoro de Almeida Sodré, encaminhou os autos para parecer da Procuradoria Geral. Em 31 de outubro de $1934,{ }^{20}$ o procurador adjunto requereu a conversão do julgamento em diligência, por ser impossível apreciar o caso com as informações existentes. Ao não considerar a manifestação inicial da empresa como citação oficial, solicitou repetição do ato, a fim de que apresentasse defesa nos autos e encaminhasse o inquérito administrativo que deveria ter instaurado para a despedida dos empregados estáveis, bem como para que os empregados comprovassem seu tempo de serviço.

Designado o conselheiro Manoel Tibúrcio da Silva ${ }^{21}$ como relator do processo pelo presidente do $\mathrm{CNT},{ }^{22}$ a reclamação foi apreciada na $6^{\mathrm{a}}$ sessão da $2^{\mathrm{a}}$ Câmara do CNT, em 16 de novembro de 1934. Estavam presentes os conselheiros Francisco Barbosa Rezende ${ }^{23}$ (presidente do conselho), Irineu Malagueta ${ }^{24}$, Gualter José Ferreira ${ }^{25}$ e o relator. Iniciada a sessão, o relator informou aos demais membros que o processo em apreço deveria ser um inquérito administrativo. Acrescentou, em seu relato, que eram

\footnotetext{
${ }^{18}$ Fl. 31 do processo $n^{\circ} 9.582 / 1934$.

${ }^{19}$ Fl. 32 do processo $n^{\circ} 9.582 / 1934$.

${ }^{20}$ Fl. 36, verso, do processo $\mathrm{n}^{\mathrm{o}} 9.583 / 1934$.

${ }^{21}$ Foi conselheiro do CNT, representante dos empregados. Tomou posse em 21 de setembro de 1934 e exonerouse em 22 de dezembro de 1938 (Fonte: registro Fundo CNT-TST, Brasília/DF).

${ }^{22}$ Fl. 37 do processo $n^{\circ} 9.582 / 1934$.

${ }^{23}$ Barbosa Rezende presidiu o CNT na maior parte do processo trabalhista que subsidia esta pesquisa. Para mais detalhes, ver Brasil (1975, p. 63-64).

${ }^{24}$ Tomou posse no CNT em 21 de setembro de 1934, atuando como técnico. Exonerou-se em 16 de agosto de 1939 (Fonte: registro Fundo CNT-TST, Brasília/DF).

${ }^{25}$ Tomou posse no CNT em 21 de setembro de 1934, exonerando-se em 22 de dezembro de 1938. Nos livros de assentos, não há registro acerca de quais forças sociais representava (Fonte: registro Fundo CNT-TST, Brasília/DF).
} 
empregados que foram dispensados pela empresa e recorreram então ao juiz distrital, apresentando testemunhas que atestaram terem alguns mais de 10 anos de serviço. A empresa não se fez representar. Também não teria, tanto é verdade que procurava o Inspetor Regional deste Conselho. $\mathrm{O}$ inspetor notificou a empresa sobre o inquérito e a empresa mandou simplesmente um memorando que vou ler, para mostrar o menosprezo da empresa: (lido). ${ }^{26} \mathrm{~A}$ empresa nem sequer quis provar o que alegou. Podia juntar certidão da autoridade estadual. Ainda diz mais: (lido). Temos aqui 4 com mais de 10 anos de serviço, sendo um com 40 anos. Agora eu pergunto se a empresa andou certa não fazendo inquérito administrativo, como era de obrigação? Se os empregados foram demitidos como mau elemento, nada mais fácil que provar no inquérito administrativo. Entretanto, a empresa não cogitou, não a interessava, o que para mim importa como má-fé. Aqui estão os depoimentos das testemunhas que declaram como companheiro há mais de 10 anos, não haver falta nenhuma, nem ainda terem ouvido sequer falar mal dos companheiros. A procuradoria dá o seguinte parecer: (lido). ${ }^{27}$

Após a apresentação do parecer da procuradoria, que pugnava pela conversão do julgamento em diligência, iniciaram-se as discussões entre os membros do conselho. $O$ voto do relator, em discordância com a procuradoria, era para que todos os empregados estáveis fossem reintegrados, "tanto mais havendo o erro da empresa por não ter feito inquérito administrativo e por ter feito o memorando", destacava Manoel Tibúrcio.

Em entendimento diverso, o conselheiro Gualter Ferreira informara que

não teria dúvida em concordar com o relator se nisto tivesse sido citada a empresa. É uma situação muito difícil para nós; pode até afetar nosso prestígio. Por isso que acho também que é caso de converter o julgamento em diligência, como opina a Procuradoria para que ela mande o inquérito administrativo, que ela tenha feito. A diligência deve ser para que a empresa mande o inquérito administrativo procedido, e até dê ofício desta gente. Aí é que vamos conhecer o tempo de serviço de cada um. ${ }^{28}$

Com a matéria em debate, o conselheiro Irineu Malagueta também acompanhou a opinião de Gualter Ferreira, tendo o relator destacado que já compreendia que seu voto não seria acompanhado pelos demais membros, que provavelmente acompanhariam a procuradoria, "mas, por uma convicção proletária minha, eu acho que a empresa errou, e como errou de início foi até o fim. De modo que o meu voto tem que ser assim, julgando procedente a reclamação". ${ }^{29}$ Diante dos votos, o conselho converteu o julgamento em diligência para que a empresa enviasse o inquérito administrativo e tempo de serviço dos operários.

\footnotetext{
${ }^{26} \mathrm{O}$ memorando em referência é o ofício de fl. 3, encaminhado pela empresa ao inspetor do CNT, oferecendo informações sobre as demissões dos reclamantes, reproduzido anteriormente.

${ }^{27}$ A sessão de julgamento encontra-se disponível para acesso no Fundo CNT, setor Notas Taquigráficas (19321946). A recuperação das discussões encontra-se registrada na $6^{a}$ sessão da $2^{a}$ Câmara do CNT, realizada em 16 de novembro de 1934, p. 1-2.

${ }^{28}$ Sessão de julgamento, p. 2.

${ }^{29}$ Sessão de julgamento, p. 2.
} 
Em 11 de dezembro de 1934, a CEFMSJ apresentou uma petição ${ }^{30}$ em que buscava embargar a decisão que converteu o julgamento em diligência. Amparada por opinião jurídica do consultor da empresa, o delegado diretor da companhia apresentou novos argumentos, indicando a impossibilidade de enviar o inquérito administrativo para apurar falta grave por entender que tal medida somente se aplicaria a empresas que tivessem demitido empregados estáveis, conforme nova disposição do art. $2^{\circ}$ do Decreto $\mathrm{n}^{\circ} 22.096$, de 16 de novembro de 1932. ${ }^{31}$ Para a empresa, o afastamento dos trabalhadores não ocorreu pela despedida, mas, sim, pela prisão efetuada pela polícia, o que, em seu entendimento, não ensejava a obrigação de instaurar inquérito administrativo. Sobre o assunto, a empresa justificava que:

De fato, nenhuma demissão foi lavrada ou dada aos reclamantes por esta empresa, tendo eles em sua maior parte, sido privados de trabalhar pela polícia local, em consequência de prisão por ela efetuada, devido à denúncia recebida de estarem tramando uma greve geral entre os mineiros, denúncia, aliás, a que a Direção desta empresa foi completamente estranha. Afastados, assim, do serviço, por motivo, não de demissão, que não houve, mas de prisão efetuada pela polícia, é claro que a nenhum inquérito administrativo estava obrigada a empresa a qual, diante do inopinado afastamento, forçado, dos reclamantes, não podia deixar de logo dar-lhes substituto, conforme fez, em legítimo resguardo dos interesses da mesma que lhe incumbe precipuamente zelar. ${ }^{32}$

Em decorrência desse argumento, caracterizando o "abandono de emprego forçado", a companhia pretendeu contornar eventuais prejuízos causados aos reclamantes utilizando o disposto no art. 171 da nova Constituição, em vigor desde 16 de julho de 1934, que previa ser de responsabilidade do funcionário público indenizar, em solidariedade com o Estado e municípios, situações que, por negligência, omissão ou abuso no exercício de seus cargos, ${ }^{33}$ viessem a causar prejuízos a terceiros. Ao utilizar esse dispositivo, a companhia pretendia afirmar que, uma vez comprovada posteriormente a "injustiça da prisão", o responsável direto pelos prejuízos causados, decorrentes de negligência, omissão ou abuso no exercício de suas funções deveria ser acionado judicialmente - nesse caso, a polícia e não a empresa, cuja obrigação de readmitir os empregados e pagar-lhes salários não procederia, visto não ter contribuído para a privação a que foram sujeitos. Assim, a empresa utilizava o argumento da culpa de terceiro como exclusão de eventual responsabilidade para ressarcir os prejuízos causados aos empregados. Remetendo, novamente, aos dispositivos da Constituição de 1934,

\footnotetext{
${ }^{30}$ Fls. 40 e ss. do processo no $9.582 / 1934$.

${ }^{31} \mathrm{O}$ decreto estendia aos serviços de mineração, em geral, as disposições do Decreto $\mathrm{n}^{\mathrm{o}} 20.465$, de 1 de outubro de 1931, com as modificações constantes do de $\mathrm{n}^{\circ} 21.081$ de 24 de fevereiro de 1932, prevendo as CAPs e a estabilidade decenal aos empregados.

${ }^{32}$ Fl. 40 do processo $n^{\circ} 9.582 / 1934$.

${ }^{33}$ No original, a empresa grifou o termo.
} 
a empresa afirmava que essa obrigação só seria possível se houvesse lei que determinasse tal ressarcimento, pois conforme o art. 113, parágrafo $2^{\circ}$ da Constituição, "ninguém será obrigado a fazer ou deixar de fazer algo se não em virtude de lei”.

Assim, argumentava que, naquele caso, por não se tratar de despedida dada pela empresa, mas de impedimento dos operários para comparecerem ao serviço por motivo de prisão efetuada pela polícia, a responsabilidade pelo ressarcimento dos prejuízos pesaria contra a autoridade policial, inquestionavelmente prevista no art. 1.550 do Código Civil de 1916, que preceituava que "a indenização por ofensa à liberdade pessoal consistirá no pagamento das perdas e danos que sobrevierem ao ofendido, e no de uma soma calculada nos termos do parágrafo único do art. 1.547”.

Em relação ao empregado Domingos Mantilha, a empresa informou que não houve despedida, mas transferência das funções de patrão da galeria 39 do poço 4 para furador, que seriam “de mesma classe e ordenado", para manter a expressão da época sobre remuneração. Alegando que Domingos atuava com habitual desídia, "dava seguidamente prejuízos à empresa. No mês de maio p. passado, após o desconto regulamentar das despesas de peões, explosivos, quota de papel, assim como a diária do referido mineiro, verificou-se um déficit de Rs 1:440\$000, desembolsado pela suplicante". Acrescentando que o rebaixamento era "de categoria inferior, porém de mesma classe", adicionou que "a lei não via com maus olhos o rebaixamento de categoria, e também do salário senão quando usado como castigo, ou pelo fato de associar-se o empregado ao sindicato de sua classe, ou por ter, no seio do sindicato, manifestado ideias ou assumido atitudes em divergência com os seus patrões, referenciando o art. 13, do Decreto $n^{0} 19.770,{ }^{34}$ de 19 de março de 1931". Em relação ao tempo de serviço, também contestou a estabilidade decenal de Domingos, sob a alegação de que a estabilidade somente se configura pelo cumprimento ininterrupto do prazo decenal, ausente em sua situação. Reiterando o pedido de rejeição aos pedidos de reintegração dos reclamantes, a empresa deixou de apresentar as certidões de tempo de serviço.

Acompanhando a manifestação, a empresa apresentou um ofício da Inspetoria Regional do MTIC, no qual constatava que o inspetor Ernani de Oliveira, em atendimento ao SMAR, acompanhou as causas que teriam determinado a prisão e despedida dos operários Raphael Mezza, Adalberto Azambuja dos Santos, Ricardo Pavio, João Herrera, Liberalino Machado, Antônio das Pedras e José Francisco.

\footnotetext{
${ }^{34} \mathrm{O}$ decreto regulava a nova lei de sindicalização das classes patronais e operárias.
} 
No ofício, Ernani de Oliveira destacava que a Chefatura de Polícia do Estado informou-lhe que esses operários foram denunciados à polícia como comunistas e promotores de um movimento grevista entre o pessoal de mineração. Todavia, após rigorosa sindicância promovida pelo $3^{\circ}$ delegado auxiliar da capital, concluiu-se que as imputações eram destituídas de fundamento. O ofício indicava, por fim, um pedido do inspetor à direção da empresa: "afigura-se-me, assim, ato de boa justiça a readmissão desses operários, tão rudemente atingidos por infundada e aleivosa imputação. Acredito que diverso não será o vosso juízo, o que me autoriza a confiar nessa reparação".

Em 5 de fevereiro de 1935, a procuradoria apresentou novo parecer sobre o caso Domingos Mantilha e outros. Refutando os argumentos da empresa, compreendeu que "desde que forçado pela polícia, deixava de se caracterizar o abandono de emprego pelos reclamantes e ainda apurada a improcedência da denúncia, cabia à companhia readmiti-los em seu serviço, uma vez que não se verificavam as hipóteses do art. 53 dos decretos n. 20.465 e 21.081 " ${ }^{35}$ Os decretos em referência se interconectam com as razões que permitiriam o reconhecimento da falta grave. A par desses argumentos, a procuradoria também sugeria a readmissão de Domingos Mantilha por duas razões: i) a empresa, ao confessar ser ele empregado estável, deveria ter procedido ao inquérito administrativo para apurar falta grave; e ii) a estabilidade decenal, conforme entendimento do ministro do Trabalho, aplicava-se à comprovação de tempo superior a dez anos na mesma categoria profissional e não exclusivamente na mesma empresa (jurisprudência firmada no caso de João Rolino Xavier e Edison Guerra Dias). Ao reiterar o pedido de envio dos novos certificados de tempo de serviço dos demais reclamantes, a procuradoria também contestou o entendimento da empresa sobre responsabilidade indenizatória, apontando que "seria estranho que o Poder Público ficasse tolhido em sua ação preventiva por indenizações dessa natureza"; esclareceu, ainda, que as indenizações previstas no Código Civil brasileiro, especificamente, no art. 1.550, referiam-se a constrangimento da liberdade causado pelas pessoas naturais e jurídicas de natureza civil, ausente no caso em tela.

Promovido o expediente ao relator Manoel Tibúrcio Silva em 14 de fevereiro de 1935, o processo retornou em 14 de março de 1935, entrando na pauta de julgamento para o Conselho Pleno do CNT na $28^{\mathrm{a}}$ sessão, de 25 de abril de 1935. Registrou-se a presença dos conselheiros Barbosa Rezende, Tavares Bastos, Gualter José Ferreira, Augusto Paranhos Fontenelle, ${ }^{36}$ Luiz

\footnotetext{
${ }^{35}$ F1. 46 do processo $n^{\circ} 9.582 / 1934$.

${ }^{36}$ Atuou no conselho como técnico, a partir de 11 de abril de 1935. Foi exonerado em 16 de agosto de 1939 (Fonte: registro Fundo CNT-TST, Brasília/DF).
} 
Augusto de Rego Monteiro, ${ }^{37}$ Antônio Ribeiro França Filho, ${ }^{38}$ Manoel Tibúrcio da Silva (relator), Luiz de Paula Lopes, ${ }^{39}$ Alvaro Correa da Silva, ${ }^{40}$ José Mendes Cavalleiro ${ }^{41}$ e Américo Ludolf. ${ }^{42}$ Nas notas taquigráficas do Fundo CNT, foi possível identificar os processos julgados na referida sessão, porém não há referências sobre debates no julgamento que originou o primeiro acórdão, com decisão de mérito, no processo em análise.

$\mathrm{O}$ acórdão ${ }^{43}$ proferido rejeitou a manifestação da empresa. Determinou a reintegração de Domingos Mantilha, ${ }^{44}$ por ficar comprovado que o reclamante contava com mais de dez anos de serviço, conforme interpretação dada pelo ministro do Trabalho, bem como por não ter respondido inquérito administrativo. $\mathrm{Na}$ sequência, determinou, ainda, à empresa a remessa dos certificados de tempo de serviço dos demais reclamantes.

Por acúmulo de serviço, a empresa somente fora notificada da decisão em 29 de junho de 1935. Ao que tudo indica, uma manifestação do Sindicato dos Mineiros de Arroio dos Ratos não foi apreciada no julgamento de 25 de abril de 1935. Protocolada na secretaria do CNT em 21 de março de 1935, dias após o relator ter ser manifestado nos autos para a sessão de julgamento, o sindicato se manifestava em busca de informações sobre o andamento processual. Alegando que obtivera informações do processo apenas pelo representante do governo junto às Caixas de Aposentadoria e Pensão em Porto Alegre, este teria dito que "a Cia. Estrada de Ferro e Minas de São Jerônimo, por seus advogados, havia feito juntar aqueles autos, uma defesa, que, na opinião de sua Senhoria, era um trabalho brilhante". Diante da ausência de informação e retardo nas comunicações e intimações, o sindicato representante dos reclamantes estabeleceu

\footnotetext{
${ }^{37}$ Atuando como técnico no conselho, tomou posse em 21 de setembro de 1934 (Fonte: registro Fundo CNTTST, Brasília/DF).

${ }^{38}$ Representante dos empregadores. Nos assentos, não há registro neste período de 1935. No entanto, foi possível identificar outros dois registros de posse em 22 de agosto de 1939 e em 30 de agosto de 1943 (Fonte: registro Fundo CNT-TST, Brasília/DF).

${ }^{39}$ Tomou posse em 21 d setembro de 1934 e atuou como representante dos empregados. Foi exonerado em 16 de agosto de 1939 (Fonte: registro Fundo CNT-TST, Brasília/DF).

${ }^{40}$ Atuou como representante dos empregados. Tomou posse em 21 de setembro de 1934, com exoneração em 16 de agosto de 1939 (Fonte: registro Fundo CNT-TST, Brasília/DF).

${ }^{41}$ Representante dos empregados, tomou posse no CNT em 21 de setembro de 1934. Foi exonerado em 22 de dezembro de 1938 (Fonte: registro Fundo CNT-TST, Brasília/DF).

42 Tomou posse no CNT em 21 de novembro de 1929 e permaneceu até 1939. No assento de registro dos conselheiros, disponível no fundo CNT, há informação que este conselheiro foi indicado pelo presidente da República como representante dos empregadores (Fonte: registro Fundo CNT-TST, Brasília/DF).

${ }^{43}$ Os acórdãos eram redigidos por funcionários auxiliares da secretaria do CNT. À fl. 52, há informação de que este acórdão foi redigido por Bergamine de Abreu, em 14 de maio de 1935.

${ }^{44}$ A empresa cumpriu a determinação do CNT, reintegrando Domingos. À fl. 51, verso, há a indicação de que a empresa reintegrou também Thomaz, porém, sem indenizar qualquer um dos dois pelo tempo que ficaram impedidos de trabalhar. A notícia de pagamento de indenização a Domingos, referente aos salários não pagos durante o tempo do afastamento, ocorreu à fl. 105, de 2 de outubro de 1937, após exaustivas denúncias de não cumprimento total do acórdão.
} 
um histórico sobre o processo, informando que o pedido de reintegração não foi apresentado logo após o término da justificação judicial (22 de junho de 1934) porque aguardavam o retorno de Evandro Lobão, representante da inspetoria do CNT no Rio Grande do Sul, que se encontrava na cidade gaúcha de Rio Grande por mais de dois meses. Reiterando a ausência dos procedimentos previstos pela instrução do CNT sobre a instauração de inquérito administrativo para apurar falta grave, necessária para o deslinde do caso, pugnou pelo "restabelecimento do império da lei, e com ela os direitos dos operários prejudicados". Por fim, afirmou que os reclamantes Domingos Mantilha e Thomaz Gonçalves da Silva foram readmitidos, mas não indenizados pelo tempo em que foram impedidos de trabalhar. ${ }^{45}$

Em agosto do mesmo ano, a companhia apresentou ao CNT os certificados de tempo de serviço dos operários. ${ }^{46}$ Segundo os documentos apresentados, Liberalino Machado de Lima trabalhou na companhia de julho de 1931 a 6 de março de 1934 (dois anos e oito meses); Adalberto Azambuja dos Santos, de $1^{\circ}$ de janeiro de 1927 a 6 de março de 1934 (sete anos e dois meses); Thomaz Gonçalves da Silva, de $1^{\text {o }}$ de dezembro de 1912 "até a presente

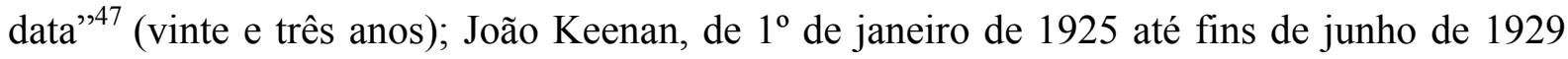
(quatro anos e cinco meses), - acrescentando que, devido a um incêndio ocorrido no almoxarifado da companhia em meados de 1927, não seria possível precisar dados de período anterior ao incidente; Antônio Nunes das Pedras, de $1^{\circ}$ de janeiro de 1928 a 6 de março de 1934 (seis anos e dois meses); Raphael Mezza, de $1^{\text {o }}$ de setembro de 1919 a 6 de março de 1934 (catorze anos e seis meses); e Domingos Mantilha, de 5 de outubro de 1918 a agosto de 1931, e de setembro de 1933 "até a presente data" (superior a catorze anos). Acompanhando as certidões, foi juntada uma declaração do delegado de polícia de São Jerônimo, José Maria de Carvalho, de 20 de julho de 1935, na qual se informa a Georges Gougenhein, diretor da Estrada de Ferro e Minas, que Adalberto, Raphael e Liberalino, quando em serviço na mina, foram acusados de envolvimento em fatos subversivos da ordem, "como diz a ata da sessão do Sindicato dos Mineiros daquela mina, ${ }^{48}$ de 15 de fevereiro de 1934 ” e que, por tal motivo,

\footnotetext{
${ }^{45}$ Após essa manifestação, o diretor geral da secretaria do CNT, em 12 de agosto de 1935, encaminhou ofício para o sindicato informando o andamento dos autos.

${ }^{46}$ Fls. 56-63 do processo no 9.582/1934. As certidões eram de 13 de julho de 1935.

${ }^{47}$ Até aquele momento, o pedido de Thomaz não fora apreciado pelo conselho. Porém, há indicação de que a reintegração deste empregado possa ter ocorrido sob outras razões não disponíveis nos autos. Em documentos existentes no arquivo do Museu Estadual do Carvão, há a indicação de que a partir de setembro de 1937, a presidência do sindicato dos mineiros fora assumida por Thomaz Gonçalves da Silva.

${ }^{48}$ Os registros iniciais da ação sindical, a exemplo das atas de reuniões, não foram encontrados. No que se refere às razões para a ausência desses documentos, segundo informações fornecidas por Oniro da Silva Camilo, atual presidente do Sindicato Intermunicipal dos Trabalhadores na Indústria de Extração de Carvão, Ouro, Calcário, Cal e Barro da Região Central do Rio Grande do Sul (entrevista realizada em 23 de março de 2015, em
} 
compareceram perante as autoridades judiciárias estaduais se comprometendo a abandonar a mina.

Após trocas de ofícios entre o CNT e o sindicato, somente em 16 de abril de 1936 houve nova manifestação nos autos, quando o sindicato ${ }^{49}$ reagiu às informações da companhia sobre as certificações de tempo de serviços, passando a questioná-las, inclusive, com a apresentação de outras declarações de tempo de serviço emitidas pela própria companhia. ${ }^{50}$ Assim, argumentou que o incêndio no almoxarifado da empresa não isenta a responsabilidade de atestar o tempo de serviço de João e Liberalino (também conhecido, segundo o sindicato, como Januário).

Em defesa do empregado Liberalino Machado de Lima ou Januário, o sindicato juntou duas declarações ${ }^{51}$ emitidas pela CEFMSJ, as quais registram que Januário atuou entre $1^{\circ}$ de janeiro de 1925 a junho de 1931 , e Liberalino, de $1^{\circ}$ de julho de 1931 a 6 de março de $1934 .{ }^{52}$ Invocando o incêndio de 1927 no almoxarifado, a companhia declarou que Januário trabalhou em época anterior, mas que não seria possível precisar devido à destruição dos arquivos. Para o sindicato, essa seria a prova necessária para comprovar a violação da estabilidade. Acompanhando o argumento, também foi acostada aos autos outra declaração, emitida por Carlos Theodoro e Alberto Avila, informando que conheciam pessoalmente Januário como trabalhador da companhia entre 1914 e 29 de junho de 1931, tendo este retornado, com o nome de Liberalino, em julho de 1933 e trabalhado até 2 de março de 1934. Atestado de conduta em favor de Liberalino também foi expedido pela Subdelegacia de Polícia do $5^{\circ}$

\footnotetext{
Butiá/RS), foram as sucessivas transferências de sede do sindicato entre as cidades exploradoras de carvão e outros minérios. Com o golpe de Estado em 1964 e a constante perseguição de sindicalistas, busca e apreensão de documentos nos sindicatos, grande parte do acervo documental, segundo o entrevistado, foi incinerada ou descartada no Rio Jacuí.

${ }^{49}$ Nessa petição, o sindicato informa o nome de sua nova agremiação, passando-se a chamar Sindicato dos Mineiros e Classes Anexas do Município de São Jerônimo. Esta alteração possui correlação com a criação do Sindicato dos Mineiros de Butiá, vinculados a Companhia Carbonífera Rio-Grandense, no distrito de Butiá. O sindicato foi criado em 1933, mas por várias razões, sua homologação foi postergada pelo MTIC. Com a ausência de reconhecimento em suas ações, principalmente com as greves de outubro e dezembro de 1934, o sindicato das minas de Arroio dos Ratos incorporou os sindicalizados de Butiá, fundando a nova agremiação, cujo reconhecimento pelo MTIC ocorreu em julho de 1936. Uma nova procuração judicial fora apresentada nos autos, informando que Castor Bispo era o presidente, Junqueira Saraiva, secretário e Affonso Seifert, tesoureiro do sindicato. João Genez Porto foi constituído como advogado da agremiação sindical. Essa história será resgatada nos próximos tópicos.

${ }^{50} \mathrm{O}$ sindicato apresentou uma justificativa judicial em busca da comprovação de que Liberalino e Januário eram a mesma pessoa, com vinculação de tempo de serviço superior a dez anos. No entanto, a justificação foi desentranhada do processo, sem cópia nos autos.

${ }^{51}$ Fls. 83 e 84 do processo $n^{\circ}$ 9.582/1934. As declarações foram emitidas em 2 de abril de 1936.

${ }^{52}$ Possivelmente, outra justificativa judicial de Liberalino ou Januário foi desentranhada dos autos devido à ausência das fls. 79-83 do processo $\mathrm{n}^{\circ}$ 9.582/1934. A procuradoria do CNT, à fl. 94, faz referência a esta justificação judicial quando a considera inaceitável por ter sido realizada sem a intimação e assistência da companhia.
} 
Distrito em Arroio dos Ratos, ${ }^{53}$ pela Subdelegacia de Polícia do $3^{\circ}$ Distrito em São Jerônimo ${ }^{54}$ e pela Prefeitura Municipal de São Jerônimo, ${ }^{55}$ sem que constassem registros criminais ou “outros inconvenientes”. Já em defesa do empregado João Keenan, foi juntada uma declaração assinada por três mineiros atestando que Keenan era empregado da companhia há mais de 40 anos.

Reconhecendo que Domingos Mantilha foi reintegrado pela companhia, o sindicato também reclamou que "até a presente data", o reclamante não fora indenizado pelo tempo em que ficou demitido injustamente, pugnando pelo pagamento.

O sindicato também se manifestou sobre documento fornecido pelo delegado de polícia, apontando que o comparecimento dos operários junto à delegacia não foi espontâneo, pois foram forçados diante das acusações que haviam surgido. Acrescentou, ainda, a própria informação da empresa, segundo a qual os operários foram expulsos das minas em razão de uma acusação que se verificou infundada.

A ação da polícia, bem como sua vinculação aos administradores da Estrada de Ferro e Minas, passou a ser questionada apenas a partir desse momento pelo sindicato. Às fls. 73 e seguintes dos autos, há uma acusação formal de que o delegado José Maria de Carvalho "era autoridade truculenta, perseguidor sistemático de operários a soldo das companhias de mineração".

Acompanhando a petição, havia um ofício ${ }^{56}$ emitido pelo sindicato e endereçado ao inspetor regional do MTIC, Ernani de Oliveira, no qual se questionava se: $i$ ) a inspetoria tinha conhecimento da despedida dos operários Adalberto, Raphael, Liberalino e outros; ii) houve comprometimento espontâneo dos mineiros com as autoridades policiais de abandonarem as minas ou se foram obrigados pela autoridade policial a firmar esse compromisso em virtude de uma denúncia em que se achavam envolvidos por tentativa de subversão da ordem; iii) a delegacia de polícia da capital do estado, encarregada de apurar o inquérito sobre as prisões dos operários, apurou serem infundadas as acusações contra os envolvidos; iv) na qualidade de

\footnotetext{
${ }^{53}$ A certidão era um atestado de conduta, assinado em 7 de março de 1934 pelo então subdelegado, o capitão Luiz F. Pereira. Fl. 88 do processo ${ }^{\circ}$ 9.582/1934.

${ }^{54}$ Em 30 de março de 1935, o atestado de conduta informando que não havia nada contra Liberalino Machado de Lima foi emitido pelo subdelegado Candido do Amaral Batalha, nas Minas do Butiá. F1. 89 do processo.

${ }^{55}$ Essa correspondência, em forma de atestado/pedido, foi emitida pelo prefeito de São Jerônimo, José Maria de Carvalho, em 10 de março de 1934. Dirigida ao vice-prefeito e ao subdelegado do $3^{\circ}$ Distrito, Candido Batalha, informava que Liberalino Machado de Lima (conhecido como pequeno Machado), era ex-mineiro em Arroio dos Ratos e pretendia uma ocupação nas minas do Butiá. Acrescentou que nada havia de inconveniente, "o amigo poderia encaminhá-lo como lhe parecer". Fl. 90 e verso do processo.

${ }^{56}$ F1. 86, processo $n^{\circ} 9.852 / 1934$.
} 
inspetor, tinha conhecimento de que o delegado, em São Jerônimo, era considerado pelos operários das minas de Arroio dos Ratos e de Butiá como uma autoridade atrabiliária e algoz dos trabalhadores, para satisfazer a diretoria da companhia de mineração, tendo mesmo chegado ao ponto de se apossar ilegalmente de móveis, utensílios e arquivos do sindicato dos mineiros de Butiá para atender a um pedido do diretor-presidente das minas.

Em resposta ao ofício, o inspetor informou que tinha conhecimento das demissões e acreditava não ter havido declaração espontânea dos operários, pois as considerava como demissões injustas. Após a devida investigação, reconhecendo que as acusações eram infundadas, relatou que era de seu conhecimento a indisposição dos operários contra o delegado, registradas, inclusive, nos arquivos da $17^{\text {a }}$ Inspetoria Regional do MTIC. Acrescentou que tinha conhecimento da intervenção do delegado de polícia, José Maria de Carvalho, no fechamento da sede do sindicato dos mineiros de Butiá, ${ }^{57}$ por solicitação de Roberto Cardoso, diretor da Companhia Carbonífera Rio-Grandense (CCR), com apropriação dos móveis e arquivo.

Em 19 de maio de 1936, a procuradoria lançou aos autos um parecer ${ }^{58}$ conclusivo para o $^{2}$ deslinde do feito. Considerando as conclusões da empresa como ilógicas, o parecer apontou que a simples prisão pela polícia, mesmo sob efeito de processo de investigação instaurado perante a autoridade policial, não era suficiente para confirmação de falta grave, uma vez que esta deveria ser provada em inquérito administrativo, nos termos do art. 53 do Decreto $\mathrm{n}^{\mathrm{o}} 20.465$, de $1^{\mathrm{o}}$ de outubro de 1931, cumulado com o Decreto n 22.096, de 16 de novembro de 1932.

Ao acrescentar que "o sofisma não colhe, nem convence", a procuradoria apontou a ausência de um critério de julgamento por parte da companhia: "se se tratasse de um processo criminal regular, ainda se poderia firmar um critério de julgamento, mas nunca num ato policial, tomado como medida imediata e urgente de manutenção da ordem pública, e de cuja consequência resultou justamente provada nenhuma culpa dos acusados".

Recusando a justificativa de despedida por se ater a ato policial que efetuou prisão para averiguação, a procuradoria pugnou pela: $i$ ) notificação da empresa para pagamento da indenização devida a Domingos Mantilha; ii) reintegração e indenização de Thomaz Gonçalves da Silva e Raphael Mezza, por preencherem os requisitos da estabilidade, reconhecidas pela empresa, sem apuração da falta grave mediante inquérito administrativo; iii) rejeição dos pedidos de reintegração de Adalberto Azambuja dos Santos, João Keenan e

\footnotetext{
${ }^{57}$ Sobre o sindicato dos mineiros de Butiá, ver Witkowski e Freitas (2006).

${ }^{58}$ Fl. 92, verso, processo no ${ }^{\circ}$ 9.852/1934.
} 
Antônio Nunes das Pedras, por não possuírem ou comprovarem mais de dez anos na relação de emprego; iv) rejeição do pedido de Liberalino Machado de Lima ou Januário por ausência de prova de que se tratavam da mesma pessoa, "mas sim que usou nomes diferentes em ocasiões diversas"; contudo, mesmo que fossem a mesma pessoa, os atestados apresentados não preenchiam o requisito decenal.

Encaminhado para julgamento, o caso foi sorteado para novo relator, o jurista Luiz Augusto do Rego Monteiro, ${ }^{59}$ e em 2 de junho de 1936, o CNT lançou decisão sobre a reclamação trabalhista. $\mathrm{O}$ acórdão ${ }^{60}$ produzido pelos membros da $3^{\mathrm{a}}$ Câmara ${ }^{61}$ relatou as duas decisões anteriores do conselho e sustentou que "à vista dos elementos constantes dos autos, fica[va] evidenciado que os empregados reclamantes, por terem tramado uma greve geral entre os mineiros, foram expulsos do serviço da mina pela polícia, que os prendeu para averiguação e processo criminal posterior". Ao considerar improcedente a argumentação da CEFMSJ de que não lhe cabia promover inquérito administrativo devido à prisão efetuada pela polícia, e por se tratar de prisão que não resultou em condenação criminal, o CNT entendeu que era dever da empresa proceder à abertura de inquérito para apurar falta grave eventualmente cometida por empregados estáveis. Nesses termos, o conselho determinou: $i$ ) o pagamento das indenizações a que teria direito Domingos Mantilha; ii) a reintegração de Thomaz e Raphael, com pagamento de indenizações salariais pelo tempo que ficaram privados do trabalho; iii) a rejeição do pedido de Adalberto e Antônio, devido à ausência de provas do tempo de serviço superior a dez anos, necessários para configurar estabilidade profissional; iv) rejeição do pedido de Liberalino ou Januário, por serem imprecisas os documentos juntados aos autos para provar que se tratava da mesma pessoa, e mesmo se fosse acolhida, por não cumprir os dez anos de trabalho necessários para a estabilidade decenal; e v) em relação a João Keenan, a conversão do julgamento em diligência, na qual se exigia da empresa informações sobre a comprovação do tempo de serviço do empregado.

$\mathrm{O}$ ofício $^{62}$ comunicando a decisão do CNT à CEFMSJ foi emitido em 6 de agosto de 1936. Sem resposta, segundo informação da secretaria do conselho, o ofício foi reenviado

\footnotetext{
${ }^{59}$ Foi professor na Faculdade de Direito da Pontifícia Universidade Católica do Rio de Janeiro (PUC-RJ), delegado de polícia no Distrito Federal, diretor do Departamento Nacional do Trabalho e procurador do trabalho. Teve atuação destacada nos trabalhos que resultaram na Consolidação das Leis do Trabalho. Tomou assento como conselheiro do CNT a partir de 1934 (Fonte: jornal Correio da Manhã, Rio de Janeiro, de 13 de janeiro de 1967, ao noticiar seu falecimento; Fundo CNT-TST, Brasília/DF).

${ }^{60}$ Fls. 96-99, processo $\mathrm{n}^{\circ} 9.582 / 1934$.

${ }^{61}$ Não há no fundo CNT registro das notas taquigráficas desta sessão, impossibilitando, novamente, acesso aos debates dos conselheiros no julgamento.

${ }^{62}$ Fls. 101-102, processo $\mathrm{n}^{\mathrm{o}} 9.582 / 1934$.
} 
pouco mais de um ano após o primeiro, em 16 de setembro de 1937. A Companhia Estrada de Ferro e Minas de São Jerônimo, nessa época, já pertencia ao grupo Consórcio Administrador de Empresas de Mineração (Cadem). Em 2 de outubro de 1937, o Cadem informou o cumprimento do acórdão de 2 de junho de 1936, tendo indenizado Domingos, assim como reintegrado Thomaz e Raphael, que receberam suas respectivas indenizações. Contudo, o consórcio reiterou ser impossível informar o tempo de serviço de João Keenan devido ao incêndio, ocorrido no almoxarifado em 1927 e não apurado em inquérito policial por se tratar de incêndio casual.

Nos autos, foi possível verificar uma constante troca de ofícios entre a secretaria do conselho e Vicente de Oliveira Moliterno, o novo inspetor representante do CNT em Porto Alegre/RS. A alternativa encontrada foi a solicitação de ação de justificação judicial a ser promovida pelo próprio reclamante, João Keenan. Entre os ofícios, ${ }^{63}$ o sindicato dos mineiros, então sob a presidência de Thomaz Gonçalves da Silva, ex-reclamante, informou, mediante telegrama de 7 de junho de 1938, que a justificação judicial foi entregue pessoalmente na repartição "há muito [...] visto haver sido extraviado aí [no conselho]".

Em 25 de junho de 1938, a secretaria lançou informação ${ }^{64}$ de que a justificação de João Keenan foi encontrada e juntada aos autos. ${ }^{65}$ Nessa justificação foram colhidos dois depoimentos. O primeiro foi do inglês João Thomaz Beardworth, viúvo, mineiro, com 72 anos de idade, o qual informou que Keenan trabalhou nas minas de 1888 a julho de 1929, como manobreiro no subsolo do poço 2. Vítima de um acidente de trabalho, gozou de licença médica justificada até 1933, quando, ao se apresentar à chefia da mina para recomeçar a trabalhar, a admissão no serviço lhe foi negada. Também depôs Felipe Teixeira da Silva, casado, mineiro, com 68 anos de idade, o qual informou que Keenan iniciou seu trabalho na mina em 1888, até 1929, quando se envolveu em um acidente de trabalho. Após receber alta do acidente que sofreu, a empresa recusou-se a readmitir Keenan. Acrescentou que o justificante exercia a função de manobreiro de subsolo da mina e recebia 9 mil réis por dia.

\footnotetext{
${ }^{63}$ Fls. 109-113 do processo $n^{\text {o } 9.582 / 1934 . ~}$

${ }^{64}$ Fls. 114 do processo $n^{\circ} 9.582 / 1934$.

${ }^{65}$ Nos autos, há ausência das fls. 118-127, possivelmente, a justificação judicial de Liberalino ou Januário Machado de Lima, conforme relato de informação da secretaria do conselho à fl. 137. A justificação judicial de João Keenan, extraviada em um primeiro momento e encontrada posteriormente pela secretaria do conselho, foi juntada nos autos a partir das fls. 128-136. Produzida em 28 de setembro de 1936, na Justiça Estadual de São Jerônimo, na justificação foram ouvidas as testemunhas João Thomaz Beardworth (inglês) e Felippe Teixeira da Silva (fls. 135 e 136, respectivamente). Outra ausência foi registrada a partir das fls. 138 a 143, referente a outra justificação judicial de Liberalino ou Januário Machado de Lima.
} 
Na sequência, o sindicato apresentou duas justificações judiciais de tempo de serviço de João Keenan e Liberalino Machado de Lima. ${ }^{66}$ Consta dos autos apenas a justificativa de Keenan, ${ }^{67}$ em que foram ouvidos como testemunhas Max Seifert, alemão, maquinista, com 68 anos de idade e, novamente, o inglês João Thomaz Beardworth. Ambos informaram conhecer João Keenan e que este trabalhava nas minas de carvão de 1888 até 1929, quando sofreu um acidente de trabalho. Recuperado em 1933, retornou à empresa, quando lhe foi negado o emprego.

Em 16 de agosto de 1938, a procuradoria jurídica do CNT emitiu um parecer em que rejeitava as justificativas apresentadas por Liberalino ou Januário Machado de Lima tendo em vista o registro de improcedência de sua reclamação já transitada em julgado desde 2 de junho de 1936. Em relação a João Keenan, o parecer foi positivo e pugnava por sua reintegração, em virtude da comprovação de estabilidade decenal, já contando com 40 anos de trabalho na mina.

Com o impedimento do relator Rego Monteiro, eleito vice-presidente do CNT, Arthur Hortêncio Bastos foi designado como novo relator. ${ }^{68} \mathrm{~A} 3^{\mathrm{a}}$ Câmara do CNT, durante sessão realizada em 6 de setembro de $1938,{ }^{69}$ acolheu o pedido de João Keenan e determinou sua reintegração. A discussão dos membros do CNT nesse julgamento pode ser recuperada nas notas taquigráficas do arquivo. Tomaram assento na sessão Américo Ludolf, Arnaldo Sussekind (ajudante técnico da procuradoria), Arthur Hortêncio Bastos (relator do processo), Luiz de Paula Lopes, Oscar Saraiva e Humberto Smith de Vasconcellos. ${ }^{70}$ As justificações de Liberalino ou Januário foram rejeitadas, pois já havia decisão de mérito negando seu pedido.

Informado sobre a decisão, em 29 de dezembro de 1938, o Cadem comunicou o falecimento de João Keenan, ocorrido em 14 de janeiro de 1938. Com a notícia da morte, em julho de 1939, a procuradoria do CNT buscou informações sobre eventuais herdeiros do reclamante $^{71}$ junto à Caixa de Aposentadoria e Pensões dos mineiros, registros da antiga CEFMSJ (Cadem) e em publicações de editais no Diário Oficial e jornal Correio do Povo. Sem habilitação de herdeiros, a procuradoria propôs o arquivamento do processo em 14 de dezembro de 1939.

\footnotetext{
${ }^{66}$ Essas justificações foram juntadas aos autos em 28 de junho de 1938 . Ver. fls. 115 e ss. do processo $\mathrm{n}^{\mathrm{o}}$ 9.582/1934.

${ }^{67}$ Fls. 144-150 do processo $\mathrm{n}^{\circ}$ 9.582/1934.

${ }^{68}$ Bastos tomou assento como conselheiro no CNT, na condição de representante dos empregadores, em 30 de maio de 1935, com exoneração em 16 de agosto 1939 (Fonte: Fundo CNT-TST, Brasília/DF).

${ }^{69}$ Fls. $154-155$ do processo ${ }^{\circ} 9.582 / 1934$.

${ }^{70}$ Tomou posse no CNT em 23 de abril de 1936, exonerando-se em 16 de agosto de 1939.

${ }^{71}$ Fls. 160 , verso; 161; 165; 166; 168; 174 e 175, verso.
} 
O processo foi desarquivado em outras duas ocasiões, quando Liberalino Machado de Lima, por intermédio do sindicato, solicitou o levantamento de suas justificativas judiciais. Desde 1941, ficou depositado nos arquivos do CNT.

Neste capítulo, os principais atos processuais da reclamação trabalhista foram apresentados por meio de uma narrativa que possibilitou identificar a trajetória judicial de sete empregados demitidos das minas de carvão de Arroio dos Ratos. No próximo capítulo, será possível destacar como essas trajetórias se inserem dentro de um panorama contextual complexo, inovador e imprevisível, marcado pelo processo de constitucionalização dos direitos sociais. 


\section{NOS LIMITES DO CONFLITO: os mineiros, o sindicato e a companhia de mineração} em Arroio dos Ratos

À margem da reclamação trabalhista n 9.582/1934, apresentada no Conselho Nacional do Trabalho, a vida de sete trabalhadores das minas de carvão de Arroio dos Ratos se cruzaram. Ao que tudo indica, as razões que os uniram na reclamação não foram decorrentes do mesmo fato. Compreendê-las, então, passa a ser uma tarefa complexa, por um lado, pela forma como o sindicato, no exercício da representação dos mineiros, promoveu a reclamação trabalhista. As estratégias utilizadas pelos advogados Alcides de Oliveira Carracho ${ }^{1}$ e, posteriormente, João Genez Porto ${ }^{2}$ evitaram um maior enfrentamento em relação às razões levantadas pela empresa. Ao usar as "regras do jogo", o sindicato discutia o não cumprimento da legislação social recémimplantada, em especial no que se refere à violação da regra de se instaurar inquérito administrativo para apurar falta grave de empregados estáveis, com tempo superior a dez anos na profissão. Por outro lado, tem-se a tentativa da companhia de legitimar uma conduta que, em período anterior, era comum no espaço privado das relações trabalhistas, mas que, desde então, passava por uma profunda inflexão na dinâmica que envolvia a regulamentação dos direitos do trabalho, legitimada de modo ascendente pela política varguista.

Avançando-se no enredo dessa reclamação trabalhista, foi possível identificar três grupos especiais. O primeiro representa trabalhadores que, segundo a empresa, foram expulsos das minas de carvão pela autoridade policial local, acusados de tramarem e insuflarem uma greve geral entre os demais trabalhadores. Considerados indesejáveis, Liberalino Machado de Lima (ou Januário), Raphael Mezza, Antônio Nunes das Pedras e Adalberto Azambuja dos Santos foram demitidos por abandono de emprego. O segundo grupo envolve um único trabalhador, Domingos Mantilha, que, tendo sido transferido do lugar que ocupava por conveniência de serviço, deixou de se apresentar ao novo posto de trabalho. Por fim, o terceiro grupo corresponde à situação de João Keenan e Thomaz Gonçalves da Silva, que, segundo a empresa, deixaram de comparecer ao serviço da companhia por sua livre e espontânea vontade, "sendo o primeiro em março de 1929 e o último, em dezembro de 1933, sem nos darem nenhuma satisfação”.

\footnotetext{
${ }^{1}$ Em consulta aos registros pessoais de Carracho junto à seccional da Ordem dos Advogados do Brasil do Rio Grande do Sul, foi possível encontrar informações sobre seu pedido de inscrição nos quadros da advocacia gaúcha em 19 de junho de 1932. Carracho nasceu em Bagé, em 31 de março de 1893. Era fillho de Francisco Ferreira Carracho e Lidália de Oliveira Carracho e bacharelou-se em direito pela Faculdade de Direito de Pelotas, em 1920. Foi casado com Maria Conceição Gomes Genro até 17 de dezembro de 1923, quando se desquitou judicialmente em Pelotas. Inscrito na ordem, recebeu o número de registro 233, em 31 de julho de 1932. Após exercer a profissão de advocacia por 49 anos, solicitou baixa na inscrição em 16 de setembro de 1966, após sua aposentadoria.

${ }^{2}$ Nos registros da OAB-RS não foi encontrado nenhum dado sobre o advogado.
} 
No decurso do processo, os reclamantes Domingos, Thomaz e Raphael foram reintegrados pela companhia. João Keenan teve a reintegração determinada pelo CNT nove meses após seu falecimento. ${ }^{3}$ Liberalino (ou Januário), Antônio e Adalberto não foram reintegrados: o primeiro, porque o CNT não reconheceu se tratar da mesma pessoa; e os últimos, por não terem sido considerados empregados estáveis.

A complexidade da situação em que cada um desses grupos de empregados arrolados no processo estava inserido proporciona um grande lastro de possibilidades históricas, as quais podem auxiliar na contextualização do período e nas próprias razões das demissões. Neste capítulo, o objetivo central é diminuir a escala de observação sobre os personagens mineiros, o sindicato e a companhia. O levantamento de algumas informações tornou-se fundamental para seguir os rastros deixados no processo $n^{\circ}$ 9.582/1934. Por um lado, a partir da leitura do processo, foi possível identificar um fio que conduziu a reclamação dos mineiros até as decisões finais de mérito - representadas pela busca de reintegração de alguns mineiros ou a confirmação da despedida. Por outro, não se pode negar a existência de alguns silêncios (da constituição, da política e do direito) que foram igualmente reproduzidos pela trama processual. Tal como a metáfora de Carlo Ginzburg (2007, p. 7), segundo o qual é preciso desvendar "o fio do relato, que ajuda a nos orientar no labirinto da realidade", a partir dos rastros deixados pelo processo, parte dos silêncios construídos pelos atores é evidenciada. Nesse sentido, a expectativa é que, com o resgate da história do sindicato e da companhia, seja possível avaliar o impacto que a reclamação trabalhista produziu na configuração entre direito e política sob a luz da história do direito constitucional - o que será feito no próximo capítulo.

Desde 1924, Arroio dos Ratos destacou-se no cenário de produção de energia elétrica. Ao lado do poço $\mathrm{n}^{\circ} 1^{4}$ de exploração de carvão, a CEFMSJ construiu uma das primeiras usinas termelétricas na região carbonífera do Rio Grande do Sul, impulsionada com a queima do pó do carvão extraído das minas.

Localizada em área de planície, Arroio dos Ratos, em 1934, era um distrito de São Jerônimo. A CEFMSJ era proprietária das maiores minas de carvão e, assim, ditava as regras de ocupação urbana, as econômicas e as do trabalho na vila. No centro do vilarejo, concentravam-se as residências dos mineiros, constituídas por casas individuais, repúblicas e habitações coletivas. Os armazéns, de propriedade da companhia, ditavam os valores dos

\footnotetext{
${ }^{3}$ A decisão no CNT ocorreu em 6 de setembro de 1938, já o ofício da companhia, emitido em 29 de dezembro de 1938, informou que o óbito ocorreu em 14 de janeiro de 1938 (fls. 155 e 159/160, respectivamente, do processo $\left.n^{\circ} 9.582 / 1934\right)$.

${ }^{4}$ Segundo Santos (1966, p. 48), o poço nº 1 possuía 66 metros de profundidade.
} 
produtos necessários para a exploração do carvão, como dinamites, picaretas, pavio, querosene, entre outros e os gêneros de alimentação e higiene. Pouco mais de trezentos metros abaixo, localizava-se um dos escritórios da companhia, que se estabelecia na vila com cinco prédios: usina termelétrica, almoxarifado, oficina, escritório e laboratório de análise química. Dia e noite, a chaminé da usina expelia a fumaça negra, que, em conjunto com o "ar preto" ou "ar ruim" decorrente da movimentação do pó de carvão depositado próximo à usina após o uso na termelétrica, produzia um odor de enxofre, característico da região.

Figuras 1 e 2 - Habitações dos mineiros, vilas operárias
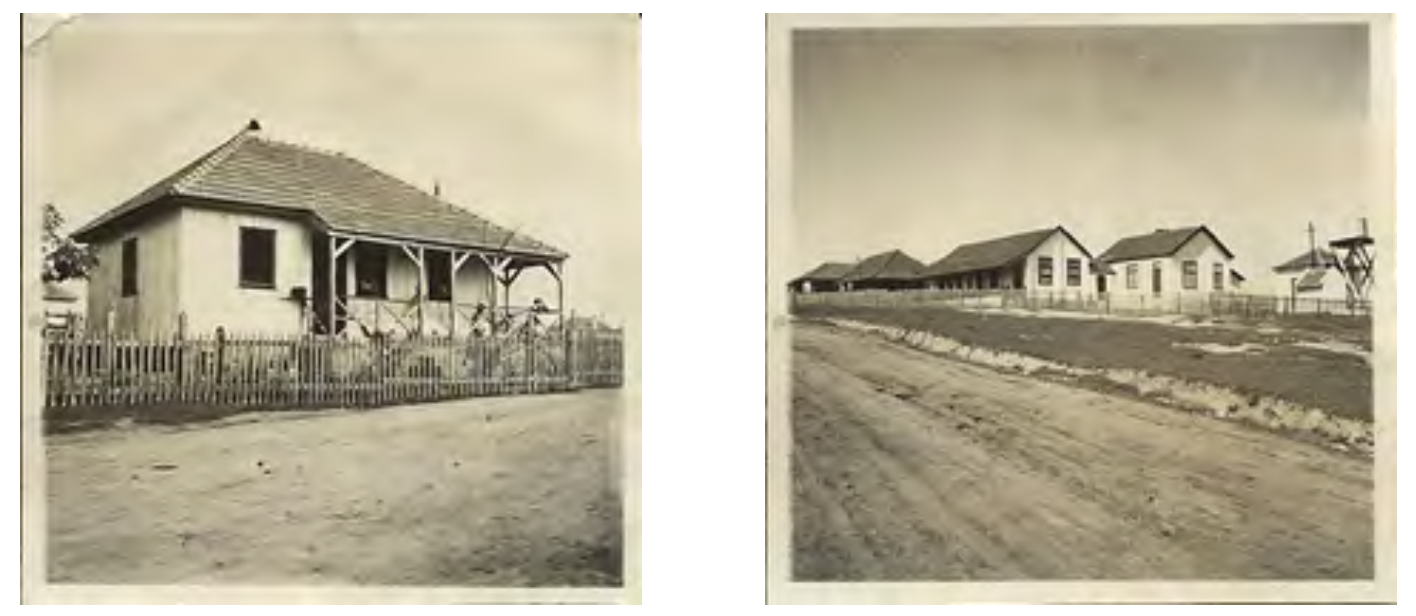

Fonte: Museu Estadual do Carvão.

Desativada no início da década de 1960, a estrutura da usina, o escritório da companhia e o laboratório de análise do carvão ficaram em ruínas. A partir de 1986, a recuperação desse espaço de memória se concretizou com a criação do Museu Estadual do Carvão (MCAR), ${ }^{6}$ que implementou a restauração dos prédios e a preservação de documentos, bem como passou a desenvolver ações contínuas em prol do resgate da memória de trabalhadores mineiros e da mineração como um todo naquela região.

Parte dessa história não poderia ser resgatada sem a intensificação de pesquisas sobre a região carbonífera do Rio Grande do Sul. Nos últimos anos, muitos trabalhos acadêmicos e a própria ação do MCAR têm se destacado ao refletirem sobre: i) o impacto das ações de mineração no desenvolvimento econômico e social da região; ii) a relação econômica

\footnotetext{
${ }^{5}$ Segundo Sulzbach $(1989$, p. 73 ), ar ruim ou ar preto era comum nas galerias subterrâneas onde faltava ventilação. "Ele era produzido pelo gás que se desprendia das camadas do próprio carvão, na ausência de oxigênio necessário. Sua inalação era mortal. Sua presença era assinalada pelo lampião do minerador. Ao se apagar sozinho, estava confirmada a existência do "ar ruim". E então, o recurso: retirar-se rapidamente".

${ }^{6} \mathrm{O}$ museu foi visitado por este pesquisador em março e setembro de 2015, oportunidade em que o acervo, parcialmente organizado, composto por documentos do grupo Cadem, ficou à disposição para análise.
} 
exercida pelas empresas e sua atuação com as políticas estatais; iii) o resgate da memória dos trabalhadores mineiros, com realce para as condições de trabalho, lutas por reconhecimento de direitos e proteção trabalhista; e, por fim, iv) as configurações sindicais estabelecidas por trabalhadores, com vistas a uma mediação entre capital versus trabalho.

Figura 3 - Ruínas da CEFMSJ. Hoje, abriga o acervo do MCAR

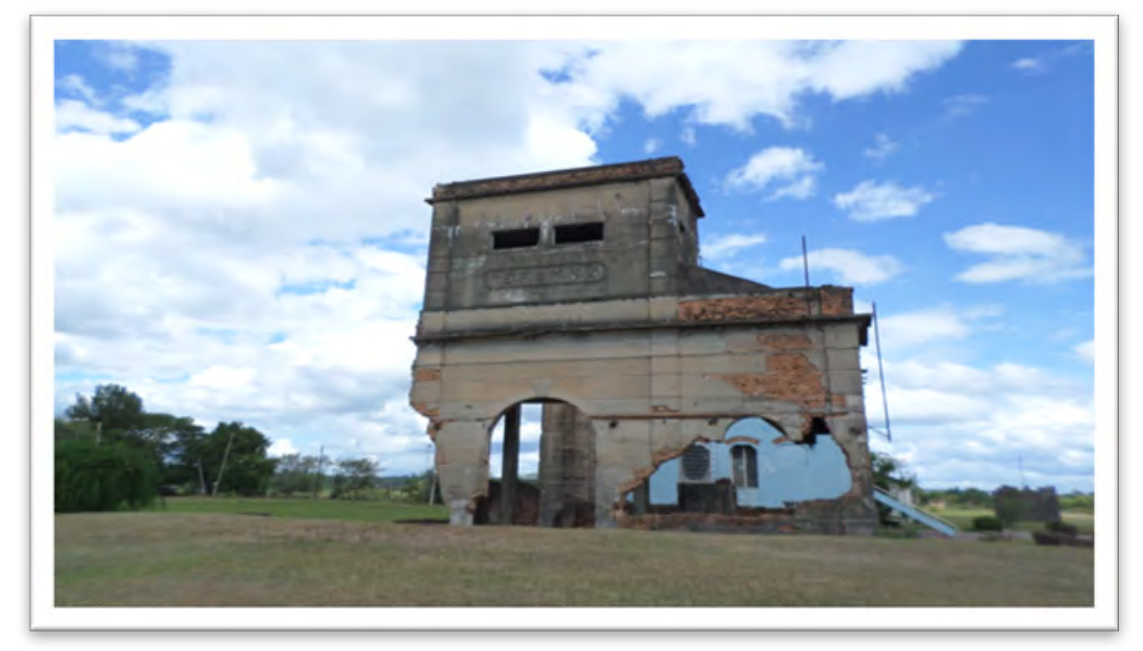

Fonte: Museu Estadual do Carvão.

$\mathrm{Na}$ prática, essas pesquisas auxiliam a compreensão contextual do período, principalmente, por registrarem dados e fontes nem sempre apropriados pela história do direito. Nesse sentido, destacam-se os trabalhos acadêmicos (teses, dissertações e monografias) elencados no quadro 1.

Quadro 1 - Teses e dissertações que tratam da região carbonífera do Rio Grande do Sul

\begin{tabular}{|c|c|c|c|c|c|c|}
\hline & Autor(a) & Título & Nível & Área & Inst. & Ano \\
\hline 1 & $\begin{array}{l}\text { Diorge Alceno } \\
\text { Konrad }\end{array}$ & $\begin{array}{l}\text { O fantasma do medo: o Rio Grande do } \\
\text { Sul, a repressão policial e os } \\
\text { movimentos sócio-politicos (1930- } \\
\text { 1937) }\end{array}$ & D & História & Unicamp & 2004 \\
\hline 2 & $\begin{array}{l}\text { Magda Barros } \\
\text { Biavaschi }\end{array}$ & $\begin{array}{l}\text { O direito do trabalho no Brasil- } \\
\text { 1930/1942: a construção do sujeito de } \\
\text { direitos trabalhistas }\end{array}$ & D & Economia & Unicamp & 2005 \\
\hline 3 & $\begin{array}{l}\text { Glaucia Vieira } \\
\text { Ramos Konrad }\end{array}$ & $\begin{array}{l}\text { Os trabalhadores e o Estado Novo no } \\
\text { Rio Grande do Sul: um retrato da } \\
\text { sociedade e do mundo do trabalho } \\
\text { (1937-1945) }\end{array}$ & $\mathrm{D}$ & História & Unicamp & 2006 \\
\hline
\end{tabular}




\begin{tabular}{|c|c|c|c|c|c|c|}
\hline & Autor(a) & Título & Nível & Área & Inst. & Ano \\
\hline 4 & $\begin{array}{l}\text { Samuel Fernando } \\
\text { de Souza }\end{array}$ & $\begin{array}{l}\text { Coagidos ou subordinados: } \\
\text { trabalhadores, sindicatos, Estado e as } \\
\text { leis do trabalho nos anos } 1930\end{array}$ & $\mathrm{D}$ & História & Unicamp & 2007 \\
\hline 5 & $\begin{array}{l}\text { Cristina Ennes da } \\
\text { Silva }\end{array}$ & $\begin{array}{l}\text { Nas profundezas da terra: um estudo } \\
\text { sobre a região carbonifera do Rio } \\
\text { Grande do Sul (1883/1945) }\end{array}$ & $\mathrm{D}$ & História & PUC-RS & 2007 \\
\hline 6 & $\begin{array}{l}\text { Clarice Gontarski } \\
\text { Speranza }\end{array}$ & $\begin{array}{l}\text { Cavando direitos, as leis trabalhistas e } \\
\text { os conflitos entre trabalhadores e } \\
\text { patrões nas minas do Rio Grande do } \\
\text { Sul nos anos } 40 \text { e } 50\end{array}$ & $\mathrm{D}$ & História & UFRGS & 2012 \\
\hline 7 & $\begin{array}{l}\text { Carmem Lúcia } \\
\text { Bezerra Machado }\end{array}$ & $\begin{array}{l}\text { O movimento operário sindical no Rio } \\
\text { Grande do Sul 1930-1937 }\end{array}$ & M & Sociologia & UFRGS & 1983 \\
\hline 8 & Cornélia Eckert & $\begin{array}{l}\text { Os homens da mina - Um estudo das } \\
\text { condições de vida e representações } \\
\text { dos mineiros de carvão em } \\
\text { Charqueadas- } R S\end{array}$ & M & Antropologia & UFRGS & 1985 \\
\hline 9 & Marta Cioccari & $\begin{array}{l}\text { Ecos do subterrâneo: estudo } \\
\text { antropológico do cotidiano e memória } \\
\text { da comunidade de minérios de carvão } \\
\text { de Minas do Leão (RS) }\end{array}$ & M & Antropologia & UFRGS & 2004 \\
\hline 10 & $\begin{array}{l}\text { Marluza Marques } \\
\text { Harres }\end{array}$ & $\begin{array}{l}\text { Ferroviários: disciplinarização e } \\
\text { trabalho }\end{array}$ & M & História & UFRGS & 1992 \\
\hline 11 & $\begin{array}{l}\text { Alvaro Augusto } \\
\text { de Borba Barreto }\end{array}$ & $\begin{array}{l}\text { O movimento operário rio-grandense e } \\
\text { a intervenção estatal: a FORGS e os } \\
\text { círculos operários }\end{array}$ & $\mathrm{M}$ & História & UFRGS & 1996 \\
\hline 12 & $\begin{array}{l}\text { Felipe Figueiró } \\
\text { Klovan }\end{array}$ & $\begin{array}{l}\text { Sob o fardo do ouro negro: as } \\
\text { experiências de exploração e } \\
\text { resistência dos mineiros de carvão do } \\
\text { Rio Grande do Sul na década de } 1930\end{array}$ & M & História & UFRGS & 2014 \\
\hline 13 & $\begin{array}{l}\text { Felipe Figueiró } \\
\text { Klovan }\end{array}$ & $\begin{array}{l}\text { Sob o fardo do ouro negro: as } \\
\text { experiências de exploração e } \\
\text { resistência dos mineiros de carvão do } \\
\text { Rio Grande do Sul na primeira metade } \\
\text { da década de } 1930^{7}\end{array}$ & G & História & UFRGS & 2009 \\
\hline 14 & $\begin{array}{l}\text { Márcia Elisa de } \\
\text { Oliveira }\end{array}$ & $\begin{array}{l}\text { Mineiros de São Jerônimo no final do } \\
\text { Estado Novo: na encruzilhada entre a } \\
\text { legislação trabalhista e as leis de } \\
\text { guerra (1943-1945) }\end{array}$ & G & História & UFRGS & 2009 \\
\hline
\end{tabular}

Elaboração do autor.

Obs.: $\mathrm{D}$ = doutorado; $\mathrm{M}$ = mestrado; e $\mathrm{G}=$ graduação.

Em complemento a esse grande acervo de trabalhos sobre a região carbonífera na década de 1930, entre março e setembro de 2015, este autor realizou visitas in loco no Rio

\footnotetext{
${ }^{7} \mathrm{O}$ autor produziu sua dissertação de mestrado (2014) como um desdobramento de seu trabalho de conclusão de curso (2009) daí a manutenção do mesmo título.
} 
Grande do Sul, em especial a Porto Alegre, São Jerônimo, Arroio dos Ratos e Butiá. O objetivo de ir a campo foi identificar e aperfeiçoar o levantamento das fontes que porventura ainda existissem em "espaços de memória" sobre a história da mineração, dos mineradores, do sindicato e da companhia. Em Porto Alegre, obteve-se acesso aos jornais da época, tais como Correio do Povo, Diário de Notícias e A Voz do Trabalhador. ${ }^{8}$ Consultas a fontes históricas sobre o período também foram empreendidas junto ao Arquivo Público do Rio Grande do Sul, ao Arquivo Histórico do Rio Grande do Sul, à Superintendência do Ministério do Trabalho e à Cúria Diocesana. ${ }^{9}$ Em Butiá, foi possível realizar uma entrevista com o presidente do sindicato dos mineiros, ${ }^{10}$ sr. Oniro Camilo, e uma pesquisa junto ao cartório de registro civil. ${ }^{11}$ Nas visitas a Arroio dos Ratos, foi possível ter acesso a informações relevantes por meio de visitas ao Museu Estadual do Carvão, à Delegacia de Polícia e ao cartório de registro de pessoas naturais e imóveis. ${ }^{12}$ Atualmente, o referido museu agrega um arquivo sobre a história das companhias de mineração da região. A organização das fontes e a catalogação em fundos estavam a cargo do projeto do Acervo Histórico do Museu Estadual do Carvão (Arquivistas Sem Fronteira/Surya Produções). No cartório de registro civil e imóveis, foi possível encontrar certidões de nascimento, casamento e óbito de alguns dos mineiros. Em visita a São Jerônimo, os historiadores Benedito Veit e Cláudio Rollo foram entrevistados. Na delegacia de polícia, localizada no prédio da prefeitura que pertenceu à Caixa de Aposentadoria e Pensões da CEFMSJ, conforme grafia exposta no edifício, o propósito era encontrar registros sobre a atuação do delegado de polícia José Maria de Carvalho. A troca de informações e interesses sobre a pesquisa em curso levou ao encontro de um material não

\footnotetext{
${ }^{8}$ Essas fontes estavam disponíveis para consulta no arquivo do jornal Correio do Povo e no Museu da Comunicação Hipólito José da Costa.

${ }^{9} \mathrm{O}$ objetivo era encontrar possíveis registros de batismo dos mineiros.

${ }^{10} \mathrm{O}$ sindicato dos mineiros é registrado como Sindicato Intermunicipal dos Trabalhadores de Carvão, Ouro, Calcário, Cal e Barro da Região Centro Sul do Rio Grande do Sul. A entrevista com o sr. Oniro ocorreu na sede do sindicato em Butiá/RS, em 24 de março de 2015. Segundo o entrevistado, não há registros sobre atas e demais documentos das ações sindicais desde sua inauguração, em $1^{\circ}$ de janeiro de 1933 . Entre as razões apontadas, encontram-se as inúmeras transferências da sede do sindicato, que percorriam a região carbonífera conforme o foco na exploração do carvão, e as constantes perseguições aos representantes sindicais na época das ditaduras: $i$ ) com Getúlio Vargas, em concomitância com a segunda Guerra mundial, quando a exploração do carvão passou a ser fundamental e ampliada devido à queda ou à impossibilidade de importação de carvão europeu - nesse período, muitos jovens que se alistaram no serviço militar foram convocados para trabalhar nas minas e as eventuais recusas eram encaradas como deserção, punidas com prisão ou trabalhos forçados (SANTOS, 1966); e ii) a partir de 1964, quando a região passou a ser considerada como área de interesse nacional e as organizações dos trabalhadores foram objeto de intensas intervenções. Na década de 1960, a sede do sindicato estava estabelecida na cidade de Charqueadas/RS, ao lado do rio Jacuí. Com as perseguições, Oniro Camilo relatou, ainda, que muitos documentos podem ter sido descartados no rio Jacuí.

${ }^{11} \mathrm{O}$ cartório de registro de Butiá é de 10 de setembro de 1896.

${ }^{12} \mathrm{O}$ cartório de registro civil e imóveis foi estabelecido em Arroio dos Ratos a partir de 1920.
} 
publicado, pertencente a uma das filhas de um mineiro, o qual iniciou sua carreira como mineiro em Arroio dos Ratos, em novembro de 1920. Tratava-se de Adalberto Thimóteo dos Santos. ${ }^{13}$ A semelhança com o nome de um dos mineiros reclamantes no processo $n^{\circ}$ 9.582/1934, Adalberto Azambuja dos Santos, trouxe à tona a expectativa de um possível parentesco. Embora não comprovado, Adalberto Thimóteo dos Santos esteve presente indiretamente no processo, quando, em 18 de maio de 1934, atestou conhecer Liberalino Machado de Lima, também conhecido como Januário, como empregado da CEFMSJ, quando foi despedido por intrigas "dum tal Cathalã, que por aqui andou, como operário, mas que depois, se soube ser um secreta da polícia."14

Organizado como livro e com aproximadamente 40 tópicos, o material registrava a história de vida de Adalberto Thimóteo dos Santos, desde seu nascimento, em 3 de abril de 1903, em Porto Alegre, até sua aposentadoria na cidade de São Jerônimo. A obra foi intitulada A legião dos condenados. As memórias de Santos contribuem de maneira excepcional para os dados já levantados na parte exploratória da pesquisa, principalmente a partir do momento em que o mineiro registrou sua condição como sindicalista e um dos fundadores do sindicato dos mineiros de Arroio dos Ratos, tendo atuado como fiscal geral na primeira diretoria do sindicato.

Em muitas situações, os dados levantados, as informações e os argumentos apresentados pelas partes permitiram um conjunto significativo de indagações que podem se alterar sempre que as fontes forem revisitadas. As evidências, os indícios e as provas presentes nos autos exigiram reflexões e, com isso, assumir riscos tornou-se inevitável. Assim, o estudo, nesse momento, tem como escopo uma maior contextualização do processo em duas dimensões: i) o histórico do sindicato dos mineiros de Arroio dos Ratos; e ii) a trajetória da companhia de exploração de carvão de São Jerônimo.

Por meio desse levantamento, busca-se evidenciar como a maximização dos resultados prefixados pelas partes nos autos, a minimização dos custos, as relações entre empregados e empregador na mina, bem como a interação entre as pessoas envolvidas naquele contexto específico subsidiaram as decisões e estratégias dos mineiros e da companhia a partir do conflito.

A influência dessa estratégia encontra-se em Giovanni Levi, em A herança imaterial. O autor aponta para a hipótese de uma racionalidade seletiva utilizada pelos camponeses do Piemonte, segundo a qual,

\footnotetext{
${ }^{13}$ Não foi possível identificar quando o material foi produzido por Thimóteo, como era conhecido. Contudo, as informações foram datilografadas no decorrer do ano de 1966, por intermédio do genro de Thimóteo, Capitão Oswaldo Souza, marido de sua filha, Eva.

${ }^{14}$ Declaração à fl. 31 do processo no ${ }^{\circ} 9.852 / 1934$.
} 
a ambiguidade das regras, a necessidade de tomar decisões em situações de incerteza, a qualidade limitada de informações, que, todavia, não impedia a ação, a tendência psicológica a simplificar os mecanismos causais considerados relevantes para a determinação de comportamentos e, enfim, a utilização consciente das incoerências entre os sistemas de normas e sanções (LEVI, 2000, p. 46),

possam ser utilizadas como eixos explicativos para os comportamentos do grupo de mineiros e da companhia diante daquilo que, subjetivamente, desejava-se e que, socialmente, era exigido.

\subsection{Os mineiros}

A petição inicial da reclamação trabalhista não apresentou dados substanciais sobre os reclamantes. Sem informações sobre nacionalidade, estado civil ou profissão, tampouco faziase referência a documentos de identificação, a seus domicílios, ao tempo exato de início de trabalho nas minas ou à atividade a qual estavam destinados na companhia. Informações estas que também não apareceram no curso do processo.

A investigação sobre quem eram os mineiros e seus antecedentes se deu por meio de buscas nos cartórios de registro civil e imóveis em Arroio dos Ratos, São Jerônimo, Minas do Leão e Butiá. Esses eram os principais distritos envolvidos na exploração das minas de carvão pelas companhias CEFMSJ e CCR. As principais descobertas ocorreram no cartório de Arroio dos Ratos.

Antônio Nunes das Pedras nasceu em 11 de maio de 1904, em Portugal. Filho de Antônio Nunes das Pedras e Maria Thereza, casou-se com Carmelina Teixeira Lopes em 30 de abril de 1931, em Arroio dos Ratos. ${ }^{15}$

Nas consultas sobre João Keenan, não foi possível encontrar outros registros além do próprio atestado de óbito contido nos autos. Na certidão, ${ }^{16}$ expedida pelo escrivão judicial do $5^{\circ}$ Distrito de São Jerônimo - Mina do Arroio dos Ratos, consta que Keenan nasceu em 1875, sendo filho legítimo de Patrício Keenan e Margarida Davis, já falecidos. De cor branca, profissão mineiro, faleceu aos 64 anos de idade em decorrência de um câncer gastroduodenal, em 14 de janeiro de 1938. Era viúvo, e o declarante do óbito foi Thomaz Keenan. Por possuir o mesmo sobrenome e ter sido o declarante do óbito, esta indicação pode ser recebida como um

\footnotetext{
${ }^{15}$ As informações foram encontradas em seu registro de casamento. Na certidão, o nome de Antônio é idêntico ao de seu pai. Após o casamento, a esposa de Antônio passou a ser chamada de Carmelina Lopes das Pedras. Registro de casamento, assento Livro B-02, fl. 182, $\mathrm{n}^{\circ} 08$ do Ofício Público de Arroio dos Ratos, em 30 de abril de 1931.

${ }^{16}$ A certidão pode ser encontrada à fl. 159 do processo $n^{\circ} 9.852 / 1934$. Na base de dados do cartório de Arroio dos Ratos, as informações da certidão de óbito foram identificadas no Livro no 3 de Registro de Óbitos, à fl. 109.
} 
indicativo de que eram parentes. No entanto, o saldo indenizatório a que João Keenan teria direito após determinação do CNT em setembro de 1939 não foi entregue a nenhum familiar, conforme se observou nos relatos contidos nos autos. Mesmo tendo sido a companhia oficiada inúmeras vezes pela procuradoria jurídica do CNT para que buscasse eventuais descendentes de João Keenan, não há indícios de parentes junto à Caixa de Aposentadoria e Pensões da CEFMSJ e, segundo consta, não compareceu nenhum descendente reclamando a indenização após publicação dos editais no jornal Correio do Povo. ${ }^{17}$

Nos autos, a necessidade de confirmar que Liberalino Machado de Lima e Januário Machado de Lima se tratavam da mesma pessoa colocou-o em uma posição sui generis. As razões pelas quais uma pessoa usaria dois nomes, atualmente, poderiam ser interpretadas de forma equivocada em relação às experiências do passado. As justificações judiciais inseridas nos autos pelo reclamante, que buscava comprovar mediante testemunhas ser a mesma pessoa, foram levantadas pelo sindicato, mediante autorização judicial, após o arquivamento do processo.

A duplicidade de nome indica, na verdade, uma atitude comum entre os mineiros. E, de certo modo, isso pode auxiliar no levantamento de possibilidades históricas sobre como, no dia a dia das minas, se dava a utilização de estratégias por parte dos mineiros. Segundo as memórias de Adalberto Thimóteo dos Santos (1966, p. 19), naquela época, para se ingressar na mina, não se exigia qualquer espécie de documento: "valia o que dizia o candidato". Esse fato representa bem a forma pela qual a mão de obra era arregimentada pela companhia para trabalhar na mina. A figura do patrão, até meados da década de 1920, era fundamental para a compreensão desse comportamento. O patrão era um mineiro experiente e atuava como um verdadeiro empreiteiro nas galerias subterrâneas e era o responsável pela contratação da mão de obra. Os pagamentos eram mensais, com valor fixado por dia de trabalho. A companhia pagava o salário ao empreiteiro, que, posteriormente, repassava os valores aos demais mineiros sob sua supervisão. Esse procedimento seria alterado nas minas de Arroio dos Ratos, segundo os relatos de Santos (1966), para evitar que alguns patrões, nas mais diversas situações, fugissem das minas com os salários dos mineiros. Considerando a extensão das minas de Arroio dos Ratos, que congregava uma população de mineiros superior a 5 mil trabalhadores, as trocas de nomes podem, de fato, ter sido utilizadas de diversas formas e por diferentes razões. Como esclarece Santos,

\footnotetext{
${ }^{17}$ Às fls. 172-173 do processo ${ }^{\circ}$ 9.582/1934, a CAP da CEFMSJ indica terem havido, em três vezes alternadas, publicações do edital convocando os herdeiros de João Keenan para se habilitarem à pensão e aos vencimentos decorrentes da decisão do CNT.
} 
por a Companhia não fazer questão de documentação para admitir ao trabalho, muitos trocaram os nomes para esconder sua identidade ou por não gostarem de seus nomes, mas depois que criaram os IAPs [institutos de aposentadoria e pensões], eles continuaram contribuindo com os nomes falsos. Porém, quando precisavam do benefício da aposentadoria ou qualquer outro benefício do instituto, este exigia documentação legal e muitos não a tinham. Foi uma embrulhada dos diabos, até que o contribuinte provasse ser o mesmo, com os papéis legais. Deu muito trabalho. Alguns não tinham certidão de nascimento, os quais se valiam da certidão de batismo, que a Cúria Metropolitana fornecia, e que era aceita pelos institutos. Muitos tiveram que mandar buscar na Europa: os que lá tinham nascido. O interessante é que não gostavam dos nomes que os pais lhe deram e nunca pensaram que aquela troca de nome, mais tarde, lhes podia trazer graves transtornos e despesas em dinheiro (SANTOS, 1966, p. 19).

Se essas foram as razões pela quais Liberalino ou Januário Machado de Lima adotou nomes distintos em diferentes períodos, não é possível determinar. Seria possível que a duplicidade de nomes fosse uma alternativa para conseguir dois trabalhos, com patrões/empreiteiros diversos? Ou seria uma alternativa utilizada pelos mineiros para que pudessem dobrar, de forma extraordinária, turnos de trabalho? Como Santos (1966) relatou, não havia entre os patrões uniformização pelo valor pago a determinado trabalho. O puxador de carro de uma galeria poderia ganhar salário/dia maior ou menor que outro mineiro de mesma categoria. Embora essas questões permaneçam abertas, outro fato chama a atenção. No cartório de registro de pessoas naturais de Arroio dos Ratos, por meio de um registro de casamento, foi possível encontrar referência a um mineiro chamado Liberalino de Lima, que se casou com Ana Vales Fortes ${ }^{18}$ em 3 de julho de 1954. Este Liberalino, nascido em 6 de julho de 1903, em Minas do Butiá/RS, era filho de Antônio Machado de Lima e Catarina Amalia da Fonseca. No registro oficial, há a ausência do sobrenome Machado, que, porém, era sobrenome de seu pai. O registro de óbito de Liberalino de Lima também foi encontrado, ${ }^{19}$ registrando seu falecimento em 15 de fevereiro de 1959, aos 55 anos de idade, e indicando a mesma filiação e a profisssão de mineiro aposentado.

Em relação ao mineiro Raphael Mezza, existe um registro em nome de Raphael Meza Vaz. Tratava-se de um registro de casamento, segundo o qual Raphael contraiu núpcias com Alice Nunes de Assis, em 15 de outubro de 1927. Raphael Meza Vaz, filho de Serafim Meza e Manoela Vaz, teria nascido em 29 de abril de 1905 e era natural da Argentina. No registro, a indicação da profissão de Raphael era eletricista. Segundo a companhia, Raphael Mezza trabalhou entre $1^{\circ}$ de setembro de 1919 até 6 de março de 1934. Na reclamação trabalhista, a possível supressão do

\footnotetext{
${ }^{18}$ Após o casamento, sua esposa passou a se chamar Ana Fortes de Lima. Registro de casamento de Liberalimo de Lima, assento no Livro B-12, fl. 198 verso, $\mathrm{n}^{\circ}$ 2.146, do Ofício de Registro de Arroio dos Ratos, em 3 de julho de 1954.

${ }^{19}$ Registro de óbito de Liberalino de Lima, assento no Livro C-11, fl. 104, ${ }^{\circ}$ 4.602, do Ofício de Registro de Arroio dos Ratos, em 18 de fevereiro de 1959.
} 
sobrenome Vaz, de origem hispânica, pode ter sido diretamente influenciado pelas dificuldades enfrentadas por estrangeiros em decorrência da lei que impedia a contratação ou manutenção de empregados de outros países acima de $1 / 3$ dos nacionais. ${ }^{20}$

Thomaz Gonçalves da Silva também foi encontrado. O primeiro registro, datado em 30 de novembro de 1921, foi autorizado judicialmente na modalidade de registro tardio de nascimento. ${ }^{21}$ Thomaz era filho de Sepulvio Gonçalves Pinheiro e Albina Maria da Silva. Nasceu em 20 de junho de 1898, em Arroio dos Ratos.

Em 25 de março de 1933, Thomaz, com profissão de mineiro, casou-se com Acelina Francisca Serpra. ${ }^{22}$ Em 25 de fevereiro de 1939, foi encontrado novo registro de casamento em nome de Thomaz Gonçalves da Silva, com a mesma indicação de filiação, profissão e data de nascimento, contraindo núpcias com Nathalina Pedroso. ${ }^{23}$ Thomaz faleceu em 9 de setembro de $1971,{ }^{24}$ como mineiro aposentado, aos 73 anos de idade, tendo Rosa da Silva como quarta esposa.

Os dados referentes a Domingos Mantilha foram encontrados por via diversa dos demais. Na ausência de registros sobre seu nome nos cartórios de registro de pessoas e nos de imóveis consultados, o nome de Domingos Mantilha Gonzales surgiu nos arquivos do Tribunal Regional do Trabalho da $4^{\mathrm{a}}$ Região. A ausência do sobrenome Gonzales na reclamação trabalhista, mais uma vez, pode ser reflexo da Lei do $1 / 3$, já mencionada no caso de Raphael Mezza Vaz.

O memorial da Justiça do Trabalho do Tribunal Regional do Trabalho (TRT) da $4^{\mathrm{a}}$ Região contempla uma coleção de processos trabalhistas que tramitaram na Junta de Conciliação e Julgamento em São Jerônimo entre 1938 e 1947. Com o apoio do memorial do TRT e da Universidade Federal do Rio Grande do Sul (UFRGS), a experiência, desenvolvida pelo projeto Uma Luz no Fim do Túnel, tornou possível o acesso a inúmeras reclamações ocorridas no período. Entre elas, encontra-se uma reclamação de Domingos Mantilha, agora,

\footnotetext{
${ }^{20}$ No fundo da CEFMSJ, por exemplo, foi possível encontrar ofício da companhia endereçado ao inspetor do MTIC, Ernani de Oliveira, datado de 31 de outubro de 1934, que informava, em atendimento a solicitação de discriminação das nacionalidades dos empregados das minas, ter 2.667 auxiliares: 2.254 eram nacionais e 313 estrangeiros, correspondendo $87,806 \%$ de brasileiros e $12,194 \%$ de estrangeiros.

${ }^{21}$ Registro de nascimento de Thomaz Gonçalves da Silva, assento no Livro A-01, fl. 109, no 166 do Ofício de Registro de Arroio dos Ratos, em 30 de novembro de 1921 (registro tardio).

${ }^{22}$ Certidão de casamento, assento no Livro B-03, fl. 46, $\mathrm{n}^{\circ}$ 13, do Ofício de Registro de Arroio dos Ratos, em 25 de março de 1933. Após o casamento, Acelina passou a se chamar Acelina Serpra da Silva.

${ }^{23}$ Nathalina passou a se chamar Nathalina Pedroso Gonçalves. Registro de casamento, assento no Livro B-05, fl. 49, n 538, do Ofício de Registro de Arroio dos Ratos, em 25 de fevereiro de 1939.

${ }^{24}$ Certidão de óbito, assento no Livro ${ }^{\circ}$ C-13, fl. 155, $n^{\circ} 5.635$, do Ofício de Registro de Arroio dos Ratos, em 9 de setembro de 1971 .
} 
com a inclusão do sobrenome Gonzales. O indício de que se tratava da mesma pessoa sobreveio com análise do processo $n^{0} 14 / 1945$, tramitado na referida Junta de Conciliação e Julgamento, em que Domingos promovia nova reclamação contra a CEFMSJ.

Diante da nova fonte, foi possível identificar que Domingos era espanhol, com permanência legal no país e residência em Porto Alegre e nas Minas do Butiá. A indicação de que começou a trabalhar nas minas de Arroio dos Ratos pela CEFMSJ era idêntica, com data registrada na certidão de registro de trabalho emitida pela companhia quando do processamento da reclamação no $9.582 / 1934$, isto é, 5 de outubro de $1918 .{ }^{25}$ No processo de $1945,{ }^{26}$ além da identificação de que era solteiro, houve a certificação, por lavra do funcionário da Justiça do Trabalho, de que na carteira profissional de trabalho de Domingos, $\mathrm{n}^{\mathrm{o}} 14.978$, série $5^{\mathrm{a}}$, constava o registro de emprego junto à CEFMSJ, com o cargo de empreiteiro-mineiro, desde 5 de outubro de 1918, assinada pelo engenheiro-chefe Louis Dormerval.

Os registros de nascimento, casamento ou óbito de Adalberto Azambuja dos Santos não foram encontrados nos cartórios de registro. Sem qualquer referência no fundo CEFMSJ no Museu Estadual do Carvão (MCAR), não foi possível encontrar identificação de nacionalidade, naturalidade, data de nascimento e filiação. A principal menção foi o registro de sua candidatura à presidência do Sindicato dos Mineiros de Arroio dos Ratos (SMAR) em setembro de 1933, encontrada no jornal Correio do Povo.

Além de compartilharem o fato de serem requerentes na mesma reclamação trabalhista, os mineiros guardavam entre si outro ponto em comum: todos eram associados do Sindicato dos Mineiros de Arroio dos Ratos. Em 1934, dadas as condições financeiras desses trabalhadores e a ausência de uma Junta de Conciliação e Julgamento Trabalhista em São Jerônimo, ${ }^{27}$ o acesso à justiça era precário. Por um lado, situações como a ausência em

\footnotetext{
${ }^{25}$ F1. 62 do processo $n^{\circ}$ 9.582/1934. A certidão foi assinada por Louis Dormerval, engenheiro-chefe da CEFMSJ.

${ }^{26}$ Nesse processo, Domingos Mantilha Gonzales reclamava sua reintegração à CEFMSJ após o encerramento de sua aposentadoria. Alegava que foi aposentado pela CAP da companhia, em março de 1942, devido a problemas de saúde decorrentes do trabalho no subsolo das minas. Após receber alta, em 1945, buscou retornar ao trabalho, mas foi impedido e, nesses termos, buscava indenização. Na reclamação, seu pedido foi acolhido parcialmente, a fim de determinar a reintegração do reclamante e absolver o empregador de pagar indenização, uma vez que ficou demonstrado nos autos que o reclamante já fora indenizado pela companhia em outro processo pela redução de sua capacidade laborativa.

${ }^{27}$ As juntas de conciliação e julgamento foram criadas por decreto em 1932. A instituição dessas juntas pode ser compreendida em dois grandes movimentos: o que antecede a criação e instalação da Justiça do Trabalho, respectivamente em 1939 e 1941 e o momento posterior ao seu funcionamento. Em função das minas de carvão na região de São Jerônimo, a existência de uma junta de conciliação e julgamento na cidade pode ser determinada, a partir de 1938, pelas reclamações trabalhistas preservadas no memorial da Justiça do Trabalho da $4^{\text {a }}$ Região, demonstrando que os julgamentos ocorriam na sede da prefeitura municipal. Após a criação da Justiça do Trabalho, apenas em 1945 foi instalada a Junta de Conciliação e Julgamento de São Jerônimo no novo formato institucional. No Arquivo Nacional, em Brasília, o processo administrativo de instalação dessa junta se encontra disponível para consulta.
} 
um ou dois dias de trabalho ou uma despedida produziam impactos diretos na condição de cidadania dos mineiros; isto, por outro lado, ampliava as formas pelas quais os trabalhadores procuravam se organizar. Assim, a próxima seção dedica-se à formação do sindicato dos mineiros.

Figura 4 - Mineiros no subsolo das minas, com carregamento de carvão nos carros (s.d)

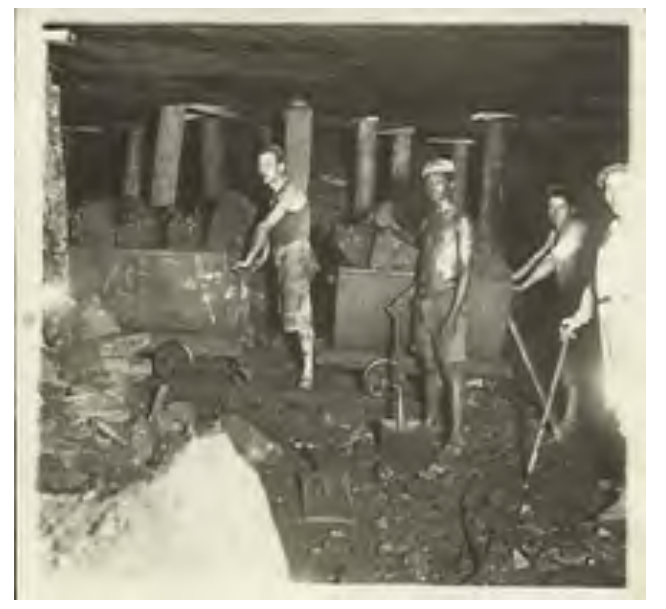

Fonte: Museu Estadual do Carvão.

\subsection{Sindicato dos mineiros de Arroio dos Ratos}

A criação do Sindicato dos Mineiros de Arroio dos Ratos, em $1^{\circ}$ de janeiro de 1933, estava em perfeita conexão com as políticas de sindicalização propostas pelo governo provisório de Getúlio Vargas. Em âmbito regional, as visitas constantes ao Rio Grande do Sul e as intervenções dos ministros do MTIC Lindolfo Collor (1931-1932) e Joaquim Pedro Salgado Filho (1932-1934) promoveram uma ampliação significativa nas agitações do movimento operário, com a primeira reforma da Lei Sindical, que ocorreu em 1931, com a edição do Decreto n ${ }^{\circ} 19.770$, de 19 de março de 1931; a criação das juntas de conciliação e julgamento de dissídios; e, no que se refere aos mineiros em especial, com a incorporação da categoria nas regras dos ferroviários, determinante para a criação das Caixas de Aposentadoria e Pensão voltadas aos mineiros e para a estabilidade decenal. ${ }^{28}$

Segundo Machado (1983, p. 95), o movimento operário sindical gaúcho configuravase em três tendências políticas claras: "uma de caráter corporativista, isto é, 'pelega' (apoiada também pelo PRL - Partido Republicano Liberal), outra comprometida com o catolicismo, os

\footnotetext{
${ }^{28}$ Para um maior aprofundamento sobre o período, ver também Fortes (1999).
} 
círculos operários, e uma terceira, a FORGS [Federação Operária do Rio Grande do Sul], vinculada ou sob a influência do PCB [Partido Comunista Brasileiro]”.

A regulamentação das organizações de classes patronais e operárias, conforme o Decreto $n^{\circ} 19.770 / 1931$, estava vinculada a uma série de precondições para que os interesses de ordem econômica, jurídica, higiênica e cultural das entidades pudessem ser instrumentalizados. Os direitos e deveres dessas agremiações somente poderiam ser defendidos perante o Governo da República e por intermédio do Ministério do Trabalho, Indústria e Comércio, como retratava o art. $1^{\circ}$ do decreto.

Juridicamente, a estrutura sindical estava atrelada ao preenchimento de alguns requisitos: um ligado ao direito privado, com foco no Código Civil de 1916; e outro, ao direito administrativo, vinculado ao exercício do poder de polícia da administração pública. Em relação à primeira exigência, a consolidação do sindicato dependeria da aquisição de personalidade jurídica, mediante instituição de um estatuto, ata de instalação e relação do número de sócios (não inferior a 30 associados, homens ou mulheres, maiores de 18 anos, com mínimo de $2 / 3$ de brasileiros ou naturalizados). O segundo requisito conectava-se à própria natureza política do sindicato, previamente definida pelo governo: considerados como órgãos de colaboração com o poder público, os sindicatos, federações e confederações sindicais apenas poderiam exercer suas funções no espaço institucional de representação de interesses se obtivessem reconhecimento do MTIC. Assim, toda estrutura sindical, além de ser única por categoria, passava a ser fiscalizada pelo ministério - sobretudo, na análise das condições necessárias para sua constituição, que previa, entre outras, a "abstenção, no seio das organizações sindicais, de toda e qualquer propaganda de ideologias sectárias, de caráter social, político ou religioso, bem como de candidaturas a cargos eletivos, estranhos à natureza e finalidade das associações" (art. $1^{\circ}$, f, do Decreto $n^{\circ} 19.770 / 1931$ ).

A par dessas construções administrativas propostas na regulamentação sindical, o governo também proibia a qualquer sindicalizado a possibilidade de se associar a sindicatos internacionais, facultando às federações ou confederações, a agremiação a organizações congêneres, fora do território nacional, depois de ouvido o ministro do Trabalho.

Os controles sobre as ações sindicais eram profundos. Os patrões ou empresas não poderiam demitir, suspender e rebaixar de categoria, de salário ou de ordenado o empregado sindicalizado e empregado que se associasse ao sindicato de sua classe, ou que tivesse, no seio do mesmo sindicato, manifestado ideias ou assumido atitudes em divergência com seus patrões. 
A legislação sindical foi estabelecida em um contexto que pode ser caracterizado como um limbo ideológico. A abertura política para novos atores sociais e o intenso controle político sobre seus desdobramentos refletia a constante tensão que caracterizou as ações administrativas do governo provisório varguista. Temas como centralização ou descentralização política e econômica, representação classista no legislativo federal e regulamentação de direitos sociais, como o direito do trabalho, compõem o acervo de exemplos expressivos que ajudam compreender o período. ${ }^{29}$

Nesses termos, a condição de limbo ideológico se refletiria diretamente no contexto da organização do trabalho. O espaço de experiência produzido pela Primeira República, sobretudo pelas greves gerais em setores de relevância econômica para a produção nacional na década de 1910, colocava em destaque as atuações de comunistas, anarquistas e trabalhadores estrangeiros no foco da crise. ${ }^{30}$ De certo modo, a legislação produzida refletiu não apenas esse ambiente, mas também a forma como a transição do modelo agrárioexportador para o modelo industrial ocorreria quando o tema era o mundo do trabalho. Ao mesmo tempo que protegia o empregado sindicalizado que entrasse em divergência com o empregador, exigia do sindicato a abstenção de propaganda de ideologias consideradas sectárias, de caráter social, político ou religioso.

As tendências políticas observadas por Machado (1983) em relação ao movimento operário sindical no Rio Grande do Sul podem ser justificadas diante do ajuste político e jurídico que marcou a expansão da organização do trabalho e dos sindicatos no governo provisório, principalmente, por corresponderem às alternativas da classe trabalhadora aos limites impostos pela legislação sindical de 1931. Nesse aspecto, a experiência do Rio Grande do Sul se destaca para a fundação do Sindicato dos Mineiros de Arroio dos Ratos.

Autores como Machado (1983), Fortes (1994), Barreto (1996) e Speranza (2012) traçam um quadro comum quando o foco se direciona às experiências sindicais pós-1931 no Rio Grande do Sul. A recepção da legislação sindical promovida pelo MTIC, como reforçam Fortes (1994) e Barreto (1996), refletia não só o engajamento do operariado gaúcho com a Revolução de 1930 mas também as tentativas da incorporação do proletariado na sociedade moderna (como a influência do positivismo, acrescenta Fortes), além da representatividade que Vargas e o ministro do Trabalho, Lindolfo Collor, exerciam no estado. Embora a

\footnotetext{
${ }^{29}$ Para maior aprofundamento, ver Cabral (2011).

${ }^{30}$ A dissertação de mestrado de Maria Pia dos Santos Lima Guerra (2012) resgata algumas destas contradições utilizadas na primeira República, quando houve repressões à organização de trabalhadores e expulsão de estrangeiros, imigrantes e de brasileiros natos do país, considerados como indesejáveis. Para maiores detalhes, ver ainda Bonfá (2009), Chaloub (2012), Costa (2013) e Gomes (1979).
} 
retomada sindical no Rio Grande do Sul, a partir de 1931, passasse a ser um dado relevante, Barreto (1996, p. 116) não ignorou o fato de que a mobilização das entidades sindicais ecoava as "reminiscências de períodos anteriores da história do movimento de trabalhadores e que pouco tinham a ver, diretamente, com o contexto propiciado pelo Decreto 19.770”.

Com a criação do Ministério do Trabalho e a reforma na lei de sindicalização, o sindicato passou a ser definido, politicamente, como um órgão de colaboração com o poder público, utilizado como um instrumento hábil para vetar conflitos entre as novas tendências que surgiam no âmbito do capital e trabalho. Quanto aos fins econômicos, como compreendera Vianna (1976, p. 146), "visava disciplinar o trabalho como fator de produção".

Para que pudesse alcançar autonomia e liberdade dentro do modelo legal corporativo, a partir de 1931, a reorganização do movimento operário sindical gaúcho teve de superar a supervisão governamental da inspetoria regional do MTIC em Porto Alegre.

A escolha de Ernani Oliveira para a inspetoria do MTIC foi articulada entre o Centro da Indústria Fabril do Rio Grande do Sul e o ministro do Trabalho Lindolfo Collor. Machado (1983, p. 103) cita uma reunião em que os industriais gaúchos solicitavam a indicação de um "homem neutro" para a inspetoria, que estivesse acima de todas as contendas naturais, isento de paixões, agindo com imparcialidade, para reconhecer o direito de todos.

Nesse período é que surgiram as primeiras organizações proletárias: o Comitê PróOrganização Proletária (CPOP), em 1931; a Liga dos Operários Republicanos, em 1932; e a Federação Operária do Rio Grande do Sul (FORGS), ${ }^{31}$ em 1932. A FORGS e o inspetor do MTIC, Ernani Oliveira, exerceriam influência relevante para a sindicalização dos mineiros de Arroio dos Ratos. E, por representarem duas tendências que entre uma concertação política ou outra também exteriorizavam conflitos, não deixavam de se destacar neste contexto. Por sua vez,

\begin{abstract}
o movimento operário entrou em compasso de espera em relação às mudanças que os novos direitos sociais estabelecidos trariam às condições de vida dos trabalhadores. Quando Salgado Filho assumiu o ministério em 1932, a expectativa já começava a se transformar em impaciência, diante do sistemático descumprimento da legislação pela imensa maioria dos empresários e da impotência, ou falta de vontade política do governo provisório em assegurar a sua efetivação (FORTES, 2004, p. 303).
\end{abstract}

Ainda com uma constituição provisória, desde sua criação, em 22 de julho de 1932, a FORGS $^{32}$ se consolidaria com a realização de um Congresso Operário, previsto para a

\footnotetext{
${ }^{31}$ Nos anos 1910, havia uma agremiação operária com o mesmo nome, porém sem data específica de quando encerrou suas atividades. Com as inovações na década de 1930, comitês de reorganização da FORGS foram criados, visando à ampliação das sindicalizações de inúmeras categorias profissionais no estado.

${ }^{32}$ Segundo Machado (1983) e Barreto (1996), a FORGS seria responsável pela edição, a partir de 1933, do jornal A Voz do Trabalhador, que circulou entre outubro de 1933 e dezembro de 1934, com 58 edições.
} 
segunda quinzena de janeiro de 1933. O objetivo do congresso era formalizar os requisitos necessários para o reconhecimento da federação junto ao MTIC, bem como ampliar a coordenação das classes trabalhadoras para a organização de seus sindicatos.

O Congresso Trabalhista da FORGS aconteceu de fato apenas entre os dias 3 e 5 de fevereiro de 1933. Analisando o jornal Correio do Povo, ${ }^{33}$ Barreto (1996) organizou um quadro em que contabilizava a presença de 56 entidades sindicais, destacando que os operários da Companhia Estrada de Ferro e Minas de São Jerônimo e das Minas de Arroio dos Ratos, embora não organizados em uma entidade, ${ }^{34}$ enviaram os mineiros Alberto Santos e José Franco como representantes. No entanto, ao se referir a Arroio dos Ratos, também registrou, com base nas informações do Correio do Povo, ${ }^{35}$ que essas categorias haviam saído de uma greve que se encerrou em 2 de fevereiro de 1933, um dia antes da realização do Congresso da FORGS. Em verdade, a greve que se encerrou em 2 de fevereiro de 1933 ocorreu nas minas de carvão de Butiá, ligadas a Companhia Carbonífera Rio-Grandense, cujo diretor era Roberto Cardoso.

Aliada à constante pressão de Ernani Oliveira sobre a necessidade de sindicalização dos operários das minas, a inclusão dos mineiros às regras dos ferroviários, por meio do Decreto $n^{\circ} 22.096$, de 16 de novembro de 1932, pode ter sido essencial para a fundação do sindicato em Arroio dos Ratos. No entanto, creditar a criação do sindicato exclusivamente às pressões de Ernani de Oliveira pode soar falso. As memórias de Adalberto Thimóteo dos Santos (1966), mais uma vez, podem colaborar para esclarecer os fatos:

\begin{abstract}
Os mineiros daquela época, em todas as minas de São Jerônimo, viviam nas mais miseráveis condições de higiene e de acomodação. É bastante dizer que a Companhia mandava vir gente até da Europa (Espanha, Polônia, Portugal) e de toda parte do Brasil, mantendo gente, sempre, de diferentes Estados, arrebanhando trabalhadores para a mesma. Mantinha pedido permanente de operários nos jornais diários da Capital, mas de cada 100 que vinham, talvez, não ficassem 3, pelas péssimas condições com que eram tratados, quando chegavam à Mina. (Nesse tempo, ou melhor, até o ano de 30, o mineiro de São Jerônimo estava na categoria social um pouquinho abaixo de cachorro) (SANTOS, 1966, p. 14).
\end{abstract}

\footnotetext{
${ }^{33}$ O jornal Correio do Povo mantinha uma seção diária intitulada "O movimento sindicalista no Rio Grande do Sul”, em que relatava as principais ações de trabalhadores no estado.

34 Embora Barreto (1996) faça a divisão, as minas de Arroio dos Ratos eram vinculadas a CEFMSJ. Acrescentou, ainda, na análise do jornal Correio do Povo (16 fev. 1933, p. 8), que o sindicato [levando a crer que se tratava de Arroio dos Ratos] foi instalado em 15 de fevereiro de 1933, com a presença de Ernani Oliveira e Waldir Niemeyer (representante do MTIC, no Rio de Janeiro), que visitava o estado. No entanto, o SMAR foi criado em $1^{\circ}$ de janeiro de 1933.

${ }^{35}$ Edição de 2 de fevereiro de 1934, p. 14.
} 
A condição de miserável, com baixas condições de sobrevivência, estabelecia uma relação de subserviência do empregado nas minas de carvão. Muitos candidatos ao emprego chegavam à mina sem condições financeiras para alimentação ou acomodação.

Figura 5 - Mineiros esperando troca de turno (s.d.)

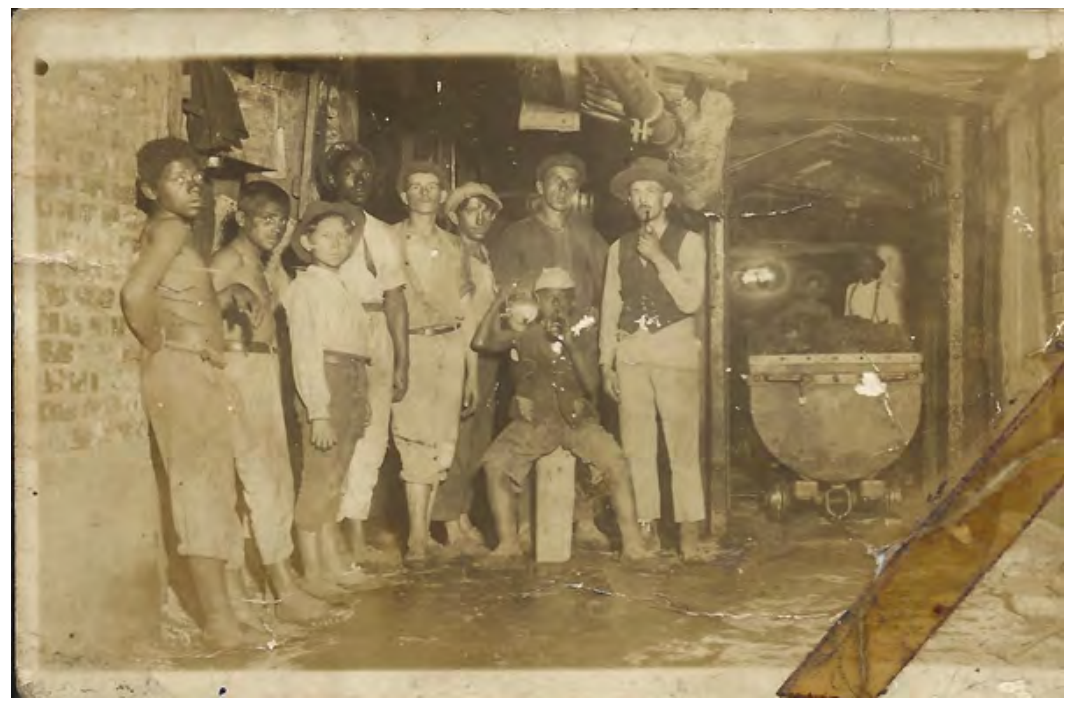

Fonte: Museu Estadual do Carvão.

Conforme relatava Santos (1966), os primeiros salários eram pagos a partir do terceiro mês de atividade, e a alimentação era possível mediante o adiantamento de pequenos "vales" 36 fornecidos aos mineiros, vinculados à compra de produtos nas mercearias da companhia. As alternativas para acomodação eram as escassas vagas nas repúblicas de mineiros organizadas pela companhia ao longo dos poços de exploração das minas ou nas pensões, também vinculadas à permissão da companhia.

Figura 6 - Mineiros esperando troca de turno

\footnotetext{
${ }^{36}$ Os vales eram tickets alimentação, que referenciavam a permissão ao portador de adquirir o produto designado. Exemplo: vale $2 \mathrm{~kg}$ de carne bovina; vale $1 \mathrm{~kg}$ de arroz etc.
} 


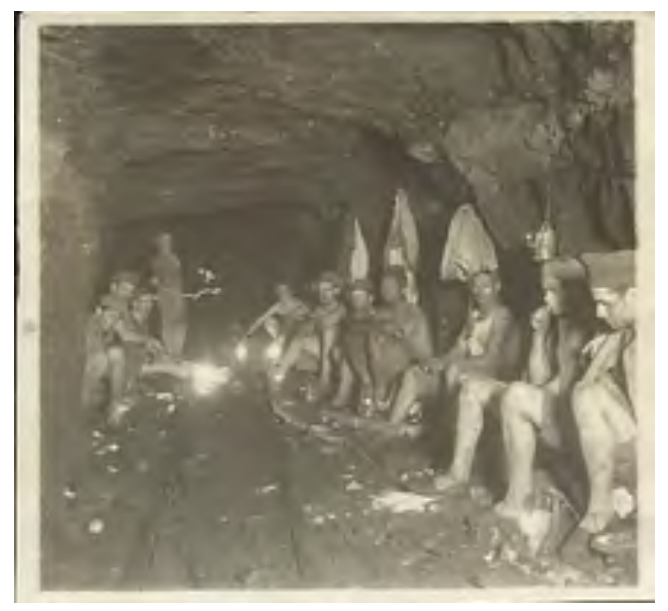

Fonte: Museu Estadual do Carvão.

Essas questões trazem à tona uma verdadeira racionalidade seletiva entre os mineiros, não apenas na forma de sua organização enquanto classe, mas nas estratégias de manutenção de suas famílias. Embora Santos (1966, p. 14 e p. 32) tenha feito referência ao fato de que “depois que o Getúlio Vargas criou as leis de trabalho, nós melhoramos muito, mas muito, mesmo", ou ainda "graças a Getúlio Vargas tínhamos direito de reivindicar o que era nosso, sem interferência da polícia”, a ambiguidade sobre as regras a serem seguidas ainda persistia no interior das minas. A tomada de decisão pela sindicalização contextualiza um pouco deste fenômeno: a criação dos sindicatos surge como uma alternativa para melhores condições de vida dos trabalhadores, mas como criar uma associação em situação de incerteza? As dúvidas também ocorriam em relação às possíveis garantias que as leis emitidas pelos decretos do governo, dentro de um espaço tão restrito e fechado como as minas de carvão, poderiam oferecer.

Diante da qualidade limitada de informações, até que ponto o inspetor Ernani de Oliveira ou o Ministério do Trabalho poderiam garantir aos empregados uma condição de segurança para a sindicalização? Que garantias a lei de sindicalização oferecia para que perseguições não ocorressem em face das já conhecidas ações da companhia? Em suas memórias, Santos (1966) relatou um caso de greve entre os mineiros em que a paralisação foi total:

A Companhia mandou vir um grande reforço policial, para manter a ordem na mina, sem necessidade, eu acho, mas tal faziam por mostrar ao presidente do Estado, então Antônio Augusto Borges de Medeiros, que nós éramos um bando de animais ferozes. Até deste reforço, armou diversos guarda-costas dos chefes, que tinham pomposos títulos na empresa, para esconder suas verdadeiras funções. Entre estes estava um de nome Alberico, que segundo o que diziam os que perto estavam, disse que ia ver se sua Winchester era boa, mas no alvo móvel. [...] Esse tal, era um tipo magro, quem conhece um rato podia conhecê-lo, que se metia em nosso meio como santinho, e começava a sondar nossas ideias de como achávamos a administração da mina, as condições de trabalho, enfim, tudo que parecesse contra a companhia; algum inocente, 
que não o conhecia, dizia-lhe a verdade do que pensava e como podia ser sanado tais defeitos. No outro dia, este infeliz era pego pela polícia e espancado tão barbaramente que, muitas vezes, ficava aleijado pelo resto da vida. Na mesma hora esse coitado era levado para Porto Alegre ou qualquer outro lugar, com ordem de nem olhar para o lado da mina e ele não olhava mesmo, porque neste tempo toda a questão concernente ao trabalho era caso de polícia (SANTOS, 1966, p. 19-20).

A polícia era um elemento persistente no enredo traçado pelos mineiros. Destaca-se, em especial, um relato sobre a atuação do delegado de polícia Elias de Araújo Lopes ${ }^{37}$ nas minas de Arroio dos Ratos:

O Delegado de Polícia, um indivíduo assim do tipo "pouco sevado" e inteligência idem, quando se dirigia a um mineiro (era um tanto delicado) tratava-o, sempre, assim: " - Escuta, cachorro, bandido, tu anda muito direito aqui, senão te mando tirar a bunda a laço”. E era bastante passar por ele e não tirar o chapéu, para cumprimentá-lo (coisa que ele nunca retribuía) para ser espancado barbaramente, e isto com todo o beneplácito dos piedosos dirigentes da Companhia, na mina. Hoje, esse santo homem, que foi nosso Delegado, deve estar sendo cozido, num dos belos caldeirões das profundezas dos infernos (SANTOS, 1966, p. 17).

Mesmo nas incertezas, as reuniões para a fundação do sindicato dos mineiros ocorriam clandestinamente. Adalberto Thimóteo dos Santos, segundo seus relatos, participou ativamente das primeiras ações e, segundo ele,

foi uma luta cruel, porque todas as vezes que aparecíamos com qualquer ideia de associação de classe, éramos rapidamente dispersados pela Companhia e os cabeças eram despachados e entregues à polícia. [...] Não sei como nunca fui despachado da Companhia: não por ter feito algo de mal, mas por querer ter uma associação de classe. Sempre encabecei todas estas, mas tinha sorte. Chamavam-me à ordem, porém, continuava trabalhando. Por muito menos, outros foram despachados, espancados pela polícia. [...] Não é preciso dizer como eram bonzinhos estes policiais! Como lutamos e quantas derrotas! Éramos vencidos pela prepotência. Mas não convencidos que não éramos, também, filhos de Deus! Não pense o operário brasileiro (os moços de 30 para cá) que todas estas leis que hoje o protegem, foram recebidas de mão beijada. Não! Foi cimentada com sangue e lágrimas! (SANTOS, 1966, p. 42-43).

Parte dessas lutas foi registrada em suas memórias na obra $A$ legião dos condenados. Desde a reorganização da reforma sindical de 19 de março de 1931, passaram-se quase dois anos para que o sindicato dos mineiros fosse, efetivamente, criado. No entanto, Santos já descrevia que há muito tempo um grupo de aproximadamente 45 homens costumava reunir-se secretamente, em diferentes lugares, para evitar perseguições por parte das autoridades policiais. Considerando o grupo como "verdadeiros idealistas", as reuniões tinham por objetivo a formalização de uma associação que fosse capaz de dar respaldo às questões previdenciárias e melhores condições de trabalho aos mineiros. Com as inovações legislativas promovidas pelo governo provisório, a representação dos mineiros poderia ser um forte

\footnotetext{
${ }^{37}$ Segundo Adalberto Thimóteo dos Santos, o delegado Elias atuou nas minas por mais de 30 anos, com algumas substituições por pouco período. O relato se refere aos anos 1920. Em dados oficiais, Elias de Araújo Lopes, apareceu como subintendente em São Jerônimo, em 1930. Para mais informações, ver Laemmert (1930).
} 
elemento para exigir o cumprimento da lei por parte da companhia. Em seus relatos, houve alguns exemplos de como o sindicato atuou contra os médicos da CEFMSJ que se negavam a reconhecer acidentes de trabalho, prejudicando os mineiros em relação aos benefícios oferecidos pelas CAP.

Assim, registrava Santos (1966, p. 59): "quando veio a lei [da sindicalização], resolvemos arriscar e ver se aquela lei era para valer. E, para não arriscar todo o grupo, elegemos entre nós, 10 para aparecer como cabeças, porque, se fossemos despachados, sobraria 35 para continuar a luta". Conforme ele mesmo afirmou, Santos era um dos componentes desse primeiro grupo que se lançou abertamente a aliciar os mineiros. "Os companheiros vieram em massa... Imediatamente, a companhia reagiu. E o primeiro a ser despachado foi um espanhol de nome José Freire. Mas nós também reagimos, apelando para a lei e, em 48 horas, tínhamos vencido a primeira etapa. A lei nos protegeu”. A proteção se refere à reintegração de José Freire, que, posteriormente, foi eleito para a diretoria do sindicato em setembro de 1933. A atuação do representante do Ministério do Trabalho, Ernani de Oliveira, foi essencial nesse processo de sindicalização nas minas de Arroio dos Ratos, principalmente, pelo papel de mediador dos conflitos entre os mineiros e a CEFMSJ. Nos registros de correspondência da empresa, ${ }^{38}$ entre 1932 e 1934, foi possível verificar intensa troca de ofícios entre Ernani de Oliveira e o diretor da companhia, Georges Gougenhein.

A partir daquele momento, aproveitando o entusiasmo dos companheiros, acrescentava Santos, em poucos dias foram aliciados mais de 2.000 associados. As principais dificuldades eram a falta de tempo para organizar as reuniões, sempre realizadas nas horas de folga. Ao lado dessas questões, as ameaças e rumores de que "os cabeças seriam despachados" eram constantes.

Com a disposição de grande número de mineiros para a formação do sindicato, as reuniões públicas não eram permitidas nos espaços da companhia. A resistência, segundo alegava Santos (1966), era do engenheiro-chefe Louis Dormerval, que não cedia o cinema local e nenhum outro lugar nos terrenos da companhia. Diante da negativa, as lideranças sindicais resolveram fazer a reunião de qualquer maneira, e o local escolhido foi na frente do cinema, "por ser uma praça muito ampla". No entanto, antes de darem início aos trabalhos, consultaram o delegado de polícia, Elias de Araújo Lopes: "levamos a seu conhecimento o que íamos fazer. Ele aconselhou a não contrariar o engenheiro e fazermos nossa reunião em terras de fazendeiros, nas cercanias das minas" (SANTOS, 1966, p. 60).

\footnotetext{
${ }^{38}$ Disponível no acervo do Museu Estadual do Carvão, fundo CEFMSJ.
} 
O conselho do delegado foi recusado por entenderem que poderiam ser acusados de invasão de propriedade privada e, nesses termos, resolveram fazer a reunião na mesma praça do cinema, sob a expectativa de que se o delegado "não achasse bem, e julgasse crime, mandasse seus soldados nos dispersar".

Na sequência, os editais de convocação para assembleia geral foram fixados "em todo canto da mina", convocando os mineiros para a criação oficial do sindicato. Embora Santos faça referência à criação do sindicato em 2 de janeiro de $1932,{ }^{39}$ os dados disponíveis no fundo CEFMSJ do Museu Estadual do Carvão indicam que a assembleia ocorreu em um domingo, às 14 horas, do dia $1^{\circ}$ de janeiro de 1933.

Para a surpresa das lideranças sindicais, no dia marcado, "nos caiu o queixo: não só compareceram os operários das minas, oficinas, tráfego, e demais trabalhadores de todos os setores e, mais que isso, as mulheres destes trabalhadores" (SANTOS, 1966, p. 60). No entanto, Santos informou também que houve um pequeno incidente, que podia ser de grave consequência, quando no melhor dos discursos do presidente provisório do sindicato, Antônio Cardoso,

o engenheiro inventou de passar no meio da multidão [...], começou a buzinar, pedindo passagem! A multidão tomara aquilo como provocação e, enfurecida, investiu contra o carro! Mas, alguns, mais ponderados, conseguiram por um momento, conter a multidão, e que deu tempo ao engenheiro para dar volta e perder o sabugo!... Não vimos nem cheiro da polícia ali. Todas aquelas derrotas de outros tempos estavam pagas; ao ver toda aquela multidão sentia-me emocionado, por tanta felicidade consentida por Deus à minha alma de idealista! (SANTOS, p. 1966, p. 60).

Após a constituição do sindicato, a diretoria foi eleita no dia 8 de janeiro de 1933, com Castor Bispo (presidente), Euclides de Campos Barbosa (secretário), Gustavo Muller ${ }^{40}$ (tesoureiro) e o próprio Adalberto Thimóteo dos Santos (fiscal geral). O reconhecimento do sindicato dos mineiros pelo MTIC ocorreu em 5 de junho de 1933, com a emissão da carta sindical $n^{\mathrm{o}} 622 \mathrm{~S} 33$. $^{41}$

\footnotetext{
${ }^{39}$ Talvez, possa haver um erro de digitação ou lapso de memória sobre o ano de 1932 ou 1933 no registro de Adalberto Thimóteo dos Santos.

${ }^{40}$ Muller atuou como delegado-eleitor, representando o sindicato dos mineiros de Arroio dos Ratos na eleição de representantes classistas no estado do Rio Grande do Sul, para a composição da Assembleia Nacional Constituinte de 1933-1934. Fonte: Diário Oficial da União, 19 de julho de 1933, p. 14.341 e 14.345.

${ }^{41}$ Essas informações estão disponíveis nos arquivos do Museu Estadual do Carvão. Um exemplar do Estatuto dos Mineiros em formato de caderneta, junto com a comprovação da filiação do sócio mineiro João Conceição Souza (chapa 2909), encontra-se disponível para consulta. A referência à filiação foi em 30 de março de 1938. Também foi possível identificar a filiação de um mineiro, João Batista Filho, em época mais recente (1963), mas como uma identificação de chapa $\mathrm{n}^{\circ} 240$. Desde o início das atividades de mineração nos subsolos, os mineiros que se dirigiam àquele tipo de trabalho eram identificados com um número escrito em uma chapa de ferro, que ficava depositada na "boca do poço". Com o término do trabalho, conforme os mineiros saíam do poço pegavam sua chapa e, com isso, era possível identificar se algum mineiro ficou preso ou não no fundo da mina.
} 
Mesmo após a criação da lei e a formalização oficial do sindicato, destaca-se que, diante das incertezas, os mineiros não abandonaram as estratégias consideradas relevantes para a defesa dos direitos e interesses profissionais de seus associados. Contudo, avaliar até que ponto a utilização dessas estratégias poderia ser considerada consciente diante das incoerências a que eram submetidos, passa a ser outro elemento a compor o cenário perturbador provocado pela tensão entre os avanços dos direitos trabalhistas e as práticas de resistência coordenadas pela empresa.

Santos (1966) indicou que, após a constituição do sindicato, o engenheiro-chefe, Louis Dormerval, "vendo aquele bloco unido", reuniu-se com a diretoria do sindicato no escritório da companhia para firmar um acordo a fim de que, quando houvesse qualquer questão relacionada ao trabalho, antes de ser levada à Justiça do Trabalho, fosse oportunizada a conciliação do conflito no local.

Não é possível afirmar até que ponto esse suposto acordo relatado pode ter influenciado na forma como a companhia e o sindicato agiam para lidar com os conflitos. Nos arquivos do fundo CNT-TST, o processo $\mathrm{n}^{\circ}$ 9.582/1934 foi o único registro contra a CEFMSJ arquivado e, possivelmente, pode ser considerado um dos primeiros processos que chegaram ao CNT, desde a ampliação da estabilidade decenal aos mineiros, em outubro de 1932.

A constituição provisória do sindicato durou pouco mais de seis meses. Como esclarece Klovan (2014), em 17 de setembro de 1933, parte da direção do sindicato foi reeleita para uma gestão de dois anos, mantendo-se, dessa forma, a presidência do sindicato com o mineiro Castor Bispo, que comandaria o sindicato ainda após sua reeleição em $1935 .{ }^{42}$

O jornal Correio do Povo, de 19 de setembro de 1933, trouxe notícia sobre as eleições sindicais, informando, inclusive, que, na assembleia geral do sindicato, atuaram nas apurações o secretário-geral da FORGS, o barbeiro Polycarpo Hibernon Machado e o presidente do sindicato dos Operários em Fábricas de Tecidos, Augusto Rosner.

Aproximadamente 800 mineiros participaram das eleições. Com duas chapas, a vitória coube ao já presidente Castor Bispo, reeleito com 592 votos, derrotando a chapa de Adalberto Azambuja dos Santos, que contabilizou 111 votos. Observe-se que Adalberto Azambuja era um dos protagonistas que deram início à reclamação trabalhista no processo ${ }^{0}$ 9.582/1934.

\footnotetext{
${ }^{42}$ No fundo de arquivo da CEFMSJ, no MCAR, há o registro de um ofício do sindicato para o chefe da mineração da companhia informando o resultado das eleições de 20 de setembro de 1935, com a seguinte composição: Castor Bispo (presidente), Affonso Pereira Martins (vice-presidente), Amaro Junqueira Saraiva $\left(1^{\circ}\right.$ secretário), Nicolau Tolentino ( ${ }^{\circ}$ secretário), Affonso Seiffert ( $1^{\circ}$ tesoureiro), Gustavo Muller $\left(2^{\circ}\right.$ tesoureiro), Pedro Lougue Sobrinho (fiscal geral), Patrício Garcia (bibliotecário), e Graciliano Gonçalves, Horário Gomes da Rocha e João Latoschiscky no conselho fiscal.
} 
Sua despedida ocorreu em março de 1934, em decorrência de sua expulsão das minas de Arroio dos Ratos pela polícia local, por ser considerado indesejável e estar envolvido em um possível movimento de greve entre os mineiros.

Ao lado de Castor Bispo, ligado ao inspetor do MTIC, Ernani Oliveira, foram eleitos Aristeu Alfama (vice-presidente), Euclydes Barbosa (primeiro-secretário), João Berg (segundo-secretário), Gustavo Muller (primeiro-tesoureiro), José Freire ${ }^{43}$ (segundotesoureiro) e Adalberto Thimóteo dos $\operatorname{Santos}^{44}$ (fiscal geral).

Não há registro de greves com grande repercussão em Arroio dos Ratos, em 1932. No entanto, logo após a nomeação de Ernani Oliveira para a inspetoria de Porto Alegre/RS, foram publicados relatos no jornal Correio do Povo, em novembro e dezembro de 1932, de que o inspetor fora fundamental em uma negociação entre mineiros e a CEFMSJ, decorrente de um conflito por atraso de pagamento e majoração desproporcional de materiais oferecidos pelo barracão ${ }^{45}$ da estrada de ferro. Nas negociações, conforme indicam Barreto (1996) e o Correio do Povo, o inspetor incentivou os mineiros a promoverem sua sindicalização bem como a enviarem representantes ao congresso operário da FORGS, que ocorreria em janeiro de 1933.

Os dados registrados nos trabalhos acadêmicos que subsidiam esta pesquisa, bem como as fontes primárias localizadas no MCAR, realçam os impasses sobre a natureza ou as influências que vinculavam os mineiros do SMAR dentro do movimento operário sindical gaúcho. Isso porque, conforme destacou Machado (1983), as três linhagens que indicavam as tendências políticas do movimento sindical estavam presentes na própria configuração do SMAR. A princípio, a questão corporativista esteve presente devido à influência do inspetor do MTIC na primeira etapa de sindicalização. Mas logo na sequência, a FORGS, vinculada ao movimento do partido comunista brasileiro, também passou a se fazer presente no cotidiano do sindicato, aumentando a pressão contra as péssimas condições de trabalho vivenciadas pelos mineiros. E não só isso, mas também em função da impaciência do movimento operário com as reiteradas desobediências da legislação social por parte dos empregadores.

\footnotetext{
${ }^{43}$ Era o mineiro espanhol, demitido pela CEFMSJ quando das tentativas de instalar o sindicato e reintegrado após intervenção de Ernani Oliveira, amparados pela lei de sindicalização de 1931.

${ }^{44}$ Autor das memórias A legião dos condenados (1966), que subsidiam parte desta pesquisa.

${ }^{45} \mathrm{O}$ "barracão", como era conhecido na época, assemelhava-se a um armazém, que era controlado pela empresa e oferecia produtos de primeira necessidade, além de instrumentos de trabalho para a perfuração das rochas.
} 
A institucionalização sindical promovida no Rio Grande do Sul entre 1931 e 1932 tinha como elemento-chave a Inspetoria Regional do Trabalho, que atuava como principal interlocutor do movimento operário sindical. Com a constante organização operária, era muito comum observar nos discursos sindicais o tom laudatório dirigido ao Ministério do Trabalho e a seu representante em Porto Alegre.

A característica de "colaboração", de uma sindicalização "tudo dentro da lei", respeitosa às propostas do governo, não resistiu ao efeito do tempo. $\mathrm{O}$ confronto de interesses entre os representantes sindicais e o governo repercutiu no vínculo de solidariedade das classes. Como exemplo desses fatos, Machado (1983), reproduzindo a cobertura dada pelo jornal Correio do Povo de 21/11/1933, cita o rompimento da FORGS com o inspetor Ernani Oliveira, quando em assembleia geral, foi aprovado por unanimidade o envio de telegrama ao ministro do Trabalho, Salgado Filho, solicitando o afastamento do inspetor. A FORGS

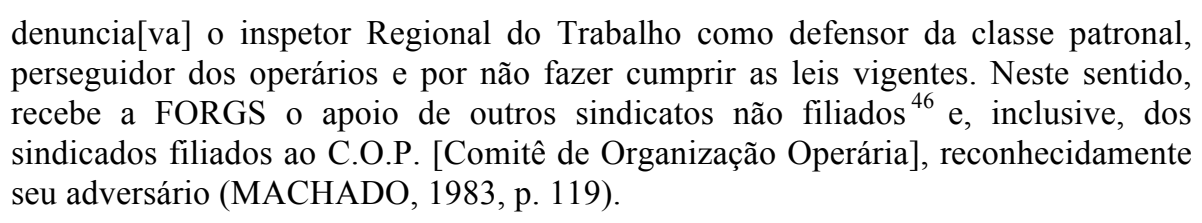

Em parte, um dos pontos conflitivos estava no posicionamento do inspetor em impedir a intervenção da FORGS no caso da greve dos padeiros de Porto Alegre, após a edição do Decreto $\mathrm{n}^{\mathrm{o}} 23.104$, de 19 de agosto de 1933 (que regulava a jornada de trabalho nas indústrias panificadoras). ${ }^{47} \mathrm{O}$ argumento do inspetor era de que a federação não poderia intervir, pois ainda não tinha sido reconhecida pelo MTIC. Segundo Fortes (2004), o conflito foi tão grande que o próprio ministro do Trabalho foi a Porto Alegre, em fevereiro de 1934, e entregou pessoalmente aos diretores da FORGS a carta sindical da entidade, oportunidade em que teria manifestado apoio incondicional a Ernani de Oliveira.

À margem desses conflitos, um maior protagonismo dos Círculos Operários Católicos (COC), já presentes no cenário sindical, também foi perceptível. A legislação sindical, desde 1931, proibia aos sindicatos a vinculação religiosa. Em reação à proibição, a Igreja Católica lançou inúmeros programas de aproximação com o Estado, inclusive, com a formação da Liga Eleitoral Católica (LEC), na Assembleia Nacional Constituinte de 1933-1934. Na arena social/trabalhista, a solução católica foi criar os círculos operários, como registram Barreto

\footnotetext{
${ }^{46}$ A FORGS não era hegemônica na organização sindical gaúcha. Entre os sindicatos que apoiaram a cisão com a representação do inspetor estava o SMAR.

${ }^{47}$ No início da década de 1930, uma das principais greves no Rio Grande do Sul foi a promovida pelos padeiros.
} 
(1996) e Machado (1983), caracterizados como uma reação às organizações tidas como extremistas e vinculadas ao anarquismo, socialismo e comunismo.

Vianna (1978) sintetiza bem esse movimento, ancorando-se em Alceu Amoroso Lima, ${ }^{48}$ para afirmar que a Igreja via no formato do sindicato oficial embaraços à sua política para com as classes subalternas.

O sindicalismo começa a organizar-se no Brasil com uma feição oficial, que aberra
integralmente do sentido sadio, livre e natural da instituição... Esse sindicato
oficializado, laicizado, desumanizado e tendendo fatalmente à hipertrofia da
autoridade, e, portanto, ao sovietismo, é que a nossa Revolução de 30 , por seus
membros do Ministério do Trabalho, tomou como modelo para organizar nosso
sindicalismo (VIANNA, 1976, p. 171).

A Igreja conjecturava, na criação dos círculos operários, a possibilidade de articular o reforço de seu poder e influência social, sobretudo, ao promover a organização da sindicalização sob parâmetros católicos. Assim, os trabalhadores eram incentivados a constituir sindicatos independentes das forças comunista, representada pela FORGS, e corporativista, representada pelo inspetor do MTIC - mesmo que em relação a este, a oposição não ocorria de maneira inflexível. Em Arroio dos Ratos, a partir de 1934, também havia uma célula do Círculo Operário Católico (COC). ${ }^{49}$

Os anos de 1933 a 1937 marcaram uma radicalização no combate e na repressão ao movimento sindical gaúcho. Na mineração, também foi possível registrar esses movimentos e, até certo ponto, essa radicalização trouxe em seu bojo argumentos, ações e conflitos que contribuem para a retomada dos silêncios produzidos no âmbito da reclamação trabalhista $n^{\circ}$ 9.582/1934. Exemplo disso é o uso do termo "greve" pela companhia e pelo CNT em um novo ambiente político mediado pela Constituição de 1934.

Em 1933, a greve mais significativa ocorreu nas minas de Butiá, vinculadas à Companhia Carbonífera Rio-Grandense (CCR), entre 27 de janeiro e 3 de fevereiro, quando mais de 400 mineiros interromperam a exploração do minério de carvão nas minas. Entre julho e agosto de 1933, as minas de Recreio, também distrito de São Jerônimo, promoveram duas greves contra as baixas condições de trabalho, ausência de pagamento de salários e falta de alimentos nos barracões da companhia.

A partir de 1934, novamente, as greves em Arroio dos Ratos e Butiá tornaram-se marcos significativos no conflito entre mineiros e as empresas de mineração. Sem a existência de registros de movimento paredista em março de 1934 nas minas de Arroio dos Ratos, tudo

\footnotetext{
${ }^{48}$ LIMA. Alceu Amoroso. Problema da burguesia. Rio de Janeiro: Schmidt, 1932.

${ }^{49}$ No Museu Estadual do Carvão, há registros fotográficos do pequeno prédio onde o Círculo Operário Católico se reunia, em Arroio dos Ratos e Butiá.
} 
leva a crer que as razões apresentadas pela companhia na reclamação trabalhista que subsidia esta pesquisa consistiam em apenas uma possível tentativa de greve, rapidamente contida pela ação policial, sem paralisação das atividades. Esses argumentos merecem esclarecimentos e serão revisitados no próximo capítulo.

A tensão entre a organização do trabalho nas minas e os interesses das companhias carboníferas delineia outro contexto. $\mathrm{O}$ interesse nacional sobre a produção de carvão na região carbonífera do Rio Grande do Sul já havia sido levantado tanto pelo governo estadual quanto pelo federal. Em expansão, o carvão passava a ser uma fonte energética com potencial a ser explorado, pois se tratava de meio alternativo para a ampliação da produção e circulação de produtos no mercado interno. Na própria Constituinte de 1933-1934, a nacionalização das jazidas de minérios e o controle sobre a exploração estava na pauta política e econômica do governo provisório. Qualquer interrupção na produção de carvão impactava de forma imediata nos interesses econômicos e políticos nacionais. Assim, as jazidas de minérios passavam a configurar dentro do modelo básico e essencial de defesa econômica ou militar do país.

A história da reclamação trabalhista que move as intenções desta pesquisa tem como pressuposto uma expulsão de mineiros pela polícia em fevereiro ou março de 1934, denunciados justamente por "tramarem uma greve geral entre os mineiros".

A partir dessa informação, buscou-se encontrar, nos arquivos policiais e históricos de Porto Alegre, Arroio dos Ratos e São Jerônimo, dados, fontes, relatos ou vestígios que apontassem a existência ou não do movimento de greve no SMAR em fevereiro ou março de 1934. O próprio processo $n^{0}$ 9.582/1934 não foi muito claro sobre a existência do movimento grevista, muito embora, mesmo sem evidências claras, os membros do CNT, em julgamento, acolheram os argumentos sem questioná-los. Às fls. 03, 40 e 63 do processo, há três documentos que apontaram o possível movimento de greve. Os dois primeiros, emitidos pela CEFMSJ - um em 22 de agosto de 1934 e outro em 11 de dezembro de 1934, respectivamente -, assinalam o mês de março de 1934 ao fazer referência ao princípio de greve. À fl. 63, o próprio delegado de polícia, José Maria de Carvalho, em 20 de julho de 1935, declarou que Adalberto Azambuja dos Santos, Raphael Mezza e Liberalino Machado de Lima compareceram perante a autoridade policial, em 15 de fevereiro de 1934, acusados de estarem envolvidos em fatos subversivos da ordem, comprometendo-se, então, a abandonarem as minas.

Nos jornais Diário de Notícias, Correio do Povo e $A$ Voz do Trabalhador, não foram encontrados relatos sobre nenhum movimento de greve em fevereiro ou março de 1934, 
tampouco no MCAR e nos arquivos da polícia civil em São Jerônimo e em Porto Alegre. Contudo, entre fevereiro e março de 1934, todas as atenções se voltaram à visita que o ministro do Trabalho, Joaquim Salgado Filho, faria ao Rio Grande do Sul. E em 28 de fevereiro de 1934, o ministro esteve presente em Arroio dos Ratos. Tanto o Correio do Povo quanto o Diário de Notícias descreveram o tom amistoso com que o ministro fora recebido pelo sindicato dos mineiros e pela companhia.

Figura 7 - Sede do Sindicato dos Mineiros de Arroio dos Ratos

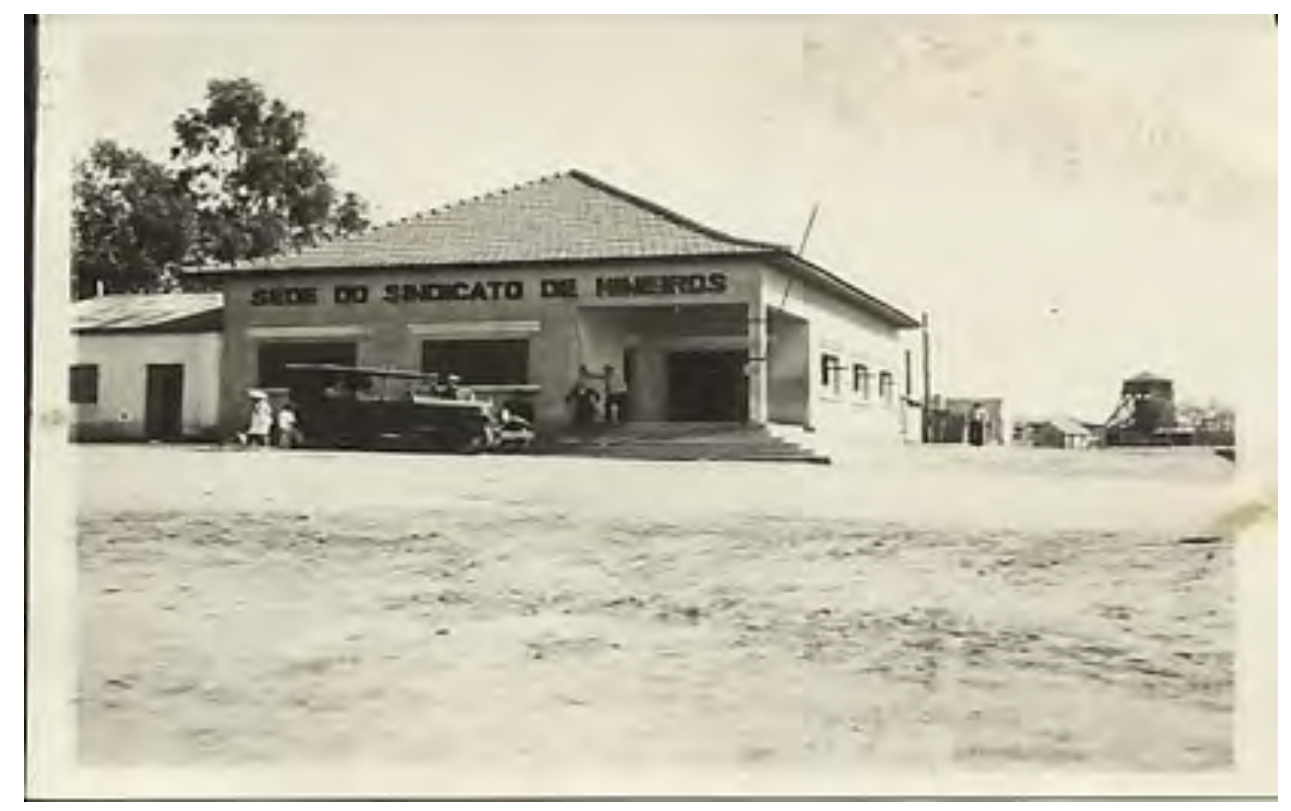

Fonte: Museu Estadual do Carvão.

Em Arroio dos Ratos, a principal greve de 1934 ocorreu entre os dias 15 e 16 de outubro. Segundo Machado (1983), desde maio de 1934 o jornal A Voz Proletária já relatava a tensão entre os mineiros e a empresa, destacando que:

Quando se formou o sindicato, o célebre perseguidor dos trabalhadores, engenheiro da mineração Mário Pena, lembrou-se do tempo em que os trabalhadores organizados souberam lutar contra o seu maquiavelismo, denunciando os seus escândalos administrativos e perseguições, planejou a prisão da diretoria provisória, em conivência com o sr. Ernani Oliveira, digno inspetor regional do "Trabalho" [...] e outros membros da comitiva que visitou as minas em 14 de fevereiro de 1933. Iniciou mesmo uma perseguição contra essa incipiente organização e, por engano, contra indivíduos que são hoje seus braços fortes apesar de fazerem parte da diretoria do sindicato (A VOZ PROLETARIA, 1934, p. 3).

Segundo os jornais Correio do Povo (out./1934) e Diário de Notícias (out./1934), e de acordo com Machado (1983), Klovan (2009) e Speranza (2012), os relatos registraram a 
paralisação (ou parede, termo utilizado à época para se referir à greve) de aproximadamente 2 mil mineiros. O movimento acabou tendo como motivação central a indisposição com o engenheiro-chefe da CEFMSJ, muito embora a outros motivos marginais também existentes pudessem ser mais relevantes para a compreensão do conflito. Organizado pelo SMAR, o movimento se encerrou com a mediação do inspetor Ernani Oliveira, que esteve em Arroio dos Ratos.

Entre 7 e 9 de dezembro de 1934, cerca de 700 mineiros do sindicato de Butiá promoveram uma greve, que teve como motivação defender os diretores do sindicato das ofensas de um enfermeiro da CAP. Em linhas gerais, mesmo contando com a intervenção e mediação do inspetor do MTIC e com o retorno dos trabalhadores, a diretoria do sindicato foi demitida pela companhia. Houve busca e apreensão de documentos e móveis do sindicato de Butiá, sob autoridade de José Maria de Carvalho, delegado de polícia de São Jerônimo, ${ }^{50}$ o mesmo delegado responsável pela expulsão dos mineiros em Arroio dos Ratos.

Em reclamação trabalhista promovida pelo Sindicato dos Mineiros de Butiá na Junta de Conciliação e Julgamento do MTIC em Porto Alegre, a ausência de reconhecimento do sindicato junto ao ministério foi fundamental para a rejeição dos pedidos.

Esses fatos permitiram o uso de novas estratégias dos mineiros frente aos impedimentos ao exercício do direito sindical, mesmo sob a égide da Constituição de 1934, que protegia a sindicalização.

Segundo Machado (1983), os mineiros de Butiá, aconselhados pelo advogado do sindicato, estabeleceram concertações com o SMAR, a fim de promoverem uma unificação entre as duas agremiações.

No processo em análise, a informação desta alteração sindical veio aos autos à fl. 70, quando, em peça processual de 28 de março de $1936,{ }^{51}$ o sindicato apresentou o novo nome da agremiação: Sindicato dos Mineiros e Classes Anexas do Município de São Jerônimo. Até outubro do mesmo ano, a mina de Arroio dos Ratos era o local em que se agregava o maior número de mineiros em toda a região carbonífera. Com a inundação das galerias subterrâneas da mina, devido à enchente de outubro de 1936, não apenas os

\footnotetext{
${ }^{50}$ Conforme Klovan (2009), essa informação foi veiculada no jornal Correio do Povo e no processo $\mathrm{n}^{\circ}$ 9.582/1934.

${ }^{51}$ Para Márcia Elisa de Oliveira (2009), o sindicato dos mineiros de Arroio dos Ratos só obteve reconhecimento no MTIC em 1936, quando passou a se chamar de Sindicato dos Mineiros e Classes Anexas de São Jerônimo. No entanto, a autora ignorou o reconhecimento deste sindicato em 5 de junho de 1933. Registra-se, ainda em Butiá, a criação do Círculo Operário Católico, em julho de 1935.
} 
mineiros se deslocaram para Butiá, mas toda a estrutura sindical também seguiu essas modificações territoriais.

\subsection{Companhia Estrada de Ferro e Minas de São Jerônimo}

A Companhia Estrada de Ferro e Minas de São Jerônimo (CEFMSJ) estava inserida em uma conjuntura muito peculiar em 1934, principalmente por estar localizada na principal região de exploração carbonífera do país. As perspectivas políticas, econômicas e sociais podem ser utilizadas como chaves interpretativas para uma melhor contextualização.

Politicamente, a estrada de ferro, por suas explorações nas minas de carvão mineral, encaixava-se em uma ação estratégica para o desenvolvimento das fontes energéticas do estado do Rio Grande do Sul. O impacto das políticas varguistas na modificação da estrutura agrário-exportadora para o modelo industrial refletia na forma como as forças produtivas, não tão hegemônicas, configuravam-se nas novas alianças econômicas que dariam suporte ao Estado.

$\mathrm{Na}$ prática, como compreendia Machado (1983, p. 80), o Rio Grande do Sul apresentava-se, na época, "como um estado onde a baixa acumulação/concentração de capital acaba[va] por ampliar a já existente diversificação da produção". As empresas de exploração de carvão mineral e as ferrovias exerceram um papel relevante no processo de acumulação de capital regional de vários setores econômicos.

A abertura política iniciada por Getúlio Vargas, após a Revolução de 1930, principalmente por sua ligação direta com o Rio Grande do Sul, onde foi presidente, ampliou as etapas do desenvolvimento gaúcho e, com isso, novos atores políticos e sociais passaram a disputar espaços e voz nas decisões políticas.

Entre as possíveis abordagens desses fatos, a condição do trabalho chama a atenção por duas razões: primeiro, por se constituir como força de trabalho que exerce influência direta na estrutura produtiva (economia) e, com isso, matizar a heterogeneidade de interesses que passam a ditar o tom do conflito entre capital e trabalho (social, política e jurídica); e segundo, por permitir o mapeamento de como as acomodações dos interesses da política (Estado) refletiam na forma de intervenção para a construção das narrativas de nacionalidade, nação e desenvolvimento que tiveram curso na década de 1930.

À margem desse fragmento, que alia conflitos e concertações na relação entre trabalho e capital, encontra-se outro elemento que pode ter sido marginalizado nas análises sobre a década de 1930 até então observadas. Trata-se da estratégia nacional para a proteção das 
fontes energéticas produzidas nas jazidas de minérios de carvão no país. Na década de 1930, especialmente na Assembleia Nacional Constituinte de 1933-1934, a construção dos aparatos que delimitavam a segurança e a defesa nacional das minas e jazidas de minérios era preponderante e, nesse sentido, não se pode ignorar o impacto que os conflitos trabalhistas promoviam nesse arranjo produtivo.

Figura 8 - CEFMSJ, anos 1923-1924

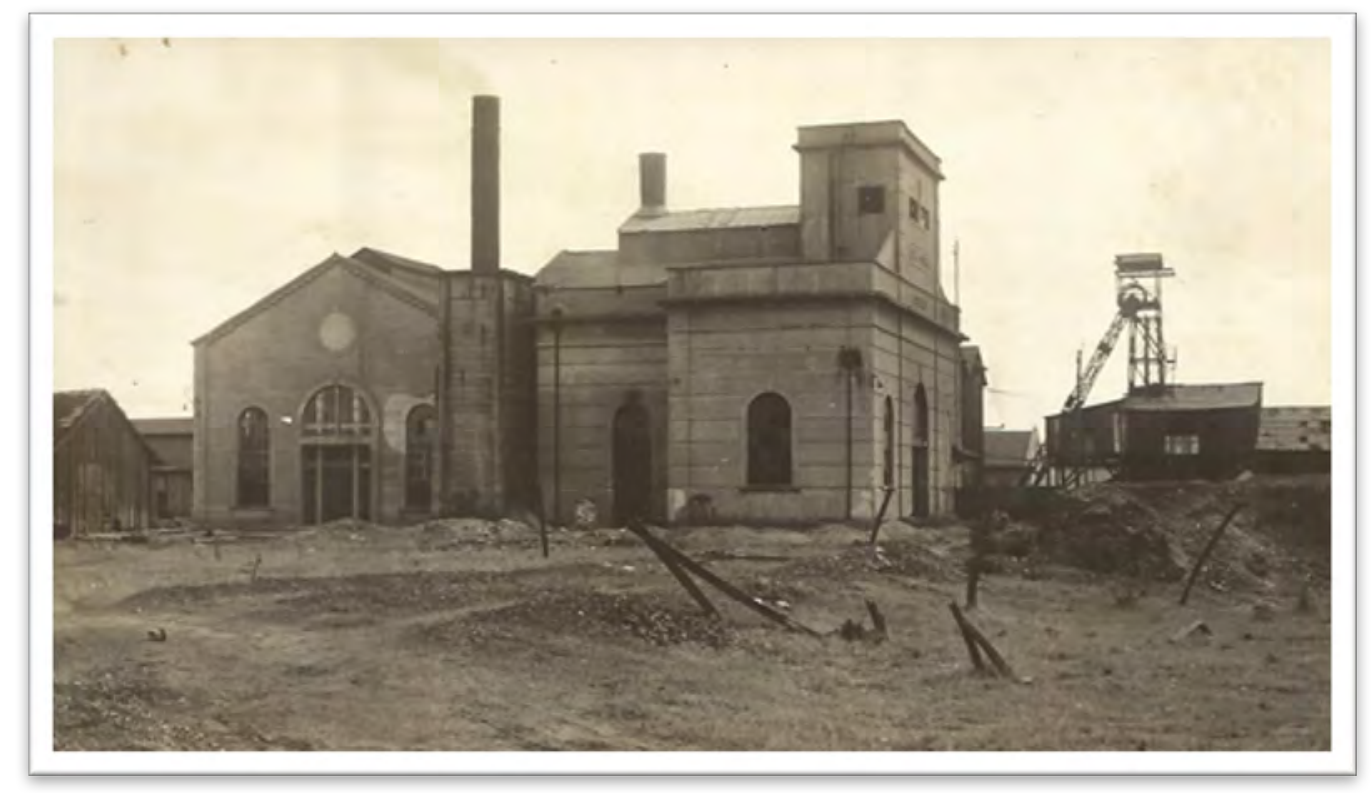

Fonte: Museu Estadual do Carvão.

Na prática, a política nacionalista de Vargas determinou um ajuste técnico para que as estradas de ferro passassem a usar o carvão nacional nas locomotivas, possibilitando ainda incentivos físcais para mais estudos e ampliação da produção de gás e energia em usinas termelétricas. ${ }^{52} \mathrm{O}$ impacto dessas políticas assegurou não apenas a ampliação da produção de carvão em Arroio dos Ratos, mas a majoração de circulação da produção em todo o território nacional, pois o decreto também previa a isenção, por dez anos, de impostos ou taxas que atingissem as empresas de mineração do carvão nacional ou seus produtos. No entanto, a

\footnotetext{
${ }^{52}$ Uma das primeiras usinas termelétricas do país foi construída pela CEFMSJ, em Arroio dos Ratos, por volta de 1924, tendo como fonte primária de combustível o uso do carvão mineral. Atualmente, no prédio anexo da antiga usina, funciona o Museu Estadual do Carvão, cujo acervo documental foi analisado, parcialmente, nesta pesquisa. Com o decreto, em 1931, a companhia passou a ampliar seus mercados, avançando por todo país.
} 
projeção do carvão nacional no cenário econômico não se vinculava exclusivamente às ações políticas de valorização e proteção das explorações de jazidas carboníferas na região.

O relevo estratégico da CEFMSJ surgiu e se desenvolveu no final do Império. Segundo Bunse (1984) e Sulzbach (1989), os primeiros relatórios que apontavam a existência de carvão no Rio Grande do Sul datavam de 1792. Em Arroio dos Ratos, os pioneiros na exploração de carvão foram o inglês James Johnson e o brasileiro Ignácio José Ferreira de Moura. O Decreto Imperial $\mathrm{n}^{\mathrm{o}} 3.715$, de 6 de outubro de 1866, concedeu prazo de 30 anos para essa exploração. Em 1872, o governo imperial autorizou a empresa de Johnson, The Imperial Brazilian Collieries C. Limited, com capital inglês, a explorar o carvão e, desse modo, iniciou-se a construção da estrada de ferro até os poços de Arroio dos Ratos, próximos aos arroios que se interligavam com o rio Jacuí. A partir desse período, mineiros alemães, ingleses, espanhóis, portugueses e nacionais passaram a construir as primeiras vilas, projetando as configurações dos distritos vinculados ao município de São Jerônimo.

Como destaca ainda Bunse (1984), a empresa de Johnson passaria por algumas transformações e, em 1883, converteu-se na Companhia das Minas de Carvão de Pedra do Arroio dos Ratos. Em 1887, a família imperial, representada pela princesa Isabel, participou de uma cerimônia de inauguração de um poço em Arroio dos Ratos. ${ }^{53}$ Novamente reconfigurada, em função de crises econômicas decorrentes do alto custo da produção, a empresa passou por uma nova etapa e refundou-se, em 1889, como Companhia Estrada de Ferro e Minas de São Jerônimo. A produção de carvão das minas vinculadas à CEFMSJ chegou a 9.492,8 toneladas em 1891 . Segundo Bunse (1984), em 1893, existiam os poços n. 5; Poço Velho, n. 9; Surpresa, n. 6; Presidente, n. 7; Dona Isabel; Poço de Ventilação, n. 8; e Poço Fé, n. 10. “A povoação da Mina”, prosseguia Bunse $(1984$, p. 26), “conta[va] com mil almas e [...] umas duzentas casas quase todas de pau a pique, cobertas de sapé, havendo entre elas algumas cobertas de telhas e caiadas. Entre aquelas casas há[via] 50 ranchos que a Cia. aluga[va] a seus mineiros e trabalhadores da mina por $5 \$ 000$ mensais. Há[via] um hotel, oito casas de negócios e uma fábrica de cerveja agora parada”.

O primeiro relato de manifestação de trabalhadores, representada por uma greve geral dos mineiros da CEFMSJ, ocorreu em 1895. Segundo Speranza (2012) e Bunse (1984), o relatório da companhia sobre o movimento apontava que a greve se originou pela mobilização de imigrantes europeus, com "bandeiras encarnadas e manifestações anarquistas”. A seguir, registra-se um fragmento do relatório:

\footnotetext{
${ }^{53}$ No Museu Estadual do Carvão, em Arroio dos Ratos, é possível ter acesso a documentos sobre a visita, bem como correspondências da princesa com seus familiares no Rio de Janeiro.
} 
Os 20 [mineiros] que tínhamos obtido das colônias Jaguary e Lucena eram trabalhadores, porém socialistas, querendo ganhar muito em pouco tempo, e sempre descontentes, tínhamos desorganizado completamente o serviço, aproveitando-se sempre que nos recrutavam o pessoal nacional para obrigar o gerente interino a aumentar os preços que se lhes pagava por tonelada de carvão extraído, e os salários a todo o pessoal; [...]. No dia $1^{\circ}$ de maio apresentaram novas imposições, organizando passeatas com bandeiras encarnadas e manifestações anarquistas e em princípios de junho, tendo sido recrutados todos os nossos mineiros nacionais, maquinistas e foguistas da locomotiva, ferreiros, carpinteiros das oficinas e mais empregados nacionais e muitos estrangeiros até velhos e meninos, de 13 anos, e tomados os cavalos, mulas e carroças da companhia, ficando aqueles mineiros sós em campo, valeram-se deste fato para fazerem como fizeram greve, declarando que não trabalhariam mais nem deixariam qualquer empregado da companhia trabalhar sem aumento de $25 \%$ em todos os preços e ordenados! Assim, conservaram-se durante mais de quinze dias em greve (CEFMSJ, 1895, p. 12). ${ }^{54}$

Ao final, o relatório apresentou ainda uma reflexão, que indicava uma reavaliação da empresa sobre a vinda de europeus: "Deste fato, retiramos a lição que os mineiros colonos, em regra, são socialistas repelidos das minas, porque mineiro na Europa é operário muito bem remunerado e cercado de confortos e somente se expatria espontaneamente atraído por vantagens superiores às que aufere no seu país natal" (CEFMSJ, 1895, p. 13).

Ao resgatar a história da CEFMSJ, Cristina Silva (2007, p. 70-85) traçou um perfil sobre as principais tensões políticas vividas nas atividades de exploração do carvão desde sua constituição. Em parte, os conflitos estavam pautados nas políticas econômicas do governo em relação à concorrência exercida pela importação do carvão inglês, às dificuldades na produção, com elevados custos, e à baixa qualidade do carvão, quando comparado ao da concorrência.

Desde a crise de abastecimento proporcionada pela $1^{\mathrm{a}}$ Guerra Mundial, com a paralisação do tráfego marítimo internacional, as minas de carvão da região estabeleceram um protagonismo para o desenvolvimento econômico da região e do país. Em termos econômicos, a CEFMSJ se inseriu nesse grande movimento de fomento inédito à indústria de carvão nacional. Com a necessidade de suprir as necessidades energéticas do mercado interno, o minério nacional,

associado a outros aspectos, foi o responsável pela promoção de ações dos poderes públicos, como a implementação de leis protecionistas específicas para a indústria carbonífera, a construção de infraestrutura de transportes e a concessão de empréstimos e de benefícios físcais, como por exemplo, a isenção do pagamento sobre o sello e demais impostos federais (SILVA, 2007, p. 98-99).

Essas ações de proteção à produção e à circulação do carvão nacional, segundo Silva (2007, p. 105), consolidavam o discurso da diretoria da CEFMSJ, que, em seus relatórios, “indicava que apenas a interferência governamental visando à ampliação dos mercados

\footnotetext{
${ }^{54} \mathrm{O}$ fragmento original do relatório também foi pesquisado e analisado por este autor no MCAR.
} 
consumidores poderia alavancar o desenvolvimento da indústria carbonífera". Com a encampação das estradas de ferro gaúchas pelo governo estadual em 1920,

a ação governamental oportunizou não apenas o incremento na atividade de extração mineral do estado, no que se refere ao volume de minério produzido, como ampliou sua comercialização, pois a "Viação Férrea do Rio Grande do Sul" tornou-se uma fonte constante do consumo de carvão do estado e, consequentemente, da "Companhia Estrada de Ferro e Minas de São Jerônimo" (Arroio dos Ratos) e da “Companhia Carbonífera Rio-Grandense" (Butiá) (SILVA, 2007, p. 111).

Assim, os primeiros anos da década de 1930 foram marcados por um conjunto amplo de reformas e avanços na infraestrutura de exploração e circulação dos minerais. Desde 1928, Vargas, na função de presidente do estado, celebrou um acordo entre a Estrada Férrea do Rio Grande do Sul e a CEFMSJ, em que esta se comprometia a fornecer 10 mil toneladas de carvão mensalmente àquela. Esses ajustes permitiram a construção de uma estrada de ferro sobre o Rio Jacuí e silos para desembarque da produção, favorecendo o abastecimento do minério diretamente nas locomotivas com seus vagões (SILVA, 2007). A CCR também se beneficiou com essas iniciativas. A partir de 1932, a empresa iniciou um projeto de construção de cabo aéreo-teleférico sobre o rio Jacuí, levando de uma margem a outra a produção de carvão para abastecer os vagões da viação férrea (SILVA, 2007). Entre 1932 e 1939, a produção de carvão mineral do Rio Grande do Sul correspondia a $82 \%$ da produção nacional.

A partir de 1932, a empresa de Butiá foi adquirida pelo grupo Martineli, tendo Roberto Cardoso como diretor geral. ${ }^{55}$ Figura controversa na história carbonífera da região, Cardoso pode ter sido determinante para os ciclos de desenvolvimento econômico e político dessas companhias, principalmente após a fusão da CEFMSJ com a CCR em 23 de junho de 1936. A fusão deu origem ao Consórcio Administrador de Empresas de Mineração (Cadem), cujo auge na exploração de carvão ocorreu no final dos anos 1930 e início dos anos 1940, durante a Segunda Guerra Mundial.

Ao projetar um desenvolvimento acelerado para a indústria nacional, a aposta era uma iniciativa para se superar o atraso econômico desenhado, longamente, pelo modelo exportador de matérias-primas e alimentos que caracterizou o país. Essa política de desenvolvimento acelerado, como reconhece Francisco Corsi, não refletia apenas o problema de proteção dos setores fundamentais, mas

o discurso e as medidas implementadas no sentido de criar um verdadeiro mercado nacional sugerem que o projeto de desenvolvimento era muito mais do que um programa de crescimento acelerado; consistia em um verdadeiro projeto de

\footnotetext{
55 Para Simch (1961, p. 212), Roberto Cardoso era lembrado por "uma obra de assistência social de extraordinário alcance". Para maiores detalhes, ver também Speranza (2007; 2013).
} 
consolidação da nação a partir da hegemonia do capitalismo industrial. Ou seja, a política industrializante implementada no pós-1930 parece ter sido muito mais decorrente da necessidade de consolidar a nação do que garantir a reprodução ampliada do capital (CORSI, 2002, p. 6).

No campo econômico, os primeiros anos do governo provisório podem, de fato, ser explicados pela constante referência ao termo nação. Em uma visão ampla, o termo era utilizado como uma nova estratégia de união entre as regiões, ressentidas pelas experiências de exclusão promovidas no âmbito da política dos governadores, ou política do café com leite, como ficou reconhecida na literatura política nacional. Assim, todas as regiões, setores produtivos e novos atores políticos e sociais inseriam-se em uma plataforma política inédita. Como registrou Cabral (2011, p. 12), "a pactuação levada a cabo por Vargas e seu staff, capaz de garantir algum tipo de coesão, organicidade e funcionalidade ao poder entre 1930 e 1937, [ao apoiar-se] na ressignificação do tema federalismo, invocando fortemente o conceito de integração nacional", estabeleceu alterações expressivas na forma como a consolidação das políticas econômicas ecoava entre as regiões. ${ }^{56}$

Desse modo, como registra Corsi (2002), em uma visão ampla sobre a aposta na industrialização nacional, e Silva (2007), em uma visão mais localizada nas minas de carvão, as conjunturas econômicas mundial e nacional promoveram uma alteração na pactuação política e econômica que as empresas de mineração passariam a incorporar em seus discursos sobre as dificuldades e a crise na exploração do carvão. Contudo, não se pode ignorar o fato de que as jazidas de minérios passaram a ser elemento de grande interesse nacional, sobretudo, por serem consideradas essenciais à defesa econômica e militar do país (art. 119, parágrafo $4^{\circ}$, da constituição de 1934).

Abandonando os discursos de crise, a CCR - principalmente após o grupo Martineli assumir todas as minas de carvão em Butiá, sob a liderança de Roberto Cardoso - promoveu "um modelo de administração que manteve o direcionamento de suas atividades na busca pela ampliação e diversificação de investimentos, bem como de uma postura de parceria com os órgãos governamentais e os principais dirigentes do país" (SILVA, 2007, p. 154).

Nesse aspecto, as ligações entre Cardoso e o ex-ministro do Trabalho, Lindolfo Collor, podem ser exemplificativas. No fundo de arquivo dedicado ao ex-ministro no CPDOC/FGV, foi possível encontrar trocas de correspondência entre Roberto Cardoso e Lindolfo Collor. ${ }^{57}$ Segundo Speranza (2012), tanto a CEFMSJ e a CCR eram companhias de capital aberto, e o ex-ministro

\footnotetext{
${ }^{56}$ Para um aprofundamento deste tema, ver também Bastos e Fonseca (2012).

${ }^{57}$ CPDOC, Arquivos pessoais. Fundo Lindolfo Collor, Manuscrito, Série Correspondência, Classificação LC c 1932.07.13, microfilmagem rolo 2 fot. 956.
} 
possuía ações da empresa CCR na bolsa de valores. ${ }^{58}$ Na correspondência de 13 de julho de 1932 , Cardoso convidou Collor para ser diretor da Companhia Carbonífera Rio-Grandense.

Silva (2007) destacou outra missiva entre os dois, em que Collor solicitava a Cardoso que se dedicasse à leitura de um artigo seu, que sairia na imprensa sobre suas opiniões em uma visita realizada nas minas de Butiá. No artigo A organização social da Carbonífera RioGrandense: as impressões do Dr. Lindolfo Collor na recente excursão às minas do Butiá, ${ }^{59} \mathrm{o}$ ex-ministro lançava uma série de elogios à organização social da empresa, especialmente, aos serviços de assistência social, "dos melhores e mais adiantados no país", acrescentando, ainda, a remuneração compatível dos trabalhadores e a perfeita confraternização entre dirigentes e dirigidos. Paradoxalmente, em 27 de janeiro de 1933, as minas de Butiá enfrentariam uma greve geral com mais de 400 mineiros. Entre as pautas, destacavam-se os atrasos de salários no decorrer de 1932, pagos, muitas vezes, por vale-alimentação vinculados às próprias cooperativas de alimentos e produtos das companhias mineradoras, e as péssimas condições de trabalho no interior das minas.

Enquanto ministro do Trabalho, Lindolfo Collor foi o principal responsável pelas transformações na relação entre capital e trabalho no início do governo provisório de Vargas. Os decretos de reforma nas CAPs, sindicalização, nacionalização do trabalho na marinha mercante, regulamentação da jornada de trabalho e do projeto de constituição das juntas de conciliação e julgamento, por exemplo, foram articulados em sua gestão. A principal característica de suas ações na pasta do trabalho era a matriz de solidariedade nacional para a composição dos conflitos entre capital e trabalho. Deixando o ministério em março de 1932, por divergências com a ala tenentista do governo provisório, exilou-se na Argentina após a derrota dos paulistas na Revolução Constitucionalista de 1932.

Retornando à estratégia das empresas de estabelecer novos parâmetros de cooperação com os órgãos públicos estaduais e, especialmente, com Getúlio Vargas, a fusão das companhias Carbonífera Rio-Grandense e Estrada de Ferro e Minas de São Jerônimo, em 23 de junho de 1936, refletiu uma nova etapa da mineração no Estado. Com a criação do Cadem,

\footnotetext{
${ }^{58}$ Speranza (2012, p. 46, notas de rodapé 46 e 47) identificou ainda dois acionistas conhecidos nessas companhias. Guilherme Guinle, pela CEFMSJ, provinha da família proprietária da concessão da Companhia Docas de Santos, da qual foi presidente. "Durante o Estado Novo, foi vice-presidente do Conselho Técnico de Economia e Finanças do Ministério da Fazenda. Nesse órgão, manifestou-se contrário à participação de capitais estrangeiros na exploração das riquezas minerais brasileiras e defendeu a montagem de uma grande empresa estatal no setor siderúrgico. Foi também o primeiro presidente da Companhia Siderúrgica Nacional". O Barão de Saavedra, vinculado à CCR, foi o presidente do Banco Boavista. Foi um dos financiadores da edição do periódico $A$ manhã, pelo jornalista barão de Itararé.
}

59 CPDOC, Arquivos pessoais. Fundo Lindolfo Collor, Manuscrito, Série pi - Produção Intelectual, Classificação LC pi 1932.06.00, microfilmagem rolo 06 fot. 0039. 
que assumiu as responsabilidades da CEFMSJ - inclusive atuando no processo $\mathrm{n}^{\circ}$ 9.582/1934 por sucessão -, a exploração e a circulação de carvão mineral atingiram novos patamares.

O Cadem foi organizado em sociedade por Roberto Cardoso e o grupo Martineli, Paes Leme e Otávio Reis pela CEFMSJ. Sua organização administrativa e econômica era diferenciada. As fontes consultadas no Museu Estadual do Carvão permitem vislumbrar que o Cadem, sob liderança de Roberto Cardoso, patrocinou o desenvolvimento econômico e estrutural das minas, ampliando o sistema das vilas-fábricas com crescente urbanização. Em Arroio dos Ratos e Butiá, há relatos de construção de escolas, residências, hospitais, cinemas, clubes de lazer e igrejas pelo Cadem. Essa estrutura, por consequência, promoveu complicações para a delimitação entre público e privado nas minas, especialmente pelo vínculo dos engenheiros diretores das companhias (que, embora consorciadas, ainda exerciam relativa autonomia em seus poços de mineração) com os delegados de polícia nos distritos de São Jerônimo, conforme demonstravam os relatos dos historiadores decorrentes de pesquisa in loco.

Poucos dias após a fusão, o governo provisório permitiu o aumento no percentual mínimo de consumo de carvão brasileiro no país para 20\%, tornando o Cadem líder absoluto na industrialização do carvão. Speranza (2012, p. 47, gráfico 1), com base nos anuários estatísticos do Instituto Brasileiro de Geografia e Estatística (IBGE), ${ }^{60}$ apontou que, entre $1936^{61}$ e 1944, a produção de carvão no Rio Grande do Sul aumentou de 500 mil toneladas para mais de 1.300 milhão de toneladas.

Com a constatação do aumento na produção e na ampliação da infraestrutura das minas de carvão, compreender a perspectiva social em que se inseria a CEFMSJ torna-se necessário. Se Bunse (1984) registrou a presença de 1.000 mineiros em Arroio dos Ratos em 1895, as projeções em 1930-1940 apontavam para a existência de, aproximadamente, 7.000 mineiros atuando diretamente na exploração carbonífera.

Logo após a criação do Cadem, em outubro de 1936, as minas de Arroio dos Ratos sofreram os efeitos de uma grande enchente, com inundação de poços e galerias das minas. A região era permeada por arroios interligados diretamente ao rio Jacuí, ao norte das minas. Comprometida a vazão das águas do Jacuí, o curso do rio adentrou nos arroios locais, prejudicando diretamente a empresa em Arroio dos Ratos. Com a paralisação das atividades

\footnotetext{
${ }^{60}$ IBGE - Instituto Brasileiro de Geografia e Estatística. Anuário estatístico do Brasil. Ano VI - 1941/1945). Rio de Janeiro: IBGE, 1946.

${ }^{61}$ Silva (2007, p. 163) registrou que em 1936 foram extraídas pelo Cadem 69.594 toneladas de minério. Em 1937, a produção chegava a 762 mil toneladas, ultrapassando a cifra de 1 milhão de toneladas já em 1939. Com a fundação da Companhia Siderúrgica Nacional, em 1943, e com a Segunda Guerra Mundial, a região produzia mais de 2 milhões de toneladas.
} 
de mineração, toda a estrutura foi deslocada para as minas de Butiá, Recreio, Minas do Leão e Charqueadas, inclusive com transferência de trabalhadores.

Segundo Silva (2007), a formação do consórcio foi essencial para evitar o colapso no fornecimento de carvão em decorrência da inundação de 1936. Isso permitiu um maior protagonismo das minas de Butiá, que assumiram os compromissos de abastecimento com as empresas ferroviárias e de energia em Porto Alegre, antes compartilhado com as minas de Arroio dos Ratos.

Os principais trabalhos que resgatam as memórias desses trabalhadores nas minas de carvão registram a organização desses operários nos sistemas de vilas-fábricas, em que as empresas de mineração promoviam infraestruturas semelhantes às das cidades, com construções de ruas, casas, escolas, hospitais, clubes sociais, cinemas, farmácias, serviços de água e energia, conforme já mencionado anteriormente. A história da cidade de Arroio dos Ratos, emancipada em 28 de dezembro de 1964, confunde-se com esse sistema das vilasfábricas, desenvolvido ao longo do tempo.

Desse modo, como acrescenta Speranza (2012), até a ordem pública era regulada por policiais ligados às empresas de mineração. Assim, sob a perspectiva social, a CEFMSJ pode ser compreendida sob dois pontos de vista: o primeiro, relacionado ao processo de desenvolvimento local, com prestações de serviços como educação, saúde, lazer, etc.; e o segundo, pela forma como os conflitos sociais entre capital e trabalho eram compatibilizados dentro dessa estrutura. Por ser mais próximo ao objeto desta pesquisa, o foco se dará nesse último aspecto.

As baixas remunerações, a inexistência de condições de salubridade e os desafios técnicos para a segurança do trabalho nas companhias carboníferas se conectavam diretamente com as reações dos trabalhadores mineiros, que, diante da publicização dos decretos que estabeleciam garantias trabalhistas, passavam por uma ressignificação política de sua própria condição. Essas reações eram captadas, essencialmente, pelos movimentos de greve dos mineiros.

Nesse sentido, por um lado, o sindicato dos mineiros transformou-se em um instrumento expressivo para a composição dos conflitos e a pactuação de estratégias na relação entre capital e trabalho.

Por outro lado, a interferência do Estado - com suas práticas reguladoras do mundo do trabalho -, aliada à atuação do Conselho Nacional do Trabalho, e posteriormente, à criação da Justiça do Trabalho, não pode ser ignorada. A médio e a longo prazo, tal configuração 
promoveu transformações de comportamento e ações de empregadores e empregados diante do novo cenário industrial, alcançando impacto inédito com a Consolidação das Leis do Trabalho (CLT), em 1943.

A partir da leitura da reclamação trabalhista, foi possível encontrar, nos documentos pesquisados e nas fontes consultadas, amplas possibilidades narrativas, que estimularam questionamentos sobre os testemunhos que foram emergindo.

O caso dos mineiros de Arroio dos Ratos deve ser compreendido dentro de um movimento de mudança, a ser analisado pela perspectiva do desafio que o uso do direito conferiu aos novos "locais de direito" 62 . A presença do sindicato, a ritualização do processo que aplica o direito escrito a um caso concreto, mediado por uma instituição com força cogente, produz uma narrativa de resistência por parte da empresa que, até certo ponto, pode auxiliar a análise sobre eventuais contradições, avanços e limites dentro da nova ordem constitucional em 1934.

Para decifrar essas questões, o caminho seguido foi o de inseri-las em um contexto documental mais vasto. A partir do processo, a atuação do sindicato dos mineiros e a construção da defesa por parte da empresa se sobressaíram, pois colocaram em destaque o uso do direito dentro de um procedimento amplo em que se disputava a (des)politização da reclamação. São duas perspectivas que se situam em camadas sobrepostas; empresa e sindicato competem pela institucionalização de um novo espaço inédito.

Neste capítulo foi possível oferecer uma contextualização dos mineiros delineada a partir de seus registros civis e do testemunho narrativo e documental da criação do sindicato em 1933, situando-o dentro de um espaço de institucionalidade que, a todo momento, buscou respaldo na nova ordem constitucional. Com o levantamento dos dados sobre a condição política, econômica e social da companhia, suas estratégias e contradições podem ser apreciadas dentro de uma perspectiva de resistência e, por mais que possa fazer sentido naquele momento, não deixa de refletir os limites que o direito impôs sobre o “comportamento privado" da companhia em relação aos novos direitos do trabalho.

\footnotetext{
${ }^{62}$ Indiretamente, o uso do termo "locais de direito" faz referência a Giddens (2008). Em sua crítica sobre o suposto caráter evolucionista dos direitos em civis, políticos e sociais, proposto por Marshall (1967), Giddens acentua o papel das lutas dos trabalhadores em seu estabelecimento de trabalho, a ponto de substituir o próprio conceito de direitos sociais por direitos econômicos. Nesse sentido, Domingues (2008, p. 19) ainda acrescenta que "essa decisão teórica parece derivar de sua busca por um 'local' onde se realizariam os direitos, que, por outro lado, associavam-se historicamente, e em grande medida nascem mesmo, de tipos específicos de vigilância, em torno dos quais 'disputas' e 'conflitos' se desdobram”.
} 


\section{TRABALHO, CONFLITO E NOVOS DIREITOS: o processo de transformação social} a partir da nova ordem constitucional

A reclamação trabalhista $n^{0}$ 9.582/1934 foi processada perante o Conselho Nacional do Trabalho entre setembro de 1934 e janeiro de 1941, quando foi arquivada. Em pouco mais de cinco anos, as principais decisões de mérito ocorreram em novembro de 1934, abril de 1935, junho de 1936 e setembro de 1938.

Em cada uma dessas decisões, foi possível identificar, a partir do tratamento intensivo das fontes, uma circularidade de regras jurídicas e outras estratégias que afloraram as contradições e imprecisões de práticas cotidianas, especialmente as ligadas aos sistemas repressivos que margeavam as relações de trabalho.

A riqueza dessas fontes reside, precisamente, na natureza contraditória das várias tensões que marcam o processo de constitucionalização dos direitos do trabalho para os mineradores. Ao se colocar as fontes em diálogo com os registros de intertextualidade produzidos nos autos, a leitura do processo permite construir uma realidade historiográfica que se situa dentro de um paradigma constitucional inédito, preconizado pela transição do governo provisório varguista para a Constituição de 1934.

O processo foi instruído com estrita observância das "regras do jogo". Das estratégias dos mineiros à contestação da companhia, os usos do direito foram explorados em várias ocorrências. O jogo de interesses trouxe à tona mecanismos de solidariedade típicos do mundo do trabalho: para evitar o enfrentamento, os mineiros buscavam desconstruir a representação da empresa com o apelo à lei. Essa escolha, ao mesmo tempo que legitimava o pedido de reintegração dos mineiros, escondia uma realidade diversa da história oficial sobre o tema trabalho, sindicalismo e direitos (civis, políticos, sociais e econômicos) divulgada pelo governo provisório (1930-1934).

Em muitas situações, o contraste produzido pelas realidades diversas camuflou os limites, avanços e retrocessos no mundo do trabalho em face da nova ordem constitucional. Assim, reconhecê-los passou a ser relevante em decorrência das contradições que fundamentavam. Um dos desafios da micro-história é trabalhar no nível das contradições e ambiguidades e não contra estas ambiguidades, a fim de que seja possível tirar partido delas (BARROS, 2007). É nessa perspectiva que esta pesquisa se desenvolveu: a partir do processo, reduzir a escala de observação visando compreender aspectos que poderiam passar despercebidos em uma determinada prática social e, com isso, oferecer uma contribuição à história do direito constitucional. 
O ponto de partida é o retorno às primeiras informações de demissões dos mineiros emitidas pela companhia em 22 de agosto e 11 de dezembro de 1934. Movimento de greve, desobediência ou desistência do trabalho foram as principais razões levantadas para a empresa promover a despedida dos sete mineiros, configurando, desse modo, o abandono de emprego. No curso do processo, outras razões vieram à tona e a partir desses indícios, identificar como as regras jurídicas e estratégicas eram marcadas pela circularidade do medo e expectativas sobre a condição de cidadania, a partir do trabalho, passa a ser uma das metas deste capítulo.

\subsection{Greve, expulsão e abandono de emprego: revisitando os argumentos da companhia a partir de novos indícios}

Em 22 de agosto de 1934, a companhia oficiou ao inspetor da $11^{\text {a }}$ Inspetoria do Conselho Nacional do Trabalho, Evandro Lobão dos Santos, um sucinto relato sobre as demissões dos trabalhadores.

No primeiro grupo, Liberalino Machado de Lima, Raphael Mezza, Antônio Nunes das Pedras e Adalberto Azambuja dos Santos foram demitidos da empresa por abandono de emprego. Segundo o diretor da companhia, Georges Gougenheim, "foram expulsos das minas em março do corrente ano, pelas autoridades policiais, como indesejáveis”. Desses trabalhadores, Raphael e Antônio eram estrangeiros, não sendo possível identificar a nacionalidade de Adalberto. Pesava contra Adalberto, Antônio e Liberalino ou Januário a comprovação de estabilidade decenal. A Liberalino ou Januário somava-se o agravante de comprovar que se tratava da mesma pessoa.

A narrativa sobre a greve não foi construída nesse primeiro momento pela CEFMSJ. Curiosamente, o argumento surgiu depois de 16 de novembro de 1934, quando o CNT, ao julgar o caso, posicionou-se pela conversão do julgamento em diligência. Com essa medida, a companhia ficaria obrigada a enviar o inquérito administrativo original que deveria ter precedido a despedida dos reclamantes, bem como os certificados de tempo de serviço e a folha de antecedentes dos mineiros reclamantes.

Assim, o termo "greve" surgiu nos autos pela primeira vez quando a companhia embargou a decisão do conselho. Colocando-se como "isenta de responsabilidade" nas demissões, a companhia ampliou seus argumentos, a ponto de incluir a força policial em outro nível de ambiguidade. Explorou um arranjo contextual linguístico e situacional que não indicava, precisamente, qual a interpretação mais correta para o caso, e buscava a legitimação diante do CNT como uma empresa que cumpria as normas trabalhistas. Ao mesmo tempo que 
inseriu nos autos a informação de que os trabalhadores foram expulsos das minas pela autoridade policial acusados de tramarem uma greve geral entre os mineiros, a companhia responsabilizou a polícia pelos prejuízos causados, uma vez que, após apurações, verificou-se que tais denúncias eram destituídas de fundamento.

As fontes examinadas não permitiram afirmar se houve movimento de greve ou não. Contudo, uma vez que a empresa passou a utilizar esse suposto movimento como justificativa para a expulsão dos trabalhadores pela polícia, o termo "greve" se incorporou às decisões do CNT. A ponto de constar do acórdão de 2 de junho de 1936 a afirmação de que "à vista dos elementos constantes dos autos, fica evidenciado que os empregados reclamantes, por terem tramado uma greve geral entre os mineiros, foram expulsos do serviço da mina pela polícia, que os prendeu para averiguação e processo criminal posterior". ${ }^{1}$ Tratava-se da primeira acepção que o termo indesejável assumia nos autos, empregado para qualificar os trabalhadores que promoviam greves.

A forma como o vocábulo "greve" foi utilizado no processo pode ser reveladora em relação aos problemas sociais que emergem dessa investigação. A primeira abordagem a ser destacada corresponde aos documentos indicando tempo de serviço dos trabalhadores apresentados pela companhia. Adalberto, Antônio, Raphael e Liberalino foram considerados empregados da companhia até o dia 6 de março de 1934. Se os dados oferecidos pela empresa podem ser considerados corretos, o abandono de emprego foi configurado na mesma ocasião em que a autoridade policial compareceu às minas, devido à suposta greve, e expulsou os trabalhadores, ou seja, na segunda-feira do dia 6 de março de 1934. Mas até que ponto as fontes disponíveis podem auxiliar na reconstrução desse fato?

A primeira iniciativa foi buscar indícios, provas, relatos e quaisquer registros que pudessem subsidiar os desdobramentos que o eventual movimento de greve - alegado pela companhia como justificativa para a expulsão dos mineiros pela polícia - provocou no início de março de 1934. Com a redução na escala de observação, o foco de busca concentrou-se no livro de registro de correspondências do diretor da companhia em Arroio dos Ratos, com especial atenção aos meses de fevereiro e março de 1934. Na análise do fundo CEFMSJ - no MCAR - não há registros de troca de ofícios entre o diretor e polícia local e, consequentemente, não constam referências a qualquer movimento de greve. Assim, a alternativa foi pesquisar nos arquivos históricos da polícia em São Jerônimo e Porto Alegre. Sem provas do movimento de greve ou inquérito policial sobre a prisão e expulsão dos

\footnotetext{
${ }^{1}$ Fls. 96-97 do processo $n^{\circ}$ 9.582/1934.
} 
mineiros, a reconstrução do suposto movimento tornou-se mais complexa, tornando difícil oferecer explicações plausíveis sobre o que realmente acontecera, principalmente para auxiliar na reflexão sobre as atuações da empresa e da polícia nas minas de carvão.

A confirmação da expulsão dos trabalhadores foi realizada pela empresa e ratificada pelo delegado de polícia, José Maria de Carvalho, mas sua justificativa gerava desconfiança. Muito embora o CNT tenha acatado sem resistência o discurso da companhia de que a reclamação havia se originado com um movimento de greve, as evidências indicavam para outras possibilidades.

Com essa perspectiva, foram consultados os jornais Correio do Povo, A Voz do Trabalhador e Diário de Notícias. O objetivo era encontrar, nas seções sobre o movimento sindical gaúcho ou nas reportagens sobre as cidades, ${ }^{2}$ eventuais notas que fizessem referência à greve ou confronto de trabalhadores com a polícia. Entre fevereiro e março de 1934, os registros não indicavam possíveis movimentos de greve; as atenções jornalísticas eram voltadas à visita oficial do ministro do Trabalho, Joaquim Pedro Salgado Filho, a várias cidades do Rio Grande do Sul.

Em 28 de fevereiro de 1934, o ministro Salgado Filho chegou a São Jerônimo. Na edição de $1^{\circ}$ de março de 1934, o Correio do Povo apresentava a manchete: "Depois de receber nas minas de São Jerônimo uma grande manifestação dos operários, o ministro do Trabalho foi, ontem à noite, homenageado pelo governo do Estado com um banquete no Grande Hotel".

A informação de que o ministro fora recebido por "uma grande manifestação dos operários" chamou a atenção. Teriam os reclamantes Adalberto Azambuja dos Santos, líder sindicalista que perdeu as eleições para o sindicato dos mineiros em setembro de 1933, em conjunto com Raphael Mezza, Antônio Nunes das Pedras e Liberalino Machado de Lima sugerido resistência ou organizado indicativo de greve durante a visita do ministro? Como a empresa ou sindicato teriam respondido às possíveis movimentações desses trabalhadores?

Sobre as resistências ou manifestações contra as péssimas condições de trabalho, o jornal não trouxe notícias, mas registrou todo o percurso do ministro até as minas. Chegando de embarcação pelo rio Jacuí, o ministro do Trabalho foi recebido pelo prefeito de São Jerônimo, José Maria de Carvalho, o diretor do porto, comandante João Vicente da Cruz e "grande número de funcionários da companhia que vivaram com entusiasmo o dr. Salgado Filho", destacava o jornal.

\footnotetext{
${ }^{2}$ Nos jornais era comum uma seção destinada aos assuntos sindicais do Rio Grande do Sul.
} 
A viagem de trem até as minas de Arroio dos Ratos durou cerca de uma hora, e "ao passar o trem pela sede dos escritórios, os funcionários que ali se premiam ergueram vivas calorosos ao ministro do Trabalho. O trem foi parar bem em frente aos poços das minas, onde estavam engenheiros e chefes de serviços e se premia uma enorme multidão de mineiros, vivando com entusiasmo sua excelência”, descrevia o periódico.

Figura 9 - Mineiros de Arroio dos Ratos recepcionam Joaquim Pedro Salgado Filho, ministro do Trabalho, Indústria e Comércio, em 28 de fevereiro de 1934

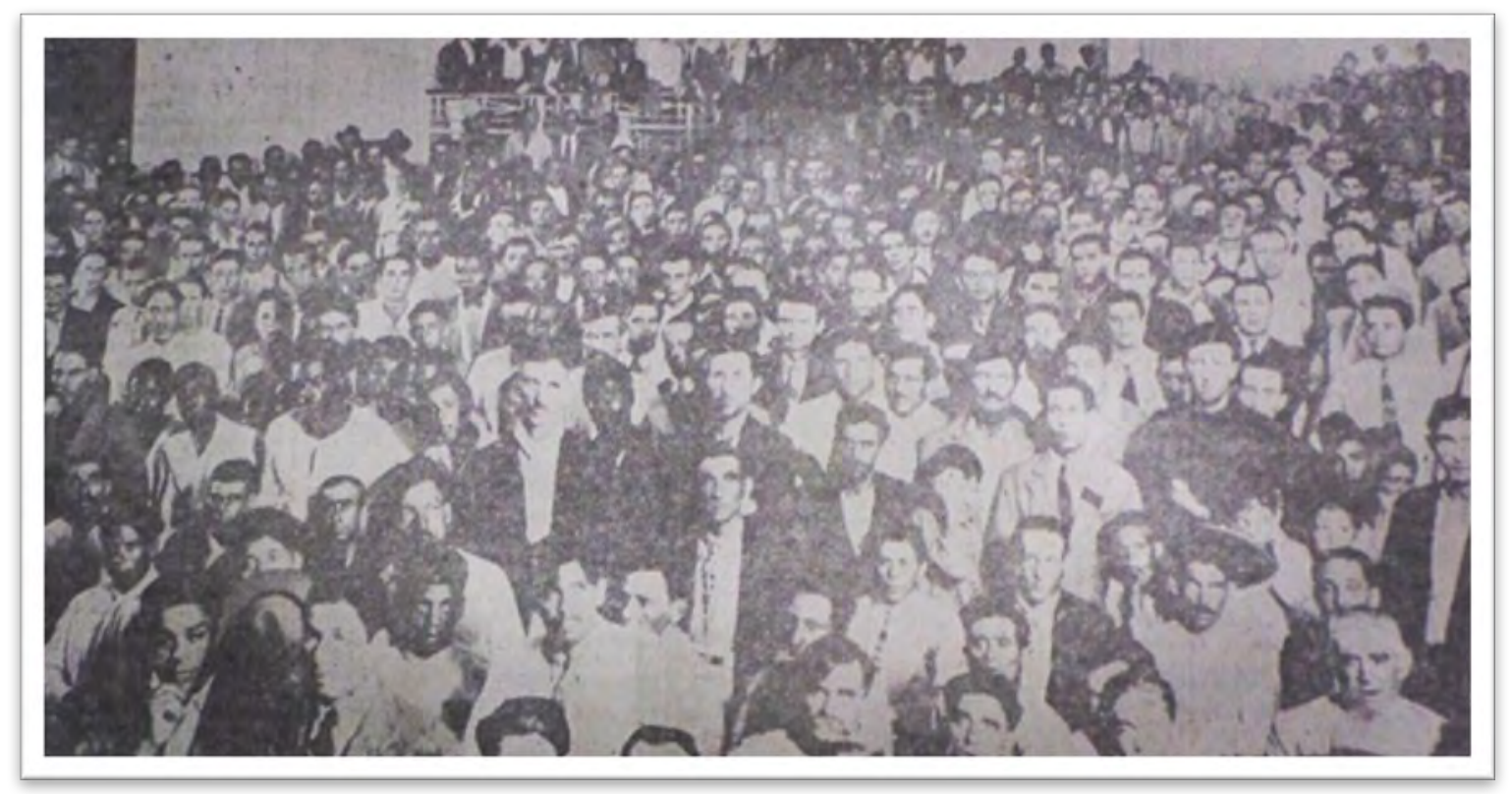

Fonte: Diário de Notícias, $1^{\circ}$ de março de 1934, p. 1.

O tom festivo que marcou a visita do ministro do Trabalho nas minas de Arroio dos Ratos contrasta significativamente com a realidade das minas. A chegada da legislação trabalhista aos mineiros não encerrava as péssimas condições de trabalho, mas oferecia, contudo, garantias de proteção que poderiam ser exploradas. Nesse aspecto, o sindicato dos mineiros exerceu papel importante na proteção dos direitos dos trabalhadores, mas que precisava ser matizado sob outra perspectiva, isto é, na verificação de ações concretas que pudessem, dentro do sistema repressivo nas minas de carvão, dar efetividade às leis de proteção.

Na visita, Salgado Filho conheceu um dos poços de extração do carvão. A todo momento, o jornal relatava a recepção entusiástica oferecida pelos mineiros com a presença do ilustre representante do governo provisório. Segundo o relato, o ministro foi saudado, em nome do sindicato dos mineiros, por Casemiro Villa Nova. Descendo pelo elevador do poço a 
65 metros de profundidade, "empunhando uma bengala de mineiro que lhe deram, percorreu as galerias à luz das respectivas lanternas, ouvindo e pedindo explicações de tudo que observava. Viu o trabalho no fundo das minas, com cujos operários falou, interessando-se pelo seu labor".

Após a visita na mina, o ministro foi recebido no escritório da companhia pelo advogado Euribyades Dutra Villa, que, em nome da CEFMSJ, saudou-o, salientando que aquele momento representava "o resultado da soma de sacrifícios ingentes" e que a companhia sempre contava com o apoio dos poderes públicos. Ainda na presença do ministro, pretendeu com seu discurso construir uma narrativa que privilegiasse as ações da companhia em face do mundo do trabalho, alegando que

Quanto às leis sociais [...] posso dizer que a companhia tem procurado cumprir à risca as diversas leis emanadas do Ministério do Trabalho. Se é verdade que dúvidas têm surgido na interpretação da "mens legis", é verdade também que sempre temos encontrado nos drs. Ernani de Oliveira e Evandro Lobão dos Santos, todas as vezes que os procuraram, os necessários esclarecimentos. Aqui há a verdadeira democracia do trabalho - chefes e operários se dão as mãos e se ajudam mutuamente (CORREIO DO POVO, $1^{\circ}$ de março de 1934, p. 9).

No discurso, Dutra Villa não deixou de fazer referência ao sindicato dos mineiros, principalmente, ao comunicar que a companhia havia mandado construir, com recursos próprios, "um alteroso edifício para a sede do sindicato". Em resposta, o ministro do trabalho afirmou que:

Ao chegar a este lugar, onde o trabalho se executa para o bem do Brasil, folguei em ser bem recebido pelos diretores desta importante empresa ao lado da comissão de operários que com eles me esperava no cais para darem-me as boas-vindas. Este fato encheu-me de satisfação, demonstrando, finalmente, que a nossa legislação vai ser compreendida, isto é: o operário e o patrão cooperando para um fim único, o progresso da empresa para o bem de todos. Assim sendo, agradeço as homenagens a mim prestadas e faço ardorosos votos para que essa confraternização continue para o progresso desta empresa, que é um dos grandes fatores do progresso do Brasil [...] Vamos visitar o Sindicato dos Mineiros [...]. (CORREIO DO POVO, $1^{\circ}$ de março de 1934, p. 9).

O jornal Correio do Povo também cobriu a visita ao sindicato. Ao sair do escritório da companhia, Salgado Filho, acompanhado dos mineiros, foi em comitiva para o teatro central, na praça Borges de Medeiros. O referido jornal informava que "regurgitava de operários e suas famílias, penetrando o ministro sob palmas estrondosas e ao som de uma excelente orquestra formada por operários". Compuseram a mesa o ministro, o prefeito de São Jerônimo, José Maria de Carvalho, o inspetor do MTIC, Ernani de Oliveira, major Venâncio Baptista, cônsul Di Pasca, capitão Luiz Pereira, subprefeito do distrito das Minas, Castor Bispo e Gustavo Muller, respectivamente, presidente e tesoureiro do sindicato dos mineiros. 
Figura 10 - Sessão do Sindicato dos Mineiros, em 28 de fevereiro de 1934. Ao centro, o ministro Joaquim Pedro Salgado Filho, à sua esquerda, o prefeito José Maria de Carvalho

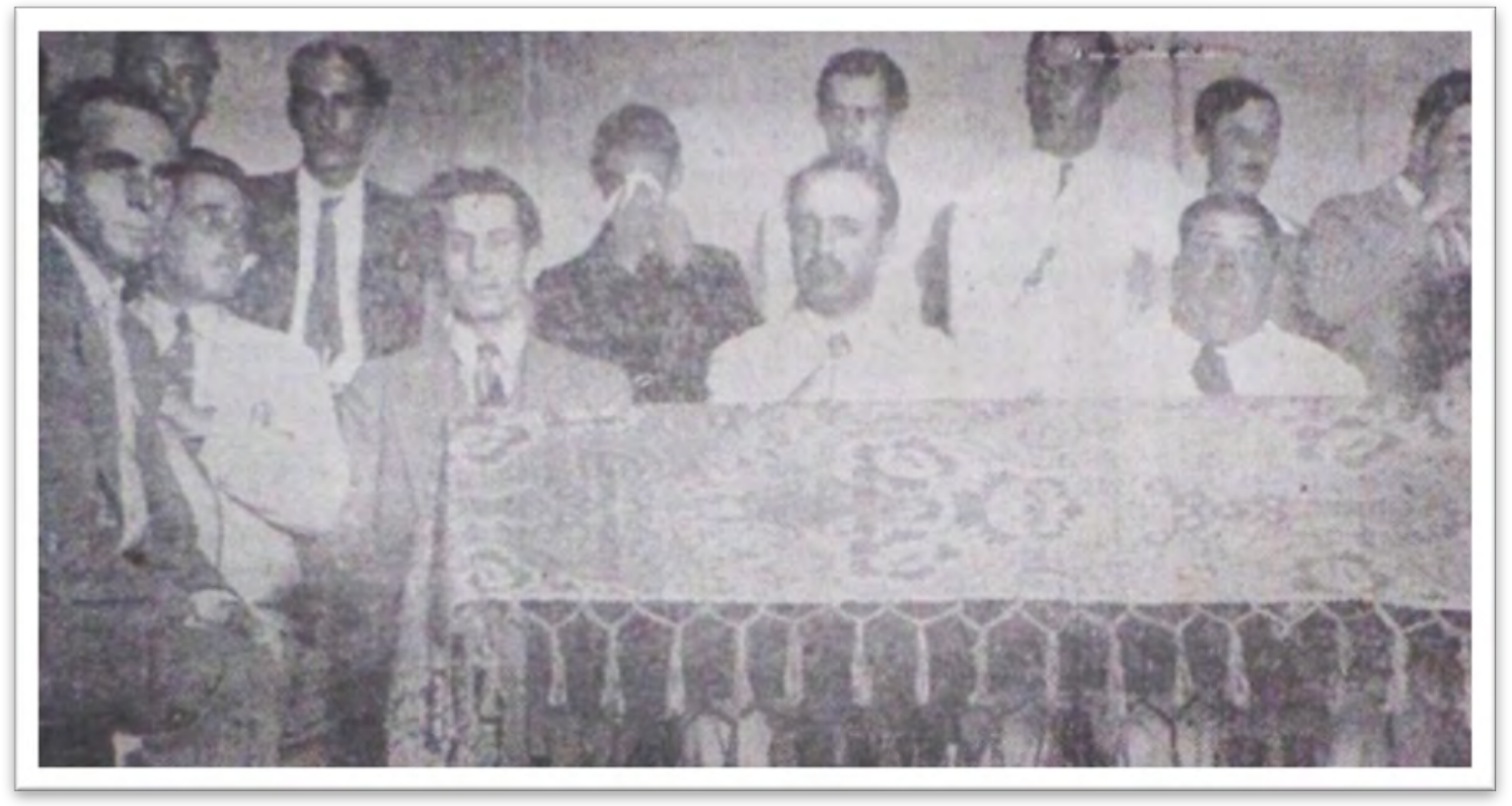

Fonte: Diário de Notícias, $1^{\circ}$ de março de 1934, p. 1.

$\mathrm{Na}$ reunião, o secretário do sindicato, João Pereira, registrou que a principal solicitação dos mineiros era o cumprimento das leis emanadas pelo ministério, "leis essas que já um pouco os têm confortado". E, na sequência, promoveu uma defesa pública ao presidente do sindicato, destacando que este havia sofrido ataques recentes por "elementos que perturbam a classe".

O jornal não avançou sobre o discurso, deixando de esclarecer a natureza do dissenso anunciado. No entanto, acrescentou que, após a defesa, o secretário do sindicato pediu desculpas ao ministro para perguntar aos mineiros presentes se estavam ou não satisfeitos com a atuação do presidente do sindicato. Em uma só voz, os mineiros teriam dito que estavam satisfeitos.

O jornal Diário de Notícias, por sua vez, trouxe um relato mais completo da fala do mineiro frente ao ministro. Segundo consta, João Pereira teria dito:

Sr. Ministro do Trabalho. Não sei com que expressões hei de externar o imenso contentamento dos operários das minas do Arroio dos Ratos ao ter-vos como hóspede por alguns instantes. $O$ sindicato das minas, representado por seu presidente, me delegou poderes para vos saudar e agradecer vossa gentileza de terdes atendido a humilde solicitação de que viésseis visitar a nossa sede. Damos, todos, graças, entre estes heróis do progresso que, soterrados mesmo em vida, promovem a estabilidade e o estímulo da indústria nacional! Sr. Ministro, estes homens, que não medem esforços para corresponder à confiança que lhes é 
depositada, nada exigem que não o cumprimento das leis emanadas por vossa excelência, as quais já muito nos têm beneficiado. Entretanto, sr. Ministro, há de lamentar que alguns elementos, indiscutivelmente indesejáveis, tentem, de vez em quando, lançar entre nós a discórdia por meio de intrigas e inverdades, como se verificou há pouco, em entrevista concedida a um jornal portoalegrense por um graduado da Federação Operária que, certamente, mal informado, afirmou: "Nas minas do Arroio dos Ratos os operários são pagos "com fichas e vales e o comércio só é permitido num círculo de 18 quilômetros". Também um jornal ali publicado, e que se intitula a voz da classe trabalhadora, cobriu de doestos a pessoa do nosso presidente. Daí ser de inteira justiça que a diretoria deste sindicato tratasse, como tratou, de desmentir categoricamente tais aleives, pois, não os merece o nosso presidente, um homem que há dezesseis anos exerce a contento geral a modesta, mas honrosa profissão de operário; o que não sucede com seus detratores, os quais vivem no mais suave conforto... Felizmente, graças à ação das autoridades locais, essas "doutrinações" aleivosas não têm surtido o desejado efeito. Em parte, têm razão os incentivadores da desordem: eles não conhecem, como deviam, a vida de nossos mineiros. Estejais certo, porém, sr. Ministro, de que esses elementos terão a resposta à altura dos aleives veiculados pela imprensa, não neste momento, em que é motivo de júbilo a vossa presença entre nós e seria importuno perturbá-lo. Ainda assim, dr. Salgado Filho, teríamos desejo que interrogásseis um a um, todos os operários, para terdes a melhor confirmação do que acabo de dizer. Meus amigos: Ao terminar, convido a que nos descubramos respeitosamente em homenagem ao ministro e sua comitiva (DIÁRIO DE NOTÍCIAS, $1^{\circ}$ de março de 1934, p. 5).

O discurso de Salgado Filho aos mineiros pode ser sintetizado em três palavras: cordialidade, harmonia e solidariedade. O Diário de Notícias publicou na íntegra suas palavras:

\begin{abstract}
Senhores operários. É com grande satisfação que eu gozo o prazer de vosso convívio. Orgulho-me de sentir este ambiente de cordialidade e de harmonia entre o capital e o trabalho. Somente dessa harmonia, respeitando-se os direitos e deveres de cada um, nascerá o progresso para o bem geral. Dentro desse ambiente, podereis reclamar os vossos direitos, porque direitos lhes foram concedidos pelo governo da República. Hoje, o governo vos deu mais: a garantia de uma vida tranquila com a Caixa de Aposentadoria e Pensões que, no dia da invalidez ou da velhice, dá-vos a certeza de que vos será assegurado o pão e a saúde. E quando faltardes, vossas famílias não morrerão de fome, com as garantias necessárias, asseguradas por aquela instituição. Dentro de poucos dias, tereis, aqui, as habitações higiênicas e confortáveis, construídas pela carteira predial. Elas vos darão o conforto necessário e indispensável à saúde do corpo para prolongar a vida. [...] Prosseguia dizendo da satisfação que lhe produzia aquela assistência compacta e unida, e terminou pedindo que todos tivessem sempre em memória que as leis de amparo social emanam de um homem que viveu do trabalho e no trabalho se fez, e ergueu um viva ao sr. Getúlio Vargas. (DIÁRIO DE NOTÍCIAS, $1^{\circ}$ de março de 1934, p. 5).
\end{abstract}

O discurso do mineiro, relatado pelos jornais Correio do Povo e Diário de Notícias, chamou a atenção. Ao que tudo indicava, a natureza do conflito relatado estava no âmbito da própria organização trabalhista dos mineiros que, até certo ponto, não deixava de exteriorizar suas divergências. A referência à publicação na fala de João Pereira foi ao jornal $A V o z d o$ Trabalhador, periódico veiculado pela Federação Operária do Rio Grande do Sul e com fortes ligações com o partido comunista brasileiro, bem como o jornal A Voz Proletária. A presença do ministro Salgado Filho e de Ernani de Oliveira na sessão do SMAR, em 28 de fevereiro de 
1934, pode ser um indício relevante para compreender o alinhamento ideológico da direção do sindicato naquele momento: a orientação corporativista, capitaneada pelo governo provisório desde a instauração da legislação sindical e trabalhista. Possivelmente, essa orientação já movesse o sindicato desde quando assumiu um protagonismo ao participar como delegado nas eleições para a representação classista na Constituinte de 1933. Assim, esse movimento não refletia apenas as bases da organização dos mineiros mas também as demonstrações de resistência aos outros formatos sindicais, como os círculos operários e a FORGS.

Por mais que esse pleno apoio do SMAR às diretrizes do Ministério do Trabalho seja relevante, não se pode desprezar o conflito entre Ernani de Oliveira e a FORGS em outubro de 1933. Conforme relatado no capítulo anterior, o jornal Correio do Povo, ${ }^{3}$ na seção "Movimento Sindicalista no Rio Grande do Sul”, anunciou que a federação operária, em nome de 24 sindicatos, dirigiu ao ministro do Trabalho um telegrama denunciando a atuação do inspetor Ernani de Oliveira. Na prática, a reclamação era um pedido de afastamento do inspetor, acusado de praticar, inalteradamente, atitudes "contra legítimos interesses diretos dos operários e indisfarçável patrocínio sistemático da classe patronal”. O conflito, em si, mencionava a atuação do inspetor nos contratos de trabalho coletivos de certa empresa, com decisões sempre favoráveis aos interesses dos patrões. O inspetor é então denunciado como não cumpridor das leis do ministério, perseguidor gratuito, injusto aos direitos operários e, ainda, como estorvo à harmonia e tranquilidade de classes necessárias para a fácil e desejada colaboração entre capital e trabalho. E a alternativa pleiteada pela federação era abertura de sindicância contra Ernani de Oliveira para apuração dos fatos praticados contra os operários.

Nesse ponto, o interesse no conflito entre a FORGS e Ernani de Oliveira reside na forma como o SMAR reagiu ao impasse. Segundo a edição de 31 de outubro de 1933 do Correio do Povo, o sindicato dos mineiros não subscreveu a carta da FORGS contra Ernani para o ministro do Trabalho, porém, como esclareceu Fortes (1994, p. 163), houve uma reação em cadeia de descontentamentos que, até aquele momento, não estava exteriorizada no meio sindical. Segundo o Correio do Povo, na edição de 21 de novembro de 1933, ${ }^{4}$ houve a indicação de que o SMAR havia encaminhado, em relação aos conflitos, uma carta em solidariedade à FORGS.

A demonstração de apoio do sindicato à FORGS contra o inspetor Ernani releva um nível abstrato de contradição. Partindo desse fato, não seria impossível verificar que esse

\footnotetext{
${ }^{3}$ Edição de 31 de outubro de 1933, p. 6.

${ }^{4}$ Para mais informações, ver Lucas (1978).
} 
apoio encontrava guarida nas próprias estratégias de sobrevivência do sindicato frente à organização política dos trabalhadores. O jogo de interesses ditava o ritmo das estratégias. A federação operária contemplava um número relativamente alto de representação junto aos sindicatos, e suas ações traziam reflexos para o fortalecimento das próprias ações sindicais. Um dos principais exemplos foi a greve dos padeiros em Porto Alegre, que, de certo modo, antecipou a visita de Salgado Filho ao Rio Grande do Sul. ${ }^{5}$

Nesses termos, o apoio do sindicato à FORGS não representou um rompimento com Ernani de Oliveira e, certamente, não se constituiu como ponto de partida para resistências às ações do Ministério do Trabalho nas minas de carvão. No tratamento intensivo das fontes, por um lado, essas observações refletem uma interpretação possível, mas, por outro lado, não deixam claro até que ponto o apelo à linha tradicional do modelo corporativista camuflava os conflitos internos do sindicato dos mineiros.

As memórias de Adalberto Thimóteo dos Santos (1966), mais uma vez, podem auxiliar. Em seu livro, há vários registros em que a relação entre os operários e a empresa foi detalhada de maneira ambígua. A leitura dessa fonte não foi trilhada com o intuito de apontar essas contradições ou ambiguidades, mas, uma vez identificadas, pode-se tirar proveito delas para melhor compreender o momento histórico analisado. Assim, foi possível identificar passagens em que o protagonismo dos mineiros encontrava limite na contrapartida da empresa. Esses relatos merecem destaque. Frases como “em 1933, já tínhamos um sindicato de classe, graças a Getúlio Vargas: tínhamos direito de reivindicar o que era nosso, sem interferência da polícia" (Santos, 1966, p. 32) ou "é bom lembrar que eu sempre fui contrário às greves, porque cedo compreendi que todas elas ou $99 \%$ eram fomentadas pelos patrões e continuam sendo, porque sempre quem ganha com a greve é o patrão" (Santos, 1966, p. 21) revelam não apenas opiniões e sentimentos mas também uma forma indireta de reconhecer que, embora as mudanças fossem perceptíveis, na prática, a resistência às mudanças eram significativas. Em outra passagem, Santos relembrava que:

\footnotetext{
no meio em que vivi e vivo até hoje, o operário pede ao patrão, mas nada oferece em troca, a não ser o que já lhe estavam dando (como já disse, sempre fui contrário às greves). Por que não vamos aos nossos chefes, expor os meios que nós temos de melhorar nossa produção com menos despesas [...]. Mas todos os companheiros que eu expunha este plano, pela maioria era taxado de puxa-saco e outros diziam que os patrões não queriam ouvir. O que era verdade, porque toda vez que queríamos uma conversa com nossos chefes, para falar sobre melhoria salarial, já se estava cometendo insubordinação e a polícia entrava em ação (SANTOS, 1966, p. 45).
}

\footnotetext{
${ }^{5}$ Para mais detalhes, ver Fortes (2004).
} 
Por mais que a narrativa da mudança se torne presente, as memórias de violência nas minas eram persistentes. Os limites da mudança encontravam-se na ação da polícia. Em outra passagem, já em referência à inundação das minas de Arroio dos Ratos, ocorrida em 1936, Santos (1966, p. 83) afirma que "esta empresa já tinha sido cruel com seus operários, mas de uns poucos anos para cá, tornou-se humana. E pela ocasião da catástrofe foi super-humana. Não dispensou ninguém. Continuou a fornecer a alimentação a todos”. Mais à frente, afirma: "Onde o operário tem moradia digna de cristão, pão e respeito como membro da sociedade (e não como um pária ou um leproso), ali o comunismo não tem onde se firmar".

O que essas contradições e ambiguidades podem revelar? Adalberto Thimóteo dos Santos era um dos líderes sindicais desde a fundação do sindicato dos mineiros em $1^{\circ}$ de janeiro de 1933. Suas memórias, possivelmente produzidas ou organizadas em 1966, podem refletir de alguma maneira a influência do tempo histórico em que veio à tona. Em 1966, a ditadura militar havia, nos dois últimos anos, trabalhado arduamente para assentar um panorama contextual de contrariedade àquilo que representava o comunismo. Considerando esse aspecto, as afirmações de Santos não deixam de representar o discurso oficial do governo de Vargas sobre a real função do sindicato em face das decisões da empresa, visando uma colaboração direta com o Estado. A vivência cotidiana daqueles sindicalistas nas minas permitia conjecturar alternativas de resistência que tinham como limite a função de colaboração com o poder público. Talvez os usos da greve e sua demonstração de discordância a movimentos dessa natureza possam ser consideradas como indicativo desses limites.

A greve estava na pauta política, jurídica e sindical entre 1933 e 1934. Se, na prática, era o principal instrumento que os trabalhadores utilizavam para melhoria de suas condições de trabalho, também era a forma encontrada para que os mesmos trabalhadores pudessem exigir o cumprimento da legislação outorgada pelo governo varguista. Neste cenário, a legalidade ou não da greve como direito também estava na pauta dos tribunais, principalmente, pela forma como era compreendida e exposta diariamente pelos jornais que cobriam as discussões dos constituintes na Assembleia Nacional Constituinte de 1933-1934.

Por mais que as memórias de Santos (1966) refletissem o discurso oficial do governo provisório, o dia a dia nas minas - cuidadosamente detalhado em sua obra - refletia que havia um distanciamento significativo entre a lei e sua prática, muitas vezes dificultada pela própria companhia. Em uma situação aparentemente privilegiada, Santos, por diversas razões, poderia ter gozado de vantagens em relação à companhia e, a partir daquele instante ter estabelecido inimigos comuns. 
A influência da política partidária dentro dos sindicatos também foi registrada por Santos (1966). Em uma passagem de alta relevância, o ex-mineiro destacou que, a partir do momento em que o sindicato passou a ser utilizado por essas agremiações partidárias, tal como o partido comunista brasileiro, “as coisas desandaram”. Ao isolar essa passagem e confrontá-la com a defesa pública oferecida pelo secretário do sindicato na visita do ministro do Trabalho na sessão do SMAR, ${ }^{6}$ alguns pontos podem ter referência com o processo em análise.

A aposta, que acaba por se configurar no cenário de possibilidades históricas, busca compreender até que ponto a notícia da visita ou a presença do ministro e os conflitos originados com a reportagem do jornal Diário de Notícias podem ter tido influência sobre a prisão dos trabalhadores e sua consequente expulsão das minas pela autoridade policial, como indesejáveis. Embora não seja possível o registro exato de quando ocorreu a expulsão, as declarações de tempo de serviço dos trabalhadores Antônio Nunes das Pedras, Adalberto Azambuja dos Santos, Raphael Mezza e Liberalino Machado de Lima indicavam que, cinco dias após a visita do ministro nas minas de carvão de Arroio dos Ratos, seus vínculos de emprego com a companhia haviam se encerrado.

O termo "indesejável" foi articulado como uma categoria político-jurídica desde as primeiras experiências que colocam em evidência os padrões da ordem pública. A construção dessa categoria relacionou historicamente um conjunto amplo de situações que poderiam representar perturbações à ordem pública. Sem maior precisão acerca do conceito e seus limites naquele período, os usos eram amplos o suficiente para abarcar agitadores sociais, estrangeiros com orientações anarquistas ou qualquer grupo que fosse capaz de contestar a ordem posta (GUERRA, 2012). Os grevistas, ao lado dos mendigos, vadios e pequenos ladrões, também eram incluídos na categoria dos indesejáveis. Aparentemente, foi nesse sentido que o termo foi usado para qualificar os mineiros expulsos das minas. Entretanto, pode-se registrar que o qualitativo indesejável também foi utilizado pelo secretário do sindicato para se referir aos ataques que Castor Bispo sofrera dias antes da visita do ministro do Trabalho em Arroio dos Ratos.

Essa indicação permite verificar que o termo indesejável não era de uso exclusivo das autoridades policiais. Nesse enredo, Adalberto Azambuja dos Santos assume posição de destaque. Emerge, aqui, o questionamento: principal oponente do presidente do sindicato, Castor Bispo, nas eleições de setembro de 1933, quando perdeu as eleições no SMAR, teria Adalberto atuado como porta-voz dos mineiros dissidentes junto ao jornal $A$ Voz do

\footnotetext{
${ }^{6}$ Conforme discurso publicado no jornal Diário de Notícias, em que o secretário mencionava que elementos estranhos haviam criticado o presidente do sindicato.
} 
Trabalhador, vinculado à FORGS e ao Partido Comunista Brasileiro? Ou teriam os mineiros expulsos contrariado as ordens do SMAR e incitado, entre os demais, manifestações contra a visita do ministro do Trabalho? Os mineiros expulsos poderiam planejar aproveitar a oportuna visita do ministro Salgado Filho para evidenciar que, a despeito do sindicato corporativista, as relações de trabalho e atendimento às leis do trabalho nas minas não ocorriam sem conflitos, conforme retratava a chapa vencedora do sindicato? Teria a FORGS atuado em busca de dissidentes sindicais nas minas de Arroio dos Ratos para ampliar as resistências contra o inspetor Ernani de Oliveira no Ministério do Trabalho em Porto Alegre? Mas se tais situações fossem factíveis, por que o sindicato dos mineiros haveria de patrocinar o pedido desses trabalhadores na reclamação trabalhista que subsidia esta pesquisa?

Embora essas questões estejam presentes em amplas possibilidades históricas, não seria desprezível o impacto que uma manifestação de mineiros (fosse por ampla maioria ou não) causaria durante a visita do ministro. Isso porque, por um lado, qualquer movimento de resistência projetaria uma visão diversa da preconizada oficialmente de colaboração entre as classes, não apenas pela companhia, mas também pelo sindicato. Por outro lado, a deflagração de resistência também denunciaria uma possível divisão interna no sindicato, que, a curto ou a médio prazo, poderia fragilizar as ações sindicais frente a Ernani de Oliveira e à própria companhia.

Como silenciar as possíveis manifestações? Nas margens do conflito, cada um de seus personagens atuava estrategicamente à sombra dos silêncios que produziam, e suas atuações enredavam um contexto de pleno desafio ao novo plano institucional desenhado. A greve, por exemplo, estava sendo utilizada como um instrumento que buscava afastar a ideia de direito, qualificando-a em um espaço de abuso de direito. Havia uma associação entre militância política e greve e, ao abusar da categoria indesejável, aplicava-se ao caso uma desobrigação que a lei impunha, ou seja, a ausência de instaurar inquérito administrativo para apurar falta grave dos mineiros estáveis.

O silêncio que emerge dessa conduta evidencia o afastamento das regras de direito por parte da companhia para outro espaço de institucionalidade, ou seja, o praticado pela autoridade policial. Assim, o movimento de greve foi utilizado discursivamente como uma estratégia sofisticada para excluir os trabalhadores dos benefícios da cidadania que, ao ser ratificado com a expulsão dos mineiros (indesejáveis) pela autoridade policial, justifica a despedida pelo abandono "imediato" de emprego. 
Nenhuma fonte pesquisada sobre o período permitiu elucidar ou comprovar que a expulsão dos trabalhadores ocorreu em decorrência de um movimento de greve. Essa afirmação vinha unicamente da companhia. Já a versão do delegado de polícia, José Maria de Carvalho, relatava apenas que os mineiros foram acusados "de se acharem envolvidos em fatos subversivos da ordem", em referência ao dia 15 de fevereiro de 1934, e que ao comparecerem perante a autoridade judiciária estadual, comprometeram-se a abandonar a mina. Há, ainda, o registro de expedição de um ofício do inspetor Ernani de Oliveira endereçado à companhia, solicitando a reintegração dos operários demitidos, visto que as denúncias de que estes seriam comunistas não foram comprovadas. É possível que esse movimento de greve não tenha acontecido, mas foi concretizado discursivamente na medida em que foi usado pela companhia.

Quando as atenções se voltam para a autoridade policial, todos os dados levantados colocam em evidência a organização político-administrativa da intendência de São Jerônimo. No período em que a reclamação trabalhista surgiu (1934 a 1938), ${ }^{7}$ o prefeito também se chamava José Maria de Carvalho, ou seja, o mesmo nome do delegado de polícia que, nos autos do processo, encaminhou declaração à companhia relatando que os mineiros haviam sido acusados de cometerem atos subversivos à ordem. Seria possível que fossem a mesma pessoa?

Na pesquisa, foi realizado um levantamento sobre a trajetória política de José Maria de Carvalho na região. Segundo Simch (1961), José Maria de Carvalho chegou a São Jerônimo para atuar como engenheiro civil na Estrada de Ferro e Minas do Jacuí em 1920. Embora não haja clareza sobre o ano de posse, consta que foi eleito em 20 de junho de 1923 ou $1924^{8}$ para exercer o cargo de prefeito na Intendência de São Jerônimo. Reconhecido por ter realizado uma "administração que agradou o povo", foi reeleito prefeito em 1928, governando o município até a Revolução de 1930. Nesse mesmo período, por decisão do interventor do Estado, foi nomeado prefeito de Rosário. Retornando a São Jerônimo, foi eleito novamente prefeito, exercendo o cargo entre 1933 e dezembro de 1936; renunciou a seu mandato para dedicar-se à engenharia civil, sua profissão de formação. Em Porto Alegre, José Maria de Carvalho foi um dos fundadores do sindicato dos engenheiros do Rio Grande do Sul, em 1941, sendo seu primeiro presidente.

\footnotetext{
${ }^{7}$ Consta no processo que a última referência à decisão de mérito é do ano de 1938.

${ }^{8}$ O registro em Simch (1961, p. 163) menciona que o ex-prefeito, cel. João Rodrigues de Carvalho (conhecido como Coronel João Menino), dirigiu a intendência até 1923. Nos registros da Prefeitura Municipal de São Jerônimo, na galeria dos ex-prefeitos, a imagem de José Maria de Carvalho aponta que este esteve à frente da prefeitura entre 1924-1929 e 1933-1936.
} 
Não foi possível obter, em nenhuma das investidas, outros registros da vida política de José Maria de Carvalho. Não há dados sobre campanhas eleitorais, panfletos ou demais documentos sobre as eleições nas quais concorreu que pudessem fornecer mais informações. Com a ausência de dados, a alternativa foi coligir as informações em cada espaço específico de sua vivência institucional, ou seja, foram empreendidas buscas sobre sua atuação como engenheiro na Companhia Estrada de Ferro e Minas do Jacuí (1920-1924), como prefeito municipal (1933-1936), como presidente do sindicato dos engenheiros (a partir de 1941) e como delegado de polícia (1934).

No fundo de arquivo da Companhia Estrada de Ferro e Minas do Jacuí, ${ }^{9}$ foi possível identificar trocas de ofícios do engenheiro civil José Maria de Carvalho com seus superiores. O principal objetivo era encontrar registros da assinatura do engenheiro, a fim de avançar em um possível estudo grafotécnico.

Dos documentos arquivados, dois chamaram a atenção devido à semelhança na assinatura. Foram registrados em 20 de junho e 5 de outubro, respectivamente, sendo ambos de 1920, quando o então engenheiro ajudante José Maria de Carvalho se comunicou com o superintendente da Estrada de Ferro de Jacuí, Roberval G. Medeiros. A partir de 8 de agosto de 1921, Carvalho se tornou engenheiro-chefe da Estrada de Ferro de Jacuí.

No fundo CEFMSJ, arquivado no MCAR, há outros registros de troca de ofícios entre a direção da companhia e o prefeito José Maria de Carvalho. ${ }^{10}$ Segundo esses registros, Carvalho também era o presidente da comissão do Partido Republicano Liberal em São Jerônimo. Embora o livro representasse apenas o conteúdo dos ofícios sem assinatura desses remetentes, foi na própria reclamação trabalhista que a assinatura de José Maria de Carvalho veio à tona, também enquanto prefeito. No dia 10 de março de 1934, o prefeito Carvalho encaminhou para o vice-prefeito em Butiá, Candido Batalha, um bilhete apresentando o exmineiro de Arroio dos Ratos, Liberalino Machado de Lima, conhecido como "Pequeno Machado", informando que seu portador desejava obter qualificação nas minas de Butiá. ${ }^{11} \mathrm{~A}$ assinatura do bilhete registra os mesmos contornos nas assinaturas de José Maria de Carvalho enquanto engenheiro (1920), delegado (1935) e, na ocasião, prefeito municipal (1933-1936).

Curiosamente, o bilhete foi emitido 4 dias após o término do vínculo de emprego de Liberalino nas minas, isto é, em 10 de março de 1934. Esse fato permite levantar uma observação importante: ao que tudo indica, sendo José Maria de Carvalho ao mesmo tempo

\footnotetext{
${ }^{9}$ O fundo se encontra disponível para consulta no Museu Estadual do Carvão, em Arroio dos Ratos.

${ }^{10}$ Fundo CEFMSJ, livro de registros de correspondências, ano 1933-1934, Cx. Correspondências, maço 02.

${ }^{11}$ Fls. 90 do processo $n^{\circ} 9.582 / 1934$.
} 
prefeito e delegado de polícia quando ocorreram os fatos que originaram o caso Domingos Mantilha e outros, possivelmente, este não foi o responsável direto pela expulsão dos mineiros. Nesse sentido, a declaração do delegado sobre as denúncias contra os mineiros apresentada pela companhia junto ao CNT teve o propósito apenas de constatar os fatos ocorridos e não permite a afirmação de que ele teria agido, pessoalmente, para a expulsão.

A par dessa consideração, outro dado explicativo pode ser levantado. Nos autos, Candido Batalha foi identificado como vice-prefeito e subdelegado em Butiá. Provavelmente a autoridade policial em Arroio dos Ratos também acumulasse as mesmas funções. ${ }^{12}$ Desse modo, as atenções se dirigem ao subdelegado de Arroio dos Ratos, cap. Luiz Pereira, mesmo porque, nos autos, havia um atestado de conduta emitido pelo subdelegado de polícia de Arroio dos Ratos, cap. Luiz F. Pereira, em 7 de março de 1934, documentando que nos arquivos da subdelegacia nada foi encontrado que desabonasse a conduta de Liberalino Machado de Lima, operário da CEFMSJ.

$\mathrm{O}$ que essas configurações podem trazer à tona? O processo em si constituiu-se como uma forma de resistência a uma estrutura em que a correlação de forças não oferece muitas alternativas ou condições objetivas para conquista de ações políticas efetivas por parte dos trabalhadores. O desafio não era apenas chegar ao CNT, mas no plano interno, fundir textualidades capazes de produzir prática social, fomentar uma aquisição evolutiva dentro um espaço privilegiado em que fosse possível promover os direitos dos trabalhadores. Nesse meio tempo, o elemento greve e a designação de indesejável precisavam ser superadas.

4.1.1 O status de elemento "indesejável" e o direito de greve nos primeiros anos da década de 1930

A associação dos trabalhadores ao termo indesejável pode ser matizada. Afinal, o que significava ser considerado indesejável em uma mina de carvão? Por quais razões atribuía-se a alguém a categoria, a designação de indesejável? Sob a perspectiva da história constitucional, o uso do referido termo para qualificar trabalhadores em greve não era inédito. Essa foi uma prática comum durante a Primeira República, principalmente quando se leva em consideração os conflitos trabalhistas ocorridos entre as décadas de 1910 e 1920.

A partir dos indícios levantados no processo, foi possível identificar, preliminarmente, os limites e possibilidades que o uso do termo indesejável causou naquele caso concreto. No

\footnotetext{
${ }^{12}$ No jornal Diário de Notícias, consta a referência de que cap. Luiz Pereira era subprefeito de Arroio dos Ratos quando da visita do ministro do Trabalho, em 28 de fevereiro de 1934.
} 
entanto, pela própria característica fluída do termo e a multiplicidade de seus usos, um exercício mais austero se impôs e, por isso, o resgate das experiências de seus usos tornou-se necessário.

Entre os inúmeros trabalhos acadêmicos que se dedicaram ao estudo dos movimentos de greve na Primeira República e aos movimentos de imigração de estrangeiros, o trabalho de Lená Medeiros de Menezes (1996), intitulado Os indesejáveis, tem um reconhecido destaque, a ponto de subsidiar, nesse ponto, essa investigação.

Desde a fundação da República, em 1889, um novo programa disciplinar sobre o espaço público marcou a capital do país. As promessas de modernização que atingiram as esferas política, econômica e social foram lançadas para todas as regiões brasileiras e, no drama da modernidade prometida, como bem sintetiza Menezes (1996, p. 37),

a virada republicana tinha ocorrido num momento de tomada das ruas por uma
população que, concentrada em habitações coletivas, sem conforto e mal ventiladas,
ou à margem do mercado formal de trabalho, transformava as vias públicas numa
morada complementar.

Colocado como protagonista da aceleração do processo civilizatório, coube ao Poder Público a iniciativa de uma série de ações que dessem andamento aos novos padrões estabelecidos pela modernidade. Urbanização, vigilância e disciplina se constituíram como um dos principais traços daquele período.

À margem dessas promessas, o deficit habitacional, a ausência de emprego formal e estável, os baixos salários e o aumento da pobreza colocavam a classe trabalhadora e a criminalidade em uma zona fronteiriça complexa: "vários foram os indivíduos que circularam pelos dois mundos [...]; sujeitos a um código moral embasado numa leitura diferenciada do mundo burguês e de seus valores", foram, paulatinamente, "colocados em seu lugar" (MENEZES, 1996, p. 51) ${ }^{13}$.

Em reação às tensões causadas pela extrema pobreza e criminalidade que se avolumavam no contexto urbano da capital, Menezes (1996) identificou que, no início do século XX, a imposição da vigilância e da disciplina era reflexo da definição do espaço público como um espaço político e da vida privada como um dos maiores valores dos novos tempos. Assim,

preservar a boa ordem, concebida como o resultado da conjugação dos esforços individuais no sentido de respeito às leis, significou manter sob controle o espaço da desordem, constituído pelo crime, pelas contravenções, pela imoralidade, pelo vício

\footnotetext{
${ }^{13}$ Em Seelaender (2006), é possível verificar o impacto que o princípio da igualdade constitucional promoveu na Primeira República e como as políticas governamentais fomentaram (diretamente ou não) segregação social, colocando os pobres em seu lugar.
} 
e pela mobilização operária. Manter a ordem tornou-se um exercício de modernidade, sem o qual, qualquer projeto de mudança parecia inócuo (MENEZES, 1996, p. 53).

Nessa nova dimensão que se abriu com as promessas da modernidade, a manutenção da ordem passou a ser um elemento indispensável para a realização dos atos civilizadores que a República pavimentava em nome do estado de direito. Dentro desse quadro, o Estado, teoricamente comprometido com a organização do exercício do poder e com a proteção dos direitos individuais, acabava por agir subsidiariamente para evitar conflitos que colocassem em risco o estado da ordem e a harmonia programadas.

Sem uma definição precisa sobre os limites de ordem pública, competiam à polícia as principais ações na promoção do caminho para o progresso, de sorte a eliminar quaisquer obstáculos. ${ }^{14}$ A política assumia, dessa forma, a função de coordenar um programa de disciplinamento social (SEELAENDER, 2006), destinado tanto aos pobres e à criminalidade quanto ao controle sobre os movimentos dos trabalhadores nas cidades. A partir da instrumentalização dessas ações pela autoridade policial, foi possível observar um aperfeiçoamento dos mecanismos de controle sobre os espaços público e privado. Com o alastramento da carestia nas cidades, o aumento da mendicância, da vadiagem e a proliferação de outras formas de comportamento desviantes (cáftens, viciados em jogos, prostituição etc.), o mundo do crime passava a ditar os primeiros elementos que viriam a ser configurados e apontados como indesejáveis pela ação policial. Por sua vez, a mobilização operária também passava a ser foco de atenção, principalmente quando, no contexto de sua organização, a reivindicação assumia um tom de contestação.

Ainda, segundo apontou Menezes (1996, p. 59), com o aperfeiçoamento dos mecanismos de controle, desenvolveu-se "um processo seletivo nas correntes migratórias que se dirigiam para o país, através da eliminação dos elementos indesejáveis e da negação de hospedagem aos indivíduos considerados nocivos à sociedade e perigosos à ordem pública, quer no mundo do trabalho, quer no mundo do crime".

Assim, o uso do termo "ordem pública" era amplo o suficiente para abarcar dois mundos distintos e independentes, mas que dadas suas condições de constituição, eram tratados pelo mesmo filtro - ou seja, o filtro policial. De tal modo, qualquer um que protagonizasse ações ou proferisse palavras que soassem como atos de contestação ou de reivindicação contra a ordem pública, econômica e social vigentes poderia ser considerado pela polícia como indivíduo desordeiro, capaz de oferecer resistência ao projeto civilizador: "inseridos nos mundos do

\footnotetext{
${ }^{14}$ Nesse sentido, ver ainda Seelaender (2009).
} 
trabalho e do crime, os indesejáveis tornaram-se peças fundamentais no embate entre as forças da ordem e as da contestação sob suas diferentes formas” (MENEZES, 1996, p. 91).

Durante as primeiras décadas republicanas, a classe trabalhadora foi foco central da ação repressiva do Estado, e os anarquistas tiveram papel relevante nesse processo. Organizados sob múltiplas bandeiras, ${ }^{15}$ as ações desses trabalhadores culminaram na construção de um estereótipo que representava os anarquistas como amantes da violência e da destruição (MENEZES, 1996). No Rio de Janeiro, esse estereótipo concretizou-se em torno de três grandes aspectos. Entre 1912-1913 e 1917-1918 e 1918-1921, o movimento anarquista circulou, primeiramente, no plano das ideias, valores e comportamentos que atingiu os segmentos médios da população; em seguida, ganhou força junto ao movimento de trabalhadores, com foco em setores profissionais em que havia muitos estrangeiros. Por fim, irradiou-se para o conjunto dos excluídos, postos à margem do mercado formal de trabalho (MENEZES, 1996).

Dentro desse amplo panorama, o uso do termo indesejável não pode ser restrito a um fato (uma greve, por exemplo) ou a determinado grupo político-ideológico e, por isso, sua interpretação só faz sentido se for compreendida como resultado de um processo histórico. Ao interpretar a categoria indesejável como produto de um processo, e dado o interesse da pesquisa em investigá-lo a partir da organização trabalhista, foi possível verificar que os trabalhadores estrangeiros, em muitas ocasiões, eram qualificados como indesejáveis.

Embora ser considerado indesejável pela autoridade policial, principalmente nas primeiras décadas republicanas, não fosse algo inédito e tampouco surpreendente, a manutenção dessa condição por um longo tempo chamou a atenção. Desde a transição do Império para a República, uma quantidade significativa de estrangeiros emigrou para o país. Em diferentes níveis, suas experiências em sindicatos, ações de reivindicações e contestações no mundo do trabalho foram utilizadas para as lutas de mudança social em várias cidades, "transformando os locais de trabalho, as associações profissionais, as ruas e as praças em tribuna livre e permanente de contestação" (MENEZES, 1996, p. 111).

A reação do poder público às constantes manifestações e reivindicações, aliada ao permanente aperfeiçoamento do sistema de vigilância e controle sobre as classes sociais,

\footnotetext{
${ }^{15}$ Segundo Menezes (1996, p. 97), destacavam-se: “a defesa da comuna revolucionária; a crença no potencial revolucionário das massas à espera dos apóstolos da redenção pela via do terror; a fé numa hipotética bondade inerente ao ser humano, que justificava a prática da violência como ato transitório; a confiança no papel da educação na formação da sociedade futura; a importância da greve geral como ato revolucionário, capaz de liquidar a ordem burguesa; e, finalmente, a importância dos sindicatos como instrumento de intervenção capaz de desencadear a mudança social".
} 
proporcionou a criação de inúmeras práticas autoritárias. O principal instrumento para o combate a estrangeiros contestadores foi a expulsão sumária. Detidos pela autoridade policial, os estrangeiros eram submetidos a um sistema rápido e eficiente (e, não raro, fraudulento) de produção probatória, que poderia determinar a expulsão imediata do país.

O governo republicano produzia uma narrativa duvidosa sobre a natureza dos processos contestatórios dos trabalhadores estrangeiros. Enquanto construía pelo discurso o viés nacionalista das políticas de Estado, insuflava na sociedade o contraste entre o nacional e o estrangeiro apoiando-se na ideia da suposta existência de um caráter ordeiro do brasileiro em detrimento do estrangeiro. Como registra, ainda, Menezes,

Na mesma dimensão, ganhou destacada importância a opção pela utilização do conceito de estrangeiro ao invés do de imigrante, tanto nos documentos oficiais quanto na imprensa, caracterizando uma mudança significativa no nível das representações a um novo posicionamento frente aos indivíduos não nascidos em território nacional (MENEZES, 1996, p. 188).

$\mathrm{Na}$ prática, as ações contra os estrangeiros fomentavam o isolamento dos imigrantes, parcialmente já considerados como classes perigosas em relação ao conjunto da população. Menezes (1996) identificou, ainda, que os estrangeiros passaram a ser enquadrados em dois grupos distintos: os úteis, ordeiros, trabalhadores e desejados; e os nocivos, desordeiros, perigosos e indesejáveis.

Analisando o Correio da Manhã, periódico diário publicado na cidade do Rio de Janeiro, foi possível encontrar notícias que relatavam o tratamento dado aos estrangeiros. Em 21 de maio de 1916, por exemplo, a redação do jornal relatava um decreto editado pelo governo argentino que submetia a entrada de imigrantes naquele país a novas condições, proibindo a imigração de indesejáveis. $\mathrm{O}$ apelo da notícia era cuidadosamente dirigido ao Brasil, como se pode destacar:

Temos sido sempre pela ampla immigração no Brasil, atendendo à necessidade que ele tem de povoar-se e desenvolver-se. Sempre nos pareceu que não era entre os immigrantes pobres, acossados de seus paizes pela fome, que se encontravam os estrangeiros mais perigosos ao paiz. Pensamos com Sarmiento quando dizia que se de algum immigrante se devia desconfiar era do immigrante fino e bem trajado. Mas, agora, deante da perspectiva que move a Argentina a precatar-se, entendemos que o Brasil deve fazer lei egual (CORREIO DA MANHÃ, 1916, p. 1).

Notícias de expulsão de estrangeiros considerados indesejáveis também eram constantemente anunciadas pelo periódico. ${ }^{16}$ Em 5 de outubro de 1917, outra edição do

\footnotetext{
${ }^{16}$ Ao lado dessas notícias, também haviam opiniões da redação do periódico com pedido de providências. Em 16 de setembro de 1916, por exemplo, o Correio da Manhã solicitava a proibição da imigração de indesejáveis após o fim da primeira Guerra, pugnando pela recusa de imigrantes inúteis e improdutivos, como os mutilados, doentes mentais e os afeitos a vícios orgânicos que inutilizem total ou parcialmente para o trabalho. Em 19 de
} 
Correio da Manhã noticiava o habeas corpus impetrado por estrangeiros no Supremo Tribunal Federal. Em defesa da possibilidade de expulsão sumária dos estrangeiros indesejáveis pelo Estado, o jornal afirmava que assistia razão ao Estado a regular expulsão dos elementos capazes de comprometer interesses nacionais ou de ameaçar a tranquilidade pública.

O ponto em comum dessas notícias e também demonstrado nas pesquisas de Menezes (1996) e Guerra (2012), que analisaram inúmeros processos que culminaram na expulsão de estrangeiros no país naquela época, reside na forte interligação que o termo indesejável assumia com os dispositivos do direito penal vigente.

Nesse aspecto, considerando que a primeira instituição especializada na aplicação da lei penal era a autoridade policial, a questão social naquele período, vinculada aos conflitos trabalhistas, acabava por ser considerada como uma questão de polícia.

Essa construção estereotipada que identificava o elemento indesejável com o estrangeiro, a pobreza, a militância política e quaisquer ações que pudessem contestar a ordem pública, contribuía para a consagração de um projeto específico que marcou a Primeira República. Nesse sentido, Menezes identificou que essa construção tinha consequências políticas e econômicas, que podem ser sintetizadas do seguinte modo:

\begin{abstract}
$\mathrm{Na}$ dimensão política, ela era fruto da existência de uma república oligárquica que tinha na exclusão uma de suas principais características, e que tendia a ver com muita apreensão a projeção dos segmentos populares no cenário político. Sob o ponto de vista econômico, havia os interesses de elites altamente conservadoras, voltadas para a manutenção de seus privilégios que, em última instância, repousavam na defesa da ordem a qualquer custo. Num plano mais geral, o discurso enquadrava-se num contexto de afirmação nacional, que passava pela definição da brasilidade através da alteridade. Esta foi uma construção eminentemente política, que transformou o estrangeiro na antítese do modelo que se buscava consagrar, refletindo as dificuldades existentes na moldagem de uma consciência nacional, numa terra de ex-escravos, com percentual significativo de imigrantes, grande parte dos quais portugueses. Colocada a necessidade de a República falar em nome da Nação, num país carente de identidade, a dialética da contraposição funcionou como importante elemento de sustentação para os grupos representados no poder (MENEZES, 1996, p. 189).
\end{abstract}

Essas iniciativas de expulsão de indesejáveis observadas na Primeira República podem ser assinaladas em várias ações legislativas, como o Código Penal de 1890 e as leis de 1893, 1907, 1913, 1917 e 1921. Em cada um desses períodos, essas legislações foram questionadas em sua constitucionalidade, pois, muitas vezes, as ações de vigilância e controle policial sobre

setembro de 1917, o Correio da Manhã lançou duro editorial intitulado O problema dos indesejáveis, em que, mais uma vez, defendia o recurso à expulsão sumária de estrangeiros indesejáveis. 
trabalhadores - estrangeiros ou não - afetavam uma gama relativa de direitos constitucionais previstos na Constituição de 1891.

A ordem constitucional era evocada pelos trabalhadores considerados indesejáveis para impedir um de seus principais efeitos: a expulsão sumária emitida pelo Poder Executivo. Os habeas corpus analisados pela pesquisa de Guerra (2012) ilustram essa disputa constitucional durante as greves que marcaram a transição das décadas de 1910 e 1920.

Apenas com a reforma constitucional de 1926, que culminou na substituição do art. 72, é que se consagrou, no parágrafo 33, a permissão ao Poder Executivo de expulsar do território nacional os "súditos estrangeiros" perigosos à ordem pública ou nocivos aos interesses da República.

A emenda constitucional não pôs fim à polêmica, e tampouco o termo indesejável deixou de ser explorado no mundo do direito ou da política. Desde a suspensão da Constituição de 1891 pelos revolucionários de 1930, o imigrante estrangeiro continuava na pauta política como um problema a ser equacionado, e as ações da polícia contra esses imigrantes refinaram-se, principalmente, quando se volta o campo de análise ao novo momento que o movimento trabalhista representou a partir de 1930.

Desde a criação do Ministério do Trabalho, Indústria e Comércio em 1930, a equipe de Lindolfo Collor e, posteriormente, de Salgado Filho e Agamenon Magalhães, colocou em ação um conjunto de medidas que visavam regulamentar os direitos trabalhistas. Essas medidas iam desde a configuração de direitos mínimos a serem considerados nos contratos de trabalho - como férias e descanso remunerado, proibição de trabalho noturno para crianças e mulheres, jornada de trabalho, entre outros - a uma reconfiguração na organização trabalhista mediada pelos sindicatos.

As transformações legislativas produzidas no campo trabalhista estavam ligadas às chamadas promessas da Revolução de 1930 e, aliadas ao discurso nacionalista, que projetavam o processo de modernização defendido por Vargas e colocavam a questão social em evidência. Esse processo foi marcado por avanços, mas, ao mesmo tempo, também fomentou resistências e contradições, como se pode observar com a política de restrição ao pleno emprego destinada aos imigrantes estrangeiros.

A primeira experiência marcante foi o Decreto $n^{\circ}$ 19.482, de 12 de dezembro de 1930, que limitava a entrada, no território nacional, de passageiros estrangeiros de terceira classe e dispunha sobre a localização e amparo dos trabalhadores nacionais. Entre as razões levantadas pelo governo provisório para a edição do decreto encontravam-se os argumentos de que o 
grande número de desempregados criava sérios embaraços para a administração pública e, considerando-se a situação econômica e de desorganização do trabalho, a intervenção do Estado em favor dos trabalhadores era necessária.

O desemprego também era justificado pela entrada desordenada de estrangeiros, "que nem sempre trazem o concurso útil de quaisquer capacidades", acrescentava o decreto, mas que "frequentemente contribuem para o aumento da desordem econômica e da insegurança social". Na prática, esse decreto ficou conhecido como a Lei dos $2 / 3,{ }^{17}$ pois estabelecia a todos os indivíduos, empresas, associações, companhias e firmas comerciais que explorassem ou não concessões, fornecimentos, serviços ou obras com os governos federal, estadual ou municipal, que ficariam obrigados a comprovar perante o Ministério do Trabalho que, entre seus empregados, de todas as categorias, dois terços, pelo menos, deveriam ser de trabalhadores brasileiros natos.

Muito embora o decreto permitisse a contratação de brasileiros naturalizados ou de estrangeiros caso fosse constatada a ausência de brasileiros natos para serviços rigorosamente técnicos, a juízo do Ministério do Trabalho, a medida não deixou de causar conflitos práticos entre o operariado nacional e estrangeiro. As memórias de Santos (1966), mais uma vez, remetem aos conflitos que a Lei dos $2 / 3$ causou nas minas de carvão da CEFMSJ, principalmente, pelo alto número de estrangeiros que, formalmente ou não, lá trabalhavam.

O decreto também previa que todos os desempregados, nacionais ou estrangeiros, deveriam se apresentar às delegacias de recenseamento do Ministério do Trabalho e, na falta destas, às delegacias de polícia para fazer declaração sobre sua identidade, profíssão e residência. Desse modo, seriam tomadas as medidas convenientes para que lhes fosse destinada uma ocupação, principalmente em serviços agrícolas. Caso não se apresentassem a esses órgãos do Poder Público, os desempregados estariam sujeitos a processo de vadiagem, nos termos da lei penal em vigor. Em decorrência dessa medida, nas minas de carvão a apresentação dos trabalhadores às delegacias de polícia era fundamental, evitando, assim, eventuais acusações de vadiagem em decorrência de desemprego.

Essa medida, no governo Vargas, pode ser considerada como um ponto de partida muito interessante para se compreender como se forjou a condição de estrangeiro, de trabalhador e de indesejáveis nos primeiros anos da década de 1930. Pobreza, desemprego e o

\footnotetext{
${ }^{17}$ O Decreto $n^{\circ} 20.291$, de 12 de agosto de 1931, regulamentou a fiscalização e o controle sobre a manutenção de contração de $2 / 3$ de empregados brasileiros natos. O decreto representava os esforços do governo provisório em promover a nacionalização do trabalho e evitar os conflitos, pressões e resistências que sofria desde a restrição à contração de estrangeiros em número superior ao permitido no decreto.
} 
fato de ser estrangeiro, mais uma vez, estavam na pauta política. Como evidencia Maria Luiza Carneiro,

\begin{abstract}
O imigrante era bem-vindo desde que se integrasse ao "nós", atendendo às regras impostas pelos ordenadores da sociedade brasileira. A partir do momento em que se tornava inoportuno à ordem instituída, propondo reformas sociais e políticas - ou seja, procurando instituir uma nova ordem segundo ideologias exóticas -, sua identidade era questionada como "perigosa à composição racial da população ou à segurança da Nação" (CARNEIRO, 2003, p. 23).
\end{abstract}

Colocado nesses termos, o estrangeiro estava no foco da crise: poderia ser considerado indesejável se apresentasse potencial resistência à ordem pública. A política sustentada pelo governo Vargas era produto da radicalização de um nacionalismo que se exacerbava. Indiretamente, cedia-se espaço para correntes de cunho xenófobo mascararem o argumento de que a intenção do governo era garantir a integração étnica e a capacidade física e cívica do imigrante com os ditames da nacionalidade brasileira.

Como bem identificou Endrica Geraldo (2009), as medidas restritivas à imigração não resultaram apenas de uma decisão direta do governo Vargas. Muito embora o governo possa tê-las fomentado, as ações de restrição foram claramente construídas nos debates da Assembleia Nacional Constituinte (ANC) de 1933 e em virtude da repercussão pública provocada pela apresentação de emendas sobre imigração e colonização.

Os debates constituintes podem se consolidar como um recurso metodológico de grande valia para se compreender como o termo indesejável foi representado entre 1933 e 1934 até a concretização do texto constitucional em 16 de julho de 1934. Os processos constituintes, como destacou Vera Cepêda (2010, p. 200), "revelam o desenho da mudança social, das transformações em curso nas sociedades" e, em cada etapa de sua configuração, é possível verificar como os interesses e o embate de forças políticas demonstradas pelos grupos que compunham a assembleia formalizaram, politicamente, entendimentos para a composição de um instrumento jurídico que se transformou em uma Constituição.

Nesse cenário, os temas imigração e colonização não eram articulados de maneira independente. Considerados na pauta política como um tema sensível entre os constituintes, a imigração e a colonização eram atreladas aos problemas do mundo do trabalho. Durante longo tempo, o discurso republicano conservador, que se estendeu de 1890 a 1920, produziu uma narrativa que associava a contestação da ordem do trabalho, os grevistas e anarquistas a imigrantes (GUERRA, 2012; CARNEIRO, 2003; GERALDO, 2009). Qualificados como indesejáveis, os imigrantes eram submetidos a um sistema de repressão estabelecido pelo 
governo que, muitas vezes, culminava em expulsões sumárias do país. Nos debates constituintes de 1933-1934, essa associação também pode ser captada.

A ANC foi convocada pelo governo provisório de Vargas em fevereiro de 1932. Eleita em maio de 1933, seus trabalhos foram iniciados em novembro do mesmo ano. Desde a convocação até sua instalação, o governo provisório criou uma subcomissão constitucional, conhecida como subcomissão do Itamaraty, para que um conjunto de notáveis estabelecesse um anteprojeto constitucional a ser apresentado aos constituintes. ${ }^{18}$ Assim, os debates iniciais estavam centrados na proposição de emendas ao anteprojeto constitucional do governo.

Visitando os anais da constituinte (BRASIL, 1934-1937), o termo indesejáveis era identificado em situações envolvendo estrangeiros que emigravam de algumas partes do mundo. As principais restrições eram aos africanos, árabes e asiáticos. Nas justificativas apresentadas pelos constituintes, os argumentos remetiam à necessidade de se impor limites à entrada de estrangeiros no país, principalmente aos elementos indesejáveis, assim considerados por sua incapacidade moral e intelectual ou inadaptabilidade ao meio social brasileiros. Foi nesses termos que a regulação da imigração foi articulada pelo Clube 3 de Outubro, ligado ao movimento tenentista na constituinte. ${ }^{19}$

Em regra, as demandas dos constituintes sobre o tema imigrante refletiam os estudos sobre a questão da raça. Nesse aspecto, os resultados do Primeiro Congresso Brasileiro de Eugenia, presidido pelo constituinte Levi Carneiro, representante classista pelos profissionais liberais na ANC, foram utilizados retoricamente pelo constituinte Miguel Couto para ampliar as manifestações contrárias à imigração. Entre as deliberações referenciadas no congresso, a constituinte destaca que
V - O Primeiro Congresso Brasileiro de Eugenia, considerando que, entre as manifestações mais frequentes de táras hereditárias que incapacitam o imigrante como elemento étnico indesejável, figuram formas de desequilíbrio mental traduzido em tendências anti-sociais, aconselha a exclusão inflexível de todos os imigrantes com antecedentes criminais.
V - O Primeiro Congresso Brasileiro de Eugenia, considerando que, nos atuais paízes superpopulosos de alta civilização, os indivíduos que gravitam para o pauperismo atestam com esse próprio fato a sua inferioridade mental e moral, condena todas as formas de imigração subvencionada, que apenas podem concorrer para a entrada no nosso país de elementos indesejáveis (BRASIL, 1935b, p. 492).

A tendência às causas antissociais era um desdobramento da qualificação de indesejável dada ao imigrante que, considerado desordeiro, em detrimento do suposto caráter

\footnotetext{
${ }^{18}$ Para mais detalhes, ver Cabral (2010).

${ }^{19}$ O Clube 3 de Outubro apresentou uma série de ponderações sobre o anteprojeto. No volume 3 dos anais, é possível resgatar as propostas sobre a regularização da imigração (BRASIL, 1935a, p. 234 e ss.).
} 
ordeiro do brasileiro, poderia facilmente se tornar um risco à ordem pública ou nocivo aos interesses do país. Mas como essa nocividade era caracterizada? No mundo do trabalho, os movimentos de contestação às violações de direitos e de garantias trabalhistas eram apreciados de maneira dúbia, podendo ser considerados como exercício de um direito ou uma completa violência contra a ordem pública. O contexto entre 1931 e 1934 caracterizou-se como um espaço de transformações, envolvendo as regulações ao direito do trabalho promovidas pelos decretos do governo provisório e também as resistências à regulação e os ajustes empreendidos por parte dos empregadores.

Esses avanços, ajustes e resistências que moviam a regulação do trabalho estavam representados em proporções desiguais na constituinte. Como exemplo, pode-se citar os usos retóricos que o direito ou não à greve representava. Considerada por muitos constituintes como medida antissocial do trabalhador contra a ordem pública e econômica do país, o caráter subversivo que representava colocava os trabalhadores adeptos dos movimentos de greve na condição de indesejáveis.

A defesa ao direito de greve na constituinte foi amplo o suficiente para promover uma série de interpelações sobre sua manutenção ou não no texto constitucional. Conforme se lê no volume 9 dos anais da ANC (BRASIL, 1936a, p. 268 e ss.), em defesa do direito de greve, o constituinte Francisco Moura, em sessão da ANC de 6 de março de 1934, representando os interesses da Federação do Trabalho do Distrito Federal, levantou estudo sobre o direito de greve em outras experiências constitucionais. No destaque, Moura defendia que o direito de greve possuía característica de um direito constitucional e que, por essa razão, seu reconhecimento era medida a se impor para assegurar ao proletariado bases sólidas de proteção e amparo.

Por mais que as defesas pela inclusão do direito a greve pacífica na futura constituição fossem majoritárias, a comissão de sistematização das emendas dos constituintes (conhecida como comissão dos 26) sofrera duros ataques e pressões para não incluir emendas que consagrassem o direito à greve pacífica em seus dispositivos constitucionais. Essa discussão pode ser mapeada no debate entre Acir Medeiros e Levi Carneiro. Membro da comissão dos 26, Levi Carneiro afirmava que no anteprojeto constitucional elaborado pelo governo provisório não havia a previsão da grave pacífica como um direito e, em sua opinião, o direito de greve pacífica era indiscutível, fora de qualquer controvérsia. No entanto, alegava que "se alguém criou restrições, no Brasil, foi, aliás, a legislação trabalhista do governo provisório, que, como V. Ex. sabe, ao estabelecer as Juntas de Conciliação e Arbitragem, determinou que, 
nos casos de conflito de interesse, a desobediência seria motivo para expulsão do operário" (BRASIL, 1936a, p. 406). À margem dessas considerações, Levi Carneiro relatava, ainda, que a comissão constitucional havia se deparado com a proibição absoluta da greve e de lock out, tanto de empregados quanto de patrões. Assumindo a responsabilidade, Carneiro acrescentou que a comissão suprimiu esses dispositivos, por entenderem ser a melhor medida a se aplicar.

Conforme anunciado por Levi Carneiro, o projeto substitutivo $n^{0} 1$ da Constituição, apresentado pela comissão dos 26 na sessão de 13 de março de $1934,{ }^{20}$ contemplava o direito à greve pacífica aos trabalhadores. Sob sua chancela, a lei promoveria o amparo da produção e estabeleceria as condições de trabalho na cidade e nos campos, tendo em vista a proteção social do trabalhador e os interesses econômicos do país.

Embora as discussões de apoio ao direito de greve continuassem na ANC, na prática, o contexto político, econômico e jurídico do país, especialmente no período da constituinte, refletia o distanciamento real entre aquilo que disciplinava a lei e o que se praticava no mundo do trabalho. Os debates entre os constituintes Acir Medeiros, João Vitaca, Gilbert Gabeira, Antônio Rodrigues, Vasco de Toledo e outros, na sessão de 9 de abril de 1934, ilustra esse panorama. Reagindo à persistência das denúncias de violações de direitos dos operários, Acir Medeiros questionava-se, perante a assembleia, acerca das razões pelas quais os responsáveis pela execução das leis no Brasil não as cumpriam. Nesse mesmo sentido, acrescentou Acir Medeiros:

Venho, pois, Srs. Constituintes, lançar desta tribuna o protesto do proletariado
contra a intromissão da Polícia nos dissídios de trabalho, em que são partes
empregados e empregadores. É preciso, outrossim, que tenhamos o direito de greve,
afim de forçar esses cidadãos, que exploram o operário ao fiel cumprimento do seu
dever, que não é mais que um dever de humanidade. Com a greve, estamos certos de
que acabará a exploração de algumas empresas plutocratas, amparadas por alguns
Governos políticos. É também necessário que se termine com o vexame que ocorre
ao operário que sai à rua e pratique a greve. Ele é expulso da fábrica e,
imediatamente, as outras recebem comunicação, acompanhada do retrato do operário
que, assim, não mais consegue trabalho. Por que? Porque o direito de greve é
questão de polícia (BRASIL, 1936c, p. 463 ).

As constantes denúncias de violação ao exercício de direito de greve pacífica pelos trabalhadores na constituinte também permitiram discussões sobre a natureza do direito a greve. Segundo o constituinte João Guimarães, o direito de greve era considerado como um direito natural, não sendo necessário que ficasse registrado na Constituição. Sob a alegação de que a greve já existia antes de existir a Constituição, ou seja, antes de a lei reconhecer esse direito, reiterava ser desnecessária sua inclusão no texto constitucional. Acir Medeiros

\footnotetext{
${ }^{20} \mathrm{O}$ projeto substitutivo pode ser resgatado no volume 11 dos anais (BRASIL, 1936b, p. 215 e ss.).
} 
protesta, argumentando ser necessário tornar expresso na Constituição o direito de greve, uma vez que não são dadas as garantias para manifestá-lo livremente: "quando exercemos esse direito, a polícia resolve o caso à pata de cavalo e a metralhadoras” (BRASIL, 1936d, p. 485).

As forças políticas presentes nas bancadas constituintes reagiram à proposta da comissão dos 26 de alterar o dispositivo que consagrava o direito de greve para "direito a resistência pacífica, nos termos da lei”. O destaque foi apreciado com muitas críticas pelos constituintes, sob o argumento de que, com a criação da Justiça do Trabalho, seria desnecessário consagrar o direito à resistência pacífica. Horácio Lafer, chegou a ponderar:

\begin{abstract}
Ou a resistência se estabelece antes da intervenção da Justiça, e neste caso, um dos fundamentos mais fortes que levaram os deputados a votar por aquela providência está invalidado, porquanto o que se visava era evitar os dissídios, ou se vai operar depois da sentença da Justiça, e nessas condições, a inutiliza. Sejamos lógicos: ou reconhecemos o direito de greve, de resistência e acabamos com a Justiça do Trabalho, ou criamos essa Justiça e suprimimos o direito à resistência (BRASIL, 1937, p. 498-489).
\end{abstract}

Com esse argumento, alegava que manter o direito a resistência pacífica daria espaço aos empregados de, pacificamente, deixar de cumprir as determinações da Justiça do Trabalho, sob a alegação de que exerciam o direito de resistência.

$\mathrm{O}$ destaque que alterou o direito de greve para direito à resistência foi aprovado com 99 votos a favor e 82 contrários. Aberta a fissura da fragilidade, nem o direito de resistência permaneceria na futura Constituição. Silenciosa sobre o direito de greve, a Constituição não resolvia, de maneira clara, os limites e as possibilidades a que a organização dos trabalhadores estaria sujeita em situações de greve.

$\mathrm{Na}$ prática, os empregadores se beneficiaram dessa medida e o reconhecimento da legalidade ou não das greves ficaria a cargo do Conselho Nacional do Trabalho (CNT). Sem regulamentação sobre o direito de greve, as ações dos trabalhadores grevistas poderiam ser apreciadas individualmente e, apenas nas situações de empregados estáveis (com mais garantias) e sindicalizados. No processo $n^{\circ}$ 9.582/1934, os usos da greve e sua interligação com a categoria indesejável foram explícitas. Ao levantar o elemento greve, sob a perspectiva jurídico-política (de ser um direito ou não) e econômica (como ação antissocial contrária ao capital e ao trabalho), a empresa tentou se beneficiar desse panorama de disputa. Ao resistir à ordem judicial que se constitucionalizava e não promover a abertura de inquérito administrativo para apurar falta grave dos mineiros estáveis, a empresa inviabilizou que o CNT fosse capaz de averiguar se o eventual movimento de greve poderia ou não ser enquadrado como causa que justificasse a despedida. 
Enquanto a não inclusão do direito de greve e sua regulamentação pela constituição se mantivesse como uma decisão que atendia aos interesses e à pressão do capital econômico na ANC, o controle sobre o local de trabalho seria, no caso das minas de carvão, assegurado pela CEFMSJ, mediante o uso da autoridade policial. Investigar essa relação entre empresa e polícia, inclusive a partir de um caso concreto, também é relevante. Esse desafio se impõe às práticas utilizadas pela companhia em colaboração com as autoridades policiais nas minas. Compreender esse aparato torna-se necessário para esclarecer as ações estratégicas que ditavam o tom das possíveis repressões à linguagem dos direitos em um momento constitucional inovador proporcionado pelo advento da Constituição de 1934 e pelas leis trabalhistas por ela recepcionadas. Oportunidade esta em que os novos direitos não assumiam a posição de simples catálogos, mas de regras que poderiam ser defendidas dentro da instituição do direito, ritualizados pela reclamação trabalhista.

\subsection{A CEFMSJ, os usos da autoridade policial e a institucionalização da violência}

A organização política e social da vila de Arroio dos Ratos indicava que, embora fosse considerada um distrito da intendência de São Jerônimo, sua administração era subordinada aos interesses da companhia. Separar até que ponto a companhia exercia autonomia decisória passa a ser fundamental, principalmente, para se investigar a relação entre a companhia e a autoridade policial local.

O sistema vilas-fábricas atingiu seu apogeu após a formação do grupo Cadem, a partir de 1936. A interligação da CEFMSJ com a CCR trouxe à região um ciclo de desenvolvimento que agregava escolas, hospitais, lazer (clube, cinema) e igrejas, entre outros, com grandes semelhanças ao formato de pequenas cidades. A própria constituição da cidade de Arroio dos Ratos, a partir da década de 1960, época de sua emancipação, refletia esse período.

Os relatos de Santos (1966) e Speranza (2012, p. 47) reforçam o argumento: “do cemitério à polícia, do armazém e cooperativa ao cinema, tudo dependia e/ou era controlado pelo Cadem". No entanto, embora o Cadem tenha aprimorado esse sistema de controle, não se pode negar a existência de um mecanismo prévio de vigilância, que, articulado à propriedade privada da companhia, estabelecia outro ritmo à dinâmica de direitos.

A constatação inicial permite afirmar que, no espaço privado, o mecanismo de vigilância da companhia reproduzia um sistema de repressão típico do poder público. $\mathrm{Na}$ prática, essa substituição refletia uma estrutura que conferia direitos desiguais aos trabalhadores, solapando espaços, locais onde os direitos poderiam emergir. 
O sistema de vigilância e controle que a empresa estabelecia sobre os empregados da companhia desencadeava, outrossim, aquilo que poderia ser qualificado como "dialéticas de controle". ${ }^{21}$ À vigilância opõem-se formas específicas de concretização de direitos civis, políticos e sociais (ou econômicos). No espaço público-privado da mina, a estrutura de vigilância tem referência à ideia de ordem pública, pois era nesse âmbito que os direitos se circunscreviam. Como constantemente se argumenta em relação aos novos direitos, os limites e possibilidades eram testados nesse espaço. Em toda a trajetória de exploração de carvão dessas minas, a preocupação com a ordem pública era um ponto em comum e, com isso, a ligação entre a companhia e a autoridade policial era sólida e muito anterior ao caso de 1934.

Nos fundos da CCR e da CEFMSJ foi possível encontrar alguns momentos em que os espaços público e privado $^{22}$ - ou ainda, ordem pública e segurança privada - nas minas encontram-se em uma configuração híbrida, porém importante para a constituição das empresas naquela região. $\mathrm{O}$ domínio do privado assentava-se em um panorama superdimensionado e, com isso, uma nítida assimetria entre a relação público-privado era observada, principalmente quando suas relações se camuflavam com a roupagem dos contratos trabalhistas.

Em 17 de fevereiro de 1921, o engenheiro-chefe da CCR, Roberval Medeiros, encaminhou ofício ao intendente de São Jerônimo com o seguinte pedido:

\begin{abstract}
Tendo estas minas entrado em fase de rápido desenvolvimento, tornou-se bastante numerosa a população proletária que trabalha em nossos serviços; se bem que, em geral, o pessoal seja composto de elementos ordeiros, vai-se tornando necessária a criação, no quadro da mina, de uma seção de polícia, exclusivamente encarregada desse serviço, sendo, portanto, indispensável que o mesmo seja feito por pessoal da Polícia Municipal (FUNDO CCR, Caixa 01, Maço 02).
\end{abstract}

Em 22 de fevereiro de 1921, o cel. João Rodrigues de Carvalho, intendente de São Jerônimo, informou que estava disposto a conceder a abertura da seção policial visando regularizar o controle no quadro das minas de Butiá desde que diretor da CCR, Jaime Leal Costa, aceitasse os termos de um convênio. ${ }^{23}$ Com o acesso ao convênio, foi possível desvendar as características do acordo entre o poder público e a direção da companhia.

Na primeira cláusula, ficou determinado que o policiamento das minas do Butiá ficaria subordinado à direção, fiscalização e determinação geral do intendente do município, contudo, o

\footnotetext{
${ }^{21}$ A referência é o trabalho de Giddens (2008) e aos comentários de José Maurício Domingues na apresentação da referida obra.

${ }^{22}$ Para uma distinção entre público e privado, ver o estudo histórico produzido por Paixão (2003).

${ }^{23} \mathrm{O}$ convênio foi registrado no livro de Contratos, fls. 73, da Intendência Municipal de São Jerônimo, em 2 de março de 1921.
} 
destacamento policial composto por um chefe de seção e dois praças, prestariam imediata e direta obediência ao superintendente da companhia ou seu preposto.

A atuação do destacamento policial vinculava-se apenas ao território do "quadro das minas", em relação aos atos ou fatos concernentes ao regular e legal policiamento e respectivos serviços. Entre as prerrogativas do chefe de seção estava o dever de compartilhar instruções que julgasse conveniente ao superintendente da mina, a fim de promover o bom e eficaz policiamento. $\mathrm{O}$ chefe de seção era subordinado ao subintendente das minas de Butiá apenas nos casos puramente policiais.

Com a limitação hierárquica de se subordinar ao subintendente apenas em situações policiais, chama a atenção o papel a ser desenvolvido pelos policiais no interesse do diretor da companhia.

Com exceção do armamento, todas as despesas da força policial eram custeadas pela companhia. Os salários, combinados na cifra de Rs 169\$000 (cento e sessenta e nove mil réis) mensais ao chefe da seção e Rs $93 \$ 000$ (noventa e três mil réis) a cada um dos praças seriam pagos pela companhia no início de cada mês. No entanto, não haveria pagamento direto entre a companhia e os policiais: a empresa deveria encaminhar os salários para a tesouraria da intendência antes de cada mês, a fim de que fossem incluídos na folha de pagamento municipal. Até os fardamentos seriam custeados pela companhia, muito embora coubesse à intendência fornecê-los. A par dessas despesas, a companhia se responsabilizaria, ainda, a fornecer casa para o posto policial e residências aos praças, assumindo toda a responsabilidade com as despesas.

O convênio em si não era excepcional e retratava as relações cotidianas entre os interesses privados da companhia e os interesses públicos do município. Naturalmente, o funcionamento desse sistema não apenas estimulava a fluidez entre os espaços público e privado, mas também representava a forma pela qual a companhia conseguia neutralizar interesses que se demonstrassem contrários à "ordem pública dentro da mina".

Em outras palavras, é possível identificar que o termo ordem pública poderia ter assumido uma conotação diversa da já complexa definição de ordem pública assumida em contextos mais amplos, como os das cidades. Isso porque os movimentos que a ameaçavam eram encarados como prejudiciais à organização do trabalho. Na medida em que desavenças provocadas pelo uso de bebidas alcóolicas, furtos, roubos, bigamia e violências de todo tipo impactassem no trabalho das minas, a polícia se faria presente para cessar a desordem. Mas, à época, essas situações seriam naturalmente relacionadas à atividade policial. Assim, o que 
instiga nesse enredo é compreender até que ponto a companhia fazia uso do aparato policial para repelir ações dos empregados relacionadas às condições de trabalho nas minas.

Os relatos disponíveis sobre as atividades dos mineiros, inclusive em Arroio dos Ratos, apontavam que a companhia utilizava os policiais como verdadeiros físcais da relação de trabalho, desviando, desse modo, de sua competência originária. As atividades dos policiais não estavam vinculadas apenas à manutenção da segurança pública mas também à atuação como agentes infiltrados no convívio social dos mineiros, para conseguir informações que pudessem ajudar a controlar as opiniões dos mineiros, bem como os bens materiais da companhia.

Adalberto Thimóteo dos Santos (1966), por exemplo, relatou situações em que as opiniões dos mineiros, por vezes contrárias à empresa ou seus subdiretores, chegaram ao conhecimento dos superintendentes da companhia após terem sido obtidas pelos policiais. $\mathrm{O}$ resultado era a violência e consequente expulsão dos trabalhadores das minas.

Nos autos da reclamação, essa prática também foi denunciada, quando Pedro Logue Sobrinho e o próprio Adalberto Thimóteo dos Santos declararam conhecer Liberalino, que foi despedido por intrigas de um tal Cathalã, que andou nas minas como operário, mas que depois, soube-se ser um "secreta da polícia". 24

Opiniões divergentes, movimentos de contestação ou reclamações por melhores condições de trabalho e cumprimento da lei eram recebidas como atos de insubordinação e, não raramente, eram criminalizadas, com consequências aos trabalhadores. A insubordinação estava capitulada como falta grave, que autorizava a despedida dos empregados estáveis, isto é, com mais de dez anos na mesma categoria, desde que mediante a instauração de inquérito administrativo. A criminalização, por sua vez, não atentava apenas contra a ordem pública redefinida pelos interesses da mineradora, mas tinha um alcance muito mais abrangente.

Entretanto, a condição de cidadania conferida pelo trabalho era considerada superior às consequências de uma prisão dos mineiros. Desde as reformas trabalhistas produzidas por Getúlio Vargas, o status de cidadania estava vinculado à condição de trabalhador e, com isso, um novo panorama de efeitos e consequências vieram à tona. $\mathrm{O}$ processo de Domingos Mantilha e outros funcionou como um ponto de inflexão nesse formato, pois fica evidente que as ações dos mineiros no processo eram uma tentativa de invalidar sua qualificação de criminosos, harmonizando-se com a condição de trabalhadores.

Retomando os efeitos do convênio entre o município e a CCR, o fio que mantinha a autonomia decisória da companhia sobre os policiais era financeiro. Em 26 de março de 1921,

\footnotetext{
${ }^{24} \mathrm{Fl} .31$ do processo $\mathrm{n}^{0} 9.582 / 1934$.
} 
um ofício do superintendente da CCR ao intendente registrou que, por intermédio do escritório da Estrada de Ferro do Jacuí, remeteu-se a importância de Rs $219 \$ 994$ (duzentos e dezenove mil, novecentos e noventa e quatro réis) para o pagamento da seção policial da mina. Provavelmente, era o primeiro pagamento em decorrência do convênio.

Contudo, no acervo também foi possível encontrar outro registro de ofício do intendente de São Jerônimo para o superintendente da companhia informando que, em virtude das contínuas faltas de pagamento de impostos pela CCR, o intendente resolveu esperar e com isso, conceder novo prazo até o dia 10 do mês subsequente ${ }^{25}$ para pagamento dos impostos devidos referentes aos meses de março, abril e maio de 1921, do contrário, mandaria “embargar a saída do carvão, enquanto não for efetuado o referido pagamento". Na sequência do ofício, o intendente afirmava ainda: "espero até o mesmo dia 10 a importância do quantum para pagamento à seção policial do Butiá, referente aos meses de abril e maio, o qual não sendo efetuado, ver-me-ei forçado a dispensar a polícia da mesma mina”.

Mesmo diante desses fatos, seria possível afirmar que essa realidade representada pelo convênio poderia ser aplicada a Arroio dos Ratos? Infelizmente, nenhum documento existente nos acervos pesquisados evidenciou cláusulas contratuais tão explícitas quanto as encontradas nas minas de Butiá. Se não há como afirmar, no entanto, pelo mesmo motivo, não se pode negar a existência de arranjos institucionais dessa natureza.

Partindo-se da suposição de que em Arroio dos Ratos a relação entre a CEFMSJ e a autoridade policial constituiu-se de forma semelhante, a atenção voltou-se, forçosamente, à condição do subdelegado de polícia, cap. Luiz F. Pereira. Além de exercer a função de autoridade policial na mina, Pereira também era subprefeito. Em 27 de setembro de 1934, o prefeito José Maria de Carvalho encaminhou à diretoria da CEFMSJ um ofício no qual comunicava a dispensa do capitão Luiz F. Pereira do cargo de subprefeito do distrito de Arroio dos Ratos. ${ }^{26}$ Em substituição, fora nomeado o sr. Olavo de Araújo Ramos, que, até então, exercia o cargo de subprefeito em outro distrito.

Ao que tudo indica, a despedida de Luiz Pereira do cargo de subprefeito não estava vinculada ao movimento de greve que ocorreria nas minas de Arroio dos Ratos em 15 de outubro de 1934. Segundo o jornal Correio do Povo, a motivação da greve não estava atrelada a melhorias nas condições de trabalho, mas era determinada pelo desconforto causado por um

\footnotetext{
${ }^{25} \mathrm{O}$ ofício está danificado parcialmente na parte superior, impedindo a identificação do mês em que foi emitido. A indicação do dia (21) e ano (1921) dão conta de que se trata de junho, pois o conteúdo registrou os meses de março, abril e maio como referência.

${ }^{26}$ Esse ofício foi reconstruído a partir das informações contidas na resposta ofertada pela diretoria da companhia, em 2 de outubro de 1934.
} 
engenheiro graduado da CEFMSJ. No acervo da companhia, foi possível identificar o engenheiro: tratava-se de Mário Pena. O movimento de greve foi então intermediado pela presença de Ernani de Oliveira, do MTIC.

De alguma maneira, a substituição do capitão Pereira na subprefeitura de Arroio dos Ratos afetou os interesses da companhia. Curiosamente, as lideranças do sindicato dos mineiros encaminharam, provavelmente em 20 de dezembro de 1934, um pedido especial para a CEFMSJ. ${ }^{27}$ Solicitavam uma "colocação" do cap. Luiz Pereira nos quadros da companhia. Em resposta ao ofício, a companhia informou, em 5 de janeiro de 1935, ter conhecimento de que o "amigo capitão Luiz Pereira foi dispensado do cargo que ocupava na subprefeitura, por ordem do dr. José Maria de Carvalho, M.D. Prefeito do Município", acrescentando que a companhia teria satisfação em ver a reintegração de Pereira, mas que seria impossível atender ao pedido de sua colocação, "em vista das ordens rigorosas de economia que recebiam da diretoria".

Em pouco tempo, a própria companhia viria a solicitar intervenção do prefeito José Maria de Carvalho acerca do caso Luiz Pereira. Em 28 de janeiro de 1935, o diretor da companhia dirigiu-se ao prefeito como amigo, informando sobre um desdobramento interessante do caso. Luiz Pereira era genro de um coronel na região, com influência junto ao representante do MTIC, em Porto Alegre. No ofício, o diretor da companhia relatava:

\begin{abstract}
Tendo o Cel. Sinhô Cunha apelado para o dr. Ernani de Oliveira, no sentido de obter a permanência do seu genro nas Minas, tomamos a liberdade de fornecer, particularmente, a esse nosso amigo, uma cópia da carta que V. S. nos dirigiu em 17 do corrente, a fim de melhor se inteirar da situação que o caso Luiz Pereira está criando nesse município, e resolvê-lo com maior rapidez. Estamos certos que o sr. Luiz Pereira não quererá perturbar as nossas cordiais relações e os altos interesses do município, que vez foram confiados pelo benemérito General Interventor. Aproveitamos o ensejo para reiterar-vos os nossos protestos de apreço e alta consideração e firmamo-nos (Fundo CEFSMSJ, Caixa Correspondências, Maço 02).
\end{abstract}

Não há outras correspondências entre o diretor da companhia e o prefeito José Maria de Carvalho que permitissem encontrar o desfecho sobre o caso capitão Luiz F. Pereira. O fato de a companhia fazer referência a Valentin Aragon como subchefe de polícia junto à mina de Arroio dos Ratos dá a entender que o afastamento determinado por José Maria de Carvalho foi completo, atingindo a subprefeitura e a subdelegacia. Com isso, tornou-se necessário averiguar a possibilidade de que o conflito entre o subdelegado e a companhia tivesse relação com o processo $\mathrm{n}^{\circ}$ 9.582/1934.

\footnotetext{
${ }^{27}$ Em resposta a esse ofício, o conteúdo destinou-se a Pedro Logue Sobrinho, Pedro Saraiva, Antônio Haro, Castor Bispo e Gustavo Muller Filho.
} 
As fontes até então disponíveis para análise do caso ainda oferecem espaços para incertezas. ${ }^{28}$ Essas lacunas foram sendo preenchidas a partir das evidências disponíveis nas camadas de realidade que a reclamação trabalhista contemplou. Nas estratégias oferecidas pelo advogado do sindicato em face das assumidas pela companhia, existe outra camada que camuflou uma série de desdobramentos que foram silenciados no decorrer do processo junto ao CNT.

Entre os aspectos que podem ser analisados, está a definição dos possíveis limites da camaradagem da companhia com a autoridade policial. Curiosamente, foi a partir de 11 de dezembro de 1934 que a companhia apresentou a primeira contestação na reclamação trabalhista $n^{\circ}$ 9.582/1934. O processo já tramitava no CNT desde setembro de 1934, mas só houve reação por parte da empresa quando o conselho converteu o julgamento em diligência, a fim de que a companhia apresentasse aos autos o original do inquérito administrativo aberto para apurar a suposta falta grave cometida pelos mineiros reclamantes.

$\mathrm{O}$ argumento da companhia, já apresentado no primeiro capítulo, foi de que a instauração do inquérito seria desnecessária, uma vez que não foram demitidos, mas, sim, “privados de trabalhar pela polícia local, em consequência da prisão por ela efetuada, devido à denúncia recebida de estarem tramando uma greve geral entre os mineiros, denúncia, aliás, a que a Direção desta empresa foi completamente estranha”.

Assim, a companhia buscou eximir-se de sua obrigação trabalhista afirmando que, depois de verificada a injustiça da prisão, caberia à polícia a responsabilidade de indenizar os prejudicados. Os argumentos jurídicos fundamentavam-se na Constituição de 1934 - que estabelecia que os funcionários públicos seriam responsáveis solidariamente com a Fazenda Nacional, Estadual e Municipal por quaisquer prejuízos decorrentes de negligência, omissão ou abuso no exercício de seus cargos - e no Código Civil de 1916, nos termos do art. 1.550. ${ }^{29}$ Alegava, assim, que a responsabilidade por indenizar os reclamantes seria da polícia, que restringiu a liberdade destes indevidamente.

Supondo-se que o subdelegado capitão Pereira tenha sido um dos principais responsáveis pela expulsão dos mineiros das minas em fevereiro ou março de 1934, e considerando o fato de este não estar mais à frente da polícia local desde setembro de 1934, cabe questionar se isso pode ter tido alguma influência na construção do argumento da companhia. Nesse sentido, a companhia estaria não apenas se isentando da responsabilidade

\footnotetext{
${ }^{28}$ A referência de como lidar com desafios dessa natureza encontra-se em Natalie Zemon Davis (1987).

${ }^{29}$ Código Civil de 1916, art. 1.550, dispunha que: "A indenização por ofensa à liberdade pessoal consistirá no pagamento das perdas e danos que sobrevierem ao ofendido, e no de uma soma calculada nos termos do parágrafo único do art. 1.547". O artigo estava incluído no capítulo que tratava da liquidação das obrigações resultantes de atos ilícitos.
} 
de indenizar os trabalhadores, mas transferindo essa responsabilidade a uma autoridade policial que, por sua vez, não contava com o apoio do prefeito José Maria de Carvalho. Mas o fato de a companhia atribuir culpa a parceiros institucionais não contribuiria para abalar aquela relação? Seria mais estratégico, naquela situação, enfraquecer essa relação de parceria que assumir a responsabilidade pelas indenizações? Ou o poder exercido pela companhia era tamanho que a autoridade policial sequer exercia pressão na relação de parceria?

Tudo leva a crer que o fato de Pereira não estar mais vinculado a Carvalho teve influência no argumento de exclusão de responsabilidade por parte da companhia, mas não foi determinante. A empresa acreditava que, se fosse considerada responsável pelas indenizações, haveria uma inversão na culpa, em que a responsabilidade cairia sobre a empresa na modalidade de culpa de terceiro, não existente no caso.

O caso exterioriza uma ampla rede de relações que não se esgota apenas no plano institucional. Os interesses pessoais e profissionais se fundem em uma série de situações que fogem ao controle dos parâmetros jurídicos. Desde o início, o poder econômico teve destaque na relação amigável entre a companhia e a intendência de São Jerônimo.

Conforme as explorações nas minas de carvão atingiam novos patamares, a influência financeira nessas relações também se ampliava. Nos livros de correspondência da companhia, os anos de 1930 a 1936 registraram algumas dessas relações. Alguns ofícios continham uma marca entre parênteses - "(Reservado)" -, indicando um aprofundamento no assunto a ser tratado, possivelmente, sem que seu registro de entrada fosse determinado em livros de correspondência.

José Maria de Carvalho, além de exercer o cargo de prefeito de São Jerônimo entre 1933-1936, também era líder local do Partido Republicano Liberal (PRL). A análise das fontes permitiu verificar que, durante um longo período, a CEFMSJ foi questionada sobre possíveis financiamentos ao partido político de Carvalho. Nos registros, também se verifica que os ofícios da companhia para José Maria de Carvalho não faziam mais referência ao cargo de prefeito do município, mas como "M. D. Presidente da Comissão Diretora do Partido Republicano Liberal em São Jerônimo". Em 21 de agosto de 1934, o diretor da companhia informava ao "amigo e senhor" Carvalho ter a honra de comunicar que colocaria à disposição da comissão do partido, como "contribuição", a quantia de dois contos de réis (Rs 2:000\$000).

A referência ao PRL no contexto da organização do trabalho também se destacava. Conforme Machado (1983), o modelo corporativista de organização do trabalho no Rio Grande do Sul tinha apoio direto do PRL. Criado em novembro 1932, em decorrência de uma 
cisão no partido da Frente Única Gaúcha (FUG),${ }^{30}$ o partido era liderado por Flores da Cunha. Segundo Abreu (2007), um dos objetivos principais da formação do PRL não era apenas retratar a realidade gaúcha, mas congregar forças políticas em torno da liderança pessoal de Flores, o que garantia, ainda, um ponto de apoio importante para o governo provisório de Getúlio Vargas. Foi nesse contexto que a inspetoria do Ministério do Trabalho, Indústria e Comércio, sob a liderança de Ernani de Oliveira, foi constituída.

Os apoios financeiros sustentavam a ampla rede de interesses entre as lideranças municipais e as companhias de carvão (CEFMSJ e CCR) e, em muitas situações, podem ter sido determinantes para compreender os limites que se impunham à ação sindical dos mineiros.

Por mais complexo que seja determinar o impacto que essa rede de influências produzia no mundo do trabalho desenvolvido nas minas, a comunicação oficial entre as demais esferas institucionais era clara o suficiente para precisar os limites e as possibilidades de suas realizações. Paralelamente às correspondências oficiais, foi possível detectar outras estratégias para exteriorizar diálogos e ações em torno daquilo que não se registra oficialmente. Tratava-se de um aperfeiçoamento significativo dos sistemas de controle e vigilância mantidos pela companhia não apenas contra as organizações operárias e seus trabalhadores, mas contra qualquer pessoa ou grupo que representassem resistência a seus interesses.

Uma série de códigos utilizados pela companhia em comunicações extraoficiais foi encontrada no fundo Cadem. Embora não seja possível determinar se esses códigos foram utilizados nos autos $n^{\circ}$ 9.582/1934, dadas algumas ausências decorrentes de interceptação das fontes consultadas, sua identificação pode elucidar como se dava a circulação de informações entre os dirigentes e a polícia nas minas de carvão.

Condicionados em uma pasta de arquivo com a indicação "Código de nomes próprios (alterado e completamente reformado)" os códigos ultrapassavam 40 páginas. Arrolados por ordem alfabética, as situações, pessoas, bens e empresas eram renomeadas dentro de uma linguagem específica. Não havia informações sobre datas, com exceção de uma folha em que constou o dia de seu arquivamento: 2 de agosto de 1939.

\footnotetext{
${ }^{30}$ Segundo Abreu (2007, p. 82, nota de rodapé 1), “a Frente Única Gaúcha foi formada em 1928, meses após a posse de Getúlio Vargas como Presidente do Estado do Rio Grande do Sul, reunindo o Partido Republicano RioGrandense (PRR) e o Partido Libertador (PL), liderados respectivamente por Borges de Medeiros e Assis Brasil. Em 1929, a Frente Única Gaúcha integrou a campanha da Aliança Liberal à Presidência da República, apoiando a candidatura de Getúlio Vargas". A cisão na FUG estava relacionada aos que apoiam o movimento constitucionalista iniciado pelos revolucionários paulistas e aos que a rejeitavam. No plano interno, apoios a Flores da Cunha e Vargas em detrimento de Borges de Medeiros também eram registrados como motivos que deram origem à cisão.
} 
Uma greve passaria a ser renomeada como Abdias. Já Adalberto ou Ananias fazia referência ao delegado de polícia de São Jerônimo. General Flores da Cunha era reconhecido como Adolfo. E Almeidas era a referência aos operários. Ademir representava o chefe do pessoal da Brigada Militar nas Minas de São Jerônimo. Dirceu, o Conselho Nacional do Trabalho. Getúlio Vargas era conhecido como Caetano, e Oswaldo Aranha, como Calixto. O advogado da CEFMSJ, Euribíades Dutra Vila, era renomeado como Hugo. O embaixador dos Estados Unidos da América era conhecido como Valério. Juvenal era utilizado para expressar um entendimento direto entre os operários e o diretor Roberto Cardoso para aumento de salários. Greve geral era referenciada como Eloy. Fornecimento de carne, Jardel; de gêneros, Romancino e de pão, Luiz. Família do Juvêncio significava empreiteiros; família do Ludovico, tocadores; e família do Vital, furadores. Se as greves fossem em Butiá, chamariamse Belmiro; em Arroio dos Ratos, Juvêncio; se atingissem as minas de Butiá e Arroio dos Ratos, Clodoveu. O jornal Diário de Notícias era intitulado Herculano. José Maria de Carvalho era conhecido como Zacarias. Luiz Carlos Prestes, Rufino. O presidente do sindicato dos mineiros era identificado como Laerte ou Nicacio. O partido comunista, Leopoldo. Os parentes do Abílio eram os patrões; parentes do Frederico, os ajudantes; e parentes do Oswaldo, os diaristas. O subdelegado de polícia das minas de São Jerônimo era referido por Murilo; e das Minas de Butiá, Modesto. Serafim era o nome indicado ao Ministro do Trabalho. O Tribunal de Segurança era indicado como Trobaldo. Minas de São Jerônimo, Marias. A referência ao sindicato dos mineiros alternava entre José ou Carlos. A censura era nomeada como Thiago. Intendente de São Jerônimo era reconhecido como Isaac. Esses termos são identificados e empregados, em especial na escrita de cartas e telegramas, o que não exclui a possibilidade de terem sido usados no discurso oral - uso que não pode ser confirmado pelas fontes.

O monitoramento das ações sindicais foi sendo aperfeiçoado com a implementação de novas alternativas para a vigilância e o controle permanente dos operários. Não raro, a autoridade policial era utilizada pela companhia como instrumento para disciplinar socialmente os trabalhadores, à revelia das novas diretrizes que a ordem constitucional impunha. Mesmo assim, a possibilidade de recorrer a um processo judicial era um rito essencial à redefinição de novos espaços de empoderamento para os trabalhadores, proporcionados pelo direito. 


\subsection{O impacto da reclamação trabalhista para a institucionalização de direitos inéditos}

A reclamação trabalhista $n^{\circ} 9.852 / 1934$ pode ser considerada como um ponto de inflexão relevante para a história do direito constitucional. Essa afirmação assume a perspectiva desafiadora de tentar compreender como um caso concreto pode ilustrar situações de disputa sobre novas funções de direitos em sociedades mediadas pelo direito.

$\mathrm{O}$ contexto em que a reclamação foi apreciada pelo CNT coincidiu com o momento constitucional de 1934. O ponto de partida desta análise tem como referência os avanços sociais que a Constituição de 1934 incorporou, principalmente os ligados à regulação do direito do trabalho. Em nenhum momento da reclamação, o tema "constituição" foi aventado para legitimar a demanda dos mineiros reclamantes - e talvez não fosse necessário. Mas ao recepcionar a nova ordem constitucional de maneira tímida, a textualidade produzida pelas partes foi capaz de impor silêncios significativos.

Mesmo não os explicitando textualmente, o processo em análise desvelou aspectos constitucionais que possuíam valor próprio. A resistência manifestada pelos trabalhadores, ao pleitear acesso à justiça, por exemplo, envolvia uma série de direitos reais que não estavam apenas catalogados, mas à disposição para serem implementados.

Em cada movimento dos trabalhadores, ações do sindicato, polícia, Ministério do Trabalho e da própria companhia, foi possível observar a reprodução de diversas estruturas que sempre eram capazes de produzir algo novo. Estratégias de linguagem, violência, ameaças, punições, prisão, entre outras situações, entraram em cena e compuseram o enredo de realidades sobrepostas e que margeavam o processo.

Nessas estruturas, foi possível identificar a imposição de regras, que, até certo ponto, não deixavam de ser coercitivas. No entanto, essas regras proporcionavam contrapartidas de recursos que poderiam ser utilizados para fins de contestação e, com isso, revelavam também serem recursos capacitadores. Em grande parte, essas estruturas eram regidas por mecanismos de vigilância e controle que não refletiam apenas o poder de monitoramento de um grupo sobre outro, mas estabeleciam restrições aos "locais de direito", isto é, aos locais de trabalho dos empregados, onde as disputas e conflitos se desdobravam diretamente. A luta dos trabalhadores teve um papel crucial para seu estabelecimento, sobretudo quando as resistências e afirmações dos trabalhadores colocavam-se em oposição à vigilância imposta de cima para baixo.

Considerando as limitações existentes em uma mina de carvão - para além de saber lidar com a distribuição desigual de direitos que os mecanismos de vigilância conferiam -, um 
dos principais desafios à organização do trabalho consistia em estabelecer e ressignificar "locais de direito" nos quais fosse possível um esforço de negociação capaz de interferir naquela dinâmica.

Em cada uma das esferas possíveis em que a os novos direitos se assentava (esfera civil, política e social - ou econômica), as reações contra os sistemas de controle e punição poderiam assumir um local diferente. José Maurício Domingues, na apresentação ao livro de Giddens (2008), afirma que:

Os direitos civis ligam-se à vigilância exercida pelas atividades de "policiamento" do Estado, e seu local de exercício é paradigmaticamente a corte de justiça. Os direitos políticos têm como foco o parlamento ou as câmaras, e derivam da vigilância como monitoramento reflexivo do poder administrativo do Estado. Last, but not least, direitos econômicos possuem como foco o local do trabalho, seu eixo sendo fornecido pela vigilância exercida sobre a força de trabalho; não há claro local para seu exercício e defesa, e não é, portanto, casual que sejam um grande tema de luta social no capitalismo (DOMINGUES, 2008, p. 19).

Na prática, Giddens (2008) procurava estabelecer que, na formação do Estado-nação, o desenvolvimento da cidadania não poderia ser compreendido sem levar em consideração a questão da vigilância. Assim, diferentemente de Marshall (1967), Giddens deixava de considerar as três categorias dos direitos de cidadania como fase no conjunto do desenvolvimento da cidadania para "interpretá-las como três arenas de contestação ou conflito, cada uma vinculada a tipos distintos de vigilância, onde essa vigilância é tanto necessária ao poder dos grupos superiores quanto como eixo para a operação da dialética de controle" (GIDDENS, 2008, p. 223). ${ }^{31}$

No caso dos mineiros, também seria possível observar que seus "locais de direitos" constituíram-se a partir de seus próprios locais de trabalho, duplamente vigiados - pela companhia e pela autoridade policial - em relação às regras impostas sobre sua força de trabalho. Por outro lado, a sindicalização ou até mesmo a emergência ou ameaça da greve pode ser considerada como um nível significativo de controle pelo trabalhador sobre o processo de trabalho em reação à dupla vigilância. No segundo capítulo, a contextualização sobre o sindicato dos mineiros reforça esse argumento.

A reclamação trabalhista, de certo modo, modifica essa estrutura, porque impõe e cria um espaço de institucionalização para os novos direitos - não no sentido de direitos como

\footnotetext{
${ }^{31}$ Giddens (2008, p. 226) ainda concluiria que "todas as três formas de direitos de cidadania destacados por Marshall têm duas faces. Como aspectos de vigilância, eles podem ser mobilizados para expandir o controle que os membros da classe dominante são capazes de manter sobre aqueles em posições subordinadas. Mas ao mesmo tempo, cada um é uma alavanca de luta, que pode ser usada para conter tal controle".
} 
catálogos, mas do direito de poder defender direitos a partir de uma ritualização que produz texto, proporciona a produção de provas e obtém convencimento. ${ }^{32}$

Durante muito tempo, o alcance administrativo das autoridades do Estado deixou praticamente intocadas as regras sobre o mundo do trabalho. A grande autonomia de empregadores, como as companhias de mineração na região do baixo Jacuí, no Rio Grande do Sul, sobre contratos de trabalho e seus efeitos era permitida desde que certas obrigações com o Estado fossem satisfeitas. A manutenção da autonomia vinculada ao pagamento de impostos entre a prefeitura de São Jerônimo e a CCR exemplifica a situação.

A partir da reclamação trabalhista, três novos planos de institucionalidade destacaramse: os dois primeiros referem-se aos limites da autoridade policial e à atuação de Ernani de Oliveira junto ao caso, por intermédio do MTIC; o terceiro diz respeito à forma como o CNT interveio no caso. A seguir, cada um desses planos será analisado.

4.3.1 Nos limites da autoridade policial, o Ministério do Trabalho

A organização administrativa da CEFMSJ era complexa. Em 1934, aproximadamente 3 mil mineiros estavam vinculados às atividades nas minas de carvão. ${ }^{33} \mathrm{Com}$ um número cada vez maior de trabalhadores, o tema segurança ou ordem pública sempre esteve presente nas minas, e as seções policiais foram instituídas mediante acordo entre o diretor da companhia e o poder público municipal.

A partir do momento em que essa parceria se concretizou, houve um aperfeiçoamento no sistema de controle e vigilância por parte da empresa. No entanto, este sistema constituíase de maneira radicalmente oposta à formação de uma identidade política que permitisse, a médio e a longo prazo, evitar conflitos entre as classes de empregados e empregadores.

Dentro do sistema vila-fábrica do início da década de 1930, era vedado aos trabalhadores firmar ou ter controle sobre os "locais de direito". Esse fato, por consequência, reforçava a exclusão dos benefícios da cidadania.

Com a formação do sindicato dos mineiros, a luta dos trabalhadores por melhores condições de vida e para a implementação da nova legislação social passou a ser organizada. Por mais que essa afirmação possa ser relativizada diante do contexto restritivo e limitador

\footnotetext{
${ }^{32} \mathrm{O}$ papel exercido pelo processo corrobora essa afirmação.

${ }^{33} \mathrm{O}$ número exato de mineiros em Arroio dos Ratos era incerto. Os documentos oficiais emitidos pela companhia apontavam a existência de 2.500 a 3.000 operários em 1934 (Fundo CEFMSJ-MCAR). Após a fusão entre a CEFMSJ e CCR, o Cadem ampliou o número de postos de trabalho nas minas da região. No final da década de 1930, o número já era superior a 9 mil trabalhadores.
} 
que o governo provisório concedeu à formação dos sindicatos, a partir da reforma de 1931, a simples presença do sindicato fundamenta a necessidade de um refinamento estratégico para preencher a lacuna que se perpetuou nos espaços de experiência produzidos pelos conflitos entre capital e trabalho.

Os sindicatos se constituem, desse modo, como um espaço de contestação em relação aos sistemas de controle e vigilância exercidos pelos empregadores. Em Arroio dos Ratos, a presença do sindicato indicou outros desafios que mereciam ser apreciados.

$\mathrm{O}$ primeiro deles foi o enfrentamento com a autoridade policial. $\mathrm{Na}$ fase préprocessual, ou seja, da expulsão dos trabalhadores até a chegada do processo no CNT, a autoridade policial passou a ser questionada não apenas pelo sindicato, mas também pela forma como Ernani de Oliveira, representante do MTIC, atuou no caso.

Desde 23 de abril de 1934, Ernani de Oliveira se dedicava à mediação entre a CEFMSJ e o sindicato. Com a despedida dos trabalhadores, o SMAR oficiou a Oliveira solicitando intervenção. Nos autos, foi possível identificar uma dessas influências quando Oliveira encaminhou ofício à direção da Companhia Estrada de Ferro e Minas do Jacuí, em Porto Alegre, solicitando a reintegração dos empregados expulsos das minas e afirmando que:

\begin{abstract}
Atendendo a uma representação do sindicato de operários das Minas de Arroio dos Ratos, procurou esta Inspetoria averiguar as causas que teriam determinado a prisão por autoridade policial, e consequente dispensa do serviço dessa empresa, dos operários Raphael Mezza, Adalberto Azambuja dos Santos, Ricardo Pavio, João Herrera, Liberalino Machado, Antônio das Pedras e José Francisco. Informa-me a Chefatura de Polícia do Estado que esses operários foram denunciados à polícia como comunistas e promotores de um movimento grevista entre o pessoal de mineração. O sr. $3^{\circ}$ delegado auxiliar desta Capital, após rigorosa sindicância, concluiu que aquelas imputações são destituídas de fundamento. Afigura-se-me, assim, ato de boa justiça a readmissão desses operários, tão rudemente atingidos por infundada e aleivosa imputação. Acredito que diverso não será o vosso juízo, o que me autoriza a confiar nessa reparação. Aproveito o ensejo para expressar-vos o meu grande apreço e distinta consideração. Saúde e fraternidade. ${ }^{34}$
\end{abstract}

O conteúdo desse ofício já foi apresentado no primeiro capítulo. O retorno a ele tem o objetivo de destacar o papel que o sindicato assumiu na esfera de contestação ao conflito junto ao MTIC que, naquele momento, colocara-se como um elo entre empregador e empregados.

Os quatro operários expulsos das minas de Arroio dos Ratos estavam identificados. $\mathrm{O}$ próprio Ernani de Oliveira informara que, após sindicância sobre o caso, a acusação de que Adalberto, Antônio, Raphael e Liberalino eram comunistas e teriam promovido movimento de greve entre o pessoal das minas foi destituída de fundamento. O que chamava a atenção era a possibilidade inédita de revisão de uma decisão emitida pela autoridade policial local.

\footnotetext{
${ }^{34}$ Fl. 44 do processo $n^{\circ} 9.582 / 1934$.
} 
O acesso aos resultados da sindicância realizada pelo inspetor do trabalho se consolidou como uma fonte fundamental a favor dos argumentos dos mineiros, a tal ponto que, daquele momento em diante, ele se tornou um fiel colaborador dos interesses dos reclamantes.

O erro em uma investigação policial sempre demanda prejuízos. No entanto, no caso dos mineiros de Arroio dos Ratos, a informação de que as imputações de terem tramado uma greve geral era destituída de fundamento causou um impacto maior. Primeiro, pelo fato de que o próprio órgão de segurança pública interferiu em um sistema em que público e privado se constituíam de maneira híbrida, em benefício da companhia; e segundo, por enfraquecer o argumento da empresa, que utilizava a politização do caso por intermédio da polícia.

A revisão do caso pela polícia da capital, mesmo que fosse considerada casual, evidencia os limites do formato público e privado determinado pela companhia. Em outras palavras, as estruturas que mantinham o sistema de controle, vigilância e punição da empresa passaram a ser questionadas não apenas pelos trabalhadores mas também com a intervenção direta do inspetor do Ministério do Trabalho.

Esse desafio colocou a companhia em uma situação inédita: os fatos que ora se levantavam contraditavam as informações prestadas pela empresa, obrigando-a a se pronunciar, isto é, sujeitando-a à necessidade de responder ao monitoramento reflexivo que a vigilância estatal criou com a reforma do CNT em 1934.

A existência do processo gerou uma textualidade interessante. Ao passo que consolidou um espaço privilegiado e concedeu atenção especial a um conflito, permitiu observar uma evolução dos usos do direito. Foi possível identificar o papel do sindicato e do inspetor do trabalho nas relações trabalhistas, bem como evidenciar as tênues fronteiras entre público e privado ao analisar as relações, responsabilidades e poderes da companhia no que se refere aos prefeitos, policiais, mineradores e a uma concepção de justiça trabalhista (representados pelo MTIC e o CNT).

Em dois momentos bem específicos do processo, foi possível notar que tanto a empresa quanto a polícia associavam a militância política com a greve, não restando aos trabalhadores outra definição que não a de indesejáveis. Como o processo enfrentava essas questões? Estrategicamente, ao representar os mineiros, o sindicato buscou argumentar que o caso revelava uma violação às "regras de direito". Não houve espaço para argumentos outros que não se vincular às "regras do jogo"; os argumentos eram fundamentados exclusivamente nos decretos legislativos do governo provisório. A reclamação desafiou a empresa a partir dos 
usos da linguagem jurídica, excluindo, dessa forma, qualquer possibilidade de que o argumento de serem comunistas ou terem tramado uma greve geral avançasse.

Os argumentos e ações do sindicato não estavam apenas ancorados na lei. Ao lado dela, havia uma articulação entre o SMAR e Ernani Oliveira que visava estabelecer, com as armas do texto, elementos suficientes para ampliar a margem de convencimento e a produção de provas a favor dos mineiros. A participação de Oliveira merece destaque.

No processo de institucionalização do movimento operário sindical em Porto Alegre, a inspetoria regional do MTIC foi elemento-chave para o aparelhamento do Estado como principal interlocutor entre patrões e empregados. Ernani de Oliveira transitava em locais onde as organizações sindicais, operárias e patronais mais se faziam presentes: nas juntas de conciliação e julgamento e nas comissões mistas de julgamento.

Segundo Machado (1983), a classe patronal não mantinha relações diretas com a classe trabalhadora. Na maioria das vezes, os "encontros diretos" ocorriam quando conflitos de greve ou problemas na esfera de produção surgiam. Com isso, Ernani de Oliveira assumiu um protagonismo nessa relação entre capital e trabalho.

Em cada etapa de organização dos operários em Porto Alegre, a presença do MTIC foi notada. Segundo Machado (1983, p. 97-98), a organização dos operários pode ser compreendida em três períodos. No primeiro, entre 1930 a 1932, a principal característica foi a aproximação das classes, possibilitando - com a Revolução de 30 - o desenvolvimento e a unificação nacional, trazendo em si uma perspectiva de melhoria de condições de vida e de trabalho. $\mathrm{O}$ segundo período, entre 1933 e 1934, ficou marcado pelo enfrentamento de classe, quando a classe operária, heterogênea no nível econômico, passa a contar, no nível político, com a FORGS, seu principal elemento homogeneizador e orientador da luta operária. ${ }^{35}$ Por fim, entre 1935 e 1937, período em que a classe operária encontrava-se subjugada, tanto pelo aspecto econômico quanto político, resultando na supressão e repressão do movimento operário.

No período de aproximação das classes, o MTIC atuou diretamente sobre a organização dos trabalhadores com incentivo e controle sobre o processo de sindicalização. A FORGS e o próprio SMAR são exemplos dessa atuação. Entre os mineiros, as principais greves ocorreram em 1933 e 1934, período em que Oliveira, por muitas vezes, foi pessoalmente às minas para promover a solução dos conflitos.

Com essas considerações, a atuação do inspetor do MTIC indicava que, por mais que os interesses econômicos da companhia estivessem interligados ao processo de aceleração da

\footnotetext{
${ }^{35}$ É nesse período que surgem os círculos operários e também a união sindicalista.
} 
industrialização promovida por Getúlio Vargas, ao se fazer presente, a inspetoria do Ministério pode ser considerada como órgão que impõe limites às ações dos empregadores. Não se tratava de um órgão que buscava apenas moralizar as relações de trabalho, mas que impunha a necessidade constitucional de se legitimar decisões que fossem mediadas pela lei, pelo direito.

Por um lado, não seria a Constituição de 1934 ou os decretos por si sós que cessariam as violações aos direitos do trabalhador. Por outro lado, a função da Constituição de 1934, naquele contexto, passava a ser outra, sobretudo, ao proporcionar um determinado modo de articulação entre direito e política.

4.3.2 Entre a lei e a estratégia: a conformação do direito e da política diante do Conselho Nacional do Trabalho

O Conselho Nacional do Trabalho (CNT) foi criado pelo Decreto $\mathrm{n}^{\mathrm{o}} 16.027$, de 30 de abril de 1923, constituindo-se como órgão consultivo dos poderes públicos em assuntos relacionados à organização do trabalho e à previdência social. Isento, inicialmente, de funções contenciosas no âmbito trabalhista e previdenciário, o CNT foi vinculado ao Ministério da Agricultura, Indústria e Comércio, cuja missão era dedicar-se a estudos sobre trabalho nas indústrias, sistemas de remuneração do trabalho, contratos coletivos de trabalho, conciliação e arbitragem (prevenção e resolução de conflitos), trabalho de menores e mulheres, aprendizagem, ensino técnico, acidentes de trabalho e seguros sociais, ${ }^{36}$ Caixa de Aposentadorias e Pensões (CAP) de ferroviários, ${ }^{37}$ instituições de crédito popular e caixas de crédito agrícola.

Sua instituição estava intrinsecamente ligada à Lei Elói Chaves (Decreto $n^{0} 4.682$, de 24 de janeiro de 1923). A partir da organização do sistema previdenciário de trabalhadores das estradas de ferro mediante as CAPs, o CNT seria o órgão responsável pela fiscalização e controle das caixas.

Em pouco mais de dez anos, o conselho passou a ter um papel fundamental nas soluções de conflitos entre empregados e empregadores. A primeira reforma do conselho

\footnotetext{
${ }^{36}$ Os seguros sociais eram regulamentados pelo Decreto $\mathrm{n}^{\mathrm{o}} 14.786$, de 28 de abril de 1921 . Com o CNT, a Comissão Consultiva de Seguros contra acidentes do trabalho foi dissolvida, e suas atribuições foram transferidas ao conselho.

${ }^{37}$ No campo previdenciário, uma das principais resoluções do período corresponde ao Decreto $\mathrm{n}^{\circ} 4.682$, de 24 de janeiro de 1923, conhecida como Lei Elói Chaves, responsável por determinar a criação de Caixas de Aposentadoria e Pensões para todos os funcionários de empresas de estradas de ferro.
} 
ocorreu em 19 de janeiro de 1928, com a edição do Decreto $n^{\circ}$ 18.074. No entanto, a reforma mais significativa ocorreu em 1934, dois dias antes da promulgação da Constituição de 1934.

O Decreto $\mathrm{n}^{\mathrm{o}} 24.784$, de 14 de julho de 1934, instituiu um novo regulamento para o conselho. De certo modo, o decreto já se alinhava com os dispositivos da futura Constituição, que, de maneira inédita, instituía a Justiça do Trabalho. ${ }^{38}$ Os últimos meses do governo provisório foram marcados pela aceleração na emissão de decretos. A justificativa era a limitação aos poderes presidenciais que a futura Carta Constitucional previa. O acordo entre os constituintes, de que todos os decretos do governo provisório seriam aprovados, sem qualquer apreciação judiciária dos mesmos atos, decretos e efeitos (art. 18 das disposições transitórias da Constituição de 1934), ampliou a produção legislativa do governo provisório. Foi nesse contexto que o CNT foi reformado.

As principais alterações no conselho estavam na ampliação de sua competência, que, além das atividades de consultoria técnica, congregava a possibilidade de ser órgão julgador de questões que interessassem à economia, ao trabalho e à previdência social, com funções administrativas, de fiscalização e punição.

Assim, a ampliação da competência do CNT integrava-se a um núcleo complexo que oferecia um plano de institucionalidade novo para a ampliação dos "locais de direito" do e para o trabalho. O tom dessa complexidade era ditado pelos decretos $\mathrm{n}^{\circ} 21.396$, de 12 de maio de $1932^{39}$ e $\mathrm{n}^{\mathrm{o}} 22.132$, de 25 de novembro de 1932, que instituíram as comissões mistas de conciliação. O primeiro decreto se destinava aos municípios e localidades onde existissem sindicatos ou associações profissionais de empregadores e empregados para a composição e solução de dissídios coletivos, sob responsabilidade do MTIC. O segundo decreto se destinava à composição de litígios individuais, oriundos de questões de trabalho em que fossem as partes empregados sindicalizados, mas que não se relacionassem aos dissídios coletivos.

A composição do CNT foi ampliada de 12 para 18 conselheiros, proporcionalmente vinculados a representantes de empregados e empregadores (oito no total), funcionários graduados do MTIC (quatro no total) e mais seis conselheiros com competência reconhecida

\footnotetext{
${ }^{38}$ O artigo 122 da Constituição de 1934 dispunha: "Para dirimir questões entre empregadores e empregados, regidas pela legislação social, fica instituída a Justiça do Trabalho, à qual não se aplica o disposto no Capítulo IV do Título I [referência que a Justiça do Trabalho não era vinculada ao Poder Judiciário]. Parágrafo único: A constituição dos Tribunais do Trabalho e das Comissões de Conciliação obedecerá sempre ao princípio da eleição de membros, metade pelas associações representativas dos empregados, e metade pelas dos empregadores, sendo o presidente de livre nomeação do governo, escolhido entre pessoas de experiência e notória capacidade moral e intelectual".

${ }^{39}$ Esses decretos foram expedidos na gestão Joaquim Pedro Salgado Filho no Ministério do Trabalho.
} 
em assuntos sociais. A indicação desses membros era competência do presidente da República, sendo facultada aos sindicatos e associações de classe a indicação de membros de suas categorias para apreciação presidencial. Esse dado, embora soasse democrático, arrastava uma série de situações emblemáticas, que envolviam a relação entre Estado e sindicatos no transcorrer da década de 1930.

O CNT passou a funcionar não apenas como órgão consultivo mas também como Tribunal de Embargos (embora essa disposição para apreciar embargos já constasse desde a primeira reforma do conselho em 1928).

Os órgãos que compunham o CNT eram:

1) Conselho Pleno: com competências consultivas (no atendimento de demandas e interesses do Poder Executivo), administrativas (atinentes ao regime das Caixas de Aposentadorias e Pensões) e deliberativas (funcionamento como tribunal arbitral, julgamento de recursos opostos contra as decisões das câmaras, podendo impor multas aos infratores das leis e regulamentos cuja execução lhe competia, a fim de torná-las efetivas);

2) Três Câmaras (como órgão julgador ou deliberativo de primeira instância): com cinco membros cada, responsáveis pela apreciação e julgamentos das reclamações contra atos das Caixas e Institutos de Aposentadoria e Pensões e das empresas e estabelecimentos a umas e outros ligados, no tocante à estabilidade e outras garantias asseguradas por lei aos respectivos empregados, recursos interpostos ex oficio pelas juntas e conselhos administrativos, das suas decisões e pelos terceiros a que elas afetam;

3) Procuradoria Geral e Adjunta: com competência para atuar em todos os processos, reclamações, recursos e consultas que venham ser apreciados e resolvidos pelo Conselho Pleno ou pelas três Câmaras; e

4) Secretaria Geral: composta pela diretoria geral, três seções, serviços de estatística e atuariado, contadoria, inspeção e engenharia, protocolo geral e arquivo e portaria.

A nova estruturação do CNT não deixava de ser uma alternativa para que novos locais institucionalizados de contestação em relação ao mundo do trabalho prosperassem. A forma 
como foi articulada a reforma do conselho permite associá-la a uma concepção incipiente de como se estruturaria a futura Justiça do Trabalho. Formalmente, apenas em 1939 o CNT foi considerado como órgão da Justiça do Trabalho, compreendido como seu tribunal superior. ${ }^{40}$

De certo modo, esse deslocamento parcial do controle e da vigilância sobre a força de trabalho - que primeiramente eram organizados por empregadores nos próprios locais de trabalho, e depois passam para um órgão estatal como o CNT - empodera um conjunto amplo de trabalhadores, que poderiam usar diversas estratégias para adquirir medidas substanciais de controle sobre situações que, formalmente, não possuíam. O empoderamento a que se faz referência estava ligado diretamente à extensão dos novos direitos, justamente num momento em que o que se vivenciava era um déficit de cidadania e uma crise de democracia.

O contexto de greve é bem exemplificativo. O encaminhamento de uma greve pode exteriorizar, a partir do local de trabalho, um movimento de disputa política que, por vezes, pode ainda não estar clara para a própria consciência política de seus atores. A competição entre os interesses pessoais dos envolvidos evolui a ponto de se aglutinarem em um nível corporativo capaz de lançar bases para ações, estratégias e projetos de pequeno e médio alcance. Mas tão importante quanto isso é o fato de se verificar até que ponto uma estrutura jurídico-institucional, como o CNT, pode constituir-se como um local efetivo de realização das novas regras sociais, de uma nova razão política.

As transformações mediadas pelos decretos que regulamentavam os direitos trabalhistas, como a que se propunha na transição do governo provisório para o governo constitucional pósConstituição de 1934, a estabilização de expectativas normativas tornava-se necessária para a consolidação do sistema jurídico. Nesse sentido, o CNT passava a ser a instituição que, além de fundamentar suas decisões perante esse sistema, também era compelida a lidar com as linguagens produzidas pelo sistema da política.

De certo modo, a reclamação trabalhista promovida pelos mineiros retrata um momento em que as linguagens do direito e da política radicalizam-se. A institucionalização de novos direitos voltados aos trabalhadores e a ritualização representada pelo processo geram uma textualidade que refletia os desafios da época. Mas como compreendê-los?

O conflito trabalhista que deu origem à reclamação agregou três situações diversas que não eram inicialmente conexas entre si. Diante dessas circunstâncias, os argumentos da

\footnotetext{
${ }^{40}$ O Decreto-Lei $\mathrm{n}^{\circ}$ 1.237, de 2 de maio de 1939, reestruturou o CNT. O decreto-lei, vinculado aos dispositivos da Constituição de 1934, que também previa a Justiça do Trabalho, definiu que o CNT, com jurisdição em todo território nacional, seria considerado tribunal superior da justiça trabalhista. No entanto, impende salientar que sua instituição ocorreu apenas em $1^{\circ}$ de maio de 1941, sendo inserida como parte do Poder Judiciário na constituição de 1946.
} 
companhia para justificar ou não as demissões foram lançados nos autos com vistas a explorar os limites que as razões jurídicas e políticas emprestavam ao caso.

$\mathrm{O}$ argumento da greve, mais uma vez, pode ser levantado como chave interpretativa. A greve foi utilizada naquele contexto como um veículo para definir os locais do direito. A persistência de associar, mesmo que indiretamente, a militância política dos mineiros a um movimento ilegal, assim como o fato de os mineiros terem sido classificados como indesejáveis pela autoridade policial local que os expulsou das minas, revela esse caráter exploratório que tenciona identificar tal argumento às regras de direito. Contudo, não o faz na perspectiva do direito propriamente dito, mas, sim, na forma de uma negação de direitos, criminalizando o movimento.

Essa perspectiva assumida atinge tanto o sistema do direito quanto o da política, em especial no que se refere ao tema direito de greve. Em relação aos direitos do trabalho, o direito de greve foi duramente disputado pelos constituintes na ANC de 1933-1934, inclusive, com substitutivos que permitiam o direito de greve pacífica realizado por empregados sindicalizados. ${ }^{41}$ A companhia usou o exercício da greve vinculando-o diretamente a um abuso de direito, considerado como instrumento de ataque contra o capital. No âmbito do CNT, por sua vez, a questão da greve teve outro desdobramento relevante: a exploração dos limites políticos do conselho em relação ao direito posto.

Embora essa estratégia não tenha persistido por longo tempo, sua utilização pela companhia não deixa de ser reveladora. Como referência a esse argumento, retoma-se o posicionamento de conselheiro Gualter Ferreira, por ocasião da primeira sessão de apreciação da reclamação trabalhista, ocorrida em 16 de novembro de 1934. Naquele momento, reagindo ao argumento do relator Manoel Tibúrcio - que solicitava a reintegração de todos os trabalhadores estáveis uma vez que havia a indicação de que a companhia os havia demitido sem a instauração de inquérito administrativo para apurar falta grave -, mesmo sem a indicação de que a empresa havia sido citada para responder ao processo, Ferreira afirmava ser uma situação muito difícil para os conselheiros, podendo até afetar o prestígio de seus membros.

O prestígio a que se referia Ferreira relacionava-se à própria condição administrativa do conselho que, vinculada ao MTIC, poderia sofrer repreensões políticas, para além da necessidade de promover decisões que se vinculassem às regras do direito. No entanto, a

\footnotetext{
${ }^{41}$ A expressa permissão ao direito de greve não resistiu às pressões e deixou de ser incluído no texto constitucional de 1934.
} 
exposição do relator também era circunscrita à mesma alegação de violações de direito, mas às praticadas pela companhia:

Temos aqui 4 com mais de 10 anos de serviço, sendo um com 40 anos. Agora eu pergunto se a empresa andou certa não fazendo inquérito administrativo, como era de obrigação? Se os empregados foram demitidos como mau elemento, nada mais fácil que provar no inquérito administrativo. Entretanto, a empresa não cogitou, não a interessava, o que para mim importa como má-fé. ${ }^{42}$

$\mathrm{O}$ argumento da companhia, de que não seria obrigada a instaurar inquérito administrativo por não ter demitido os quatro trabalhadores que foram expulsos pela polícia, não foi acolhido pelos conselheiros do CNT. Mesmo assim, a opção de não o instaurar acabou prevalecendo.

$\mathrm{Na}$ prática, diante da circularidade das regras jurídicas levantadas, até mesmo o argumento de abandono de emprego relativo aos demais trabalhadores reclamantes trouxe à tona a resistência da companhia em não se vincular à ordem constitucional.

Nesse aspecto, o posicionamento do CNT em relação ao caso produziu um silêncio constitucional interessante. As tentativas de enquadrar a companhia dentro das regras constitucionais eram eminentemente complexas e permissivas. As reiteradas solicitações de cumprimento de suas decisões ou ainda pedidos de remessa do inquérito não realizado pela companhia podem ser citadas como exemplo. Por mais que as decisões de mérito tenham determinado a reintegração dos empregados estáveis, as decisões políticas do CNT deixaram de apreciar argumentos e situações que exteriorizavam uma natureza muito mais complexa que integrava o conflito.

Por alguma razão, a partir do momento que o CNT se limitou a verificar a estabilidade ou não dos mineiros, acabou por ignorar situações de abuso de direito por parte da companhia que afetavam direitos que estavam constitucionalizados para os trabalhadores. Os decretos editados pelo governo provisório anteciparam muitas etapas de processo de expansão de direitos que seriam posteriormente inseridos no texto constitucional.

Esse silêncio sobre a Constituição carrega em si questionamentos sobre a função que a Constituição de 1934 poderia assumir em situações que a sociedade passava a ser mediada pelo direito. A reclamação trabalhista auxilia nesse entendimento justamente por ilustrar como os limites dos sistemas da política e do direito criam, diante da estrutura institucional, um canal interpretativo para a definição do que é direito ou não.

\footnotetext{
${ }^{42}$ Ata da sessão de julgamento do processo $n^{\circ}$ 9.852/1934, em 16 de novembro de 1934. Relator Manoel Tibúrcio.
} 
As constituições modernas têm por característica a dupla capacidade de realizar e positivar normas que estão inteiramente ligadas aos princípios da igualdade e liberdade. Ao lado dessa concepção, assumiram também o status de um plano superior, capaz de dar forma ao ordenamento jurídico de uma comunidade.

Nesse sentido, a Constituição assume a condição de ser facilitadora entre duas estruturas que se firmaram e por consequência, consolidaram-se em funções diferentes: direito e política. ${ }^{43}$ A relação entre essas duas esferas é fundamental para se compreender o processo moderno de transformação social que emerge com as constituições. Ao lado dessas asserções, a fórmula "Estado de Direito" expressa uma relação importante entre política e direito, principalmente pela necessidade de responder de maneira eficaz ao problema da fundação do Estado e, consequentemente, do direito, como instrumento jurídico-coercivo do Estado.

Enquanto o sistema político se beneficia com o fato de que o direito se encontra codificado e que, diretamente, administra a diferença do que é conforme ao direito ou não direito, o sistema jurídico se beneficia com o fato de que a paz - a diferença de poderes claramente estabelecida e o fato de que as decisões podem se impor pela força está assegurada em outra parte, ou seja, no sistema político (LUHMANN, 2003). Enquanto a política se vincula à produção de decisões vinculantes, o direito encontra seu espaço com a produção de uma decisão. As influências desse sistema interpretativo encontram-se em Luhmann (1996, 2003). Em diálogo com esta teoria, Cristiano Paixão, acrescenta que:

ao isolar e consolidar funções diferentes, o processo é irreversível: não se concebe uma sociedade que tenha seu centro na política, assim como não se permite que o direito deva suas condições de vigência a uma constelação normativa exterior ao próprio sistema jurídico (PAIXÃO, 2014, p. 418).

A ideia de se permitir a reconexão entre esses dois sistemas a partir da Constituição marcou o desenvolvimento da concepção moderna do constitucionalismo, principalmente, por possibilitar a afirmação das opções fundamentais de cada comunidade, vinculando-a às ideias de separação de poderes e direitos fundamentais (política) e o estabelecimento de uma forma nova para se compreender a vigência da ordem jurídica (direito). ${ }^{44}$

Como toda a história política elucida, os momentos de construção de novos regimes políticos - principalmente os que ensejam processos de elaboração constitucional - trazem à

\footnotetext{
${ }^{43}$ Para aprofundamento, ver Holmes (1993); Grimm (2006) e Fioravante (2001).

44 Nesse sentido, Paixão (2014, p. 418) ainda acrescenta que "essa construção conceitual produz duas importantes consequências: (i) o direito passa a referir-se a si próprio, ou seja, ele prescinde de operações de 'legitimação' ou 'validação' a partir de condensações de sentido ligadas à política, à moral, à religião ou à filosofia dos valores; e (ii) apresenta-se a necessidade de constante atualização da comunicação produzida pelo direito numa perspectiva interna, voltada à dinâmica das regras em casos concretos".
} 
tona situações que nem sempre se resolvem no texto constitucional. A Constituição de 1934 pode ser compreendida dentro desse parâmetro. Como registraram Paixão (2011) e Cepêda (2010) a Carta de $1934^{45}$ insere-se no paradigma do estado social de direito e sua curta duração pode ser compreendida não apenas pelas fortes divergências na política interna mas também pela alta carga de instabilidade (por vezes, jurídica) que a nova ordem constitucional experimentou desde sua promulgação. A fragilidade que a Constituição de 1934 representou na história política nacional pode ser compreendida sob múltiplas perspectivas. Entre as possíveis, destacam-se seu contexto. O processo de conformação da futura Constituição pela constituinte de 1933-34 pode ser identificado em meio a uma complexidade que representava um alto nível de fragmentação. O caráter autocrático do governo provisório produzia - para além de sua narrativa modernizante - uma série de resistências e dificuldades na estabilização política mediada pelos instrumentos legais legítimos (CEPEDA, 2010).

As resistências sobre a inclusão dos direitos sociais na Constituição exemplificam esse tema, principalmente, em relação ao direito de greve. O processamento da reclamação trabalhista no CNT representa esse desafio que as perspectivas do direito e da política assumiam. O pedido de reintegração realizado pelos trabalhadores pautava-se pela vigência de um direito vinculado a uma adequada compreensão das transformações sociais pela qual o país passava. Assim, o pedido se interconectava de forma imediata às transformações constitucionais de 1934, com conteúdos bem definidos.

A resistência da companhia, por outro lado, posicionava-a contra a nova ordem constitucional, em especial, pela aparente recusa aos procedimentos que o novo direito estabelecia. Verifica-se, assim, a demonstração de uma superação apenas parcial da tradicional subordinação do direito à política.

Embora o caso em apreço possa ser considerado parcialmente bem-sucedido, por determinar a reintegração dos mineiros estáveis, ele matiza exatamente esse momento de redefinições pelo qual o direito e a política passaram com o advento da Constituição de 1934. Os limites e as possibilidades do caso lançam contribuições para a história do direito, sobretudo, ao direito constitucional, por demonstrar como as tensões, conflitos e direitos são articulados dentro do aparato institucional organizado pela nova ordem a partir da tematização de indícios, provas e evidências.

\footnotetext{
${ }^{45}$ Para maiores detalhes sobre a Constituição de 1934, referencia-se os trabalhos do autor em Cabral (2010; 2011; 2015).
} 


\section{CONSIDERAÇÕES FINAIS}

Aqui há a verdadeira democracia do trabalho - chefes e operários se dão as mãos e se ajudam mutuamente.

Euribíades Dutra Villa advogado da CEFMSJ, $1^{\circ}$ mar. 1934

Em 28 de fevereiro de 1934, a mina de Arroio dos Ratos recebia a visita de Joaquim Pedro Salgado Filho, ministro do Trabalho. As festividades que marcaram a visita ocultavam uma trama complexa de contradições e ambiguidades que emergiam quando os olhos se voltavam para uma questão fundamental do período: os conflitos entre empregados e empregadores no panorama das legislações sociais introduzidas pelo governo provisório de Getúlio Vargas.

Naquela trama, alguns apelos discursivos se sobressaíram para caracterizar uma realidade que não era acessível a todos os trabalhadores. Por alguma razão, o próprio desenvolvimento da legislação social no início da década de 1930 não era o mesmo para todos os trabalhadores. Mas o fio que liga a complexidade daquele tempo histórico com a reclamação trabalhista $n^{\circ}$ 9.582/1934 ofereceu indicadores sociais, jurídicos e econômicos relevantes.

O caso Domingos Mantilha e outros chegou ao CNT exatamente em um momento de redefinição da política frente às novas disposições do sistema do direito. Instruído pouco mais de um mês após a vigência da Constituição de 1934, o caso não retratava apenas um conflito trabalhista, mas exteriorizava indicadores que lidavam com as aporias da nova ordem constitucional. O que chama a atenção nesse enredo era o surgimento de um novo "local de direito".

O apelo excessivo ao uso da nova ordem constitucional presente neste trabalho precisa ser tematizado. Seu uso não está atrelado ao efeito inspirador que as constituições assumiram nos últimos anos. Em 1934, qual seria a função da Constituição? Seria ela capaz de evitar os conflitos do trabalho? Impediria que violações a direitos dos trabalhadores continuassem? A Constituição de 1934 já era fruto de desafios não resolvidos pela própria Assembleia Constituinte que a concretizou. Com isso, o primeiro pressuposto a considerar é o de que uma Constituição, por si só, principalmente no contexto político, econômico e jurídico da transição iniciada pela Revolução de 1930, com o retorno da legalidade constitucional em 1934, não 
seria capaz de transformar uma realidade sozinha. No entanto, o texto constitucional não deixou de fixar alternativas e possibilidades.

Entre essas possibilidades, a condição de cidadania retratada pela Constituição de 1934 pode ser exemplificativa. Há um bom tempo, os trabalhos historiográficos têm questionado os termos que a palavra cidadania assumiu na história republicana. $\mathrm{Na}$ década de 1930, o termo não estava integrado no léxico político, jurídico e social. Seus usos foram interpretados em contextos mais recentes para designar um conjunto inédito de novos direitos. Contrariando a ideia evolutiva desses direitos (MARSHALL, 1967) - que teriam assumido primeiro a dimensão dos direitos civis (direitos de igualdade, liberdade, locomoção, entre outros), depois a dimensão dos direitos políticos (com direito à participação política e voto), para, enfim, alcançar a dimensão social (direito à educação, saúde e trabalho) -, no Brasil, os caminhos da cidadania foram inversos, como apontou Carvalho (2010).

O caminho que caracteriza o problema da cidadania no Brasil colocou em relevo algumas peculiaridades que individualizam a história política nacional, principalmente pela forma como os ensaios de participação política ocorreram entre 1930 a 1937, consolidando o modelo de cidadania regulada (SANTOS, 1978). A Constituição de 1934 era resultado dessa fragilidade, não apenas em decorrência da baixa participação política mas também da ausência de pactuação política que pudesse colocar os interesses nacionais acima das divergências ideológicas que se recrudesceram após o período da constitucionalização.

O desenvolvimento dos direitos sociais em detrimento dos direitos políticos e civis causou uma série de limitações ao próprio exercício da cidadania, muitas vezes vinculada apenas à condição de trabalhador. Essas experiências impuseram na cultura geral uma experiência de baixa cidadania, compreendida nas situações em que os países não são capazes de oferecer a seus cidadãos o direito de ter ou usufruir direitos. Como exemplo, pode-se citar a sindicalização dos trabalhadores. Apesar de haver a previsão legal, a organização de reuniões ${ }^{1}$ por parte dos trabalhadores estava sujeita a ser considerada como ato subversivo da ordem pela polícia, que poderia determinar a prisão de seus realizadores.

A aposta na concepção de que a lei se constituía como uma garantia de direitos passava por um teste de força. A regulação do trabalho, nos primeiros anos da década de 1930, inseria-se em um panorama que rejeitava o conflito social e insistia na cooperação entre empregados e empregadores com a supervisão direta do MTIC. A versão local que o

\footnotetext{
${ }^{1}$ Contemplada nos direitos de associação, um direito civil.
} 
corporativismo assumiu nessa trajetória tinha como objetivo controlar as contradições do mundo do trabalho brasileiro e abrigá-las dentro do aparato constitucional.

Em consequência, as regras jurídicas eram marcadas pela circularidade do medo que se refletia diretamente sobre a condição da cidadania; em outras palavras, a caracterização do status de trabalhador era fundamental nesse processo. A partir dessa constatação, a redução na escala de observação passou a ser fundamental para ancorar os estudos desta tese e o uso da micro-história auxiliou nessa tarefa.

Vestígios, indícios e provas. Em cada etapa de um processo administrativo ou judicial esses elementos se reencontram. Por sua vez, as fases do processo são construídas a partir de problemas reais que podem ser representados. O sindicato dos mineiros - representando os reclamantes - e a companhia lançaram fios que os orientavam no "labirinto da realidade" processual e, a partir de uma intensiva reconstrução dos vestígios documentados, foi possível identificar rastros importantes.

A metáfora utilizada por Carlo Ginzburg (2007) sobre a relação entre o fio e os rastros na mitologia grega do minotauro inspirou essa investigação. Os documentos produzidos no processo, bem como os que margearam sua produção, podem ser encarados como testemunhos históricos das realidades que eram representadas pelos personagens envolvidos na trama. Os documentos eram produtos de uma distorção, cuidadosamente construídos pelas situações de poder que representavam. Com isso, ler esses documentos históricos a contrapelo, em uma ação que buscava questionar as intenções de quem os produziu, tornou-se instigante, porque as representações que o sindicato e companhia reservavam ao conflito trabalhista camuflavam estruturas de alta complexidade que passavam a ser ressignificadas.

Mas o que se ressignifica? Em um primeiro momento, a reclamação trabalhista exteriorizou uma relação em que o público e o privado se encontravam radicalizados, vislumbrada na relação entre a companhia, o município de São Jerônimo e os contornos da ordem pública e privada reconstruídos pela direção da CEFMSJ. Essa rede complexa de relações era forjada também na medida em que a companhia se utilizava da autoridade policial local para o controle e fiscalização dos trabalhadores nas minas e, depois, ao tentar se isentar de suas obrigações legais, ${ }^{2}$ transferindo a responsabilidade para a autoridade policial. Em um segundo momento, foi possível compreender o conflito sob a perspectiva da inovação

\footnotetext{
${ }^{2}$ Em especial, no que diz respeito ao processo, a obrigação de instaurar inquérito administrativo para apurar falta grave.
} 
de direitos dentro do sistema híbrido dos espaços público e privado no local de trabalho e o impacto que uma reclamação trabalhista poderia causar nessa estrutura.

A partir do processo, os resultados obtidos e apresentados nos capítulos que constituem este trabalho decorrem da intenção de decifrar o impacto de uma reclamação trabalhista em um período que se conhece pouco e que não pode ser analisada apenas de cima para baixo. Para a perspectiva da história do direito, o processo pode ser muito significativo, favorecendo uma melhor compreensão daquele tempo histórico, principalmente, ao permitir a observação de como aqueles mineiros, representados por seu sindicato de classe, comportaram-se diante daquela realidade e conseguiram avançar. Talvez, em uma conclusão semelhante à de Jacques Revel no prefácio do livro de Giovanni Levi (2000), a incerteza, caracterizada pelo autor como a noção abstrata que movia comportamentos e escolhas, seja o principal elemento dessa narrativa.

A reclamação trabalhista explora uma situação de incerteza que, conscientemente ou não, impõe decisões, alternativas e estratégias diante do novo arranjo constitucional. Aqui, mais uma vez, os obstáculos postos à pesquisa são incorporados sob a forma de lacunas e, levando em consideração as distorções da documentação analisada, elas se tornaram parte do relato (GINZBURG, 2007).

Vale a pena, então, retomar o percurso utilizado nos capítulos anteriores. Localizada em um fundo de arquivo do CNT junto ao NuMEP do TST, a reclamação trabalhista $n^{\circ}$ 9.582/1934 registrou um processo administrativo que colocou em evidência a trajetória de sete mineiros das minas de carvão em Arroio dos Ratos/RS. O primeiro capítulo descreve o processo em seus detalhes, facilitando a compreensão acerca do conflito instaurado. O núcleo duro da reclamação era a denúncia de uma violação às leis do governo provisório, que estabeleciam regras aos empregadores para a despedida de empregados estáveis. A história do processo girava em torno dessa violação à lei pela CEFMSJ. Em contrapartida, a companhia contestava o pedido alegando que quatro dos mineiros foram expulsos pela autoridade policial local acusados de tramarem uma greve geral entre os mineiros, tendo sido qualificados como indesejáveis na ocasião. Já os demais mineiros foram demitidos, segundo a companhia, por abandono de emprego.

A resistência da companhia em cumprir a determinação legal de instaurar inquérito administrativo para apurar falta grave foi uma das marcas do processo. A rebeldia da companhia destacava uma ação de resistência à nova ordem constitucional. A recusa de instaurar o inquérito administrativo era justificada pela companhia por uma interpretação 
equivocada dos fatos previstos em lei, mas, se fosse considerada, poderia interferir na relação entre empregado e empregador de maneira inédita, causando impacto em uma estrutura de alta complexidade. O binômio direito versus abuso ou direito versus não direito passou a ser definido com as novas regras constitucionais.

Essa resistência da CEFMSJ foi rechaçada pelo CNT, permitindo que a maioria dos empregados estáveis fosse reintegrada à companhia - alguns, antes da própria determinação do conselho, como foi o caso de Thomaz Gonçalves da Silva. No entanto, a rebeldia confirmava a manutenção do abuso, que franqueava à companhia uma margem de ação que contrastava com as narrativas de proteção social sustentadas pelo governo provisório. Caso o inquérito administrativo fosse instaurado pela companhia, quando de sua apreciação pelo CNT, evidenciaria um ato de despedida que revelaria uma situação de abuso de direito e, consequentemente, imporia um limite à autonomia da companhia. A resistência em relação ao cumprimento da lei e a tentativa de ausência de punição sobre a violação, por parte da companhia, foram capazes de criar um efeito expressivo na relação de trabalho. Os argumentos utilizados e as disputas lançadas são interessantes, especialmente em situações de realinhamentos institucionais como os observados em 1934.

O uso argumentativo da greve, por exemplo, exteriorizava essa relação. As consequências da greve alegada pela companhia não atingiram todos os trabalhadores reclamantes. Qualificada como um desdobramento do termo indesejável e definida como ato subversivo, a greve assumiu contornos de um não direito capaz de causar danos à ordem pública. Ao se matizar os usos da greve no contexto de 1934, foi possível verificar que o termo refletia movimentos antagônicos de disputa política, jurídica e econômica. Em Arroio dos Ratos não era diferente. Na Assembleia Nacional Constituinte de 1933-1934, o tema era motivo de amplas discussões entre os constituintes. Os jornais eram os principais porta-vozes dessas discussões, com amplas coberturas. No Rio Grande do Sul, os jornais Diário de Notícias e Correio do Povo atualizavam diariamente seus leitores sobre os desdobramentos na ANC.

Durante longo tempo, o CNT também apreciava as reclamações trabalhistas ou pedidos de homologação de inquéritos administrativos ${ }^{3}$ que envolviam movimentos de greve. Embora o conselho não fosse órgão do Poder Judiciário (integração que só ocorreria a partir da

\footnotetext{
${ }^{3}$ No fundo CNT, muitos processos preservados registraram pedidos de homologação de inquéritos administrativos que apuravam faltas graves cometidas por empregados envolvidos em greves, principalmente, entre 1932 e 1937. Em linhas gerais, era possível verificar uma mudança nas diretrizes do CNT em relação ao direito de greve na década de 1930. Três momentos eram significativos: i) entre a Revolução de 1930 e a Constituição de 1934; ii) do período constitucional (1934) à intentona comunista (1935); e iii) da intentona pósconstituição de 1937. A partir de meados de 1935, houve uma nítida radicalização no conselho quando o motivo era greve, em especial ao período pré e pós-Lei de Segurança Nacional.
} 
Constituição de 1946), após a reforma de julho de 1934 passou a ter competência para julgar casos trabalhistas e, nesse sentido, dar diretrizes jurídicas sobre o direito de greve. No âmbito da economia, principalmente pelos setores ligados ao capital, o direito de greve era considerado uma violência contra o trabalho e à nação. O desequilíbrio de forças entre empregado e empregador era o ponto central para a manutenção de um modelo em que se colocava em xeque a liberdade sem proteção ou proteção sem liberdade (CARVALHO, 2010).

A companhia explorou o evento greve em uma perspectiva própria: a partir do momento em que o lançou nos autos, aqueles documentos já estavam contaminados pela interpretação da companhia, plenamente ratificadas pela autoridade policial. Seu apelo ilustrativo foi facilmente capturado pelos redatores dos acórdãos: em todas decisões, a referência ao termo greve esteve presente. Interpretar esses dados parece muito mais difícil quando, no caso dos mineiros, a potencialidade da greve passava a ser questionada pelos reclamantes de maneira indireta, sem ser contestada pela peça inicial do processo.

$\mathrm{O}$ uso argumentativo da greve no CNT assumiu outro efeito. Uma das funções do conselho era promover estudos sobre a organização do trabalho e da previdência social para assessorar as políticas do governo provisório. O impacto das greves era explorado no conselho em perspectiva de abuso de direito, muitas vezes, com a criminalização das organizações trabalhistas, acusadas de estarem conectadas com movimentos de resistência ao governo ou à orientação comunista. No CNT, as discussões sobre greve envolviam um conjunto diversificado de opiniões, não apenas por seus membros refletirem uma representação classista (capital e trabalho), mas também por representarem, na maioria das vezes, os interesses do governo provisório, que os indicou ou nomeou. Assim, a necessidade de regulamentar ou banir o direito de greve acabava por margear a pauta do conselho para a proposição de políticas de regulação ao governo.

A incerteza, mais uma vez, se fez presente, tendo sido a principal figura por meio da qual os mineiros apreenderam seu tempo. No segundo capítulo, foi empreendida uma visita aos registros pessoais dos reclamantes. Embora as trajetórias individuais não tenham sido determinantes para a reconstrução de suas histórias de vida, os levantamentos dos dados apontaram características que podem identificá-los como um grupo representativo de uma determinada classe social. Um ponto em comum se encontra na origem familiar dos reclamantes, vinculados em sua maioria à região carbonífera e a trabalhos em minas de carvão. Essas trajetórias coletivas se transformaram com a criação do Sindicato dos Mineiros de Arroio dos Ratos. 
A escolha pela sindicalização representa, novamente, a presença da incerteza. Diante da necessidade de encontrar alternativas, uma grande incerteza passava a ser reduzida quando o grupo acreditou que a criação do sindicato seria viável. Os relatos de Adalberto Thimóteo dos Santos (1966) ilustraram como a incerteza se relacionava com o medo. A trajetória do reclamante Adalberto Azambuja dos Santos, concretizada com a disputa da diretoria do sindicato em setembro de 1933, também exemplifica esse contexto. Contudo, a incerteza podia ser encontrada em toda parte: na necessidade de sobreviver ao trabalho insalubre nas minas de carvão; na necessidade de manter a condição de cidadania determinada pelo status de trabalhador; na aposta na sindicalização sem perseguição patronal e policial; nas estratégias coletivas por melhores condições de trabalho e exigências de cumprimento da legislação social; nas dificuldades de comprovarem estabilidade decenal, ou de comprovarem que eram a mesma pessoa, mesmo usando dois nomes diversos; na necessidade de desqualificar um movimento de greve para não perder a condição de cidadania garantida pelo trabalho; no quanto uma representação contra a companhia junto ao CNT custaria para a relação de emprego dos mineiros; enfim, na aposta que os mineiros realizavam ao acreditar que o cumprimento da lei poderia ser exigido da companhia pelo novo "local de direito" que se institucionaliza em 1934.

Ainda no segundo capítulo, as trajetórias do sindicato e da companhia foram apresentadas com o objetivo de realçar as estruturas políticas, econômicas e sociais que as determinavam. Situá-las dentro de um espaço de institucionalidade que, a todo momento, modificava-se diante da nova ordem constitucional tornou-se relevante para compreender melhor dos impactos que a reclamação trabalhista poderia produzir.

No terceiro capítulo, as contradições e ambiguidades do caso foram analisadas. A greve, a expulsão das minas pela autoridade policial local e a configuração do abandono de emprego foram revisitados. O retorno ao suposto movimento de greve mostrou-se impossível. Diante de escassas informações, documentação insuficiente ou ambígua, a metáfora "laboratório historiográfico", utilizada por Natalie Zemon Davis também se fez presente. Nos trabalhos de pesquisa sobre $O$ retorno de Martin Guerre, a autora afirma: "pareceu-me ter à disposição um verdadeiro laboratório historiográfico, um laboratório em que o experimento não gerava provas irrefutáveis, mas, sim, possibilidades históricas” (DAVIS, 1987, p. X).

A reconstrução das vidas dos mineiros e de seus dilemas bem como o conhecimento acerca das estratégias de organização e ação coletiva auxiliaram na captação da concretude dos processos sociais daquele período. Como já mencionado, os obstáculos postos à pesquisa 
se expressaram sob a forma de lacunas, que se tornaram parte do relato. A reconstrução da realidade dos mineiros colocou em destaque um sistema de controle e vigilância que institucionalizava a violência policial em parâmetros complexos que superdimensionavam o espaço privado.

A reclamação trabalhista representa, nesse enredo, um desafio que pode ter a capacidade de romper com os silêncios que os acordos promovidos no âmbito da companhia causaram. O desdobramento do processo impôs a necessidade de diálogo, que seria mediado em um "local de direito" inédito para a CEFMSJ.

À margem desses fenômenos, outra estrutura, já consolidada e caracterizada pela polícia local, pelo prefeito municipal e pelo diretor da companhia, passava a ser questionada em novos planos de institucionalidade. Assim, a presença do inspetor do Ministério do Trabalho em Porto Alegre foi relevante. Por mais que o processo possa ser contemplado em seus limites, ele não perde a característica de ser instrumento pelo qual a resistência ao arbítrio se efetivou, permitindo, na medida do possível, uma extensão aos benefícios da cidadania.

Esses benefícios se circunscreveram em um movimento de conformação entre o direito e a política. O processo em si não deixava de representar uma aposta na estabilização de expectativas normativas, mas também de instrumentalizar a capacidade do direito de fundamentar a confiança social e criar segurança de conduta. A concretização dessa premissa era fundamental para que o Estado pudesse dar andamento às modificações nas relações sociais trabalhistas, com vistas à realização dos objetivos sociais firmados politicamente. 


\section{REFERÊNCIAS}

ANAIS. Assembleia Nacional Constituinte (1933-1934). 22 Volumes. Rio de Janeiro: Imprensa Nacional, 1934; 1935; 1936.

ABREU, Luciano Aronne. Um olhar regional sobre o Estado Novo. Porto Alegre: EDIPUCRS, 2007.

BARROS, José D'Assunção. Sobre a feitura da micro-história. Revista OPSIS, Catalão, v. 7, n. 9, p. 167-185, jul./dez. 2007.

BARRETO, Alvaro Augusto de Borba. O movimento operário rio-grandense e a intervenção estatal: a FORGS e os círculos operários (1932-1935). Dissertação (Mestrado em História) Universidade Federal do Rio Grande do Sul, Porto Alegre, 1996.

BASTOS, Pedro Paulo Zahluth; FONSECA, Pedro Cezar Dutra (Org.). A Era Vargas: desenvolvimento, economia e sociedade. São Paulo: Editora Unesp, 2012.

BENJAMIN, Walter. "Sobre o conceito da história". In: Magia e técnica, arte e política: ensaios sobre literatura e história da cultura. v. I. Tradução de Sérgio Paulo Rouanet. 7. ed. São Paulo: Brasiliense, 1994. (Obras escolhidas).

BIAVASCHI, Magda Barros; DROPPA, Alisson. A luta pela preservação dos documentos judiciais: a trajetória do combate à destruição das fontes a partir da Constituição de 1988. História Social, Campinas, n. 21, p. 93-118, 2011.

BIAVASCHI, Madga Barros. O direito do trabalho no Brasil 1930-1942: construindo o sujeito de direitos trabalhistas. 1. ed. São Paulo: LTR, 2007.

BONFÁ, Rogério Luis Giampetro. "Com lei ou sem lei”: as expulsões de estrangeiros na Primeira República. Cadernos AEL: Trabalhadores, leis e direitos, Campinas, v. 14, n. 26, 2009.

BRASIL [REPÚBLICA DOS ESTADOS UNIDOS DO BRASIL]. Annaes da Assembléa Nacional Constituinte. Rio de Janeiro: Imprensa Nacional, 1935-1937. 22 v. Disponível em: $<$ http://bd.camara.leg.br/bd/handle/bdcamara/2/browse?value=Brasil.+Assembleia + Nacional + Constituinte $+(1933) \&$ type $=$ subject $>$. Acesso em: 10 jan. 2016.

BRASIL [REPÚBLICA DOS ESTADOS UNIDOS DO BRASIL]. Annaes da Assembléa Nacional Constituinte. Rio de Janeiro: Imprensa Nacional, 1935a. v. 3. Disponível em: $<$ http://bd.camara.leg.br/bd/handle/bdcamara/8008>. Acesso em: 10 jan. 2016.

BRASIL [REPÚBLICA DOS ESTADOS UNIDOS DO BRASIL]. Annaes da Assembléa Nacional Constituinte. Rio de Janeiro: Imprensa Nacional, 1935b. v. 4. Disponível em: $<$ http://bd.camara.leg.br/bd/handle/bdcamara/8227>. Acesso em: 10 jan. 2016.

BRASIL [REPÚBLICA DOS ESTADOS UNIDOS DO BRASIL]. Annaes da Assembléa Nacional Constituinte. Rio de Janeiro: Imprensa Nacional, 1936a. v. 9. Disponível em: $<$ http://bd.camara.leg.br/bd/handle/bdcamara/8246>. Acesso em: 10 jan. 2016. 
BRASIL [REPÚBLICA DOS ESTADOS UNIDOS DO BRASIL]. Annaes da Assembléa Nacional Constituinte. Rio de Janeiro: Imprensa Nacional, 1936b. v. 11. Disponível em: $<$ http://bd.camara.leg.br/bd/handle/bdcamara/8167>. Acesso em: 10 jan. 2016.

BRASIL [REPÚBLICA DOS ESTADOS UNIDOS DO BRASIL]. Annaes da Assembléa Nacional Constituinte. Rio de Janeiro: Imprensa Nacional, 1936c. v. 13. Disponível em: $<$ http://bd.camara.leg.br/bd/handle/bdcamara/8113>. Acesso em: 10 jan. 2016.

BRASIL [REPÚBLICA DOS ESTADOS UNIDOS DO BRASIL]. Annaes da Assembléa Nacional Constituinte. Rio de Janeiro: Imprensa Nacional, 1936d. v. 14. Disponível em: $<$ http://bd.camara.leg.br/bd/handle/bdcamara/8168>. Acesso em: 10 jan. 2016.

BRASIL [REPÚBLICA DOS ESTADOS UNIDOS DO BRASIL]. Annaes da Assembléa Nacional Constituinte. Rio de Janeiro: Imprensa Nacional, 1937. v. 21. Disponível em: $<$ http://bd.camara.leg.br/bd/handle/bdcamara/8071>. Acesso em: 10 jan. 2016.

BRASIL. Decreto no 20.910, de 6 de janeiro de 1932. Regula a prescrição quinquenal. Disponível em: < http://www.planalto.gov.br/ccivil_03/decreto/Antigos/D20910.htm>. Acesso em: 18 nov. 2014.

BRASIL. Decreto-Lei no 1.237 , de 2 de maio de 1939. Organiza a Justiça do Trabalho. Disponível em: <http://www.planalto.gov.br/ccivil_03/decreto-lei/1937-1946/Del1237.htm>. Acesso em: 10 ago. 2014.

BRASIL. Decreto no 21.396, de 12 de maio de 1932. Institui Comissões Mistas de Conciliação e dá outras providências. Disponível em:

$<$ http://www2.camara.leg.br/legin/fed/decret/1930-1939/decreto-21396-12-maio-1932526753-norma-pe.html>. Acesso em: 10 ago. 2014.

BRASIL. Decreto $n^{\circ} 21.081$, de 24 de fevereiro de 1932. Altera artigos do decreto $\mathrm{n}^{\circ} 20.465$, de $1^{\mathrm{o}}$ de outubro de 1931. Disponível em: <http://www2.camara.leg.br/legin/fed/decret/19301939/decreto-21081-24-fevereiro-1932-511792-publicacaooriginal-1-pe.html>. Acesso em: 8 ago. 2014.

BRASIL. Decreto $n^{\circ} 20.465$, de $1^{\circ}$ de outubro de 1931. Reforma a legislação das Caixas de Aposentadoria e Pensões. Disponível em: $<$ http://www2.camara.leg.br/legin/fed/decret/19301939/decreto-20465-1-outubro-1931-500674-publicacaooriginal-1-pe.html>. Acesso em: 8 ago. 2014.

BRASIL. Decreto $n^{\circ} 24.694$, de 12 de julho de 1934. Dispõe sobre os sindicatos profissionais. Disponível em: <http://www.planalto.gov.br/ccivil_03/decreto/1930-1949/D24694.htm>. Acesso em: 9 de agosto de 2014.

BRASIL. Decreto n ${ }^{\circ} 19.770$, de 19 de março de 1931. Regula a sindicalisação das classes patronaes e operarias e dá outras providências. Disponível em: $<$ http://www.planalto.gov.br/ccivil_03/decreto/Antigos/D19770.htm>. Acesso em: 9 ago. 2014.

BRASIL. Decreto $n^{\circ} 21.690$, de $1^{\circ}$ de agosto de 1932. Cria Inspetorias Regionais do Ministério do Trabalho, Indústria e Comércio nos Estados e no Território do Acre, e dá outras providências. Disponível em: 
$<$ http://legis.senado.gov.br/legislacao/ListaNormas.action?numero=21690\&tipo_norma=DEC \&data $=19320801 \&$ link $=\mathrm{s}>$. Acesso em: 9 ago. 2014.

BRASIL. Decreto n ${ }^{\circ} 23.288$, de 26 de outubro de 1933. Cria, no Ministério do Trabalho, Indústria e Comércio, mais cinco Inspetorias Regionais, com o respectivo pessoal, e dá outras providências. Disponível em: <http://www2.camara.leg.br/legin/fed/decret/19301939/decreto-23288-26-outubro-1933-526809-publicacaooriginal-81253-pe.html>. Acesso em: 4 ago. 2014.

BRASIL. Lei $\mathrm{n}^{\circ} 12.527$, de 18 de novembro de 2011. Regula o acesso a informações previsto no inciso XXXIII do art. $5^{\circ}$. Disponível em: $<$ http://www.planalto.gov.br/ccivil_03/_ato20112014/2011/lei/112527.htm>. Acesso em: 4 ago. 2014.

BRASIL. Lei $\mathrm{n}^{\circ} 8.159$, de 8 de janeiro de 1991. Dispõe sobre a política nacional de arquivos públicos e privados e dá outras providências. Disponível em:

$<$ http://www.planalto.gov.br/ccivil_03/LEIS/L8159.htm>. Acesso em: 4 ago. 2014.

BRASIL. Decreto no 22.132, de 25 de novembro de 1932. Institui Juntas de Conciliação e Julgamento e regulamenta as suas funções. Disponível em:

$<$ http://www2.camara.leg.br/legin/fed/decret/1930-1939/decreto-22132-25-novembro-1932526777-norma-pe.html>. Acesso em: 4 ago. 2014.

BRASIL. Decreto $\mathrm{n}^{\circ}$ 16.027, de 30 de abril de 1923. Cria o Conselho Nacional do Trabalho. Disponível em: <www2.camara.leg.br/legin/fed/decret/1920-1929/decreto-16027-30-abril1923-566906-publicaooriginal-90409-pe.html>. Acesso em: 1 ago. 2014.

BRASIL. Decreto $n^{\circ} 4.682$, de 24 de janeiro de 1923. Cria as caixas de aposentadoria e pensões nas estradas de ferros do país. Disponível em:

$<$ http://www.planalto.gov.br/ccivil_03/decreto/Historicos/DPL/DPL4682.htm>. Acesso em: 9 jan. 2015.

BRASIL. Decreto ${ }^{\circ}$ 18.074, de 19 de janeiro de 1928. Renova o regulamento do CNT. Disponível em: <http://www2.camara.leg.br/legin/fed/decret/1920-1929/decreto-18074-19janeiro-1928-526664-publicacaooriginal-1-pe.html>. Acesso em: 10 jan. 2015.

BRASIL. Decreto $n^{\circ} 21.396$, de 12 de maio de 1932. Institui comissões mistas de conciliação e dá outras providências. Disponível em: $<$ http://www2.camara.leg.br/legin/fed/decret/19301939/decreto-21396-12-maio-1932-526753-publicacaooriginal-1-pe.html>. Acesso em: 11 jan. 2015.

BRASIL. Decreto ${ }^{\circ} 22.132$, de 25 de novembro de 1932. Disponível em:

$<$ https://www.planalto.gov.br/ccivil_03/decreto/antigos/D22132impressao.htm>. Acesso em: 11 jan. 2015.

BRASIL. Decreto ${ }^{\circ} 19.482$, de 12 de dezembro de 1930. Disponível em: $<$ http://www2.camara.leg.br/legin/fed/decret/1930-1939/decreto-19482-12-dezembro-1930503018-republicacao-82423-pe.html>. Acesso em: 20 dez. 2015.

BRASIL. Decreto no 20.291, de 12 de agosto de 1931. Disponível em: $<$ http://www2.camara.leg.br/legin/fed/decret/1930-1939/decreto-20291-12-agosto-1931514687-publicacaooriginal-1-pe.html>. Acesso em: 20 dez. 2015. 
BRASIL. Constituição da República dos Estados Unidos do Brasil de 1934. Disponível em: $<$ http://www.planalto.gov.br/ccivil_03/constituicao/constituicao34.htm>. Acesso em: 2 set. 2014.

BRASIL. Processo de Domingos Mantilha e outros em face da Companhia Estrada de Ferro e Minas de São Jerônimo. Brasília: Fundo CNT-TST, Série Dissídios, Cx. 27, Maço 01, 195p., 1934.

BRASIL. Tribunal Superior do Trabalho. Do CNT ao TST. Brasília, 1975.

BUNSE, Heinrich Adam Wilhelm. A mineração de carvão no Rio Grande do Sul: estudo histórico-etnográfico-sociolinguístico. Porto Alegre: Secretaria de Energia, Minas e Comunicações, 1984.

CABRAL, Rafael Lamera. A contribuição da Assembleia Nacional Constituinte de 1933 para o Brasil: da Revolução de 1930 à Constituição de 1934. São Paulo: Cedec, out. 2011. (Cadernos Cedec, n. 101)

. Constituição e sociedade: uma análise sobre a (re)formulação na arquitetura do Estado-Nação na Assembleia Nacional Constituinte de 1933. Dissertação de mestrado em Ciência Política. São Carlos: UFSCar, 2010.

Uma leitura do legado constitucional brasileiro entre 1930-1937. Revista de História Constitucional, Oviedo, n. 15, 2015. Disponível em:

$<$ http://www.historiaconstitucional.com/index.php/historiaconstitucional/article/viewFile/425/ pdf_9>. Acesso em: 10 out.2015.

CARNEIRO, Maria Luiza Tucci. A imagem do imigrante indesejável. Seminários Imigração, Repressão e Segurança Nacional, São Paulo: Arquivo Público do Estado, n. 3, p. 23-44, out. 2003.

CARVALHO, José Murilo de. Cidadania no Brasil: o longo caminho. 13. ed. Rio de Janeiro: Civilização Brasileira, 2010.

CEFMSJ - Companhia Estrada de Ferro e Minas de São Jerônimo. Relatório para a Assembleia Geral dos Acionistas. Rio de Janeiro: Jornal do Brasil, 1895.

CEPÊDA, Vera Alves. Contexto político e a crítica a democracia liberal: a proposta de representação classista na Constituinte de 1934. In: MOTA, C. G.; SALINAS, N. S. C. Os juristas na formação do Estado-Nação brasileiro. São Paulo: Saraiva, 2010.

CERUTTI, Simona. Processo e experiência: indivíduos, grupos e identidades em Turim no século XVII. In: REVEL, Jacques (Org.). Jogos de escala. Rio de Janeiro: Editora FGV, 1998.

CHALHOUB, Sidney. Trabalho, lar e botequim: o cotidiano dos trabalhadores no Rio de Janeiro da belle époque. $3^{\mathrm{a}}$ ed. Campinas, SP: Editora da Unicamp, 2012.

CIOCCARI, Marta. Ecos do subterrâneo: estudo antropológico do cotidiano e memória da comunidade de minérios de carvão de Minas do Leão (RS). Dissertação (Mestrado em Antropologia Social) - Universidade Federal do Rio Grande do Sul, Porto Alegre, 2004. 
CORSI, Francisco Luiz. Política econômica e nacionalismo no Estado Novo. In: SZMRECSÁNYI, Tamás; SUZIGAN, Wilson (Org.). História econômica do Brasil contemporâneo. 2. ed. São Paulo: Hucitec, 2002.

COSTA, Adailton Pires. A história dos direitos trabalhistas vista a partir de baixo: a luta por direitos (e leis) dos trabalhadores em hotéis, restaurantes, cafés e bares no Rio de Janeiro da $1^{\text {a }}$ República (DF, 1917-18). Dissertação (Mestrado em Direito) - Universidade Federal de Santa Catarina, Florianópolis, 2013.

COSTA, Pietro. Uma questão de método: a relação entre teoria e historiografia. Trad.

Cristiano Paixão, Menelick de Carvalho Netto e Ricardo Lourenço Filho. Brasília, nov. 2010. Texto apresentado em Seminário organizado pelo Programa de Pós-Graduação em Direito, Estado e Constituição da Universidade de Brasília.

DAVIS, Natalie Zemon. O retorno de Martin Guerre. Tradução Denise Bottmann. Rio de Janeiro: Paz e Terra, 1987.

DOMINGUES, José Maurício. Anthony Giddens e a modernidade. In: GIDDENS, Anthony. O Estado-Nação e a violência: segundo volume de uma crítica contemporânea ao materialismo histórico. 1. ed. São Paulo: Edusp, 2008.

ECKERT, Cornélia. Os homens da mina - Um estudo das condições de vida e representações dos mineiros de carvão em Charqueadas-RS. Dissertação (Mestrado em Antropologia Social) - Universidade Federal do Rio Grande do Sul, Porto Alegre, 1985.

FAUSTO, Bóris. A revolução de 1930: historiografia e história. São Paulo: Brasiliense, 1987.

FERREIRA, Marieta de Morais; SÁ PINTO, Sumara Conde. A crise dos anos 1920 e a Revolução de 1930. In: FERREIRA, Jorge; DELGADO, Lucilia de A. N. (Orgs.). O Brasil republicano. Vol. 1. Rio de Janeiro: Civilização brasileira, 2003.

FIORAVANTI, Maurizio. Constitución. De la Antigüidad a nuestros días. Madrid: Trotta, 2001.

FORTES, Alexandre. "Buscando os nossos direitos...”: trabalhadores e organização sindical na Porto Alegre de 1933 a 1937. Dissertação (Mestrado em História Social) - Universidade Estadual de Campinas, Campinas, 1994.

. Da solidariedade à assistência: estratégias organizativas e mutualidade no movimento operário de Porto Alegre na primeira metade do século XX. Cadernos AEL, v. 6, n. 10/11, p. 173-218, 1999.

. Nós do quarto distrito...: a classe trabalhadora portoalegrense e a Era Vargas. Caxias do Sul: EDUCS; Rio de Janeiro: Garamond, 2004.

GERALDO, Endrica. A "lei de cotas" de 1934: controle de estrangeiros no Brasil. Cadernos AEL: Imigração, Campinas, v. 15, n. 27, 2009.

GIDDENS, Anthony. O Estado-Nação e a violência: segundo volume de uma crítica contemporânea ao materialismo histórico. 1. ed. São Paulo: Edusp, 2008. 
GINZBURG, Carlo. Checking the Evidence: the jugde and the Historian. Critical Inquiry, Chicago, v. 18, n. 1, p. 79-92, 1991.

. Il giudice e lo storico. Milão: Feltrinelli, 2006.

2007.

. O fio e os rastros: verdadeiro, falso, fictício. São Paulo: Companhia das Letras,

. O inquisitor como antropólogo. Revista brasileira de história, São Paulo, v. 1, n. 21, p. 09-20, 1991.

. O queijo e os vermes: o cotidiano e as ideias de um moleiro perseguido pela

Inquisição. São Paulo: Companhia das Letras, 2006.

GOMES, Angela Maria de Castro. A invenção do trabalhismo. $3^{\text {a }}$ ed. Rio de Janeiro: Editora FGV, 2005.

. Burguesia e trabalho: política e legislação social no Brasil, 1917-1937. Rio de

Janeiro: Campus, 1979.

. Confronto e compromisso no processo de constitucionalização (1930-1935). In:

FAUTOS, Bóris (Org.). História da Civilização Brasileira. Tomo III: O Brasil Republicano.

São Paulo: Difel, 1990.

GRENDI, Edoardo. Microanálise e história social. In: OLIVEIRA, Mônica Ribeiro de;

ALMEIDA, Carla Maria Carvalho de. (Org.). Exercícios de micro-história. Rio de Janeiro:

Editora FGV, 2009.

. Paradoxos da história contemporânea. In: OLIVEIRA, Mônica Ribeiro de;

ALMEIDA, Carla Maria Carvalho de. (Org.). Exercícios de micro-história. Rio de Janeiro: Editora FGV, 2009.

. Repensar a micro-história? In: REVEL, Jacques (Org.). Jogos de escala. Rio de Janeiro: Editora FGV, 1998.

GRIBAUDI, Maurizio. Escala, pertinência, configuração. In: REVEL, Jacques (Org.). Jogos de escala. Rio de Janeiro: Editora FGV, 1998.

GRIMM, Dieter. Constituição e política. Belo Horizonte: Del Rey, 2006.

GUERRA, Maria Pia dos Santos Lima. Anarquistas, trabalhadores, estrangeiros: a construção do constitucionalismo brasileiro na Primeira República. Dissertação (Mestrado em Direito) - Universidade de Brasília, Brasília, 2012.

HARRES, Marluza Marques. Ferroviários: disciplinarização e trabalho. Dissertação (Mestrado em História) - Universidade Federal do Rio Grande do Sul, Porto Alegre, 1992.

HESPANHA, Antonio Manuel. Cultura jurídica européia - Síntese de um milênio.

Florianópolis: Fundação Boiteux, 2005. 
HOLMES, Stephen. Precommitment and the paradox of democracy. In: ELSTER, Jon; SLAGSTAD, Rune. Constitutionalism and democracy. Cambridge: Cambridge University Press, 1993.

KLOVAN, Felipe Figueiró. Sob o fardo do ouro negro: as experiências de exploração e resistência dos mineiros de carvão do Rio Grande do Sul na primeira metade da década de 1930. Monografia (Graduação em História) - Universidade Federal do Rio Grande do Sul, Porto Alegre, 2009.

Sob o fardo do ouro negro: as experiências de exploração e resistência dos mineiros de carvão do Rio Grande do Sul na década de 1930. Dissertação (Mestrado em História) Universidade Federal do Rio Grande do Sul, Porto Alegre, 2014.

KONRAD, Diorge Alceno. O fantasma do medo: o Rio Grande do Sul, a repressão policial e os movimentos sócio-políticos (1930-1937). Tese (Doutorado em História) - Universidade Estadual de Campinas, Campinas, 2004.

KONRAD, Glaucia Vieira Ramos. Os trabalhadores e o Estado Novo no Rio Grande do Sul: um retrato da sociedade e do mundo do trabalho (1937-1945). Tese (Doutorado em História) - Universidade Estadual de Campinas, Campinas, 2006.

LAEMMERT, Almanak. Anuário comercial, industrial, agrícola, profissional e administrativo da Capital Federal e dos Estados Unidos do Brasil para o ano 1930. $3^{\circ}$ Volume - Estados do Norte. Rio de Janeiro: Laemmert, 1930.

LEPETIT, Bernard. Sobre a escala na história. In: REVEL, Jacques (Org.). Jogos de escala. Rio de Janeiro: Editora FGV, 1998.

LEVI, Giovanni. A herança imaterial: trajetória de um exorcista no Piemonte do século XVII. Rio de Janeiro: Civilização Brasileira, 2000.

. Prefácio. In: OLIVEIRA, Mônica Ribeiro de; ALMEIDA, Carla Maria Carvalho de (Org.). Exercícios de micro-história. Rio de Janeiro: Editora FGV, 2009.

LIMA, Henrique Espada. A micro-história italiana: escalas, indícios e singularidades. Rio de Janeiro: Civilização brasileira, 2006.

Pensando as transformações e a recepção da micro-história no debate histórico hoje. In: OLIVEIRA, Mônica Ribeiro de; ALMEIDA, Carla Maria Carvalho de. (Org.). Exercícios de micro-história. Rio de Janeiro: FGV, 2009.

LUCAS, Maria Elizabeth. A Federação Operária no Rio Grande do Sul e o movimento operário gaúcho no período 1931-35. Monografia (Graduação em História) - Universidade Federal do Rio Grande do Sul, Porto Alegre, 1978.

LUHMANN, Niklas. Constituição como aquisição evolutiva. Título original: Verfassung als evolutionäre Errungenschaft. Rechthistorisches Journal, v. 9, p. 179-220, 1996. Tradução de Menelick de Carvalho Netto, Giancardo Corsi e Raffaele De Giorgi. Não publicada.

. El derecho de la sociedad. [S.1.]: [s.n.], 13 jan. 2003. Título original: Das Recht der

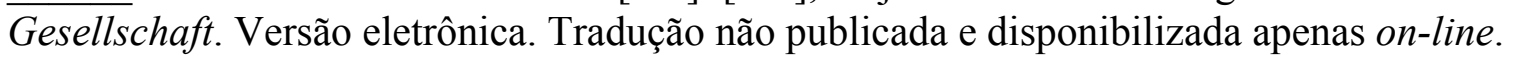


Disponível em: $<$ http://lkservicios.com/maestria-2013-

1/descargas/517derecho_luhmann.pdf $>$. Acesso em: 10 maio 2014.

MACHADO, Carmém Lúcia Bezerra. O movimento operário sindical no Rio Grande do Sul de 1930 a 1937. Dissertação (Mestrado em Sociologia) - Universidade Federal do Rio Grande do Sul, Porto Alegre, 1983.

MARSHALL, Theodore H. Cidadania, classe social e status. Rio de Janeiro: Zahar, 1967.

MENEZES, Lená Medeiros de. Os indesejáveis: desclassificados da modernidade. Protesto, crime e expulsão na Capital Federal (1890-1930). Rio de Janeiro: EdUERJ, 1996.

OIT - ORGANIZAÇÃO INTERNACIONAL DO TRABALHO. Convenções ratificadas pelo Brasil. Disponível em: <www.oit.org.br/convention>. Acesso em: 20 dez 2014.

OLIVEIRA, Márcia Elisa de. Mineiros de São Jerônimo no final do Estado Novo: na encruzilhada entre a legislação trabalhista e as leis de guerra (1943-1945). Monografia (Graduação em História) - Universidade Federal do Rio Grande do Sul, Porto Alegre, 2009.

OLIVEIRA, Moacyr Velloso Cardoso de. Um pouco de história da previdência social - o Conselho Nacional do Trabalho, suas origens. Revista de Previdência Social, Brasília, v. 12, n. 90 , p. 269-271, 1988.

PAIXÃO, Cristiano. Arqueologia de uma distinção: o público e o privado na experiência histórica do direito. In: OLIVEIRA PEREIRA, Claudia Fernanda (Org.). O novo direito administrativo brasileiro. Belo Horizonte: Forum, 2003.

- Autonomia, democracia e poder constituinte: disputas conceituais na experiência constitucional brasileira (1964-2014). Quaderni Fiorentini per la Storia del Pensiero Giuridico Moderno, Florença, v. 43, p. 415-460, 2014.

. Direito, política, autoritarismo e democracia no Brasil: da Revolução de 30 à promulgação da Constituição da República de 1988. Araucária. Revista Iberoamericana de Filosofia, Política y Humanidades, Madri, ano 13, n. 26, p. 146-169, 2011.

REVEL, Jacques. Microanálise e construção do social. In: REVEL, Jacques (Org.). Jogos de escala. Rio de Janeiro: Editora FGV, 1998.

ROJAS, Carlos Antônio Aguirre. Convite a outra micro-história: a micro-história italiana. In: MARLERBA, J.; ROJAS, C. A. (Org.). Historiografia contemporânea em perspectiva crítica. Bauru, SP: EDUSC, 2007.

. Micro-história italiana: modo de uso. Londrina: EDUEL, 2012.

SANTOS, Adalberto Thimóteo. A legião dos condenados. São Jerônimo: [s.n.], 1966.

SANTOS, Wanderley Guilherme. Ordem burguesa e liberalismo politico. São Paulo: Duas Cidades, 1978.

SEELAENDER, Airton Leslie Cerqueira Leite. A "polícia" e as funções do Estado - Notas sobre a "polícia" do antigo regime. Revista da Faculdade de Direito - UFPR, Curitiba, n. 49, p. 73-87, 2009. 
História constitucional brasileira. In: DIMOULIS, Dimiti (Coord. Geral). Dicionário brasileiro de direito constitucional. São Paulo: Saraiva, 2012.

. Pondo os pobres no seu lugar - igualdade constitucional e intervencionismo segregador na Primeira República. In: COUTINHO, Jacinto Nelson de Miranda; LIMA, Martonio Mont'Alverne Barreto (Orgs.). Diálogos constitucionais: direito, neoliberalismo e desenvolvimento em países periféricos. Rio de Janeiro: Renovar, 2006.

SILVA, Cristina Ennes da. Nas profundezas da terra: um estudo sobre a região carbonífera do Rio Grande do Sul (1883/1945). Tese (Doutorado em História) - Pontifícia Universidade Católica do Rio Grande do Sul, Porto Alegre, 2007.

SILVA, Hélio. 1930 - A revolução traída. Rio de Janeiro: Civilização Brasileira, 1966.

SIMCH, Alfredo. Monografia do município de São Jerônimo. Porto Alegre: Imprensa Oficial do Estado, 1961.

SOUZA, Samuel Fernando de. "A questão social é, principalmente e antes de tudo, uma questão jurídica": o CNT e a judicialização das relações de trabalho no Brasil (1923-1932). Cadernos AEL: Trabalhadores, leis e direitos, Campinas, v. 14, n. 26, 2009.

Coagidos ou subordinados: trabalhadores, sindicatos, Estado e as leis do trabalho nos anos 1930. Tese (Doutorado em História) - Universidade Estadual de Campinas, Campinas, 2007.

SPERANZA, Clarice Gontarski. Cavando direitos: as leis trabalhistas e os conflitos entre trabalhadores e patrões nas minas do Rio Grande do Sul nos anos 40 e 50. Tese (Doutorado em História) - Programa de Pós-graduação em História, Universidade Federal do Rio Grande do Sul, Porto Alegre, 2012.

O trabalho perante a lei: os mineiros de carvão na Justiça do Trabalho em São Jerônimo, RS (1946-1954). Topoi, Rio de Janeiro, v. 14, n. 27, Rio de Janeiro, jul./dez. 2013.

SULZBACH, Cônego Ervino Lothar. Arroio dos Ratos: berço da indústria carbonífera nacional. 2. ed. Arroio dos Ratos: PBF, 1989.

Perfil de um minerador. Arroio dos Ratos: PBF, 1989.

UNTURA NETO, Marcos. O Conselho Nacional do Trabalho e a construção dos direitos sociais no Brasil. Dissertação (Mestrado em Direito) - Universidade de São Paulo, São Paulo, 2010.

VIANNA, Luiz Werneck. Liberalismo e sindicato no Brasil. 3. ed. Rio de Janeiro: Paz e Terra, 1978.

VEIT, Benedito. Mineiros, uma raça. São Jerônimo: [s.n.], [s.d.].

WITKOWSKI, Alexsandro; FREITAS, Tassiane Melo. Sobre os homens desta terra - A trajetória de fundação do sindicato dos mineiros de Butiá no Rio Grande do Sul. Porto Alegre: Autores, 2006. 


\section{FONTES CONSULTADAS}

\section{Revistas}

REVISTA DO CONSELHO NACIONAL DO TRABALHO. Rio de Janeiro: CNT, ano 1, n. 1, 93 p., [jul. 1925] 1929. 2. ed.

REVISTA DO CONSELHO NACIONAL DO TRABALHO. Rio de Janeiro: CNT, ano 2, n. 2, 106 p., out. 1927.

REVISTA DO CONSELHO NACIONAL DO TRABALHO. Rio de Janeiro: CNT, ano 3, n. 3, 161 p., out. 1928.

REVISTA DO CONSELHO NACIONAL DO TRABALHO. Rio de Janeiro: CNT, ano 4, n. 4, 160 p., out. 1929.

REVISTA DO CONSELHO NACIONAL DO TRABALHO. Rio de Janeiro: CNT, ano 5, n. 5, vol. 1, 488 p., nov. 1930a.

REVISTA DO CONSELHO NACIONAL DO TRABALHO. Rio de Janeiro: CNT, ano 5, n. 5, vol. 2, 420 p., nov. 1930 b.

REVISTA DO CONSELHO NACIONAL DO TRABALHO. Rio de Janeiro: CNT, ano, n. 6, 482 p., jul. 1931.

REVISTA DO CONSELHO NACIONAL DO TRABALHO. Rio de Janeiro: CNT, ano 6, n. 7, 707 p., [dez. 1931], 1932.

REVISTA DO CONSELHO NACIONAL DO TRABALHO. Rio de Janeiro: CNT, n. 9, 237 p., jun. 1941.

REVISTA DO CONSELHO NACIONAL DO TRABALHO. Rio de Janeiro: CNT, n. 11, 175 p., jun. 1942.

REVISTA DO CONSELHO NACIONAL DO TRABALHO. Rio de Janeiro: CNT, n. 12, 175 p., set. 1942.

REVISTA DO CONSELHO NACIONAL DO TRABALHO. Rio de Janeiro: CNT, n. 13, 119 p., dez. 1942.

REVISTA DO CONSELHO NACIONAL DO TRABALHO. Rio de Janeiro: CNT, n. 14, 133 p., mar. 1943.

REVISTA DO CONSELHO NACIONAL DO TRABALHO. Rio de Janeiro: CNT, n. 15, 151 p., jun. 1943.

REVISTA JURISPRUDÊNCIA. Rio de Janeiro: CNT, v. 1, 134p., 1941. 


\section{Jornais}

CORREIO DO POVO. Porto Alegre, dez. 1932; jan./mar. 1933; jul., set. e out. 1933; jan./abr. 1934; out./dez. 1934.

DIÁRIO DE NOTÍCIAS. Porto Alegre, dez. 1932; jan./mar. 1933; jan./abr. 1934.

A VOZ DO TRABALHADOR. Porto Alegre, out./dez. 1933. Edição FORGS.

A VOZ PROLETÁRIA. Porto Alegre, maio 1934.

CORREIO DA MANHÃ. Rio de Janeiro, n. 22.631, 13 jan. 1967. Disponível em:

$<$ www.memoria.bn.br>.

CORREIO DA MANHÃ. Rio de Janeiro, mai. 1916; ago./set. 1916; set. 1917. Disponível em: $<$ www.memoria.bn.br $>$.

\section{Museus e arquivos}

MUSEU ESTADUAL DO CARVÃO. Arroio dos Ratos.

MUSEU DA COMUNICAÇÃO HIPÓLITO JOSÉ DA COSTA. Porto Alegre.

ARQUIVO HISTÓRICO DO MUNICÍPIO DE PORTO ALEGRE. Porto Alegre.

ARQUIVO PÚBLICO DO ESTADO DO RIO GRANDE DO SUL - APERS. Porto Alegre.

ARQUIVO DO TRIBUNAL SUPERIOR DO TRABALHO. Fundo Conselho Nacional do Trabalho. Assentamento do pessoal do CNT, Livro n. 1, 1923/1941; Termos de Posses dos membros do CNT e Assentamento Pessoal da Procuradoria Geral.

ARQUIVO NACIONAL DO MINISTÉRIO DA JUSTIÇA. Brasília.

ARQUIVO DO CENTRO DE DOCUMENTAÇÃO E PESQUISA DE HISTÓRIA

CONTEMPORÂNEA DO BRASIL - CPDOC-FGV. Rio de Janeiro. (Fundos Lindolfo Collor e Getúlio Vargas) 


\section{APÊNDICE A - Quadro sinóptico}

O quadro A.1, a seguir, apresenta um quadro sinóptico em que se destacam as principais peças processuais que compõem o processo $\mathrm{n}^{\circ}$ 9.582/1934. O objetivo deste resumo é proporcionar ao leitor desta tese uma linha evolutiva e temporal que atravessa o processo em análise.

Quadro A.1 - Quadro sinóptico do processo nº 9.582/1934

\begin{tabular}{|l|l|l|c|c|}
\hline \multicolumn{1}{|c|}{$\begin{array}{c}\text { Peça } \\
\text { processual }\end{array}$} & \multicolumn{1}{|c|}{ Autoria } & \multicolumn{1}{c|}{ Assunto } & Folhas & Data \\
\hline Petção inicial & $\begin{array}{l}\text { Empregados } \\
\text { Domingos Mantilha } \\
\text { e outros } \\
\text { (reclamantes) }\end{array}$ & $\begin{array}{l}\text { Reclamação trabalhista, acompanhada de } \\
\text { documentos e provas materiais. }\end{array}$ & $04-32^{1}$ & $1^{\text {o }}$ ago. \\
1934 \\
\hline Ofício & $\begin{array}{l}\text { Empregador }- \\
\text { CEFMSJ } \\
\text { (reclamada) }\end{array}$ & $\begin{array}{l}\text { Responde solicitação do inspetor do MTIC } \\
\text { informando as condições em que ocorreu o } \\
\text { desligamento dos empregados com a } \\
\text { empresa. }\end{array}$ & 03 & 22 ago. \\
Parecer & $\begin{array}{l}\text { Procuradoria } \\
\text { jurídica do CNT }\end{array}$ & $\begin{array}{l}\text { Requer a conversão do julgamento em } \\
\text { diligência para que a empresa fornecesse } \\
\text { certidão de tempo de serviço e encaminhasse } \\
\text { cópia do inquérito administrativo para apurar } \\
\text { falta grave. }\end{array}$ & 36 verso & 31 out. \\
\hline $\begin{array}{l}\text { Informe } \\
\text { Pedido de } \\
\text { reconsideração }\end{array}$ & $\begin{array}{l}\text { Secretaria da 3 } \\
\text { Câmara do CNT }\end{array}$ & $\begin{array}{l}\text { Expediente da secretaria informando decisão } \\
\text { da Câmara pela conversão em diligência, em } \\
\text { atendimento a procuradoria. }\end{array}$ & 37 & 21 nov. \\
\hline CEFMSJ & $\begin{array}{l}\text { Apresentação dos argumentos da empresa: } \\
\text { ausência de inquérito administrativo por } \\
\text { ausência de despedida e, sim, por } \\
\text { substituição de empregados; } \\
\text { responsabilidade da polícia do Estado do Rio } \\
\text { Grande do Sul pelas expulsões dos } \\
\text { trabalhadores. }\end{array}$ & $40-44$ \\
\hline
\end{tabular}

\footnotetext{
${ }^{1}$ Nos autos, registra-se a ausência das fls. 25-30. Possivelmente, refere-se a uma ação de justificação judicial individual de Liberalino Machado de Lima, também conhecido como Januário Machado de Lima, cujo desentranhamento foi autorizado pelo CNT, sem substituição de cópias.
} 


\begin{tabular}{|c|c|c|c|c|}
\hline $\begin{array}{c}\text { Peça } \\
\text { processual }\end{array}$ & Autoria & Assunto & Folhas & Data \\
\hline Parecer & $\begin{array}{l}\text { Procuradoria } \\
\text { jurídica do CNT }\end{array}$ & $\begin{array}{l}\text { Manifestação contrária aos argumentos da } \\
\text { empresa. Informa que o sistema de } \\
\text { responsabilidade civil não se aplica ao Poder } \\
\text { Público como pretende a empresa. } \\
\text { Acrescenta que se os empregados foram } \\
\text { forçados e impedidos de trabalhar não } \\
\text { configura abandono de emprego. } \\
\text { Indispensabilidade do inquérito } \\
\text { administrativo. }\end{array}$ & $\begin{array}{l}45 \text { verso } \\
\text { e } 46\end{array}$ & 5 fev. 1935 \\
\hline $\begin{array}{l}\text { Acórdão } \\
\text { (decisão) }\end{array}$ & $3^{\mathrm{a}}$ Câmara do CNT & $\begin{array}{l}\text { Determinou a reintegração de Domingos } \\
\text { Mantilha e o envio de certidão de tempo de } \\
\text { serviço dos demais reclamantes pela } \\
\text { reclamada. }\end{array}$ & $47-48$ & $\begin{array}{c}25 \text { abr. } \\
1935\end{array}$ \\
\hline Petição & Reclamantes & $\begin{array}{l}\text { Reitera pedido de reintegração por violação } \\
\text { dos procedimentos necessários para } \\
\text { instauração de inquérito administrativo. }\end{array}$ & 51 & $\begin{array}{l}18 \text { mar. } \\
1935^{2}\end{array}$ \\
\hline Petição & CEFMSJ & $\begin{array}{l}\text { Encaminha certidões de tempo de serviço e } \\
\text { ofício da Polícia de São Jerônimo. }\end{array}$ & $55-63$ & 5 ago. 1935 \\
\hline Ofício & $\begin{array}{l}\text { Diretor geral da } \\
\text { Secretaria do CNT }\end{array}$ & $\begin{array}{l}\text { Oficia ao presidente do sindicato que a } \\
\text { empresa apresentou as certidões de tempo de } \\
\text { serviço. }\end{array}$ & 69 & $\begin{array}{c}22 \text { nov. } \\
1935\end{array}$ \\
\hline Petição & Reclamantes & $\begin{array}{l}\text { Pedido de vistas. Destaque para alteração do } \\
\text { nome do sindicato, que passou a se } \\
\text { denominar Sindicato dos Mineiros e Classes } \\
\text { Anexas do Município de São Jerônimo/RS. }\end{array}$ & 70 & $\begin{array}{l}18 \text { mar. } \\
1936\end{array}$ \\
\hline Petição & Reclamantes & $\begin{array}{l}\text { Reação do sindicato contra as datas de tempo } \\
\text { de serviço dos reclamantes: que o incêndio } \\
\text { no almoxarifado não pode prejudicar os } \\
\text { trabalhadores; que os empregados não foram } \\
\text { à polícia espontaneamente se prontificar a } \\
\text { deixar as minas; acusação de perseguição do } \\
\text { delegado contra os trabalhadores; } \\
\text { apresentaram documentos. }\end{array}$ & $73-92$ & $\begin{array}{c}16 \text { abr. } \\
1936\end{array}$ \\
\hline Parecer & $\begin{array}{l}\text { Procuradoria } \\
\text { jurídica do CNT }\end{array}$ & $\begin{array}{l}\text { Contesta o argumento da empresa sobre a } \\
\text { desnecessidade de inquérito administrativo } \\
\text { para apurar falta grave devido prisão dos } \\
\text { empregados. Pugna pelo pagamento de } \\
\text { indenização a Domingos Mantilha; pela } \\
\text { reintegração de Thomaz Gonçalves da Silva } \\
\text { e Raphael Mezza; pelo indeferimento dos } \\
\text { pedidos de Adalberto dos Santos Azambuja, } \\
\text { João Keenan, Antônio Nunes das Pedras e } \\
\text { Liberalino ou Januário. }\end{array}$ & $\begin{array}{l}92 \\
\text { verso, a } \\
94\end{array}$ & $\begin{array}{c}19 \text { maio } \\
1936\end{array}$ \\
\hline
\end{tabular}

\footnotetext{
${ }^{2}$ A peça processual foi protocolada no CNT em 21 de março de 1935, contudo, somente foi juntada aos autos em 20 de maio de 1935 (ver informe à fl. 52 do processo no 9.582/1934).
} 


\begin{tabular}{|c|c|c|c|c|}
\hline $\begin{array}{c}\text { Peça } \\
\text { processual }\end{array}$ & Autoria & Assunto & Folhas & Data \\
\hline $\begin{array}{l}\text { Acórdão } \\
\text { (decisão) }\end{array}$ & $\begin{array}{l}\text { Membros da } 3^{\mathrm{a}} \\
\text { Câmara do CNT }\end{array}$ & $\begin{array}{l}\text { Determina o pagamento de indenização a } \\
\text { Domingos Mantilha; reintegração de Thomaz } \\
\text { e Raphael, com as respectivas indenizações; } \\
\text { julga improcedente a reclamação de } \\
\text { Adalberto, Antônio e Januário ou Liberalino, } \\
\text { por não preencherem o requisito da } \\
\text { estabilidade decenal e converte em diligência } \\
\text { o pedido de João Keenan para que a empresa } \\
\text { apresentasse comprovação de seu tempo de } \\
\text { serviço. }\end{array}$ & $96-99$ & 2 jun. 1936 \\
\hline Ofício & Secretaria do CNT & Informando teor do acórdão à CEFMSJ. & $101-102$ & 6 ago. 1936 \\
\hline Petição & $\begin{array}{l}\text { CADEM, antiga } \\
\text { CEFMSJ }\end{array}$ & $\begin{array}{l}\text { Depois de reenvio do ofício, a empresa } \\
\text { informa o cumprimento parcial do acórdão, } \\
\text { deixando de apresentar o tempo de serviço de } \\
\text { João Keenan devido incêndio no } \\
\text { almoxarifado da empresa em } 1927 .\end{array}$ & 105 & 2 out. 1937 \\
\hline Petição & Reclamantes & $\begin{array}{l}\text { Apresentação, pelo sindicato, de novas } \\
\text { justificações judiciais de tempo de serviço de } \\
\text { João Keenan e Liberalino Machado de Lima. } \\
\text { O reenvio ocorreu devido ao extravio da } \\
\text { primeira justificativa de 1936, reencontrada } \\
\text { em } 1938 \text {. }\end{array}$ & $\begin{array}{l}116- \\
150^{3}\end{array}$ & $\begin{array}{l}20 \text { out. ou } \\
21 \text { jun. } \\
1938 \\
\text { (contém } \\
\text { rasura) }\end{array}$ \\
\hline Parecer & $\begin{array}{l}\text { Procuradoria } \\
\text { jurídica do CNT }\end{array}$ & $\begin{array}{l}\text { O procurador opinou pela rejeição das } \\
\text { justificativas apresentadas por Liberalino ou } \\
\text { Januário, em decorrência da improcedência } \\
\text { de seu pedido já julgado. Comprovado os } \\
\text { requisitos da estabilidade decenal, opinou, } \\
\text { ainda, pela reintegração de João Keenan. }\end{array}$ & $151-152$ & $\begin{array}{c}16 \text { ago. } \\
1938\end{array}$ \\
\hline $\begin{array}{l}\text { Acórdão } \\
\text { (decisão) }\end{array}$ & $\begin{array}{l}\text { Membros da } 3^{\mathrm{a}} \\
\text { Câmara do CNT }\end{array}$ & $\begin{array}{l}\text { Os membros do CNT rejeitaram as } \\
\text { justificativas de Liberalino ou Januário e } \\
\text { determinaram a reintegração de João Keenan. }\end{array}$ & $154-155$ & 6 set. 1938 \\
\hline Petição & $\begin{array}{l}\text { CADEM, antiga } \\
\text { CEFMSJ }\end{array}$ & $\begin{array}{l}\text { Informa o falecimento de João Keenan, } \\
\text { ocorrido em } 14 \text { de janeiro de } 1938 .\end{array}$ & 158 & $\begin{array}{c}29 \mathrm{dez} \\
1938\end{array}$ \\
\hline Petição & $\begin{array}{l}\text { Sindicato } \\
\text { (presidente Zalmiro } \\
\text { Keenan), pelo } \\
\text { reclamante } \\
\text { Liberalino }\end{array}$ & $\begin{array}{l}\text { Requisitou desentranhamento de todos os } \\
\text { procedimentos judicias, certidão de } \\
\text { nascimento e atestado de saúde expedidos em } \\
\text { nome de Liberalino ou Januário Machado de } \\
\text { Lima. Foi deferido pelo CNT, sem } \\
\text { substituição dos documentos por cópias. }\end{array}$ & 182 & $\begin{array}{l}29 \text { nov. de } \\
1940\end{array}$ \\
\hline Arquivamento & Secretaria do CNT & & 195 & $\begin{array}{c}29 \text { abr. } \\
1941\end{array}$ \\
\hline
\end{tabular}

\footnotetext{
${ }^{3}$ A justificativa judicial de Liberalino ou Januário Machado de Lima foram desentranhadas a pedido do interessado. Não houve substituição por cópias.
} 
ANEXO A - Reclamação trabalhista n. 9.582/1934 - CNT 


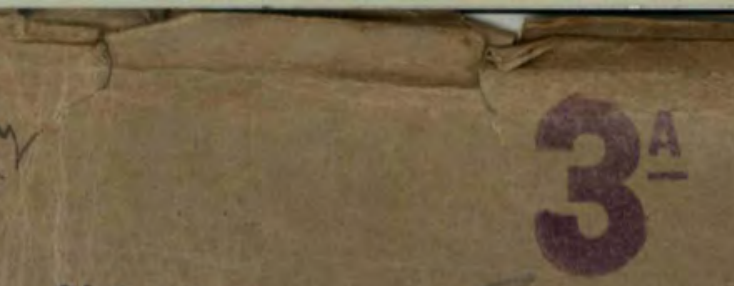

N. 9582
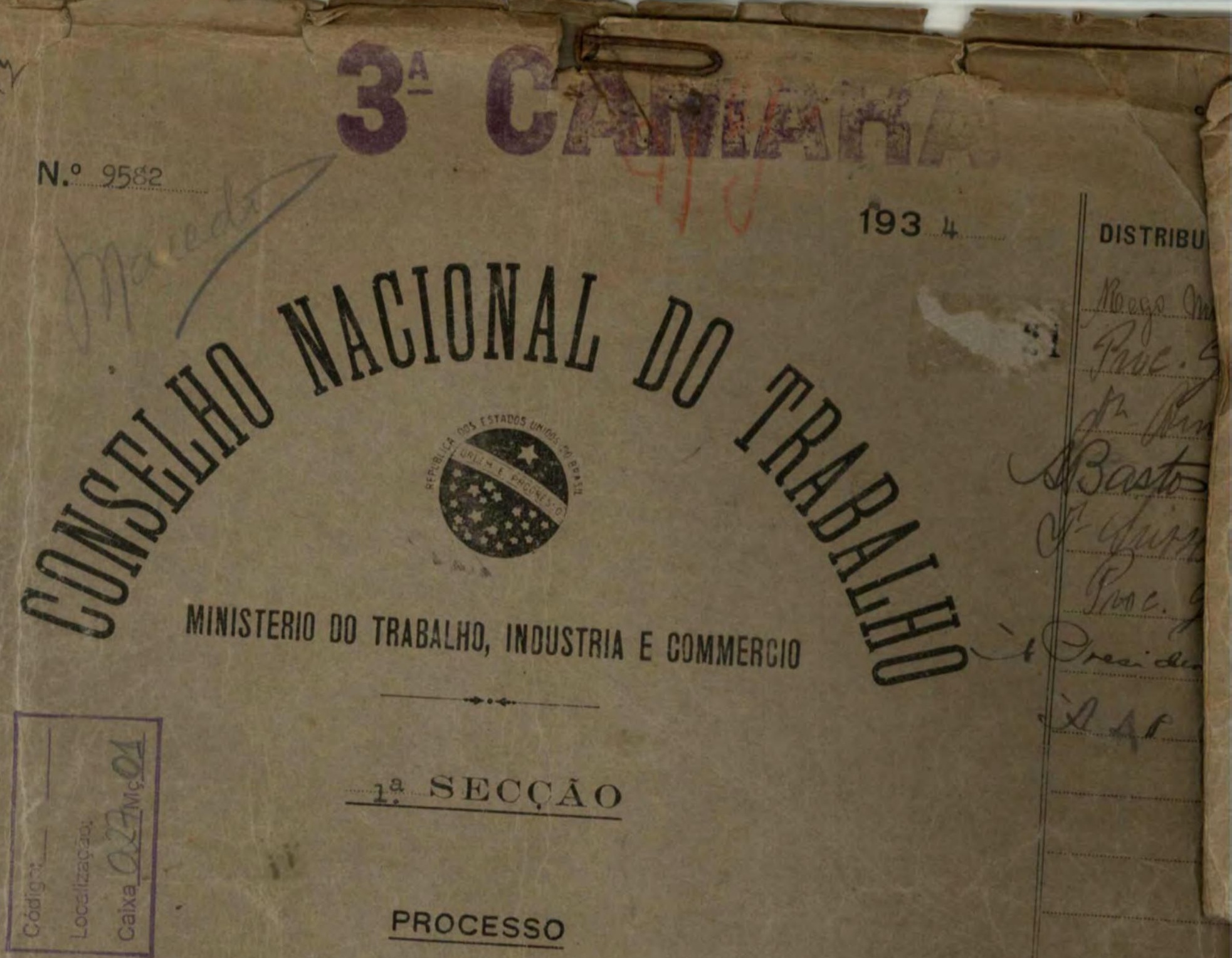

12 SECCÃO

PROCESSO

DOMINGOS MANTILHA e outros.

Ferro e Minas de สão Jeronymo

Reclamam contra a Companhia Estanda de

\section{ANNEXOS}

$2665: 3915-6086-1632$ 
MINISTERIO DO TRABALHO, INDUSTRIA E COMERCIO

END. TELEG.

"AGRILABOR" -

J. $34 / 243$.

\section{$\because$ CONSELHO NAGIONAL DO TRABAL HO}

\section{1a. Snspetaria}

Porto Alegre, deonsesto de 1934.<smiles>CC(C)(C)CC(C)(C)C</smiles><smiles>[C]1CCCC1</smiles>
CONSELHO NACIONAL DO TRABALHO,

RIO DE JANEIRO.

Tenho a honra de passar as mãos de V.S., incluso, o processo №.161/34, em que os interessados Domingos Mantilha e outros, reclamam contra a Companhia Estrada de Ferro e Minas de S\&d Jeronymo e a defesa desta Empreza, processo esse, enviado a esta Inspectoria pelo Snr. Dr. Ernani de Oliveira, digno, Inspector Regional do Ministerio do Trabalho, neste Estado.

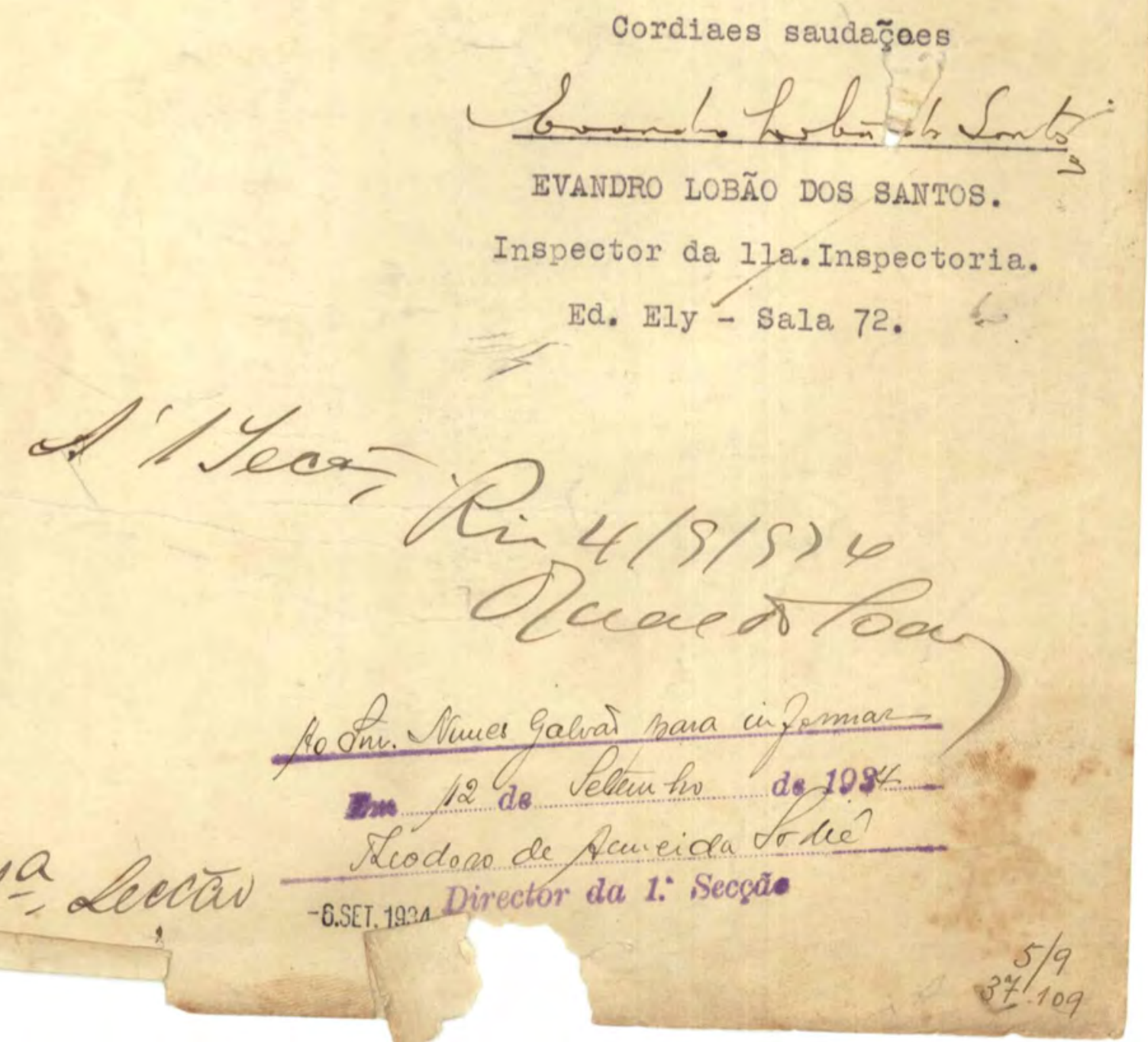


COMPANHIA ESTRADA DE FERRO E MINAS DE SÃO JERONYMO / 3

CAIXA POSTAL 329

TELEPHONE AUT', 5072
PORTO ALEGRE - ERTADO DO RIO GRANDE DO SUL

ENDEREÇO TELEGRAPHICO, ,JEROMINA“* codigos usados: RIBEIRO-BORGES-MASCOTTE

GRAPHCO, ,JEROMINA".

Sr.GG/CC/N2 166.- Porto Alegre, 22 de agosto de 1934.-

I11mo. Snr.

Dr. Evandro Lobão dos Santos, M. D.

Inspector Regional da 1la. Inspectorla do

Conselno Nacional do Trabatho

N/CAPITAL

Amigo e Snr. Attendendo ao pedido de V. S., damos abaixo as informa-
çōes que nos foram solficitacas:

Liberalino Nachado de Lima, Raphael Mezza, Antonlo Nunes das Pedras e Adalberto Azambuia dos Santos + Estes operarios forem ex pulsos das MInas em março do corrente anno, pelas autoridades pol1ciaes, como Indesejaveis, motivo por que nossa Companhia os conside rou demfttidos por abandono de emprego.-

Domingos Vantilha - 0 marginado tendo sido transferido por conveniencla de serviço, do Iugar que occupava, para outro de Igual ordenado, defxou de se apresentar no servigo que the fora destina do.-

João Keenan e Thomaz Goncalves - Estes dois s enhores def xaram o serviço da Companhia por sua livre vontade, sendo a primeíro em março de 1929 e o ultimo em dezembro de 1933, sem nos darem nenhuma satisfacçä.-

Sem mals, sempre ao vosso inteiro dispor para qualquer outro esclareefmento que poryentura V. S. desejar, subscrevemo-noa com todo apreço e consideraçäo

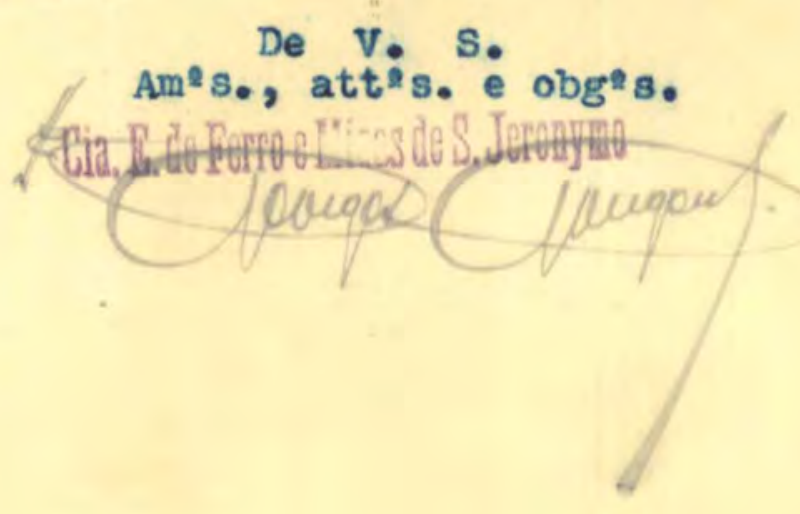


$9: 161-34 \quad 1934$

As.

Anexos

RIO GRANDE DO SUL

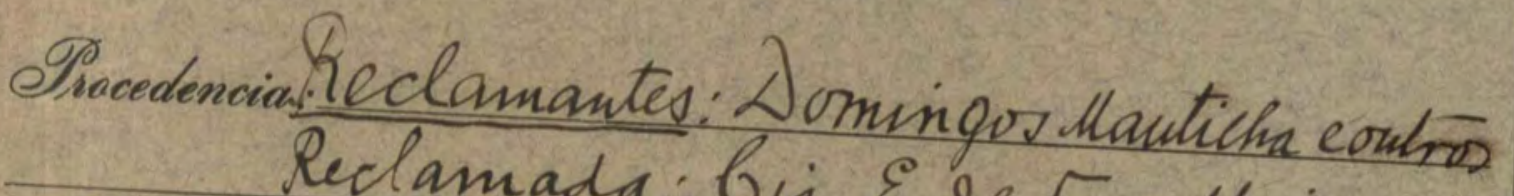

Redamada: bia. E. Lef.e dinas de

- S. yerorino

etsunta. Demistâo 
Exuno. Ir. Dr. Muspetor Reqional do Ministerio do Trabalho, Crudustria e bourercio.

геар.

16.160.1534

2.451

Os operarios Dowiungos Mautilha, Liberalivo Machado de Liura, couhecido taubeur pelo uove de Yaunario Machado. de Quma, Rafael Mersa, Yoão Keeuau e Tounar Gouçalves, ex-eupregados da Goupsuia Es trada de Ferro e Mleivas de O. Yerouivio, - con mais de dés áuos de serviço - e, Aentónio sumes das Fédras etedalkerto Arambrja dos Sautos, tambeur, et-eupregados da referida

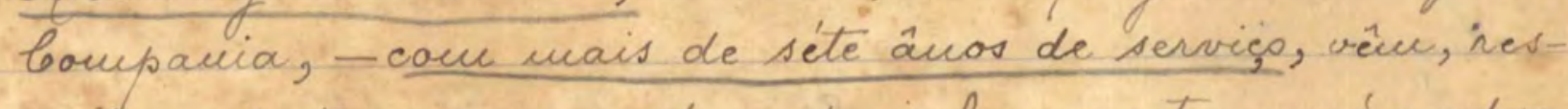
peitosanénte, por seu adrogado, iefra esereto, que éo advogado do Ciudicato Miuras do Atrois dos Patos, de que são sócios, direr a V.Exa. que forau, injustanente, despodidos, conco, á saciedade, próvaun os docunêutos áuétos.

E'verdade que os dois ulturos postuláutes podiane ser despedidos, injustaniéute, cono fórouve, senu of érsa a dispositivas de Lei, cubóra, esse fato wão devé de sêr chocáute, para qualquer pessôa, que se prére de têr un pou co de sentivéuto de justiga para coir o seu semelháute. Ya vão acoutéce assiun coul os rutros. 0 procedicuéuto da loupparia eupregadora, sobre coustituir una trawviatisante iniguidade, é una flagiante ofensa a claro dispositivo de Lei.

Jodos os uneios pacificos, anigarreis, consilia dores, etortantes, foraue, seur qualquer resultado, reiteradaneute eupregados, juito á baupania enpregadora, 
us afau de se obter una recousideraçás do seu áto.

Gausados de, por vía auigavel, pedir justiça á quéla para esse caso; certos que só un terceiro, cone uaior poder e, corr coupetencia para isso, a poderá coutranger, ua forma da Lei, e que, esse poder ía Cruspetoria, de que sois diguo titular, os postulautes onsaue pedir a V.Exa. a interveução legal indispreusavel, para que, aquéla, recousiderâudo sua atitude, uande reiutregar ene sens higares, cour todas vautagens destes 2 dencais prounuciaçães de directo, os operarios: Daviungos Noautilha, Rafael Noersa, Liberalivo Nbachado de Lina, Jourar Soucablves e Yoä Keеuan.

Frudanéutau ste clannáute pedido, no art: 53 do Dec u: 20.465 , de I de outubro de 1931, caufirmado r auphiado, cour acerto, pelo Dec. 20.081 , de 24 de fevereiro de 1932, que the alterou alguis de scus artigos; terunos en que.

$$
\text { G.E. R.R. Def.to }
$$

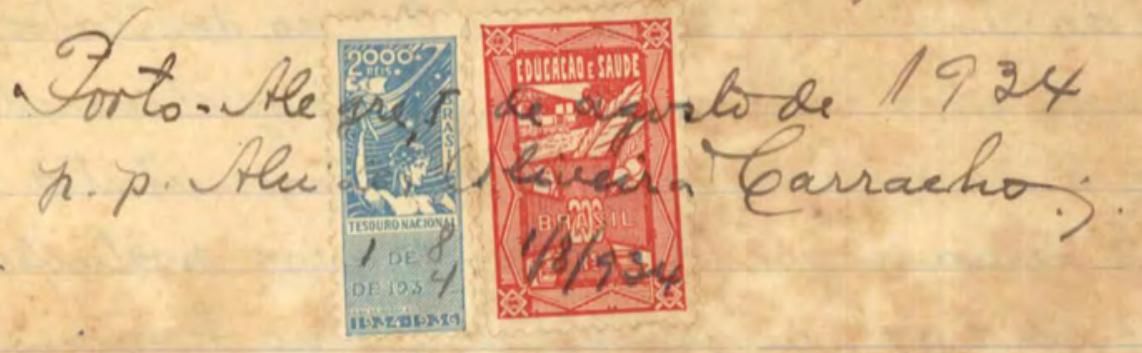




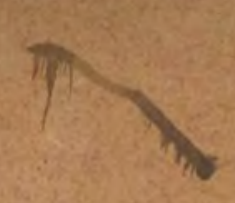

\section{Estado do Rio Grande do Sul}

\section{Juízo Distrital do Têrmo de S. Jerônimo}

\section{Cartório do Cível e Crime}

Jurisdição
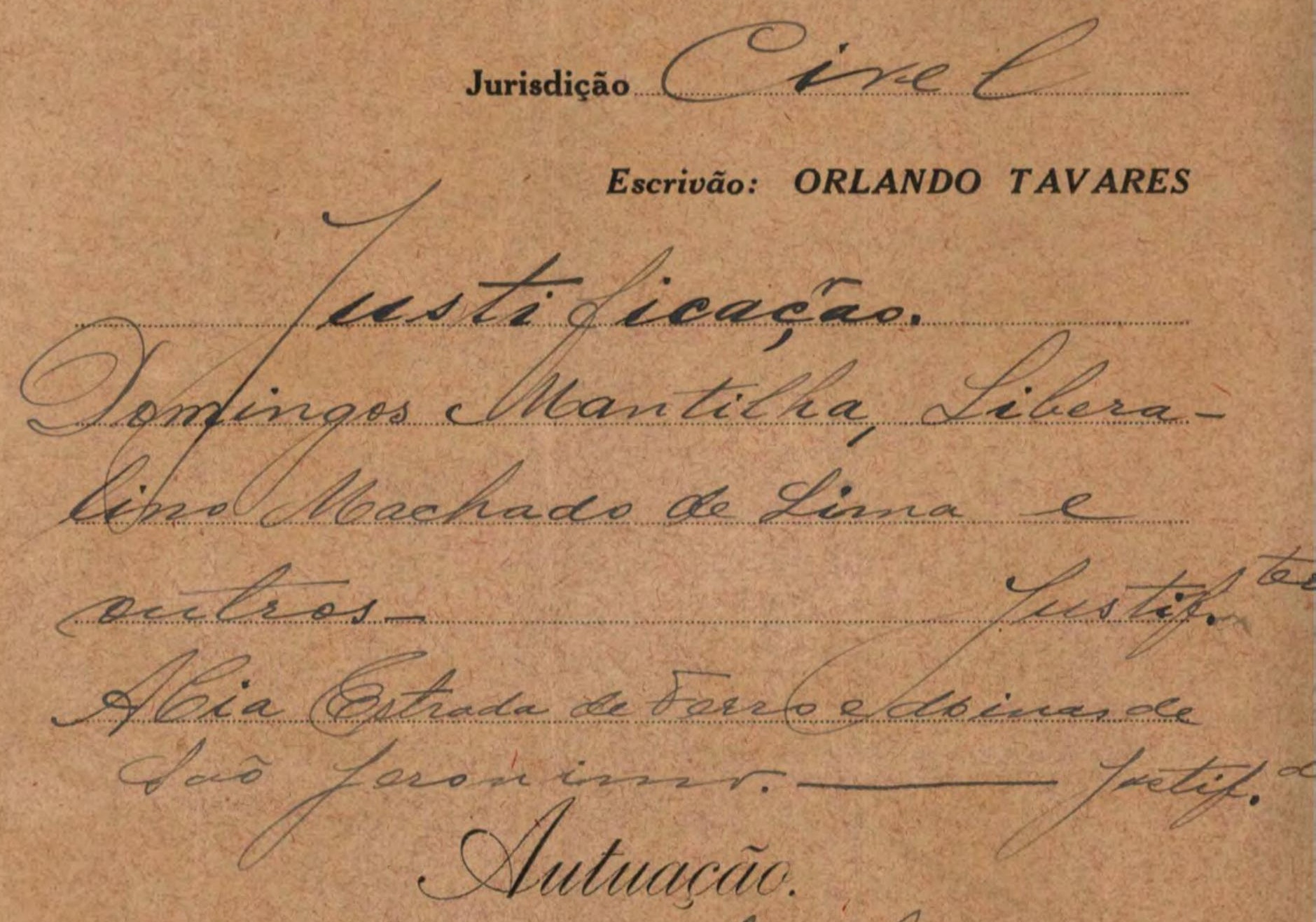

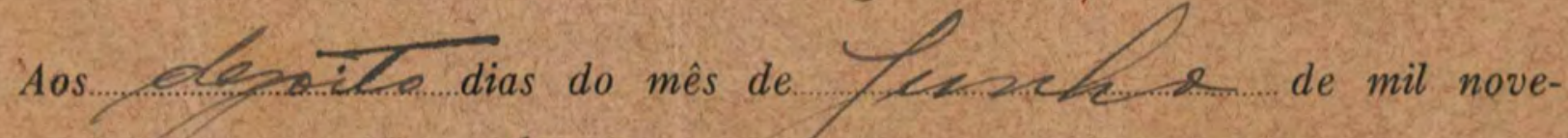
centos e trinta gecalzo., nesta Vila de Sáo Jerônimo, no meu cartório autúo as peças que se seguem do que, para constar faço êste têrmo.

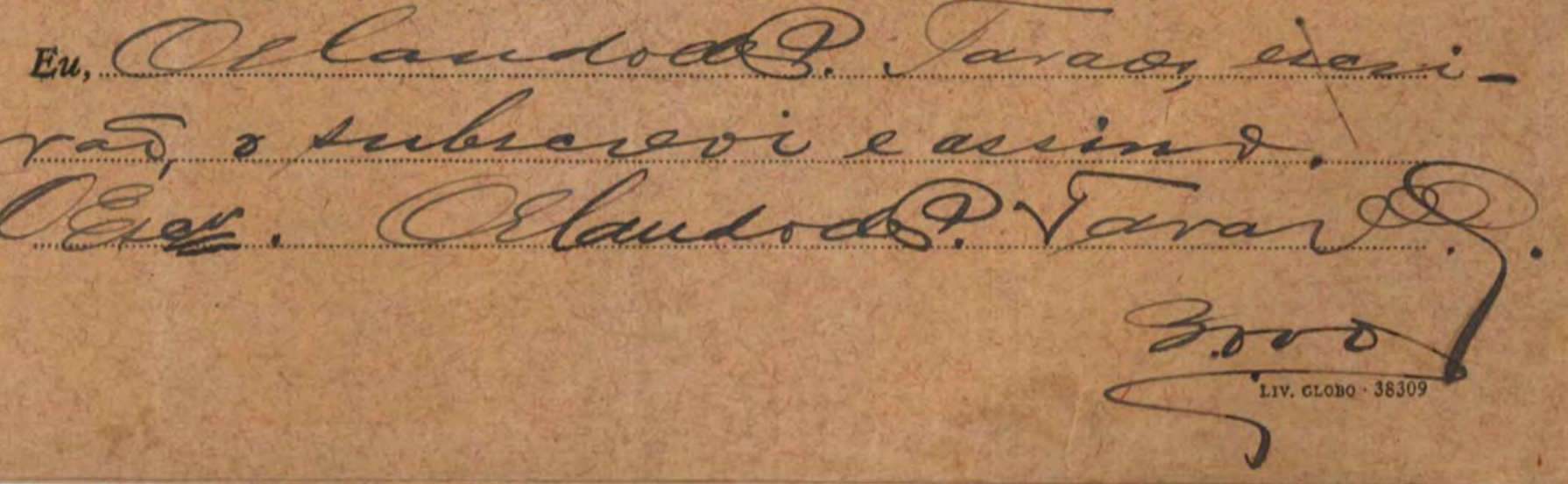


Ilevo. On. Ds. Twir- Distrital

2

C. Como pede. Aexigne. dia 19 do erria

te, is trere, dijo, quinge hrom, parm

perem ourity os testanumbs arrelars.

ai Jormin, 18, junty, 19 w.

Aleiking

Fominges. Hoantetha, Liberalies Abachado de Linea, Rafael therea, joòs Rerivane e

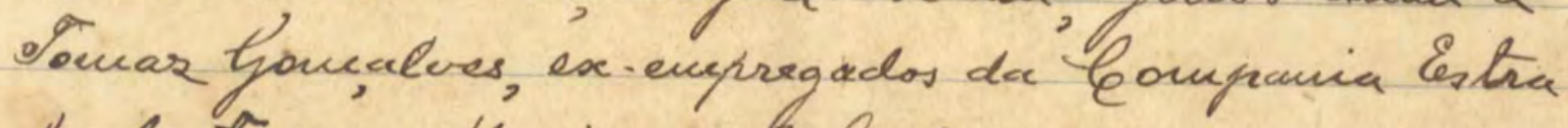
da de terro e lbuias de S. Jerónino, Ronumais de

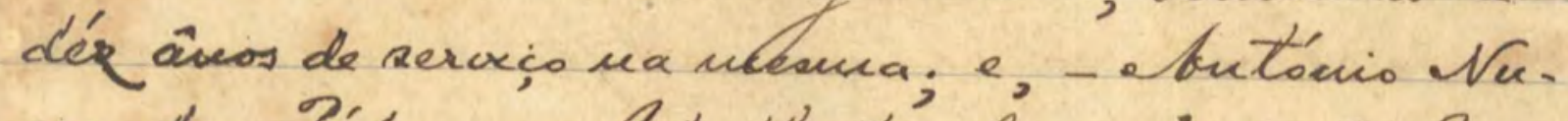

* ues das Bédras s Sdalberto Rzandbuja dos Santos, taunkem, ex- suppregados da referida bongpacía

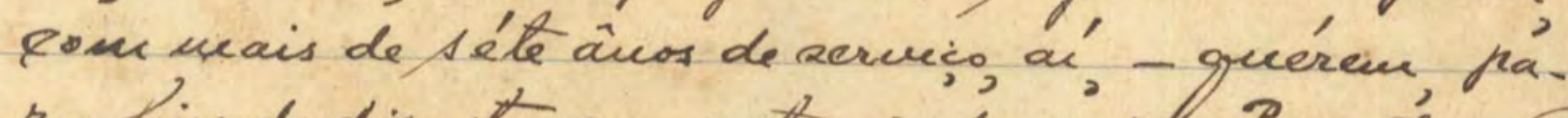
ra fius de direcito, coun citacasos do ss. St. Promotor. Pu. beis justificiar or fálos abarxo:

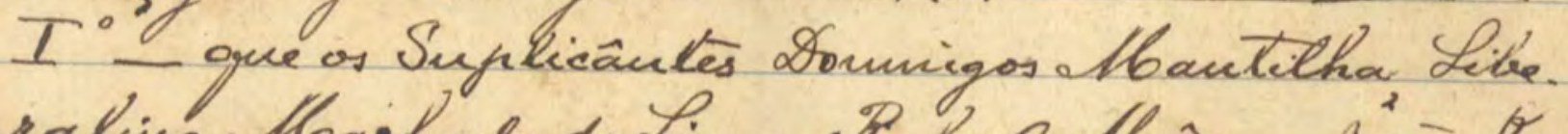

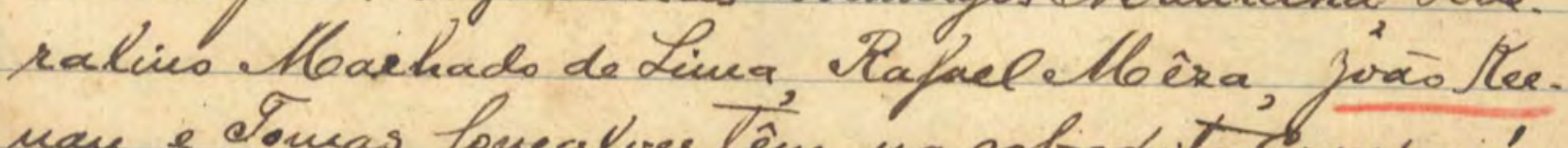

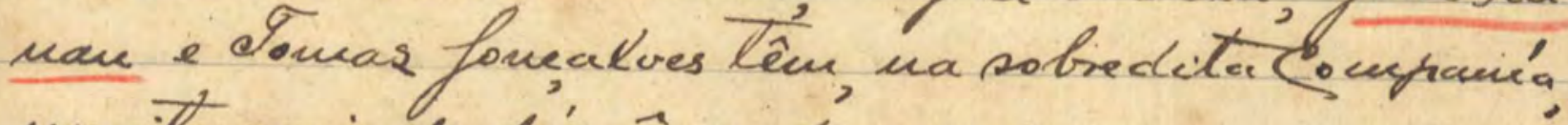
unito necis de dér âuos de serverico.

II. - que os Sufiliciantes Sutónio Tinues das Pédias - Adalberto Rrambuja dos Sautos tếu, ua sobre

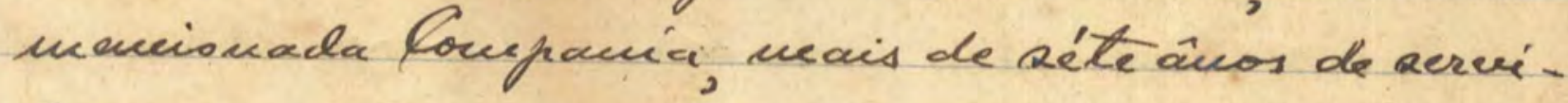

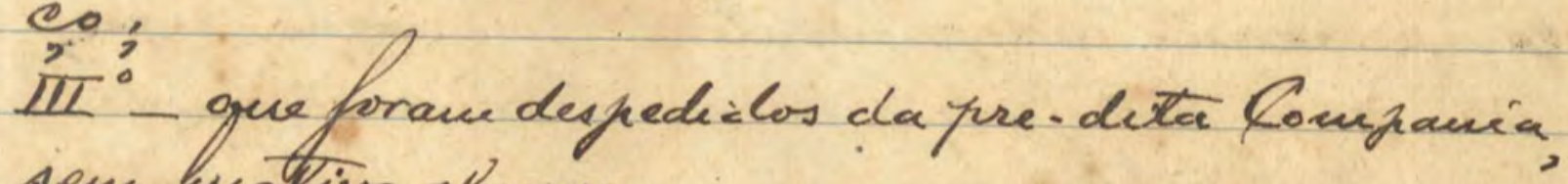
sem huotivo algune;

IV" - que unuoa jreaticáram eom a pre-cita da Corn.

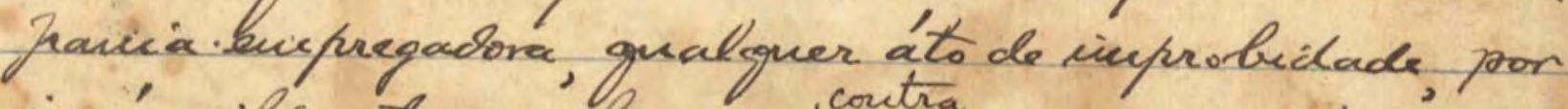

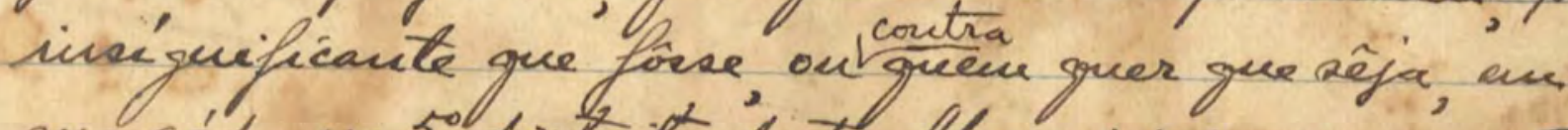
Qua réde, us 50 distritó deste llonuripipio, on en antev logar, surde estivéérem estaclo; 


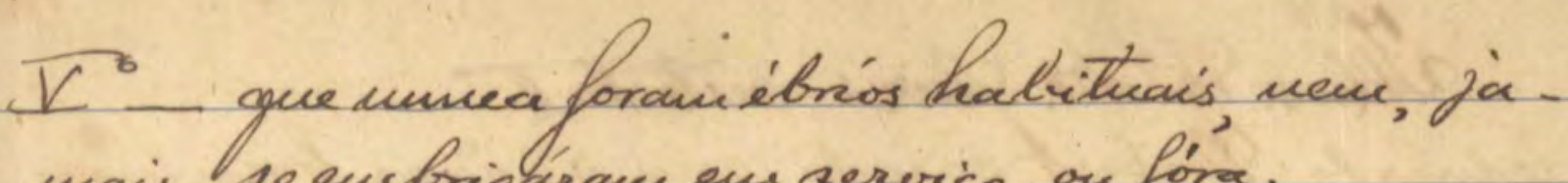
uais, se encbrighiram en service, on fóra;

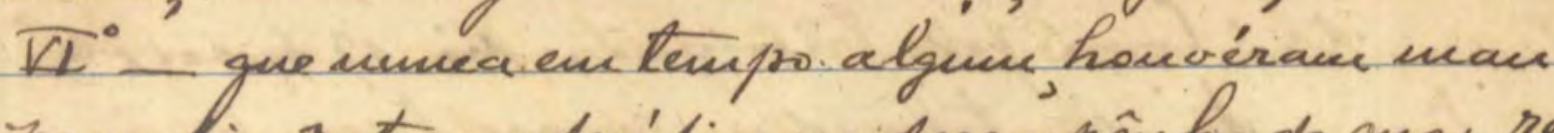
procedinesuto, on desidia us desenipênko de suas refietivas finceses;

III gue inumea thes foi confeido segrêdo algum, por forla do rargo, orgue, por ises, fica prejudeciada à heepótese de o havereni violado; VIII" -que munea en temppo algun praticaran guafguer átto de indiscijeliea ou áló grásre de inses borde nacáo;

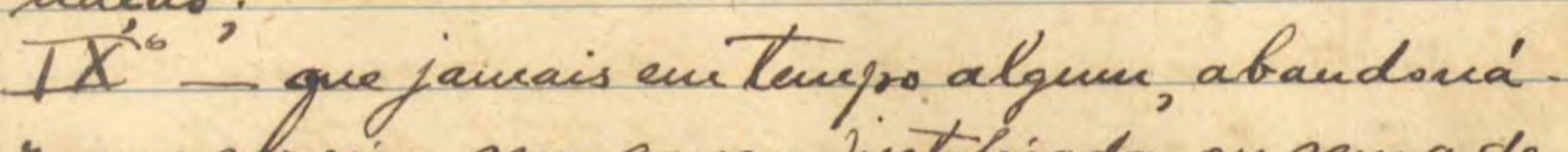

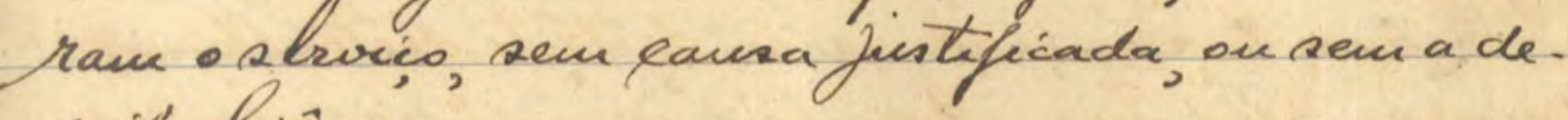
srida licéné, $X^{\circ}$-que jomrais en tenpo algum, pratiéáran

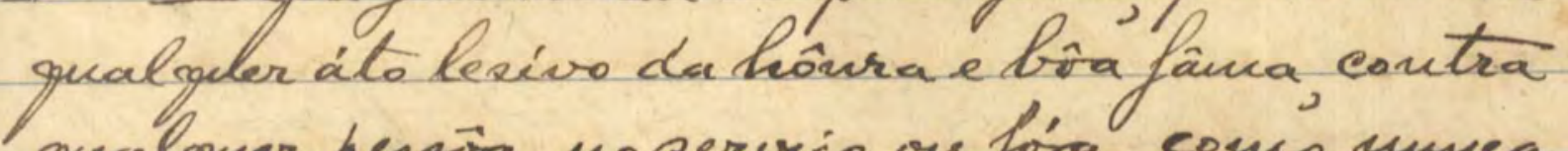
qual squer fessova, no rervicio on fóra, conis unsea

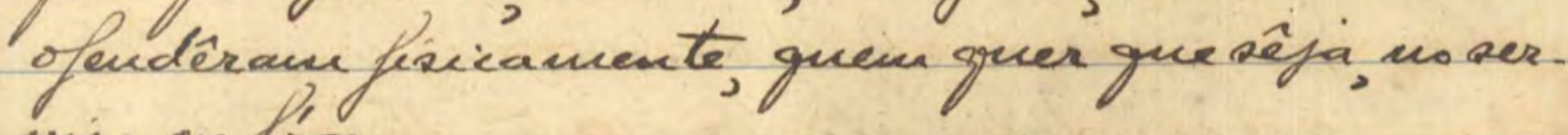
vico on fóra.

Nestas condicoés, com fundaunantó cus artos $808,8.09$ e 8110 do Rot. do Sver. Cui. Com. So Estado, prédene a S:S. ordenar a ectacañ do as or Pronvotor. Publico, e, desiguar, on ordenar gue ons. Escrivar designe, dia, hora e lugar, para sérenc on.

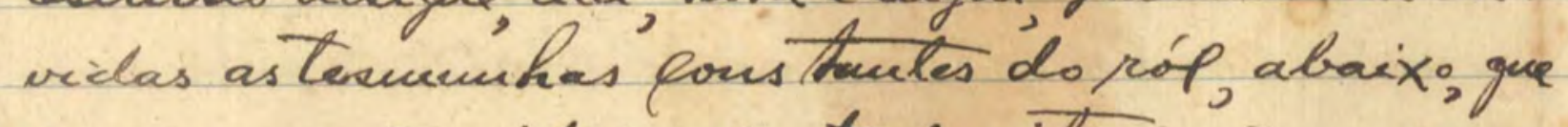

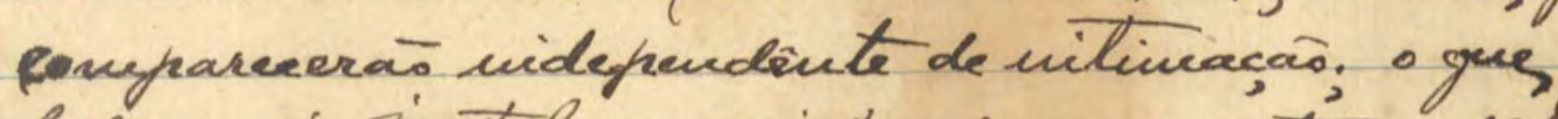

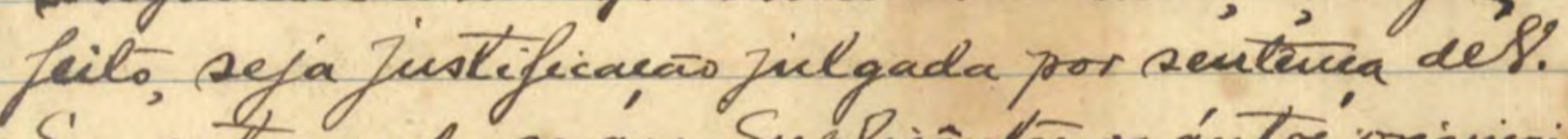

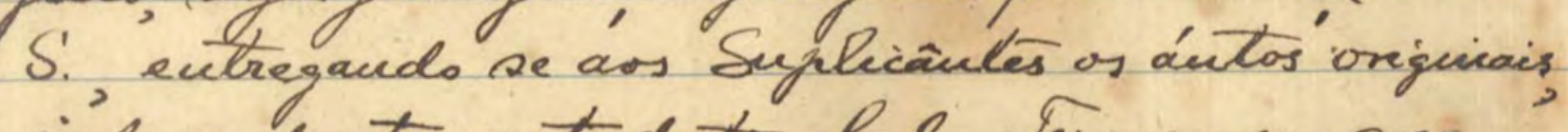
indegendentenente de trashado. Servos en guer 5. 6. A $q$. Lefó
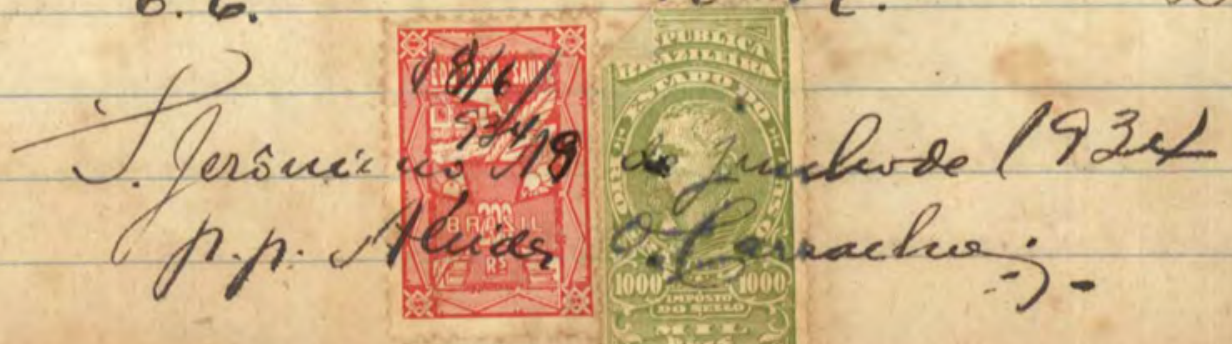
Dof detestenunhas:

क 3

3 is

A) 8

Edvardo SPesbert, casads, conu 58 ãvos, branileiva donvicitiado no Jo distrito deste Nbunicipio. Fêli: je tesceira da Silva, brasileiro, carado, conc 6 'ै ầur, donnicitives no 5 'distrito déstê Mbunicifio; joino Domar Mbianda brasileirs, easado, ence 65 anos,

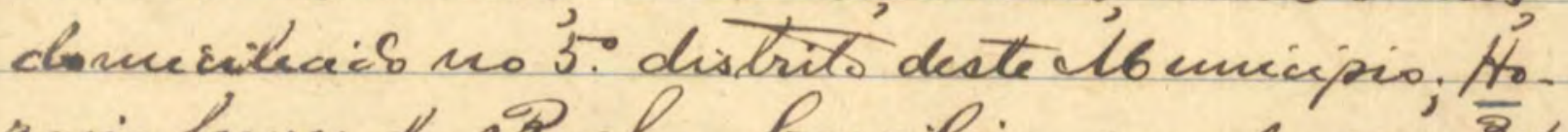

ravio fanes da Pocha, brasileiro, casads, cone It $_{4}$

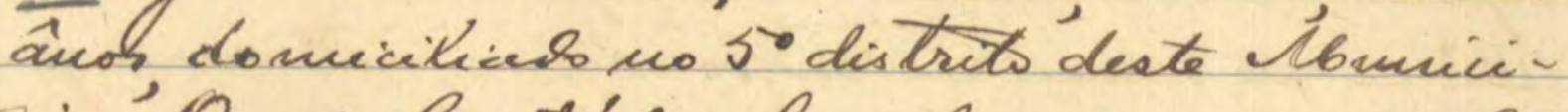
Firo; Osorio Custo'dio, brasileves, casab, cou 28 ános donuicilides uco $5 i^{\circ}$ distrito deste lbunicipio, Arrancisco Serpa, solteiro, brasileiro, con 2/ áuos, d'onncilices us so distrito deste llbune. cipio. Gow Tires, braseleiro, casar, cone $44 \hat{a}$.

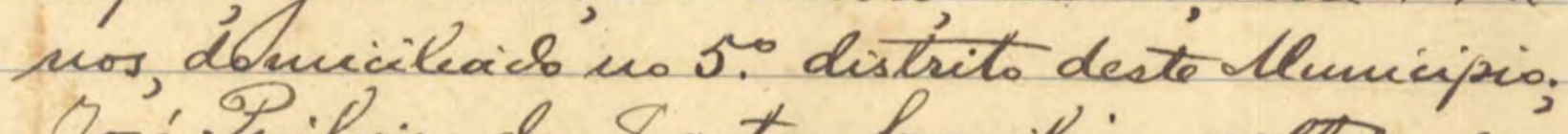
Tosé Tritheiro dos Sautos, brasileirs, solteiro, corr

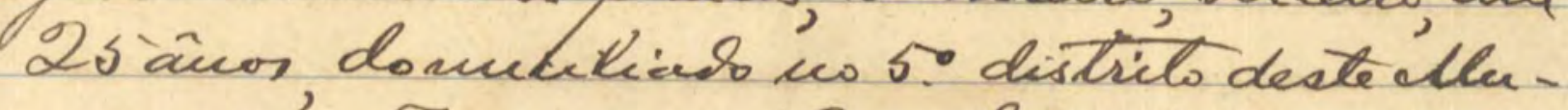
uicipio; Francis co Neues, braselairo, solteiro, cone 40 ámos doruiviliend no $5:$ distrito desté Ununicipio. 'Pedro ont tagundes, branileiro sol.

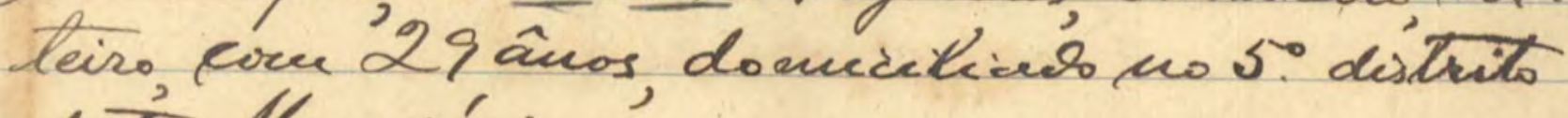
deste Houccicépio.

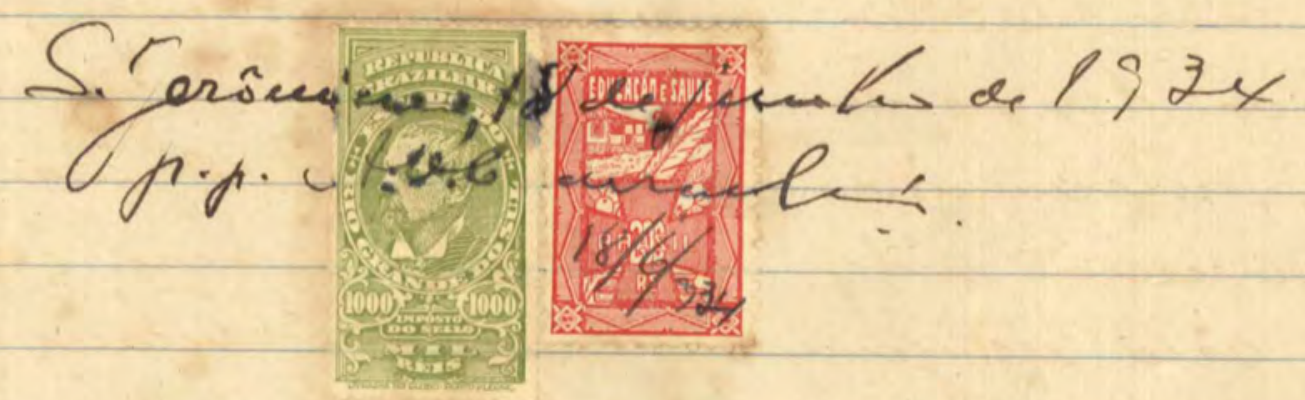




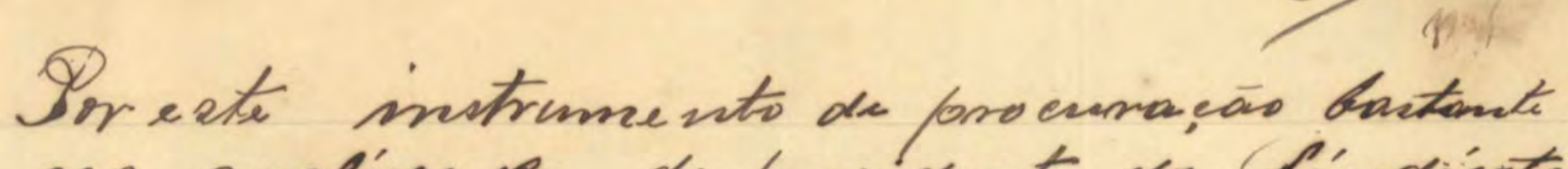
now quadivedore de frrescidente do fiúdicents

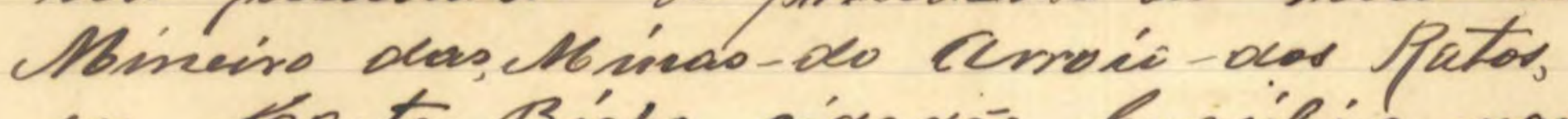

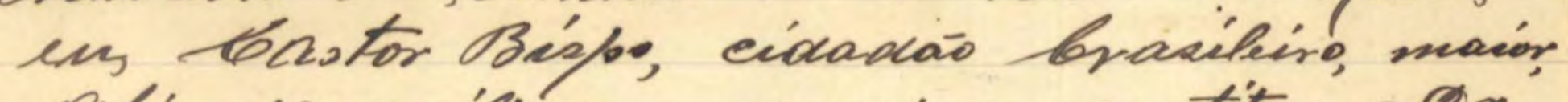

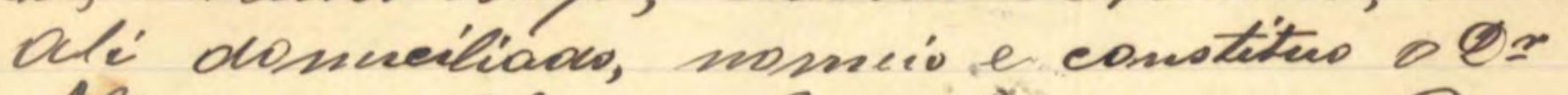

- Alevdes de Dleveira barrochs pana, no Forrende C. Teronymo, deduier Ortegos de nena - justifiea,enos cujos fatos alegara; en vela =

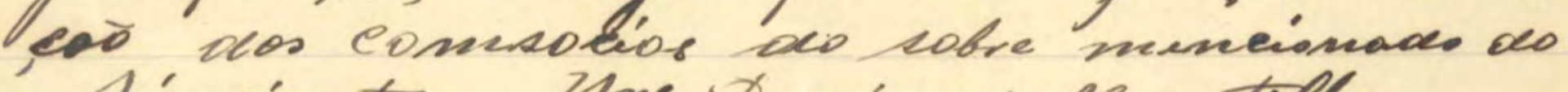
Dinguieato, Ner Doncinges Mbartitlea, * Leberalins elbachads de Lincer, Pafael-

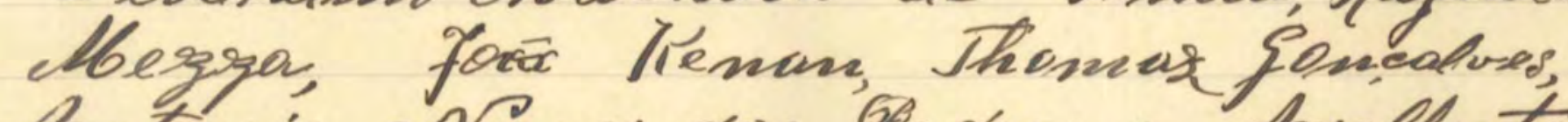
Antonio simes dos Gearus, e etroulberto- espanbujó dos Cantos, que para orefenido

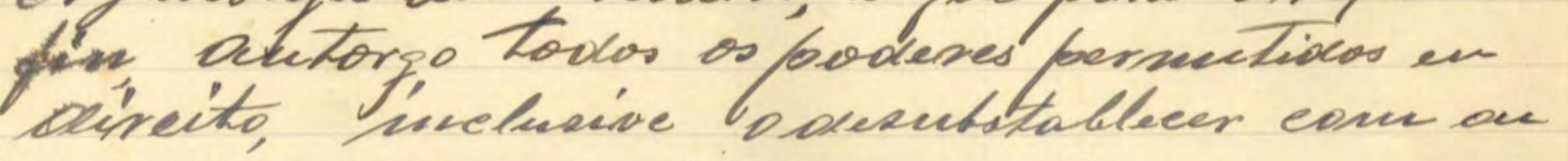
sen zeserva de podeses, guerende.

Llinas 18 ue

toos

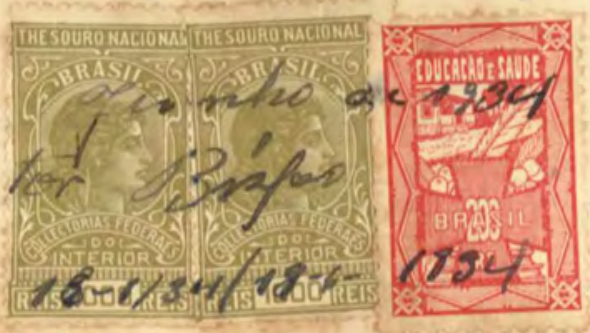

Reconhreşo verdadeiral La fuet/red L firma.-

Quplera do que cou fí.

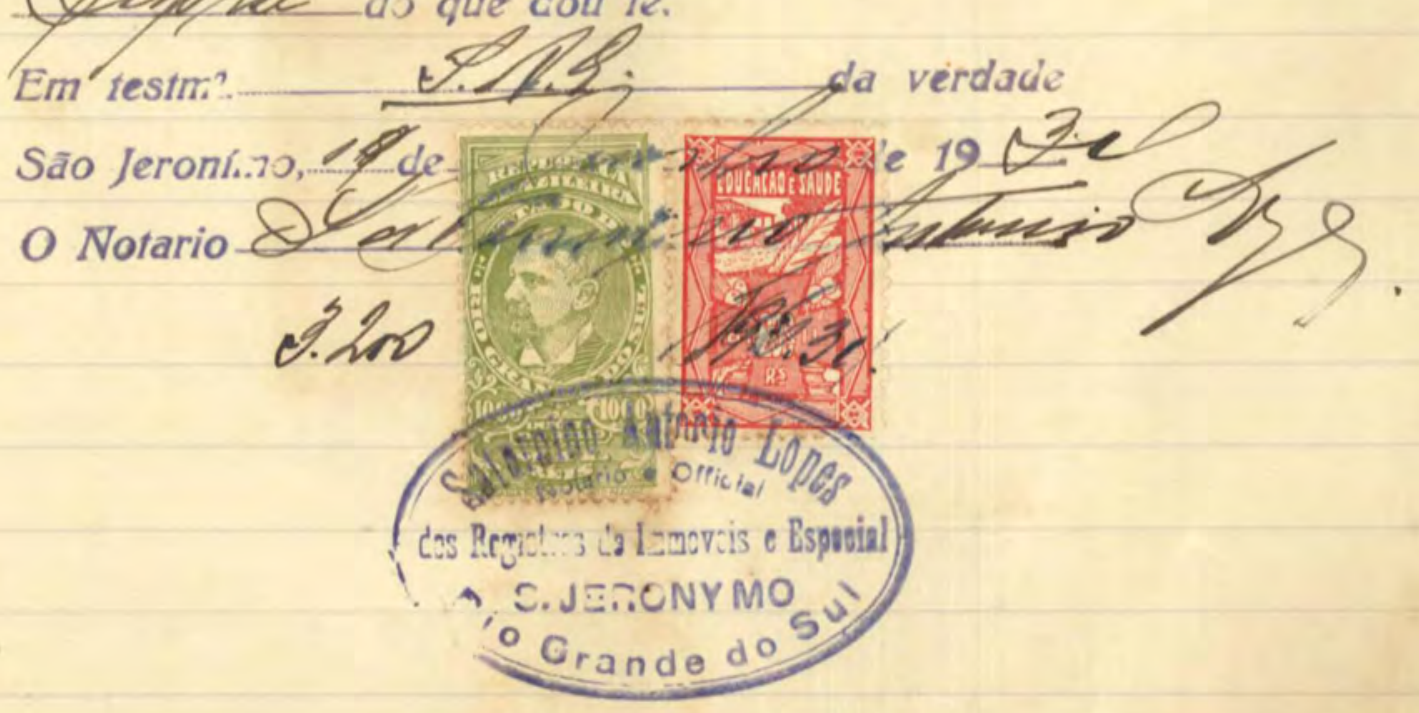


$\frac{0.40010}{t^{10}}$

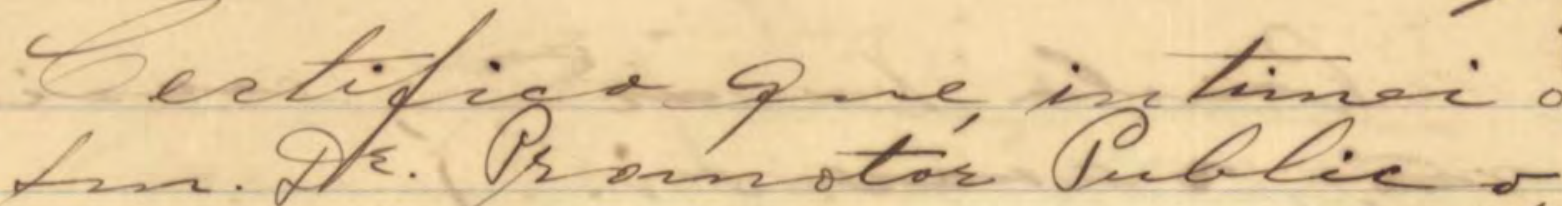
L d . ca petic p Kefo. I e kaphetir s deplowets. Diecete de den lé

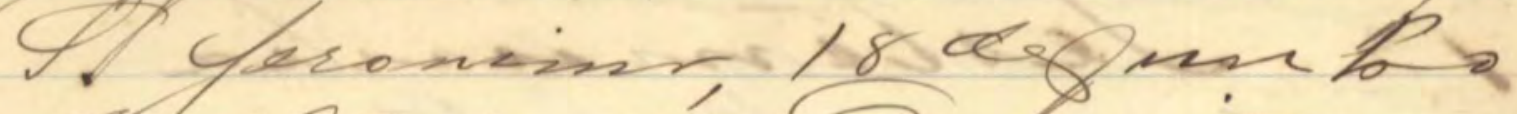

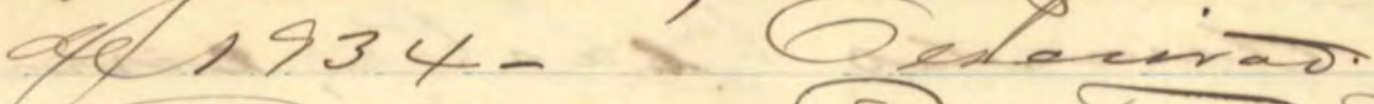

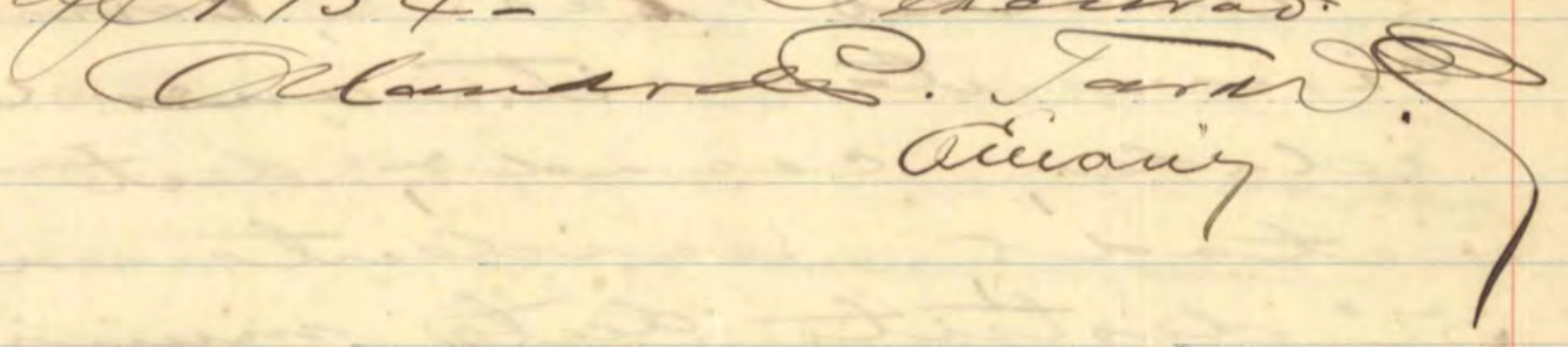

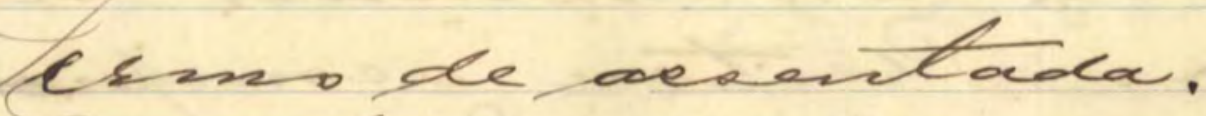

Q4. depese ore decies to sué

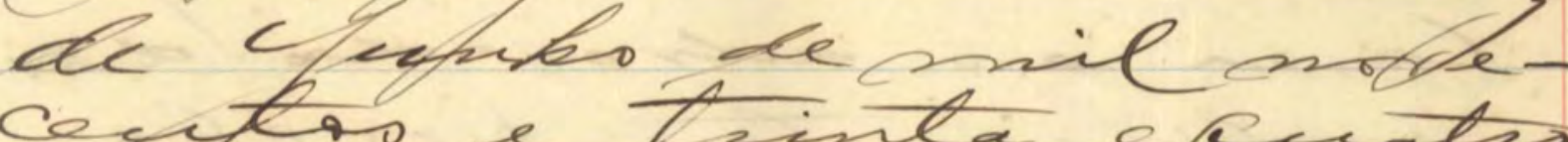

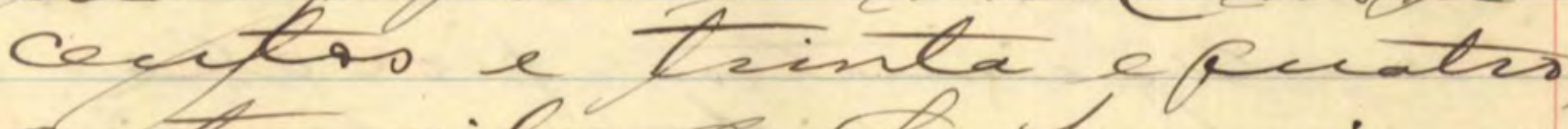

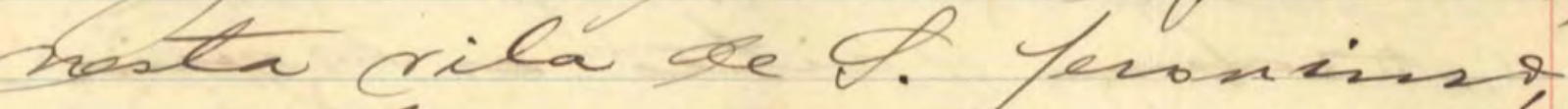

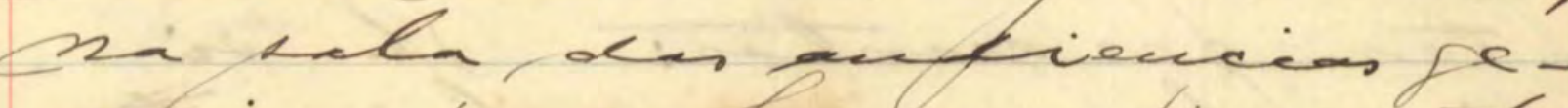

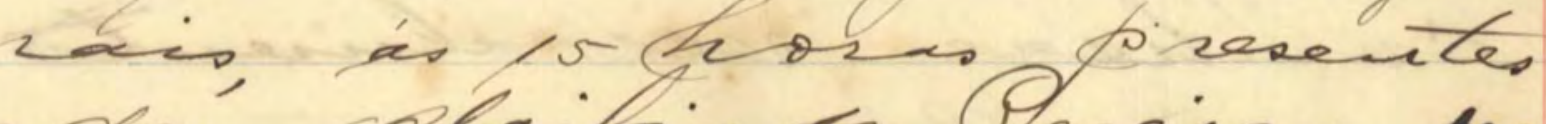

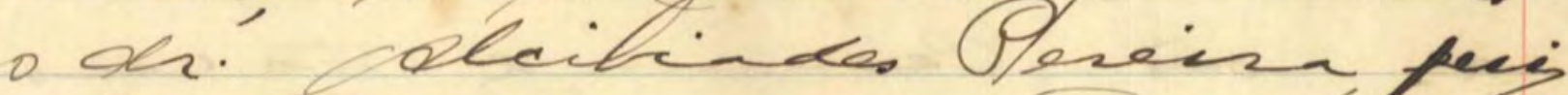

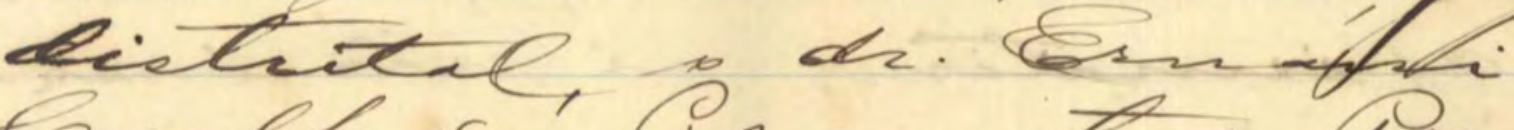

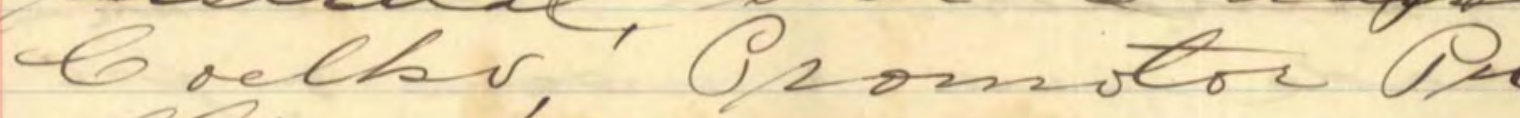

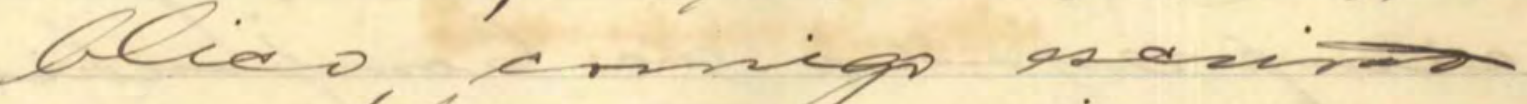
220 e. $2 \infty$

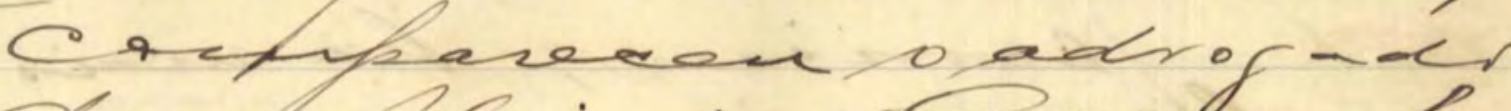

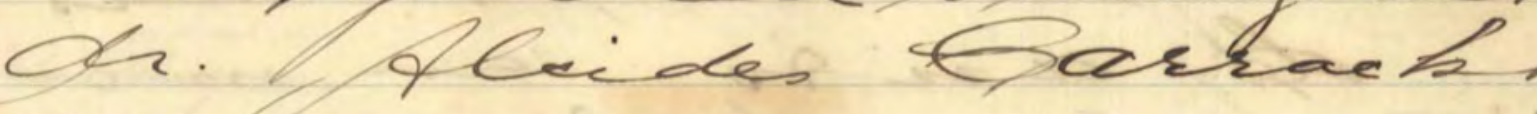

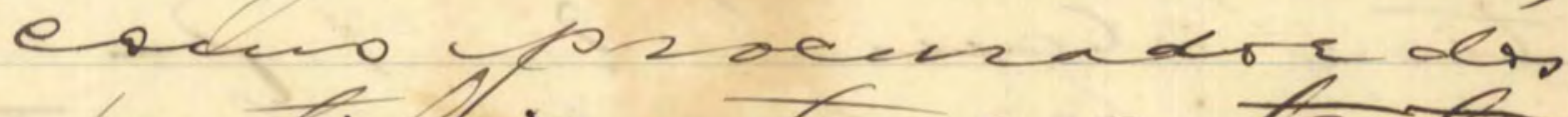

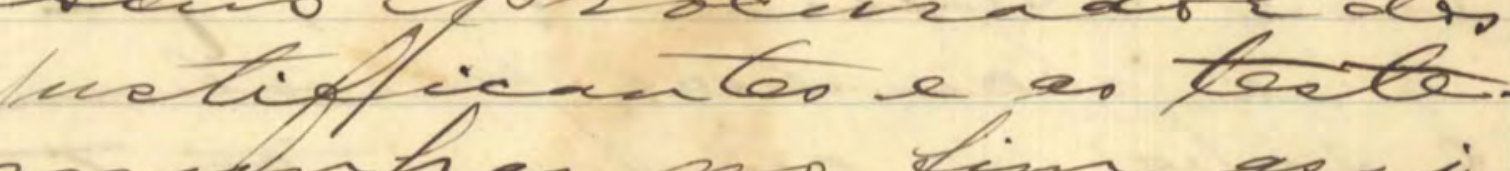

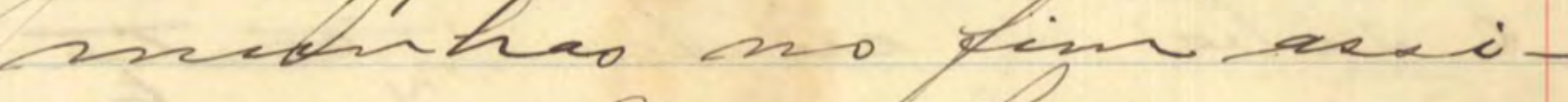

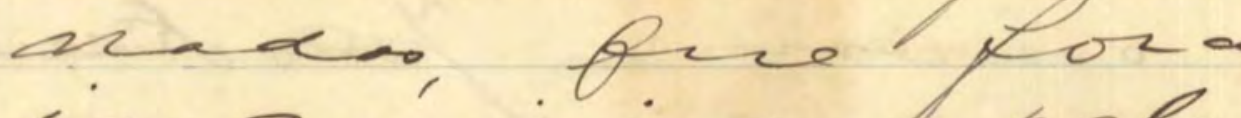

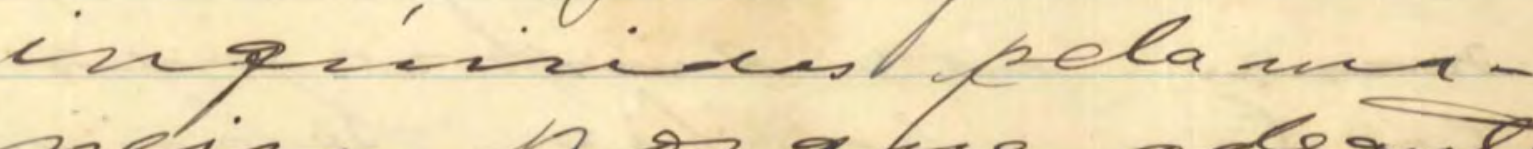

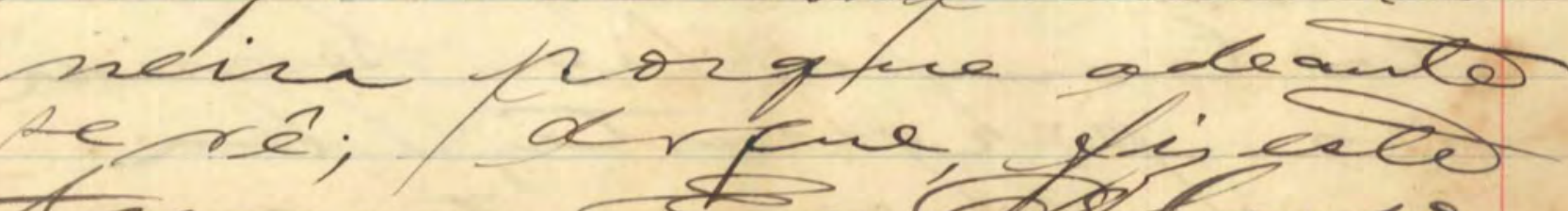
$t_{2}=2 x$. 


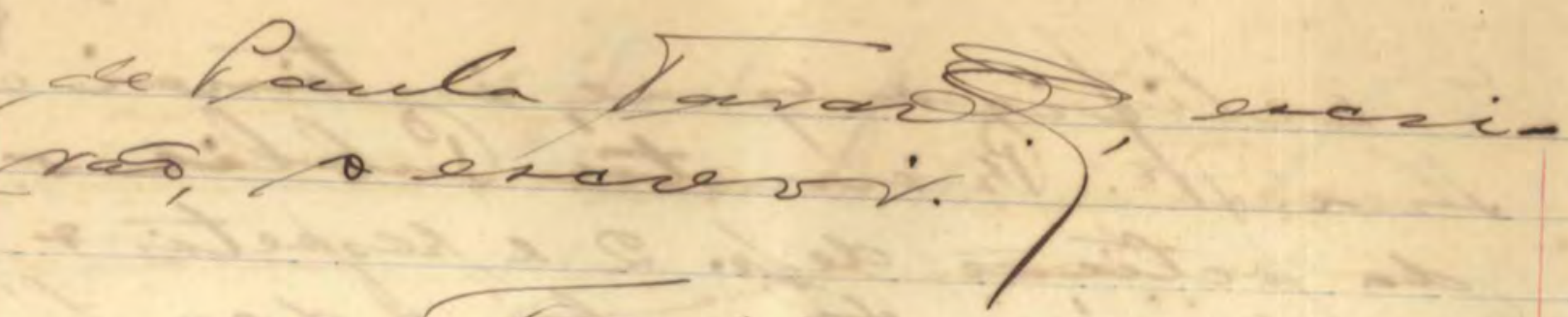

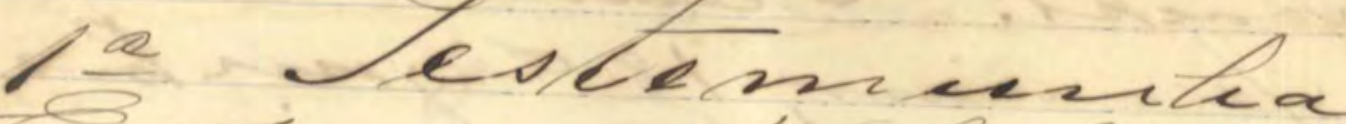

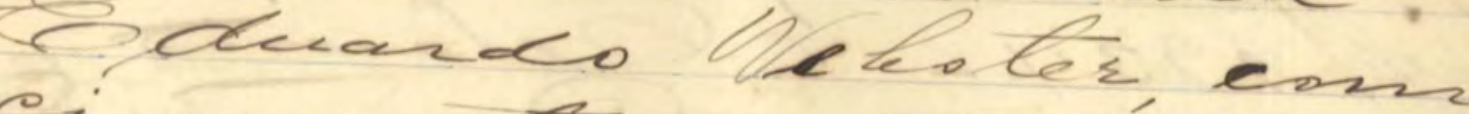

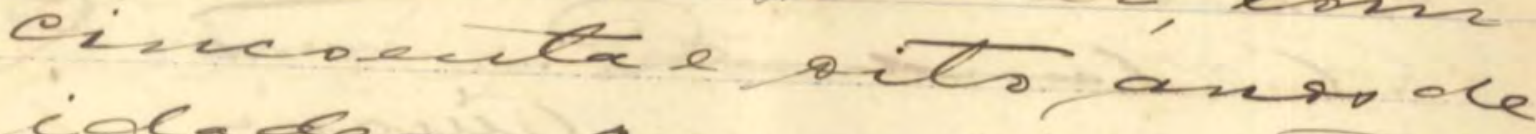

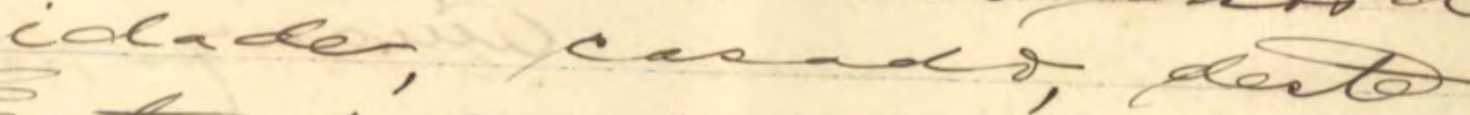
Eeter sas riakectee

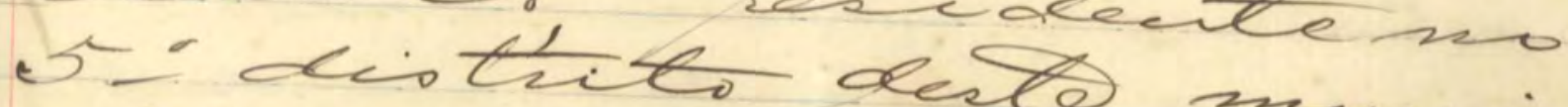

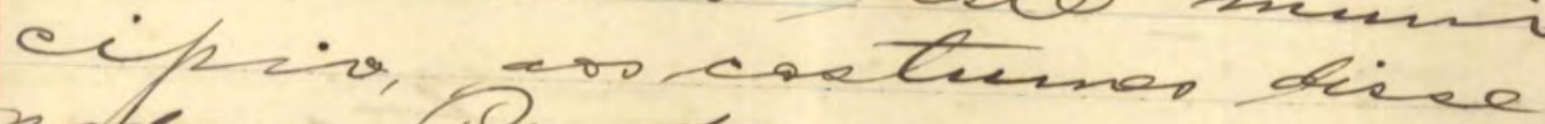

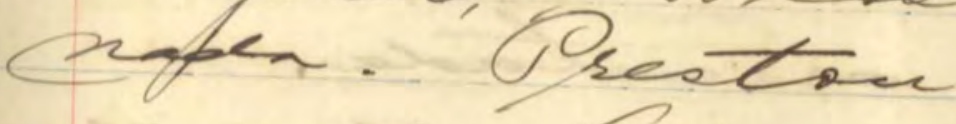

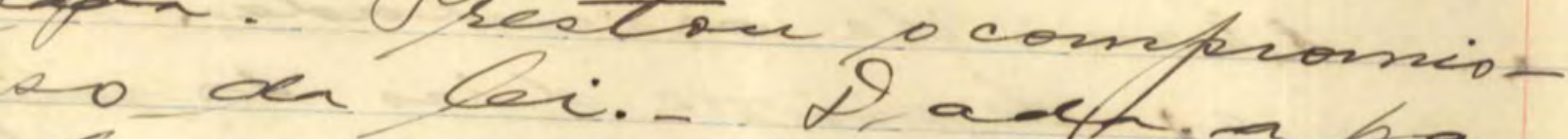

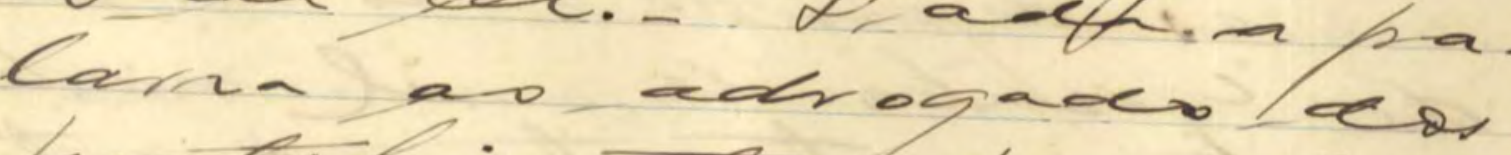

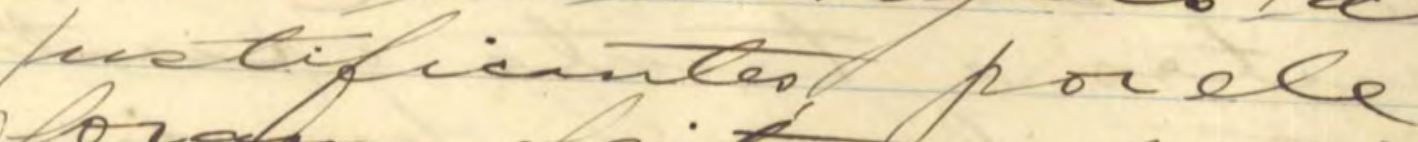

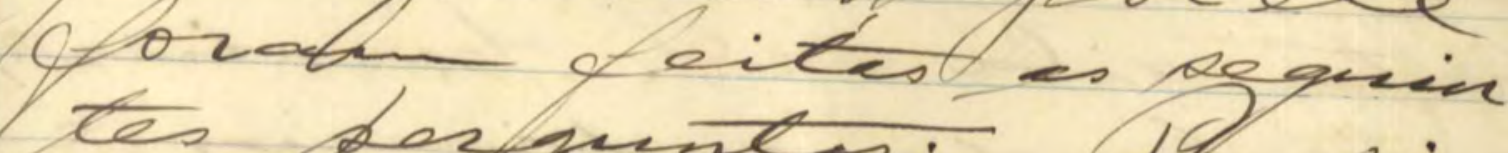

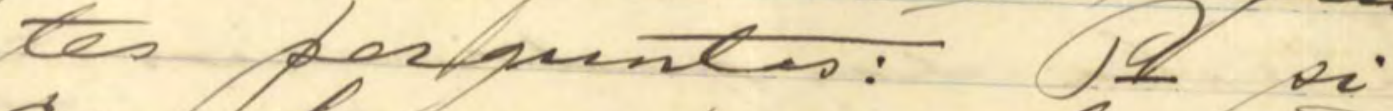

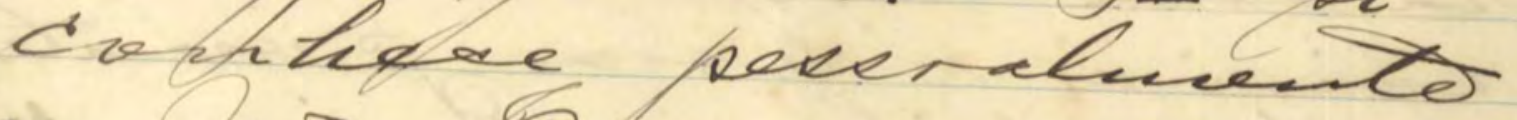

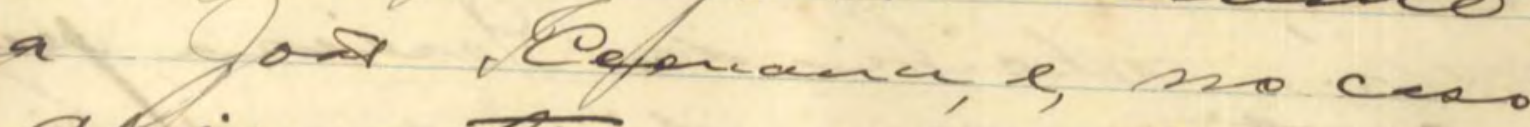

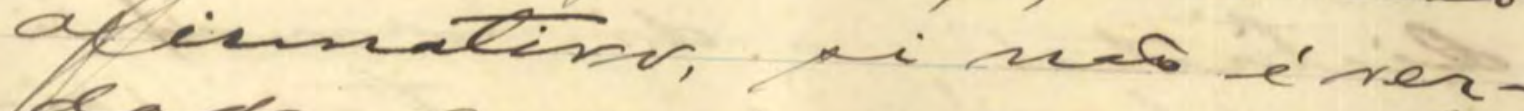

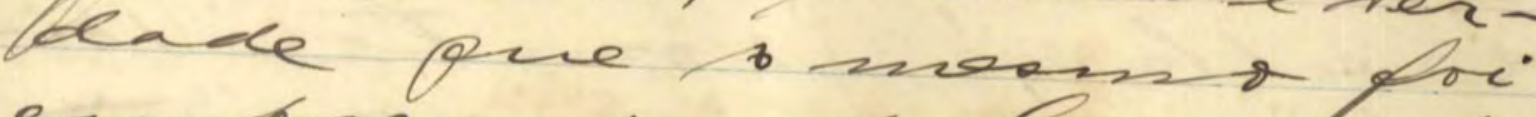

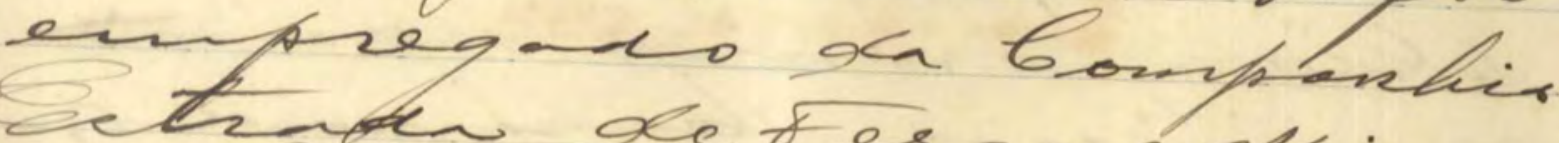

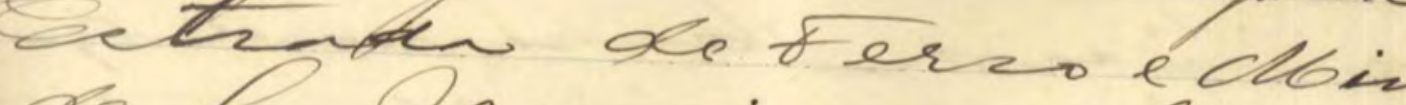
de $\mathrm{Cl}$.

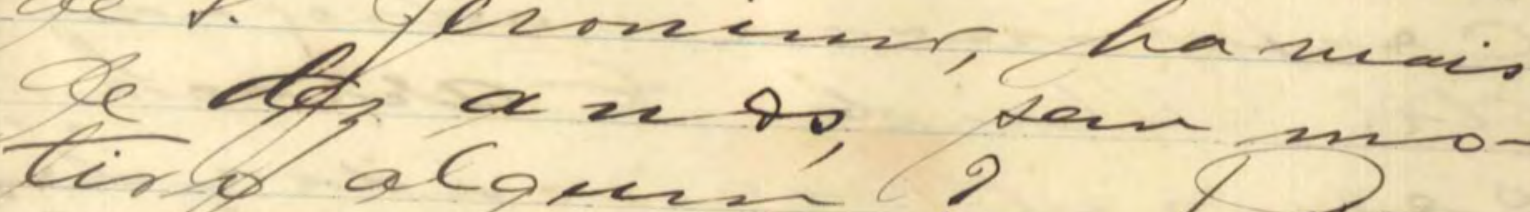

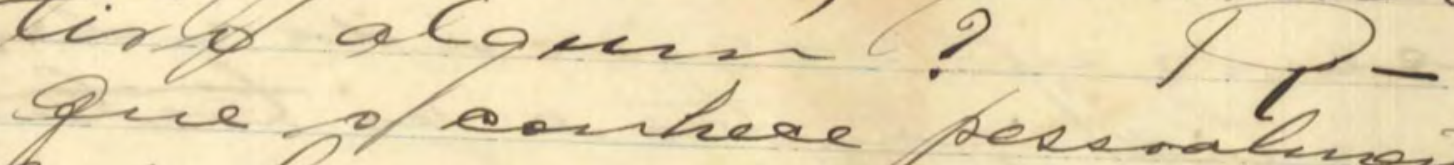

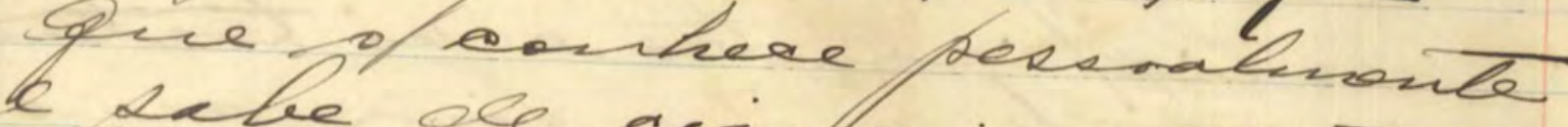

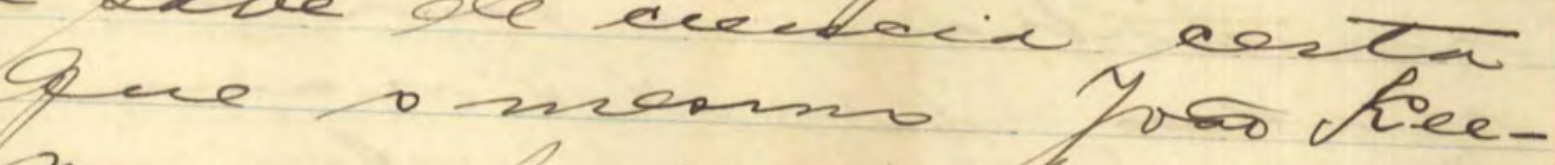

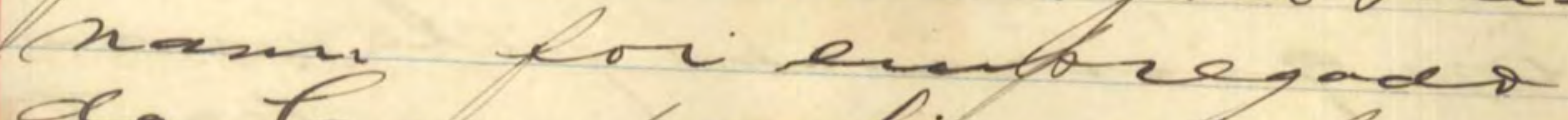

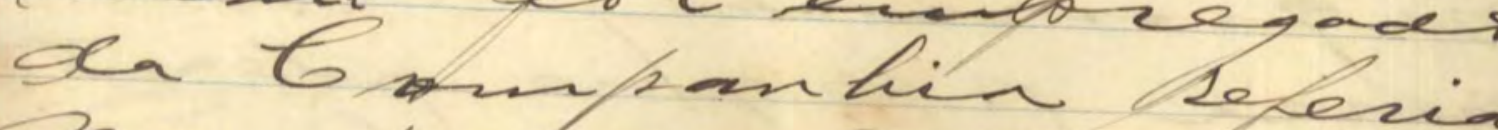

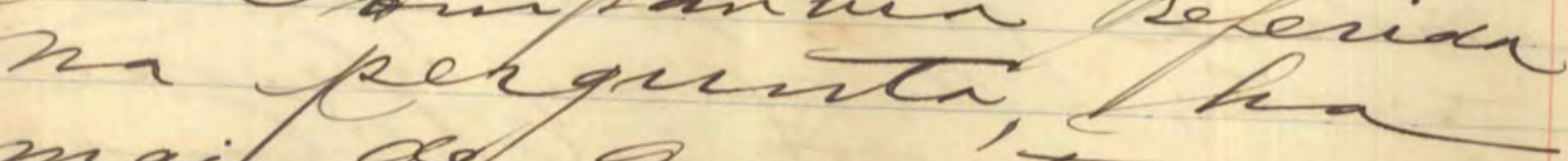

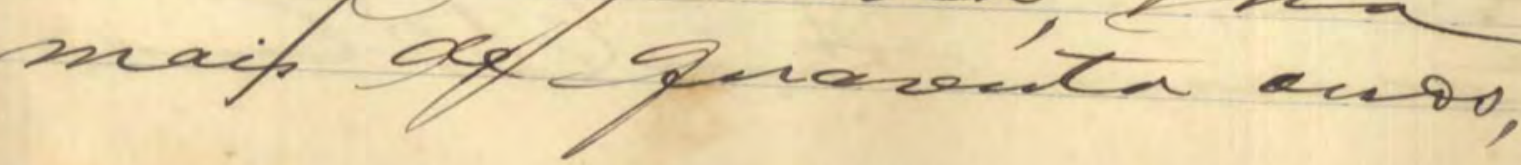


col fera trutanents

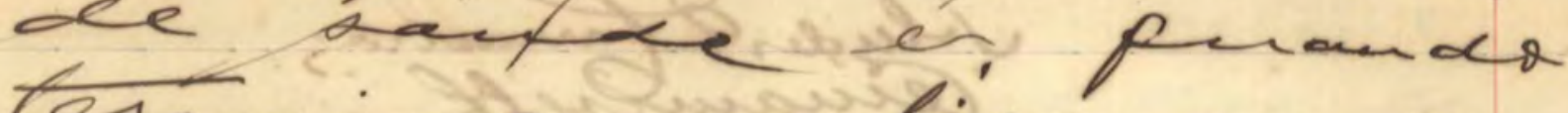

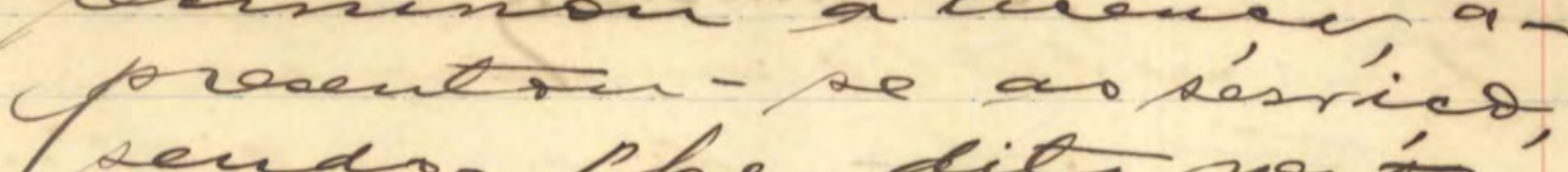
pendor the dito neté ocsis, por fusw oe diveve' hin Bompantia,

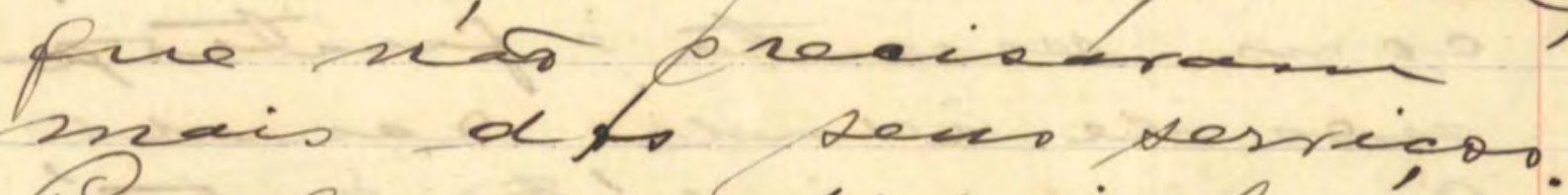
i) pere fo olia informar obre fo ilea punts, cinas, seis, sete, oizs nare édés da Kiviacé

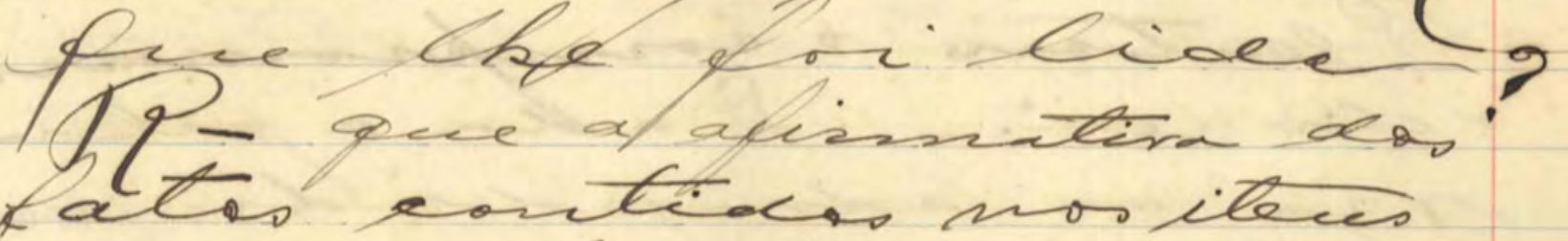
Che foram licess dectas ouh form de

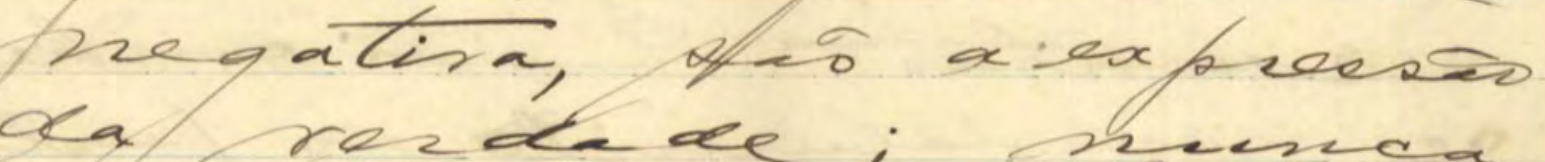

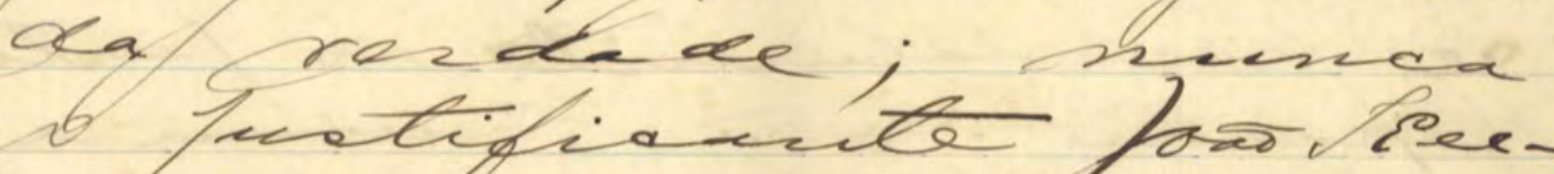
- tama aliof d ou ilferes/2e cantern. Nada

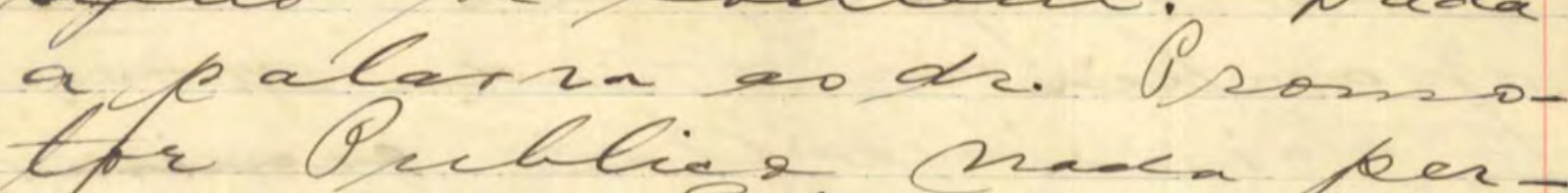

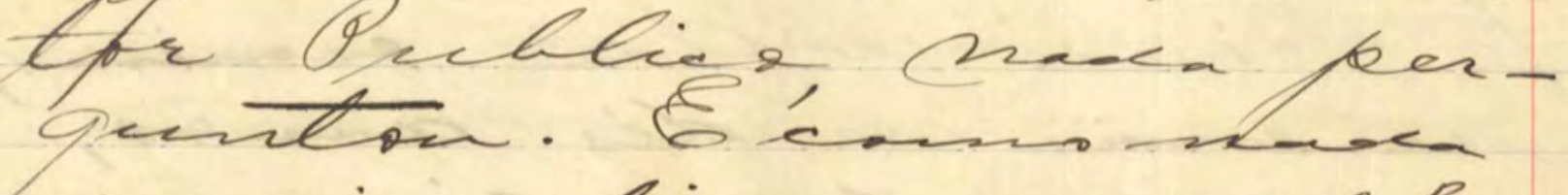
tzreis diece, man lbe

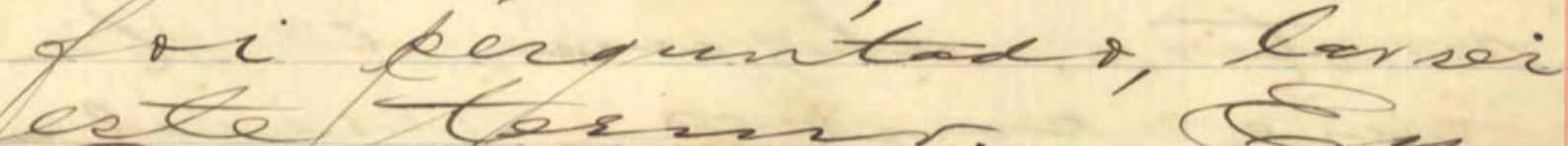

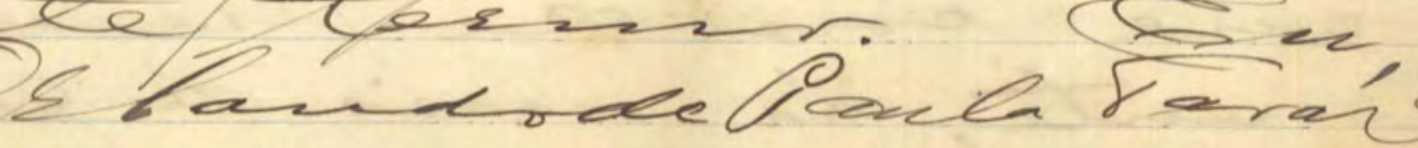
वरevirt, \& oxacoi. 
cheiliakeos

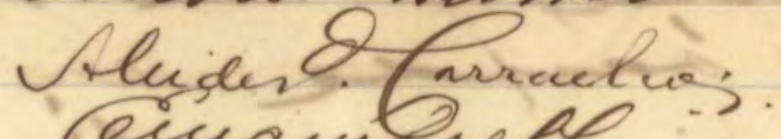
cinanoreff

D. Sesternuta.

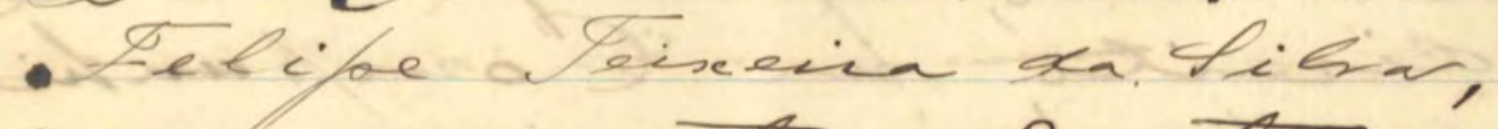
cont percutta efuterp-

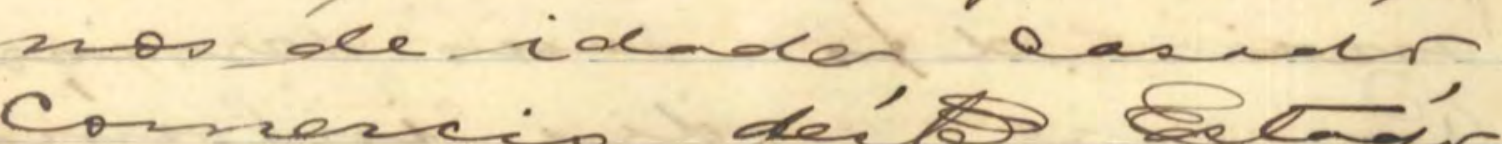
vei-late' mo or diekié dei Bo

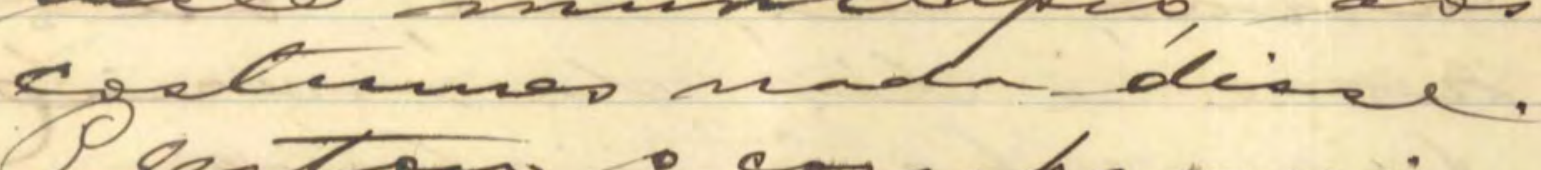

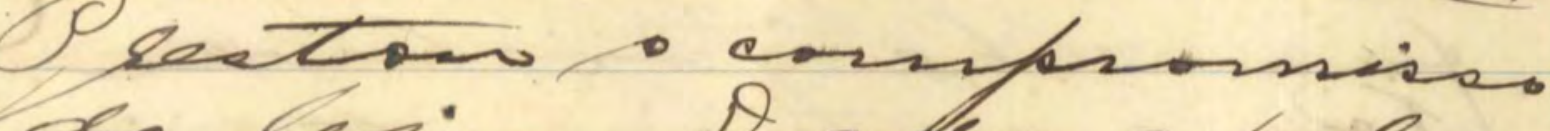
th Ceri. - Dale a pala-

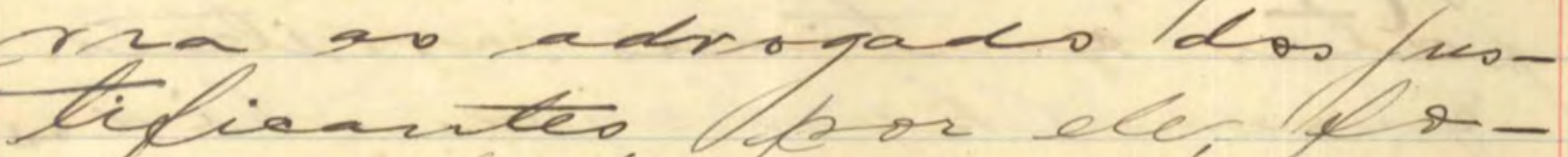
Efem gaikéto os kegilin tes perghenter: piconhe chperen-lunento nostir

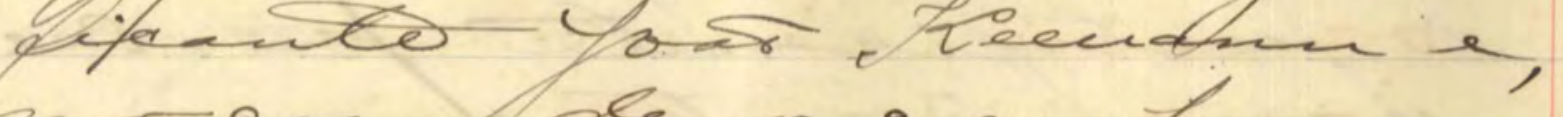

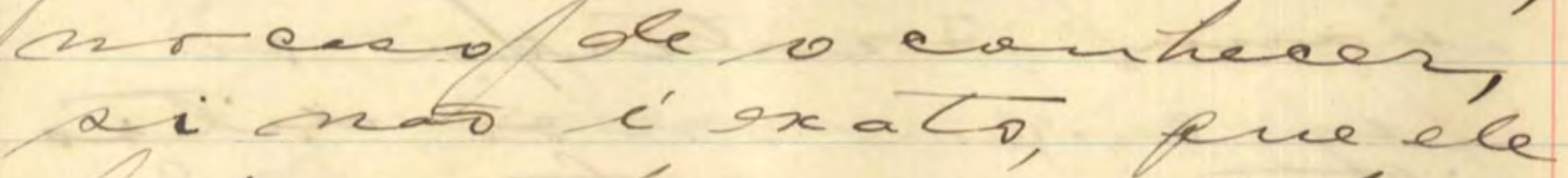
dai ecropregado da boun

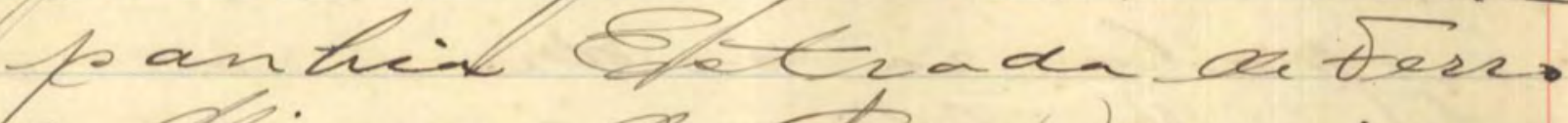
Laines de dab monim,

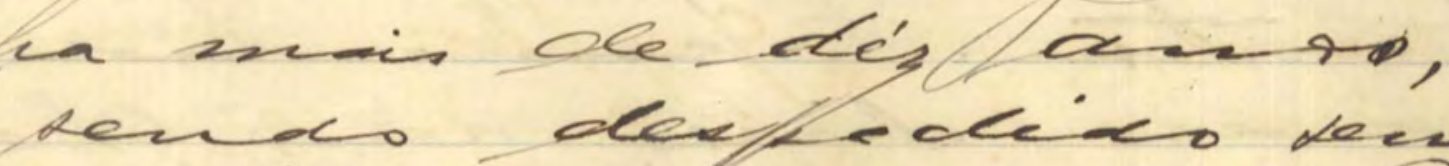
anotino algenen? R Que couthee. peren-eLurente, da matio de lenrenta ans, enus in 
Fon

A1. 12

eryoreguia oca referie

or 6 mibanhin, pais,

mill oit.oputa a aitenta e Rito, Ruanto o ok-

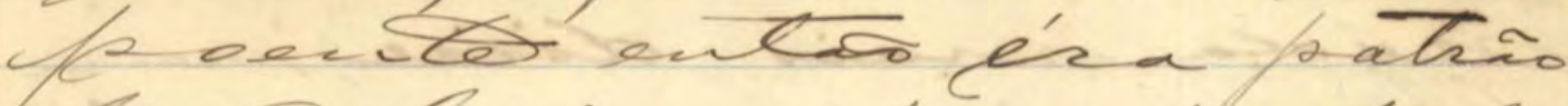
ole paleriv, cante Igor hiechan per-

in Sofh tur orders; Qub tha sowes, ele hariHe dido win a liecuger,

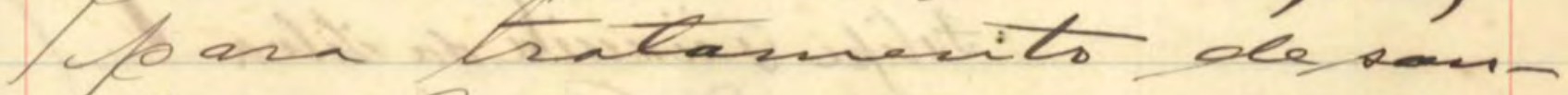
lici. Q ver parinow, apse sentón se a perric, senCo- lbe dito neere oderi-o pela reprevertante legal da Gormpantiv Ampregadaven bouno abefe alo. lesoicón, pue râ éra

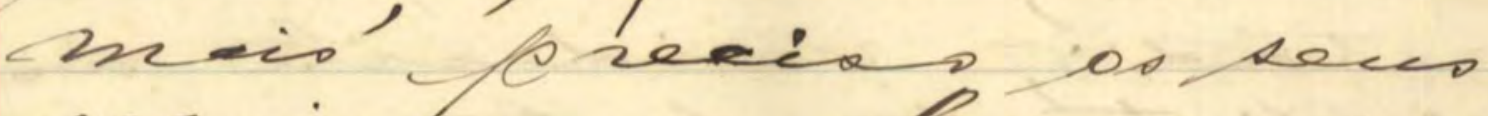
perriep, no lacyer fue ocubera, wu hanta Qurfugés. P o gre k. deir informar a mater 2.bre as per glantas énsutavter ofro lew, puatro cinco, Nei, hete aits nive, dís, quefhe foram

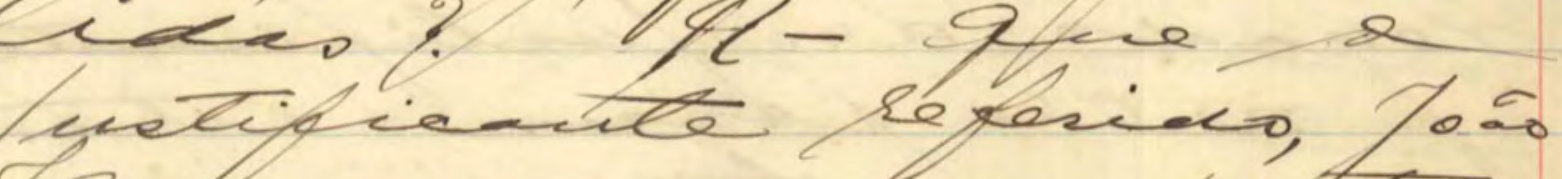
reckan, munen pifficen mernecín dro cttar se Lator, erpecifir..lo, noo 


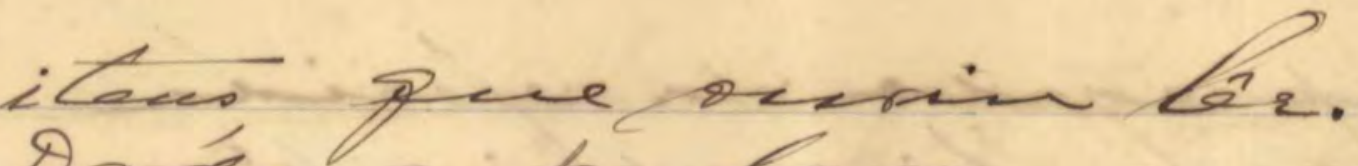

Da der a ta a lariza a o dr.

Q Eam oftor 10 cellis?, muora dos gevetor.

corses

wheca muis diexe, ners

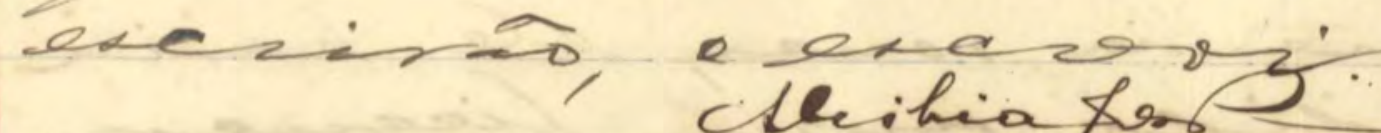

che ihia foor

- Felifar vinnerite da ctilona

Heiden? Griach.

eniviluct?

$03-a$

Sestemenutea.

Oracio Eoma da Pocka

caen-C m mineis: deptó

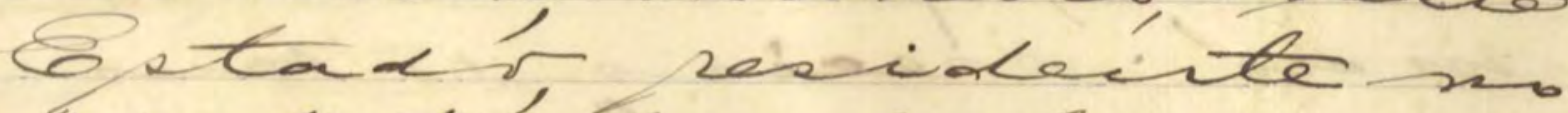

bi disteits deste numi-

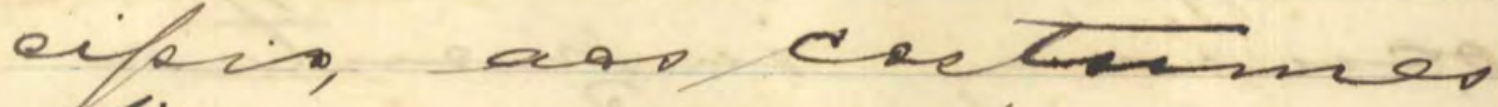

biese ter erforequa

ca boury an he iv Eetara

de ferno e dbineo he ga

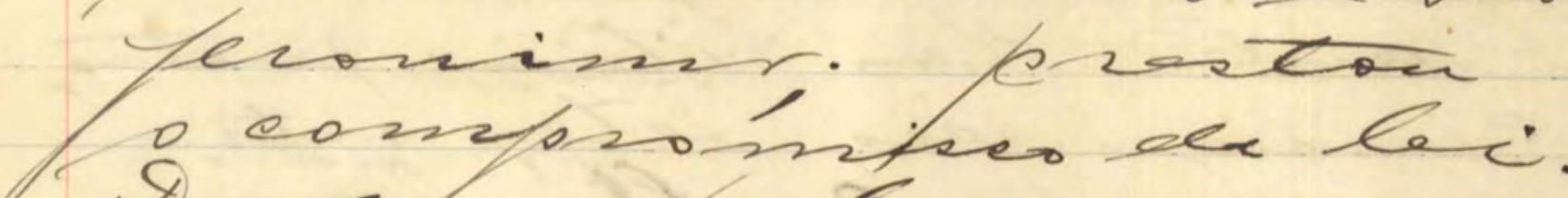

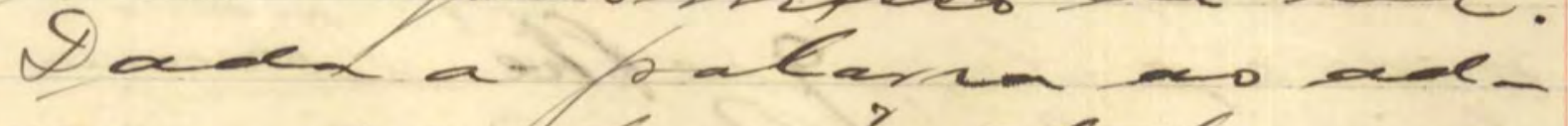

rogado do we tiflianter

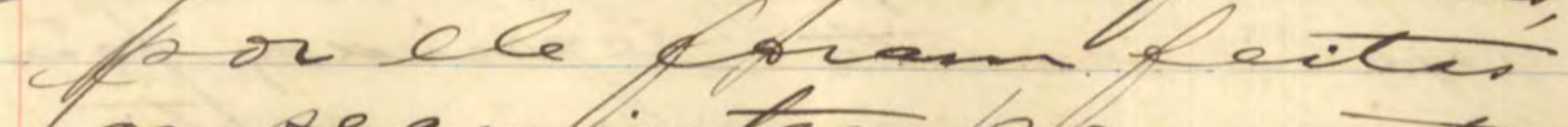

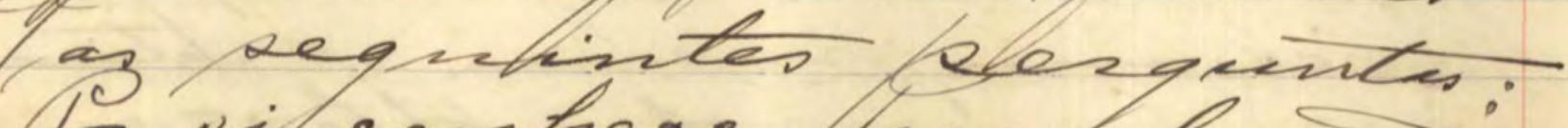

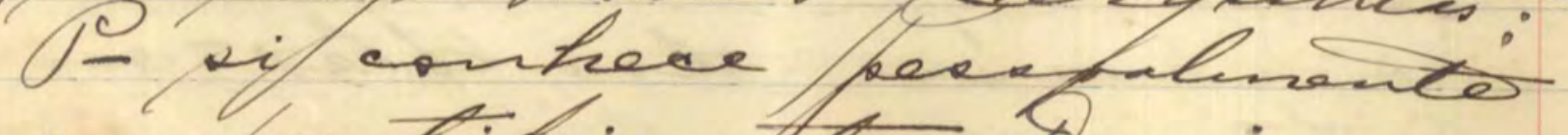

20

tificuthes Domingos 
8.09

areots

(f). 1)

toankilha Liheinkiso dbaohndo oce of insm, tratach

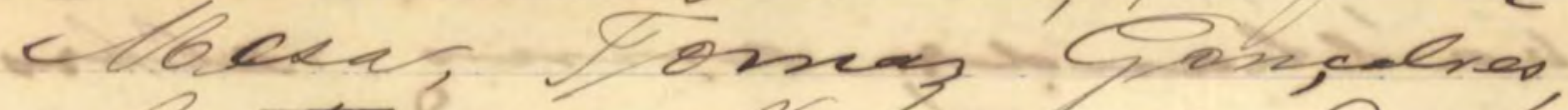

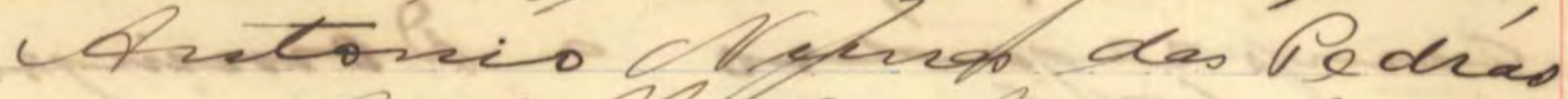
e Rolatherto Opanbuya do Itantos e, lno ed ode o Cowhecer, pinn-o é srezcade, prues o fuelifir cartes Nomeingto blentilka Liberalino dbaehado de

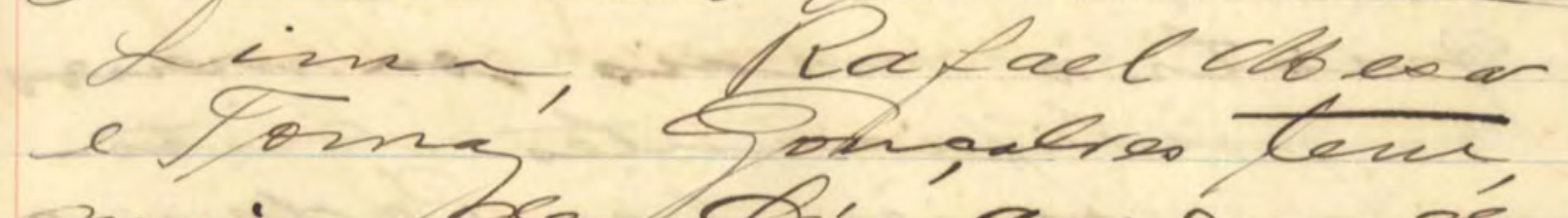
mais Ba lés ar so dé Nevich glom onplegado

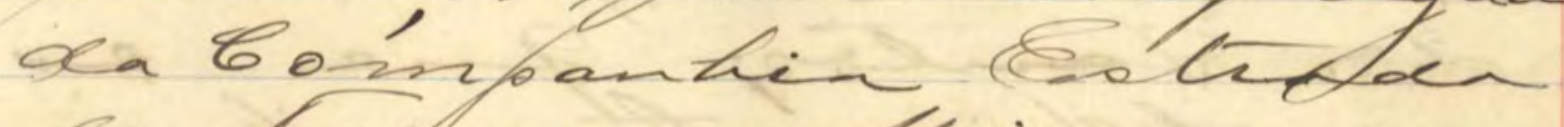
de terles c dbines de

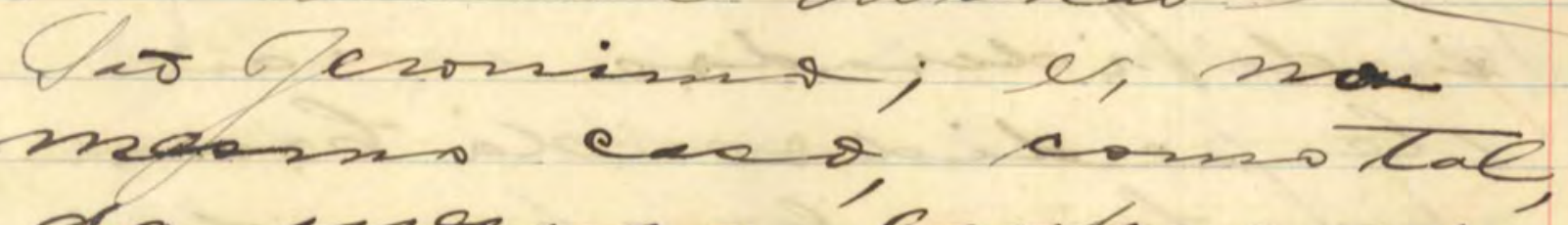
da mecura 'empergadon-

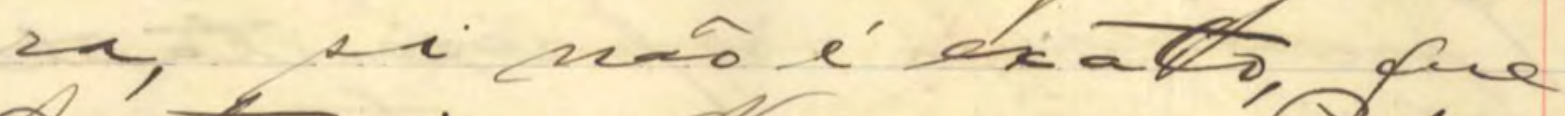
Artonio dinnes des Pedras - Malatherto op ambreya Lo Lantor teu mis ofe cte arrs ok cerriaso? Z- we conhece peropalarevte a todes bs fur tific-ter menciarfaco

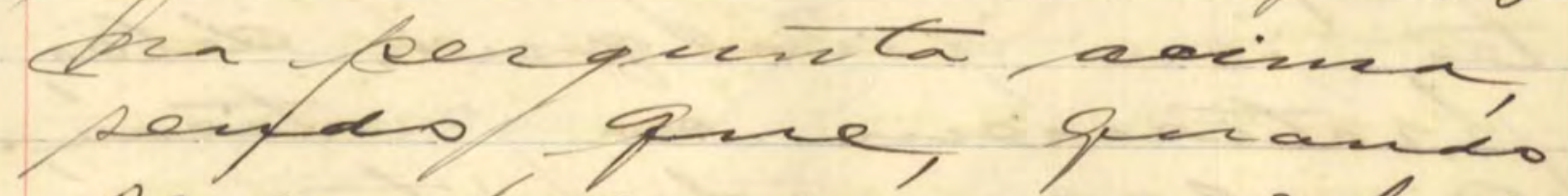

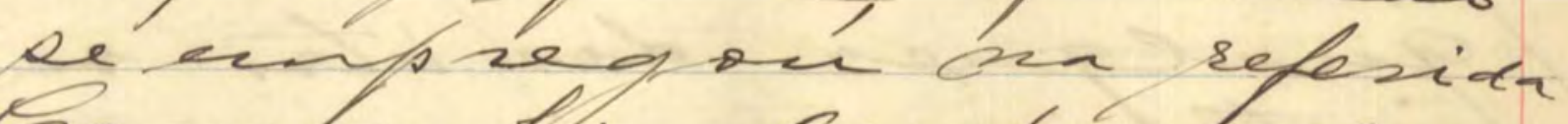

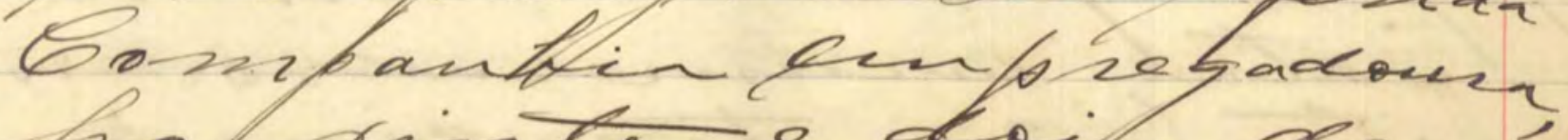
in rintere doib de?

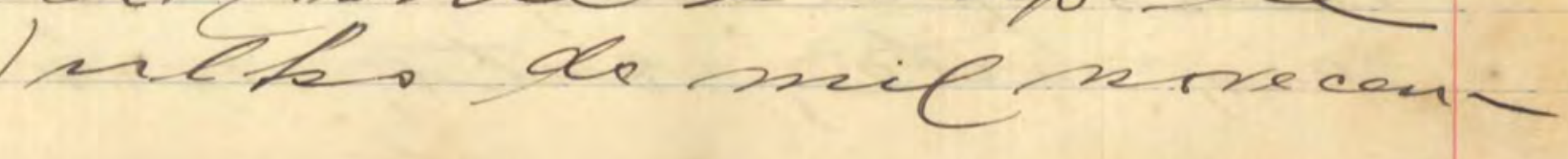




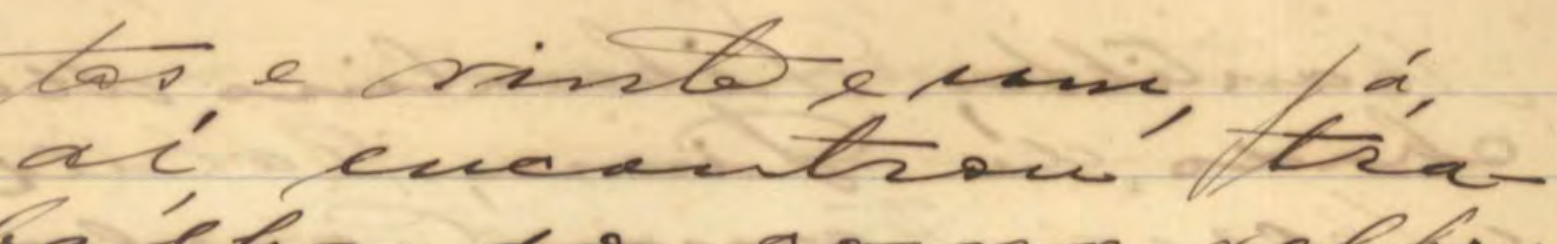

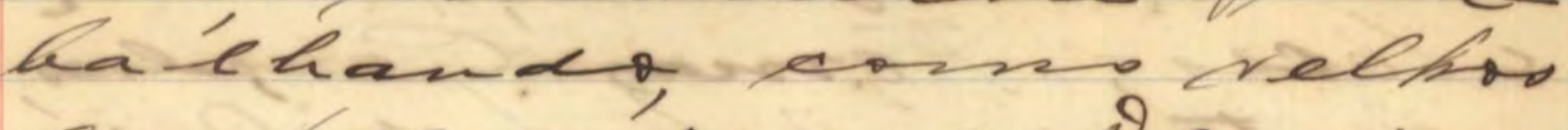

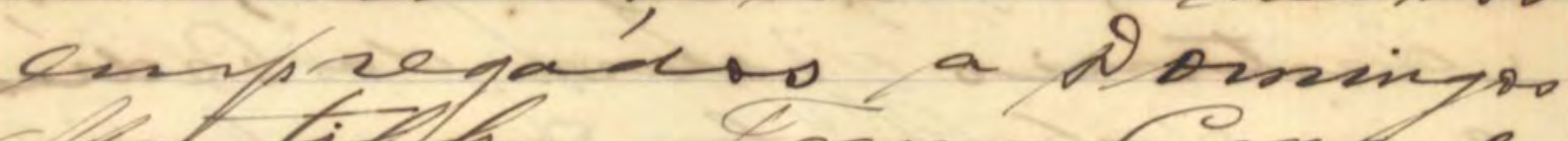
lootuliffl, lomas Sand-eres e Itaflack telloker, enfregankwo-ke as ob acepoif, pra olitu Gompankix Cssupegadoren an mic

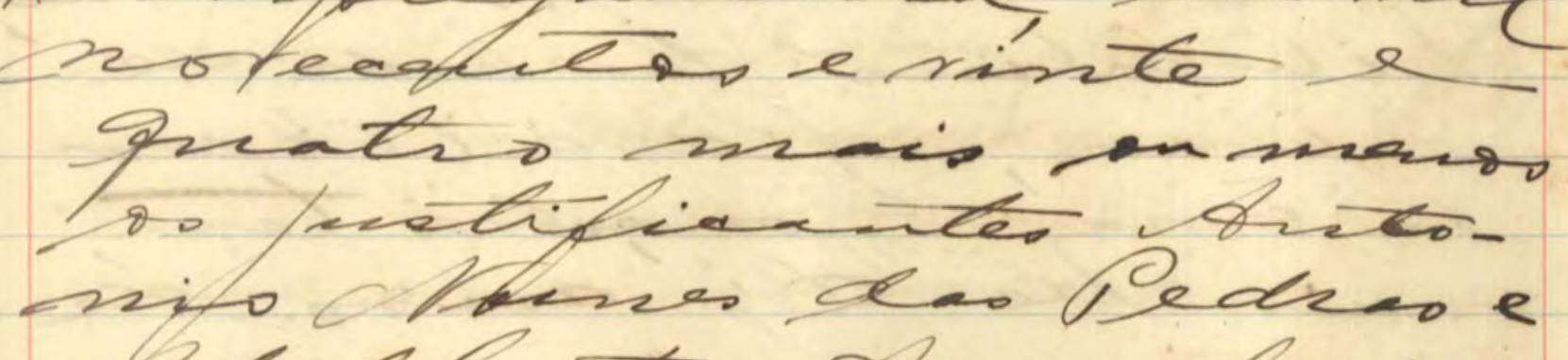
folntherts ypariana as Rarito;

tificuntes alase indifrideradob of oras deppe kidor oca bromfoofurbin erseregadous.

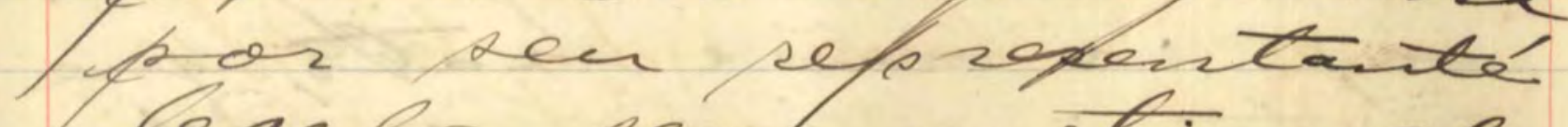
legal, kent m otcivo al-

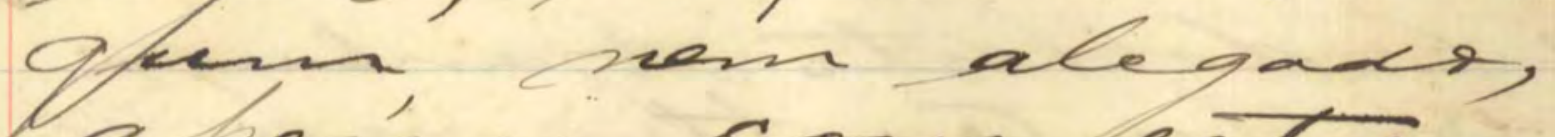
a weres corm letro Co alaruas:iv nan ha

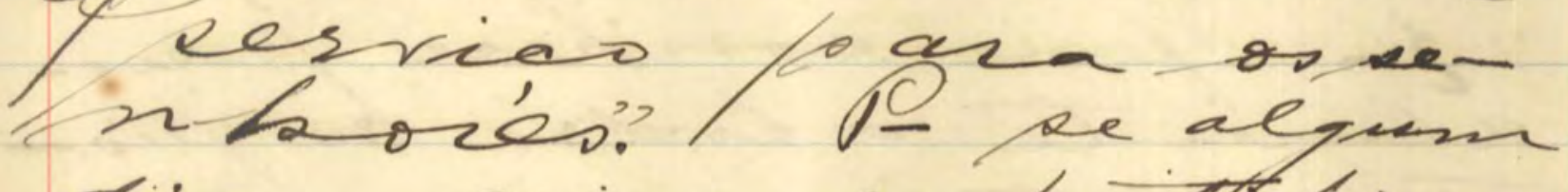

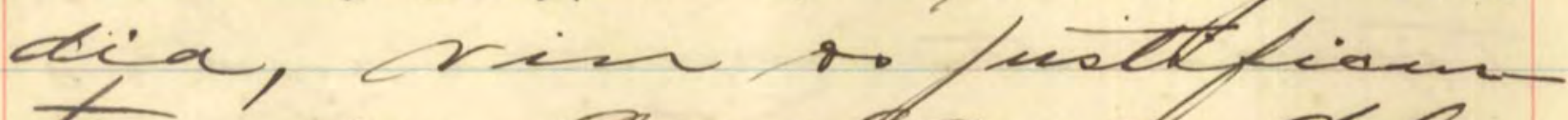

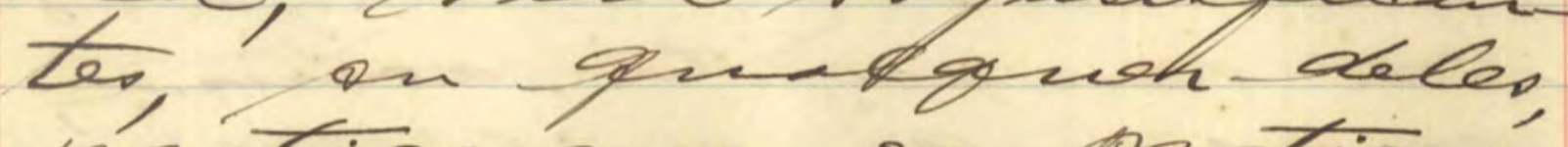
is atiecrem on pratian? Qualpuer dostátor ou

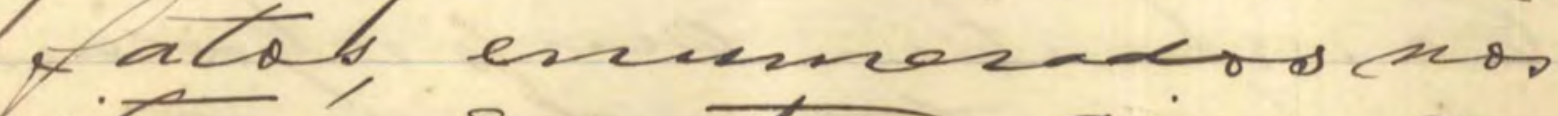

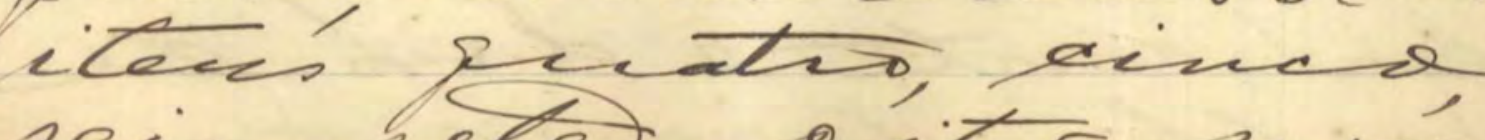

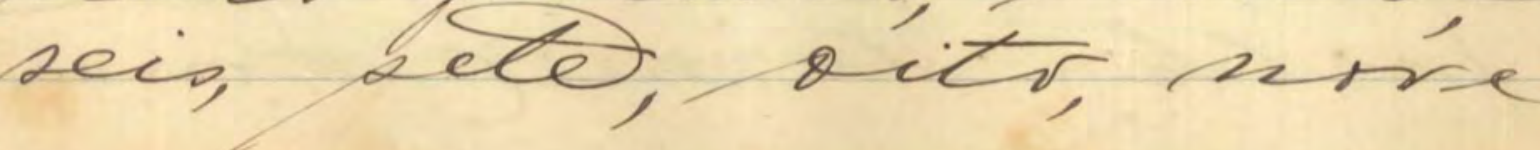


cencos

$\beta .14$

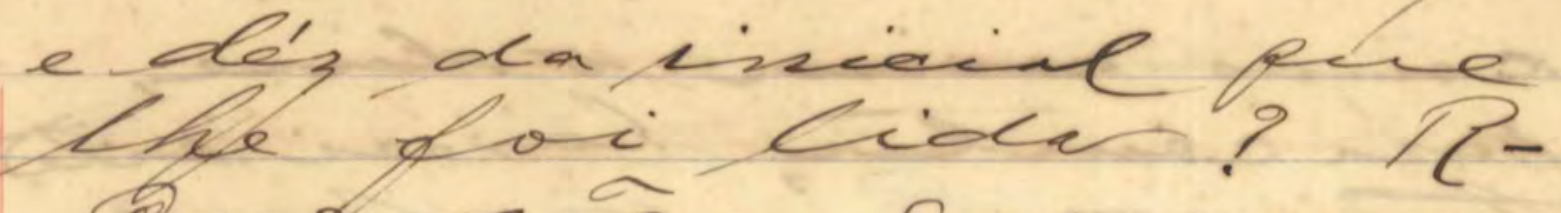

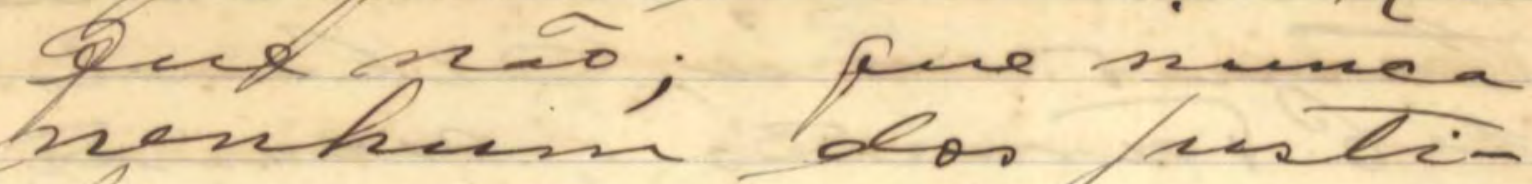
ticmetes for atibur puneQuer des áto ar for artor de puréguch do tato reperific och no. ilese, pun achbou de ourie Giz. NQ Gach a solaria ao de. Promotor Pualia for er ele
made fori selgererico. Ecento nuoch mais kiese, nom Che for perymeño Carzer data

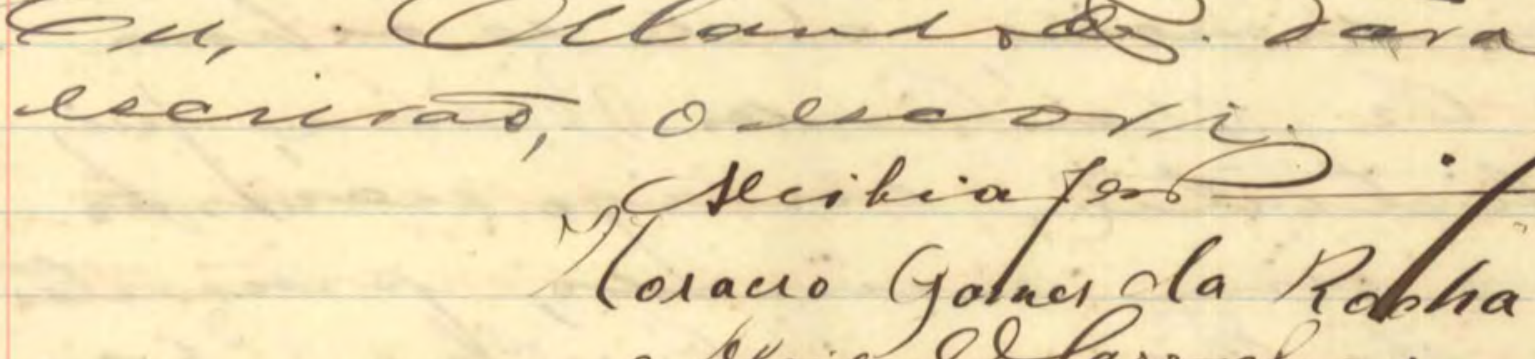
e Mcidesel Carracks.s.

0

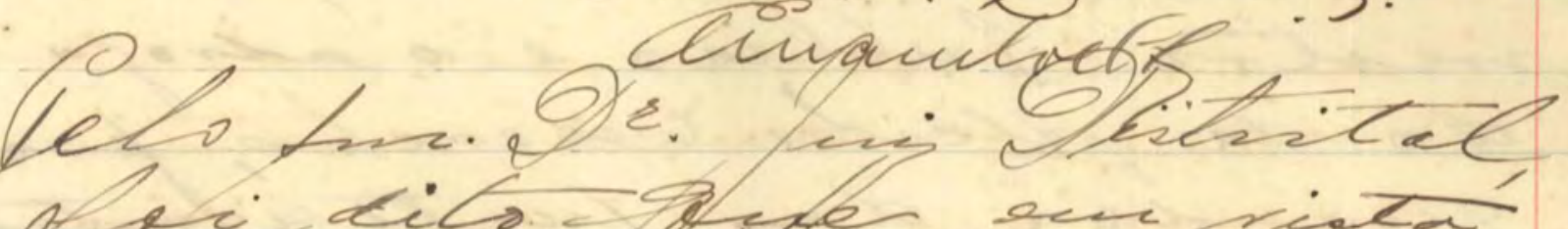

L si dilo-bule, en riata do-sclecutera da hor Aupperdial a inguisi, so das testernermher en ácescïnera 0 dia Réquinte,

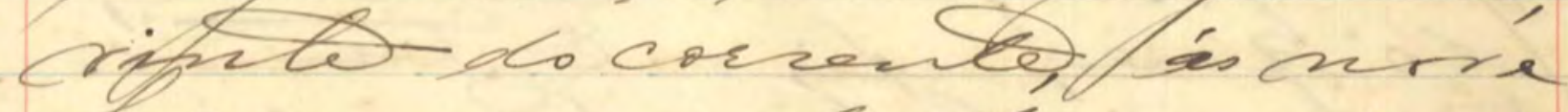
Ir gras ona sala des auriensis parr a continuated da in -

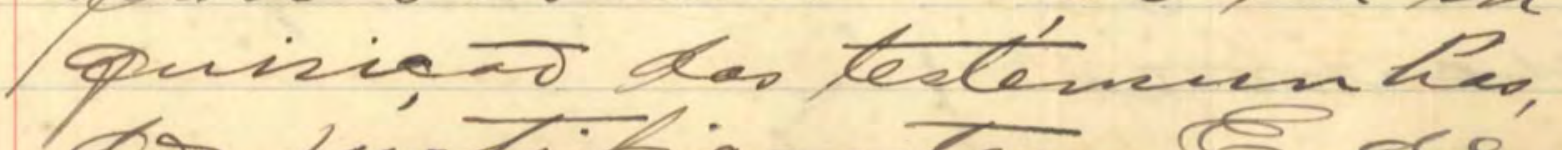
obs juntificater. 


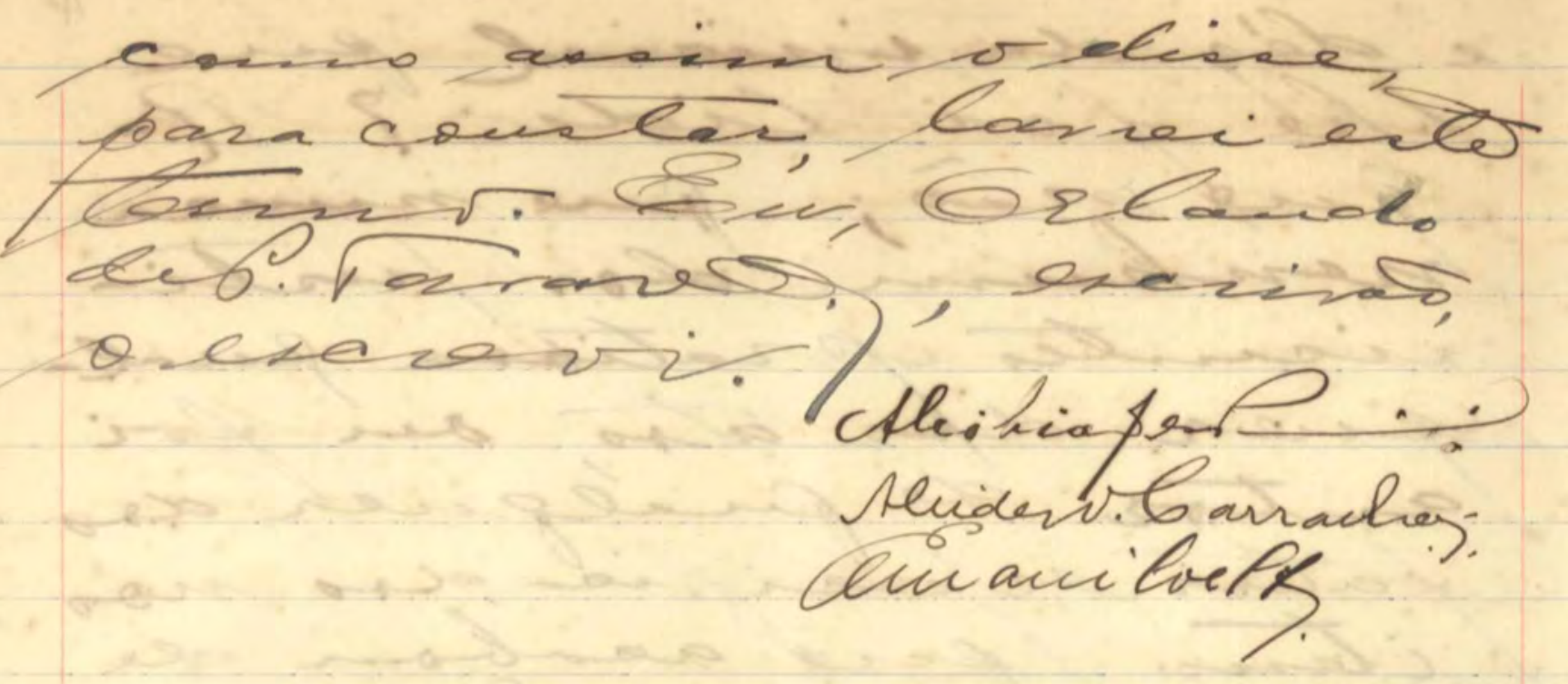

- Censo de asentada.

Lar vinto dias do nij de qu-

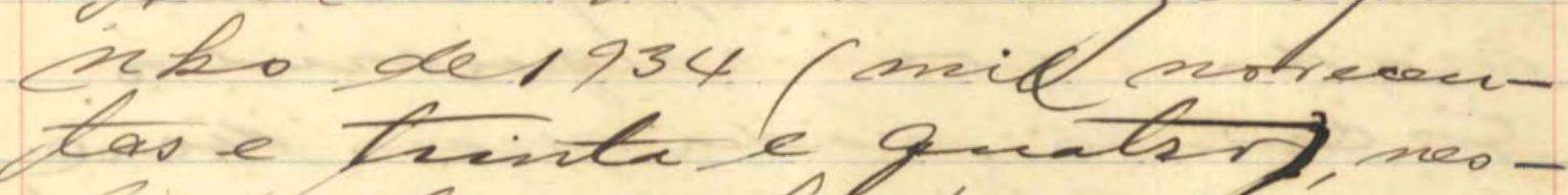
tase twirta e guats? nes-

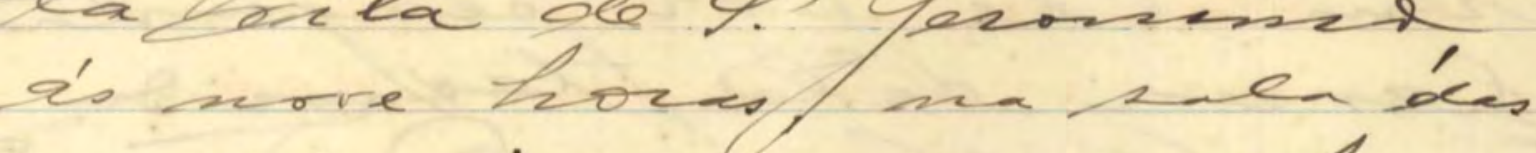
culdincils, onk ke achern Ar. Rlailiner Bereviv fuig dietcit, canijo earétiot

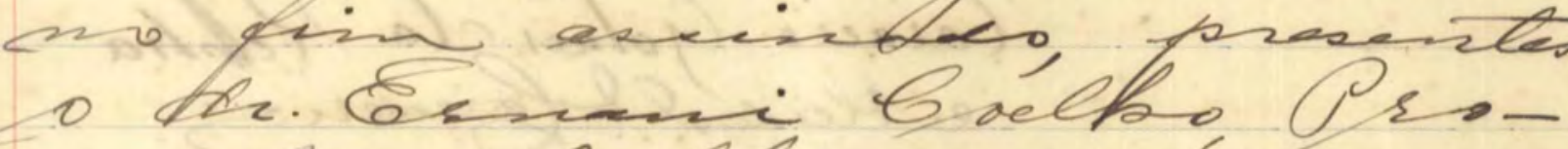
motre Anllido e ónergaAo di plicider Gorearto, psocuracor dr fuctifidarie,

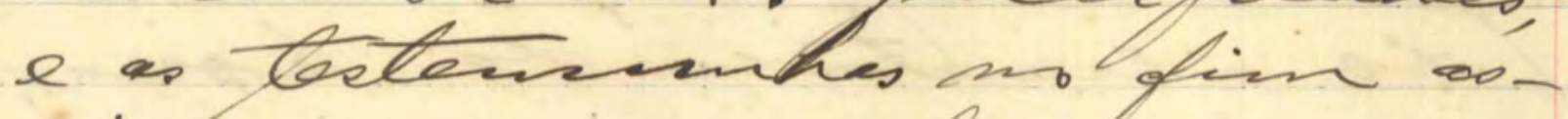
Sinice, pre porque a kantes te iê;

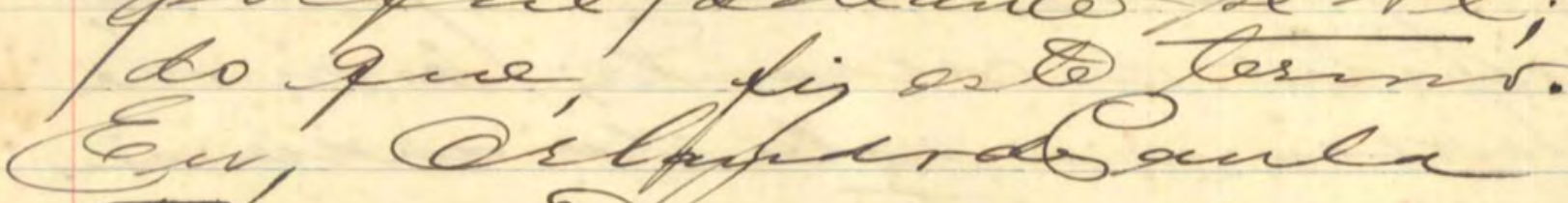
Tárat. , evarivalo exari' 


\section{$C_{0}$}

Ha lesternemin.

Edero outo faiquences,

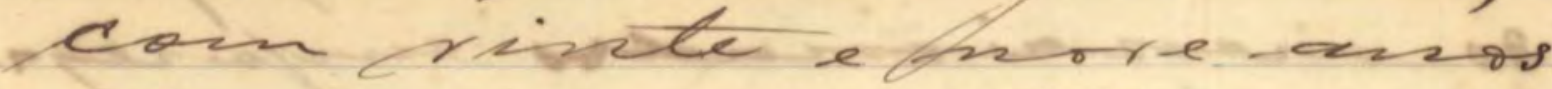
de idade, 1 alleir 0 mei. meisto, dostobetaru, he

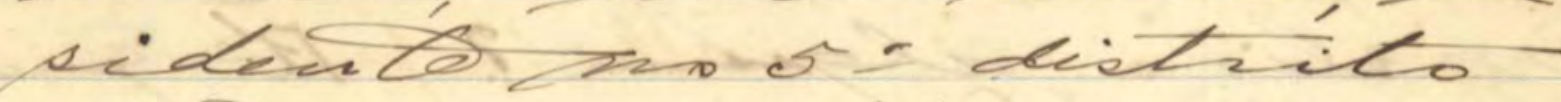
ces

tes da bix. Goted a de

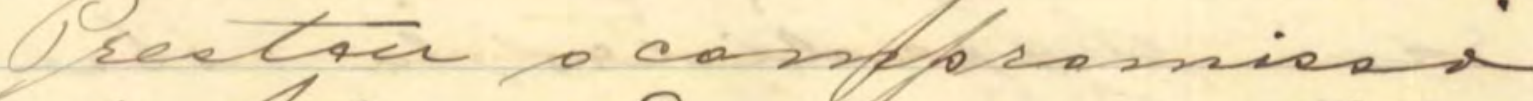
da li. - P a la a palarza w-dolrogado dos fustipieamles, porece olorar Oleita of segurinter prerQumita: HO eicantace

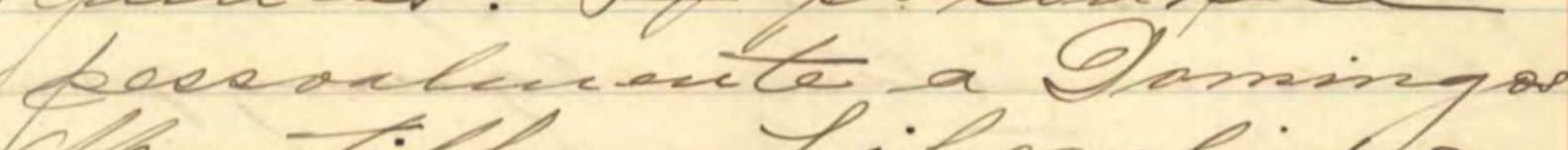

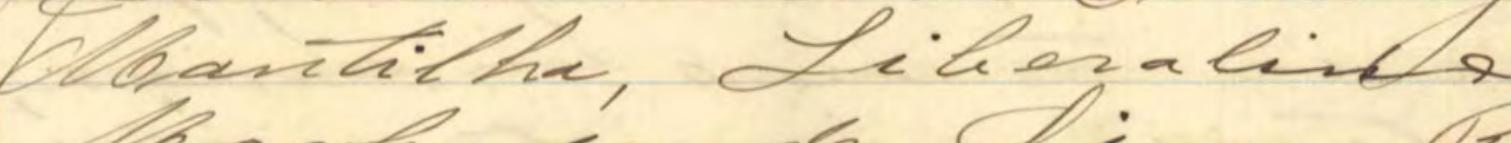
locatrado de Elisma, Vla

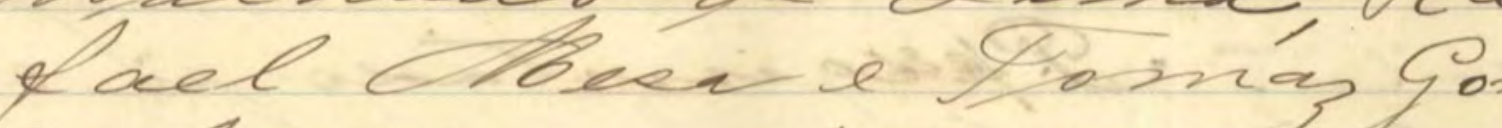

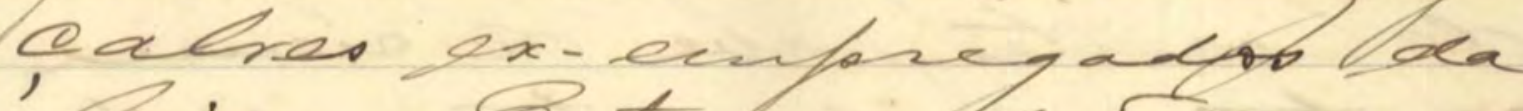
Sia. Estrda lake fere e bins de D. Peeverins Orude tiritraffer ssucit? maí de dép ando de

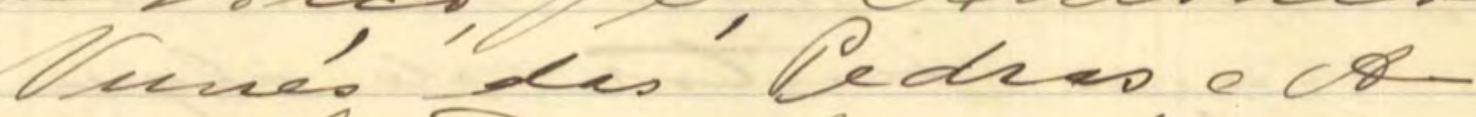

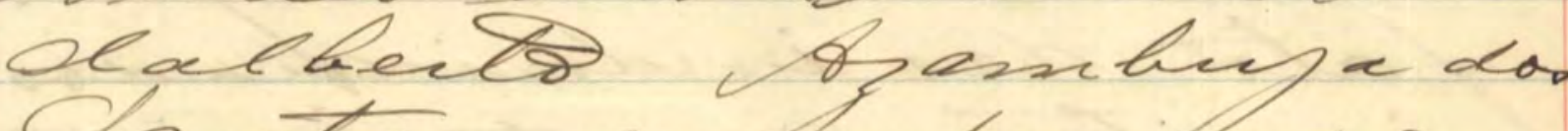

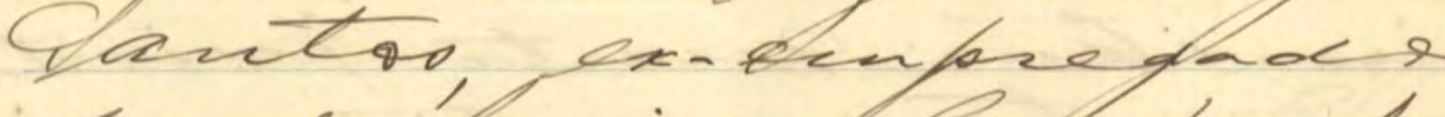

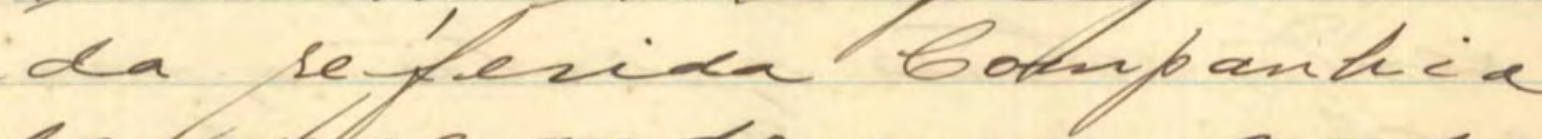

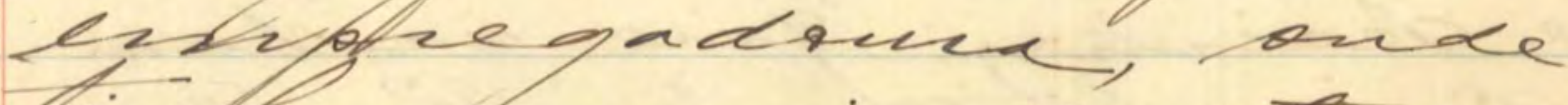

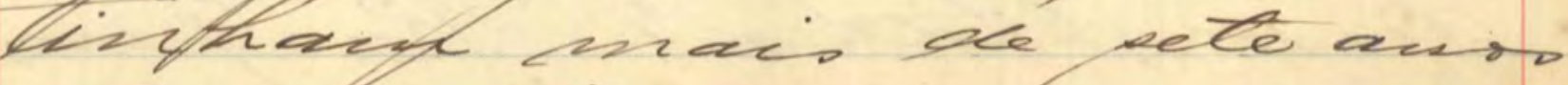
gee kespices, e, no a wo 


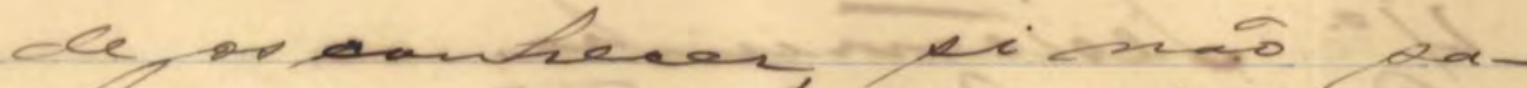

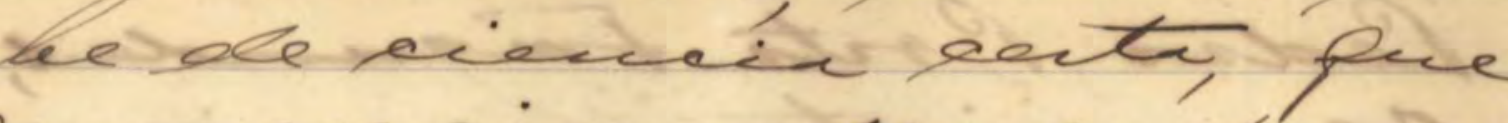

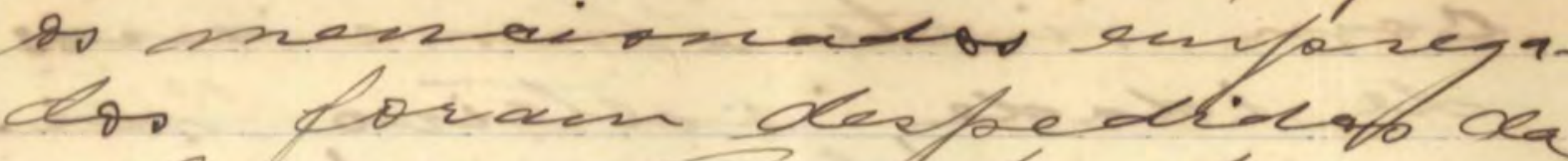

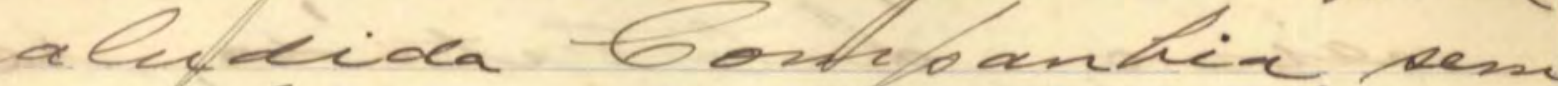

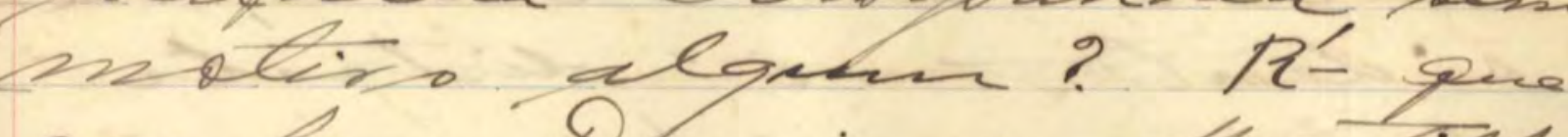

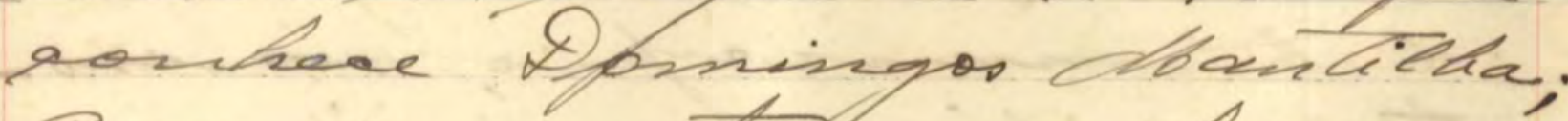

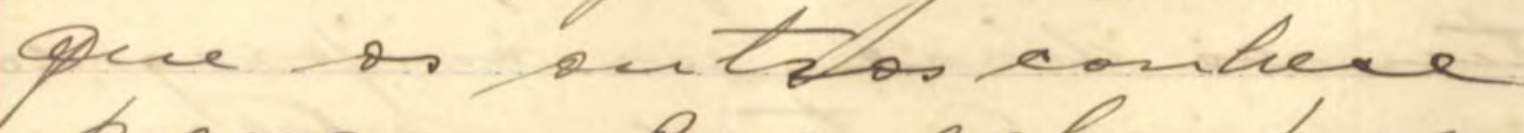

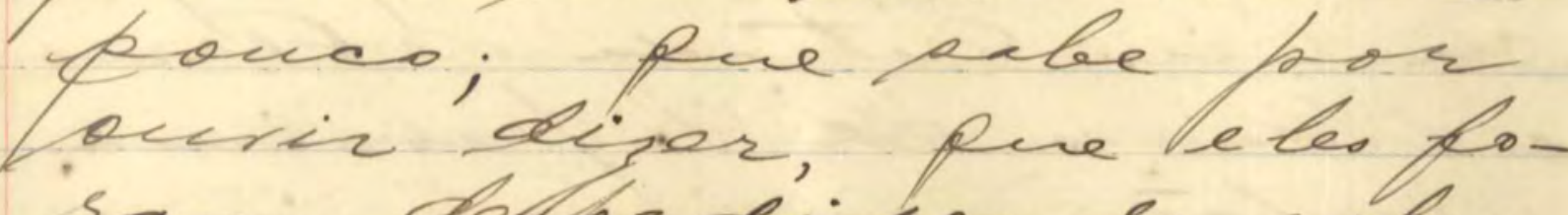

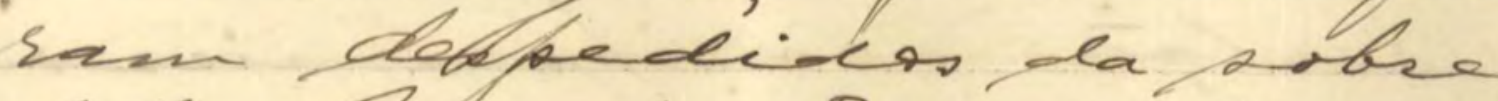

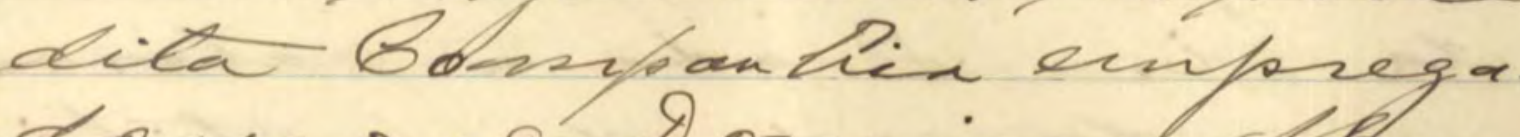

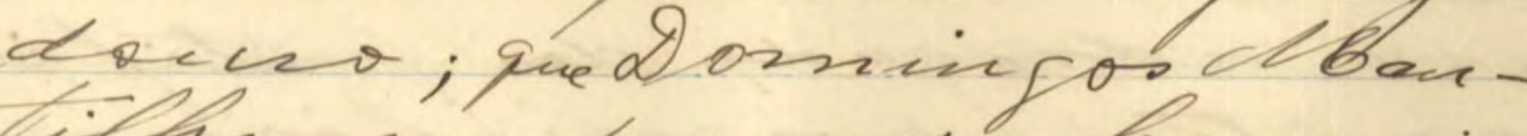

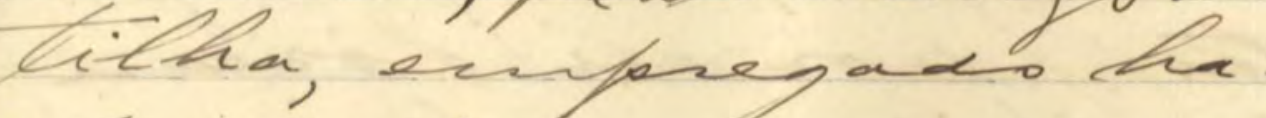

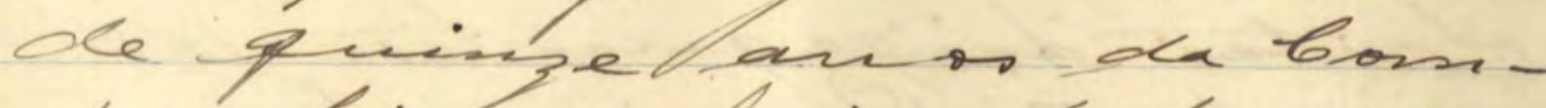
foanthin of, di depleceico

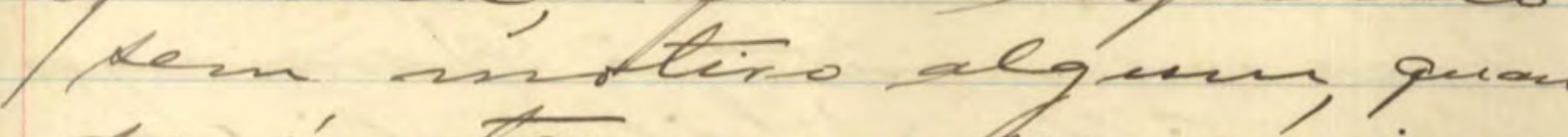

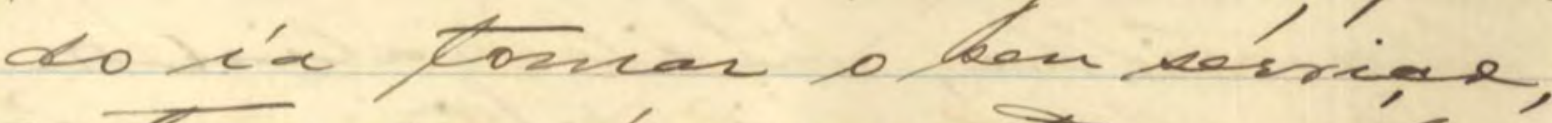

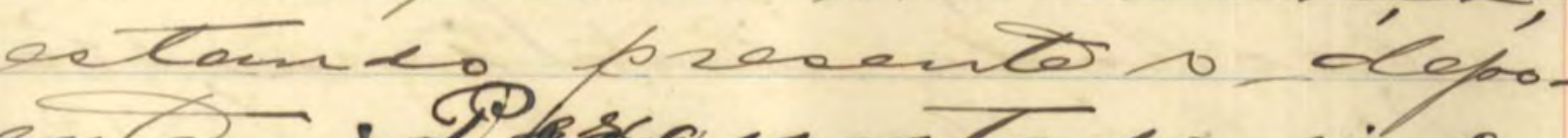

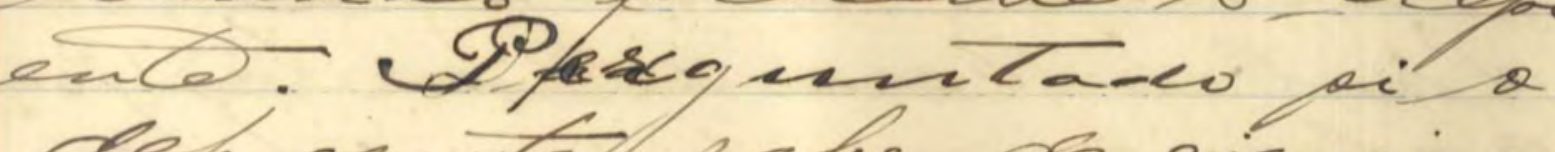

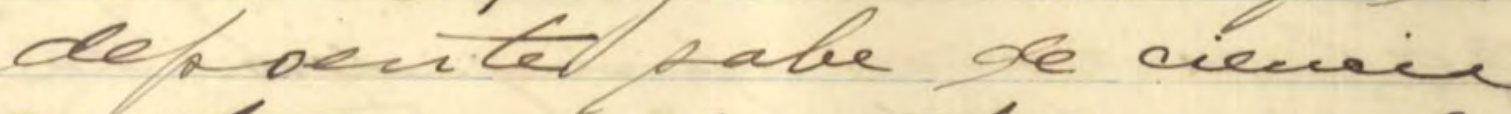

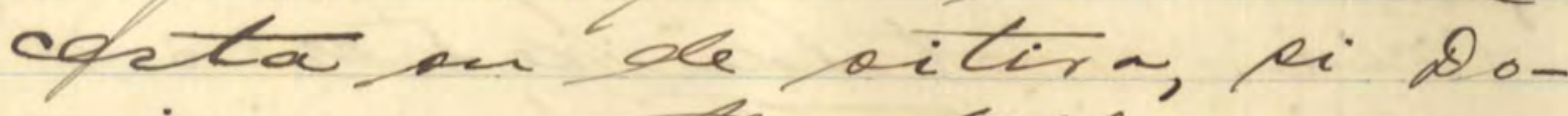

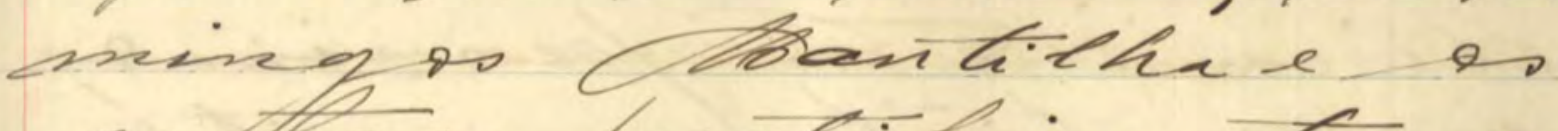

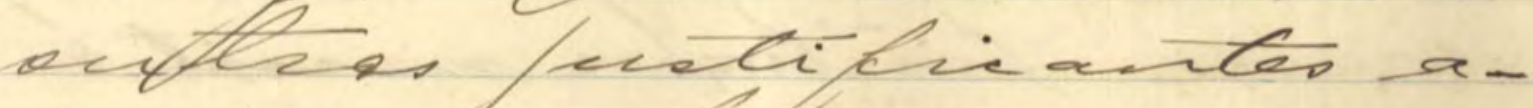

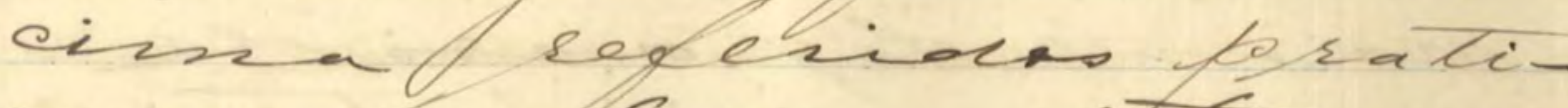

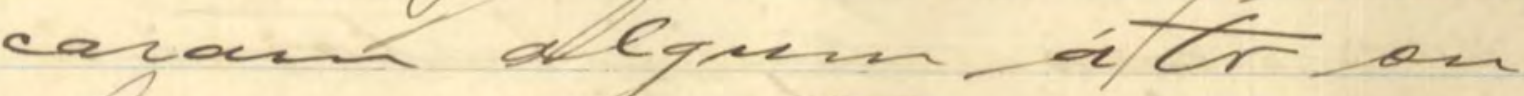

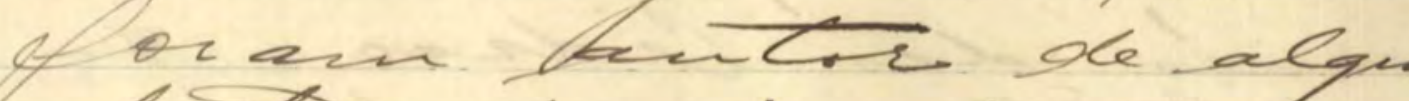

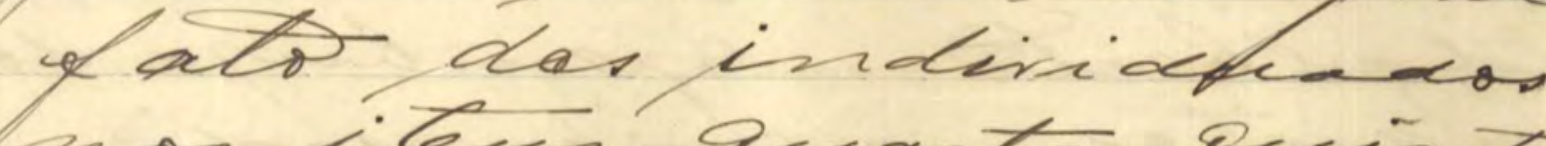

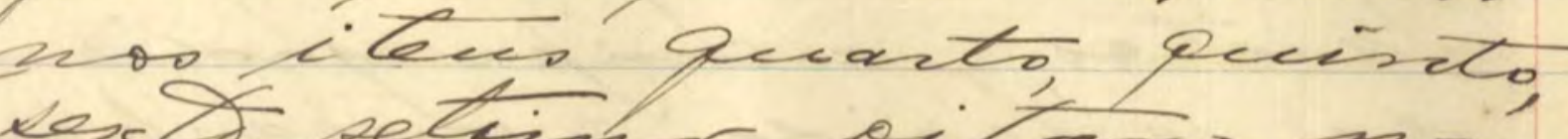

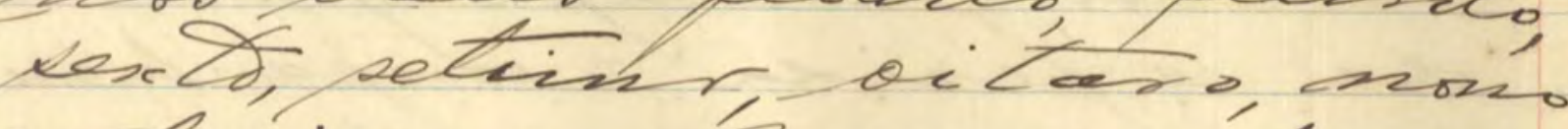
e deacizmo, of we scaban Se lar lide?

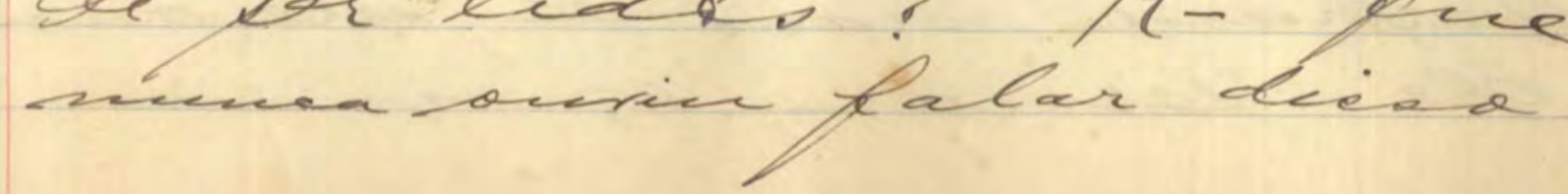




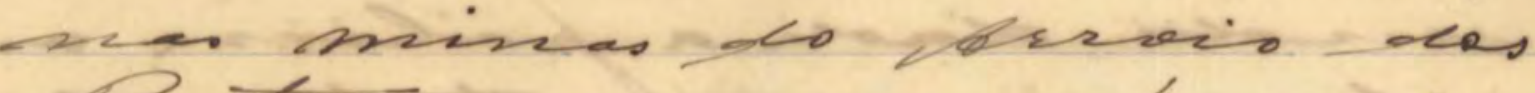
Ratar; gave sernfore rive

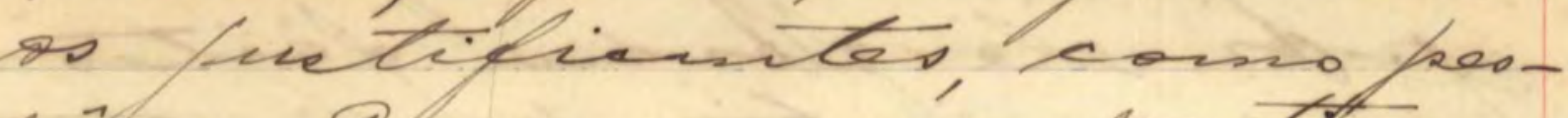

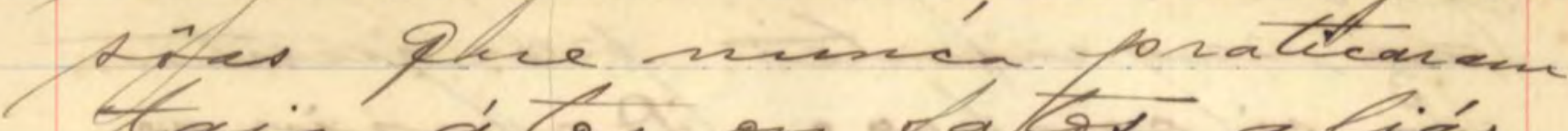
taci di tá or palor, a liás,

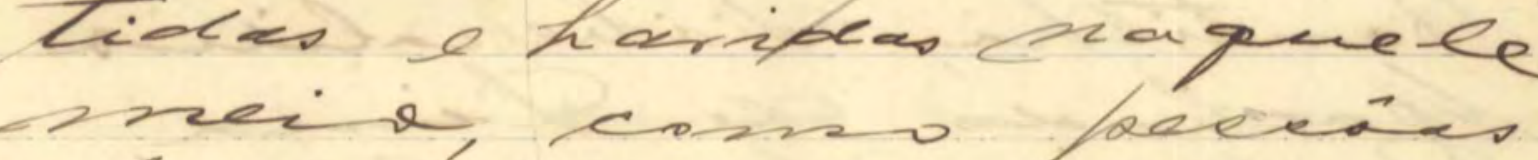

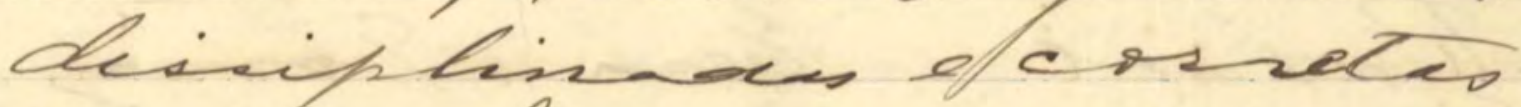
couts harmes e operasion. Dacer a palarra ab dr. Bro-

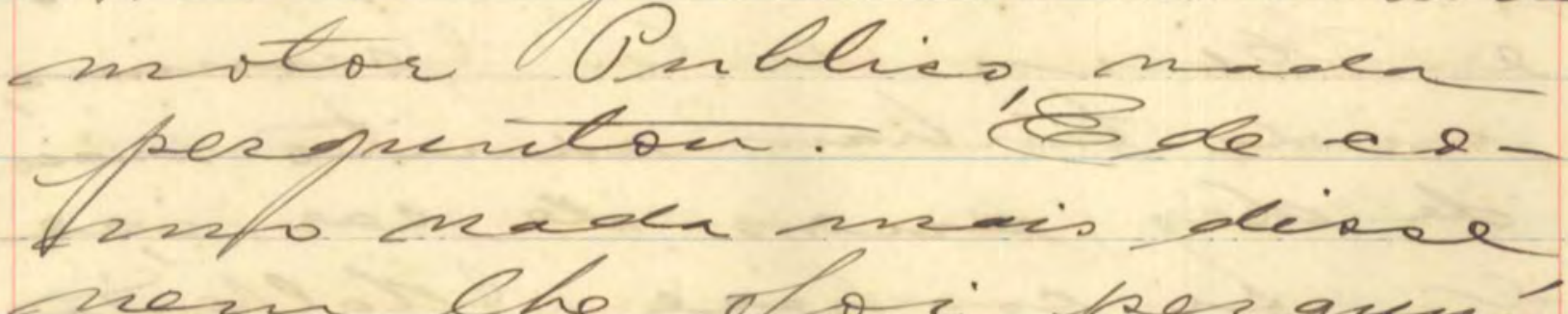
nera Che of o i kergur-

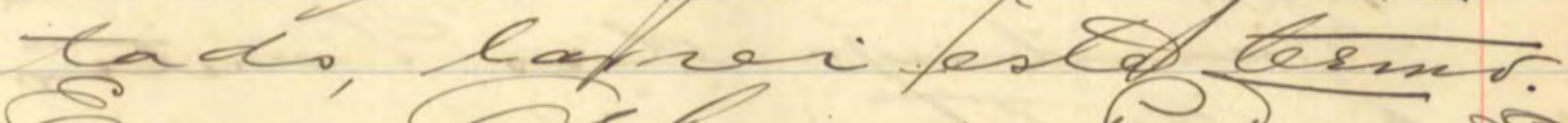
a cरa Qterib Aludes o. barrachu.j. sinamlnetf.

asu Teotersuresta. Ifo ars op ele lide de sol teir, neveci; heypanh, l, Lesidente mo st aideit.

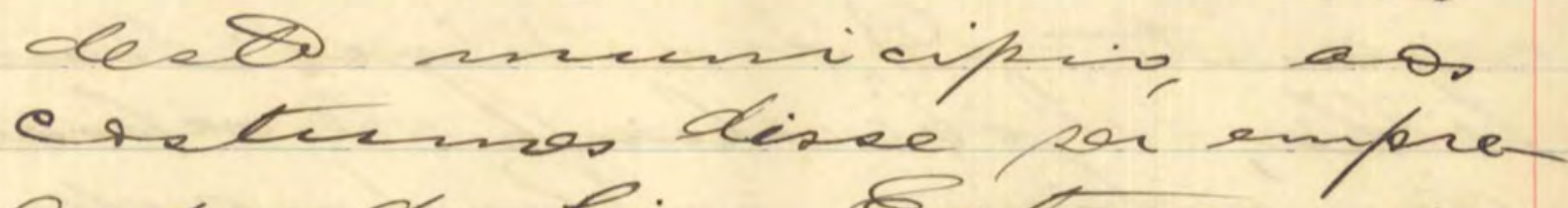

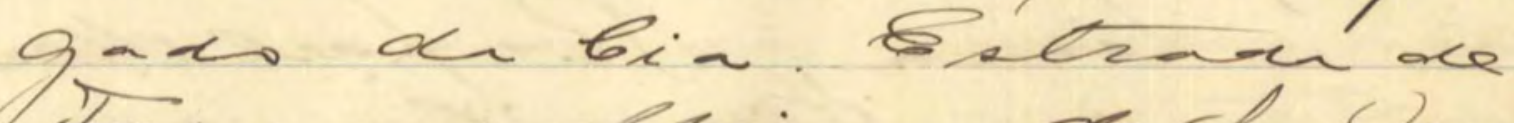
Iters o e chines de of. Clecon suciser. Prector do.

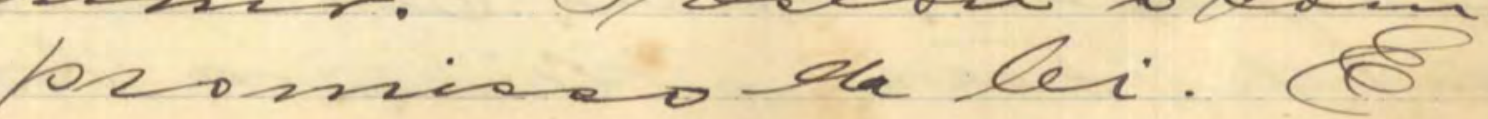




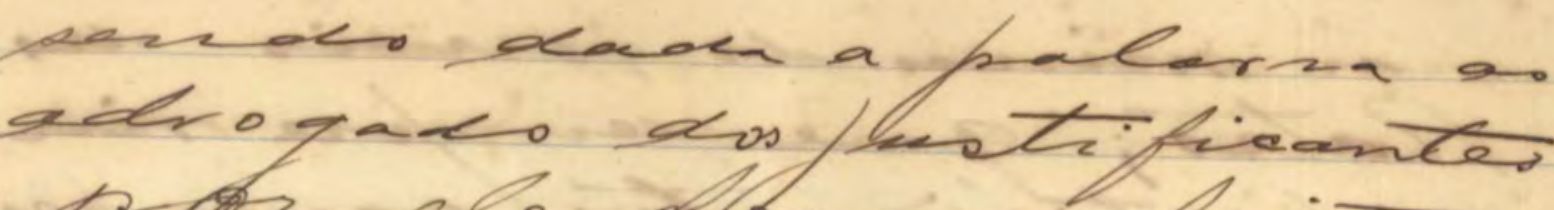
tafor ele olorair ofiz-

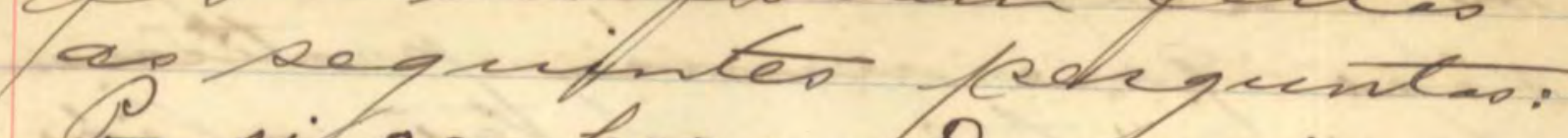

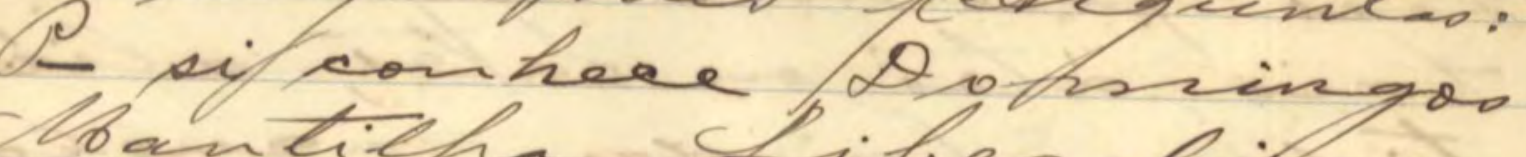
bantilha, Llibez-lill $\rightarrow$

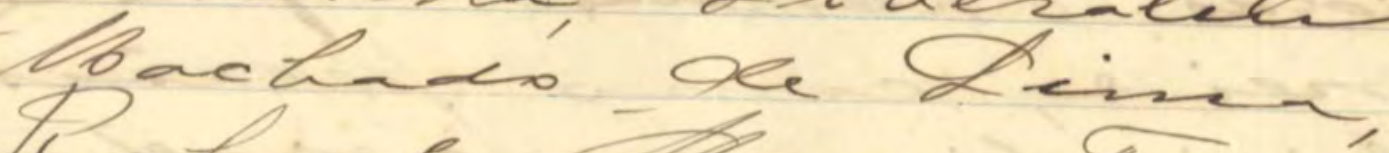
Cafaiec Doesa e Goun's

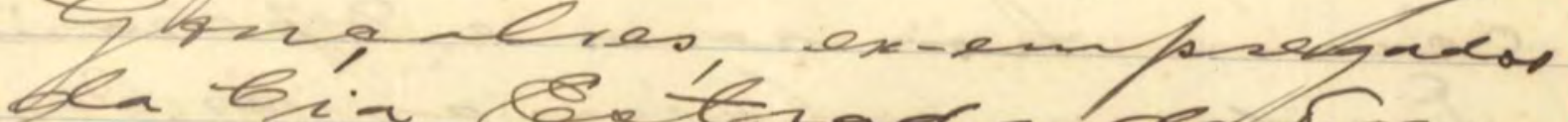
e lo. Cor dero on de tin han nherito mis

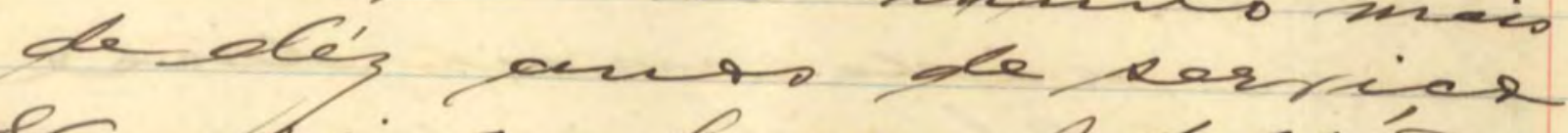

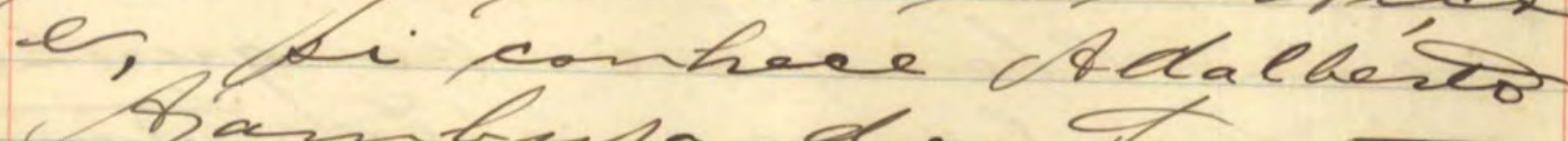

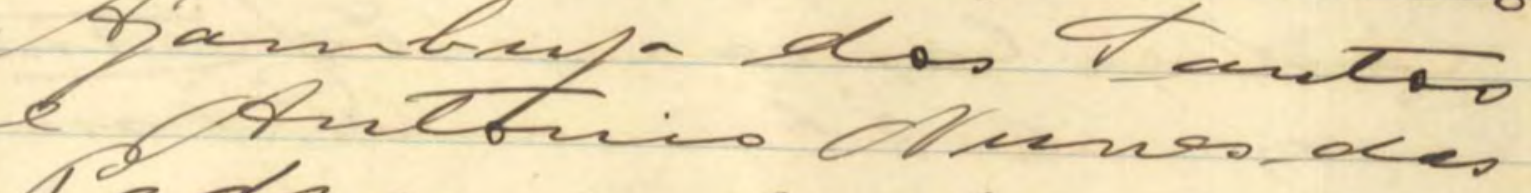
Qedres, ex-finbrogarero ta hobre-mentioharea bia. ondere

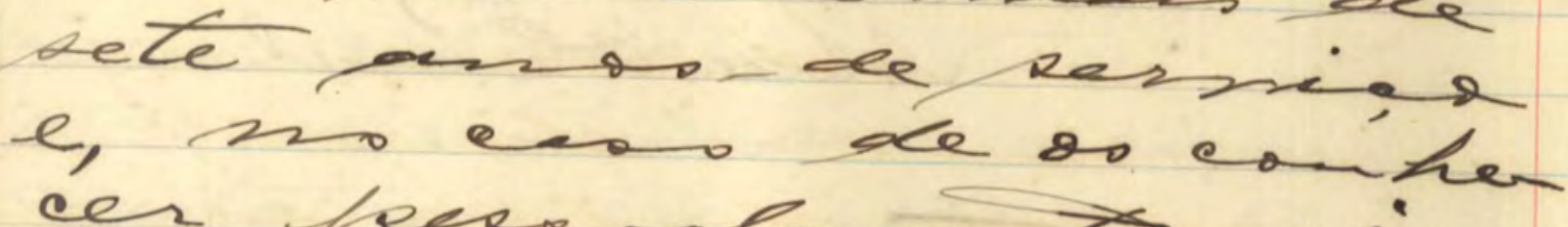
ces uscess vo foran despedi-

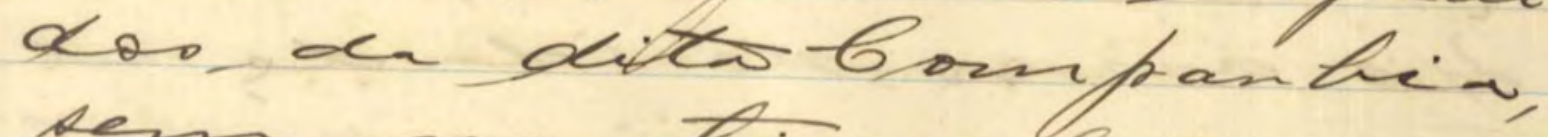

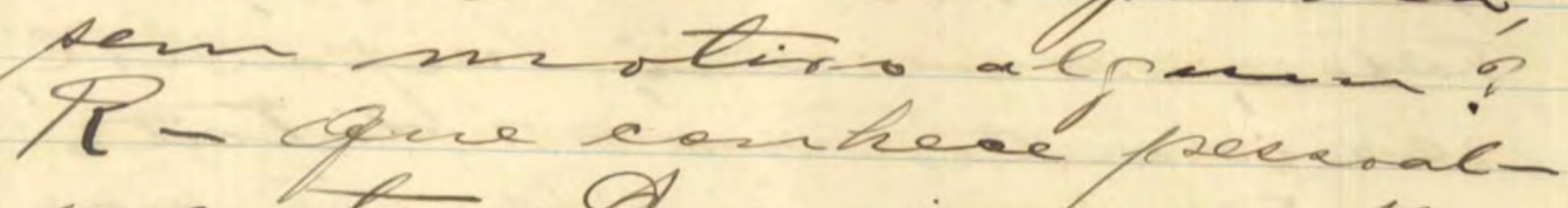

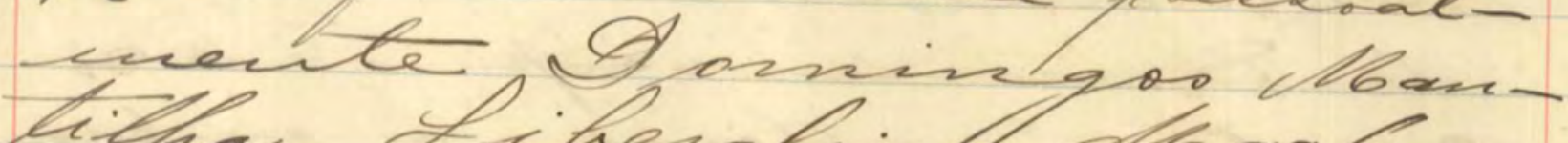

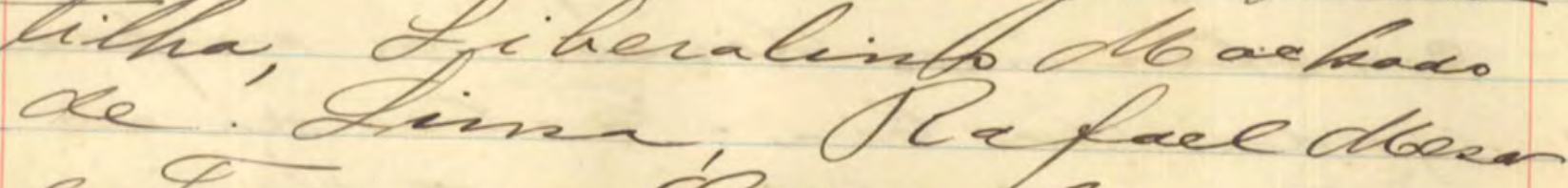

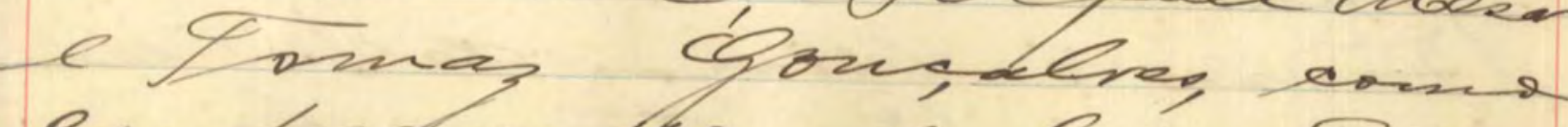

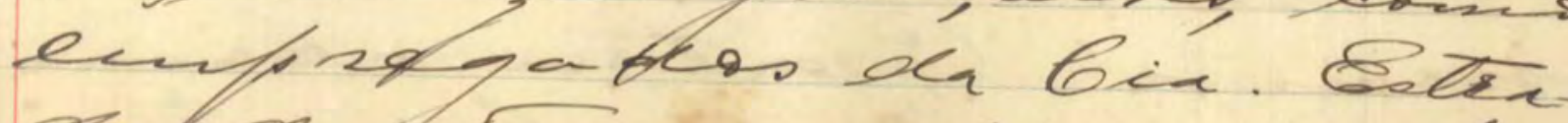

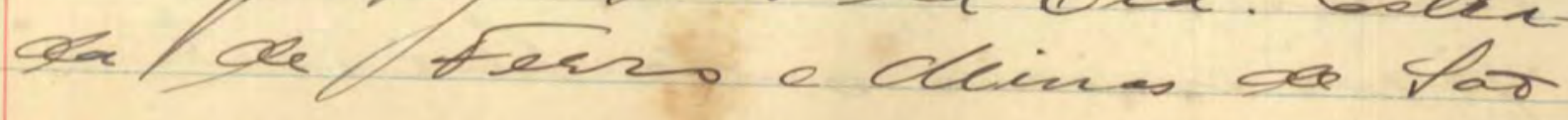




\section{$\frac{10.019}{17}$}

Servinas ha provito sures ble dés a ma, Bris, ride-

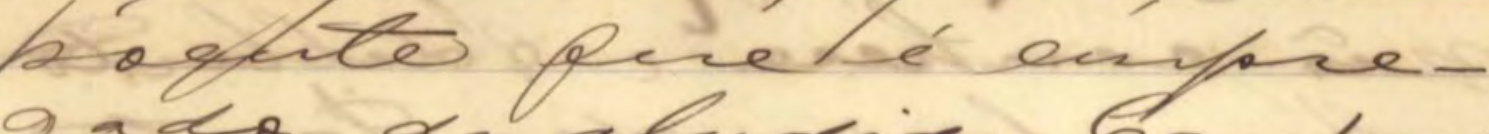

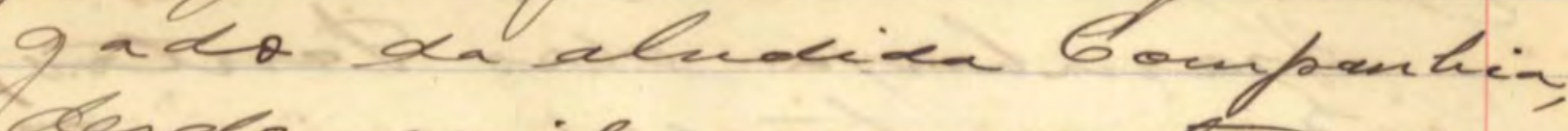
deack mile moverentes -e Qezenin ore

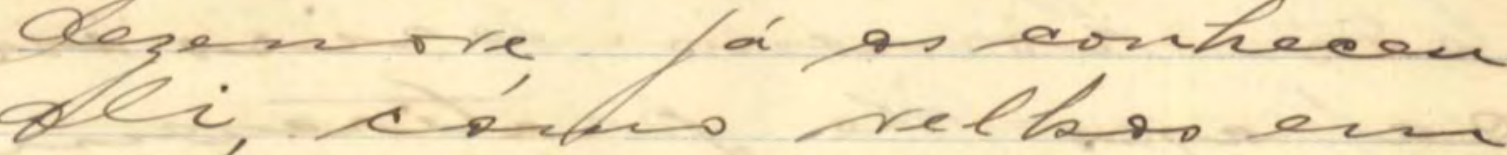
H relphermpregane oca quelu; \&ne a Artarli. Dinus desteCra, pue estere ma dizo bonikankin nus ketewos

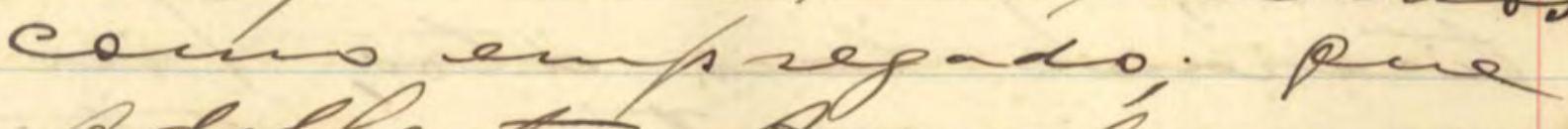
Rdalkesto opamkinga co. Coutos n-s low hele, pue Ponsingso tbantilha foi despe dido kem in otivo al privy, Is reservaineo pelo

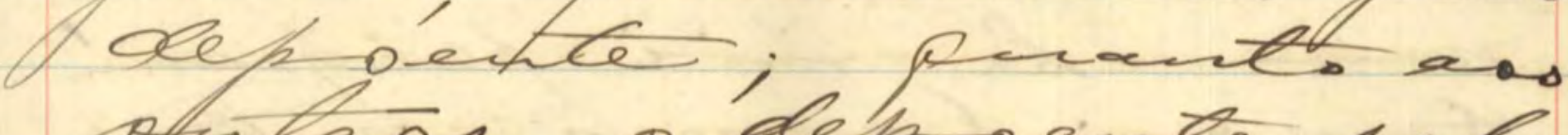
Otulsor, 0 de/p ovite habe

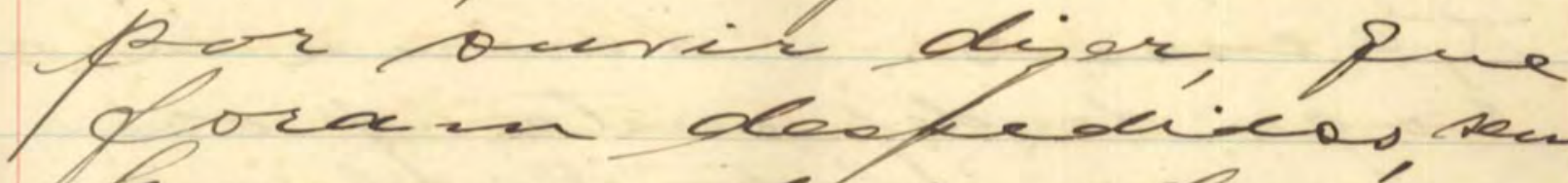
hareven deldo a bomka.

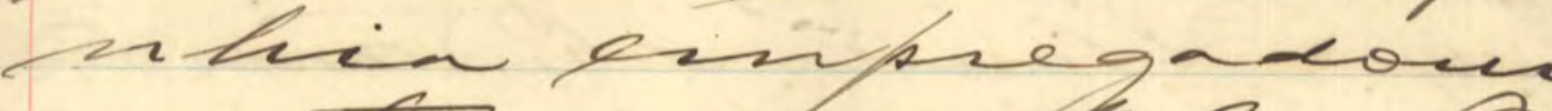

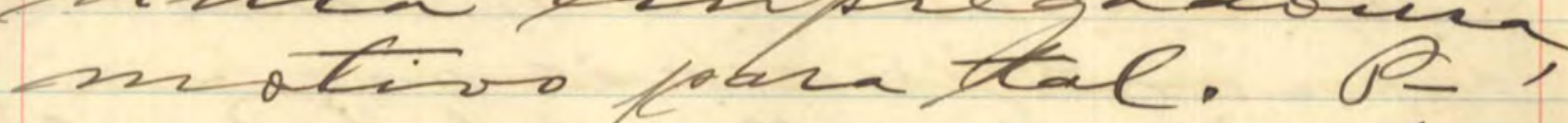
se algute dustarifi-

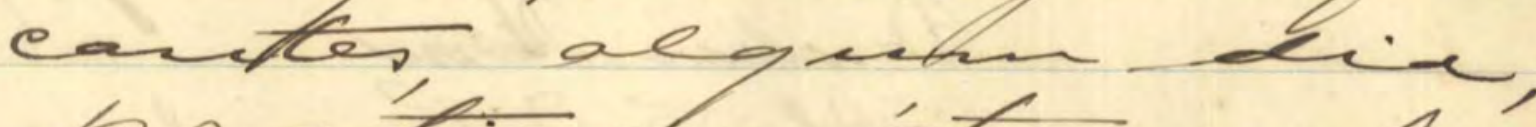
los a tic ale ák amber ge faty do, Pree ke raflew nos kilects qudart, freict;

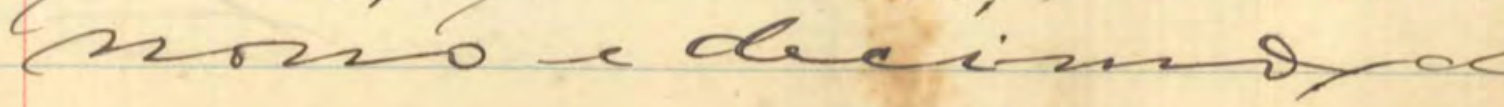




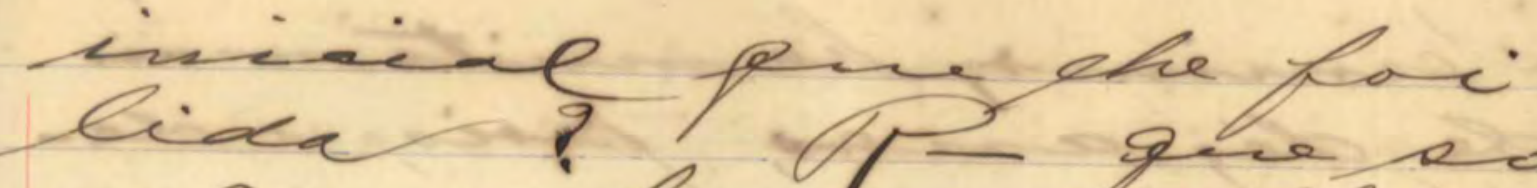

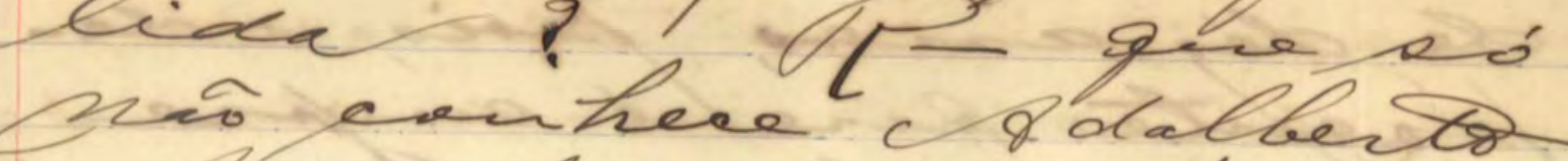

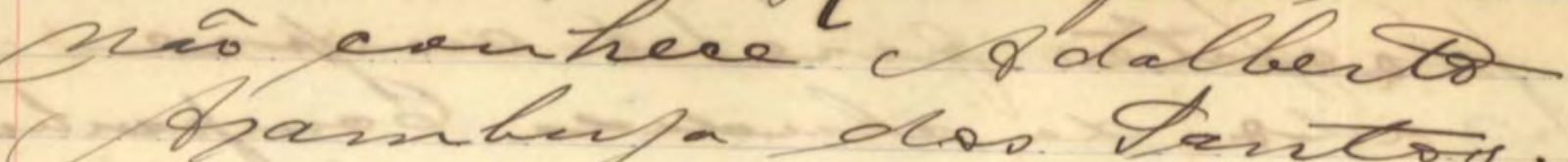
Qbere lackos larvo;

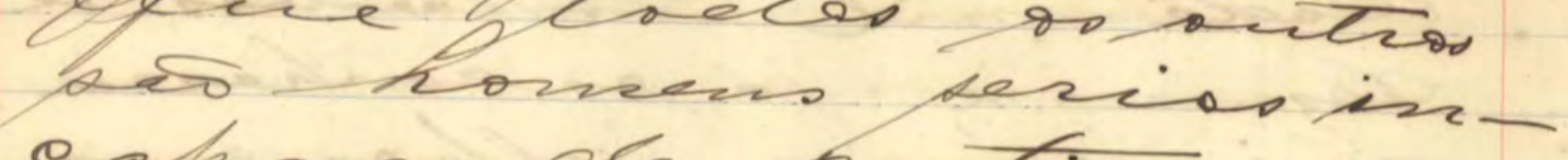
oplazes oke prationeru

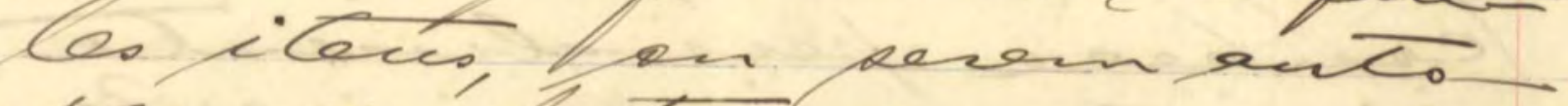
ses de

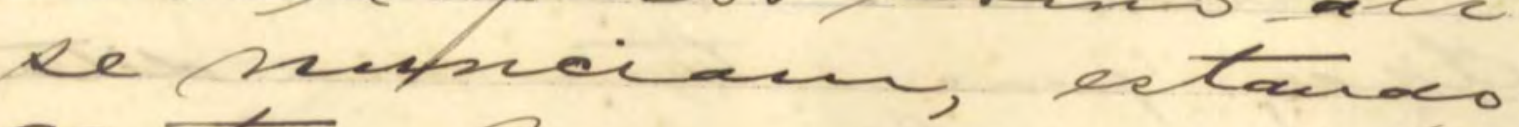

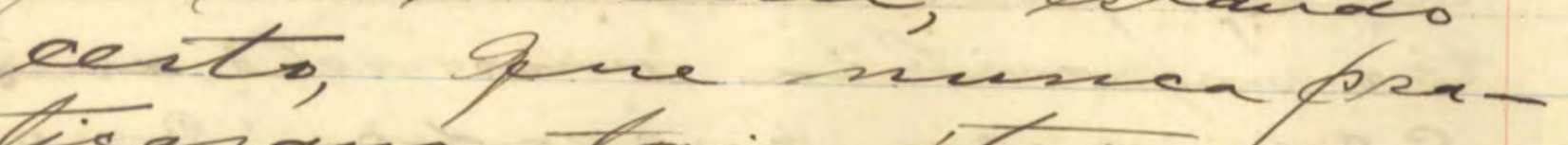
ticaran tacis ó too, Isen

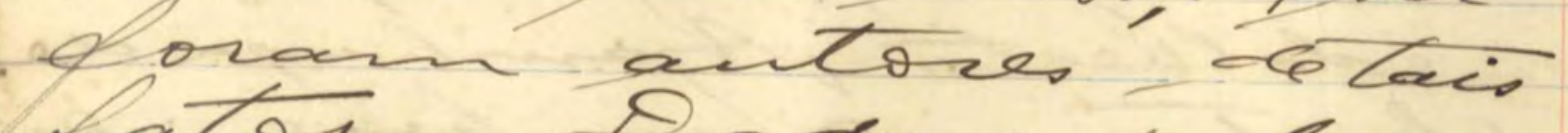

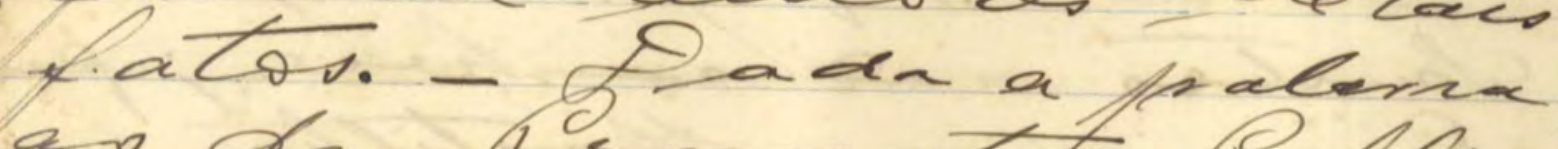
av de. Orans vtofe Oublico,

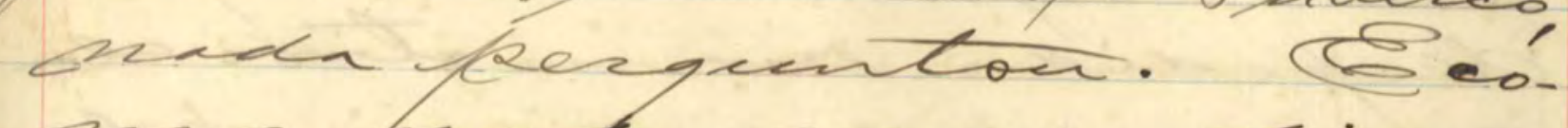
ns o fragh nacis disae trar elbe of i kergen! torat,

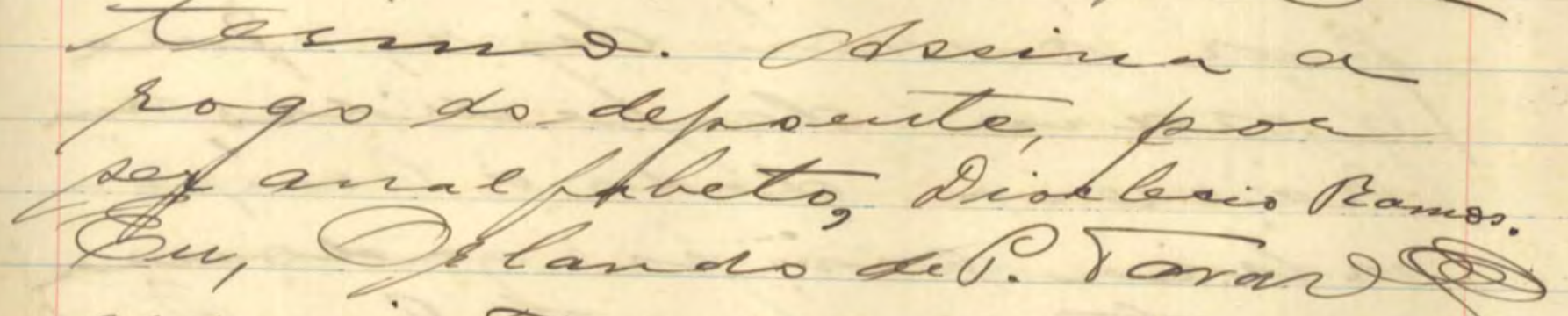

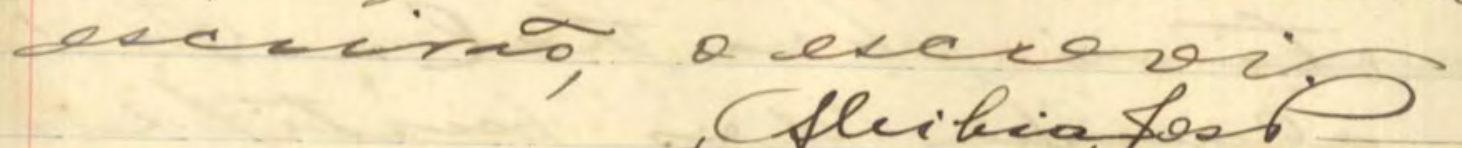
Sleibia fos Drachare Demer Aluiser Q Garrachoj Acuanker?

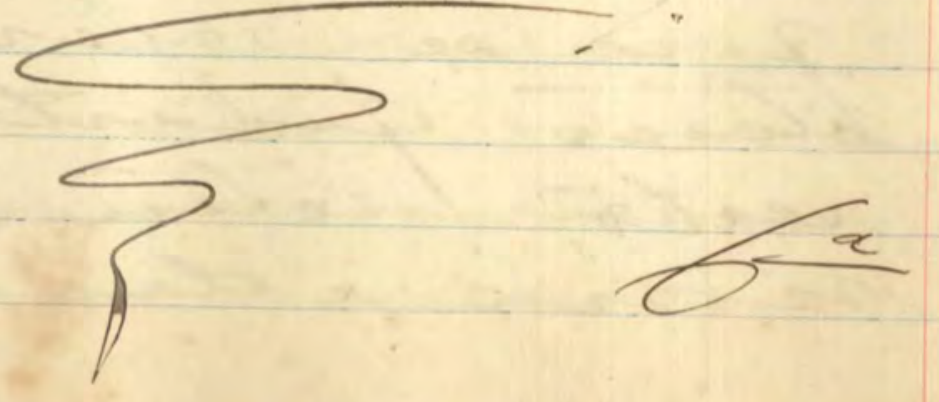



sube torernesi-co seter far Hificurtes deepedivel de Pon fantiri soferiag ken motev ? ? gée cowrhece todos as tartifi-

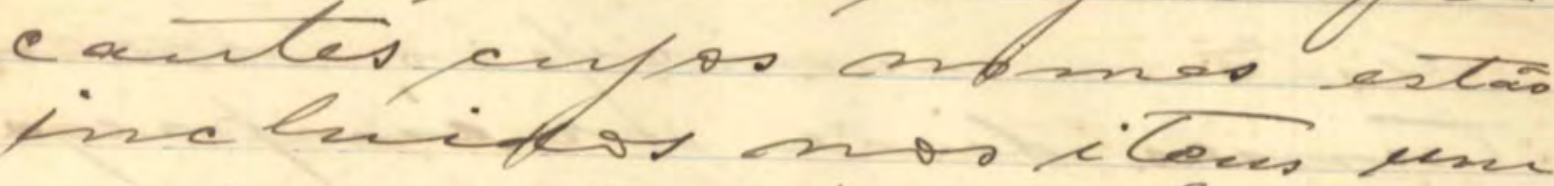

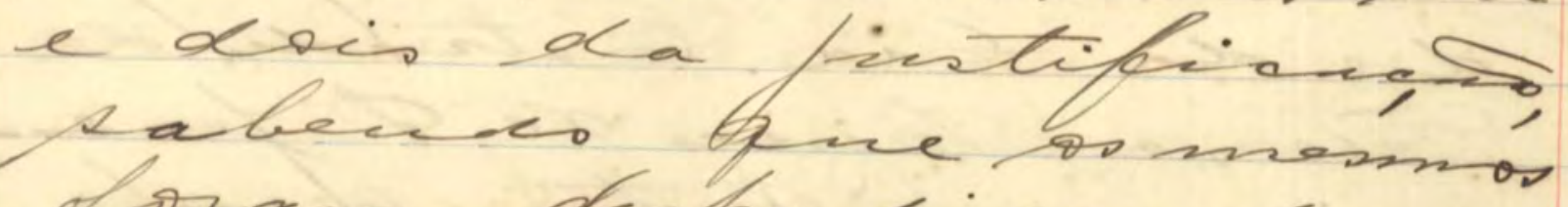
Horarn deafsedin oc a Qomfan hix pem nu metcivo fustoi geve or whlicufter cylor momos extero mo. prihneino itew Crabalhofwan wa bomparhir, mais de dép anos, e, is pom tiokos sho segerndo itom, trabacherain mais eke sete ara, ma

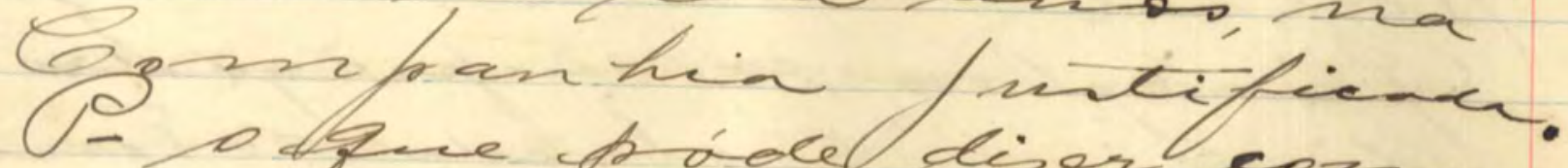

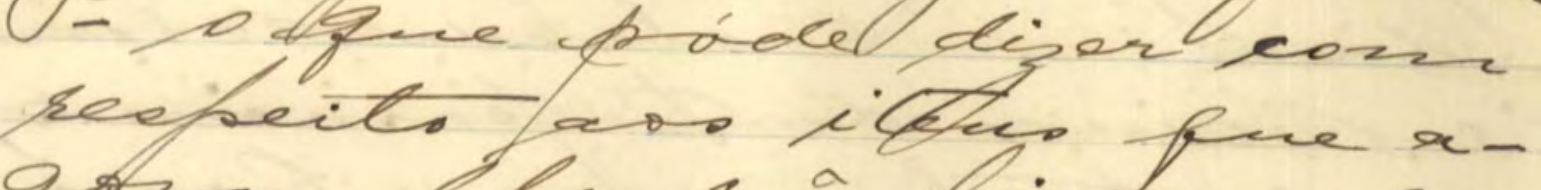
Ifor be ra kichor de mparmatro a dés? I- geve sabe

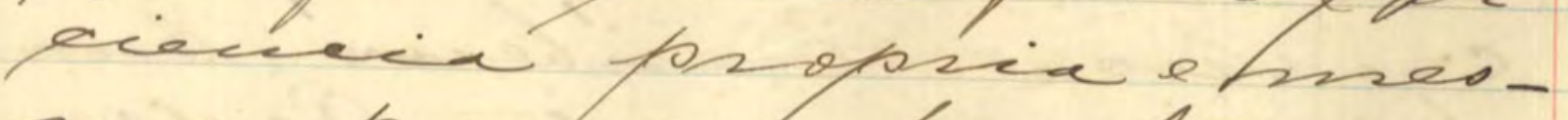

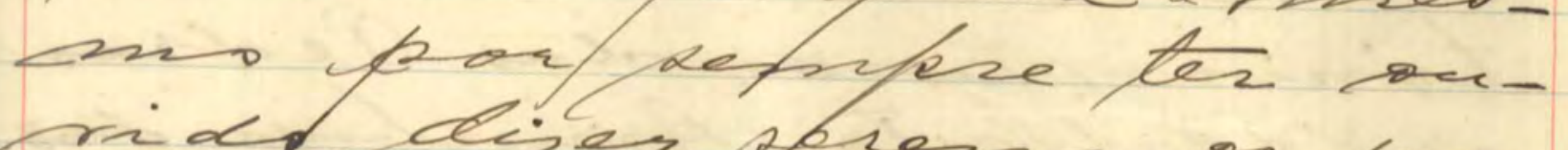
mider dijer foress or fur lipicreter hasmess oth de i-

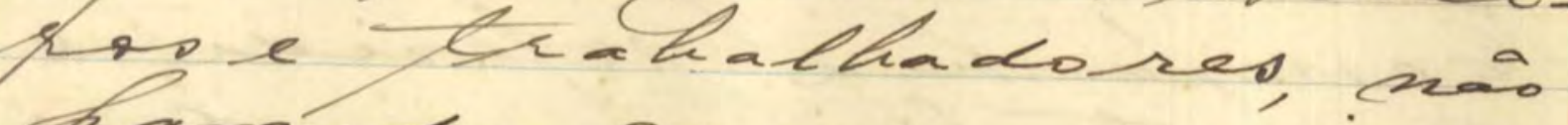

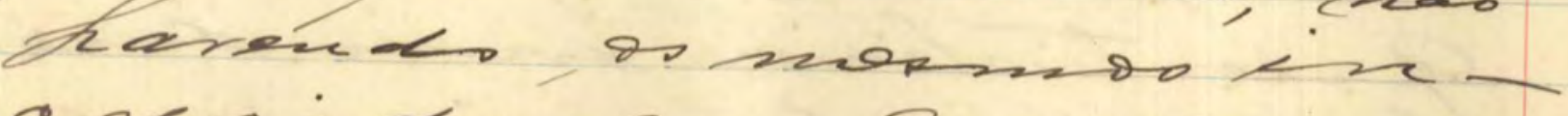
Corsi-co en Pewarer

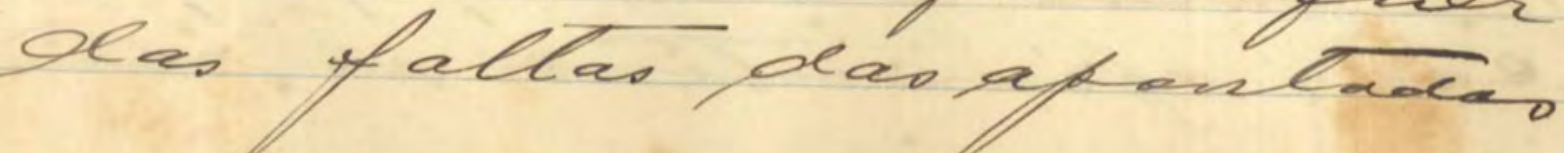


mos iteus di furlific-. wo

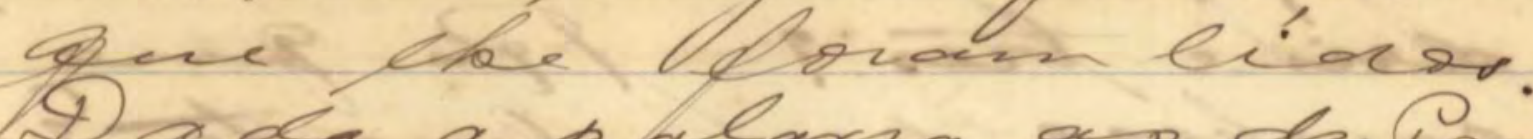

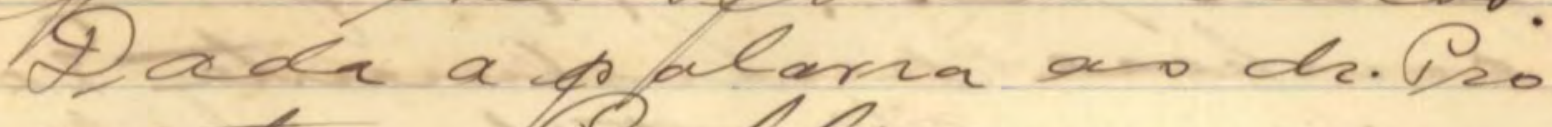
motor Oerblic? seada bierguentre. Q0 que, Q ofe tar, larivi el $8 \mathrm{ta}$ ma. Ér, Bslanwore Pacla fara o\&, dècira Qeecevivilil

\section{Gario Cubledio} aivanilvetf

If a festermenth. Toso Vises, basecleci? cacand chen 44 anes de riduder, sescidertem. So dictrits deste muni cypo, an costwases dis. Ebetend lok fere e doinas de T. Yermizin \& ha depeseter os os. promeice ola leci. - Dada a balara a o jos ocenacar Co. ustipicatuter plo 2 ele of gan deites es guifiter perlowita: of o gre pabt o deporente sober as tatop c.netanter da luptificu,as

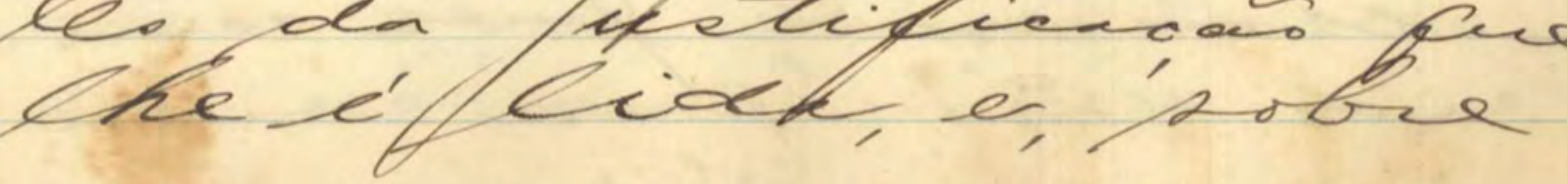




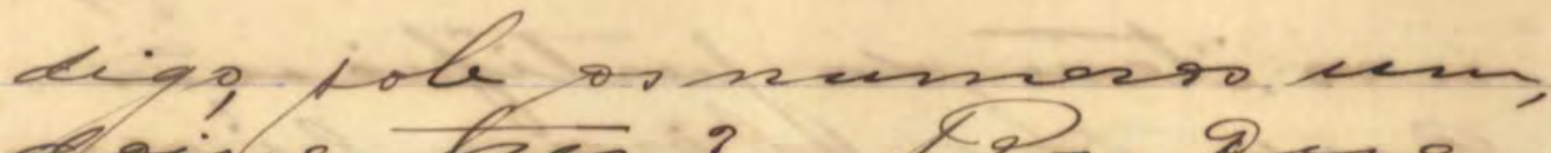

dacile tres? lque

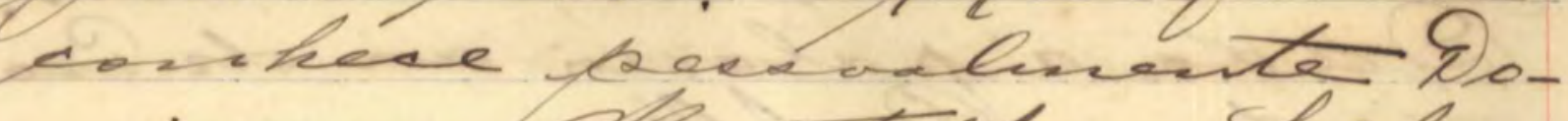

meingos Planctilla, dibe-

stowo bockato de ofin?,

Padace leera e lownes

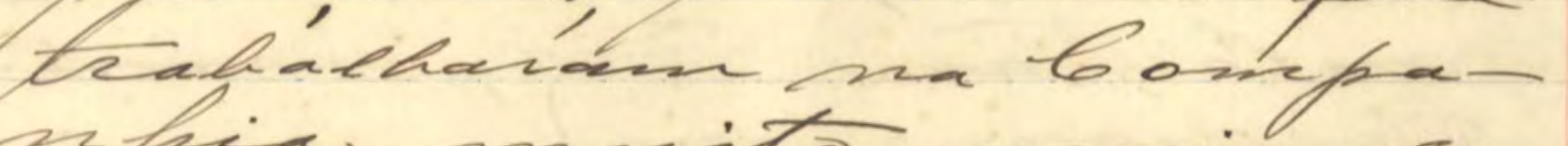

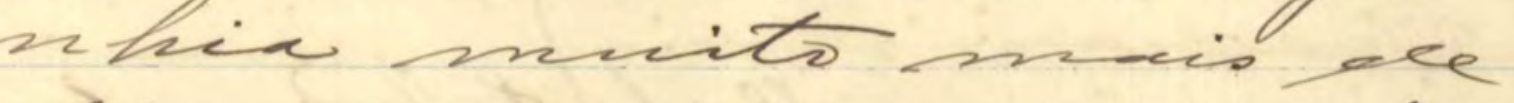
Qéri ar op: geve aseictin

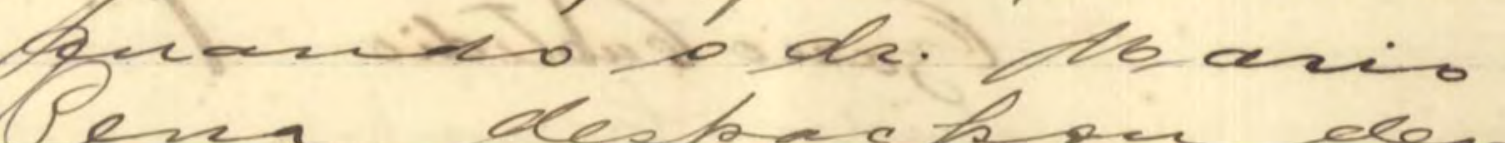
Perra, deapacher, eleo-

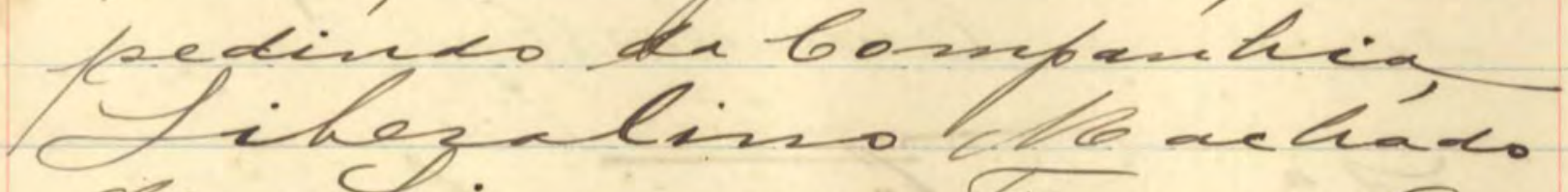

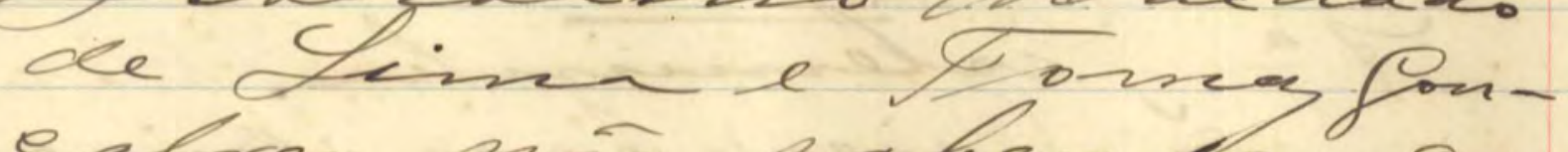
ialres, naio Raber. 8.

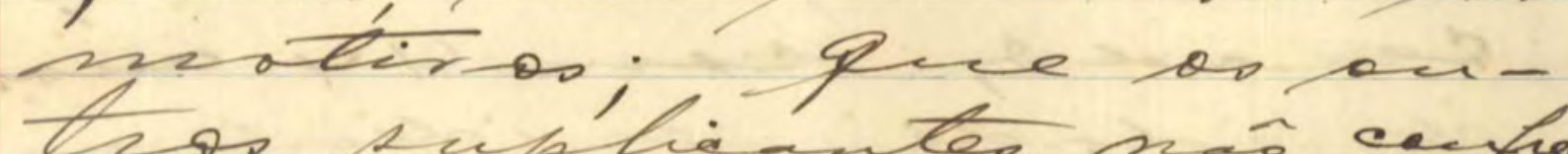

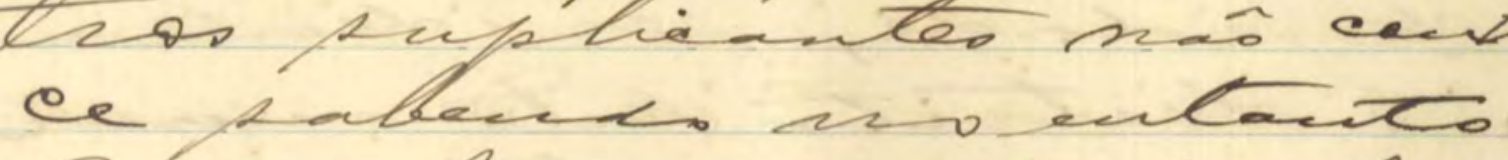
Qive Aorcen, despadradow.

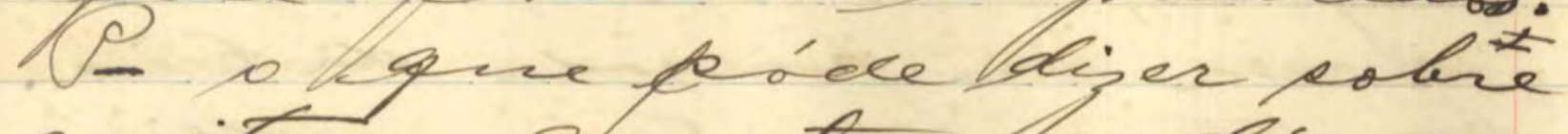
Q itever forcatro a dé ax

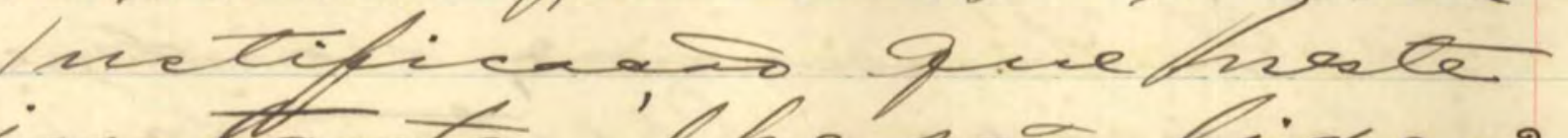
kinstarte 'lhe has kiocor?

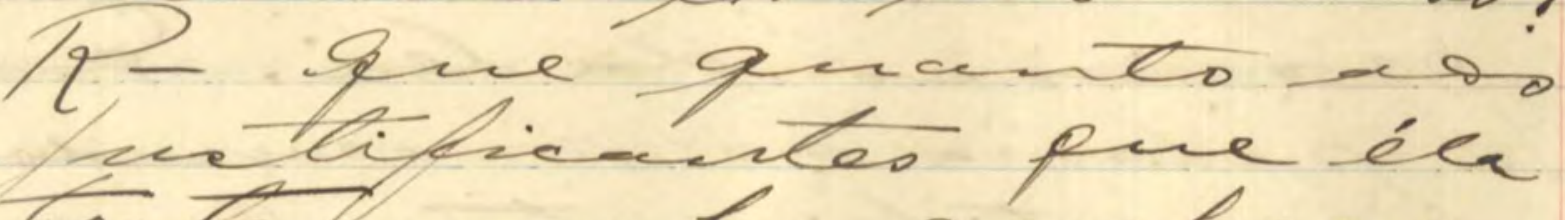

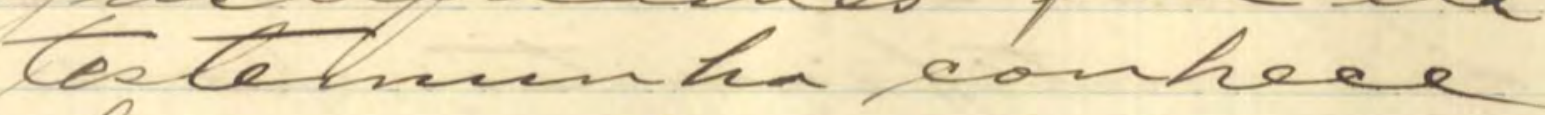
ha muvito mecis de dás are $\$$ trahalhanc.

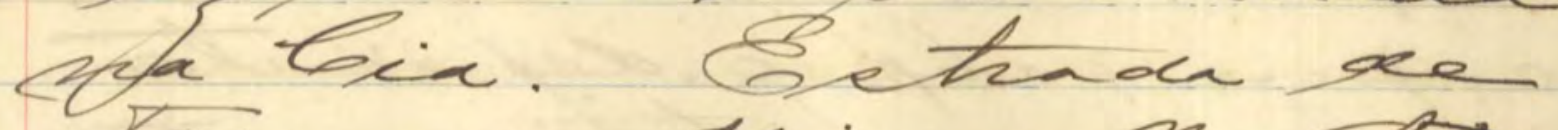
tese e doine de Ra

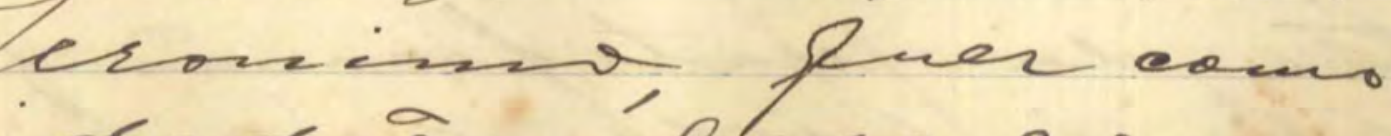

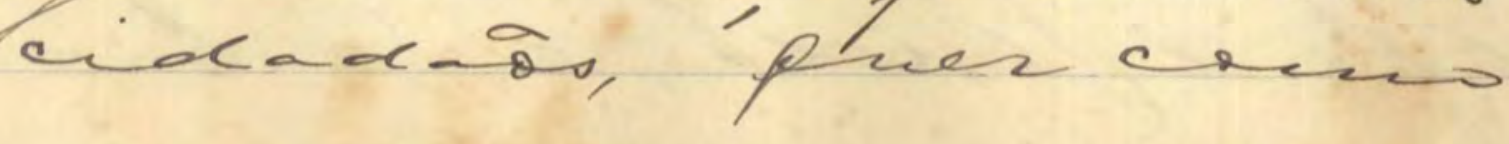




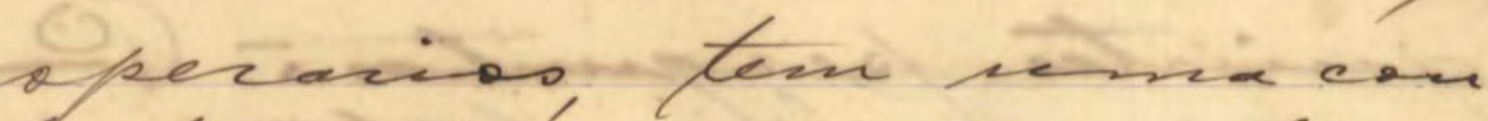
Queta de correa $\Rightarrow$ se alici-

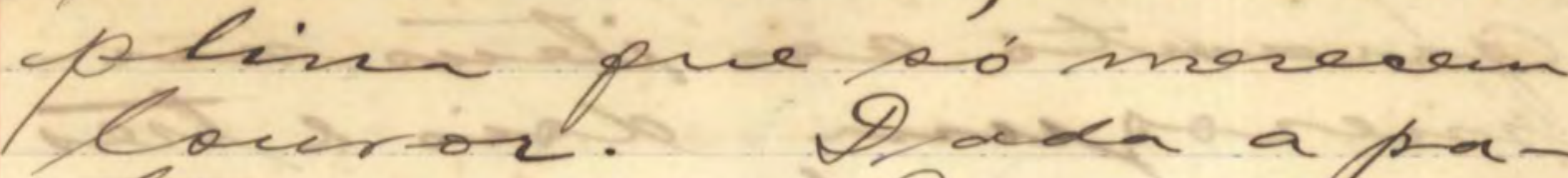
larnararar. Omalias ricka (1) ofme, of eses

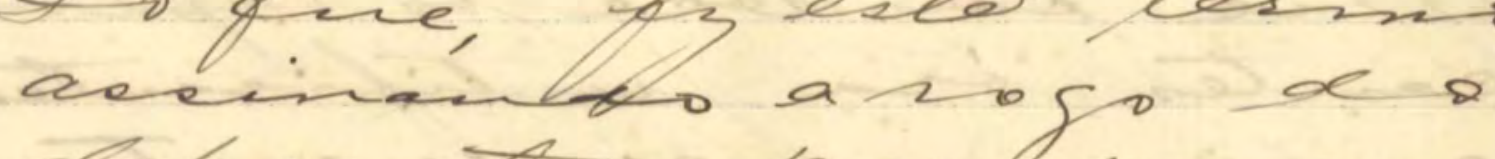

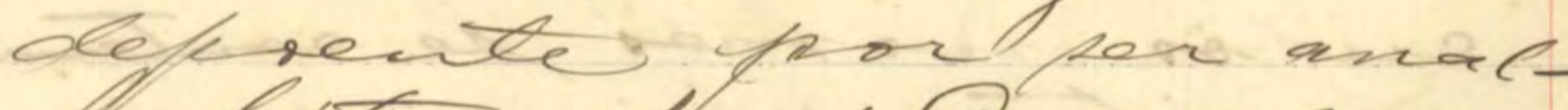

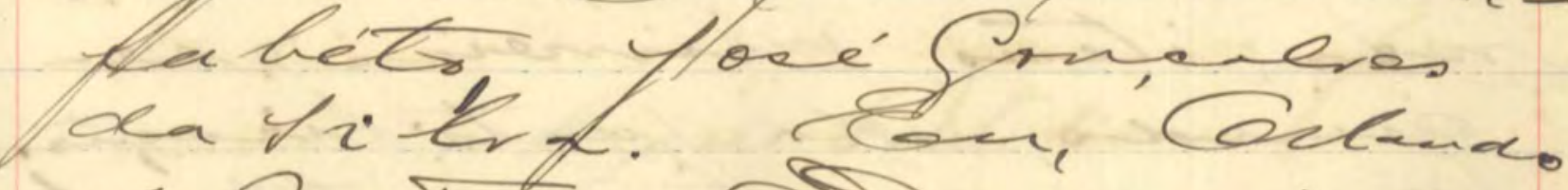

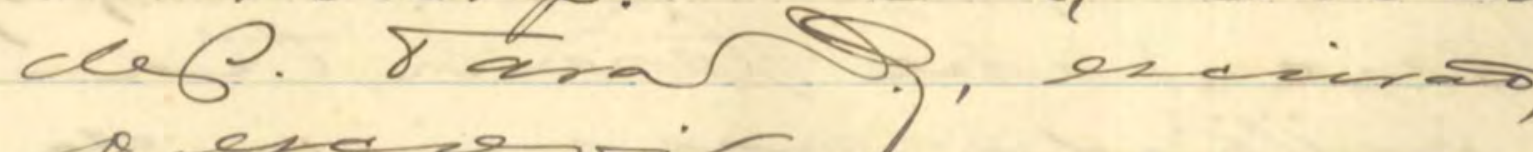
$\theta$

$$
\begin{aligned}
& \text { cLbilingo } \\
& 8 a \text { Sertersecuetea. }
\end{aligned}
$$$$
\text { fose go neatues da Sisit }
$$

\section{Naré Pisrlecizo de}

Q 02 s a

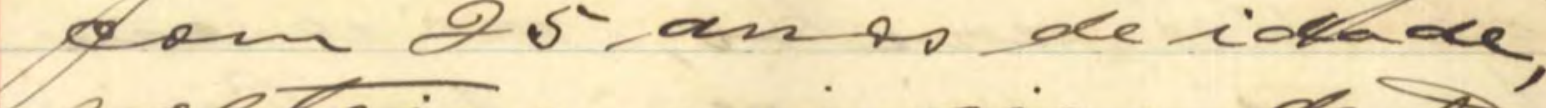

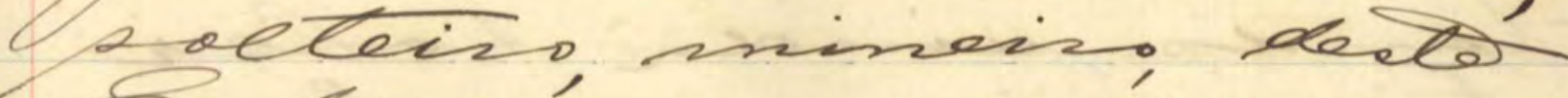

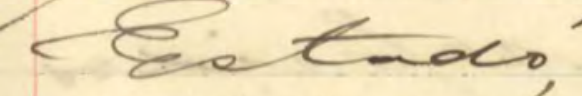
cuileive geve

Q 1 a cale:

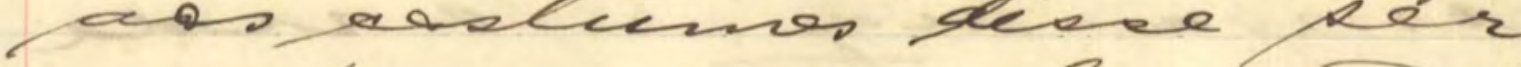

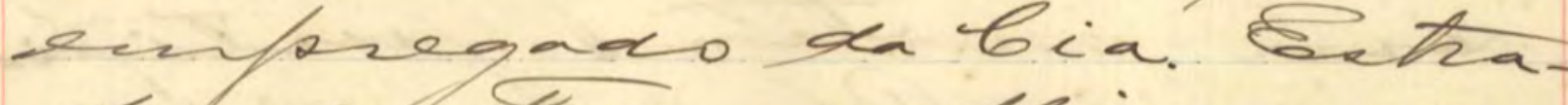

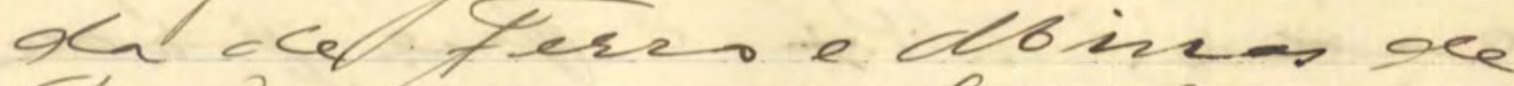

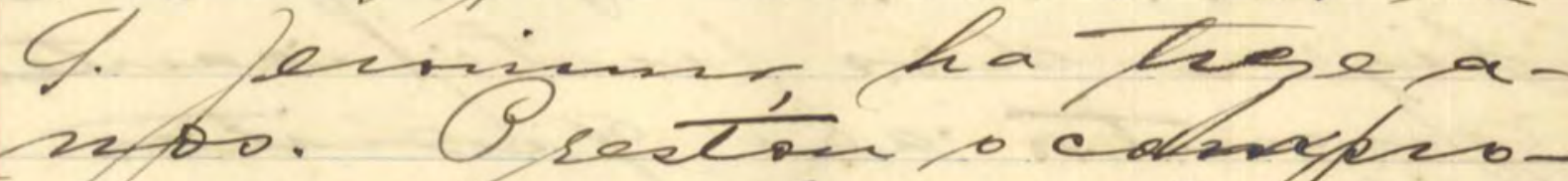
$\angle 2300$.

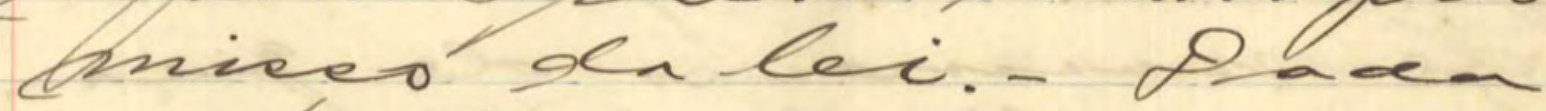

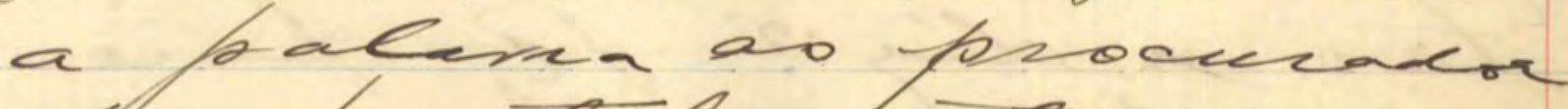

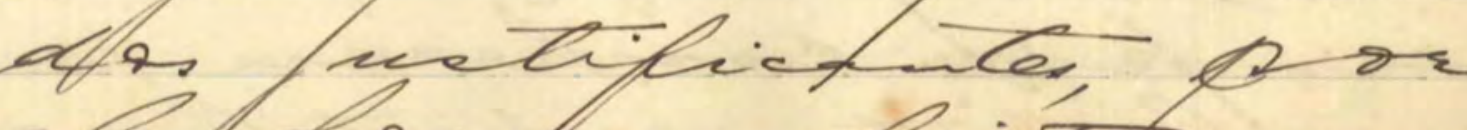

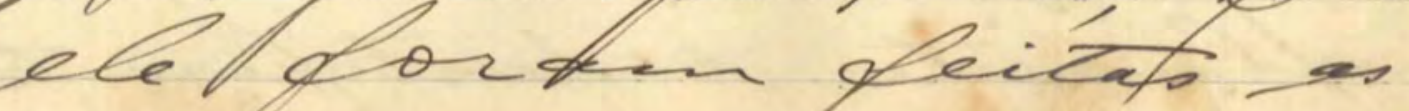




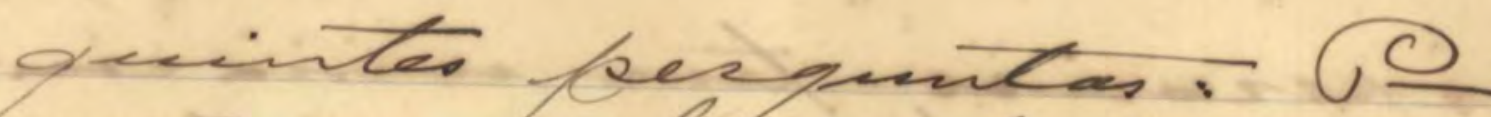

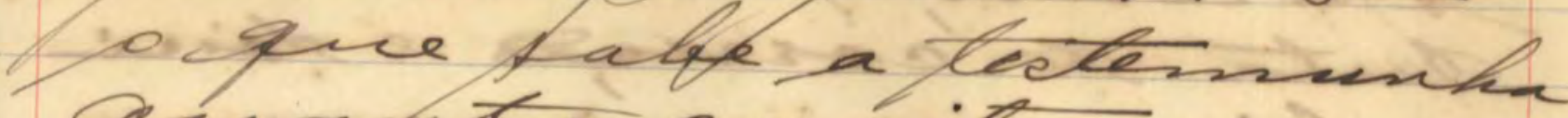

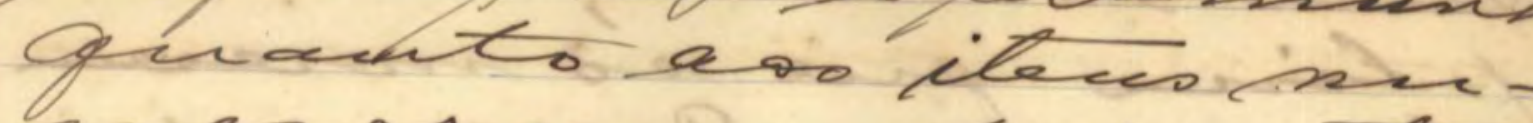

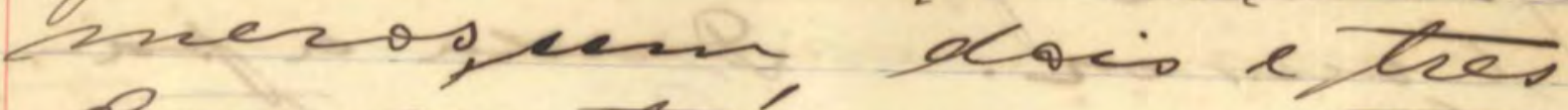

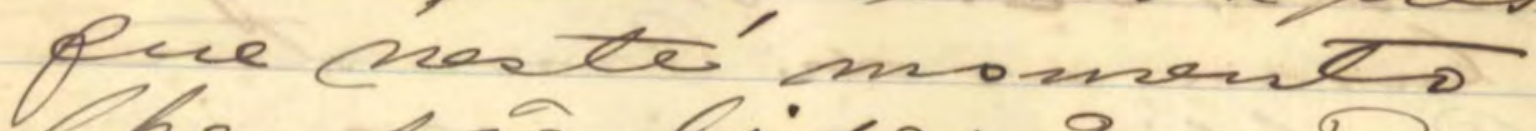
Re o-

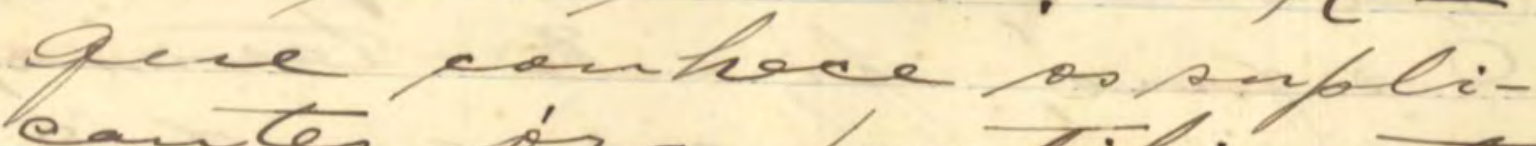

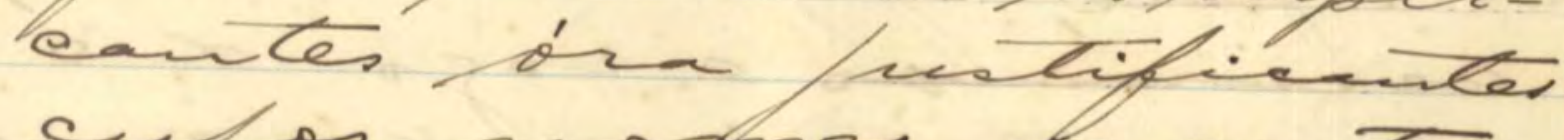

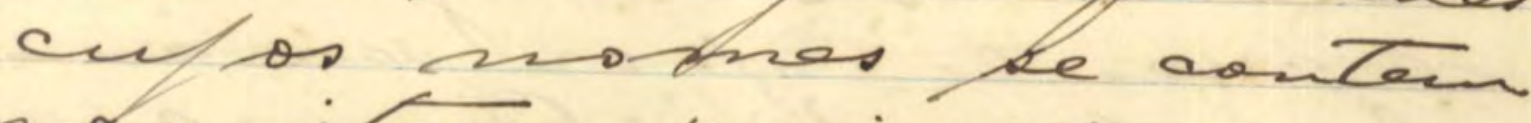

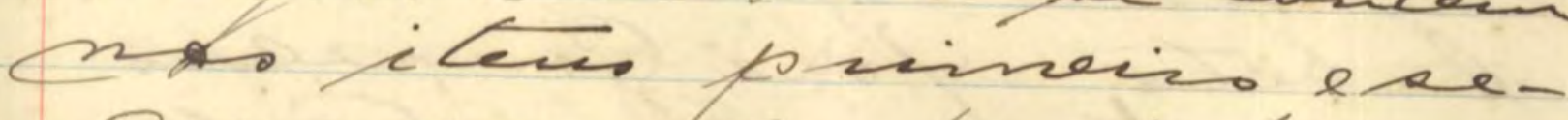

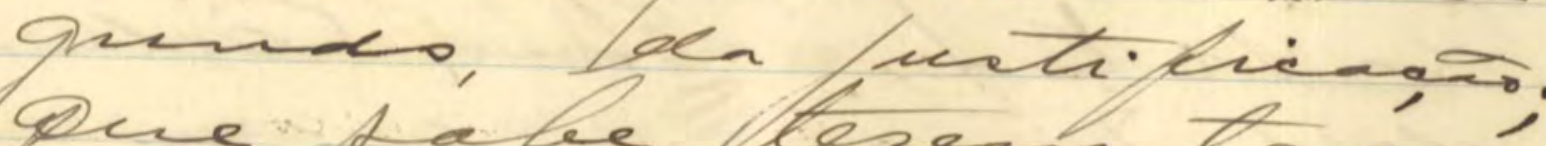

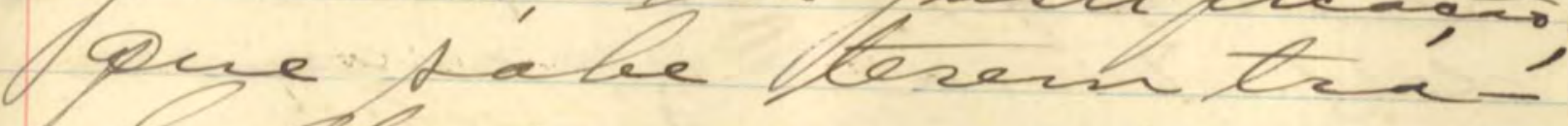

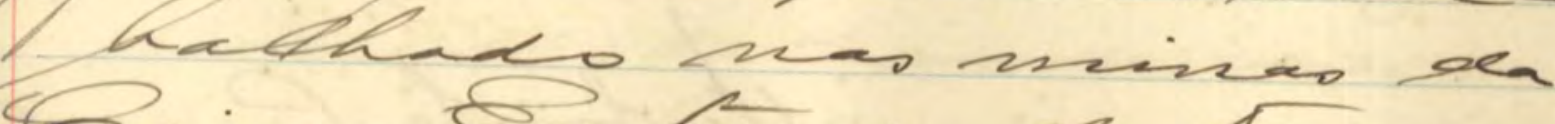

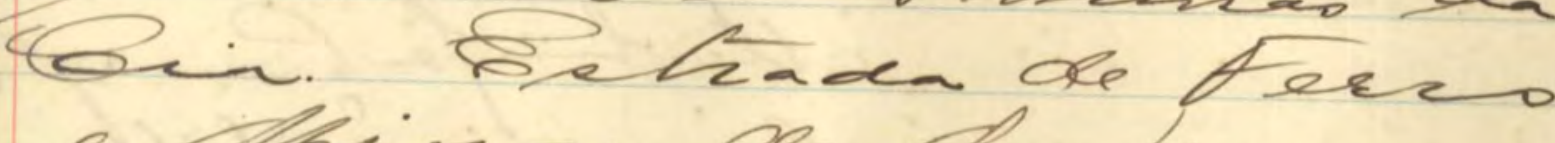

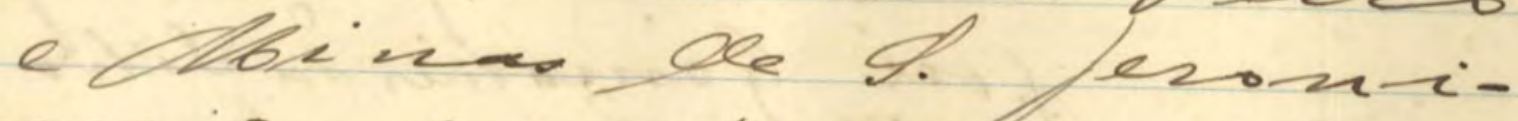

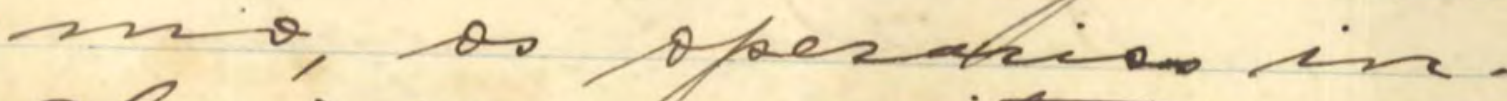

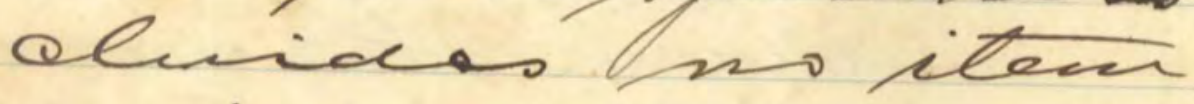

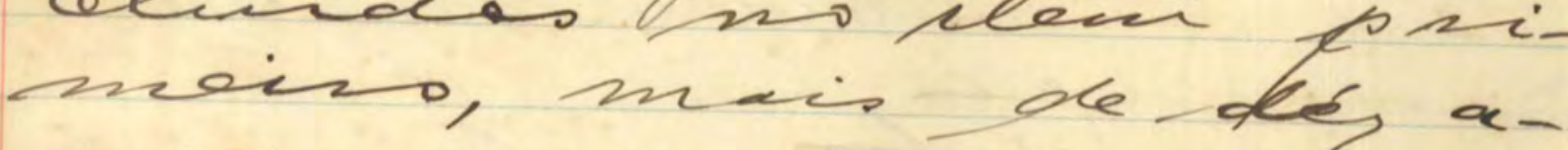

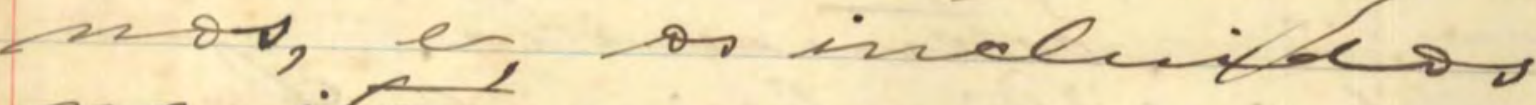
no icen se

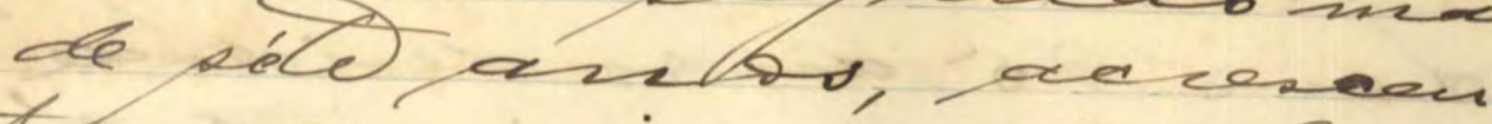

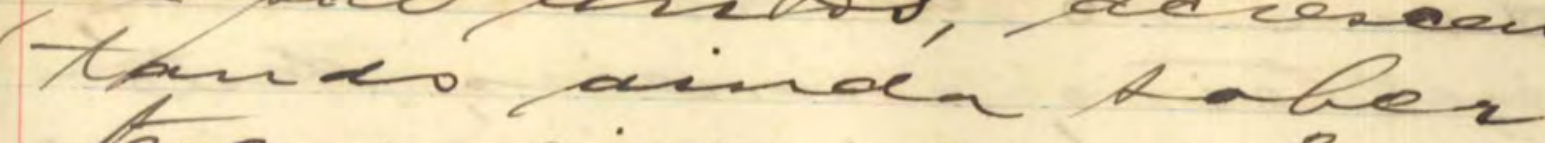

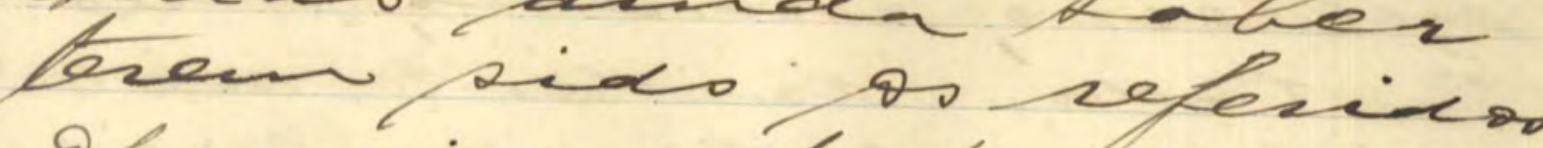

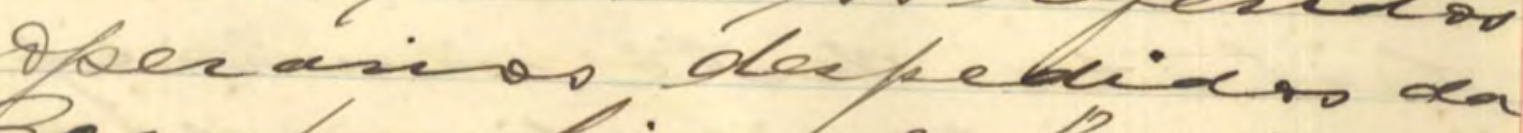

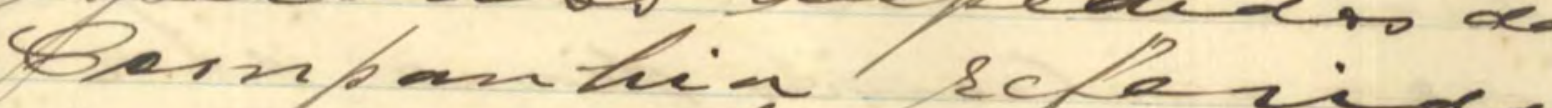

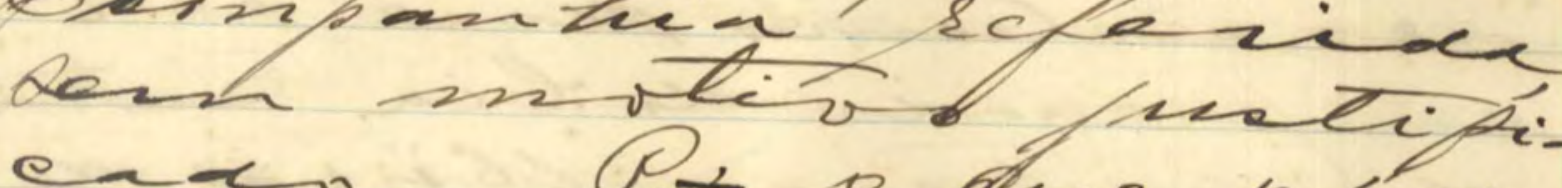

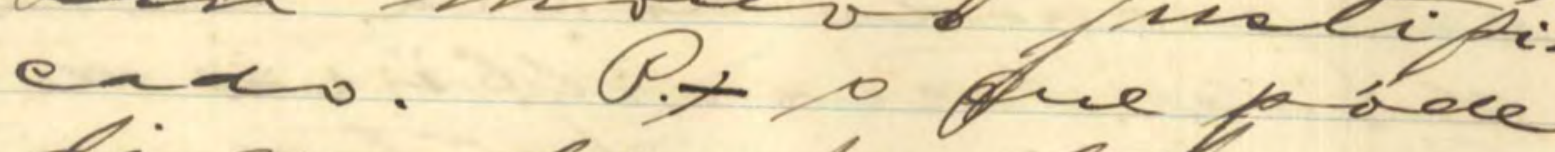

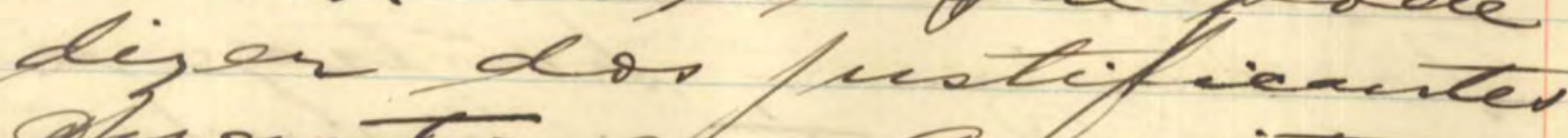

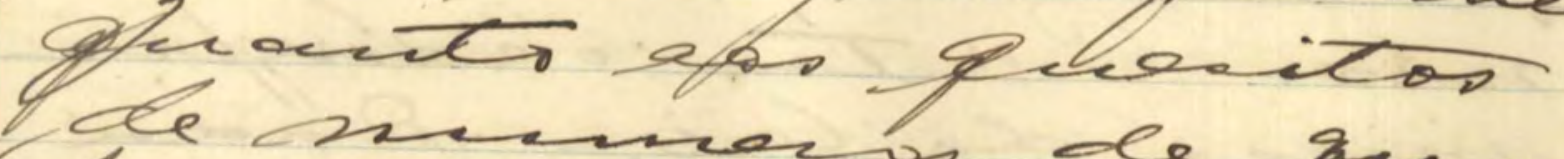

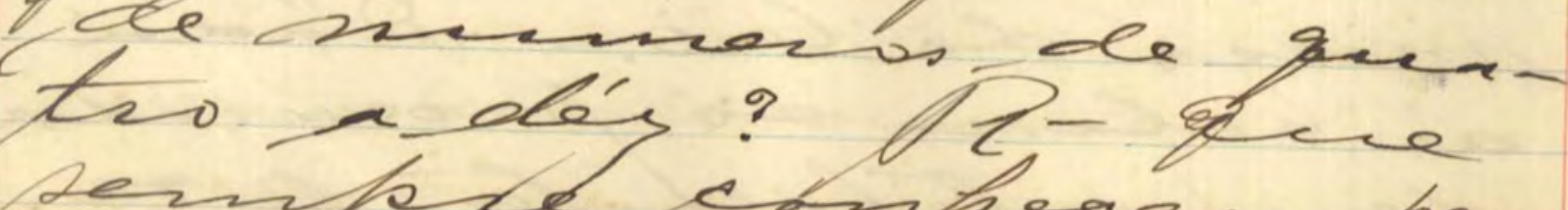

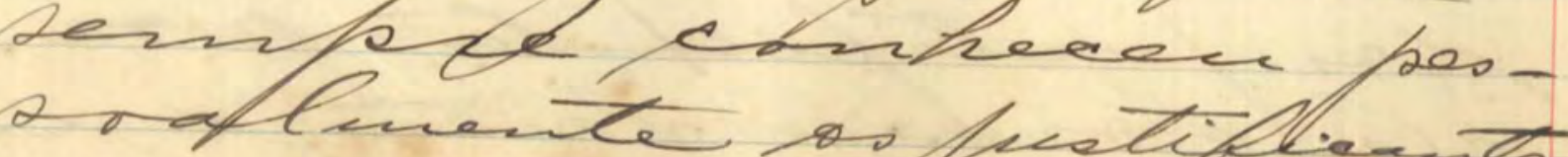

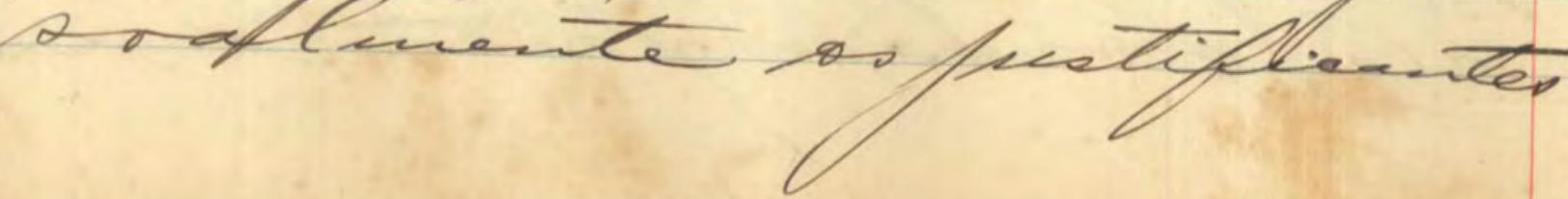


ats a lana wods. Prom otor

Qublico, and perguntar?

Do Pré, tijestertern.

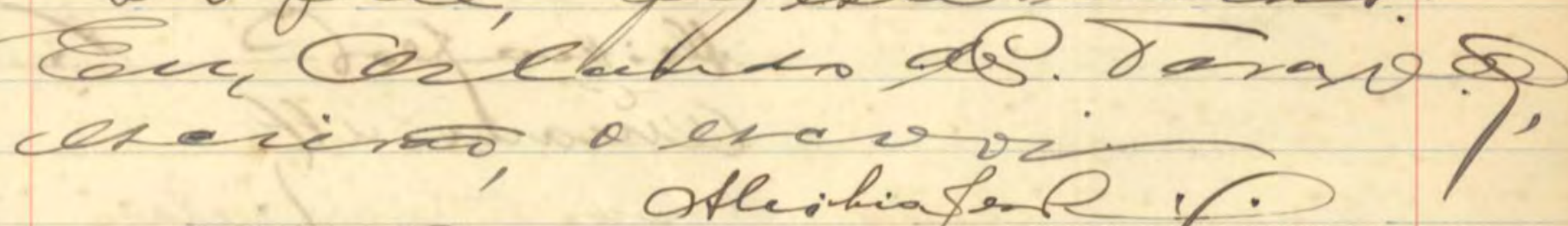
othibiafen $\%$ :

\%all. Sinfuir der simitas

Thider Ob anachs Aivanitrets.

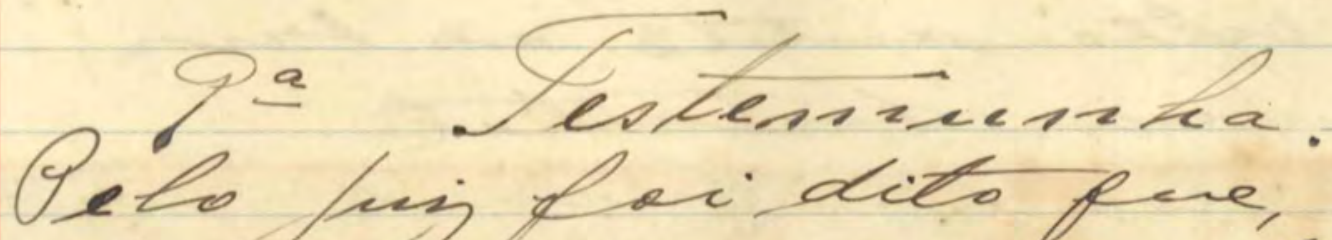

toffor do so'l eles tertewhas a de namefiancinco derpa, e, aprerentando- ve par depie a de mpriste La hiate $7 \mathrm{men}$ cires Lecpa, Leixera gue etca futtificsere elizo

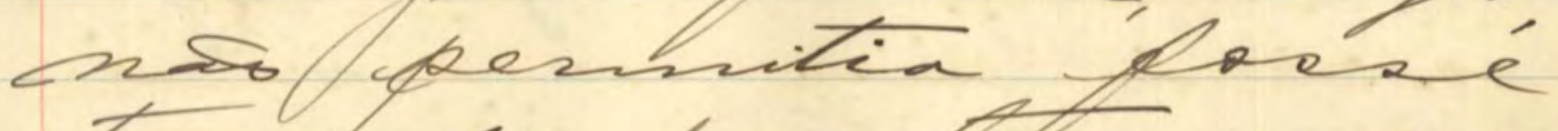
tonfaco por tareso osen

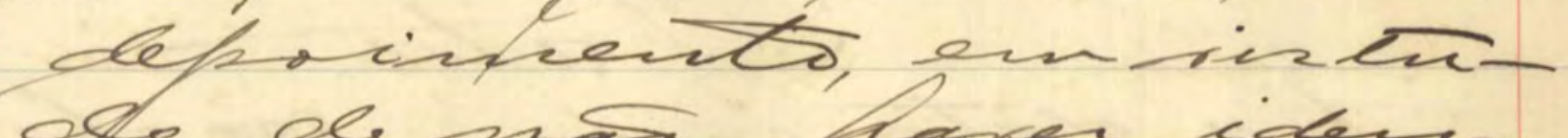
ofo de ma haver cdere $e^{\prime} d_{a}$ assbencen faelo furtificater ed el apara detse. Saracir 
Ho a laria a allogace des

t matifir ter e dr. Opa-

fmothe Publico, maxa equerarn. Do pre,

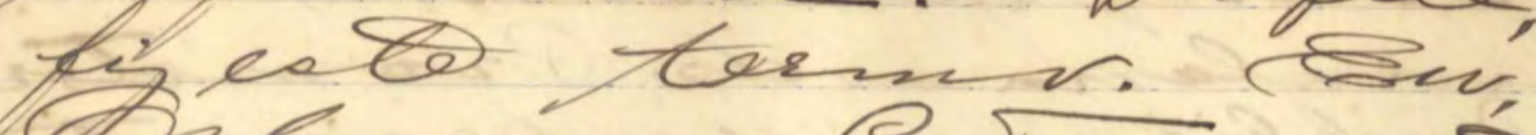
elaur vace Q.

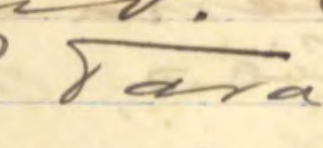

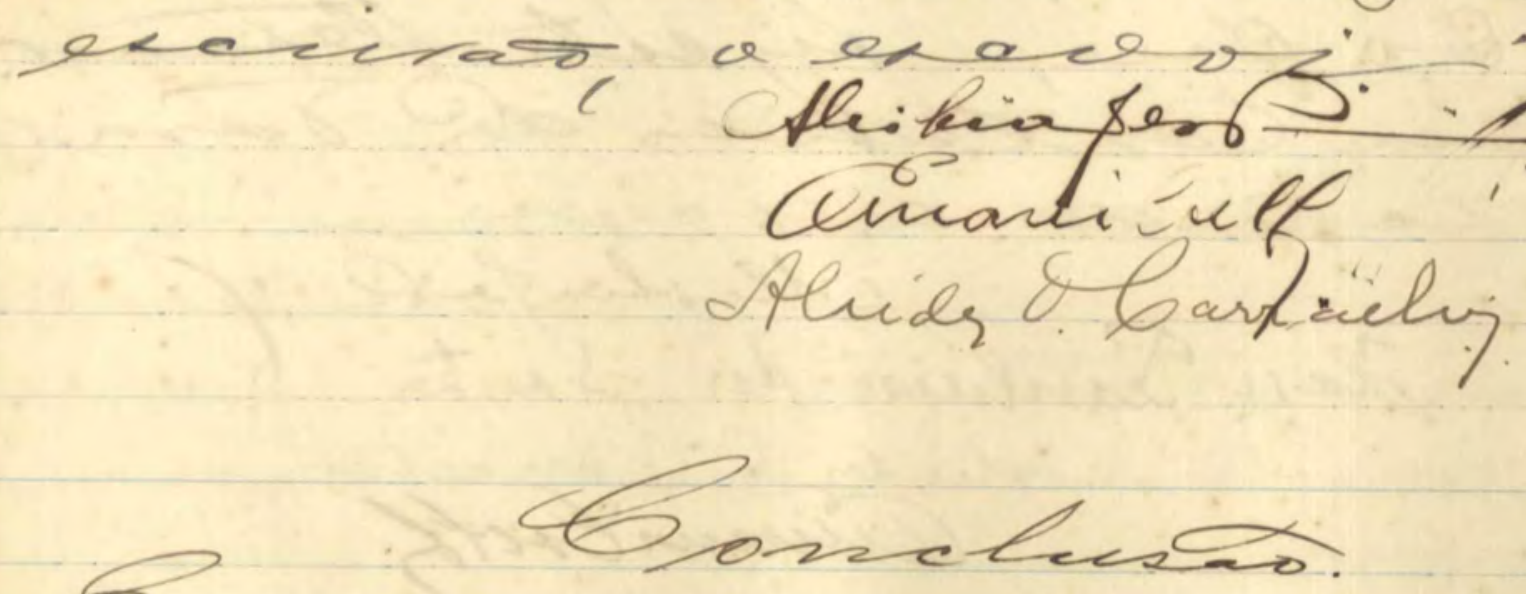

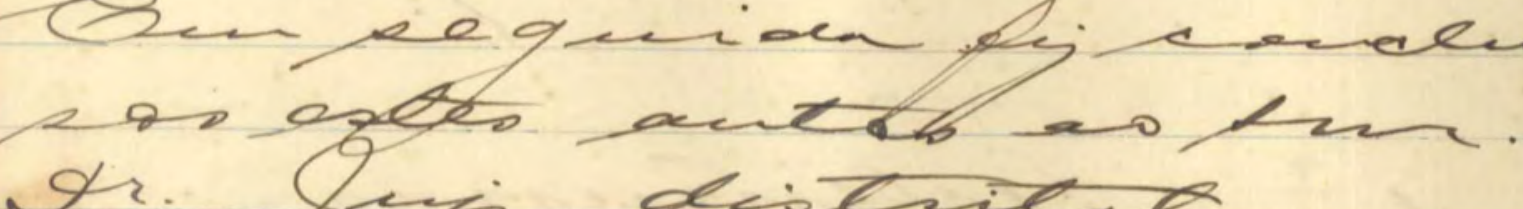

Ar. fuin ditwere

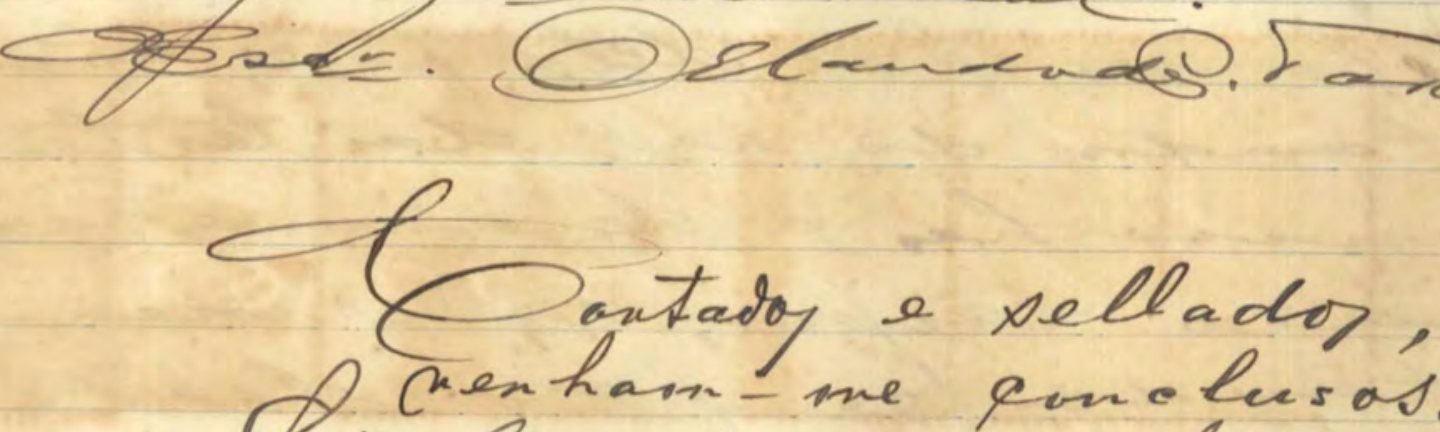
Tar jeconino, no, junho, 19j.

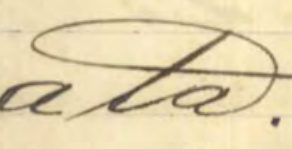

a data nuber secebi seter actor. Steraviso. S. 

Do Evint- hut $\Rightarrow-$
Ind.edeci. (1)

2- Tomnoce aceutere resu-

3.000

19.000

8.900

F-Depoimartasen-sa- 66.200

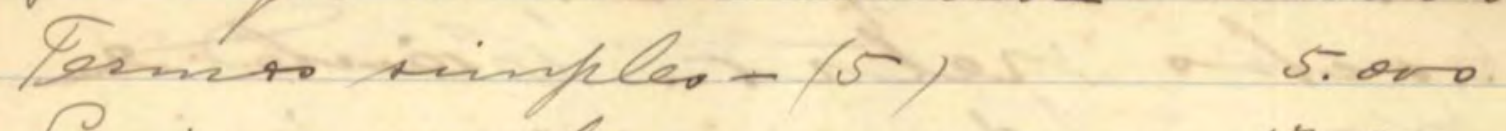

fuinis reles

$17.2,0$

bavgicñ

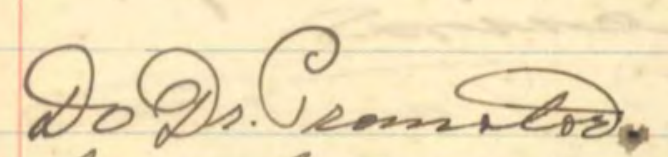

$\frac{3.900}{122.400}$

Apiaterain ing. (8) tests. 80.020

Opertore tois mil e funtrocatosos.

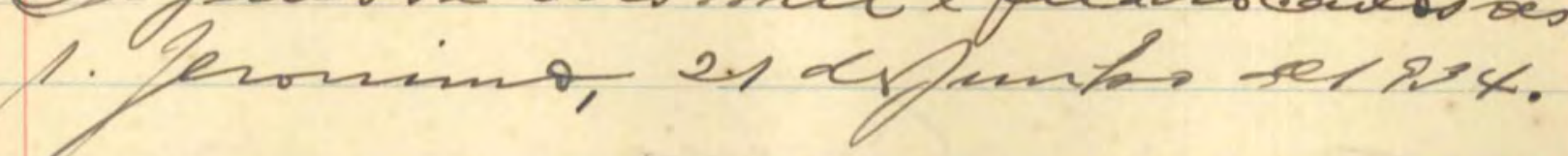

2

Te jiestific sentenca, a queven

He jiestificu, ao, en que vão jectific antes" Dómingos Moantilhas,

Ribualino bachado de tsima, Rajacl lberra, Yoaio Reenan, Topmare Soncalves, Mntoreio the nes das Gedeas e stdalbesto tgambeyja dos Santos, e, jies tificatha, a tompanhia bo trada de' Fenso e Monias de Daĩ Jewnimo.

Contreque-re a' pacte reque rente, Sindependente de tracka

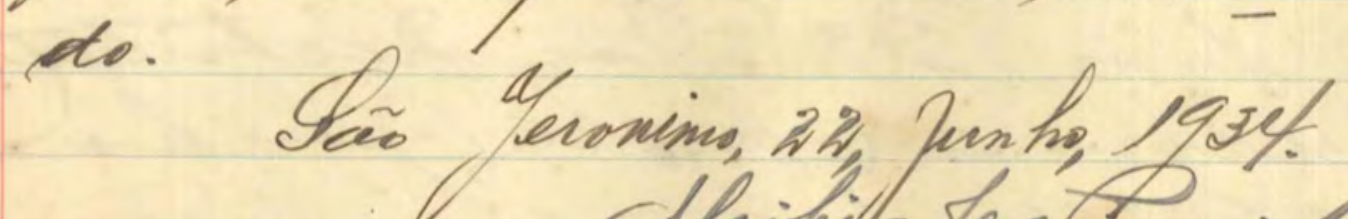
cllibita test Pata. 




\section{$\underline{D} \mathrm{E} C$ L A R A S}

Declarmos conhecer,para todos os efeitos, - nosso camarada Liberalino Machacio de Lima, conhecido tambem pelo nome de Januario, como enpregado,conosce, da Companhia Estrada de Ferro e Minas de S.Jeronymo, onde, descle 1914, exerceu varias atividacies, sendo ultimemente tocador de carros, da qual,ha pouco, foi despedido,por intrigas duntal cathalã, que, por aqui, anclou, como operario,mas que, depois, se soube ser um secreta da policia.
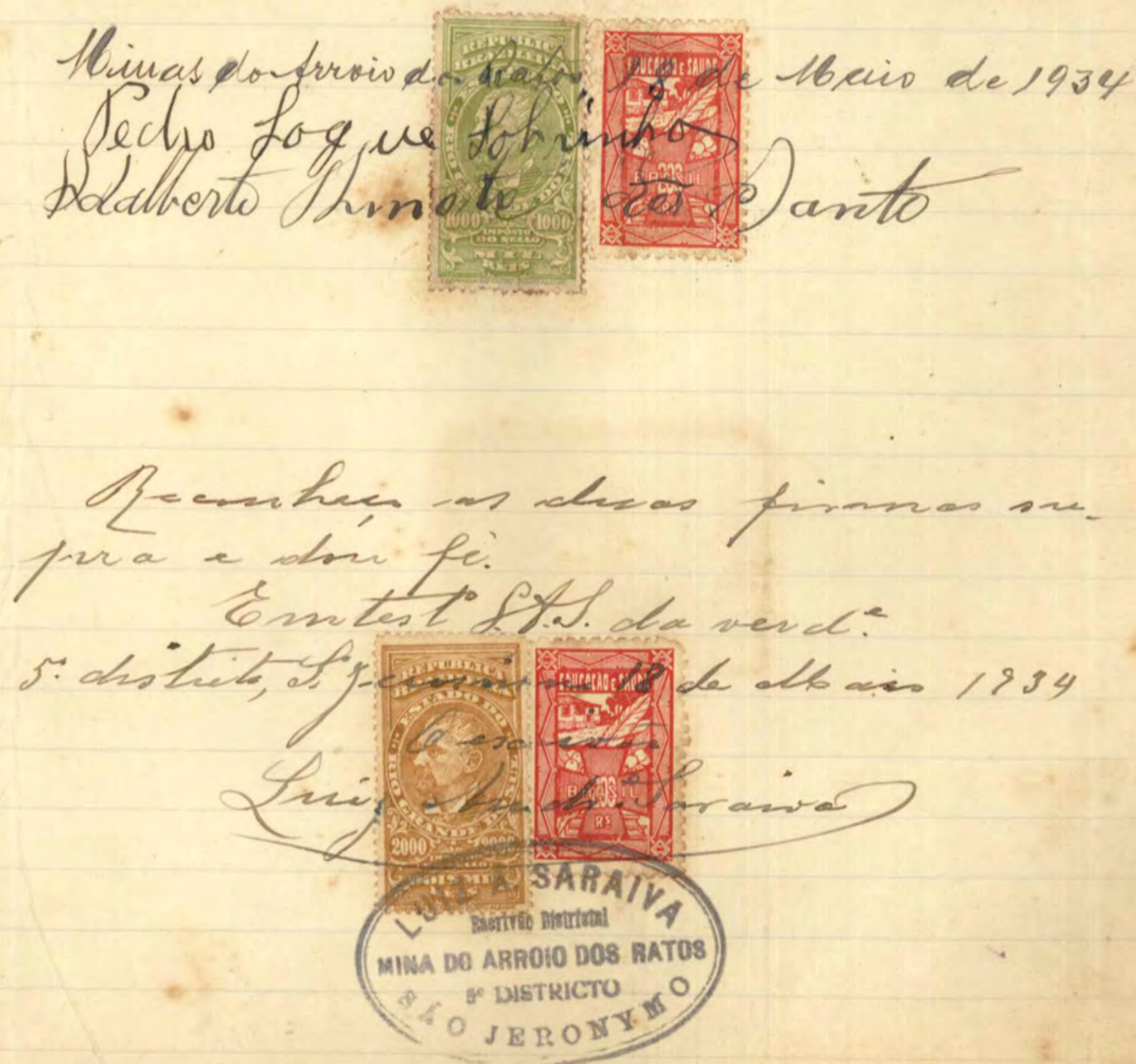


\section{DEO I A R A S $\mathbb{A} O$} N'os, aboixo assinados, para todos os efeitos, declaramos conhecer o operario Liberalino Machado de Lima, tambem conhecido pelo nome de Januario,como enpregado da Companhia Estrad de Ferro e Minas de S.Jeronimo, onde exerceu varias atividades, sendo por ultimo tocador de carros, há muitos anos, descle 1914, época em que,ai,se enpregou, sendo despedido, há pouco, por motivo que ignorsmos.

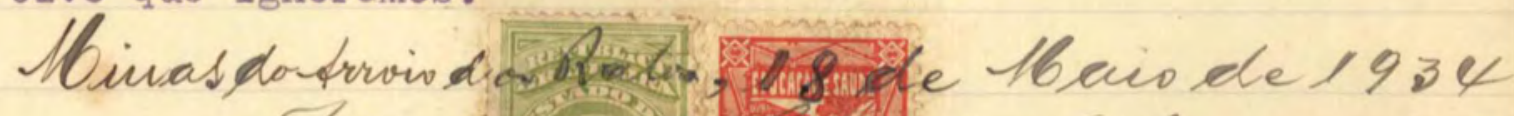
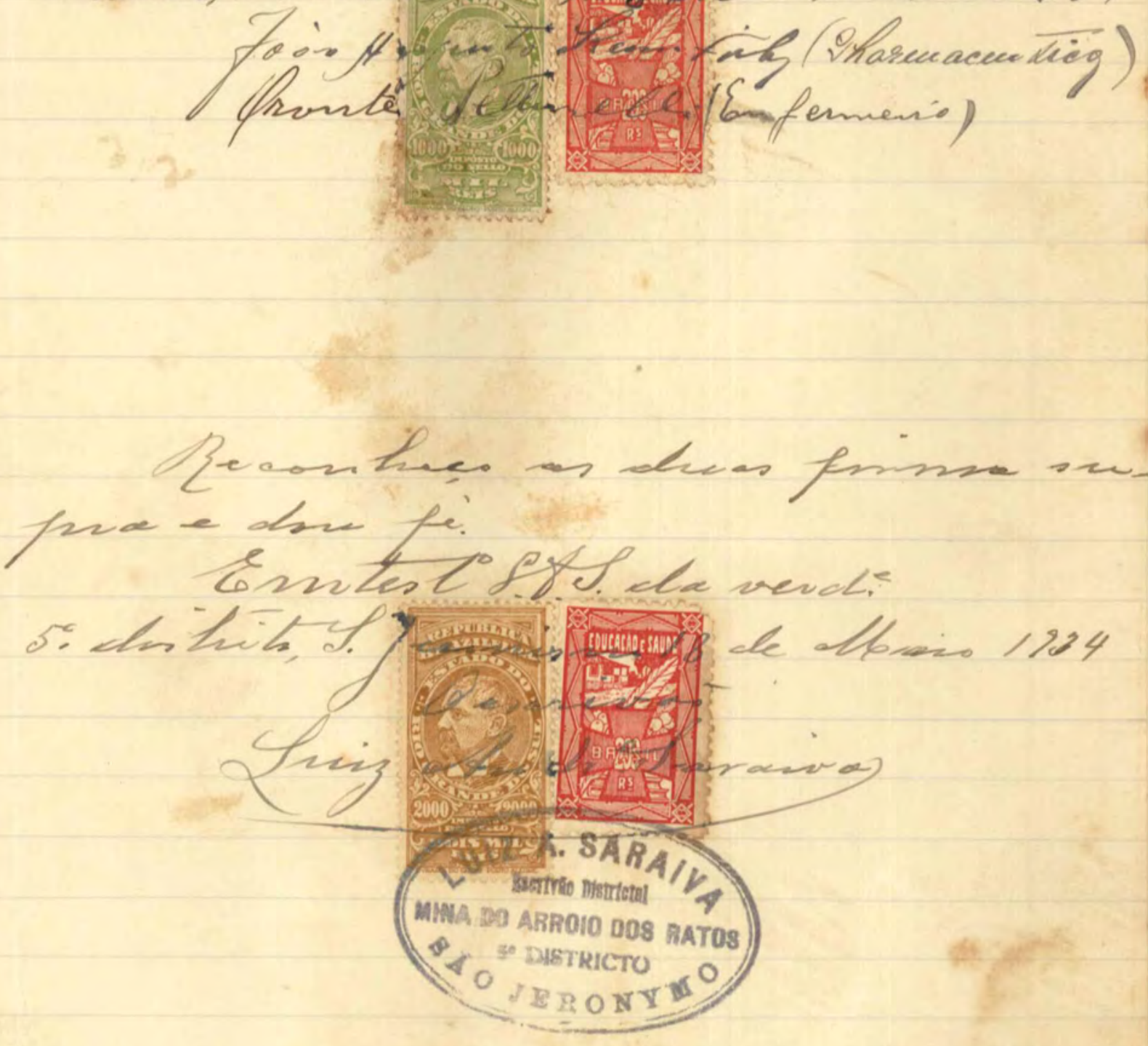
I. R. $16 /-3 / K$ de $193 \angle X$

$\mathrm{As}^{33}$

17." INSPETORIA REGIONAL DO MINISTERIO DO TRABALHO, INDÚSTRIA E COMÉRCIO PORTO ALEGRE

ivatoudo-or de nutevi ufulada per bec. 20,tbrda 1: de Qulvawo de 1935, unetorn chte procest av therpeTwhath no betavo do hi frowole do Ref, tre Gavedro tobato dos vacuts, para $v$ quis de divits.

* i-se puicen aos vitur poutos.

Sen 17.8. 34

Evencuiteolivina

$x$ 




\section{IFORMAS $\mathrm{AO}$}

Domingos Mantilha, Iiberalino Machado de Iima, Rafael Meza, João Keeman e Thomaz Gonçalves, com majs de 10 annos de servico, e Antonio Nunes das Pedras e Adalberto Arambuja dos Santos, com mais de 7 annos de servifo, pedem providencias no sentido de serem reintegrados na Cia. Estrada de Perro e Minas de S. Jeronymo, da qual, segundo allegam, foram demittidos illegalmente.

Confome se verifica dos autos, os interessados provam o tempo de serviço allegado mediante uma justi. ficação judicial.

A reclamação em apreço foi remetiida a este Conselho pelo Inspector Evandro. Lobão dos Santos, o qual solicitou da reclamada $\rho$ as ncessarias informações, tendo sido estas prestas a fls. 3 .

Para os devidos fins, passo o presente processo ás mãos da autoridade superior.

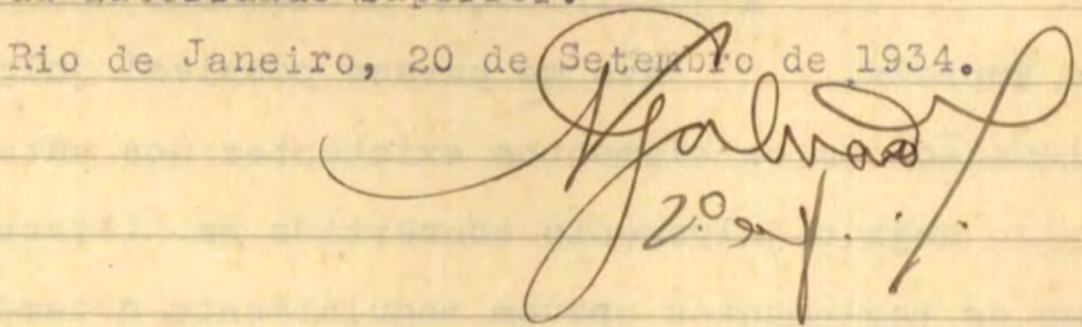

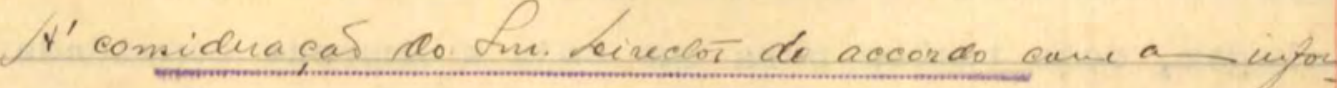
macas auna. Em 96 de velewlo de 193. Sferdro de Aemeida ordés

Director da 1." Secção

VISTO-Ao Snr. Dr. Procurador Geral, de ordem do Exmo. Snr. Presidente.

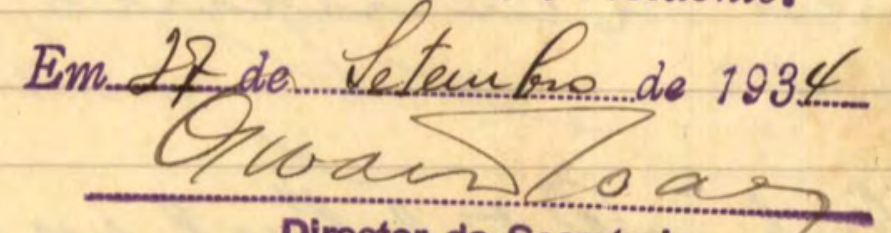
Rec. na hocunadona em 4/10/934 
Ao Dr. 2 : vistq

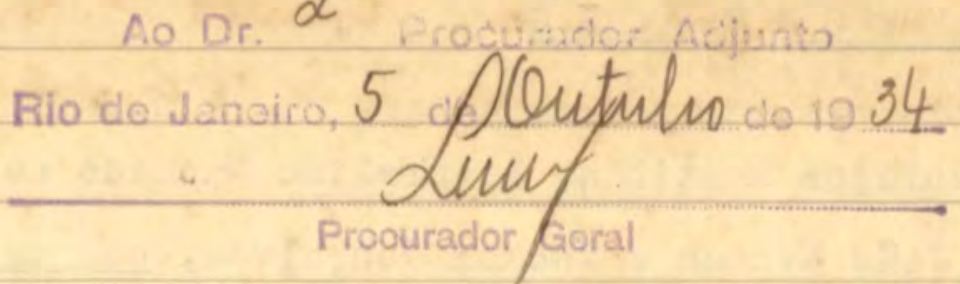

Domingos Mantilha e outros dirigiram uma reclamação so Inspetor da 11a Inspetoria que a encaminhou a este Conselho, contra a Companhia Estrada de Ferro e Minas de S. Jeronymo. Os reclamantes são os seguintes: Domingos Mantilha, Liberalino Machado de Lima tambem conhecido por Januerio Machado de Lima, Rafael Mezza, João Keenan o Thomaz Gonçalves, que alegam possuir meis de 10 anos de serviço, e Antonio Nunes das Pedras e Adalberto Azambuja dos Santos, que dizem possuir mais de 7 .

Apresentam os reelamantes uma justificação na qual pretendem provar não só o tempo de serviço, como tambem que foram despedidos da Companhia sem motivo para tal.

A Empreza prestou os esalarecimentos de fls. 3 .

A justificação processada não o 01 com citação da Empreza. Não me parece possivel julgax a presente reclamação com os elementos existentes nos autos. Por isso opino sefja o julgamento convertido em diligencia, não só para que os reclamantes poovem regularmente o tempo de serviço que alegam, como tambem para que seja a Empreza convidada a remeter 0 inquerito administrativo que deveria ter procedido para demissão dos empregados, que possuem mais de 10 anos de serviço.

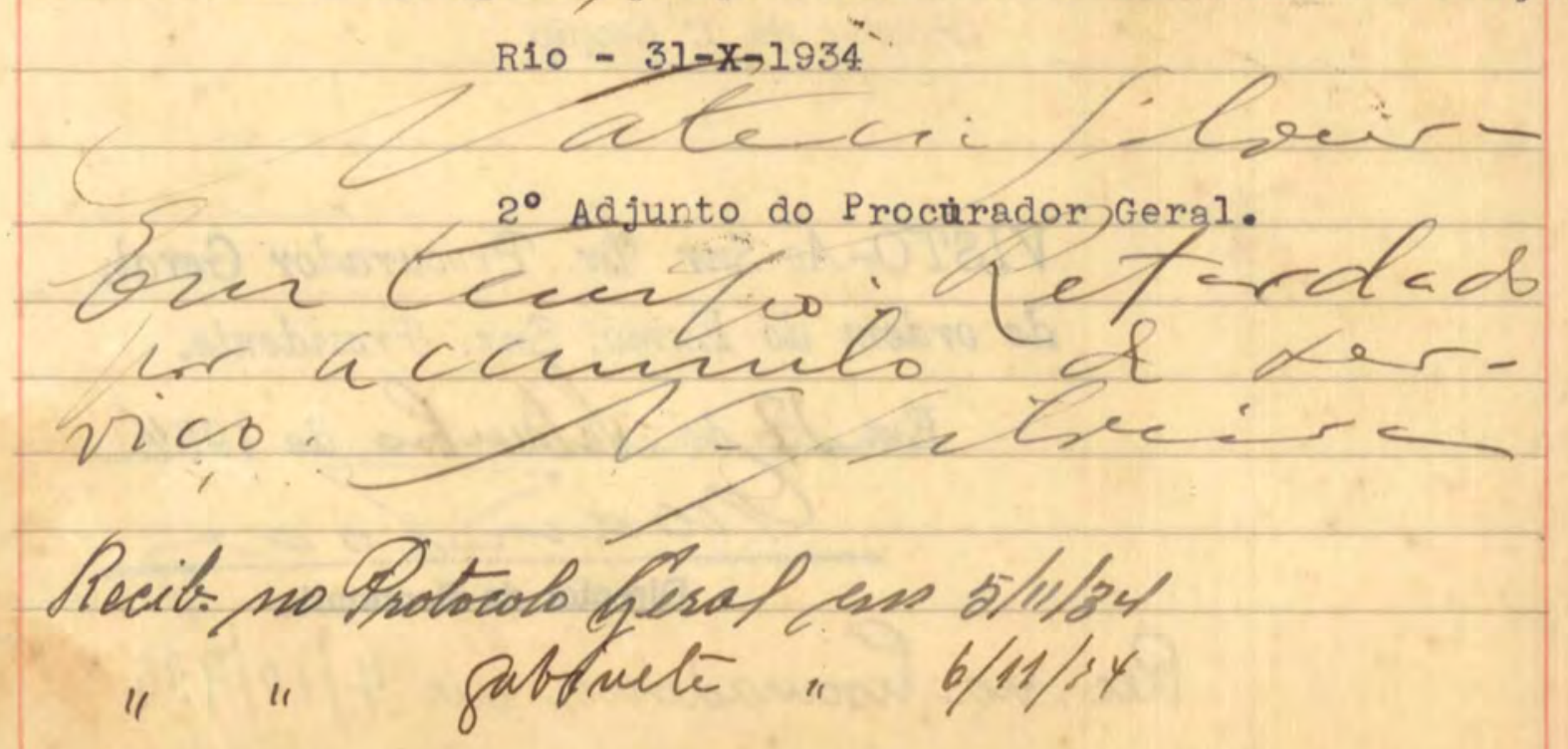


pr. 37

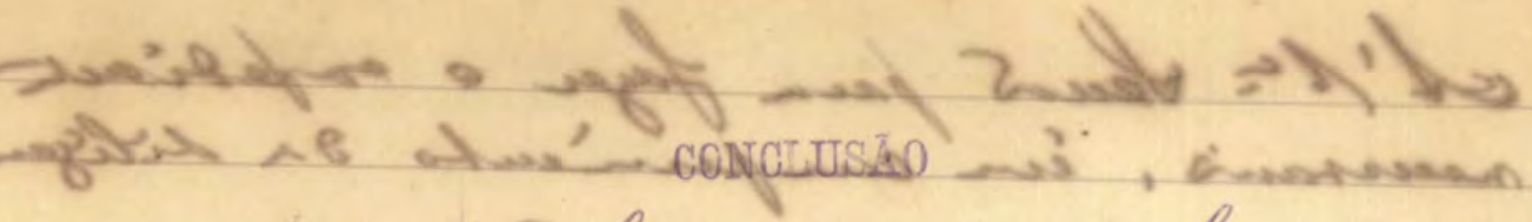

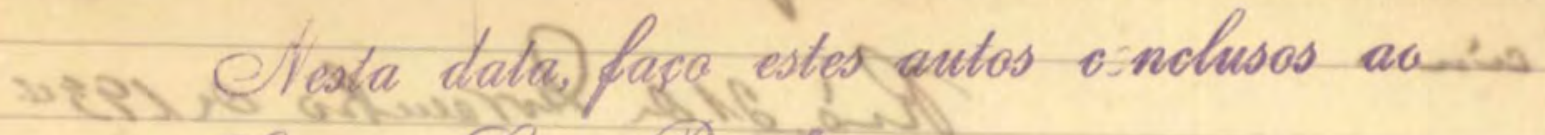
Canno. Om. Presidente.

En bo Nonem ho de 1934 ceadteren. Director da Secretaria

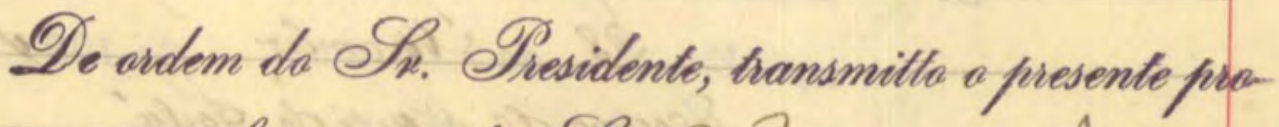

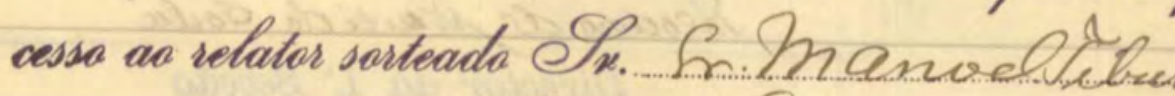
QRiv, I de Voremen-de 19 t

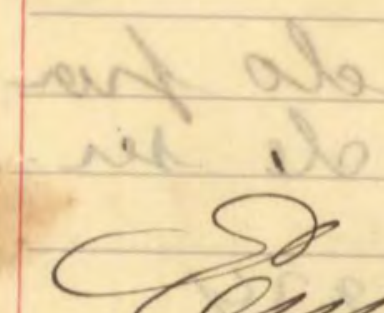

Qun cintude de ter qaid

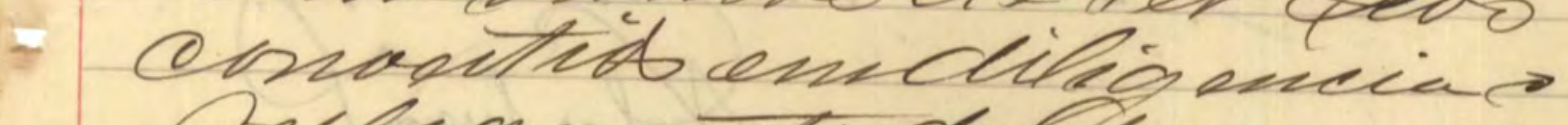

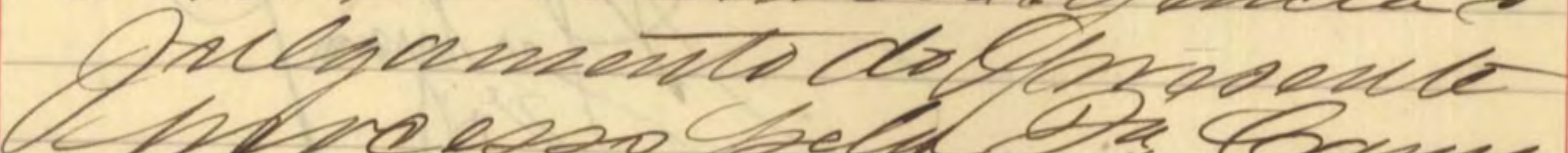

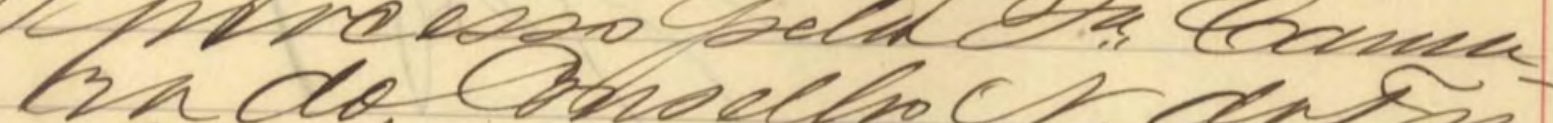

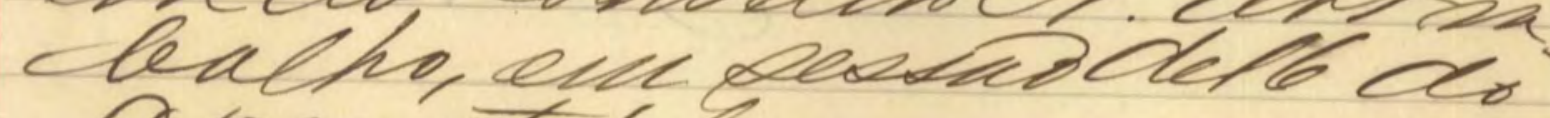

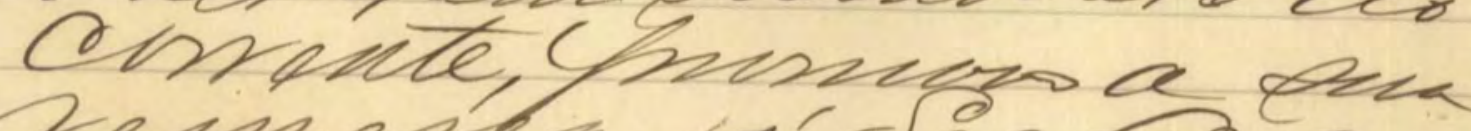

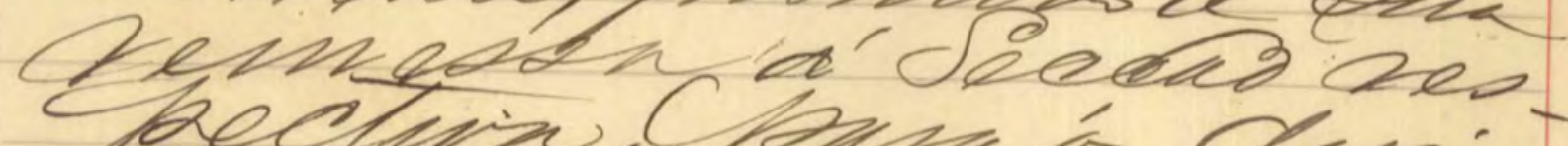

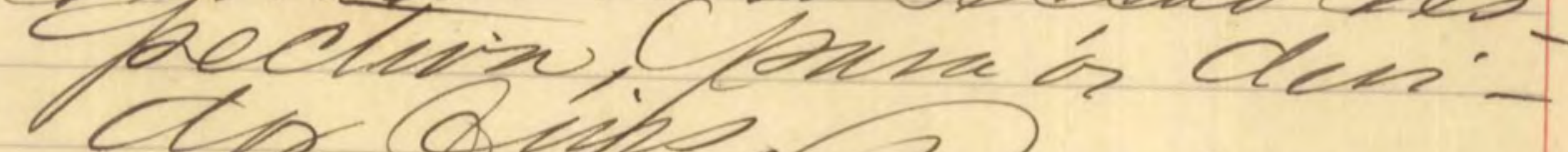
des

Rue wa Taceow 2/41.3y 
ct'ls Heews par fager o mperiact meerstanis, én cunfurieuto st dilegen ain.

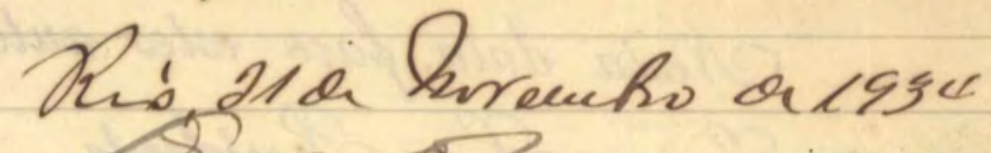
Quarolace
wriectrofieaf

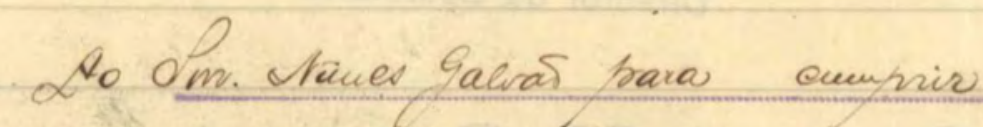

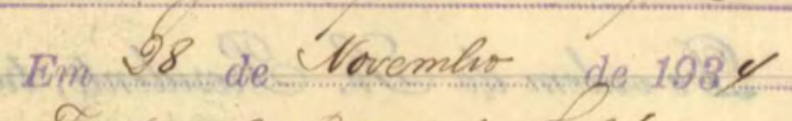

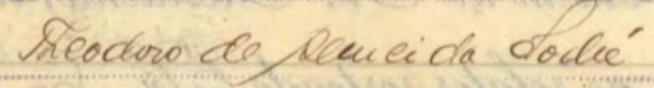
Director da I. Seccgäo

Cumpudo. Retardado fra grande acunsulo de ser.

$\min 10-12193 \%$ 
P. $9582 / 34$

17 Dezembro

4

$\mathrm{K} / \mathrm{E}$

$1-1.714$

Snr. Director da C1a. Estrada de Ferro e Minas de São Jeronymo

Rua Paysandu, 219

Porto Alegre

R10 Grende do Sul

A proposito da reclamaçño formulada pelos Snrs. Domingos Mant11ha, L1beralino Machado de L1ma, Raphaes Mezza, João Keenan e Thomæz Gonçalves e tendo em v1sta o resolv1do pela 2a Camara do Conselho Nacional do Trabalho, em sessão de 16 de Novembro do corrente anno, de ordem do Sr. Presidente, sol1c1to-vos a remessa em or1g1nal do inquerito admin1strativo que deverta ter preced1do a den1ssão dos supplicantes, v1sto contarem ma1s de 10 annos de serviço, e, bem assim um certificado do tempo de serviço e a lolna de antecententes dos mesmos.

Attenc1osas saudações 


\section{CONSELHO NACIONAL DO TRABALHO 1.12. Onspectaria \\ 18 de Dezembro

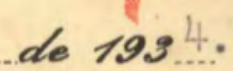 \\ UUNSEXPO NACLDNAL DO TRABALHO

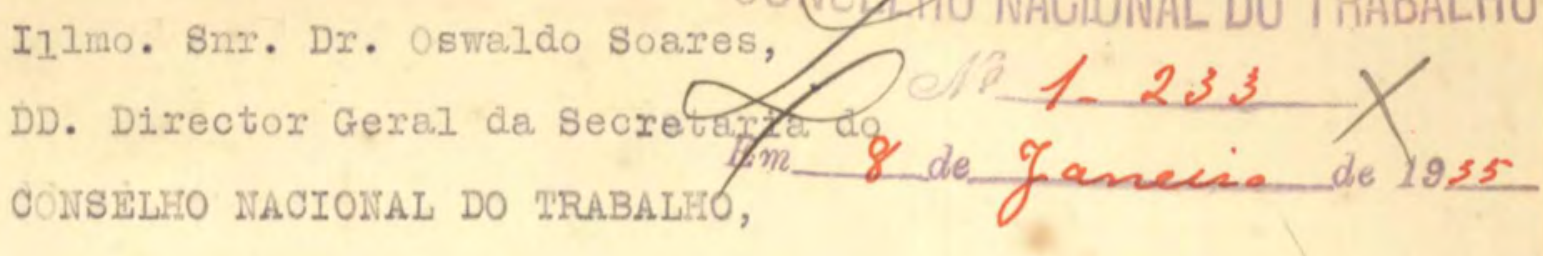

MINISTERIO DO TRABALHO, INDUSTRIA E COMMERCIO END. TELEQ.: AGRILABOR'

No. 34:38].
RIO DE JANEIRO

\section{ASSUNPIOO.}

Proc.Mro.9.582/34 - Reclamação de Domingos Mantilha o cutros, contra a Companhia Estrada de Ferro e Kinas de São Jeronymo.

Em solução ao meu pedido de providencias a fo fiel cumprimento ao venerando Accórdão proferido, por esse Egregio Conselho, no processo acima mencionado, junto a este o pedido de reconsideração do referido Accórãa,o, para ser devidamente, suas razões,apreciadas por esse Collendo Conselho.
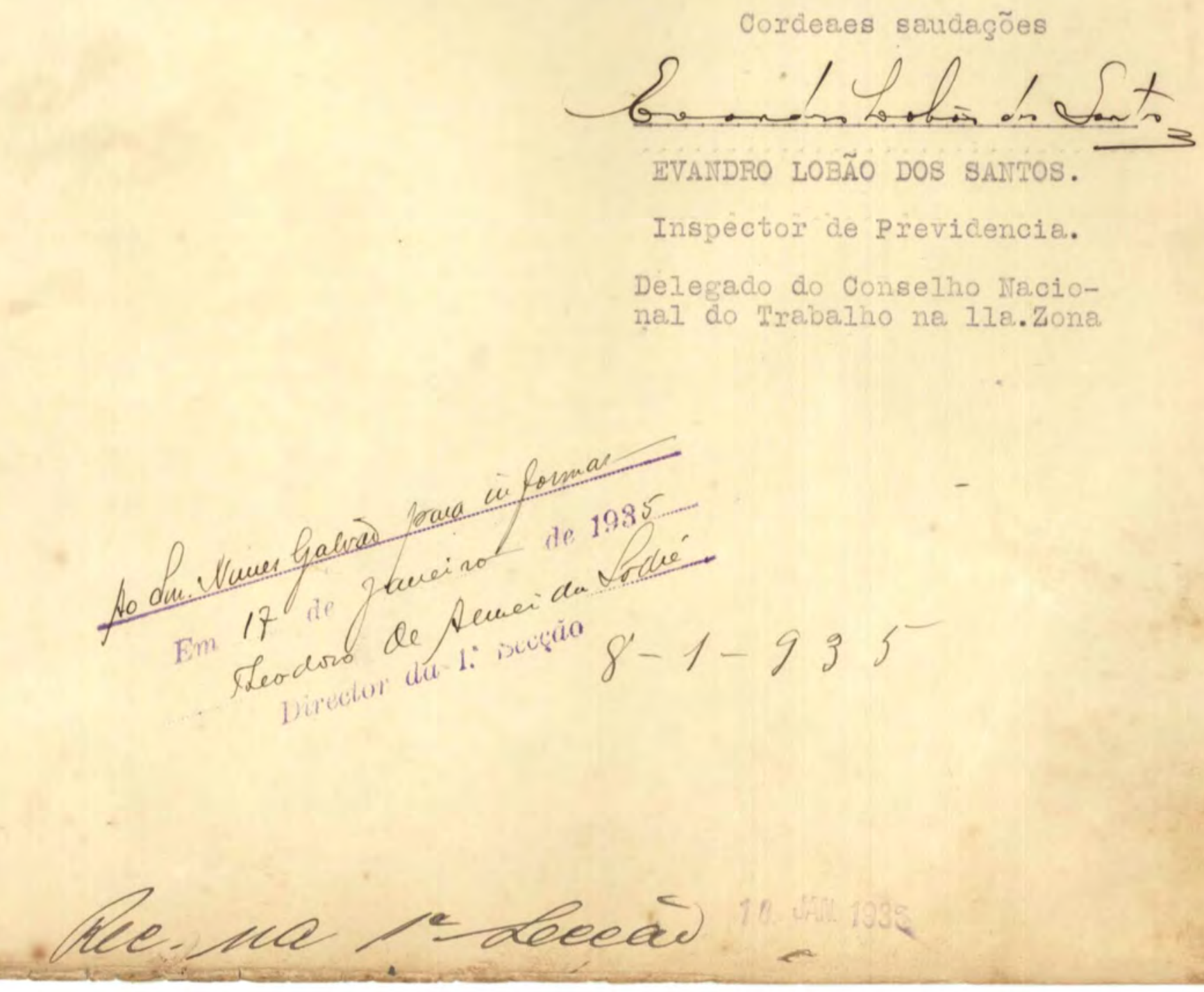


\section{Cia. O. T. OMinas de ễo Zeianymo}

Porto Alegre, 11 de Dezembro de 1934

IIImo. Snr. Dr. Evanâro Lobão dos Santos, M.D. Inspector Regíonal

da 212 Inspectoria do Conseliho Nacional do Trabalho

N/Capital

De posse do officio $n^{2} 34 / 371$, de 5 do corrente, em que V. S. nos communfica o teor do despacho interlocutorio proferiđo pelo $\mathrm{E}$. Conselho Nacional do TrabaTho, na reclamaçäo đe Domingos Mantilha e outros, despacho ordenatorio "da remessa 2.0 mesmo $\mathrm{E}$. Conselho do respectivo inquerito, foltha de antecedentes e tempo de serviço dos reclamantes" (solicitanđo-nos V. S. informação quanto ás providencias tomadas sobre o assumpto), pedimos venia para ponderar que segundo opIna o nosso Consultor Juridico, nenhum Inquerito nos é possiver remetter, visto, na especie, não caber uma tal providencia, sómente obrigatoria para as emprezas, quando hajam de dimittir empregados que contarem mais de 10 annos de antiguidade (Dec.n² 22.096, de 16 de Novembro de 1932, art. 2\%), o que, no caso, não se dêo. De facto, nenhuma demissão fo1 lavrada ou dada aos reclamantes, por esta empreza, tendo elles em sua maior parte, sido privados de trabalhar, pela policia local, em consequencia de prisão por ella effectuada, devido á denuncia recebida de estarem tramando uma gréve geral entre os mineiros, denuncia, allás, a que a Direção desta empreza fol completamente estranha.

Afastados, ass1m, do serviço, por motfvo, não, de đem1ssão, que não houve, mas de prisão effectuada pela policia, \& claro que a nenhum inquerito administrativo estava obrigada a empreza a qual, diante do inopinado afastamento, forçado, dos reclamantes, não podia deixar de logo dar-lhes substituto, conforme fez, em legitimo resguardo dos interesses da mesma, que the incumbo precipuamente zelar.

I \& bem de ver (accentía afnda o nosso Consultor Juridico) que, pelo prejuizo d'ahi advindo a cos reclamantes, no caso de verificar-se depols, a injustiça de sua prisão, conforme acontecêo, sómente pođe responđer, não a empreza, porem o causador directo desse prefuizo, - a referida policia, responsabilidade essa indubitavel, pois, consagrada, em principio, na nova Constftufigão da Repubrica, como se ve do texto expresso do seu art.' 171, 


\section{Cia. ज. . . Minas de ễo Zeianymo}

que esta terha sido apurada em inquerito regulaxmente procedido (Dec. $\mathrm{n}^{2}$. 20.465 , do $1^{2}$ de oututro de 1931, art. $53,512 \mathrm{e} 2 \%$ ).

não senđo, porem, esse o caso đos reclemantes attingiđos pela acção đa policla, é visto que nemhuma obrigagão assiste á supplicante de readmittilos e pagar-1hes salarios, para a privação dos quaes ella näo contribuio.

Para que uma tal obrigação exist1sse, nesse caso (culpa đe terceiro), mis. ter fora que houvesse lei Impondo-a aos empregadores, certo, como é, em face da Constituição Federal, art. 113, 2, que "ninguem será obrigado a fazer ou deírar de fazer alguma cousa sinão em v1rtude de 1e1." Nanifesta, pols é, neste ponto, a semrazão dos reclamantes.

Não o é menos no que se refere ao operario Domingos Mantizha, - jamais despedido pela supplicante, mas apenas transferldo das funcções de "patrão" para a.s de "furador", funçōes essas consilleradas da mesma classe, attenta a identidade do ordenädo de ambas, ou seja, $14 \$ 000$ diarios.

Este operario trabalnava ha nove mezes como patrão da geleria 39 do pogo 4, è đevido a sua habitual đesidia, dava seguiđamente prejuizos á supplicanto. No moz de Maio p. passađo, após o desconto regulamentar das despezas de peães, explosivos, quota đe papel, assim como a diaria do referiđo mineiro, verificou-se um deficit de Rs. 1:440\$000, que fo1 desembolsado pela suplicante. Paca evitar novos prejuiżos, è usando do recurso que temos, do trans ferir de serviço qualquer empregado, fol mandado o operario a margem trabaThar de furador, porem, elle se recusou a comparecer ao serviço.

Justa, portanto, foi a transferencia do referido operario para uma outra funç̧ão, embora de categoría inferior, porem da nesma classa conforme a pouco se vio, näo vendo a lei com maus olhos o rebaixamento de categoria, e tam bem do salario ou ordenado senão quando usađo como castigo, ou pelo facto de associar-se o empregado ao syndicato de suaclasse, ou por ter, no soio do syndicato, manifestado idelas ou assumido atitudes em divergencia com os seus patrões (Dec. n² 19.770, de 19 de Março de 1931, art. 13).

I releva accentuar que, no caso, não se trata propriamente de um operario com mais de 10 annos de antigujdade na me só se deve entender daquelles que nella se conservar constantemente, ou sem qualquer Ínterrupção, mesmo após o preenchimento d'aquelle lapso de tempo, 


\section{Cia. ज. F. OMinas de ễo Jedanymo}

ao declarar - que "OB funcionarios publicos säo responsaveis solidariamente com a Fazenda Naclonal, Bstadoal e thunicipal por quaesquer prejuizos decorrentes de negl1genc1a, omissão ou abuso no exercic10 dos seus cargos."

S1 abuso houve, da parte da pol1c1a, na prisão e coacção Infligla aos reclamantes, impedindo-os de comparecerem ao serviço da empreza, não é, pols contra esta que devem os reclamantes se voltar, mas, sómente contra aquelia, unica e exclusiva respondavel, eventual, pelos prejulzos de que elles se queixam.

¿ da sua prisão. pela policia, fala claramente o officio que, a proposito, a supplicante recebeo do D. Dr. Delegado do Ministerio do Trabalho, e cuja cópla vae annexa.

Fm um tal caso, em que se trata, não, de demissão dađa pelas emprezas, mas de impedimento dos operarios para comparecerem ao serviço, por motivo de prisão, effectuada pela policla (respondavel tambem, aos pacientes pelos prejuizos decorrentes đe sua substituição), em nenhuma responsabilidade, evidentemente, incorrem as emprezas, pelo facto dessa substituição, - de necessidade urgente, - mal se comprehendendo que, agindo ellas, assim, correc. tamente, dentro do seu direito e do seu dever, possam ficar prejudicadas ou oneradas, pelos salarios accumulados, dos substitutos dos operarios afastados pela policia, e destes ultimos (retirados do serviço, sem culpa das emprezas).

Seria isso fazer recahir, iniquamente, nas emprezas a culpa da policia, exonerada esta da responsabilidade que inquestionavelmente pesaria sobre ella, de indemnisar as perdas e damnos crusados aos pacientes da prisão, nos precisos termos do art. 1.550 do Codigo Civil ( $\underline{\text { sic }}$ ):

"A indernisação por offensa á liberdađe pessoal consistirá no pagamento das perdas e demnos que sobrevierem ao offendido, e no de uma somma calcuIada nos termos to paragrapho unico do artigo 1.547."

Nem uma tal Inversão de responsabilidades (pondera o nosso Consultor) encontra apoio nas leis sociaes protectoras dos empregados e operarios de mais de 10 annos de serviço. - limitando-se ellas a impôr ás emprezas a obrigação de readmittil-os ao serviço e pagar-lhes os salaxios respectivos sómente quando por ellas dispenaados do serviço, em caso de falta grave, sem 


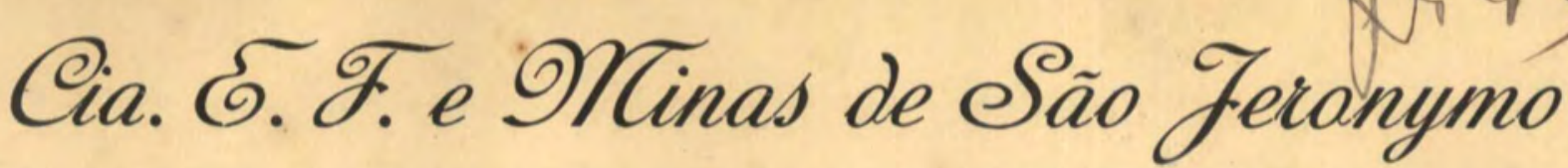

pois, s1 abandonam a empresa, para se dedicarem ao servígo de outros concurrentes, perdem com isso as vantagens do decennio, considerando-se o seu rein gresso naquelia como inicio de vida nova. E é o que acontece com o operario Domingos Nentitha, a qual, tendo deixado o serviço da supplicante depois de preenchido o decenio (1917-1927) nella reingressou ha apenas 1 anno (1933).

Fallece-The, assim, o predicađo da "estabilidade" a que setá subordinado - direito consignado no art. 53 do Dec. n²0.465 de 12 de outubro de I931, - vindo a proposito notar a profunda differença que occorre entre a contagem de tempo para o effeito de cit. art. 53 e a para o effeito do art. 28 (aposentađoria), caso, este ultimo, em que é levada em conta a descontinuidade dos serviços effectivos (vide).

Com o que vem de aduzir e o muito que supprirão as Iuzes do E. Conse Iho Nacional do mrabalho confia a supplicante em que a reclamação em fóco será julgada improcedente, como merece.

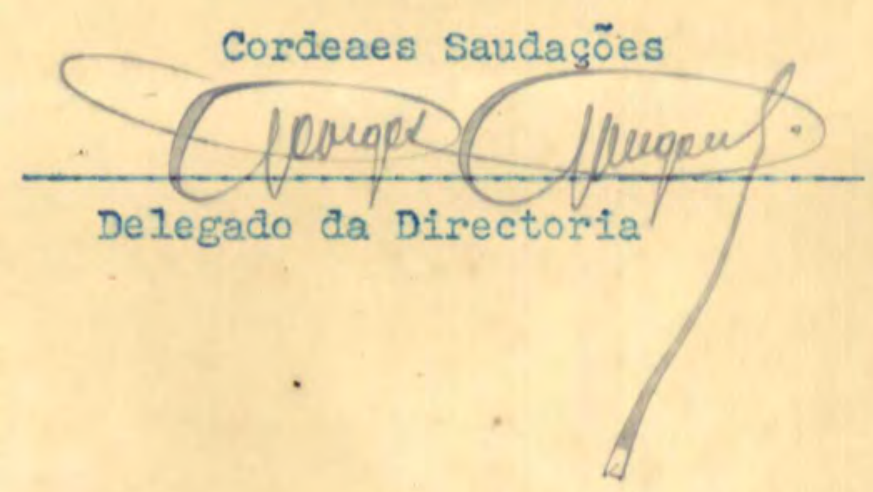




\section{INSPECTORIA REGTONAL DO NINTSTERTO DO TRABALHO

Estado do Rio Grande do Sul

\section{A Direç̧ão da Cia Estrada de Ferro e Minas de Jacui - Nesta Capital}

Atendendo a uma representação do sindicato de operarios das Minas de Arroio dos Ratos, procurou esta Inspectoria averiguar das causas que teriam determinado a prisão por autoridade policial, e consequente dispensa do serviço dessa empreza, dos operarios Raphael Mezza, Adalberto Azambuja dos Santos, Ricardo Pavio, João Herrera, Liberalino Nachado, Antonio das Pedras e José Francisco.

Informa-me a Chefatura de Policia do Estado que esses operarios foram denunciados á policia como comunistas e promotores de um movimento grévista entre o pessoal de mineração. $0 \mathrm{Sr}$. 3 delegado auxiliar desta Capital, após rigorosa sindicancia, concluiu que aquellas imputações são đestituidas de funđamento.

Afigura-se-me, assim, ato de boa justiça a readmissão desses operarios, tão rudemente atingiđos por infundada e aleivosa imputaçäo.

Acredito que diverso não será o vosso juiso, o que me autoriza a confiar nessa reparação.

Aproveito o ensejo para expressar-vos o meu grande apreço e distinta consideração.

Saude e fraternidade

Assignado:

Emani de Oliveira

Inspector Regional 
fle. 45

I I FORMACXO

A 3a. Camara do E. Conselho Nacional do Trabalho, em sessão de 16 de Novembro de 1934, apreciando - presente processo, referente á reclamação formulada pelos Srs. Damingos Manitiha e outros contra a Cia. Estrada de Ferro Minas de S. Teronymo, resolveu converter o julgamento em diligencia para que a Cia. reclamada remettesse o original do inquerito administrativo que deveria ter precedido a demissão dos reclamantes, visto contarem mais de 10 annos de serviço, e, bem assim, um certificado do tempo de serviço e folha de antecedentes dos mesmos.

Contra essa decis̃̃o, não se conformou a reclamada. I tahto assim que oppoz á mesma os embargos de fls. 40 a 44 , os quaes foram remettidos a este conselho pelo Inspector Evandro Lobão dos Santos.

Afim da douta rocuradoria Geral apreciar os embargos em causa -oppostos dentro do prazo legal passo os presentes apjítos ás mãos da autoridade superior. Rio de Janeiro, 22 dqf I/aneirg de 1935

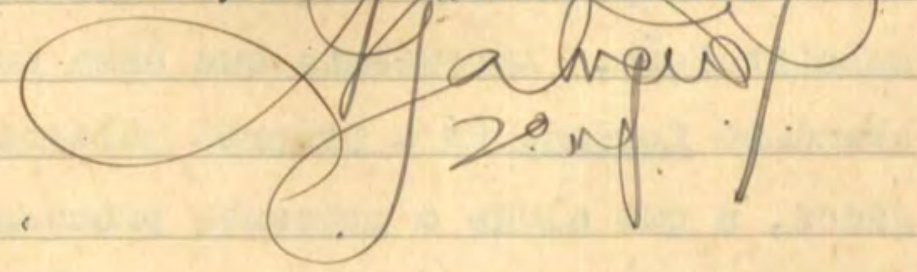

Áremideracan do Sur. Leincetor gare de acoudo

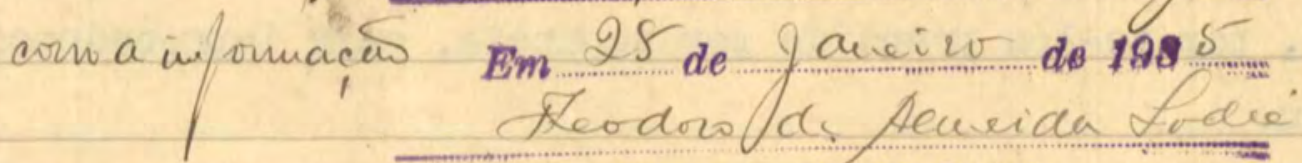

Director da 1; Becẹão

VISTO-Ao Snr. Dr. Procuraior Geral, de ordem do Exmo. Snr. Presidente. Rec. na hoc em 30/1/935 


\section{VISTa}

Ao De. Proctrador Adjunto en Coummssas

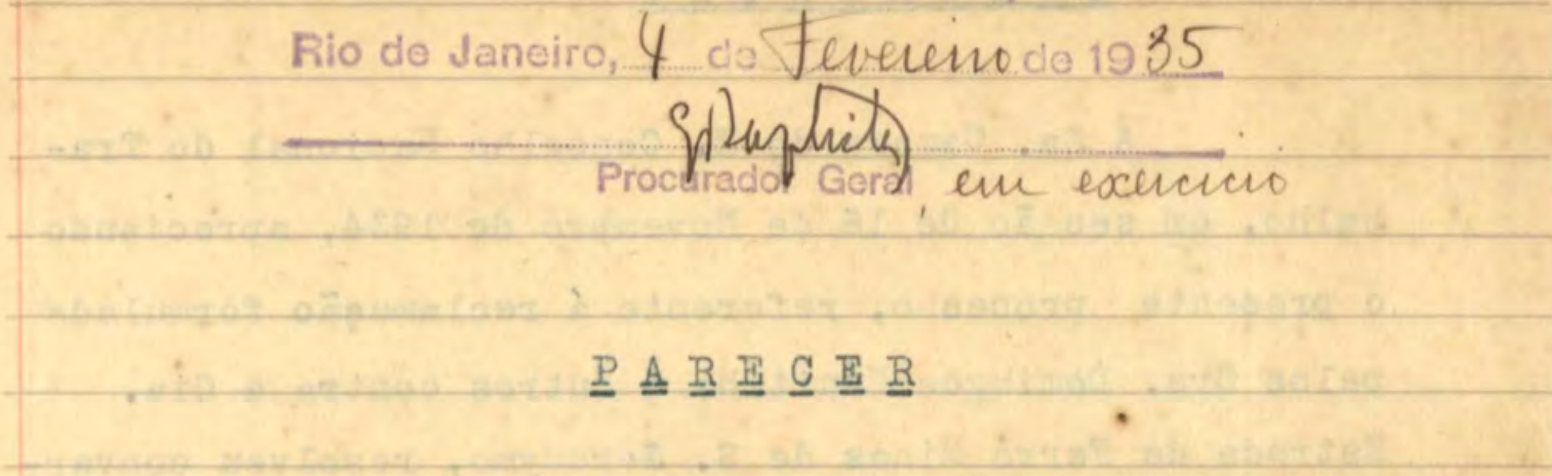

Convertido em diligencia o julgamento do presente processo pelo Igregio Conselho Nacional do Trabalho afim de serem remetidos pela Companhia Estrada de Ferro e Minas de São Jeronimo os inqueritos administrativos, a folha de antecedentes e a relação do tempo de serviço dos operarios dispensados, interpôz a Companhia os presentes embargos.

\section{Preliminarmente -}

Não cabem embargos á decisão que converte o julgamento em diligencia. Caberia á Companhia apresentạ defesa, como fez, da sua decisão, remetendo, entretanto, os documentos pedidos, uma vez que se verificou dispensa.

\section{De meritis -}

Confessa ela que não procedeu a inquerito administrativo em tempo habil, alegando não ter havido demissão e sim substituição. Acrescenta que essa substituição se deu pelo abandono forçado (é a propria palavra por ela usada) dos empregados, a que alude o presente processo, presos pela policia. E conclúe caber a esta a indenisação por perdas e danos aos reclamantes, que contra ela moveriam ação, nos termos do codigo Civil, por te-los prendido por denuncia, cuja improcedencia verificou.

Quanto ao operario Domingos Quintanitha esclarece a Companhia que, transferido de um cargo para outro com o mesmo salario, houve abandono de serviço por parte desse empregado. Acrescenta que, "após ter complotado o decenio 1917-1927", abandonou ele espontaneamente o serviço, a.o qual regressára 
em 1931. Não houve, entretanto, inquerito que precedesse essa. demissão, pois faltava a esse operario o requisito da continuidade do serviço.

T. Não cabem as alegações inieiais da Companhia:

12 - porque, desde que forcado pela policia, deixava de se caracterisar o abandono de emprego pelos reclamantes;

$2 \varrho$ - porque, apurada que foi a improcedencia da denuncia, cabia á Companhia reađmiti-los em seu serviço, uma vez que se não verificavam as hipoteses do art. 53 dos Decs. 20.465 e 21.081.

Quanto á indenisação por parte da Estrada, que, segundo a opinião por ela defendida, caberia aos operarios reclamar, seria estranho que o poder Publico ficasse tolhido em sua acção preventiva por indenisaêões dessa natureza. O Codigo Civil se refere, no art. 1.550 citado, ao constrangimento da liberdade causado pelas pessôas naturais e juridicas de natureza civil. opina, assim, esta Procuradoria, que, rejeitados os embargos, seja pedida á Companhia Estrada de Ferro e Minas de são Jeronimo a remessa do certificado de tempo de serviço e da folha de antecedentes dos reclamantes.

Quanto ao caso de Domingos Quintanilha, em que não houve inquerito administrativo e que a Companhia confessa ter mais de dez anos, deve esse reclamante, de acôrdo com a recente decisão do Sr. Ministro do Trabalho no caso de João Rolino Xavier e Edison Guerra Dias, ser readmitido ao serviço, sendoIhe pagas as quantias referentes aos selarios do tempo em que não teve remuneração de outra empresa.

Rio, 5 de fevereiro de 1935.

I.A/

odylol Adjunto do Procurador Geral, em comissão. Qur.got. $5 / 2 / 35$ 
CONCLUSÃO

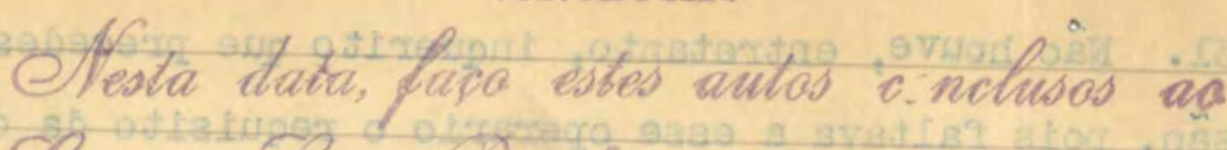
Exmo. Olmi. Eresidente.

Om 9 de Feverevio de 1935

Director da Secretaria

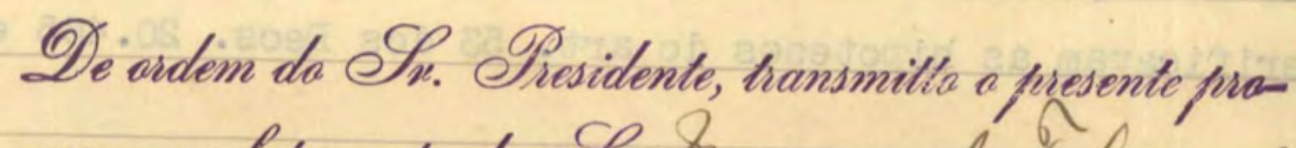

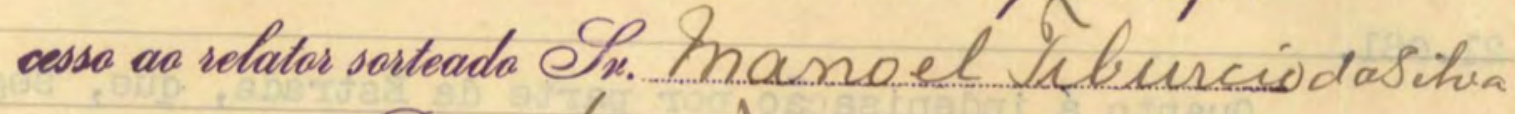

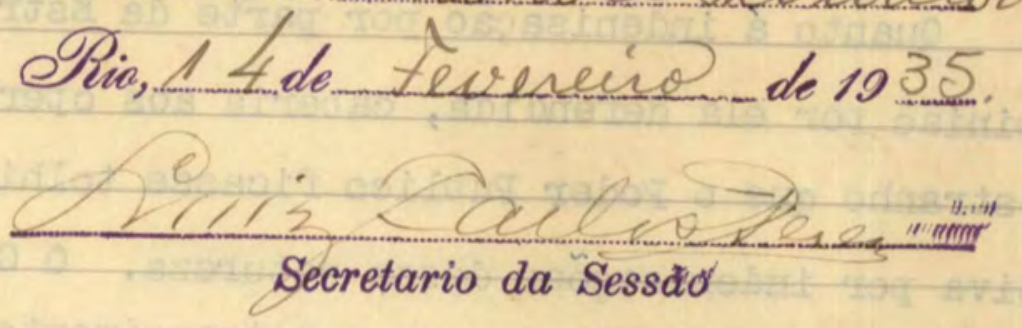

Georhido pelo Sr. hamoe fil uncio. Ris, 14.3 .35 .

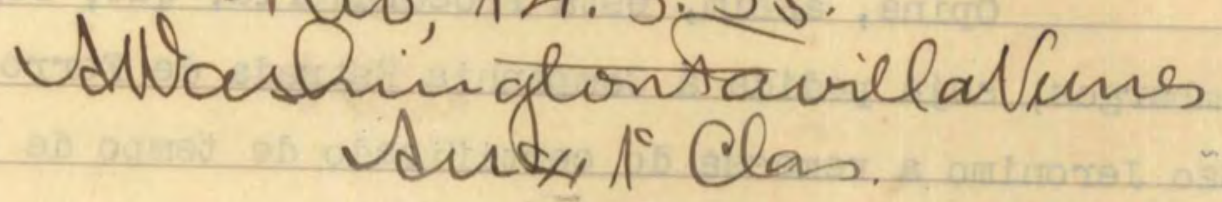

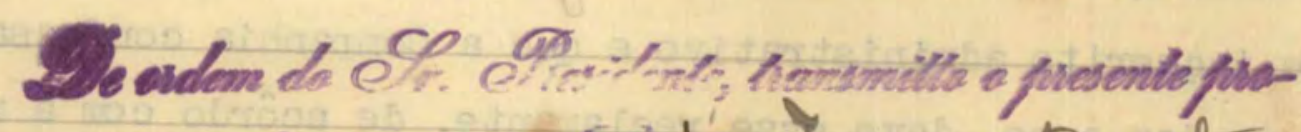

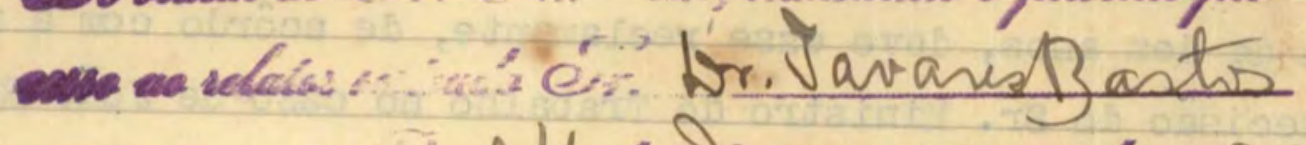
cis, 14 s. Maves de 1935 
Ministerio do Trabalho, Industria e Commercio

Secção

CONSELHO NACIONAL DO TRABALHO

Proc: $9: 582 / 34$

\section{ACC ORDÃO}

$\mathrm{Ag} / \mathrm{SSBF}:$

$19_{35}$

V1stos e relatados os autos do processo em que são partes: como embargante, a Companhia Estrada de Ferro e Minas de São Jeronymo, e embargados, Domingos Mantilha e outros;

Cons1derando que a 2 a Camera deste Conselho, em sessão de 16 de Novembro do anno proximo passado, conhecendo da reclamação apresentada por Domingos Mantilha e outros, res®lveu converter o julgamento em diligencia afim de que a referida Companhia enviasse o Inquerito administrativo a que responderam os supplicantes, e, bem assim, o certificado do tempo de serviço e folha de antecedentes dos mesmos;

Cons1derando que a essa dec1são oppoz embargos a reclamada;

Cons1derando que, no caso, não cabem embargos, visto consistir a mesma em méra diligencla, tida como necessaria para o julgamento do felto;

Resolvem os membros do Conselho Nacional do Prabalho, reunidos em sessão plena, confirmar a decisão embargada, por não caber recurso contra a dec1são que converte o julgamento em d1lalgene: cla, determinando que a Empreza:

a) reintegre Domingos Mantilha, visto ter flcado provado, por força da interpretação dada pelo Snr: Ministro do Trabalho, que - mesmo conta ma1s de 10 annos de serviço, e não ter respondido a Inquerito administrativo; 


$$
84
$$



reclamantes:

R1o de Jane1ro, 25 de Abril de 1935:

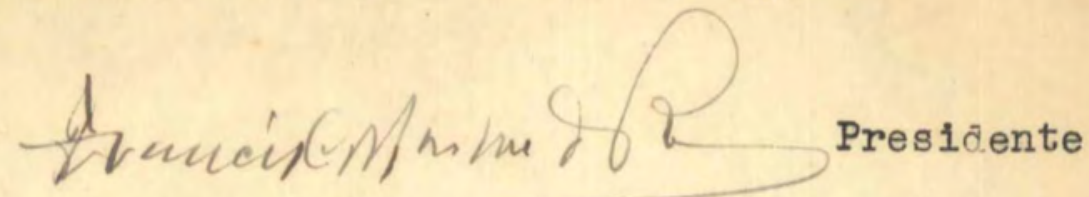

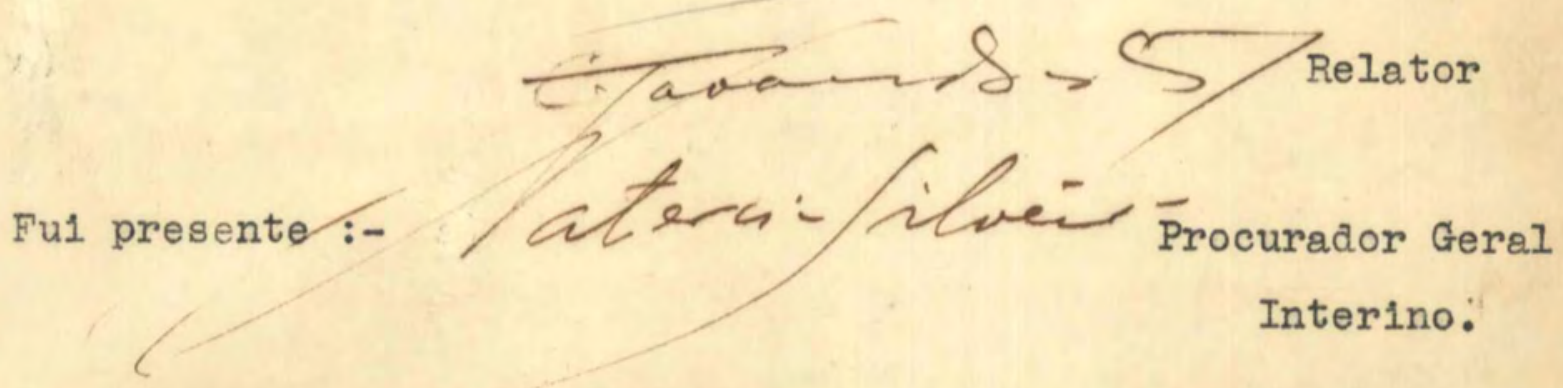

PUBITOADO NO DIARIO ORTHCTAL

Em. 28 do yumbo do 1935

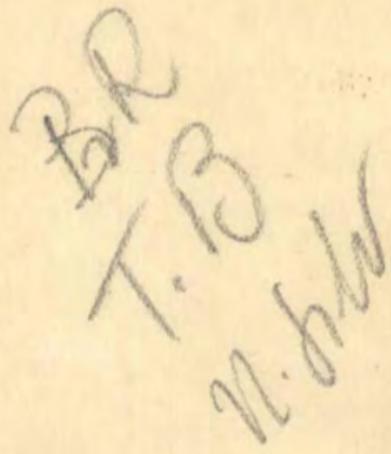


pes.49

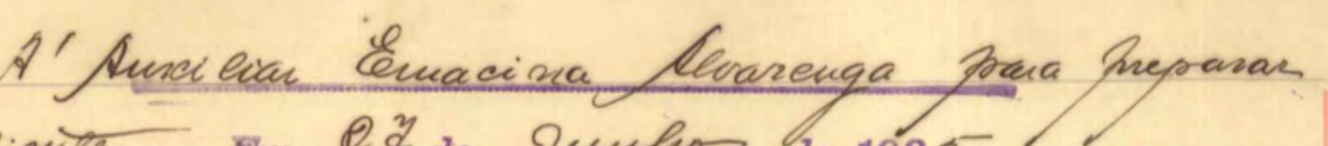

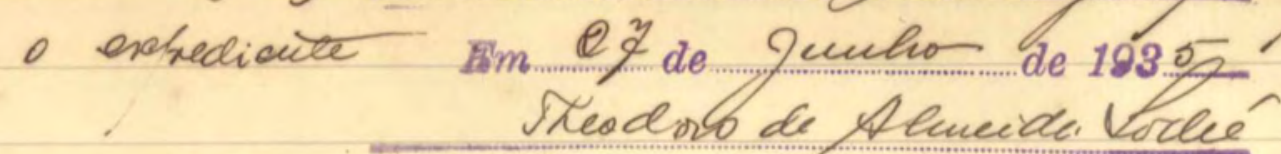

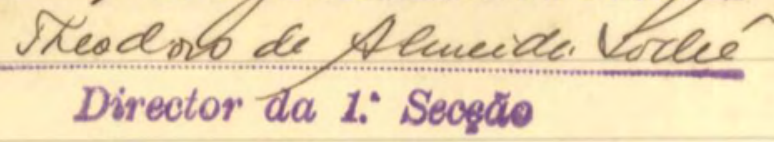

Cimprids $24 / 6 / 935$ Cemarina of Othareuga otux. 
Proc. $9 \cdot 582 / 31 / 2$

EA/

29. Junho

NOTIFICAC IO

Sr. Director da Companhia Estradade Ferro e Minas de S. São Jeronymo

$$
\begin{gathered}
\frac{\text { Rua Paysandú, 219 }-2^{\circ} \text { andar }}{\text { Porto Alegre }} \\
\text { Rio Arande do Sul }
\end{gathered}
$$

De ordem do Sr. Presidente, transmitto-vos copia authenticada do accordão proferido pelo Conselho Nacionel do Trabalho, om sessão de 25 de Abril p. passado, nos autos de processo en que são partes: como embargante essa Companhia, e embargados Domingos Mantilha e outros. Outrosin, fica essa forrovia notificada para, dentro do prazo regulanentar rointegrar aquelite empregado no serviço, bem como seja encaminhado a essa Secretaria o certificado de tempo de serviço dos demais reclanantes. Saudações 
A guisa de introito
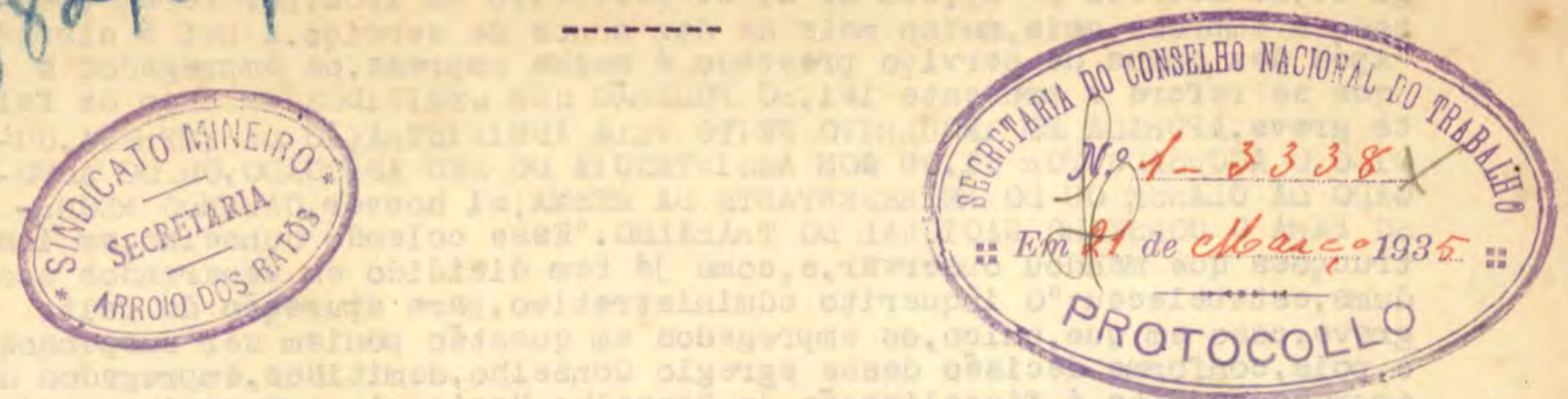

HSsa colenda Côrte de Justiça para as questões de traba tho ha, de certo,estranhar que estas allegações lhe se jam submetidas a conhecimento, não cientro dos autos, oncle foi feita a reclamação dos pre judicados, mas, por esta forma. É que desses autos, só le teve noticia, na Inspectoria Regional do Tra palho, por mera informação do snr. Histevão Lobão, auctoridade do governo junto ás Caixas de Aposentadorias e Pensóes, informou ao advogado deste syndicato, em De zembro do anno passado,sem the mostrar os referidos autos, que esse egregio Conselho os baixar em deligencia, para: a/ ser-ihes junta a folha de antecedentes dos empregados despedicios; b/ procedimento do inquerito administrativo comprobatorio da falta invocada para auctorisar a demissão dos reclamantes. Informou, ainda, sua senhoria, que nessa occasião a empresa empregaciora, -0 1a.ustracia de Ferro e Minas são Jeronymo, por seus advogados, havia feito juntar aquelles autos, uma defeza,que, na opinião a dalisada de sua senhoria,era um traba tho brilhante.0s reclamantes, este syndicato, por seu advogado, nunce conseguiram ver, nem os autos em referencia, nem sobre a alludida defeza,e, como já lá vão treis mezes, sem que se saiba, se foram ou não cumpridas as deligencias orcienaclas,é que este syndicato resolveu fazer presentes a esse egregio Conse tho estas allegaçóes.

$$
\text { -- } 0 \text { facto--- }
$$

עomingos Mantilha,liberalino Machacio, kapheel Mezza, Thomaz Gonçalves da jilve e João Keenn,empregados da empresa empregador sobre mencionada, com muito ma is de dez annos de serviços continuos, foram despedidos,sem motivo algum e sem formalidade alguma. Este syndicato, por multo tempo, insistiu para conseguir amigavelmente a reintegração dos pre-ditos operarios demitidos, seus associados. Isto fez por intermedio dos membros e sua virectoria e,por seu advogado. Vendo baldados seus esforços, fez, então, por seu advogado procederem em juizo a uma justificaçă, em que se provou:a/ que os empregados demitidos nunca praticaram qualquer acto de improbidade que os incompatibilisasse com a empresa empregaciora; b/ que nunca se deram a vicio da embriaguez habitual, ou se apresentaram embriagacios ao serviço; c/ que jamais tiveram mau procedimento, ou desidia no desempenho de suas funcȩốes; d/ que nunca violaram qualquer segredo que, por força de seus cargos,estivessem de posse; e/ que jamais praticaram actos de indisciplina ou de insoburdinação; f/ que nunca a bandonaram o serviço sem causa justificada; g/ que, emfim, jamais praticaram actos lesivos da horrra e boa fama, em serviço, ou fora, contra quem quer que se ja, ou offensas phisicas, nas mesmas condições,nem,em caso de legitima defeza propria ou de outrem. Com essa justificação, conforme figura de juizo,por não estar em Porto Alegre o Dr. Estevão Lobão, que a esse tempo,se encontrava na cidade do nio Grande, depois de esperal-o uns dois mezes, a conse tho da Inspectoria local, este unndicato, por seu advogado, entrou com uma petição de reintegração no serviço e demeis pronunciações de direito, na qual, se descreveu em linhas sobrias e exactas o facto jurigenio, para que a refericla Inspectoria encaminhasse o feito á auctoridade competente.Mils alguns mezes passaram.0 yndicato, por seu advogado recebeu da uita Inspectoria, communicação que o feito fora encaminhado a Dr. Estevão Lobão, auctoridade, a quem competia a sua tramitação.Outros mezes, se passaram, sem se saber de ma is nada, apenas, que o feito fora encaminhado para esse Colendo Conse Iho.Em vezembro do anno passacio, como acima já disse, foi o nosso 
advogado informado, 011 pelo Lr. Estevão Lobão,que o feito baixara em deligencia, para os fins supra mencionado.s, até hoje, ma is nada. A menos, que fizessemtudo á revelia deste syndicato e do seu advogado que é o clos reclamantes.

$$
\text { -- Dedução do direito-- }
$$

Pelo exposto e pelo que está provacio nos autos, ve-se á plena luz, que os empregados despedidos, não o podiam ser em absoluto, ex $-\nabla i$ do artigo 53, do Decreto $\mathrm{N}^{2} 21.081$ de 24 de Fevere 1 ro de 1932 , por terem prestado á empresa, mais, thuito mais de dez annos de serviço.A Lel é clara" "Após dez annos de serviço prestado á mesma empresa,os empregados a que se refere a presente le1, SO POLEKÁ SER DEMIT DOOS, em caso de falto grave, APURADA EMI $L$ INQUNRITO FEITO PELA ADMIN IST KAÇAO DA EMPRESA, OUVIUO U ACCUSADO POK SI, OU OOM ASOISTENO $\perp A$ DO SEU ADVOGADO, OU DO ADVOGADO LA OLASSE OU DO KEPRESENTANTE DA ME'SMA, $S I$ houver, OABENLO KEOUKSO PARA O CONSELHO NAOIONAL DO TRABALHO "EsSe colendo Conse Iho,em Instrucções que mandou observar,e, como já tem dicidido em venerandos acordums, estabeleceu: "0 inquerito administrativo, para a puração da falta grave, caso em que, unico, os empregados em questão podiam ser suspensos, e,pols, conforme decisão desse egregio conse lho, demitidos, empregados de empresa sujeita ó fiscalisação do Conse lho Nacional do Trabalho, se iniciará por portaria desta,assignada por sua directoria ou quem legalmente a represente, da qual constarão a falta a apurar, descrita com clareza e precisão e a commissão apuradora nome ada, que se comporá de tre is membros, presidente vice-presidente e secretario.Constituida a commis são, dizem nas preditas instruçóes e o accordo desse colendo conselho de 8 de Março de mil novecentos e trínta e quatro, está clentro de cinco clas se reuniré,e, lavrada e assignada a acta de installação, desig nará local, dia e hora para audiencia do accusado por si ou assisticio de seu advogado, ou representante do syndicato da classe si houver e,em seguida,das testemunhas que tiverem sido indicadas e cujo numero não poderá exceder de sete, para que ordenará as respectivas intimações, que serão feitas por carta mandado o edital.0 que feito, serãoautuadas a acta,portaria e mais peças, para formação do processo.o secretario incontinenti lavrará um requerimento de intimação e, assignado mesmo pe lo presidente, The dará ponto cumprimento, devendo delle constar não só a a falta apurada como o nome uas testemunhas e a declaraçáo de que o c1tandose poderá fazer do seu advogado, ou ser assisticio pelo advogado ou representante do syndicato a que pertencer.uumpridas estas formalidades, é Intimado o accusado. Este, no instrumento de int imação de que se Ihe de, rá segunda via, lançará o sciente datada e assignacia. Intimada as teste munhas,é feito o sumario de inquerito, podendo o accusado na forma ac ima reinquirir as testemunhas ue accusą̧a,o, of ferecer defeza juntar documentos e indicar testemunhas suas. só uepois poderá o presidente do inquerito, em linguagem serena e desapaixenada, fazer minucioso relatorio do processo apreciando provas e argumentos de perte a parte, concluindo pela procedencia ou não da accusa çắo. No caso della nacia se fez,nada fizeram, nấo cumpriram o artigo 11 das instruções em apreço, violaram o art1go 12 das mesmas e até hoje,os tentaram um descienhoso despreso pela Lei e pela juispradencia, desse colendo Conse tho.viante desse despreso erritante, infustificavel; do silencio tumular deixado cair propositadamente, teimosamente, sobre os aireitos sagrados dos empregados despedidos pela empresa e pe $1 a$ auctoridade de direito a que compete a casos tres, é que este syndicato, contra gosto, se ve constrangiclo a levar ao conhe cimento desse colendo Conse tho os factos graves soore esplanados, para que se restabeleçam o imperio da lei e, com ella os direitos dos operarios pre judicados;isto é :se jam readimitidos nos seus serviços e pagos de seus vencimentos atrazados. Domingos Mantilha, Thomaz Gonçalves da sil$\mathrm{va}$, de pois de largo tempo, não podendo trabalhar, foram readimitidos nos seus serviços mas não foram indemnisados do tempo,que foram impedidos de trapalhar. Nestes termos, confiante,espera

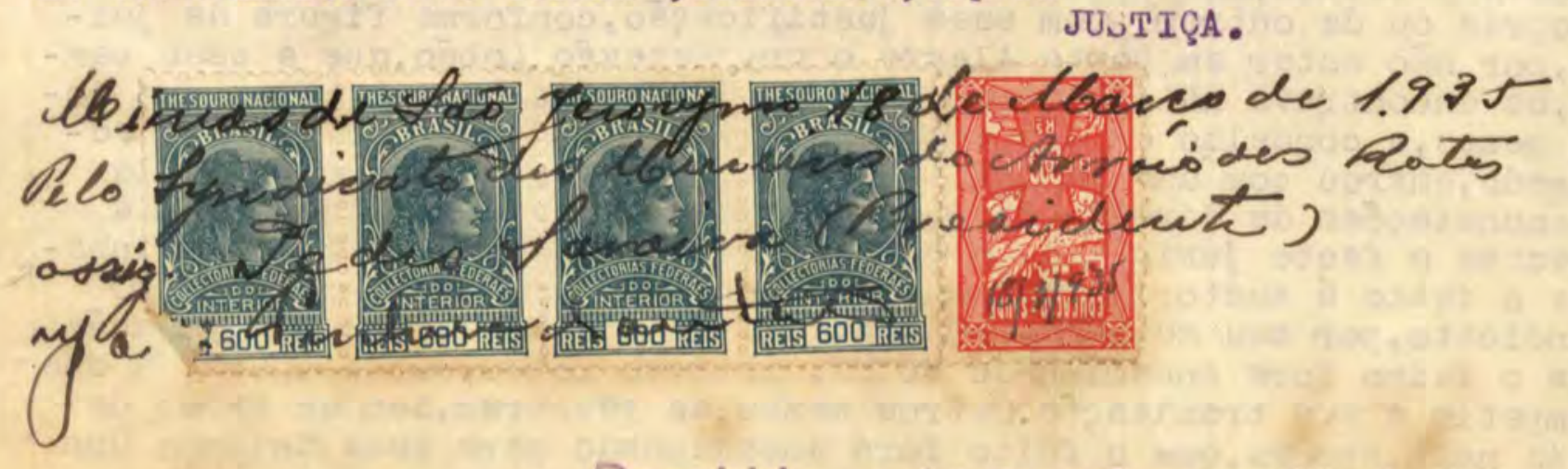

Recebido na 1.4 Secção em 22-3.35 
0 assempto de que trata o officio do Syndicato Mineiro do Arroio dos Ratos prende-se ao inquerito administrativo mandado instaurar pela Companhia Estrada de Ferro e Minas de São Jeronymo contra diversos dos. seus empregados, - qual tomou no Protocollo Geral deste Conselho o ne $9.582 / 34$.

Segundo informação do encarregado protocollo Qesta Seção, o referido processo foi distribuido ao Auxiliar Iergamine de Abreu, para redigir accordão, em 14 do corrente mez.

Devendo o citado documento ser juntado áquelle processo, transmitto-o so Snr. Director desta Seção, para as devidas providencias.

Retardado devido ao accumulo de sertifgo of meu cargo.

Primęira seçãa, 20 de Mpio de 7 \%

1 of official

Po dm Benganui de duen para/ üorma

in 28 de lecaís de $193^{5}$

Sheodoro de Acuride Noce

Director da 1. 'secsão

6 processo acima referido ainda reão está desenubaraçado.

En. $1 / 6 / 35$

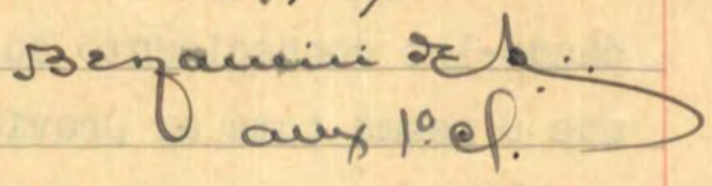

Teuto passabo o purceso acon. Airect, en if decke my, pasaso ste socumutio a S.C.

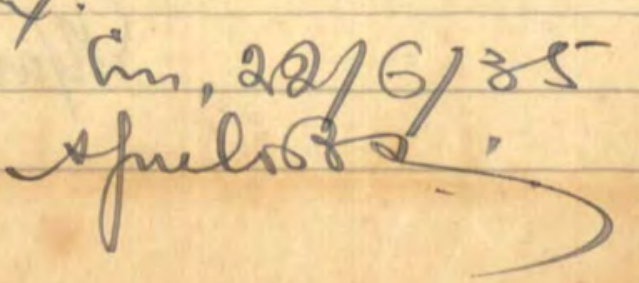




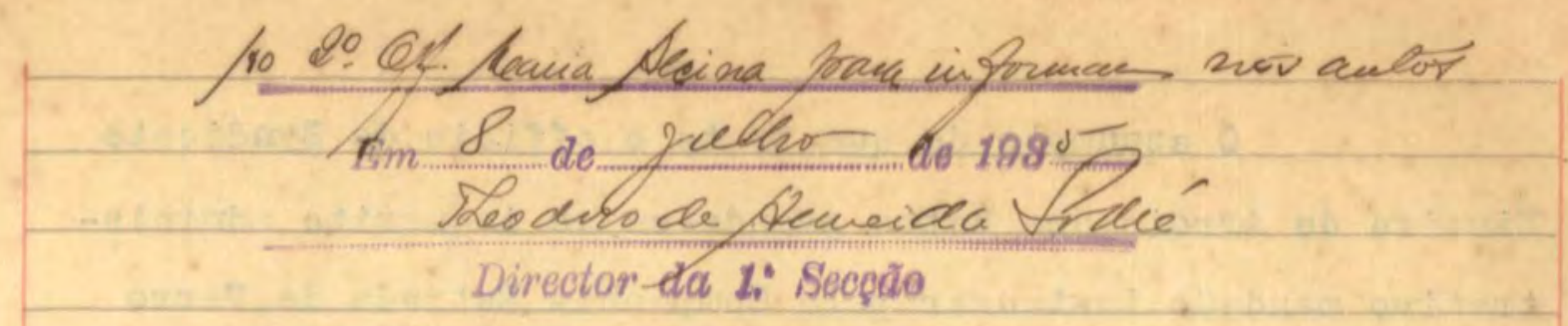

Rec. em $9 / 7 / 935$.

- INFORMACÃO -

O Synd1cato M1ne1ro Arro1o dos Ratos, tendo em v1sta a reclamação apresentada a este conselino pelos seus associados Dom1ngos Mant1lna, L1beral1no Machado e outros, dem1tt1dos pela C1a. Estradas de Ferro e M1nas de São Jeronymo sem o devido 1nquer1to administrat1vo, embora contassem ma1s de 10 annos de serv1ço, protesta contra a morosidade deste Inst1tuto emi julgar o referido processo.

Não procede a reclamação daquelle syna1cato, porquanto o Egreg10 Conselho, por accordão de 25 de Abr1l ult1mo, resolveu desprezar os embargos offerecidos pela compannia á resolução do mesmo conselno, proferıda em sessão de 16 de Novembro de 1934, conf1rmando ass1m aquella dec1são e determinando a re1ntegração de Domingos Mant11ha, bem como sol1c1tando a remessa do tempo de serviço dos dema1s reclamantes (accordão de 1ls. 47 \& 48 ). Por off1c1o ne 1.873, de 29 de junho ult1mo, desta secretar1a, fol a referida Companhia scientificada daquella dec1são.

Ass1m, proponino, salvo melnor juizo da autoridade superior, que se officie ao syndicato acima referido, dando-lhe conhec1mento do accordão deste conselho, afim de que o mesmo tome as providenclas que julgar necessarias.

Ao Sr. D1rector desta secção, jara os devidos f1ns.

Q1/ R10, 11 de Juino de 1935.

aria Aleira Marquer de La'.

$$
\text { 2. official }
$$




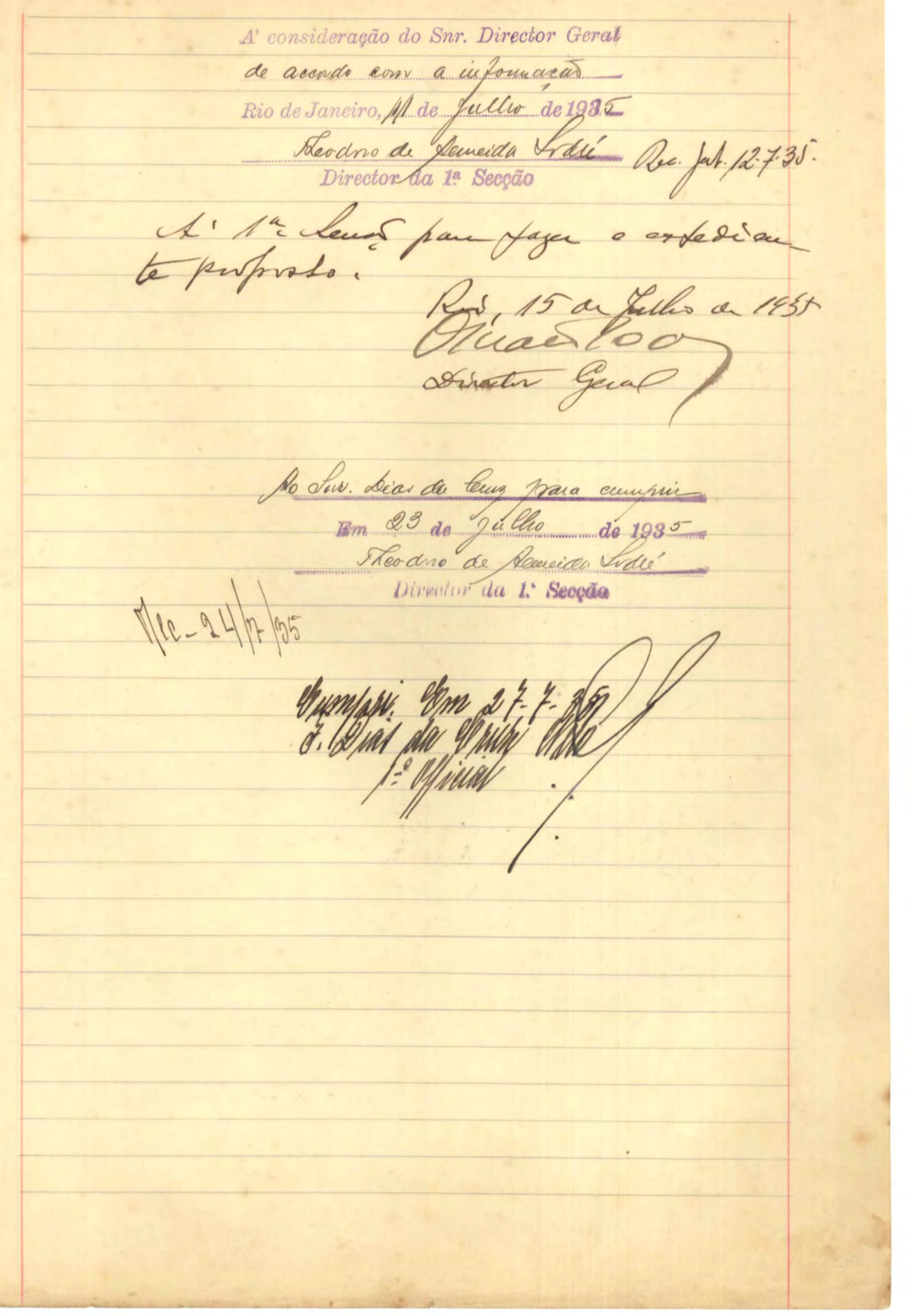


Proc. $9.582 / 34$.

$\mathrm{CN} / \mathrm{SSBF}$.

Sr. Prosidente do Syndicato Mineiro do Arroio dos Ratos. Minas Geraes.

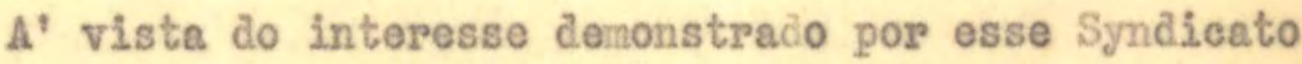
no caso do processo em que Domingos llantilha e outros reclanarn contra a Bstrada de Ferro linas de Säo Jeronymo, cabe-me decla-

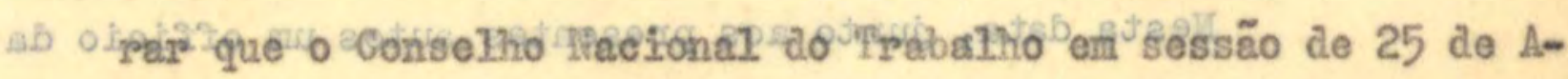

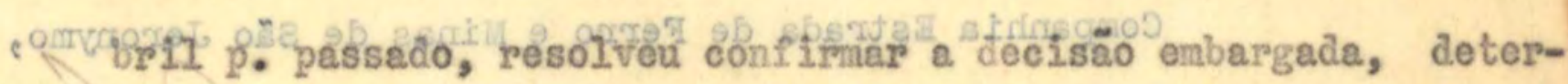
minando que a timpreza:

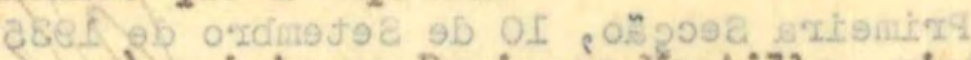

a) peintegre Doringos llantilha, visto ter ficado provado, por Porech da interpretaça cada pelousr. Ministro do Trabaltho, Industria e Comereio, que ơ mosmo conta mais de dez annos de sefviço, e näo ter respondido a inquerito administrativo;

b) ronetta o certificado de tempo de serviço dos demais reclrnantes.

Outrosim, comnunico-vos que a. Companhia Estrada de Ferro Minas de São Jeronymo foi scientificada dessa decísão, por beficio n: 1-873, de 29 de Junho ultimo, a qual foi publieada no Diario official de 28 do mesmo mez.

Attenciosas saudações.

Director Geral da Secretaria. 



\section{$11 \%$ \\ Cia. O. e\% e ellinas \\ de efre

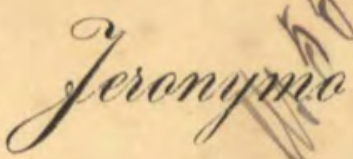

Porto Alegre, 5 de Agosto de 1935

Illmo. Snr. Presidente do Conselho Nacional do Trabalho

DISTRICTO FEDERAL

A Companhia Estrada de Ferro e Minas de são Jeronymo, na reclamação de Domingos Nantitha e outros (proc. $\mathrm{n}^{2} 9.582 / 34$ ), vem cumprir o accordão de 25 de Abril nelle proferldo pelo E.Consetho Nacional do Trabatho no attinente á remessa de certificados do tempo de serviço dos reclamantes a quen o mesmo accordão se refere; para o que, inclue ditos attestados, em numero de sete ( 7$)$, e mais um, passado pela Delegacia de Policla de são Jeronywo, relativo aos reclamantes ex-operarios Adalberto Azambuja dos Santos, Rafaez Meza e Liberalino Machado de Lima.-

\section{Respeitosas saudações.-}

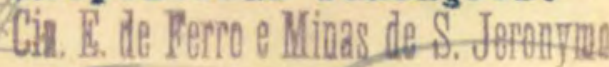

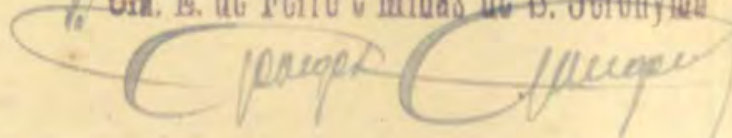

ANNEXOS: Attestados de tempo de serviço de Liberalino Nachado de LIma

Adalberto Azambuja dos Santos

Thomaz Gonçalves da Silva

Antonio Nunes das Pedras

Joäo Keenan

Raphael Nezzas

Domingos Mantilha

Attestado da Delegacia de Policia de s.Jeronymo.
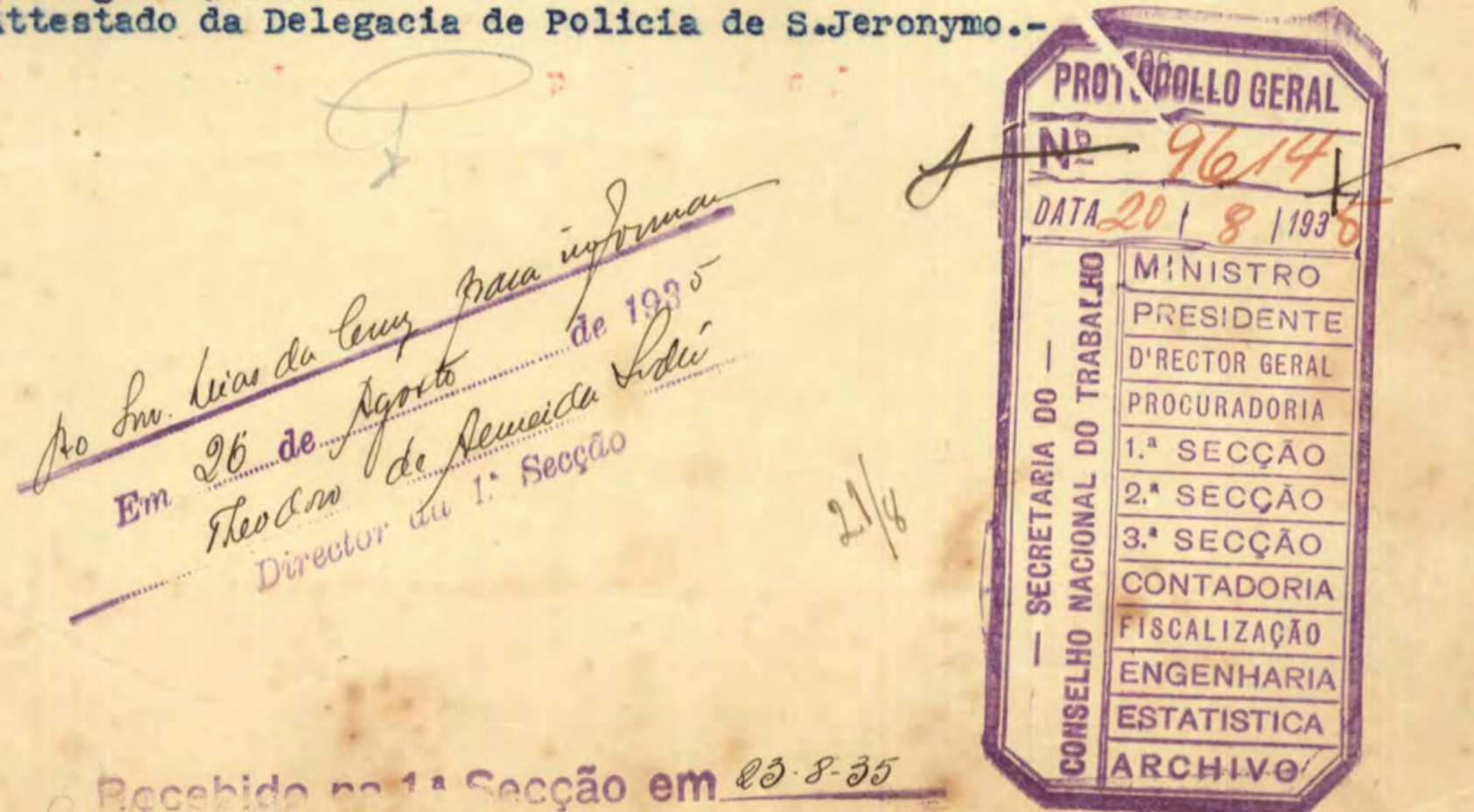
Campantia Estuada de Trevra e ellinas de Sfá

MINAS, 13 de Julho

de 1935 .

\section{A T TESTADO}

Attesto que o ope rario LIBERALINO MACHADO DE LIMA, trabalhou nesta Companhia de Julho de 1931 ate Marogo de 1934.

Mina s,13 de Julho de 1935.

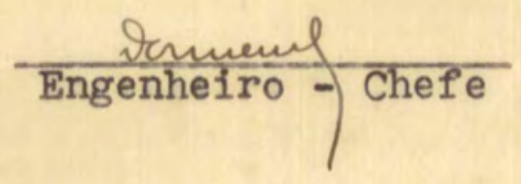


Comprantia Estrada de erevro e ellinas de efáa

$$
\text { MINAS, } 13 \text { de Julho }
$$

de 1935

\section{A T TESTA D O}

Attesto que o operario ADALBERTO DOS SANTOS AZAMBuJA, trabalhou nesta Companhia de $1^{2}$ de Janeiro de 1927 até 6 de Março de 1934.-

Mira s,13 de Julho de 1935.

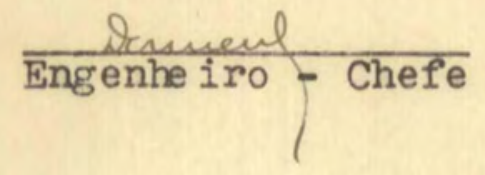




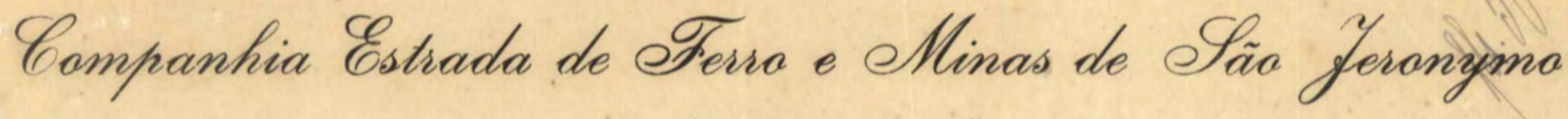
MINAS, 13 de Julho de 1935.

\title{
A T T E S T A D O
}

Attesto que o operario THOMAZ GONÇ\&LVES DA SILVA trabalha na Companhia desde $1^{2}$ de Dezembro de 1912 até a presente data.-

\author{
Minas,13 de Julho de 1935. \\ $\frac{\text { Acmuenl }}{\text { Engenheiro - Chefe }}$
}




\title{
Campanhia Estrada de Teria e ellinas de efáa feranyma MINAS, $16 \mathrm{~d} \theta$ Julho de 1935
}

\author{
A $t$ t e s $t$ a d o
}

Attesto que o operario Snr. João Ke enam, trabalhou nesta Companhia, de 18 de Janeiro de 1925 até fins de Junho de 1929, e em epocha anterior a qual não se póde precisar por terem sido destruidos os archivos em incendio occorido no nos so Almoxarifado em meados de 1927.

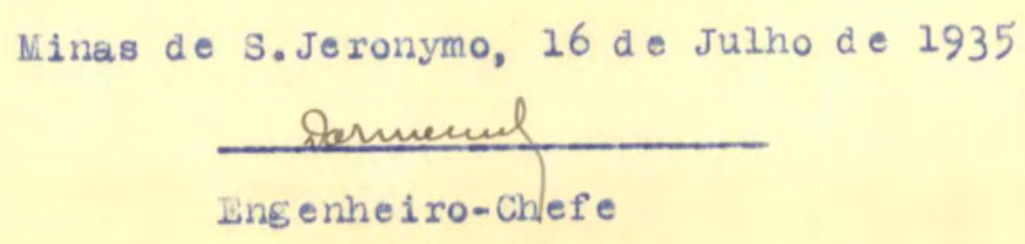




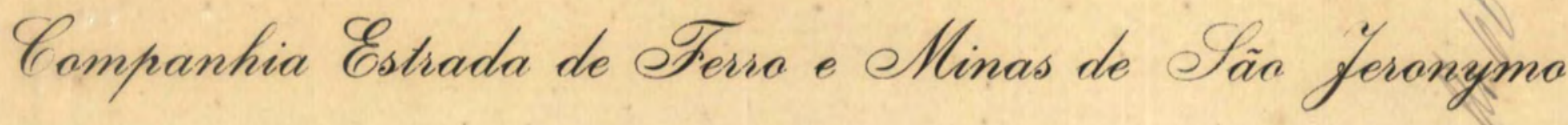
MINAS. 13 de Julho de 1935.

\section{ATTESTADO}

Attesto que o opezario ANTONIO NUNES DAS PEDRAS, trabalhou nesta Companhia de 12 de Janeiro de 1928 até 6 de Março de 1934. -

Mina s,13 de Julho de 1935.

Sarmenul

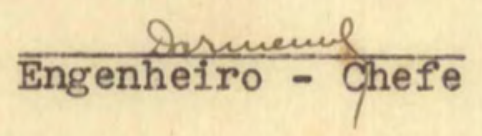




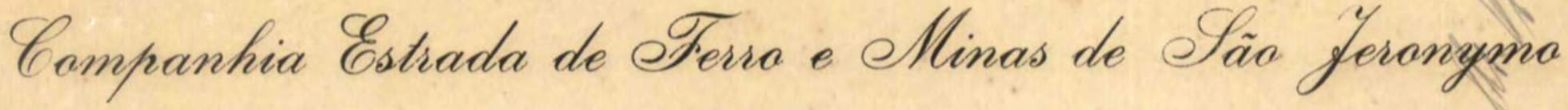
MINAS, $13 \mathrm{de}$ Julho de 1935 .

\section{A T TESTADO}

Attesto que o operar io RAPHAEL MEZZAS, trabalhou nesta Companhia de $1^{2}$ de Setembro de 1919 até 6 de Março de 1934.

Mira s,13 de Julho de 1935. Engenhe iro - Chefe 
Campantia Estuada de Trevio e ellinas de efra

\section{A T T E S T A D O}

Attesto que o operario DOMINGOS MANTILHA, trabalha nesta Companhia de 5 de Outubro de 1918 até Agosto de 1931, e de Setembro de 1933 até esta data.-

Minas,13 de Julho de 1935.

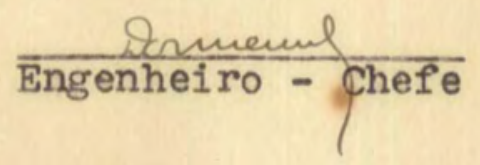


DELSGACIA DE POLICIA DE SĨO J GRONYNO,20 de Jülho de 1935.

Declaro-vos que os ex-operarios da mina de carvão de propriedade da Companhia que representaes neste Estado, Adalberto Azambu ja dos Santos, Rafael Meza e Liberalino Machado de Lima, quando em serviço na referida mina foram accusados de se ackarem envalvido em factos subversivos da ordem, como o diz a acta da sessão do Syn dicato dos Mineiros daquella mina, de 15 de Fevereiro de 1934 e por tal motivo compareceram perante autoridades judiciariasesta doais, perante as quaes se comprometeram a abandonar aquella mina. I' o que pósso informar, attendendo ao pedido que me fizestes.

Saúde e Fraternidade.

Illmo. Snr. Georges Gougenhein,

D. Delegado da Directoria da Companhia $\mathbb{Z}$. F. M. S.Jeron ymo.

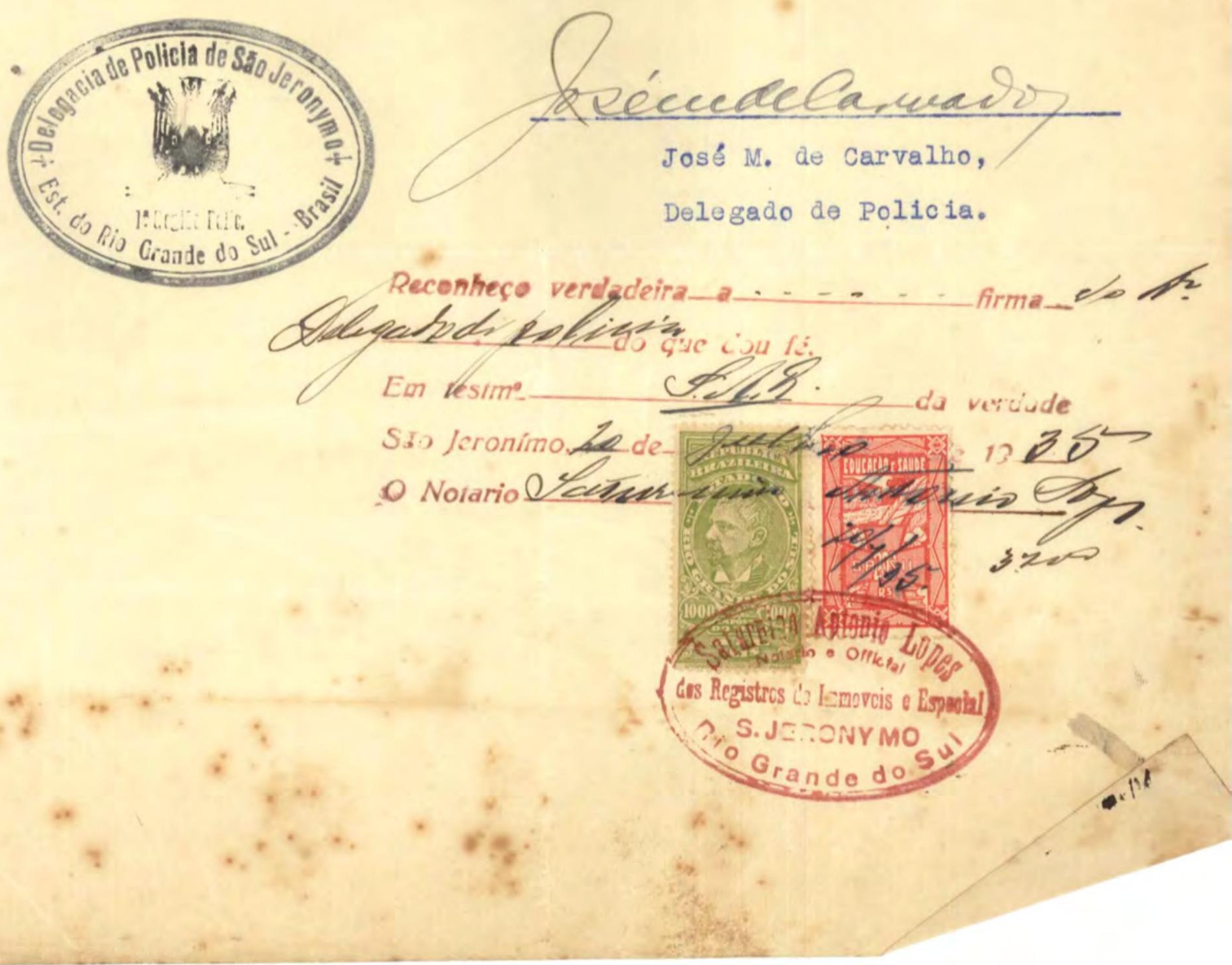




\section{INFORMACAO}

O Ifgregio Conselho Nacional do Trabalho, apreciando os presente autos de processo em que são partes: como embargante, a Companhia Estrada de Ferro e Minas de São Jeronymo, e embargados, Domingos Mantilha e outros, em sessão plena de 25 de Abril ultimo (accordåo de 1 Is. 47/48, püblicado no "Diario Official" de 28 de Junho seguinte), resolveu confirmar a decisăo embargada, por nấo haver recurso contra a decisão que converte o julgamento em diligencia, determinando que a Empreza: a) reintegrasse Domingos Mantilha, visto ter ficado provado, por força da interpretação dada pelo Snr. Ministro do Trabalho, que o mesmo contava mais de dez annos de exercicio, e năo respondeu a inquerito administrativi; b) remettesse os certificados do tempo de serviço dos demais reclamantes.

Imm cumprimento a essa ultima parte da resolução deste Conselho, Companhia Estrada de Ferro e Minas de São Jeronymo, com o officio de fls. 54, encaminha os alludidos certificados em numero de sete, e mais um, passado pela Delegacia de Policia de São Jeronymo, pelo qual, verifica-se que os reclamantes Adalberto Azambuja dos Santos, Rafael Meza e Liberalino Machado de Lima, quando em serviço da mina, foram accusados de se acharem emvolvidos em factos subversivos da ordem e, por tal motivo, compareceram perante as autoridades judiciarias estaduaes, onde se comprometeram a abandonar aquella mina.

Com a juntada dos documentos em questão fica o presente processo em condiçőes de ser submettido á alta consideração de una das Camaras deste Conselho, ouvida previamente a Douta Procusadoria Geral.

Ao snr. Director desta secção, para os devidos fins. Excedido do prazo regulamentar devido ao accumulo de serviço a meu cargo. 
Primeira secçă, 10 de setembro ad 1935

I2 official

A' consideração do Snr. Director Glral de acevido com a in Pomacar racipra Rio de Janeiro, 18 de Lecau ho dej $935-$

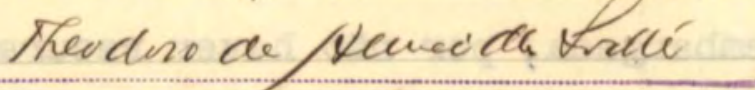

Director da 1? Seçãa

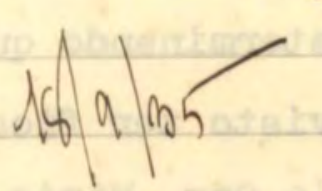

VISTO-Ao Snr. Dr. Procurador Geval, d. oriem do Exmo. Snr. Presidente.

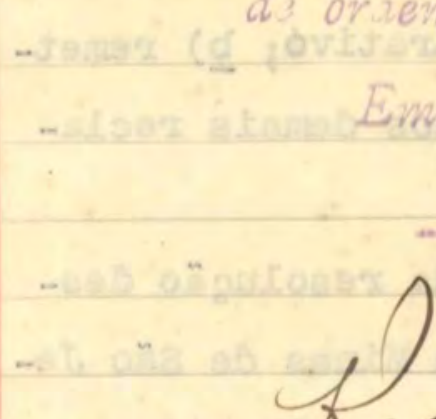

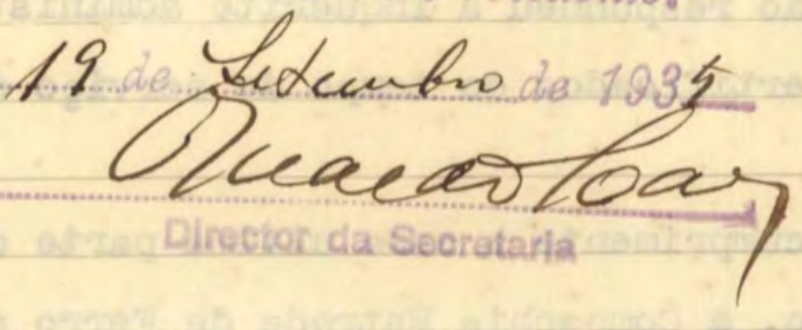

Kequin eypm avisios a vitevems.

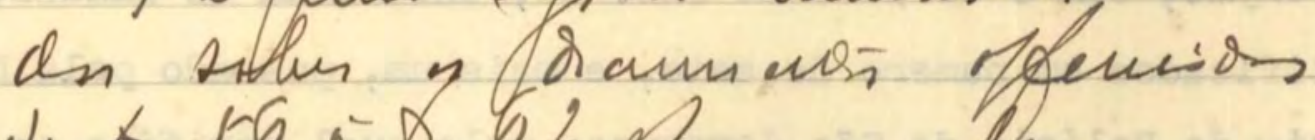
us os 56 - D. 2.

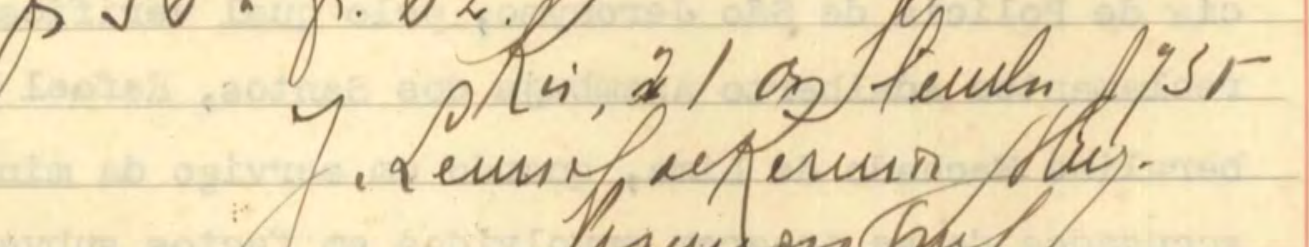
Pircuxiongef.

Reabs foh. 23-9-3r

D'Ik veuns par foger enterrent dias.

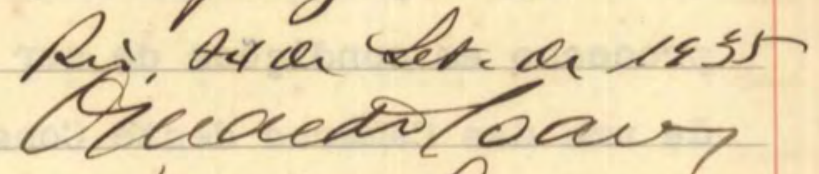

ofinectur facap

Recebido na 1: Soç̧ão em 24 / 9 / 25. 


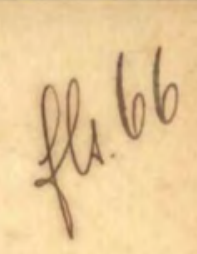

Proc.9.582/34.

$\mathrm{CN} / \mathrm{SSBF}$.

Srs. Domingos Hantil tha e outros

A/C do Syndicato Mineiro do Arroio dos Ratos

Rio Grande do Sul

De accordo com a promoção Geral deste Conselho, communico vos será concedida vista nesta Secretaria, pelo praza deriso dias, doß autos de processo em que reclamais contra a Companhia Estrada de Ferro e Minas de são veronymo, afim de que inforneis a respefto dos attestados de tempo de serviço fornecidos pela Empreza reclamada. 
Whe

- AB

- Treoviso

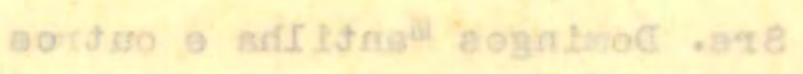

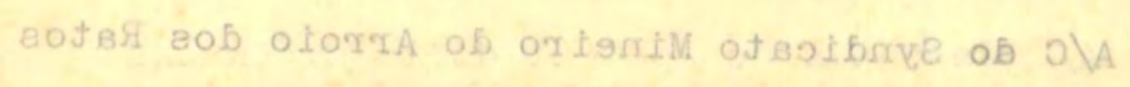

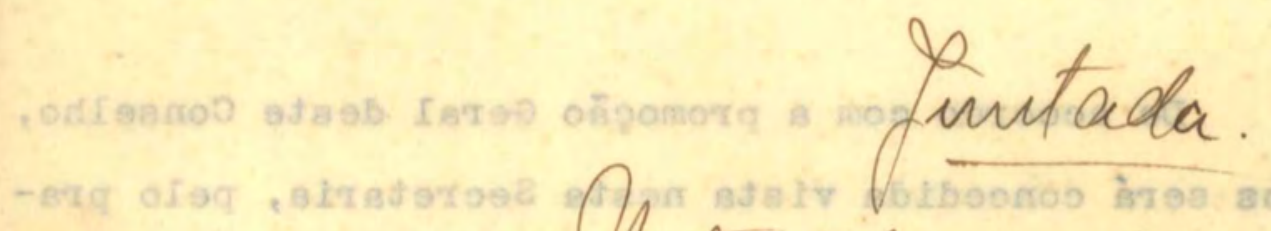

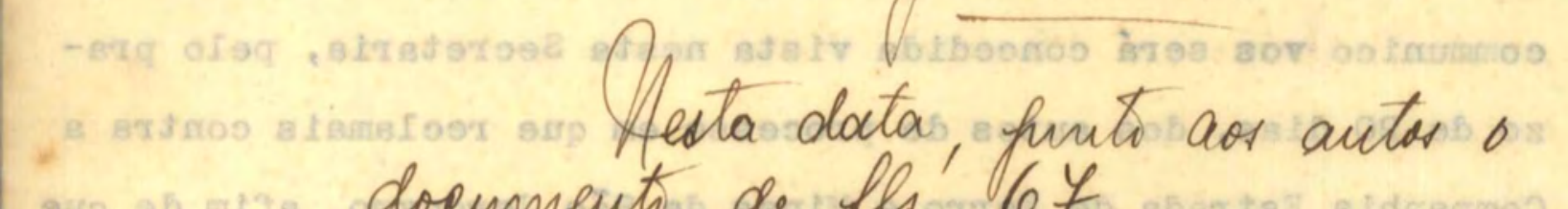

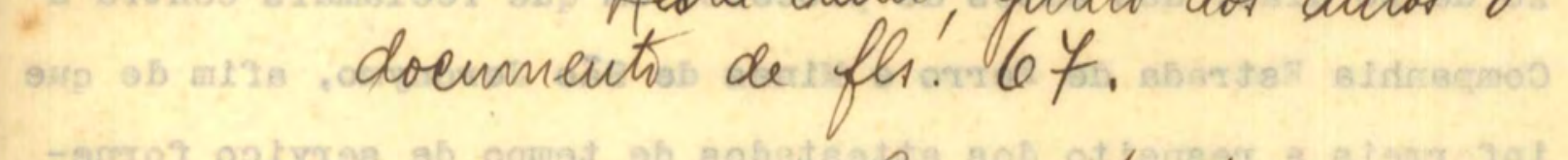

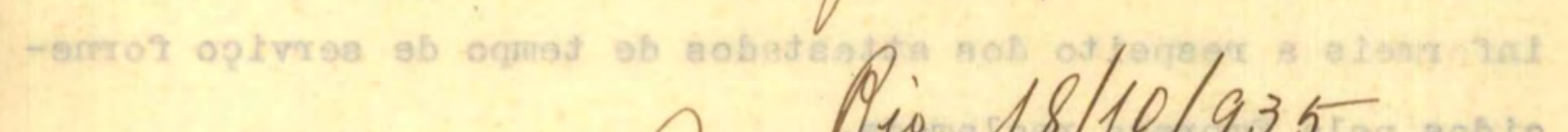

Maria Alema CHarquer abio - 2 . off.

- alceteroes ab fareo rotoerta 
1 De RECTOR GERAL

욤 PROCURADORIA

$\leq$ 1." SECCAOO

\section{Мая АЯ}

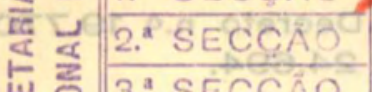




$$
\text { fla. } 108
$$

O Syndicato dos Mineiros - Arroio dos Ratões accusando o recebimento do officio desta secretaria, constante de 'ls. 54 destes autos, no qual the é communica a decisão do Igregio Conselho no processo em que Domingos Mantilha e outros reclamam contra a Cia. Estrada de Ferro e Minas de São. Jeronymo, pede the seja scientificado si já deram entrada nesta Repartição os attestados de tempo de serviço de que trata a alinea $\underline{B}$ do supra citado officio.

Sobre o assumpto cabe-me declarar que os referidos documentos já se encontram junto aos autos (docs. de fls. 56 usque 63), tendo sido feito expediente aos interessados, concedendo-Ihes vista dos autos, afim de que, dentro do prazo de 20 dias, informem sopre os attestados do tempo de serviço fornecido pela Empresa reclamada.

Penso que, com o officio de fls. 66, fica satisfeito o pedido de informações do referido syndicato, tornando-se desnecessario novo expediente nesse sentido.

Ao Sr. Director da Secção, para os fins convenientes.

Maria Aleina Yarquer de La'

$$
\text { Hec. } 12 \text { ) } 10 \text { / } 95
$$
20 official

A' consideração do Snr. Director Geral de coondo com a informacas Fivo de Janeiro, 23 de Qüuteo de 1935 23 low Steodno de Aneida todé

Director da 1a Secção 


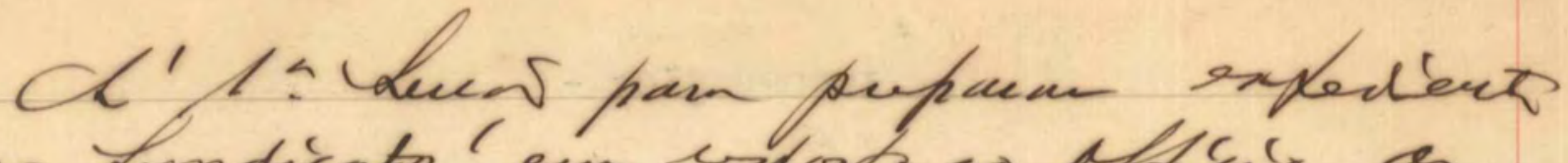
as aymdicatio! em cyfortax afficio os 67. pustants miforwaces.

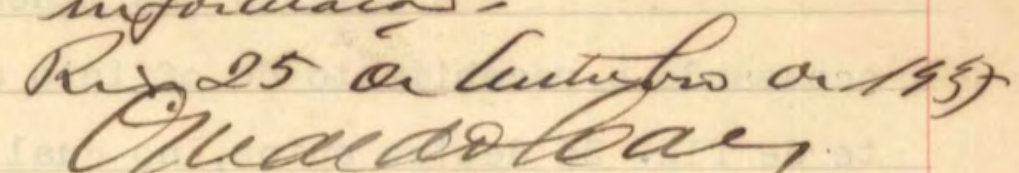

sinetw faco

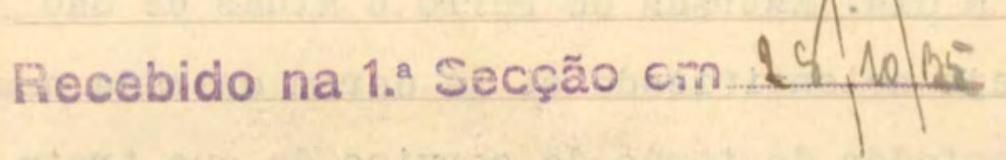

Lo Sm biar da Cung para Zaser o expediente.

$$
\text { Em of de wovembro de } 195^{\circ}
$$

Rheodro de Pemeida Vralé

Director da 1: Seçäo 


\section{Proc.9.582/34}

CN/SSBF.

$1-, 488$

Sr. Presidente do Syndicato dos Mineiros

são geronymo.

Estado do Rio Grance do suz

Attendendo á solieitagäo constante co vosso officio n: 304, de 25 de setembro ultimo, cumpre-me informar-vos que a Companhia de Istrada de Ferro Minas de são Geronymo, sctisfazendo o 1 tem $\underline{\text { }}$ da dec1são deste Conselho de 25 de Abril p. passado, encaninhou a esta secretaria diversos certificados de tempo de servico, os quaes, presentemente, aguardan a manifestagão dos interessados.

Attenciosas saudagőes 


$$
170
$$

deiente. Recebo mintas haye.

Riv de Janeiso, 6 de heral de 1996. th. Yjo ar glenge ton 
$0 \leq 10$

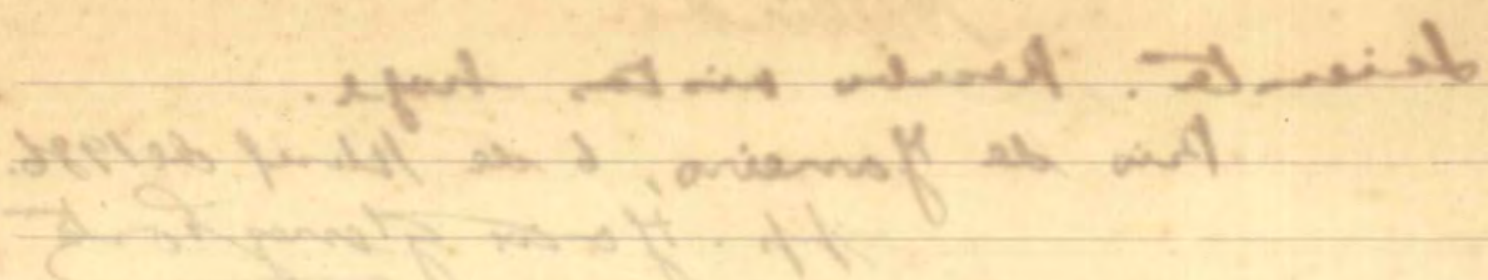

funtade

funto as Plicte-

guivtes a neuRic, $28 / 4 / 2 b$ ept Aejecide ana F $_{2} \mathrm{ECl}$ 
Illmo. Snr. Director Geral da Secretaria do Conselho Nacional do Trabalho.

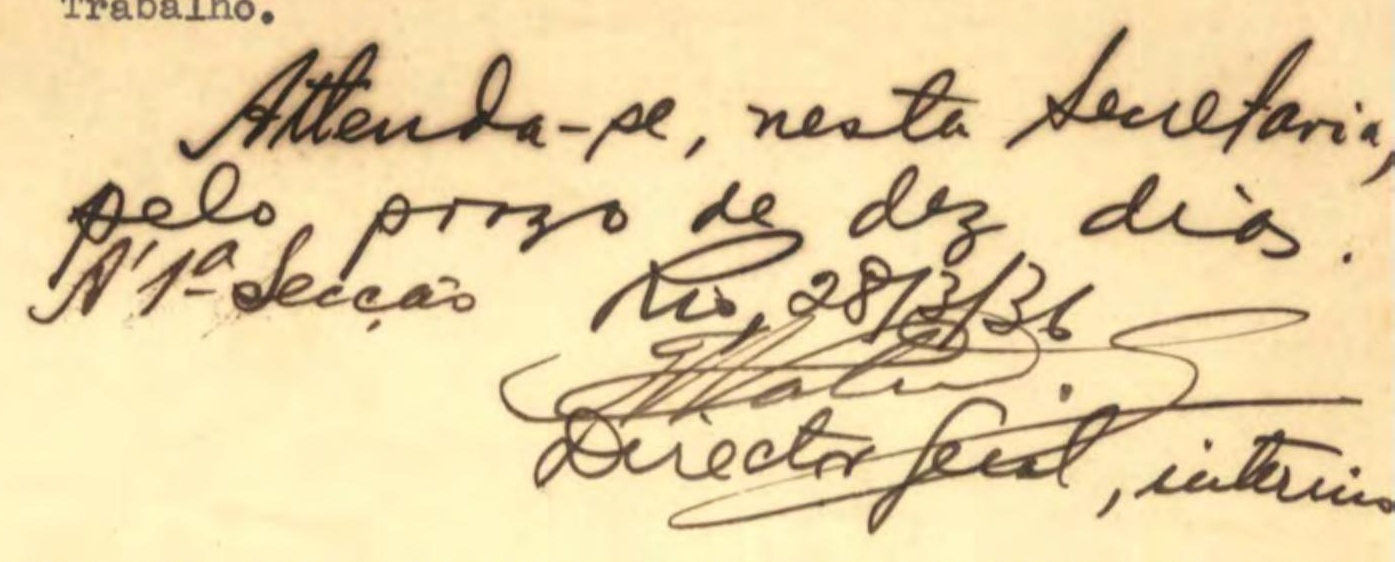

O "SYNDICATO DOS MINEIROS E CLASSES ANNEXAS DO MUNICI PIO DE SRO JERONYMO", ESTADO DO RIO GRANDE DO SUL, antes denominado "Syndicato dos Mineiros do Arrolo dos Ratos", por seu advogado do Incluso instrumento de procuraç, vem dizer e requerer a v.s. o seguinte, no processo no 958\%, de Domingos Mantilha outros :

que chegou, agora, ao seu conhecimento que esse Conselho ague da o pronunciamento dos interessados sobre os attestados de tempc de serv1ço, formectdos pela Empresa reclamada, afim de dar a sua ó c1são final no processo em apreço;

que, assim sendo, vem requerer a voso se digne mandar concede Ihe vista dos autos, para as allegaçбes que fôr de direito a bem dos interesses dos seus associados Domingos Mantilha o outros.

Nestes termos,

B. DEFERIMENTO.
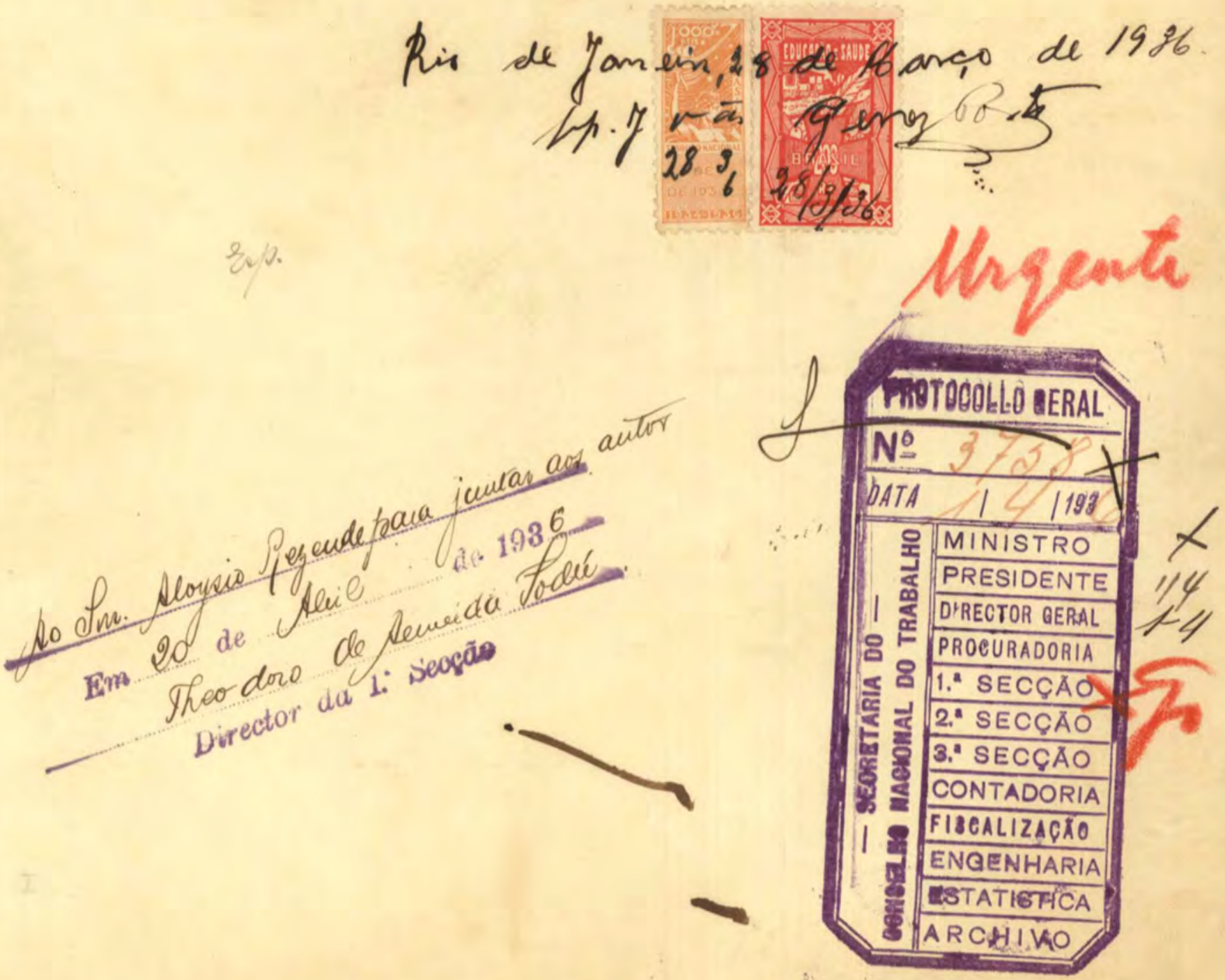


\section{REPUBLICA DOS ESTADOS UNIDOS DO BRASIL 172}

\section{Estado do Rio}

\section{Grande do}

\section{Certidão de Procuração}

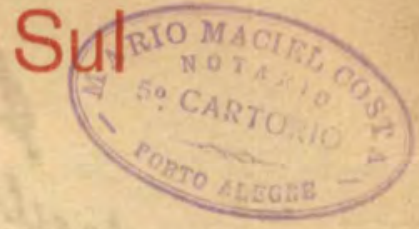

Certifico que revendo neste $50^{\circ}$ cartório de notas, o Livro de Procurações número sessenta e seis z nele a follhas cincoenta e V.ex:\$o, acha-se a procuração pedida por certidão, cujo teơr verbo ad-verbum é o seguinte: República dos Estados Unidos do Brasil. Estado do Rio Grande do Sul.

Procuração bastante que faz o Sindicato de Mineiros e Classes Anexas do Municipio de \$ão Jeronimo.

SAIBAM os que virem este publico instrumento de procuração que, no ano de mil novecentos e trinta $\theta$ cinco-, nesta cidade de Porto Alegre, capital do Estado do Rio Grande do Sul, aos seis (6) -...... dias do mês de novembro, neste quinto cartorio, compareceu o Sindicato de Mineiros e Classes Anexas do Nunicipio de São Jeronimo, neste Estado, representado por Castor Bispo,presidente;Amaro Junqueira Saraiva, secretario, e Affonso Seifert, tesoureiro,

reconhecidos pelos proprios do notario, de mim ajudante e das testemunhas adiante nomeadas e no pim assinadas, perante as quais disse que nomeava e constituia seu bastante procurador o advogado João Genez Porto, brasileiro, casado, aqui residente, para o fim de representar o outorgante onde se fizer mister, defender os seus interesses e dos seus associados,podendo aceitar intimações, firmar acordos e usar dos poderes impressos que ratifica;

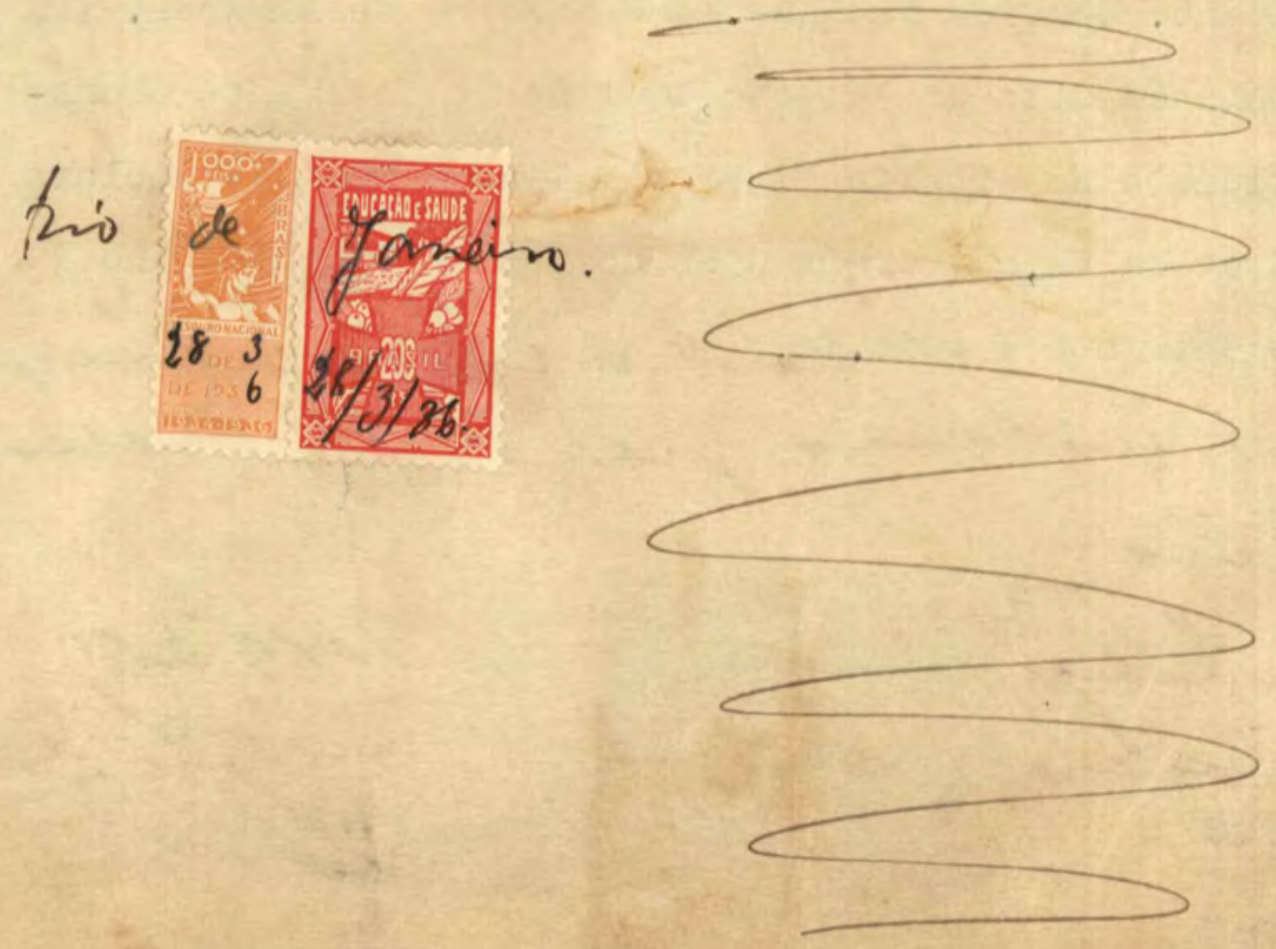




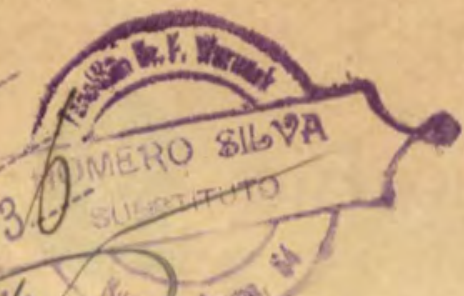

congedo todos

toda a órdem é figura de juizo ou fóra dele; requerer, alegar e defender todo o seu direito em processos judicials de qualquer natupera, em que for

autor

ou réu, assistente ou opogerte, ou de qualquer modo interessado, em um ou outro foro; fazer citar, requerer, promover e acompanbar aços em todos os seus termos e incidentes, até final sentença e sua execução, podendo usar de todos os meios de prova, dos recursos legais, dos processos preparatorios, preventivos e incidentes e de embargos do executado ou de terceiro, bem como de recurso extraordinario; opor suspeições e exceções; juntar e receber documentos; variar de ações, reservada para o outorgante a primeira citação, podendo substabelecer esta como e ém quem julgar conveniente, com ou sem reserva de poderes, que poderá revogar ou reassumir. Assim - disse do que dou fé, e me pediu este instrumento, que the 1i, aceit ou e assina com as testemunhas conhecidas de mim ajuảante e do notario, as quais são:Odorico Pacheco e Adão Bizarro de Almeida, maiores, aqui residentes.Eu, Lacy Leal Landell, ajudante do notario, o escrevi. Eu, Mario Maciel Costa, notario,o subscrevo e assino.Porto Alegre,6 de novembro de 1935.0 notario, Mario llaciel Costa, sobre dois mil e duzentos réis em selos federais, devidamente inutilizados.Castor Bispo. Amaro Junqueira Sarai va.Affonso Seifert. Odorico Pacheco.Adão Bizamo de Almeida. Era - que se continha em dita procuração, aqui bem e fielmente transcrita por certidão e ao proprio livro e folhas ao começo declara dos me reporto e dou fé,aos treis dias do mês de março do ano de mil novecentos e trinta e seis. Eu, th ar ia thacecf

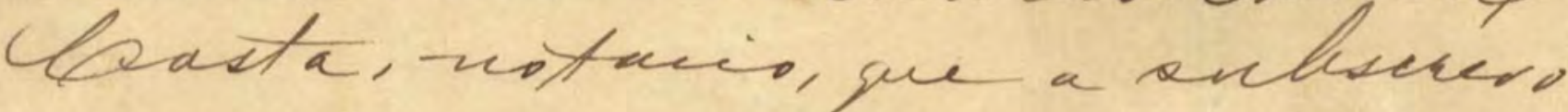
L Cokized.

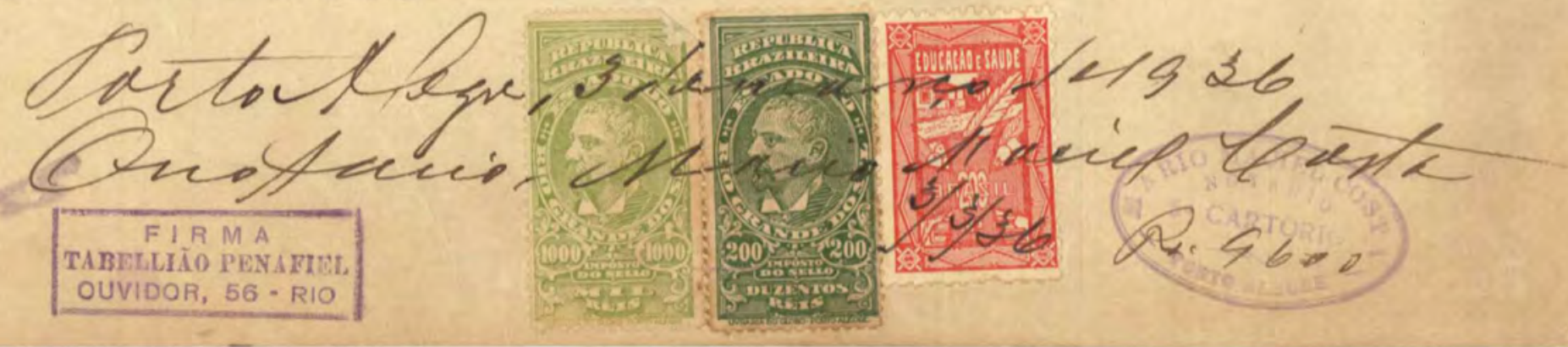


- "Syndicato dos Mineiros e Classes Annexas do Municipio de Sqo Jeronymo", antes denominado "Syndicato dos Mineiros do Arrolo dosRatos", por seu advogado infra-assignado, no processo de reclamaça contra a Companhia Éstrada de Ferro $\theta$ Minas de Sqo Jeronymo, sob numero 9582/34, vem dizer a esse Conselho o seguinte :

0 honrado Procurador Geral desse Conselho em seu parecer de fls. 45v/46, adoptado pela camara julgadora, por dispensa dos operarios Liberalino Machado de Lima, Raphael Mezza, Antonio Nunes das Pedras, Adalberto Azambuja dos Santos, Domingos Mantilha, Joro Keenan e Thomaz Gonçalves da Silva, pela Companhia Estrada de Ferro e Minas de São Jeronymo, reconheceu e opinou

1을 - QUE DESDE QUE FORAM FORÇADOS PELA POLICIA, DEIXARA DE SE CARACTERISAR O ABANDONO DO EMPREGO PELOS RECLAMANTES, PELO QUE, APURADA QUE FOI A IMPROCEDENCIA DA DENUNCIA FEITA CONTRA OS MES MOS CABIA A' COMPANHIA READMITTII-OS EM SEUS SERVIÇOS ;

20 - QUE QUANTO A DOMINGOS MANTILHA, QUE A COMPANHIA CONFESSA TER MAIS DE DEZ (10) ANNOS DE SERVICO E NRO HOUVE INQUERITO ADMINISTRATIVO, DEVE SER ESSE OPERARIO RECLAMANTE READMITTIDO AO SERVIÇO, SENDO-LHE PAGAS AS QUANTIAS REFERENTES AOS SALA. RIOS DO TEMPO EM QUE NTO TEVE REMUNERAÇO DE OUTRA EMPRESA ;

3ㅇ- - QUE A RECLAMADA CONFESSA, TAMBEM, QUE NYO PROCEDEU A INQUERITO ADMINISTRATIVO EM TEMPO HABIL EM NENHUM DOS CASOS DE DISPENSAS QUE MOTIVARAM A RECLAMAÇÃO EM APREÇO, etc.;

4음 - QUE FOSSE PEDIDA A' COMPANHIA ESTRADA DE FERRO E MINAS DE SRO JERONYMO A REMESSA DO CERTIFICADO DE TEMPO DE SERVIÇO E DA FOLHA DE ANTECEDENTES DOS RECLAMANTES.

A Companhia remetteu os attestados de tempo de serviço que se encontram de fls. 56 a 61 dos autos. Nesses documentos attesta a reclamada que os operarios DOMIN-
fo gos MANTILHA, THOMAZ GONÇALVES DA SILVA, $\theta$ RAPHAEL MEZZA tôm mals de dez (10) annos de serviço na Companhia.

Com referencia a reclamante JORO KEENAN attesta a Coinpanhis tem elle quatro annos $\theta$ se1s mezes de serviço E MAIS TEMPO "que se póde precisar por têrem sido destruidos os àrehivos da companhis em incendio occorrido no seu Almoxarifado em 1927.

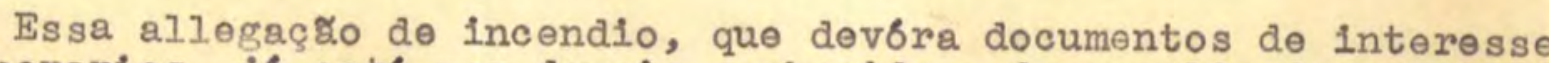
de operarios, jâ esta por demals conhecida e desmoralisada. Note, ainda, esse Conselho, que a reclamada affirma que o incendio referido occorreu em meados de 1927, e no mesmo documento attesta o tempo de serviço do reclamante a partir de lo을 de Janeiro de 1925.

Jo:o Keenan, entretanto, $\theta$ um dos mais antigos operarios da 

Companhia Estrada de Ferro e Minas de São Jeronymo. 0 Incluso attestado, ( doc. no 1 ), parecenos que deve merecer fo, princlpal. mente si esse Conselho veriflcar a lisura com que os operarlos re. clamantes se têm conduzido neste debate e a falta de argumentos da reclamada para contestar as suas akfirmativas, ats mesmo confirmadas por ella de modo surprehendehte.

- reclamante Liberalino Machado de Lima s a mesma pessoa que tambem se chamava JANUARIO MACHADO DE LIMA. ( Vide justificaçăo judiclal, incluso doc. $n \& 2$ ).

A reclamada attesta que Liberalino Machado de L1ma trabalhou para ella trinta e do1s mezes ( 32$)$ e Januario Machado de Iima trabalhou setenta 0 olto mezes $(78)$ e mais tempo, que tamber nác se pode precisar por terem sido destruidos os archivos em incendic

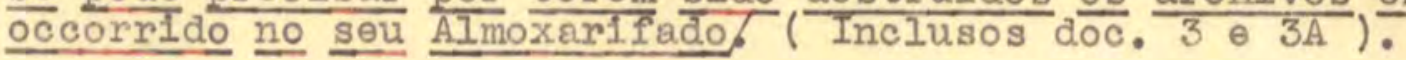

Mas vejamos: LIBERALINO MACHADO DE LIMA $\odot$ JANUARIO MACHADO DE IIMA \& a mesma pessoa ( doc. no 2). Pelos attestados cltados vê-se, assim, haver elle trabalhado na Companhia NOVE ANNOS E DOIS NEZES $\ominus$ MAIS TEEMPO QUE A RECLAMADA DIZ NIO PODER PRECISAR, por causa do tal Incendio.

Conclue-se, pois, que para completar os dez annos de serviço desse operarto a reclamada deixou de attestar apenas dez mezes, MAS CONFESSA, eIla propria, QUE 0 NESMO ESTEVE MAIS TEMPO AO SEU SERVIÇO.

Nao serk isso, por si so, sufficiente para demonstrar que 6 verdadelra a affirmativa de Liberalino Machado de Lima, de que tem mais de dez annos de serviço na Companhia Estrada de Ferro e Minas de São Jeronymo ? Afigura-se-nos, de outro lado, que tambem deve merecer fó o incluso documento nะ 4, que reforça essa verdade.

Examine-se, agora, attentamente, os inclusos documentos numeros 3 e $3 \mathrm{~A}$ e facil serk verificar as artimanhas da reclamada: no de ne $3 \mathrm{~A}$ o actual superitendente dessa empresa lançou a sua ass1gnatura $\theta$ no de $\mathrm{n}$ ? 3 corneçou a assignar..... mas se arrependeu. Mé fo ? Esta, entretanto, patente a autentecidade desse documento.

A Companhia Estrada de Ferro e Minas de Sqo Jeronymo, confessa que os operarios DOMINGOS MANTILHA, THOMAZ GONÇALVES DA SII VA $\theta$ RAPHAEL NEZZA têm multo mais de dez annos de serviço, $\theta$ delxa claro que os operarios LIBERALINO MACHADO DE LIMA $\Theta$ JORO KEENAN estro em identicas condições, quando diz não poder attestar 0 TEMPO QUE OS MESMOS TRABALHARAM EM EPOCA ANTERIOR, em virtude do Incendio em seu Almoxarifado.

Esta, portanto, habilitado esse Conselho para decidir a questão be todos os reclamantes, injustamente despedidos do trabalho.

Liberalino Machado de Lima, ( ou Januario Machado de Lima, que ( a mesma pessoa), $\Theta$ Joz̃o Keenan protestam contra a allegaç reclamada, de que não pode attestar todo o seu tempo de serviço em rasão de incendio no seu Almoxarlfado, incendlo esse que ninguen ño viu..

Os reclamantes pedem a esse honrado Conselho que julque este caso, que lhes parece sufficientemente provado o seu direito. Si, entretanto, entender que com relaça a alguns dos reclamantes ainda sqo neessarias mais provas, decida, entro, a parte dos que não admittem mais duvidas e baixe em diligencia os autos para que seja feita a prova por ventura exigida.

Iiberalino Machado de Lima e Jožo Keenan nå juntam, desde já, justificaçăo judicial que comprove os seus mais de dez annos de serviço na reclamada, porque so agora tomaram conhecimento dos capelosos attestados fornecidos pela mesma. o que a reclamada quér g ganhar tempo e forçar-los a despezas com justificaço em juíso 
que, si exigida, tergo de fazer com sacriflclos inauditos, dada a miseria em que se encontram pela injustiça de que foram victimas.

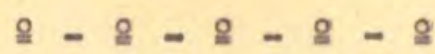

A Companhia Estrada de Ferro e Minas de São Jeronjmo affirmou, no inlcio deste processo, ( fls. ), que os reclamantes Liberalino Machado de Lima, Raphael Mezza, Antonio Nunes das Pedras - Adalberto Azambuja dos Santos haviam sido expulsos das minas, pelas autoridades policiaes, como Indesejave $\overline{i s . ~ A f f i r m o u, ~ a i n d a ~}$ ella, mals adeante, que flcara apurada a lmprocedenc1a da denuncia feita contra esses operarios, e a fis. 44 juntou a copia de um officio que, nesse sentido, Ihe dirigira o dr. Emani de Oliveira, inspector regional do Ministerio do Trabalho, fazendo referencla a esse documento em suas allegaçő de fls. 42, linhas 9,10 e 11.

Nesse officio a Inspectoria Regional do Ministerio do TrabaTho pedia a readmiss do, pela reclamada, "como acto de b8̂a justiça", pois que os mesmos haviam sido "tao mademente at ing sa imputaçăo".

E a Companhia Estrade. de Ferro $\theta$ Minas de São Jeronymo nem assim os readmittiu. E' que outro, sem duvida, - $\theta$ injusto tambem,fôra o motivo da dispensa.

Agora, sentindo perdida para ella a questro, diante do brilhante parecer do honrado snr. dr. Procurador Geral desse ConseIho, a reclamada, ja fora de tempo, procura provar que dos reclamantes os de nomes Adalberto Azambuja dos Santos, Raphael Mezza $\theta$ Liberalino Machado de Ilma "compareceram perante as autoridades judiciarias estaduaes (sic) perante as quaes se comprometteram a abandonar aquella mina, por terem sido accusados de se acharem envolvidos em factos subversivos da ordem". (FIs. 63 ).

Essa declaraç đo, que tem a assignatura do snr. Joş Marı́a de Carvalho, delegado de policia de saco Jeronymo, velo acompanhando os attestados de tempo de serviço pedidos pelo snr. dr. Yrocurador Geral em seu parecer de fls.

A folha de antecedentes dos reclamantes, tambem pedida pela Procuradoria, na fol, entretanto, mandada pela Companhia. $\mathrm{B}^{\circ}$ que essa folha é limpa, pols esses operarios são todos de conducta exemplar e dedicaçăo ao trabalho

Mas a declaração tardia do snr. Jose Maria de Carvalho, com referencia a tres dos reclamantes, mesmo que fosse verdadelra nada os prejudicaria, de vez que nella nå consta que esse comparecimento perante as autoridades e esse compromisso de abandonarem elles as minas fr̂a expontaneo. Ao contrario disso, diz, $\theta$ bem claro, que esse comparecimento fol forçado pelas accusações que haviam surjido $\theta$ que constam dos autos.

E, si a declaraç ao do snr. Jose Maria de Carvalho, compromety se os operarios a que illa se refere, nem assim poderia ser levada em consideraçăo pelo honrado Conselho,

10 - porque a propria reclamada ja confessou nos autos que os operarios referidos "foram expulsos das minas, em virtude de uma accusaç⿸丆𠃋 que se

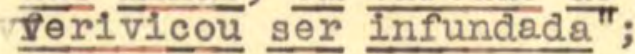

2 - porque o snr. Jose Maria de Carvalho, delegado de policla de São Jeronymo, que procurou com a sua graciosa declaraçă, salvar a reclamada, 6 uma autoridade truculenta, perseguidor systematico dos operarios a soldo das companhia de 


\section{$-4-$}

mineração. ( Vide questionario, inclusb documento no 5 , e respectiva resposta, firmada pelo Inspector Regional Ernani de Olivelra, que se encontra actualmente nesta capital á Rua Ota. vi̊o Corrôa, 19 - URCA - Phone 26 - 0411, á disposiçăo do Ministerio do Traba.Tho y.

Delxa-se de reconhecer a letra e a flrma desse funccionario do Ministerio do Trabalho por ser ella conhecida desse Conselho. mos \& mão.

Mas ainda juntamos os documentos numeros $6,7,8$ e 9 que te-

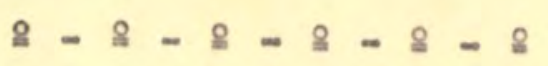

- 1llustrado snr. dr. Procurador Geral, em seu parecer de fls. opinou que o reclamante Domingos Mantilhs.

" fosse readmittido ao serviço ( por jâ naquella dada estar provado que contava mals de dez annos de serviço) sendo-the pagas as quant1as referentes aos salarlos do tempo $\frac{\theta m}{\text { neve que }}$

Domingos Mantilha foi readmittido, mas não the foram pagas essas quantias a que elle tem, incontestavelmente, dire1to.

E'o que se requer aqui, bem como a reintegração dos demais reclamantes, com o pagamento das quantias que tambem delxaram de perceber, condemando-se, ainda, a reclamada em todas as custas do processo, como acto de sq e reparadora

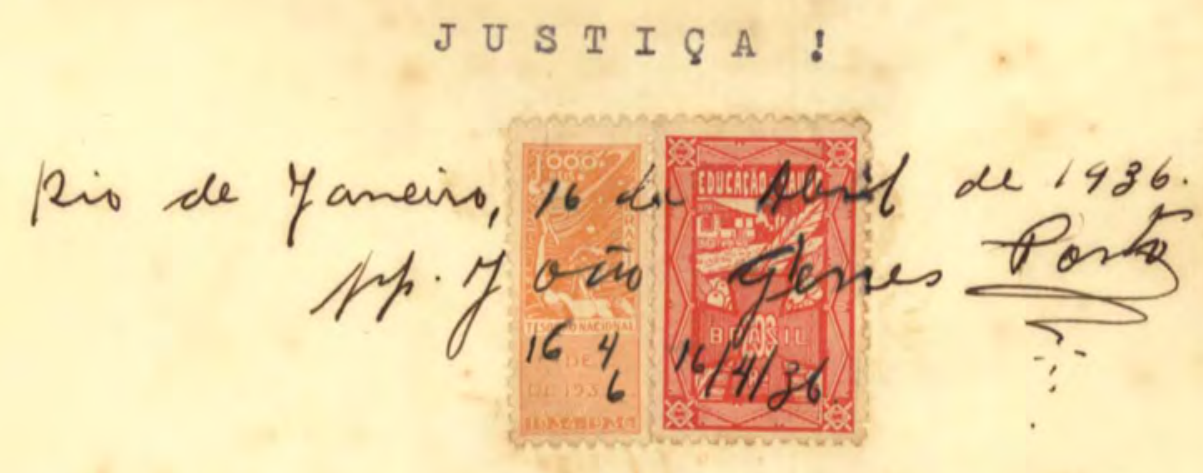


Opes abaires acriquaros, ofe vavier da boupacefin EAtradx de ferro e Abrias de Las quescryins, a wais degdarenta ancer pesitedter nesta localidare, attertawer sob a fé da

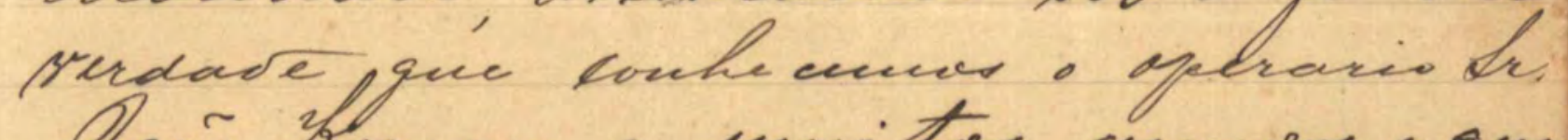

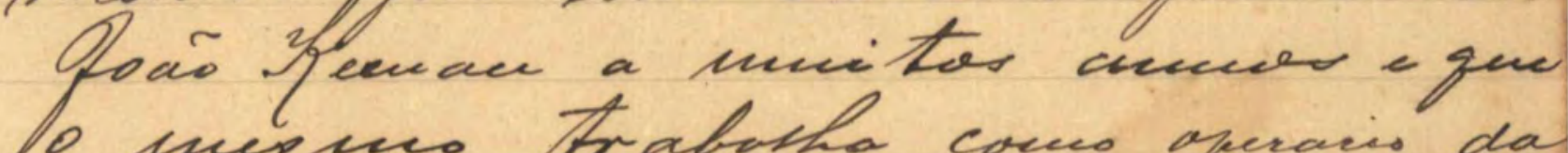
Do vesuses trabotha coues operacis da

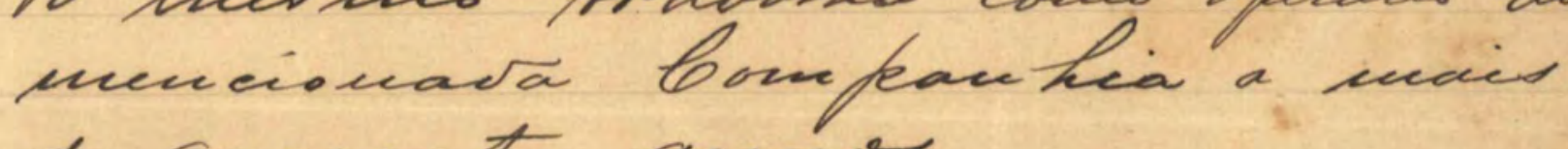
de guarenta acecos.

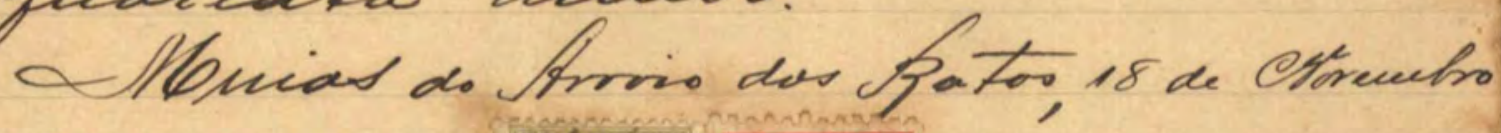
de 1933.

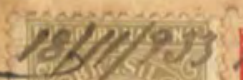

Selyer Sacrecia det oflua

Jesp thamas

178 


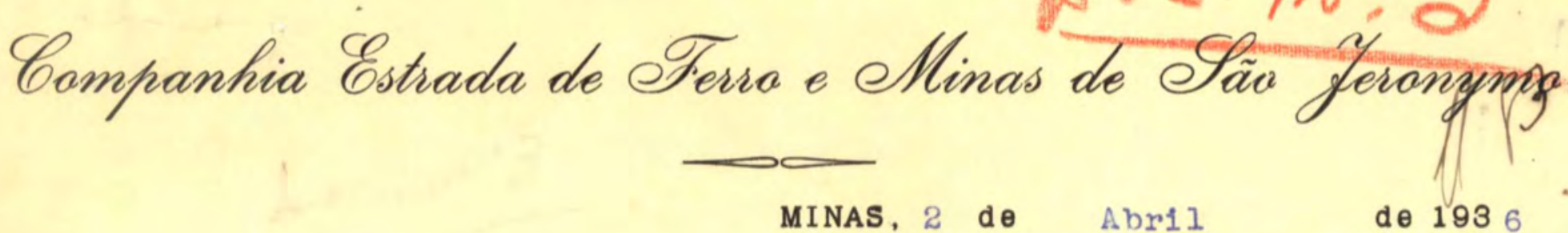

A $t$ t $\theta$ s $t$ a d o .

Attesto que o operario senhor, Janilario Mechado de Lima, trabalhou nesta Companhia de $1^{\circ}$ de Janeiro de 1925 até fins de Junho de 1931, e em épocha anterlor,a qual nãn se pode precisar por terem sido destmidos os archivos, em incendio occorido no nosso Almoxarifado, em meados de 1927.

Mines de São Jeronymo,2 de Abril de 1936

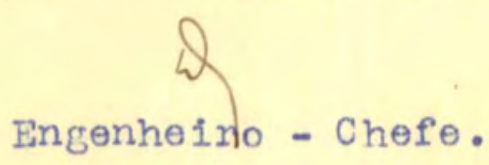

2 de Abril de 1936

Superintendente.

 
Companhia Estrada de Treva e eNinas de êâ

Copia.

MINAS, $13 \mathrm{~d} \theta$ Julho

de 1935

A $t$ t $\theta$ s $t$ \& d o

Attesto que o operario iberalino Machado de Lima, trabalhou nesta Compania de Julho de 1931 até Março de 1934.

Minas, 13 de Julho de 1935

\&

Engenheino - Chere

2 de Abril de 1936

Superintendente

1.2 . Autor 


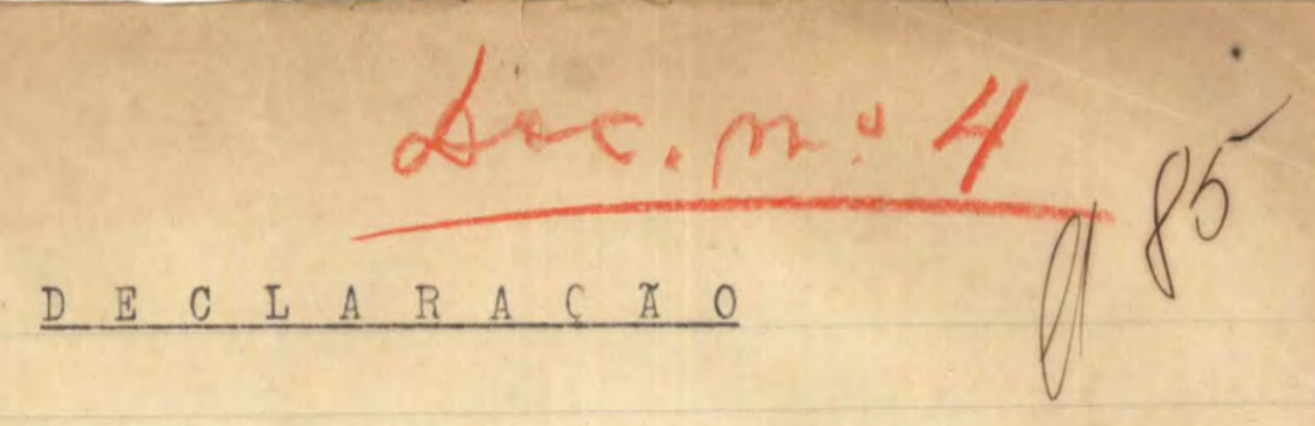

Os abaixo assignados, operarios da Companhia Estrada de Ferro e Minas de São Jeronimo, declaram que conhecem o senhor Januario Machado de Lima, trabalhando com esse nome na Companhia Estrada de Ferro e Minas de São Jeronimo do anno de mil novecentos e quatorze, (1914) á 29 (vinte e nove) de junho de 1931 (mil novecentos etrinta e um) e com o nome de Liberalino Nachado de Lima, desde julho de 1.933 (mil novecentos e trinta e tres á 2 de maŗ̧o de 1934 (mil novecentos e trinta e quatro.

Co...o prova da verdade, firmamos a presente para fins de direito.

Minas do Arroio dos Ratos, 10 de abril de 1.936. TESTENUNHAS:

Gaslos Theodoov Prunuece
Slberto Drila

Luther as deres finmes

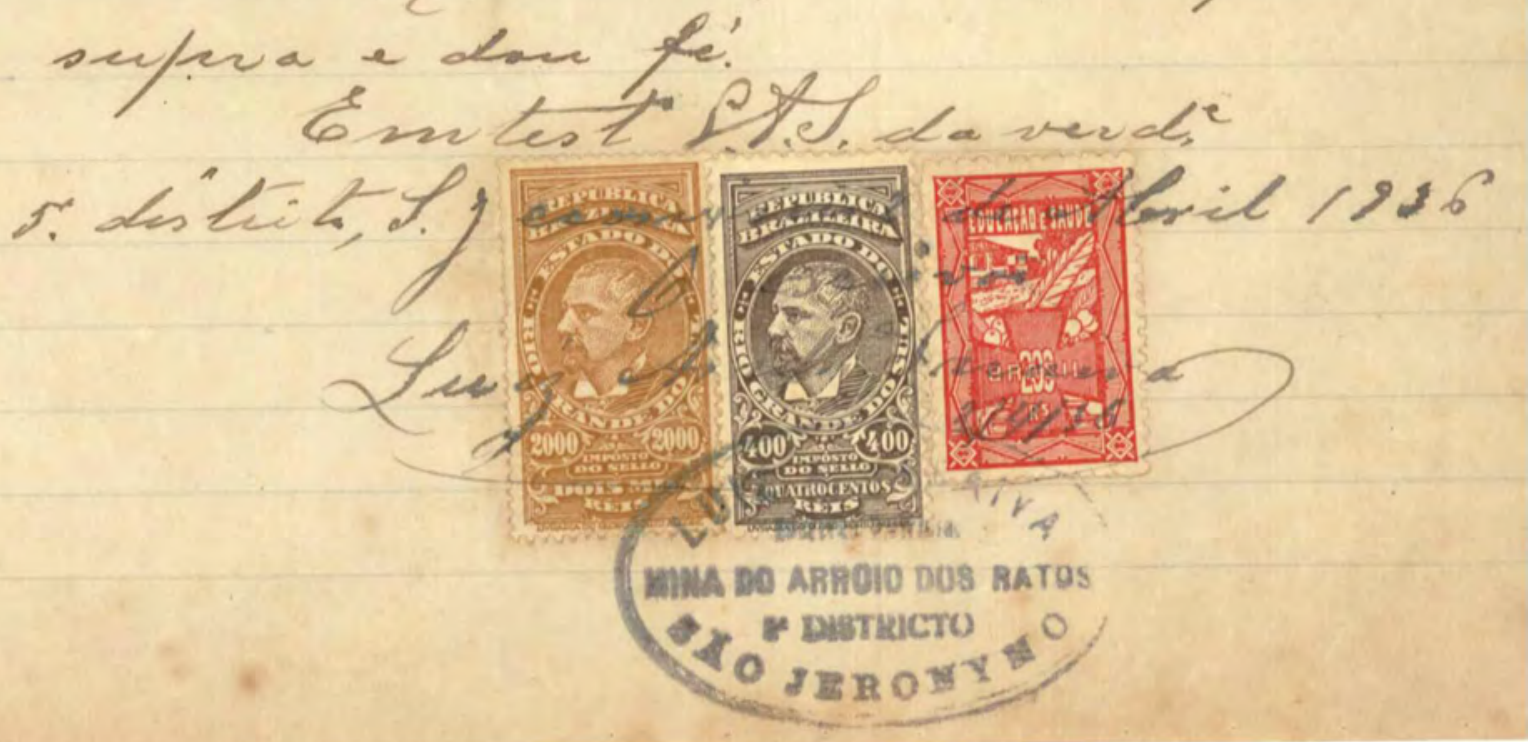




\section{Axe: $x$ is s- SYNDICATO DOS MINEIROS 6

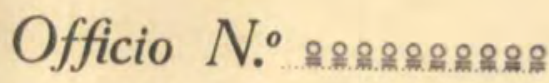 Estado do Rio Grande do Sul BRASIL}

Syndicato de de 19 de Março de 1931. E reconstituido de conformidade com o Decreto 24.694.

\section{RIO DE JANEIRO, 12 de Abril de 1936.}

Illmo. Snr. Dr...... Emani de ol1veira...

DD. Inspector Regional do Ministerlo do Trabalho.

Presente.

Na qualidade de advogado do "Syndicato dos Mineiros e Classes Annexas do Municipio de Szo Jeronymo", antes denominado "Syndicato dos Mineiros do Arrolo dos Ratos", no Estado do Rlo Grande do Sul, venho pera fins de fineza de responder, junto a este, os itens a seguir, paTrabalho :

1 - si v.s., como inspector regional do Ministerio do Trabalho, em exerciclo no Estado do Rlo Grande do Sul em 1934, tomou conhec1mento da dispensa, pela Companhia Estrada de Ferro e Minas de São Jeronymo, dos operarios ADALBERTO AZAMBUJA DOS SANTOS, RAPHAEL MEZZA, LIBERALINO MACHADO DE LIMA $\theta$ outros?

20 - si os operarios acima referidos comprometteram-se expontaneamente com as autoridades policiaes a abandonar as minas, ou, ao contra rio, foram por ellas obrigados a 1sso, em virtude de uma denuncia da ordem?

3으 - si o delegado de policia da capital do Estado, encarregado de proceder a rigoroso inquerito a respeito apurou que eram infundadas as accusaços contra os citados operarios?

40 - si exacto que v.s., na qualidade de Inspector Regional do Minis terio do Trabalho officiou \& Companhia Estrada de Ferro $\theta$ Minas de São Jeronymo, em 23 de Abril de 1934, communicando-1he que 03 을 legado auxiliar de Porto Alegre, apss migorosa syndicanc1a havia concluido serem SEM FUNDAMENTO as 1mputacós feltas contra os Ino Machado de LI Mezza, Adalberto Azambuja dos Santos, LIbora-

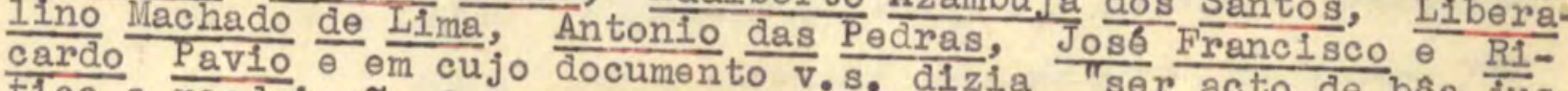

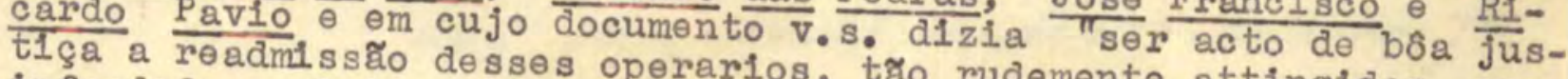
infundada $\theta$ aleivosa imputaça" ?

50 - si \& do conhecimento de v.s. que o sr. Jose Maria de Carvalho, delegado de policia do municipio de são Jeronymo, \& considerado peautoridade os minas do Arroio dos Ratos $\theta$ do Butí como uma as directorias das a ponto de se apossar dos moves de mineraçá, tendo mesmo chegado ao dos Mineiros de Butia, illeis, utensilios $\theta$ archivo do Syndicato director-presidente destas minas?

Com agradecimentos pela prompta resposta, Atto Cro 0 bro 
Vir de fanciro, It de Abil de 1936.

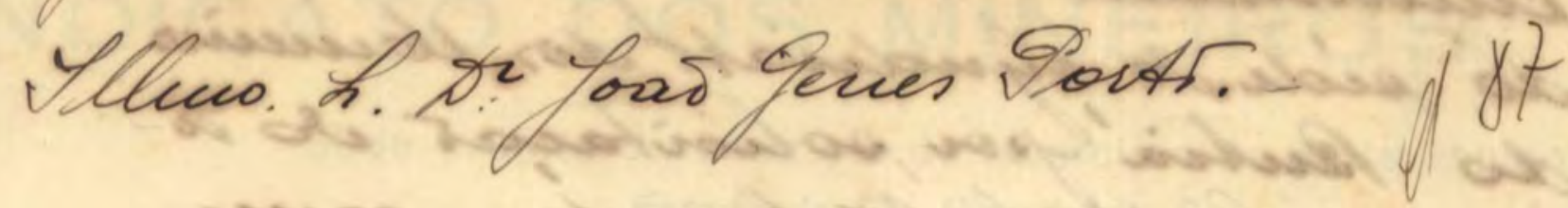

Seuho a poctisfacar de reaponoter al quesitin forculocdos relateranuente á guestat des lbinuis de tais prougeno da sequici cuacuin:

quantr do pinicens: Sizr.

- segundo: Creis que uás so cons psometerain expacta vicanunte, e, icko porque lago apo's as insestiga cates policias, recoskeram '́' Lubpectorie Regionof, reclacuacedo cautia as de uistós que eacesideravacu icpirstás;

"Itesceis: Sicu:

" "quasti; Sive;

"

"quietri Édo unen sonhecuinadr a accentucoda icolispasicow dos operasios uincius pow tha do Belegado de Policin, tees do vastas oygs, cones LerpecIn Regional, vitern do ecu fa. vos os suevers. To archion da $17^{a}$ Luspectorsi Reginal constan varios explediculs que denarstrace clasawnete a accaio do Deleyadso de Policia to fosi iloavia ber Cavallo ceupre coutiani as dircites dos operarios. 


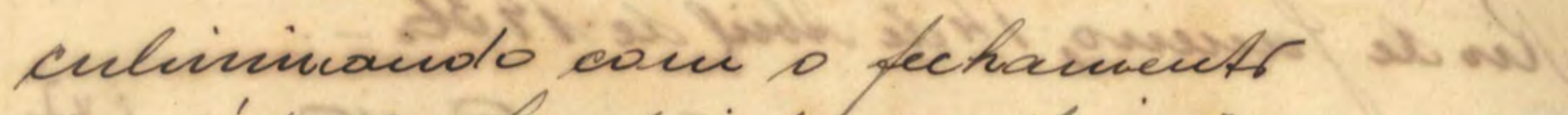
do scílenos tyndeciato dos llavicios do Rutia por volicitacar do Directs or Doberts basolóso, cau

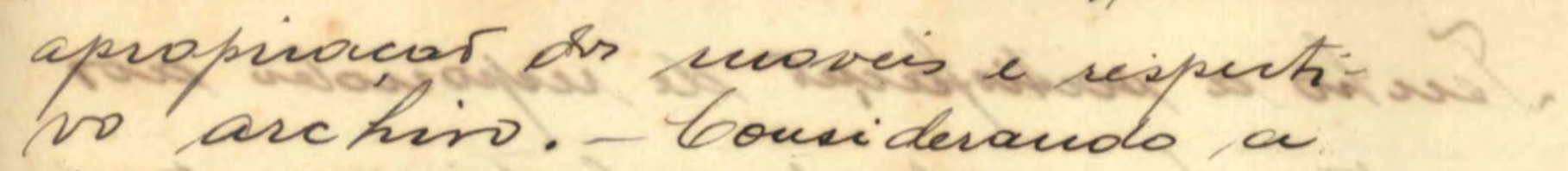

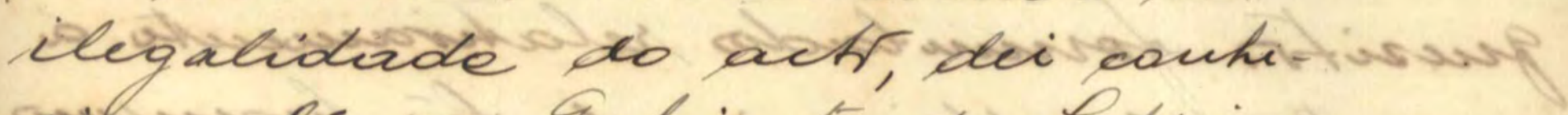

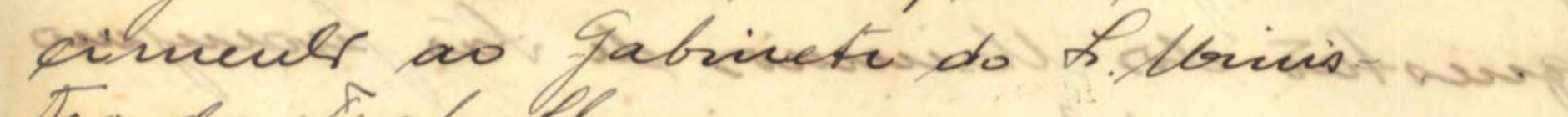
tro do viaboltio. larecte de haver patisfeis as axposas peryentas, sccborero ne attercisonecute.

Qundowateoliving 


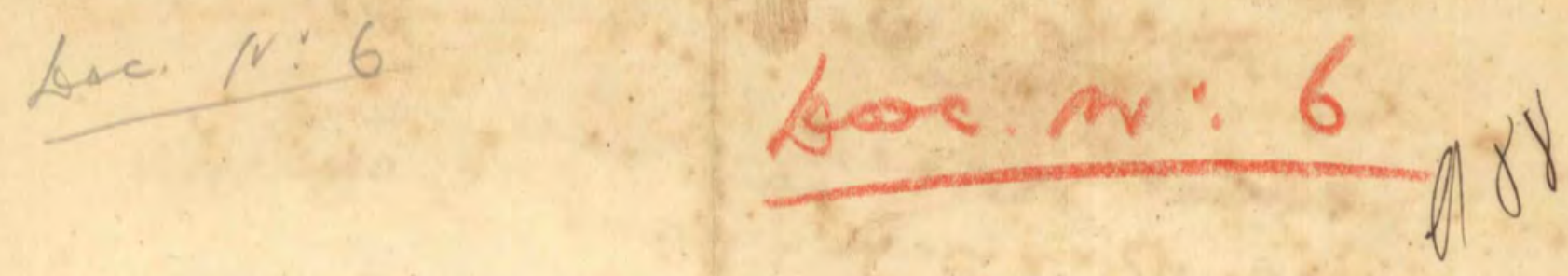

Sub. Delegacia de Policia do 5 in Distrito de Sao Jeronimo.

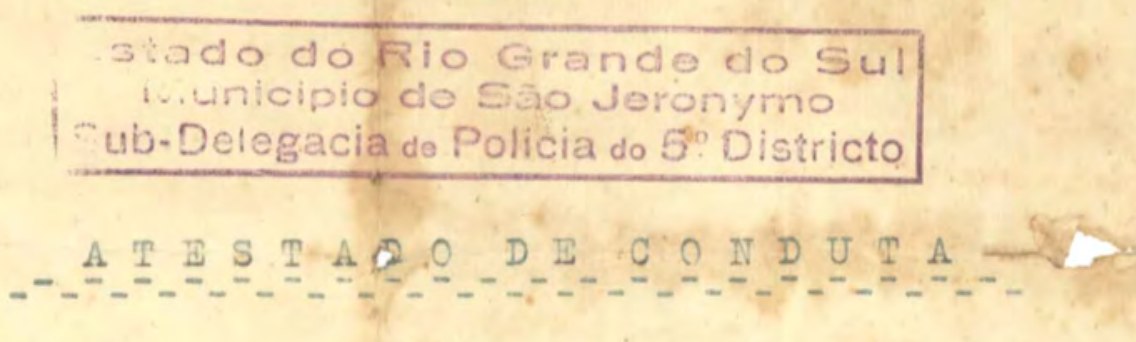

Atesto que mandando rever o arquivo desta Sub. Delo-

gacla de Policia nada foi encontraco em desabono a conduta

do Snr. IIBERAIINO NAGADO DE IIMA, operario da 'Companhia

Estrada de Ferfo e Mims de Sao Jeronimo.

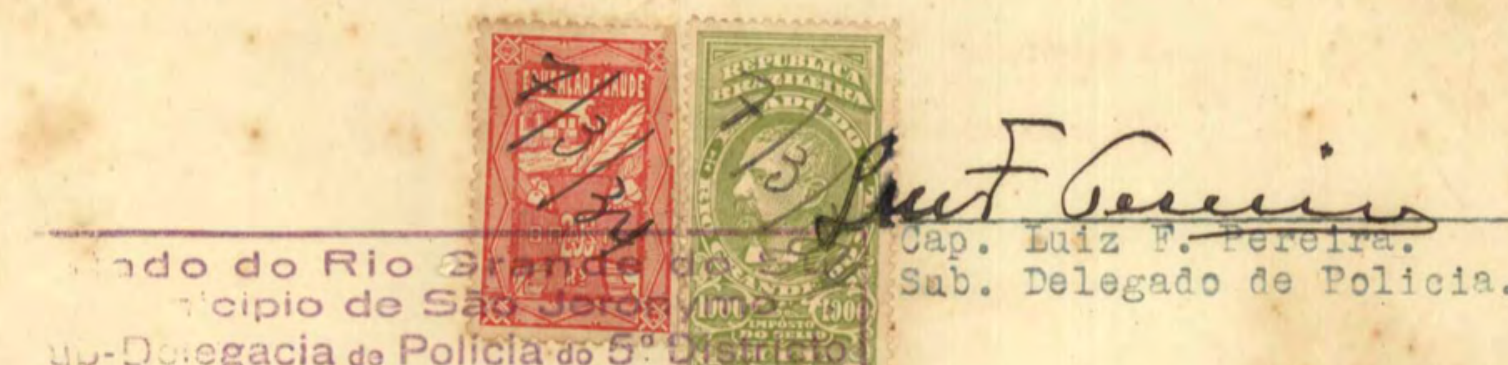

Minas do Arroio dos Ratos, 7 de Marpo de 1934. 
Are, no. 7 (19

Attestado.

Attesto que reside no 3. Distrito de são Jeronimo o snr. Liberalino

Yoghado de Iima, residando ha um anno. Nesta sub-Delegacia nada consta em seu desabono.

3. Distrito de sào Jeronimo,3o de Março de 1935.

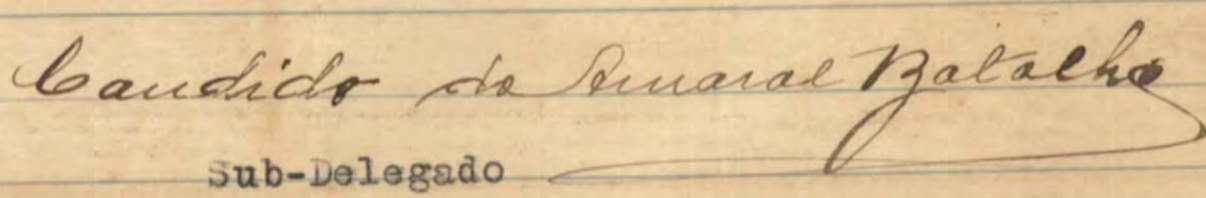

Esiado do Rio grando do

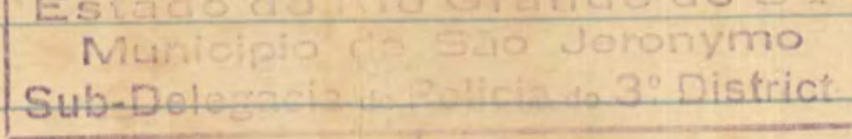




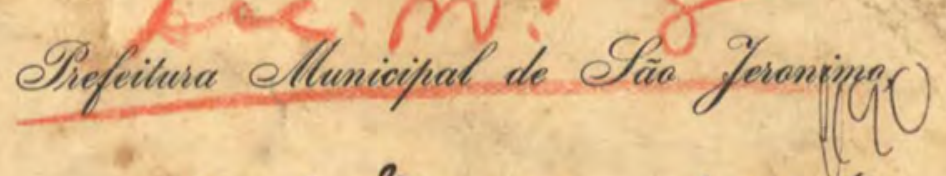

GALIVEIE DO PREFEITO

10 de hares de $19.5 \%$

Au: Vas. Causis oftack 2.8. Nax-Refaits e cax-delejás

M.os Medei:

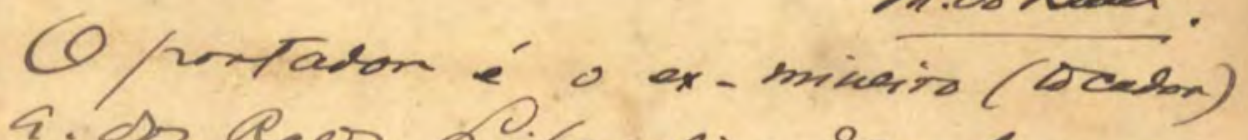

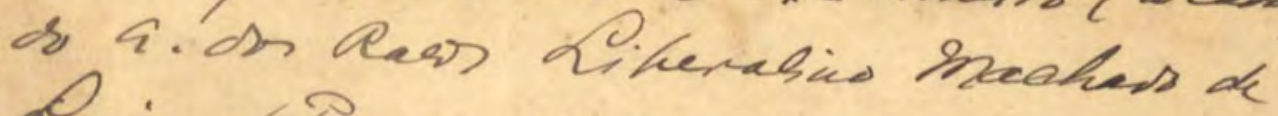

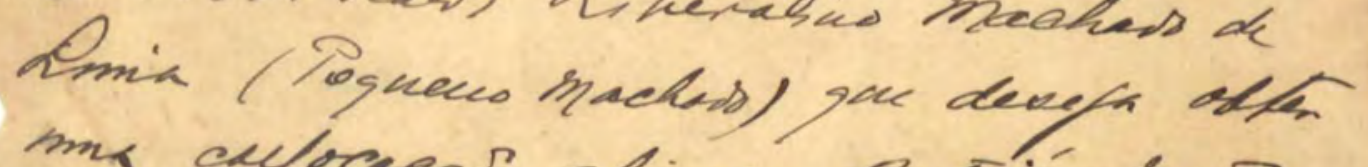

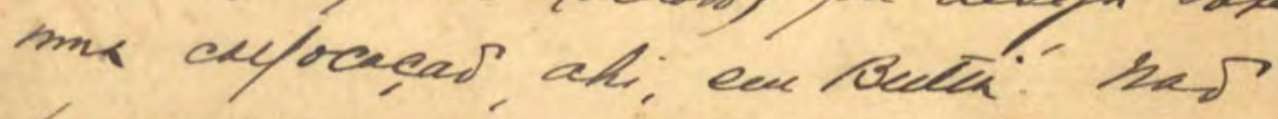
havens ineonueniente e laces wa

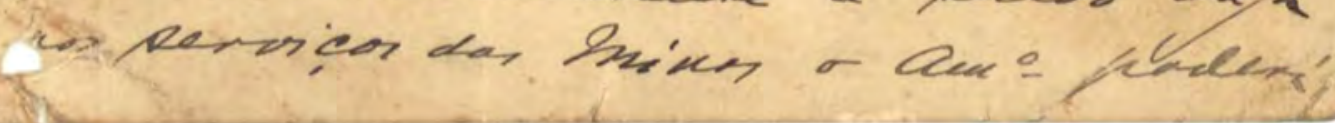


encauriatef -o, coms the freved

ven ucaid, aknee

$$
\text { acas - abs? }
$$

$$
\text { Bnbaruad }
$$


Tuformacaio 1192

Ceur pestão de 25 de

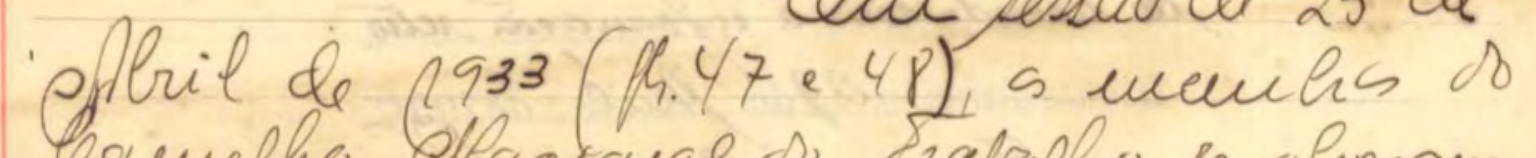
Couseho Elaciaral or rabaho resoheram nad tomar counecinento ds enbargs apreseutads pela boupanhic ERada de Feno e ellivas de Los fuoumo, para o fiue de de coufrumale o aceoracat eubluigado, da La Gaufara, k erulinaudo a reilute raças de bruierge dlantilha, wisto ter fileado prevaor, per forga de ieterpre tagect dada pelo h. Clefuirtio on rafulhe, que o memo eonta enais de (o amea de Tempo de perrico, e, ciinda, fossem rewultipls co cerificads do tempol de cemico ds deucaij reclanauta.

Cene emuprimento a essas decisog, a bia. Etrada de Feno c

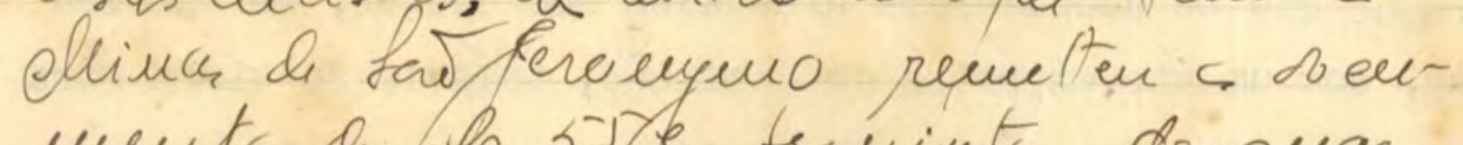

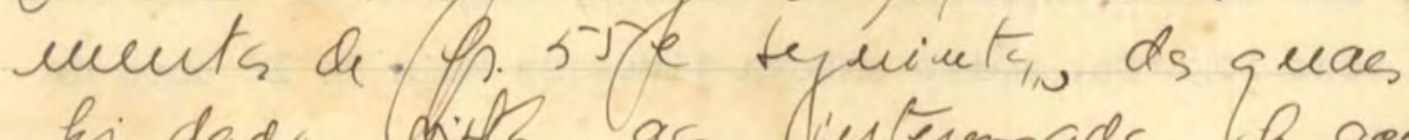
fir dado (kith as Vurtermada, ?o. acea-

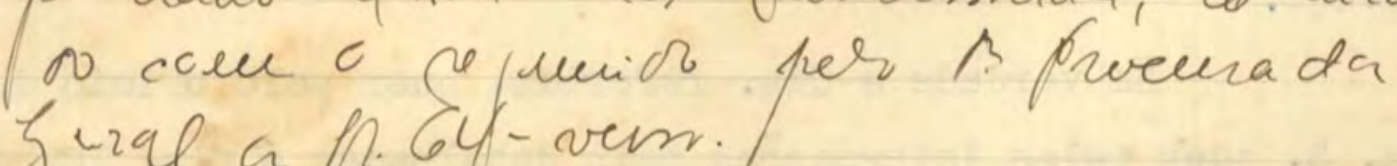
Jiral a p.64-verm.

lema dilij eucis acha-u

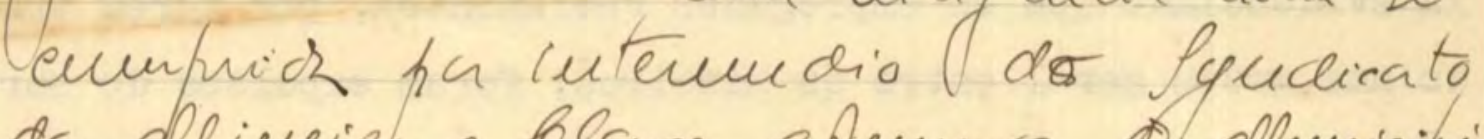

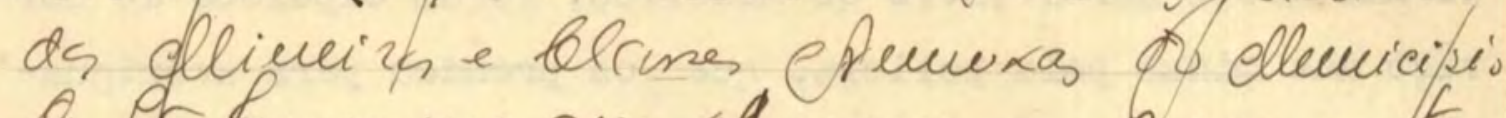

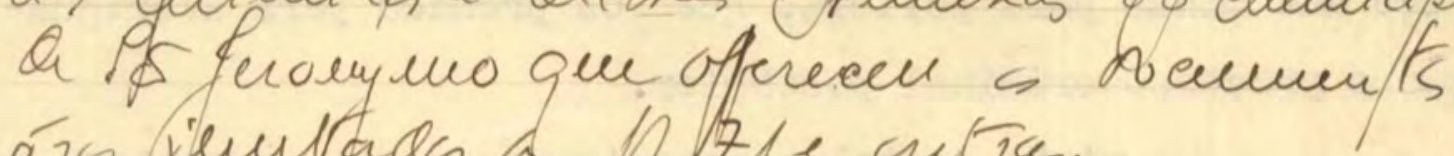

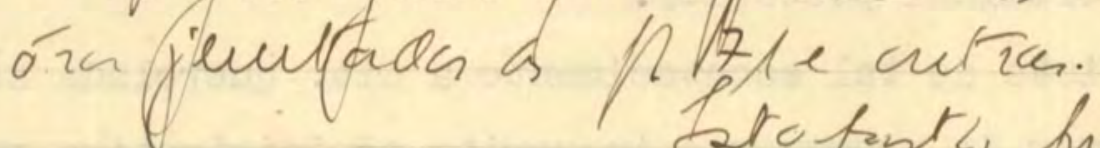

Stoponty, preparho $c$ wots ds auts a frownadui fral.

Ariv a fayrin, 25 de CAlute or 1928 epapio lewula Ageude
aur a ell 


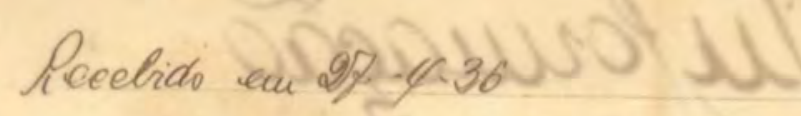

A' consideração do Snr. Director Geral

3. In de acendo com a ciffomacar reteo

Rio covaneiro, 2 'de quié de 193.

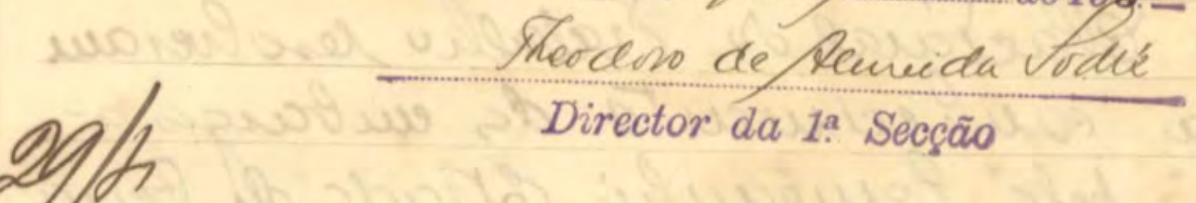

VISTO-Ao Snr. Dr. Presura'or Geral, de ordem do Exmo. Snr. Presidente.

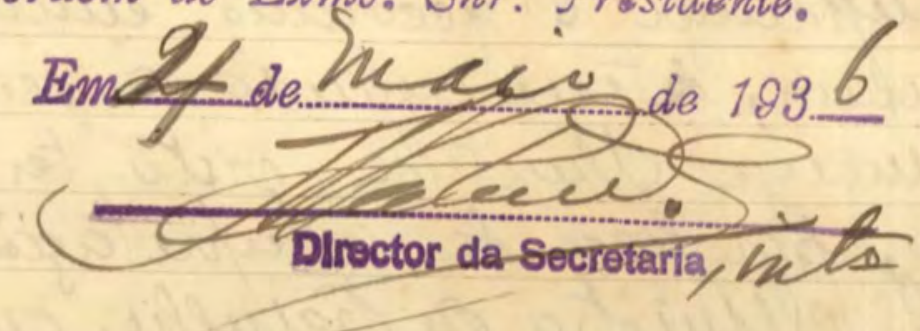

$\underline{P} \underline{A} \underline{\underline{R}} \underline{\mathrm{C}} \underline{\underline{\mathrm{E}}} \underline{\underline{R}}$

Como já foi objéto de exame e deliberação do Egregio Conselho, alguns empregados da Cia. Estrada de Ferro e Minas de São Geronimo reclamaram contra o áto da administração que os considerara afastados dos cargos, de maneira que, sem um áto expresso de demissão, todavia se viram fóra dos seus logares, muito embora tivessem mais de 10 anos de serviço.

Em verdade a Cia. referida, quer pelo oficio de fls. 3, quer pelas informações mais detalhadas á fls. 10, deixa evidenciado que os empregados reclamantes, por terem tramado una gréve geral entre os mineiros, foram expulsos do serviço das minas pela policia, que os prendeu para averiguação e processo criminal posterior.

A vista de tal acontecimento a Cia. querelada não se julgou no dever de promover o inquerito administrativo para justificar a demissão dos empregados presos, simplesmente porque os considerou de fáto e de direito demitidos em virtude do afastamento forçado do serviço que lhes impoz a policia. 
Mas dessa prisão não resultou condenação aos empregados e não obstante ficaram eles fóra do serviço, porque a Cia. deu como caso findo e como regular a dispensa pelo não comparectimento decorrente do tempo que estiveram presos.

o sofisma não colhe, nem convence.

Desde que os empregados das Cias. de Mineração, por força do art. 20 do dec. 22.096, de 16 de Novembro de 1932, que fez expressa a remissão ao art. 53 do dec. 20.465; de 1931, não podem ser demitidos, após 10 anos de serviço, senão mediante a prova de falta grave, apurada em inquerito administrativo, é obvio que para a demissão em todos os casos ha mister o inquerito administrativo, que, no caso a Cia. reclamata confessa não ter procedido, por julga-lo dispensavel.

Mas essa concluzão é ilogica, porque a simples prisão pela policia e ainda mesmo o processo de investigação feito perante a tutoridade policial, não vonvencem da certeza da falta grave porque esta deve ser provada em inquerito administrativo.

Se se tratasse de um processo criminal regular ainda se poderia firmar um criterio de julgamento, mas nunca num áto policial, tomado como medida imediata e urgente de manutenção da ordem.publica, e de cuja consequencia resultou justamente provada a nenhuma culpa dos acusados.

Logo a Cia. reclamada não podia se ater a esse áto policial para dar uma justificativa á demissão de seus empregados.

Portanto é fóra de qualquer controversia que no caso em apreço não houve inquerito aaministrativo, não ficando assim provada a falta grave de nenhum dos acusados.

Aliás o acordão de fls. 47 já se pronunciou por essa concluzão quando mandou reintegrar Domingos Nantilha no serviģo da Cia. reclamada.

Os reclamantes são: Domingos Nantilha, Liberali- 
no Machado de Lima, Raphael Mezza, João Keenan e Thomaz Gonçalves, Antonio Nunes das Pedras è Adalberto Azambuja dos Santos.

Cumprida a dilisencia constante do acordão de

fls. 47, apura-se:

- A -

Que Domingos Mantilha, cujo direito o Egregio Conselho já reconhecéra no iten a do invocado acordão, foi readmitido no serviço, como declara o adv̈ogado á fls. 76 mas não foi indenizado dos zencimentos atrazados, correspondentes ao tempo em que esteve afastado.

A indenização dos salarios atrazados é uma consequencia logica e legal da propria reintegração e desde que a Cia. São Jeronimo, por força de autoridade do acordão deste Egregio Conselho, readmitiu o eeu empregado, deve-lhe os vencimentos atrazados. Sobre o assunto não ha mais duvida $\theta$ assim opino seja a Cia. notificada a indenizar a Domingos Nantilha pelo tempo que esteve afastado.

\section{- B -}

Quanto aos reclamantes Thomaz Gonçalves da Silva, fls. 58; Raphael Mezza, fls. 61; a Cia. reclamada ofereceu prova de que ambos tem mais de 10 anos de serviço, de maneira que opino pela reintegração dos mesmos com as vahtagens legaes decorrentes. - C -

Quanto aos empregados Adalberto dos Santos Azambuja, fls. 57; João Keenan, fls. 59 e Antonio Nunes das Pedras, fls. 60 , que não chegam a ter 10 anos de serviço, não Ihes ampara - preceito legal que cria a estabilidade e portanto opino pela improcedencia do recurso nessa parte por falta de fundamento legal.

\section{- D -}

Quanto ao empregado Iiberalino Nachado de Iima, fls. 56, que na petição á Pls. 5 se declara ser tambem conhecido 


$$
\text { pal }
$$

por nome de Januario Machado de Lima, ha uma confusão que não permite uma solução definitiva.

Para a prova do que se trata do mesmo empregado, embóra com dois nomes distintos, procedeu-se a justificação á fls. 79, e se ofereceu o atestado á fls. 85.

A documentação é inaceitavel - a justificação porque não foi feita sem a intimação $\theta$ assistencia da Cia. e na eeclaração á fls. 85, porque, além de graciosa, informa que o empregado trabalhou em épocas diferentes com nomes diversos, de maneira que não prova que ele fosse conhecido por dois nomes, mas que usou nomes diferentes em ocasiões diversas.

Os documentos á fls. 83 e 84 indicam claramente que se não trata da mesma pessôa.

Pelo atestado á fls. 56 e a fls. 84, Miberalino Machado de Iima só possue 2 anos e 8 mezes de serviço; pelo atestado á fls. 83 Januario Nachado de Iima só tem 6 anos e 5 mezes.

Mesmo, porém, que os nomes sejam da mesma pessôa e que se somem os tempos de serviço indicadós, o total ree presenta 9 anos e 4 mezes de serviço

Nessas condições opino pela improcedencia do do pedido desse empregado.

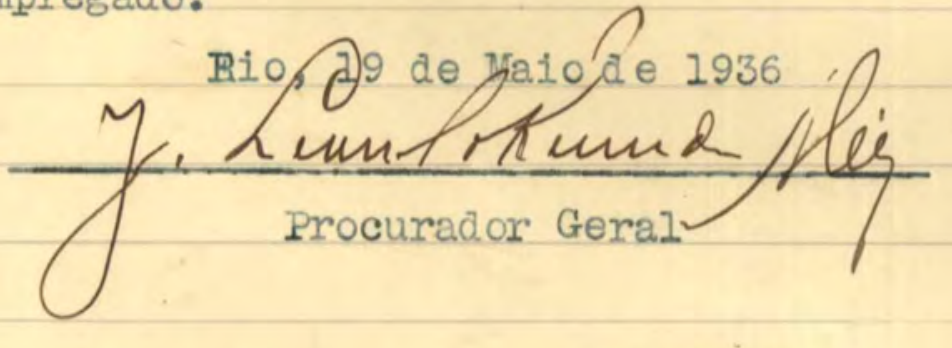

$\mathrm{SF} /$

COMGETSAO

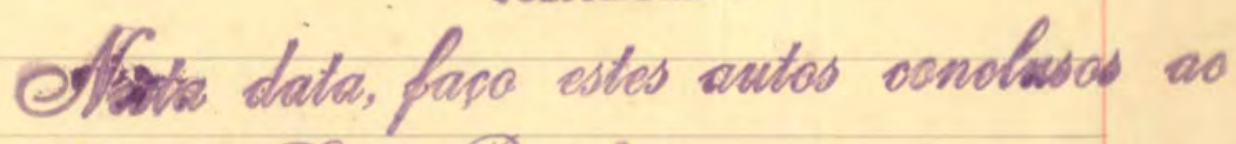

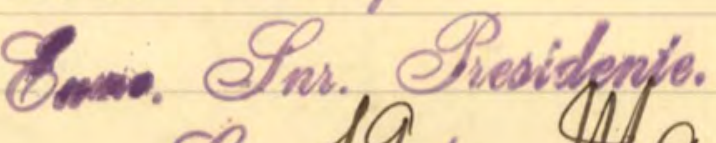




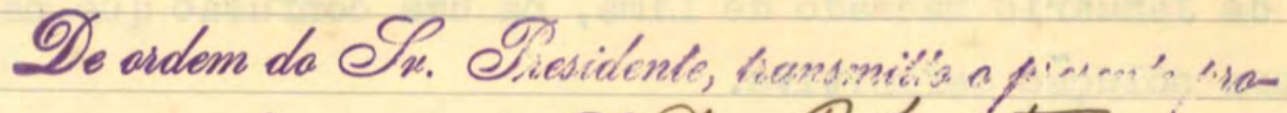

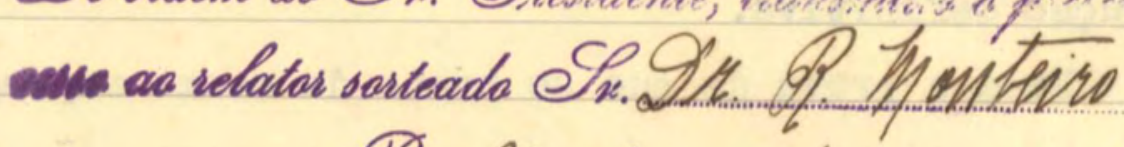

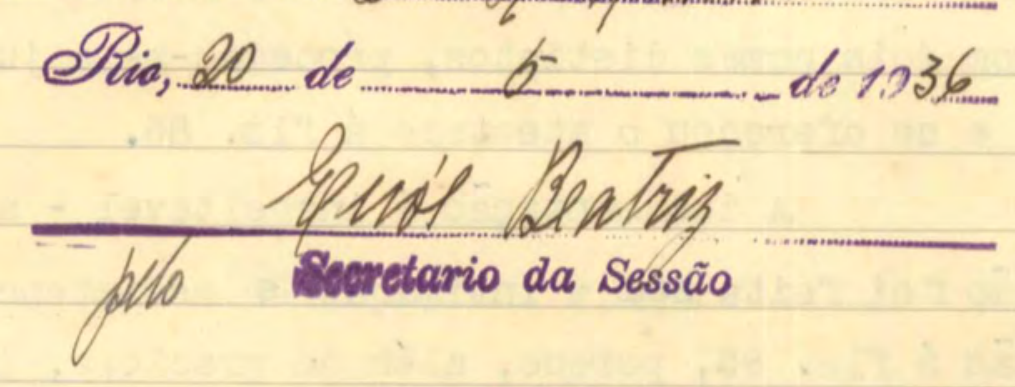

A' Secção respectiva, na forma do regulamento em vigor.

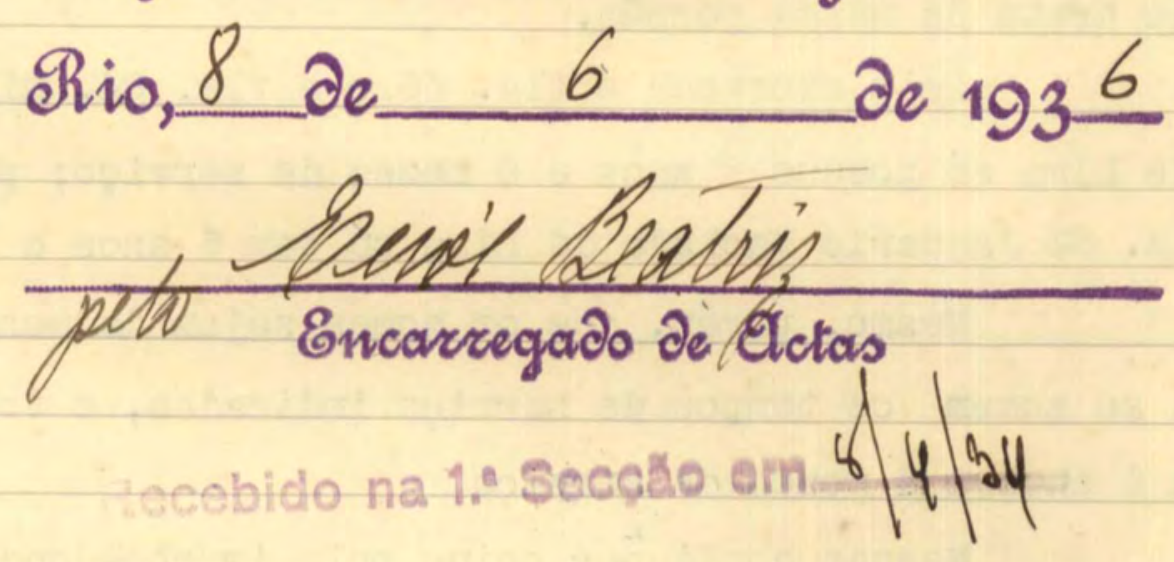


CONSELAOA NAGONAL DO LRABALHO

(I. Secçá)

PROCESSO N. 9582

${ }_{193} 4$

ASSUMPTO

Douning Mantiller e outros Recluman corte a Q is. $\}$.

7. Winas P. Jur /no

Rego Chonontivio

DATA DA DISTRIBUIÇÃo $19-5-36$

DATA DA SESSÃo

$2-6-36$

RESULTADO DO JULGaMENTO

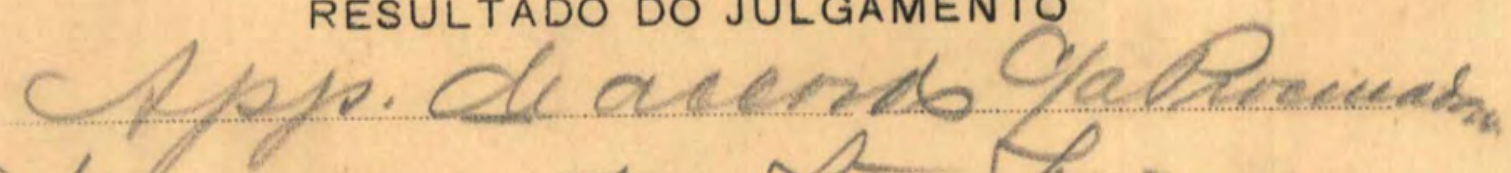

Climun quanth a fro treienam

cominter deligunein pos ceela

Avini eath an Alupriza a

do theper palie tumiso as

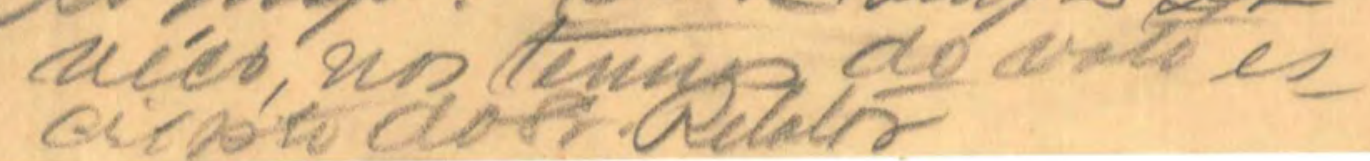


Ministerio do Trabalho,

Industria e Commercio

Secção

\section{CONSELHO NACIONAL DO TRABALHO}

Proc.9.582/34. ACCORDÃO

$\mathrm{Ag} / \mathrm{SSBF}$.

$19_{36}$

Vistos e relatados os autos do processo em que Domingos Mant1lha e outros reclamam contra a Companhia Estrada de Ferro e Minas de Sãd Jeronymo:

\section{R E L A T O R I O}

Domingos Mantilha, Liberalino Machado de Lima, Raphael Mezza, João Keenan, Thomaz Gonçalves, Antonio Nunes das Pedras e Adalberto Azambuja dos Santos reclamaram ao Sr. Inspector de Previdencia de Porto Alegre, que encaminhou o respectivo processo a este conselho, contra a sua demissão da referida Companhia, não obstante contarem ma1s de 10 annos de serviço.

Submettido o processo a julgamento, em sessão de 16 de Novembro de 1934, a Segunda Camara resolveu converter o mes mo em diligencla afim de que a reclamada enviasse o inquerito administrativo a que responderam os supplicantes, e, bem assım, o certificado de tempo de serviço e folhas de antecedentes dos mesmos:

A essa dec1são oppoz a Companhia embargos, os quaes foram reje1tados em sessão plena de 25 de Abril de 1935, v1sto não caber na espec1e os mesmos embargos, resolvendo ma1s que fosse o reclamante Domingos Mant1lha reintegrado, em face do seu tempo de serviço provado e não ter respondido a Inquerito. Em relação aos demais reclamantes, fo1 determinada a remessa do certificado de tempo de serviço. Isto posto e 
dos autos, fica evidenciado que os empregados reclamantes, por terem tramado uma greve geral entre os mineiros, foram expulsos do serviço da mina pela policia, que os prendeu para averiguação e processo criminal posterior;

CONSIDERANDO que, diante dessa s1tuação, a Companhia não se julgou no dever de promover o inquerito para justificar a demissão dos empregados presos, simplesmente porque os considerou de facto e de dire1to dem1tt1dos, em virtude do afastamento forçado que thes impoz a policia;

CONSIDERANDO que é Improcedente a argumentação sustentada pela reclamada, pois da prisão dos empregados não resultou condemnação dos mesmos, e, não obstante, flcaram elles fora do serviço; nestas cond1ções

CONSIDERANDO que, desde que os empregados das Companhias de Mineração, por força do art. 2 do Dec. n: 22.096, de 16 de Novembro de 1932, que fez expressa remissão a art. 53 do Dec. n: 20.465, de 1931, não podem ser demittidos, apos 10 annos de serviço, senão mediante a prova de falta grave, apurada em inquerito, é obvio que para a dem1ssão em todos os casos ha mister o dito inquerito, o que não se verfficou no processo, conforme confessa a reclamada; 1sto posto

CONSIDERANDO que, cumprida a diligencia determinada pelo accordão de fls. 47/48, f1ca apurado que o empregado Domingos Mant1Ina, cujo direito já reconhecera este conselho, fol readmittido ao serviço, como faz certo a declaração do advogado da Companhia, mas não fo1 Indemnizado dos vencimentos atrazados, correspondentes ao tempo em que esteve afastado;

CONSIDERANDO que a Indemnização dos venc1mentos atrazados e uma consequencia logica da propria reintegração e, des que a com- 
panhia readmittıu o reclamante ao serviço, deve pagar ap mesmo os salarios a que tem dire1to;

CONSIDERANDO que, em relação aos empregados Thomaz Gonçalves da S1lva e Raphael Mezza, a Companhia offereceu prova de que ambos tem ma1s de 10 annos de serviço, assistindoIhes, portanto, dîre1to á re1ntegração, nas cond1ções do seu companhe1ro Dom1ngos Mant1lha;

CONSIDERANDO que, quanto aos empregados Adalberto Azambuja dos Santos e Anton1o Nunes das Pedras, não consegu1ram provar o seu direıto á estabilıdade funccional, e, assım, não podem ser amparados pelo disposto no art. 53 do Dec. 20.465, de 1931;

CONSIDERANDO que sobre o empregado Liberalino Machado de Lima, que tambem é conhecido por Januario Machado de Lima, ha uma confusão que não permitte uma solução definitıva. Com effeito: para a prova do tempo de serviço, embora com dois nomes distinctos, fol procedida uma justificação judicial e offerecido o attestado de fls. 85. Todavia, a documentação é Imacceltavel, pelas falhas de que se resente, e, mesmo que fosse considerada como valida, a1nda assim não consegue o empregado o tempo necessario para sua estab1lidade;

CONSIDERANDO, finalmente, que com referenc1a ao empregado João Keenan, o attestado de tempo de serviço - Ils. 59 está concebido em termos poucos precisos;

Kesolvem os membros da l'ercelra Camara do ConseIho Nacional do Trabalho, em face do exposto:

a) - determinar sejam pagos ao empregado Domingos Mantilha os vencimentos atrazados a que tem direito;

b) - determinar que os empregados Thomaz Gonçalves da Silva e raphael Mezza sejam reintegrados, e, bem assim, inde- 
mnizados dos salarios de que se viram privados durante o tempo em que estiveram afastados do serviço;

c) - julgar Improcedente a reclamação dos empregados Adalberto Azambuja dos Santos, Antonio Nunes das Pedras e Liberalino Machado de Lima(ou Januar1o Machado de Lima), por falta de fundamento legal;

d) converter em diligenc1a o julgamento da reclamação do empregado João Keenan, para que selam sol1c1tados novos esclarecimentos á reclamada e ao Sr, Inspector da Região, sobre o tempo de serviço do mesmo reclamante.

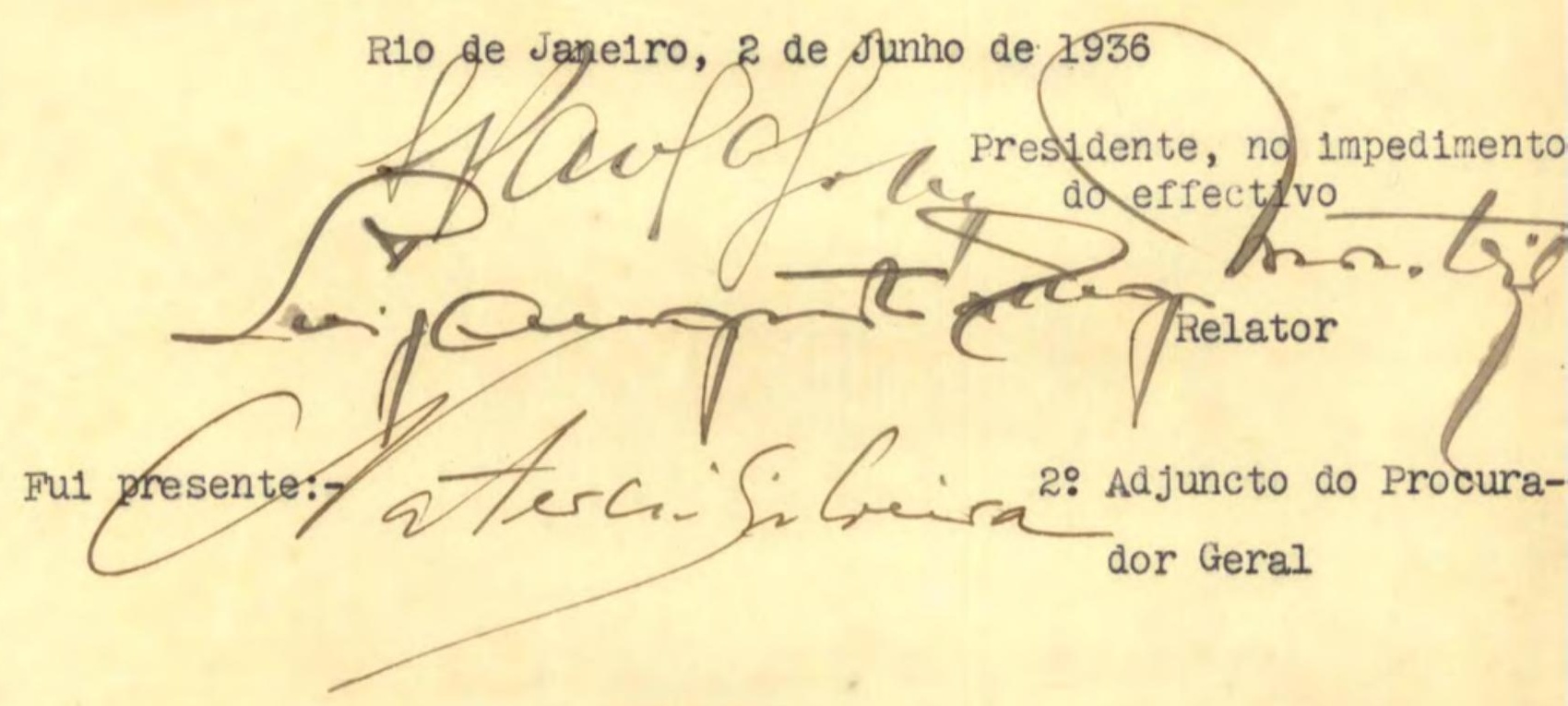

Publicado no Diarto official em 25 de yucho de 1936 
Termo de deslaráção

Consoante o resolvido pela V. Terceira Camara deste Conselho em accordão de fls. 96 - item d - esta secretaria deve officiar á Companhia reclamada para que preste esclarecimentos sobre determinado funccionario, e, bem assim, $80 \mathrm{sr}$. Inspector da Região.

Acontece, porem, que,presentemente, se encontra nesta Capital o Snr. Inspector Lobão dos Santos, que serve no Rio Grande do Sul.

Cumprindo o respeitavel julgado dei verbalmente sciencia ao dito Inspector das providencias que the cabia to mar sobre o assumpto, havendo S.S. me declarado que brevemen te reassumirá as funcções no Estado, e, então, attenderá á decisão deste $\mathbb{E}$. Conselho.

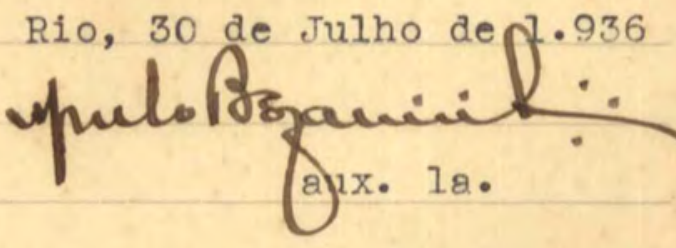

Sciente das determinacões emanadas da V. Terceird Camara, cabendo-me esclarecer que sómente quando reassumir, dentro em breve, as funcções de Inspector, no Rio Grande do Sul, tomarei as necessarias providencias sobre o que se declara no item $\underline{\mathrm{d}}$ do accordão de fls. 96.

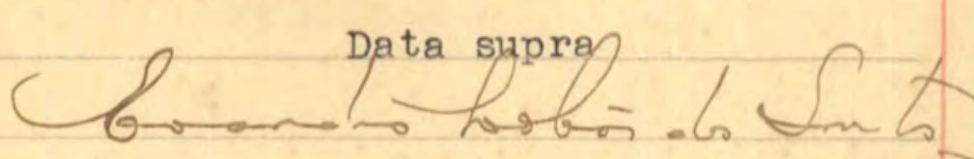

Inspactor de Previdencia. 
Proc. $9.582 / 34$

6

Agosto

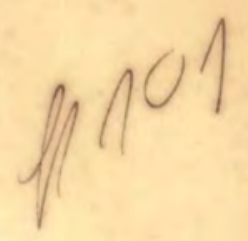

6

$\mathrm{Ag} / \mathrm{SSBP}$.

$1-1.046$

Sr. D1rector da Companh1a Estrada de Ferro e Mnas de sก̃o verunymo.

kนด Faysandú n: 219 - Porto Alegre R1o Grande do Sul

Transm1tto-vos, para os dev1dos 11ns, cop1a authent1cadn do nccordão proferido pela Tercelra Camara deste conselho, em sessño de 2 de Junho p. pessado, nos autos do processo em que sêo partes Domingos Lantilha e outros, coho reclamantes, e essa mompreza, como reclamadn.

+_ Consonnte a dec1são deve essa Empreza:

a) - pronover o pagamento dos srlanios devidos no funccioner1o Doningos knt11ha, correspondentes so tempo em cue esteve afestado do serviço;

b) - providenciar para que os funcelonarios Thonaz Gonçalves dn Silva e inphael Mezza voltem ao serviço e sejam, outros1m, 1ndemn1zados dos selarios atrazados;

c) - I1nalmente, prestar melhores esclerecimentos sobre o exacto tempo de serviço do funccionar1o Joño Keenan, v1sto serem 1nsuficientes os esclarecimentos constentes do cert111cado que 101 apresentado por essa tmpreza, con o off1c1o de 5 de igosto de 1935. Outrosim, devem ser offerec1das provas do cuintaes do alleguao em o d1to cert111cedo, sobre a 1mpossib1- 
l1dade de attestar exactamente o tempo de serviço do empregado mencionado neste 1 tem.

Attenc1osas saudações

Oswaldo Soares

Director Geral da Secretaria 
MINISTERIO DO TRABALHO

CONSELHO NACIONAL DO TRABALHO

Sur. Diector

Tão teudo havido jexposta atz' a presente da. ta ao experiente cuja cofia se enculta a tirtro, pu. so que podará ser o nesuro leiterato, wareaneso à Aupre Za o prazo $\mathrm{B}_{2}$ is bia fara Resposta.

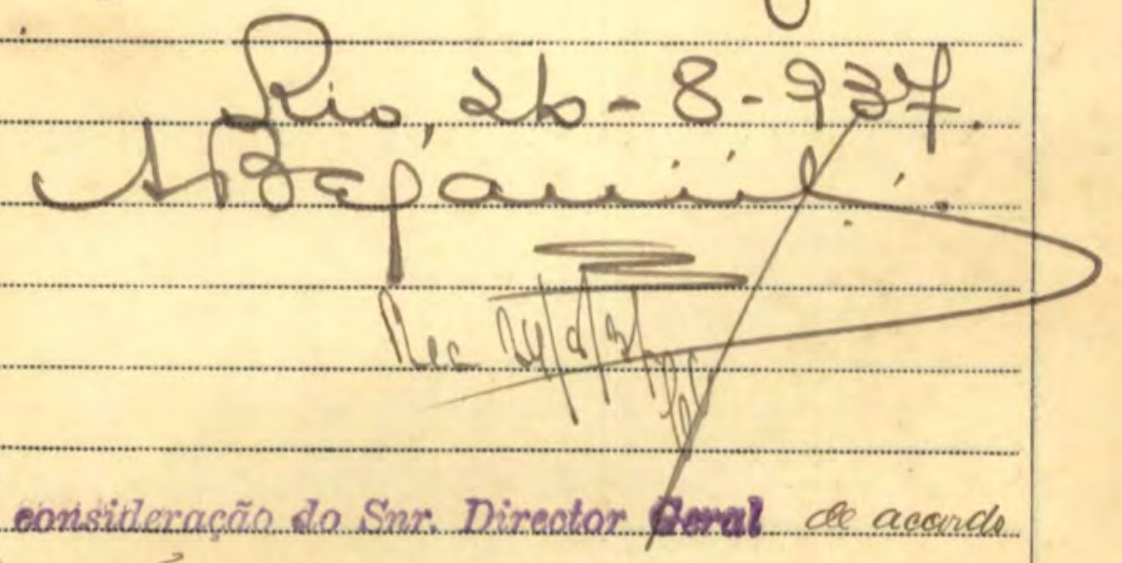

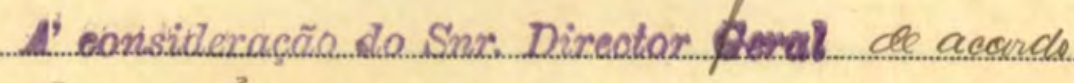
en a infomacw puma Rio de uneiro. 28 de Por, क de198. - Shodno de Rlueida Sodé

Qfficir te kovannente a'eupitita, covo Tŕpo de Leceás.

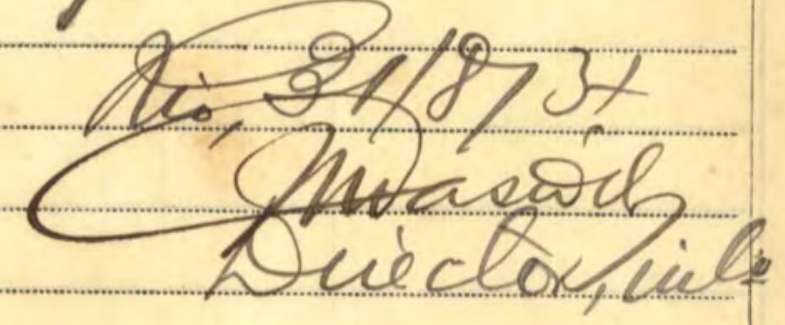

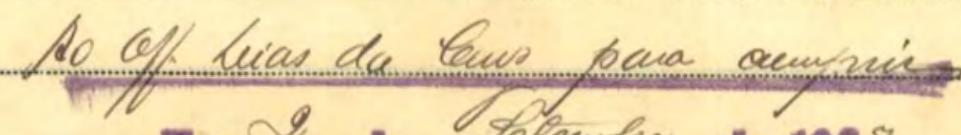

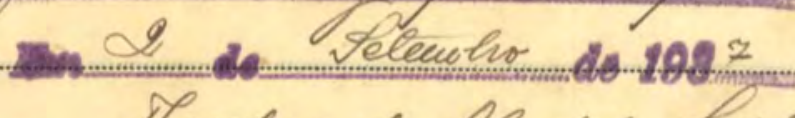

$$
\begin{aligned}
& \text { Sheoduo de Slucida to des }
\end{aligned}
$$


aina oino of pireate ar af

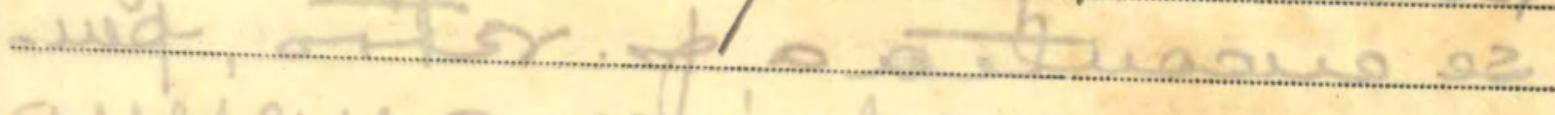
(1.

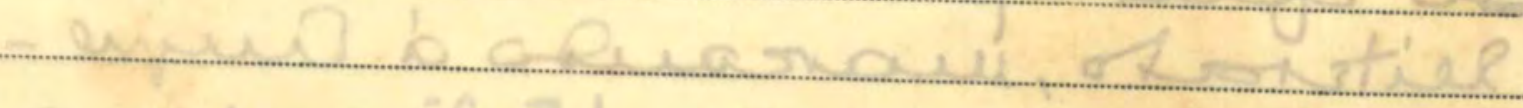
(2)

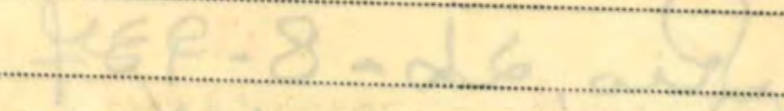

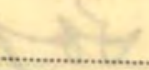

ant

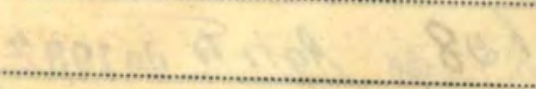
(1) 
M. T. I. C. - CONSELHO NACIONAL DO TRABALHO

$\mathrm{CN} / \mathrm{SSBF}$.

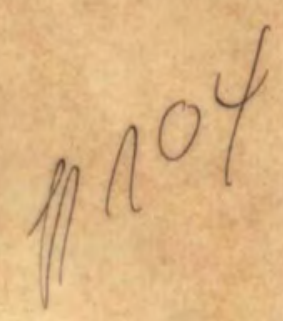

7

$1-1.471 / 37-9.582 / 34$

Sr. D1rector da Companh1a Estrada de Ferro e M1nas de São Jeronymo

Rua Paysandú n: 219

Porto Alegre - Estado do R10 Grande do Sul

Não tendo esta Secretaria recebido até a presente data resposta do officio n: $1-1.046 / 9.582 / 37$, de 6 de Agosto ultimo, cuja copla ora vos encaminho, solic1to-vos as necessarias providencias no sent1do de serem attendidas as determinacões do alludido officio, dentro do prazo de 15 dias.

Attenciosas saudações

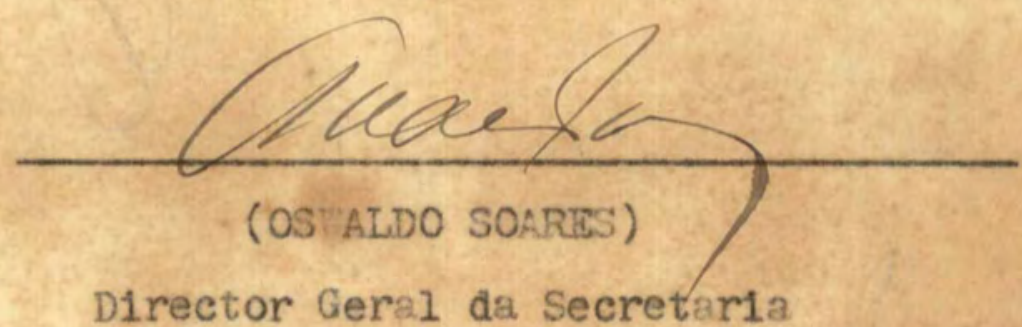

Director Geral da Secretaria 



\section{"CADEM"}

CONSORCIO ADMINISTRADOR DE EMPRESAS DE MINERAÇ̄̃o Procurador das Companhias E. de F. e Minas

End. Telegr.: "CADEM"

Caixa Postal 329
Rua Siqueira Campos 1189 Edificio Sehilling 3.0 andar

DD. Director Geral da Secretaria do

Conseltho Nacional do Trabalho

RTO DE JANIETRO

\section{5. scebido na 1. a Secção em le. 10.42}

Re spondendo vosso officio $n^{2} \cdot 1-1.471 / 37-9.582 / 34$, de 16 de Setembro p.pd², e que faz referencia ao officio de 6 de Agosto ultimo, sob ne $2-1.046 / 9.582 / 37$, cuja copia annexastes, cumpre-nos informar-vos o seguinte:

a) - A Companhia Estrada de Ferro e Minas de São Jeronymo já promoveu o pagamento dos salarios devidos ao empregado Domingos Mantilha, correspondentes ao tempo em que esteve afastado do serviço;

b) - os operarios Thomaz Gonçalves da Silva e Raphael

Mezza já foram readmittidos no serviço e tambem indennisados dos salarios atrazados;

c) - Sobre o tempo de serviço de João Keenan, não podemos provar com documentos o incendio occorrido ha 10 annos no nosso Almoxarifado, com destruigeão do respectivo archivo, por is to que, sẹdo constatado que se tratava de um incendio meramente casual, não houve inquerito policial. Entretanto, sendo um facto publico e notorio, é conhecido de toda a gente no perimetro das nossas minas.

Refteramo-vos os protestos da nossa elevada consideração e apreço, subscrevendo-nos com a mais,

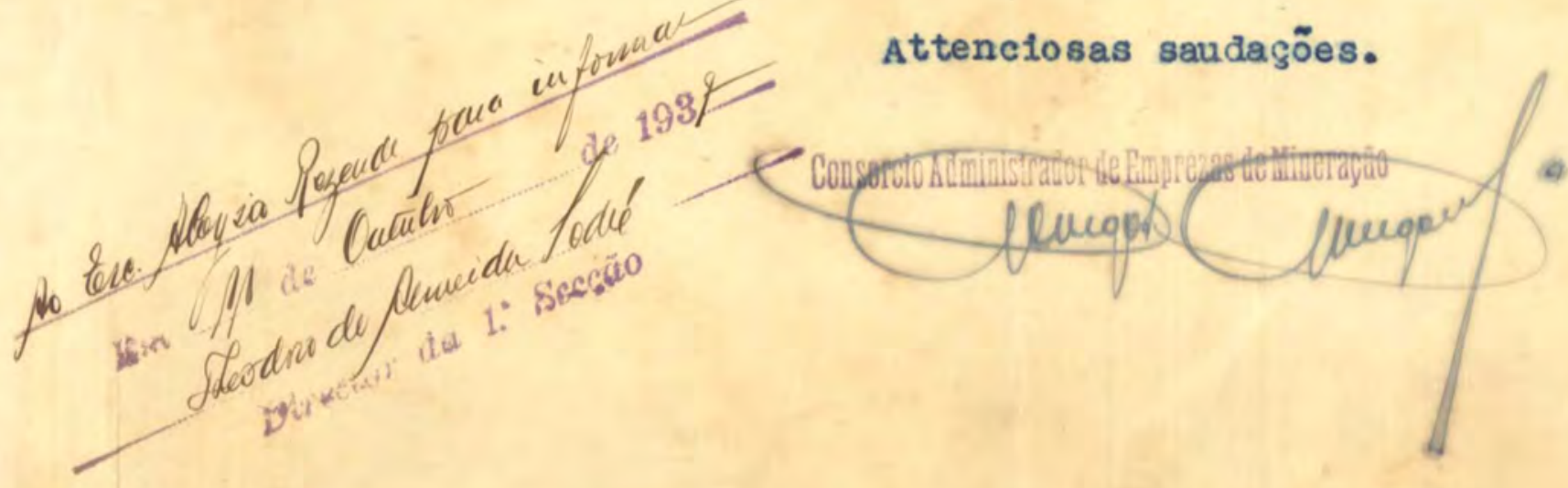




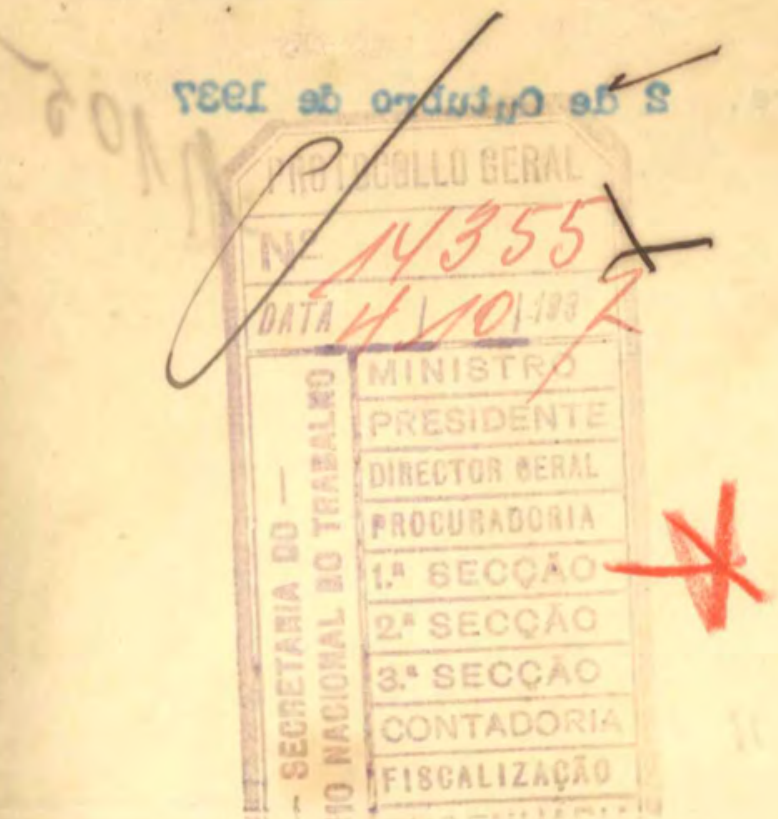

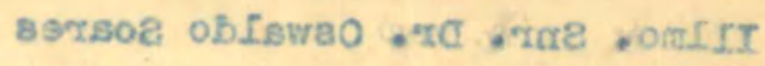

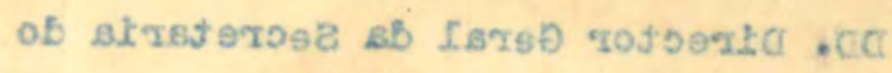
onfisdart of farotosh orleanob OETMLAT, GCI OTE

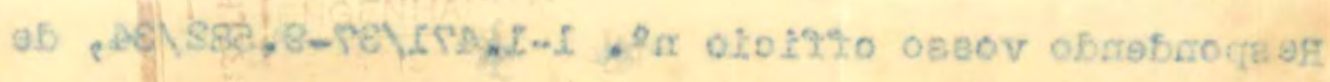

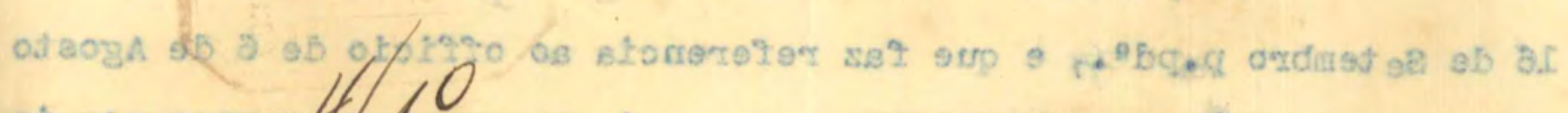

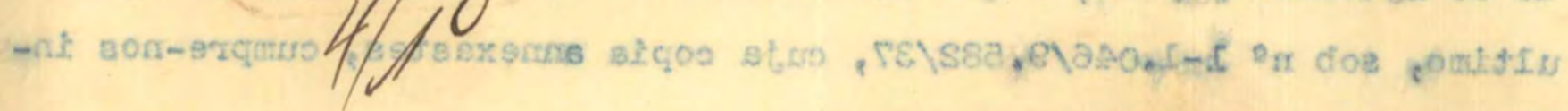

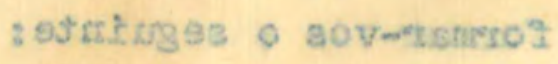

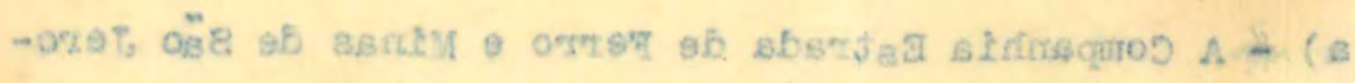

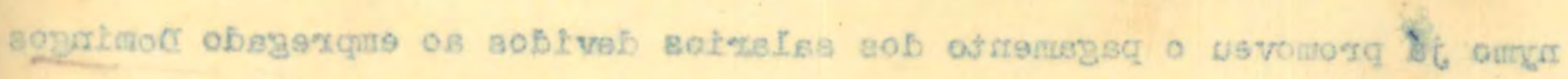

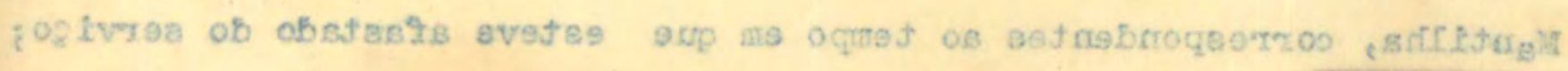

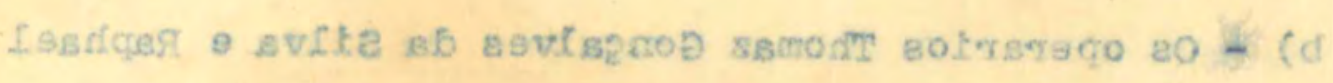

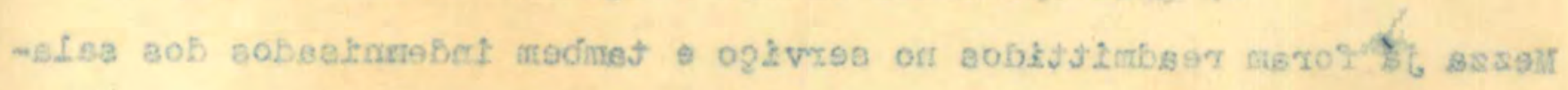
taObSSETt's toin

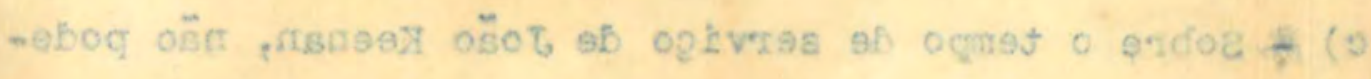

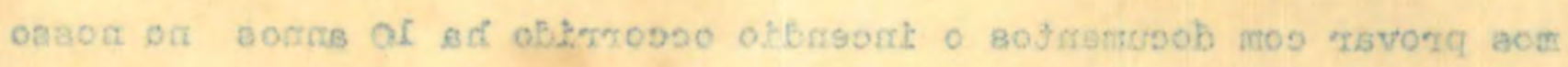

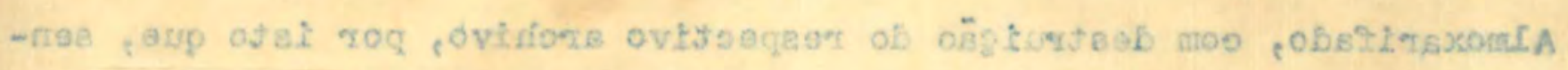

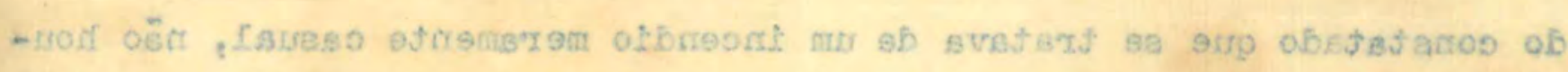

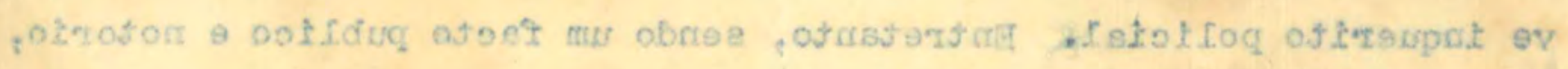

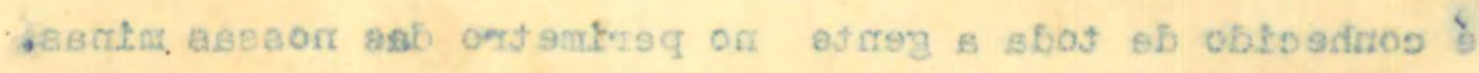

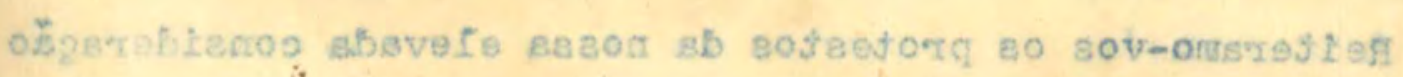

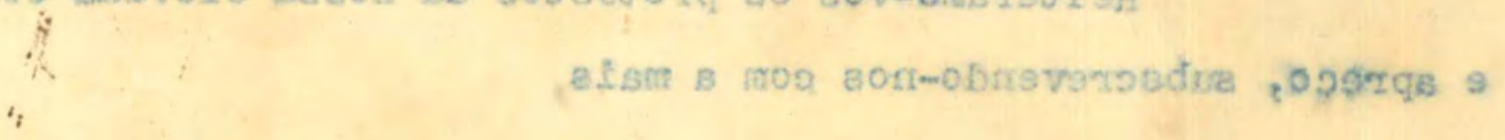

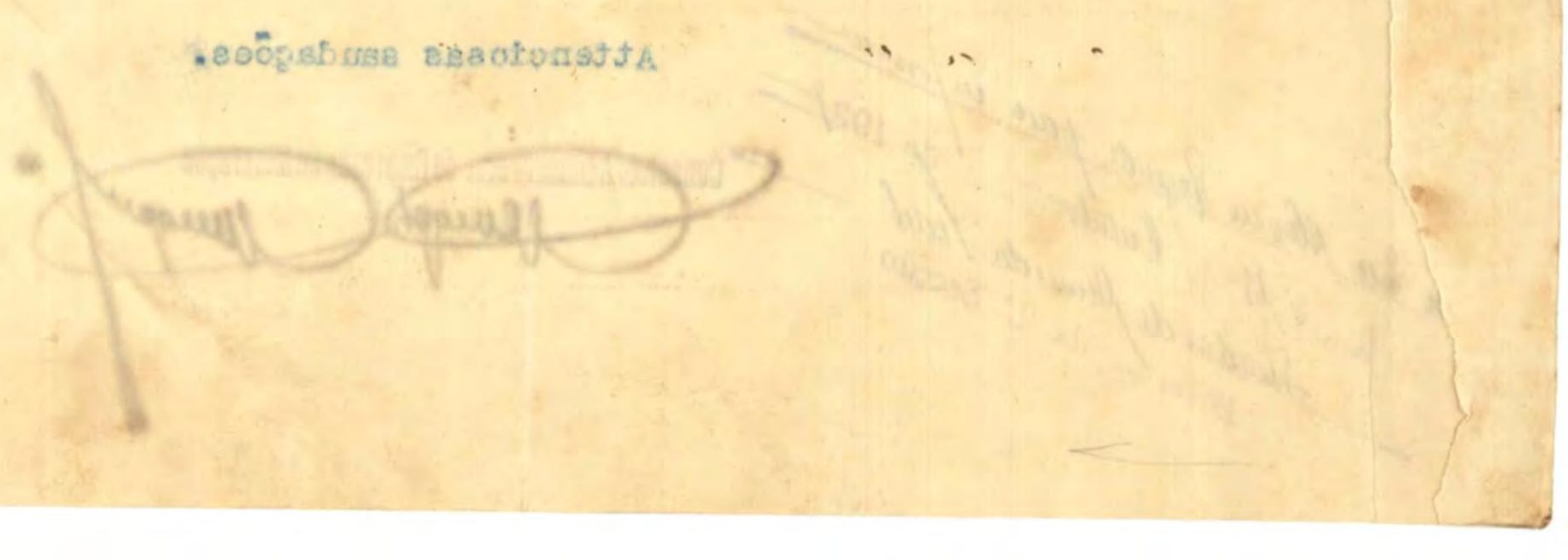


MINISTERIO do tRaballo, INDÚSTRIA E cOMERCIO CONSELHO NACIONAL DO TRABALHO

106

- Cousercio Afduvivistrador de cem-

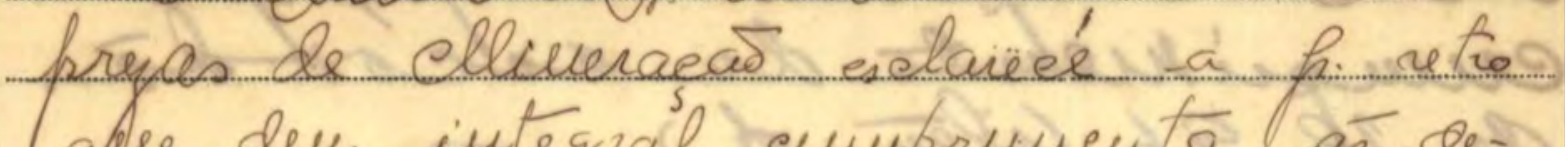
que den integral cumprumento aś deHerunivareres opentantos/des iteus a e b os aceódar de fi., incumuizann o

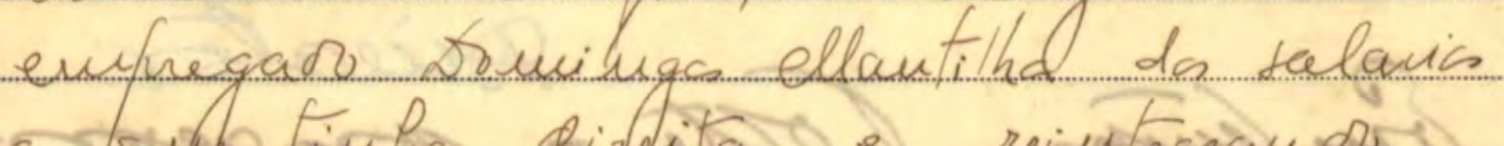

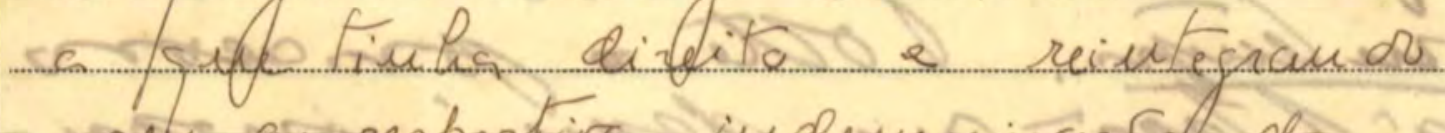

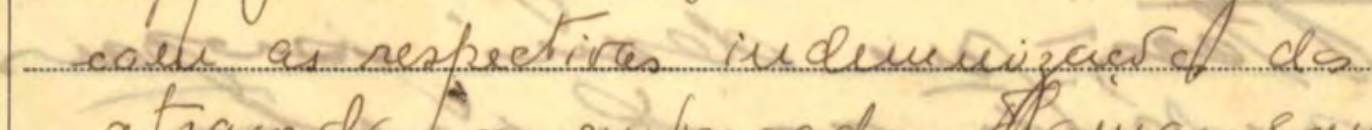

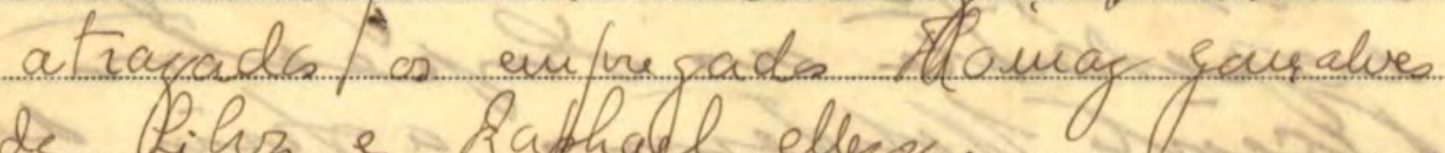
ds Ribre Rafhad ellegza.

fobre a edaveinuent pedids ne item I do aceerdat entadr o bousercio ecclavee que vas pode pestal-as a nista da destruicast fon iucudio do isen alenoxarifañ.

boun jat fir dwiguad un Luxpecto Q. Frendensia dests beuelho faur terri en staor or Ric fraur de o lest, deric cosereniente prowearer- $k$ s tua andiencis folls o ansunpto, aliá̃ cens de terunisca exfrenauneuté o aceóidar de 3. bantare.

Ai: 14 de Cutuho 1937

P. L d fleyen de

Lup.de fer ist:

$$
14 \mid 10.5)
$$

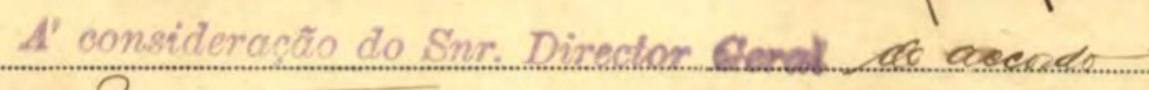
con a è fomancent reypa

thio de Janciro, 15 de Cumear de 198\%

Shoodur de fancida Sodú

Director da 1a Seceão

$15 \mid 10.92$ 
Loom. Onsootor-ahe py fou cumpinuent do accost dà de $7 k$. 96 (ilem d)

Ouleump lovt Aicator a'l tersfar dene verpan

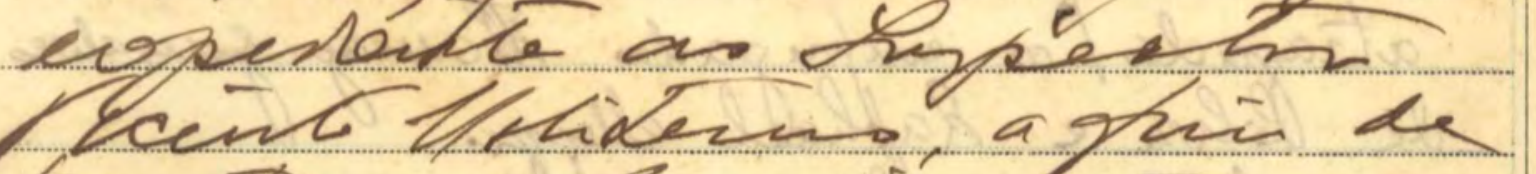
nent thateri, agher his $182 \times 1507$ Anaros loas

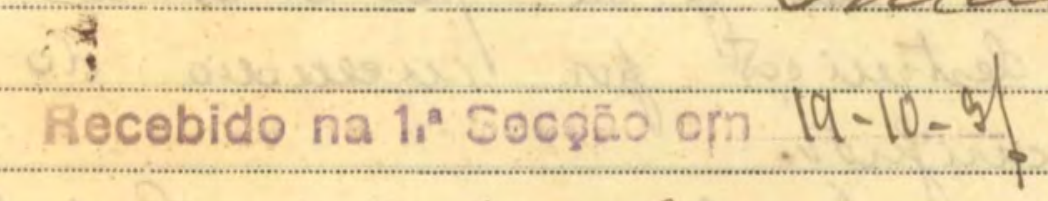

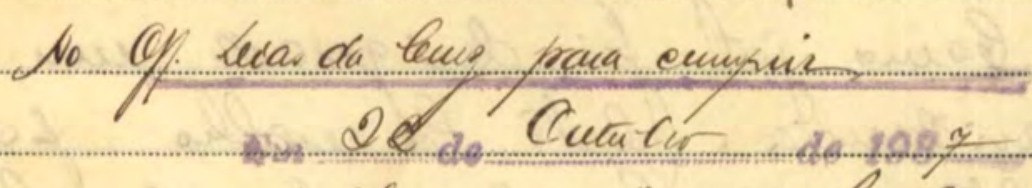
Otructer da L" Seccẽo 
CN/Cs

\section{$1-1.798 / 37-9.582 / 34$}

\section{Sr. Vicente de Oliveira Moliterno}

Inspector do Conselho Nacional do Trabalho RIO GRANDE DO SUL

De conformidade com o resolvido pela Terceira Camara do Conselho Nacional do Trabalho, en sessäo de 2 de Junho do anno passado, nos autos do processo em que Domingos Mantilha e outros reclamam contra a Companhia Estrada de Ferro e Minas de são Jeronymo, solicito vossas providencias no sentido de ser esta Secretaria informada, a respeito do tempo-de serviço exacto do funccionerlo João Keenan na Companhia reclamada, vista serem insuff $\underline{\underline{1}}$ cientes os esclarecimentos constantes do certifica do que fol offerecido pela alludida Estrada.

Attenciosas saudações

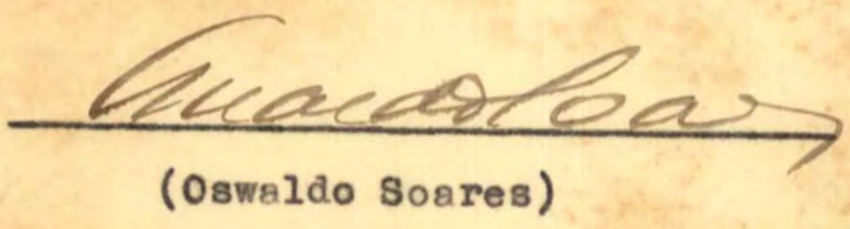

Director da Secretaria. 


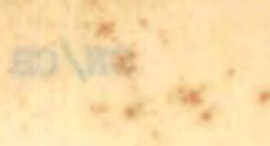

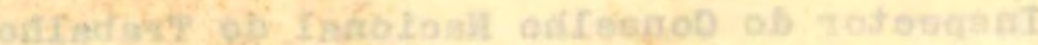

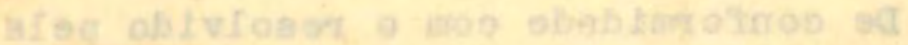

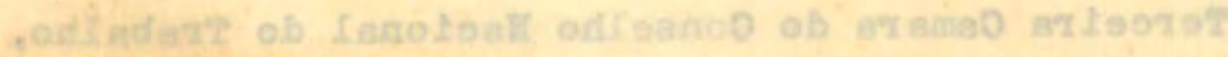

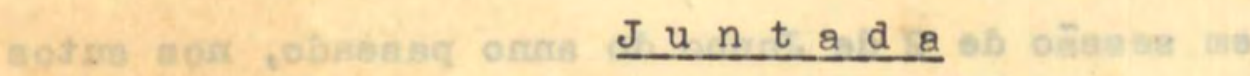

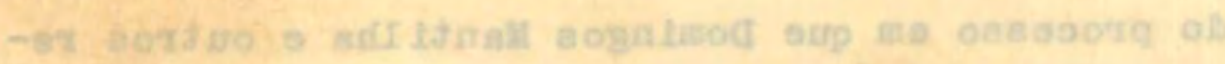

Junto, nesta data, aos presentes autos

a fls. seguintes os documentos protocolladossob. o no $19278 / 37$.

$$
\text { Rio, 3-1-38 }
$$

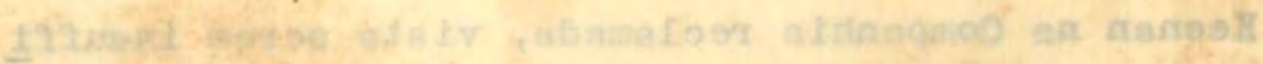

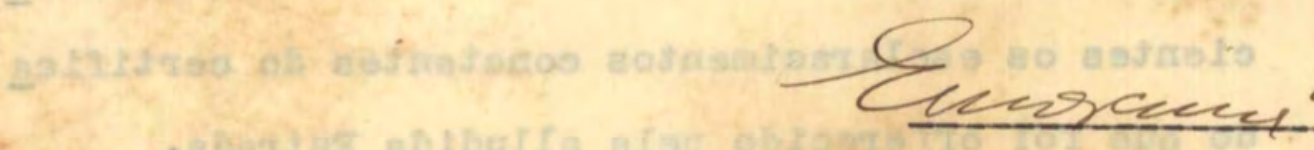

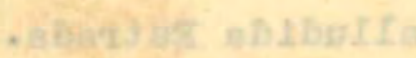

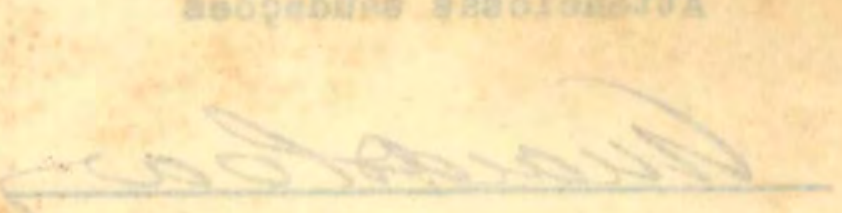

(aerace obfara) 


\section{SAN. GC/AN/.N2 293}

Porto Alegre, 22 de llovamibro de 1937

\section{IIIno. Sns.}

\section{Dr. Vicente de Oliveira Noliterno}

DD. Inspector do Conselho Nacional do Trabalho

\section{N/ CAPITAL}

Saudações.,

Accusando o recebimento de vosso offlcio de 18 do corrente, communicando-nos que a secretaria do Conselho Nacional do Trabalho solicita providencias mecessarias a respeito do tempo exacto do funccionario João Keenan, cumpre-nos communicar-vos que em data de 2 de Outubro do corrente anno, em resposta a 1dentida solicitação do Conselho Nacional do Trabalho, enviamos o officio cuja copia ora juntamos.

Por essa resposta, verificaréis a impossibilidade de attestar a Cia. Estrada de Ferro e Minas de Säo Jeronymo, o tempo exacto daquelle funccionario.

Sendo o que para a presente se nos offerece, permanecemos ao vosso inteiro dispor e subscrevemo-nos com o mais alto apreço e distinta consideração.

De V.S.

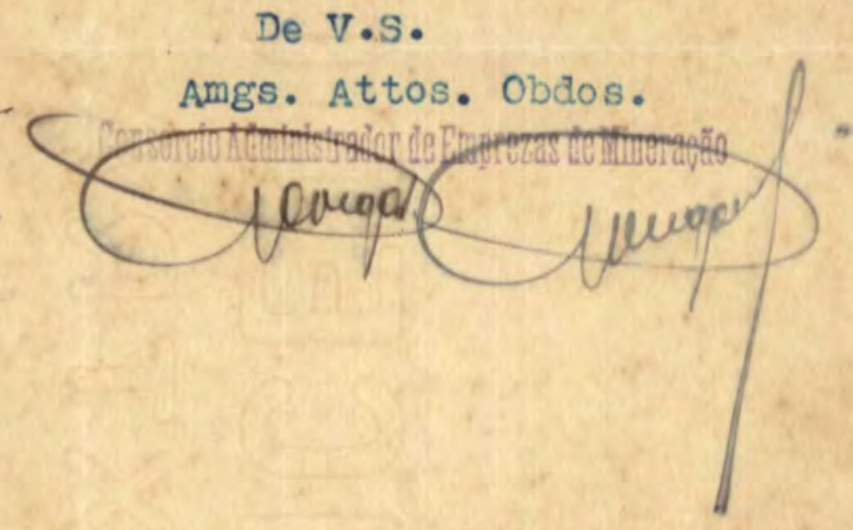
Director ad 


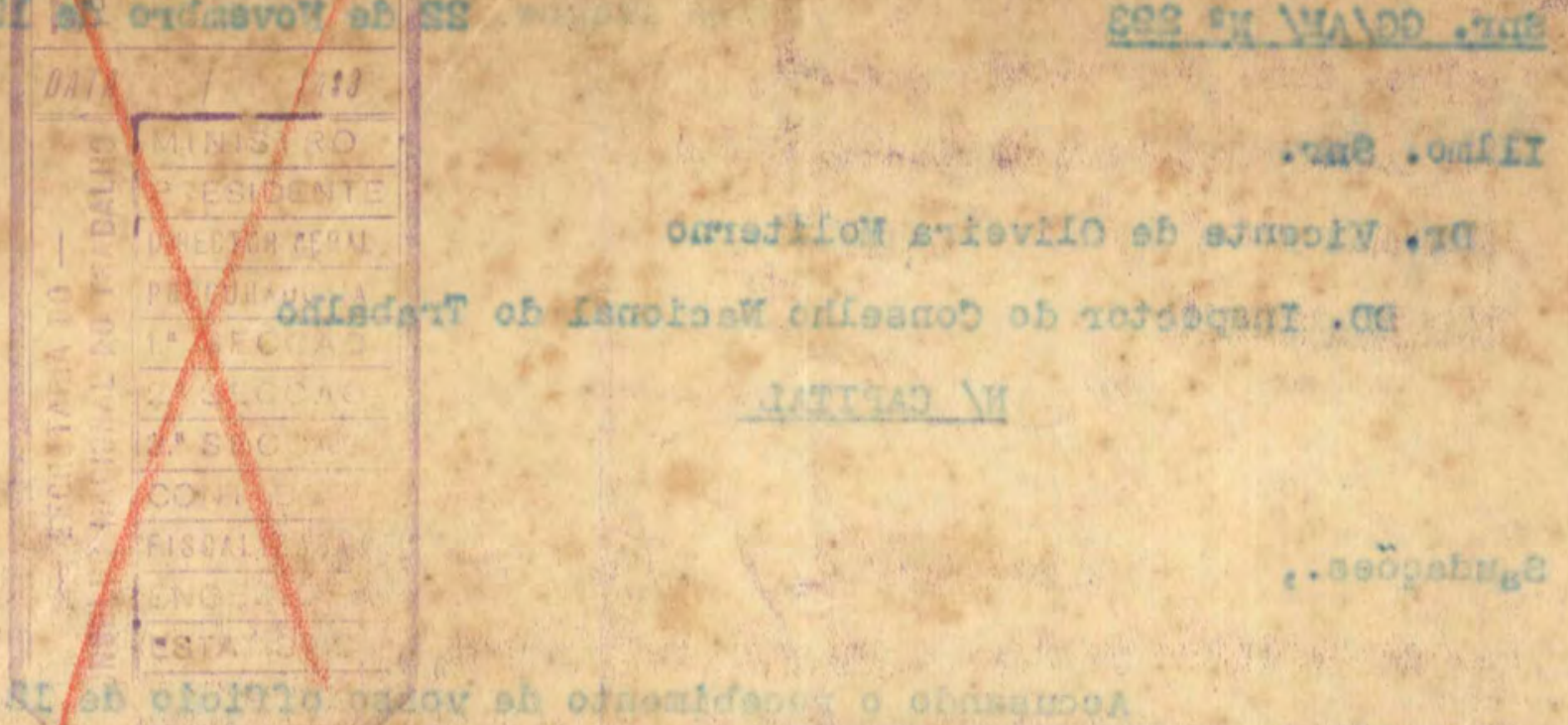

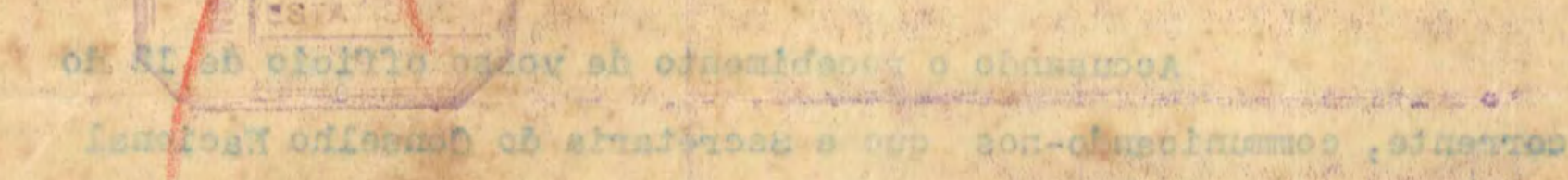

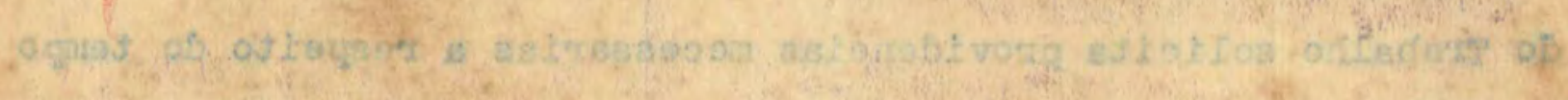

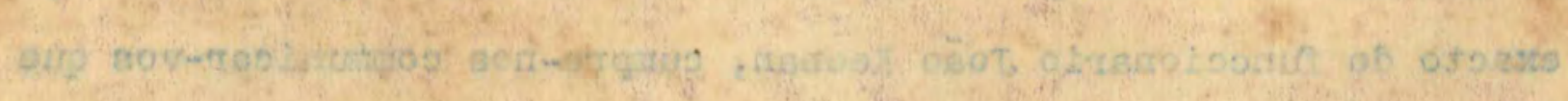

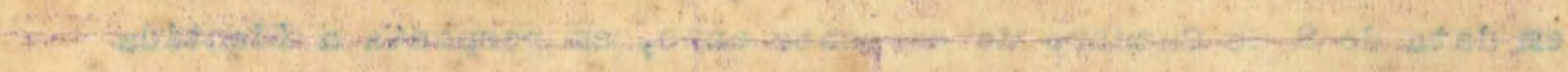

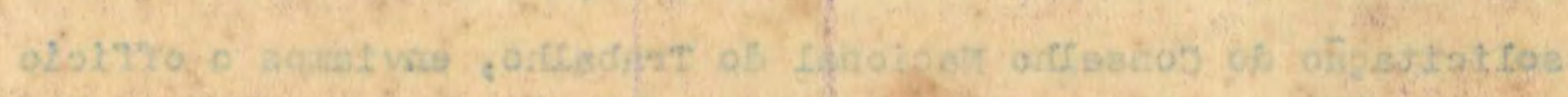

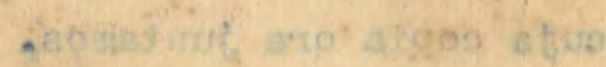

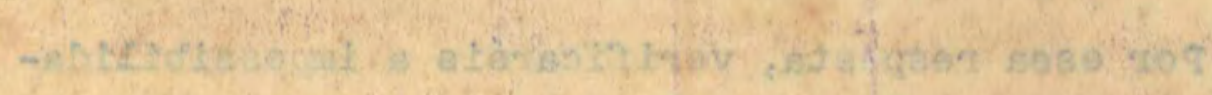

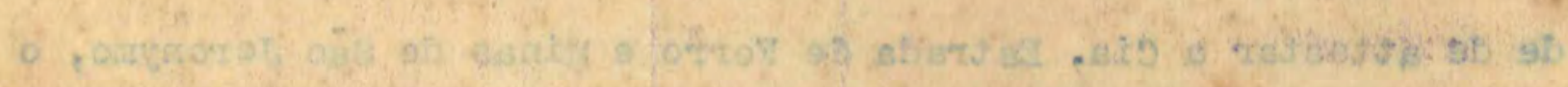

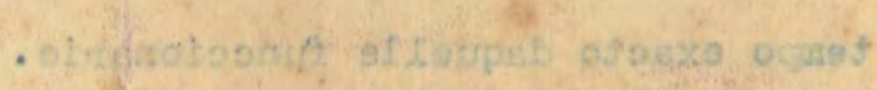

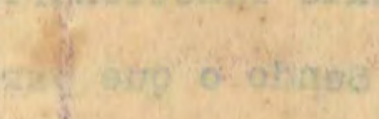

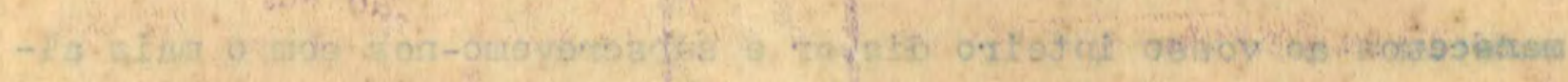

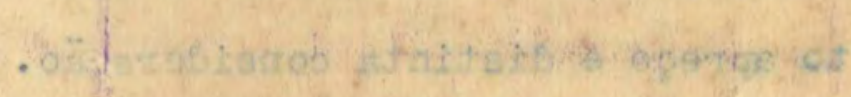


MINISTERIO DO TRABALHO, INDÚSTRIA E COMERCIO
CONSELHO NACIONAL DO TRABALHO RIO DE JANEIRO, D, F.

Porto Alegre, 8 de dezembro de 1937

IIlmo. Sr.

Dr.Oswaldo Soares

DD. Director Geral da Secretaria do

Conselho Nacional do Trabalho

Rio de Janeiro

Em resposta ao vosso officio de 28 de outubro p.p., solicitando informações sobre o tempo de serviço de João Keenan na Cia. Estrada de Ferro e Minas de S.Jeronymo, cabe-me informar o seguinte:

Tendo me dirigido á mencionada Companhia foi-me declarado que estava ella impossibilitada de attender a essa solicitação em virtude de se ter perdido o seu archivo no incendio ali occorrido ha algum tempo. E mais que, essas informações já havia ella prestado a esse egregio Conselho conforme tudo consta das cartas que junto a esta.

Solicitei então a vinda do interessado, sr. Keenan, a esta cidade, afim de providenciar sobre a prova exigida, mesmo que fosse necessaria a justificação judicial.só hoje pude entender-me com esse senhor, sendo então informado que essa justificação judicial já se havia realizado e que a respectiva certidão fôra ahi entregue, ha cerca cerca de tres mezes, ao seu procurador, sr. Juvenal Conrado, do Institato dos Bancarios, para que este a encaminhasse ao C.N.T.

Providenciei tambem para que o interessado solicitasse por telegramma ao sr. Conrado a entrega immediata desse documento a essa secretaria.

A demóra destas informações é devida ás difficuldades que encontrei para obtel-as.

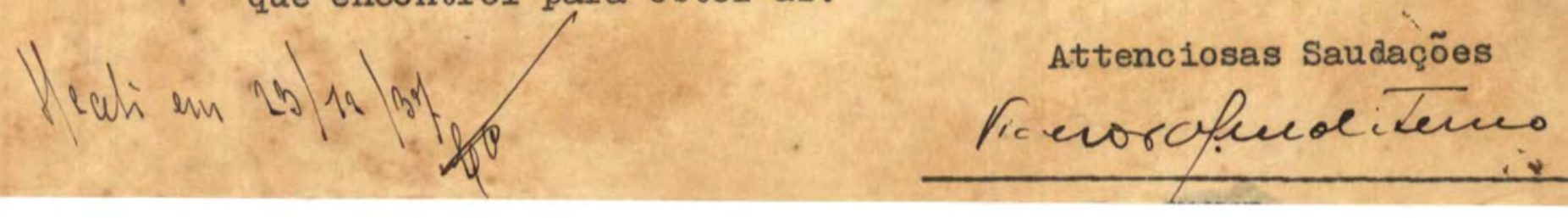



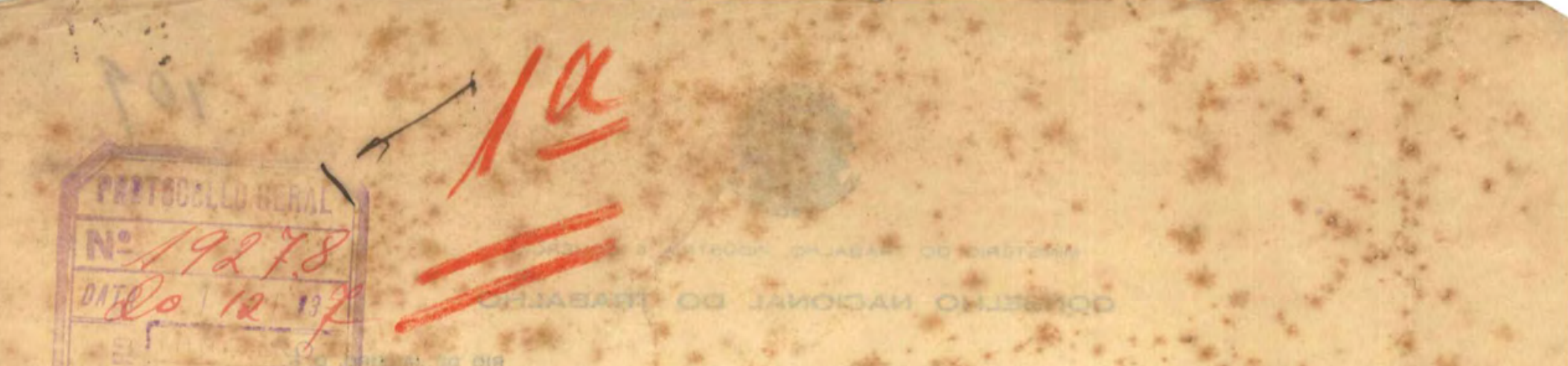

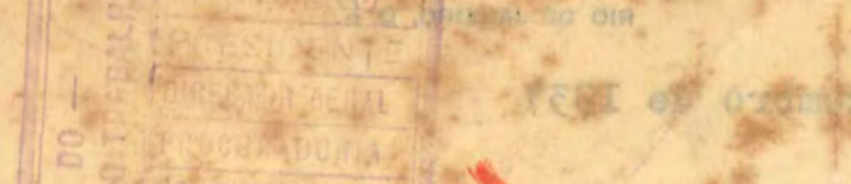

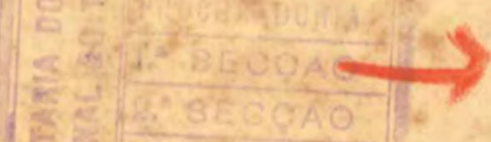

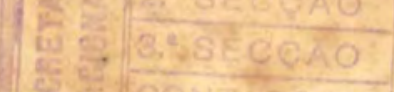

$*$ i⿱

Ais

(18) $9 / / 2$

2025

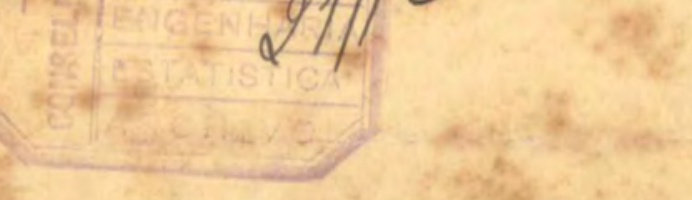

That

1. C.

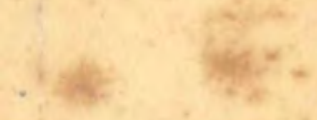

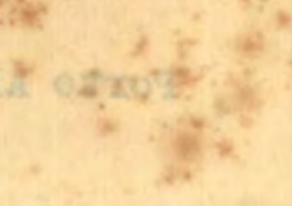

ond

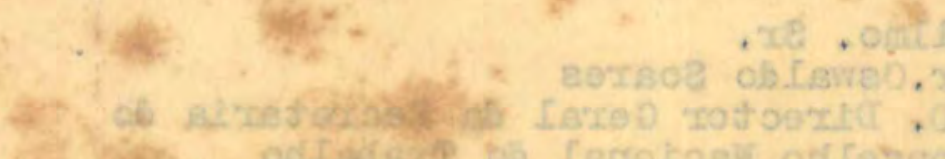

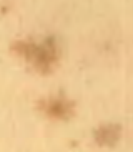

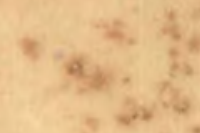

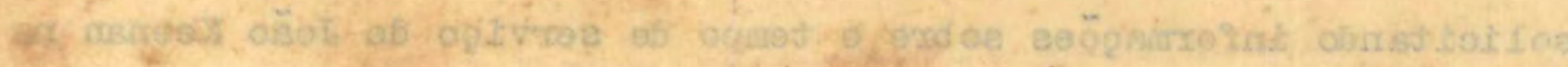

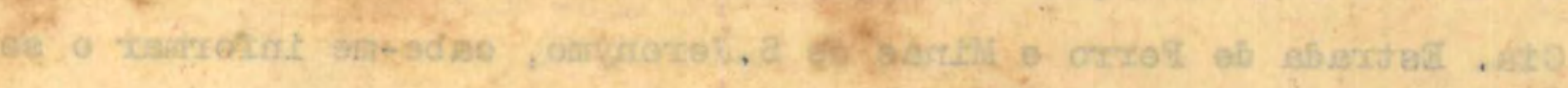

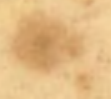

soldentirs

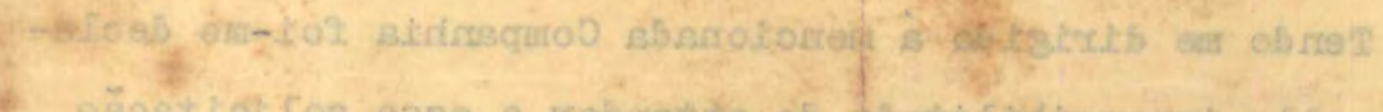

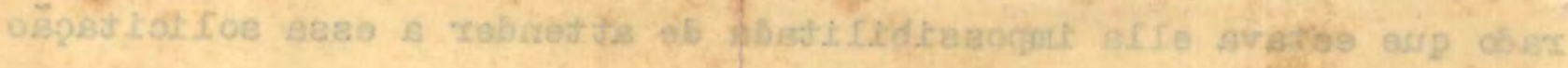

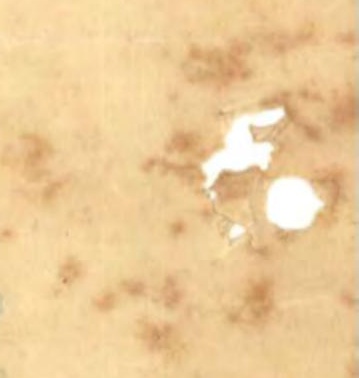

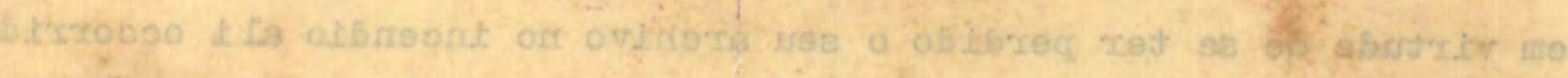

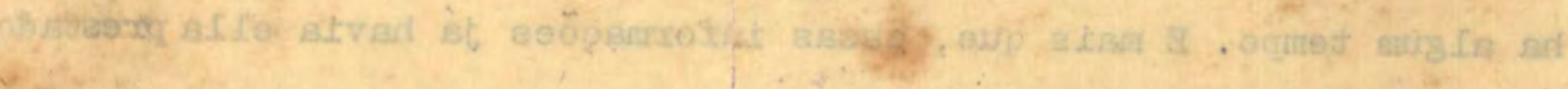

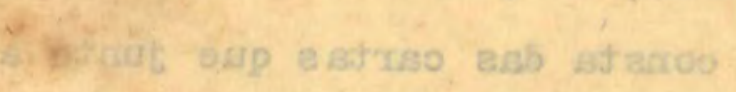

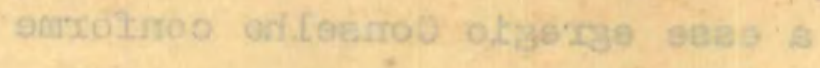

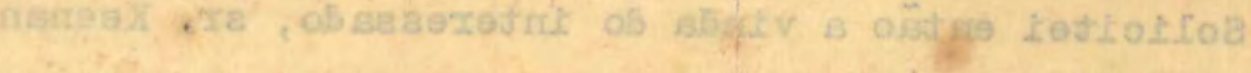

. ลงังอ

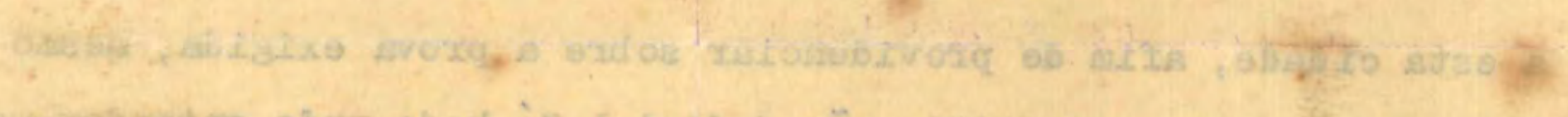

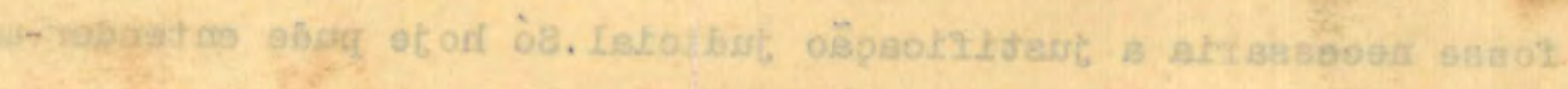

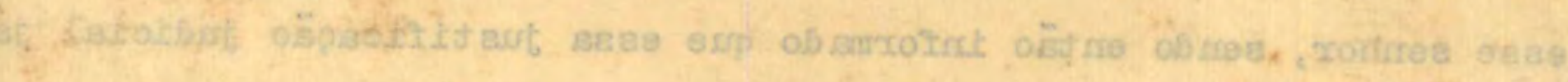

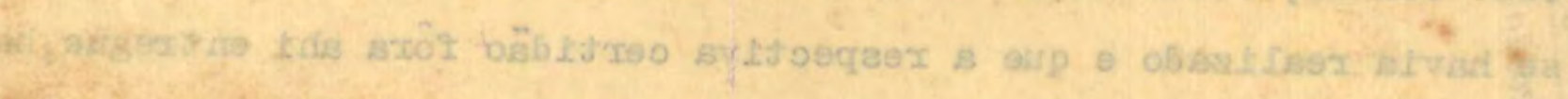

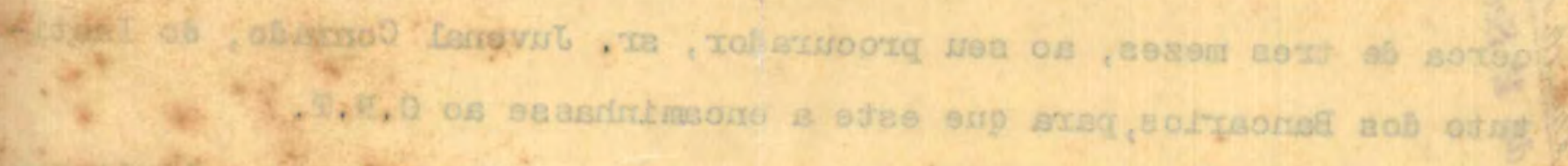

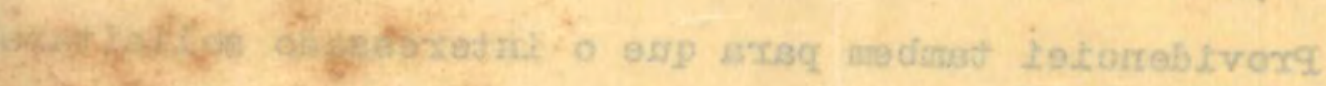

A.

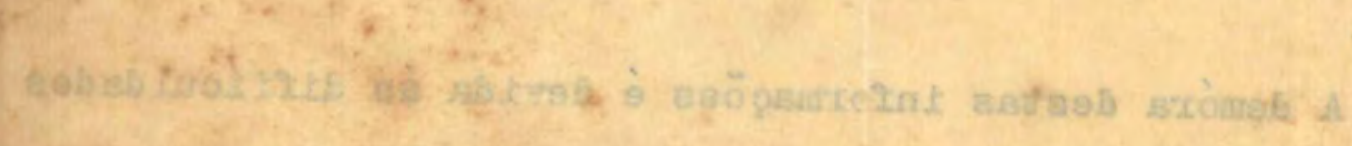

- istriat stooa saes

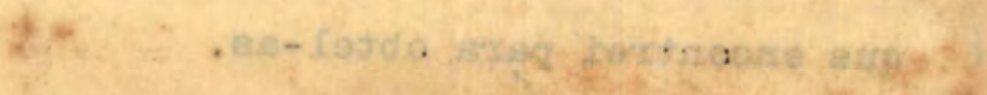

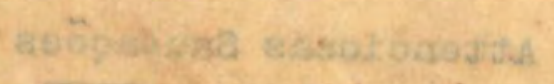

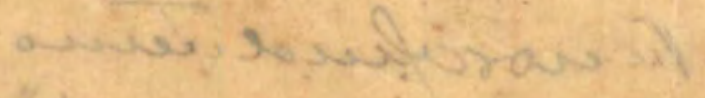


Illmo. Sme. Dr. Oswaldo soares

DDo Director seral da Secretaria do

Conselho Nacionar do rrabalho

RIO DE JANEIRO

Respondendo vosso oxelcio $n^{2} 1-1.471 / 37-9.582 / 34$, de

16 de Setembro p.pd., e que faz refermeia ao officio de 6 de Agosto ultimo, sob $n^{2} 1-1.046 / 9.582 / 37$, cuja npia annexastes, cumpre-nos Informar-vos o seguinte:

a) - A Companhía Estrada de Vemo linas de são Jeronymo já promoveu o paganento dos salarios devidos ao empregado Domingos Ilantilha, correspondentes ao tempo em que esteve afastado do servigo;

b) - Os operarios Thomaz Gongaives da Silva e Raphael Meza já foram readrattidos no serviço e tamben indenmisados dos salarios atrazados;

c) - sobre o tempo de serviço de João Keenan, nảo podemos provar com documentos o Incendio occorrido ha 10 annos no nosso Almoxarifado, com destrul ção do respectivo arch Ivo, por 1sto que, sendo constatado que se tratava de um incendio casual, não houve inquerito policial. Entretanto, sendo um facto publico e notorio, é conhecido de toda a gente no perimetro de nossas minas. peiteramo-vos os protestos da nossa elevada consideração e apreço, subscrevendo-nos com as mais,

Attenciosas saudaçōes

Consorcio Administrador đe Emprezas de Wineração

(a) Georges Gougenheim $A n^{3}-\because x$ 

CN/MP.

Snr. João Keenan

A/C do Sind1cáto Minetro do Arro1o dos Ratos

\section{R10 Grande do Sul - s. Jeronimo}

Consoante a promoção da Procuradoria Geral deste Conselno, nos autos do processo em que reclama1s con tra a Companila Estrada de Ferro e Minas de São Jeronimo, sol1c1 to-vos providenclas no sentido de ser enviada esta Secretaria, dentro do prazo de 20 d1as, a justificação Judicial proceđida para provar o vosso tempo de serviço na Companh1a reclamada, afim de oue o conselho Nacional do Trabalho possa se pronunclar sobre a reclamação em apreço.

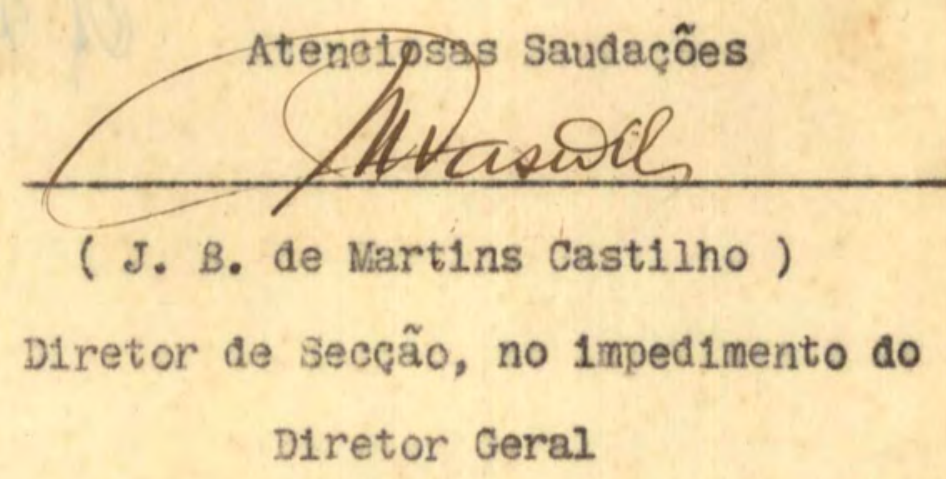



BR ASIL - DEPABTAMENTO DOS COPBEIOS E TELEGRIPHOS TELEGRAMMA

\section{TNEAMBULO}

C129 DE TRIUMPHO $14 \quad 50-47>12$

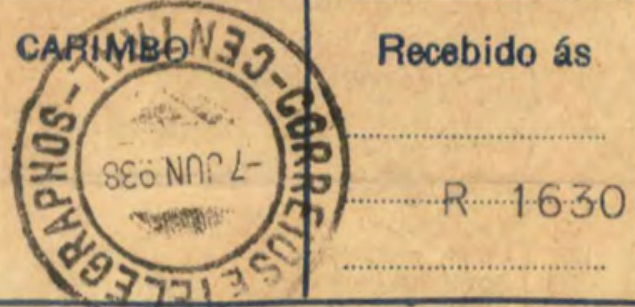

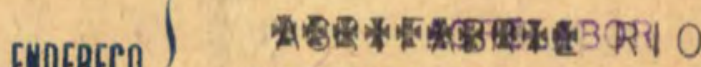

AGRFIǪLABDRR TEP J3T TCA 24

\section{SERVIÇO RADIO AUTOMATICO}

\section{EXTRANHAMOS PEDIDO SR DIRETOR GERAL CONTIDO}

OFICIO NUMERO 149-38 9582-34 POIS DOCUMENTO RECLAMADO HA MUI TO FOI ENTREGUE PESSOALMENTE ESSA REPARTICAO VISTO HAVER SIDO ESTRAVIADO AI SOLICITAMOS PROROGACAO PRAZO VINTE DIAS AFIM PROCEDERMOS MAIS UMA JUSTIFICACAO JUDICIAL SAUDACOES

\section{THOMAZ G DA SILVA PRESIDENTE} SINDICATO MINEIROS

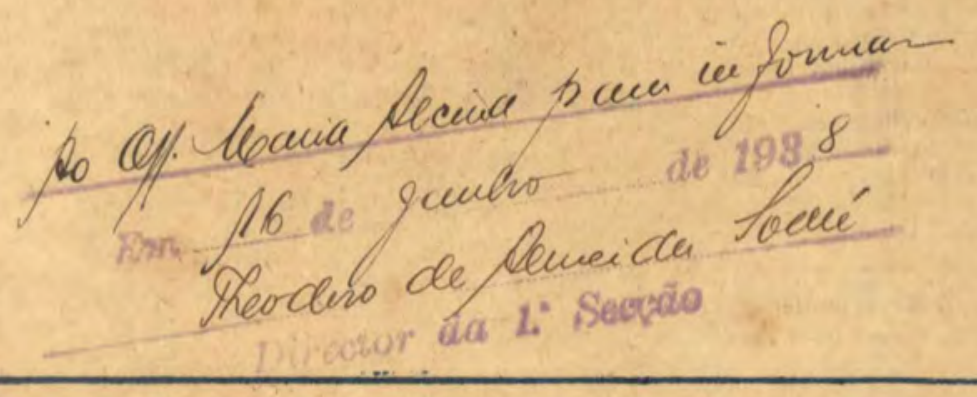




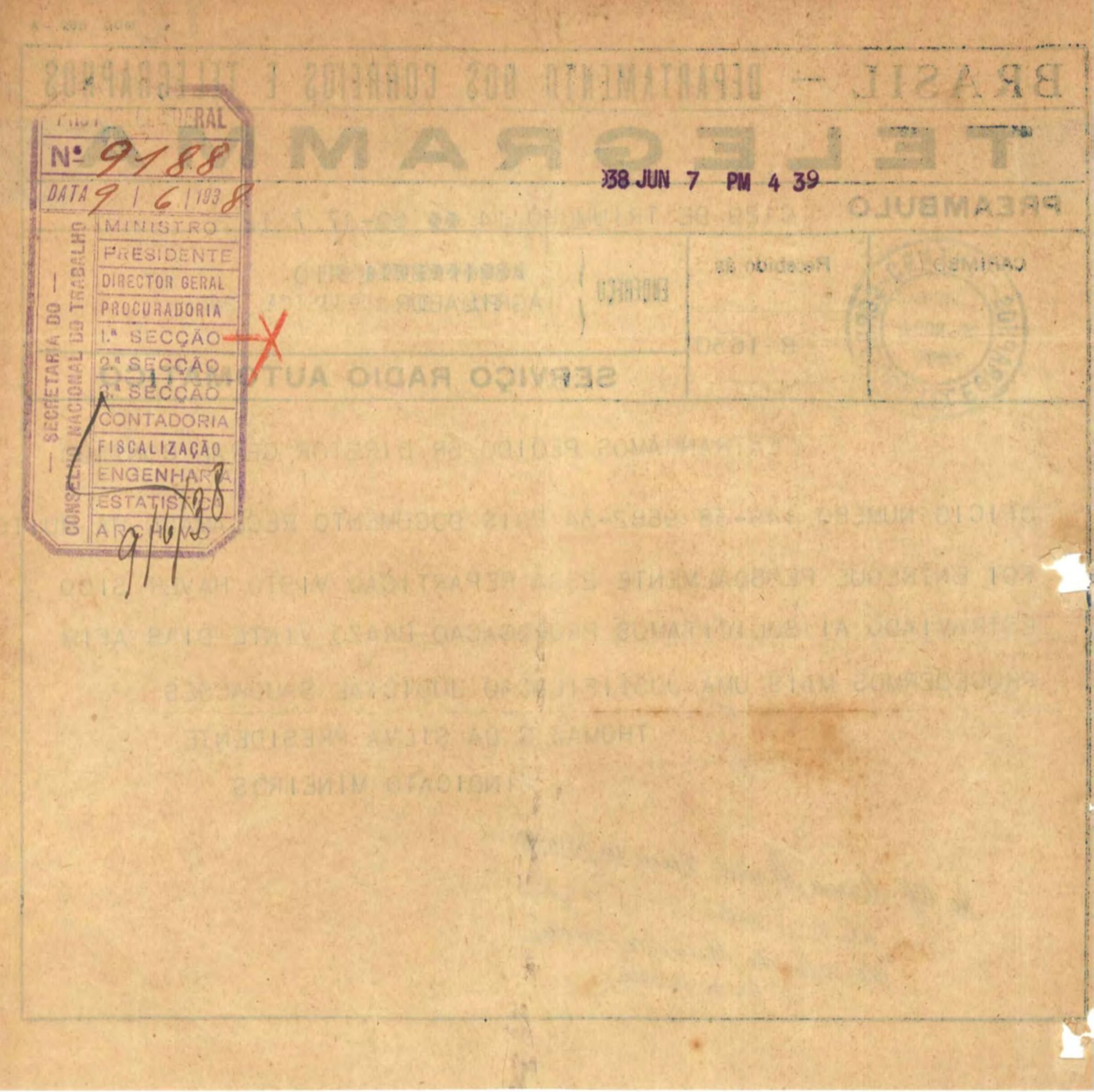


Pee. en $16 / 6 / 938$

- Iuformaciás.

Ild. $11^{4}$

aptor.

Acurando o recebimento do oficio desta Secretaria, Imito por copia a fls.112, o findicato Wineiro do Crroio dos Ratos extramha a solicita. cál uo mesmo coustante, porquarto o documento cur quentas foi, ha misto tempo, entregue a este Cousilho.

Pso entanto, en face dos termos daquele oficio, requer o alvidido findicato prorrogacas do prazo, por mais vinte dias, para proceder à wova Justificacát Indicial, en favôr de seu associado fas Keenan.

Afim de que, sobre o pedido do firidica. to en aprece, de prommeil a cutoridade competen. te, pasio os presentes autos, auin, informados, as maios do fr. Diretor desta feceás.

Pio, 18 de Himlvo de 1938

Alaria Aleira M. desáMiranda

Of. Adun. - Classe "I".

$900.20-6.88$

A' consideraşão do Snr. Director Geral protondo ceja con

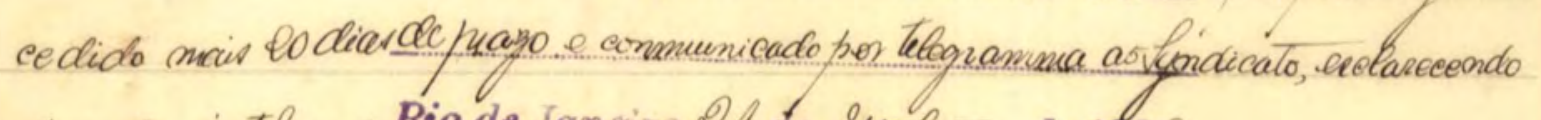

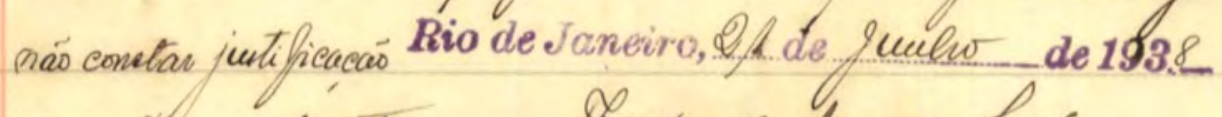
de gacosiyeenau dov autor Sherdno de Lemeida badé

Director da 1a Secção

A' 1 ' Jeçàs, para juilaî a justificasas recentemente nadre neste Enwelho (hrije).

- To na 1: Seccão ern $27-6-38$. 
Do 61. Meaniaflecina para anyrin

Ein 18 de Yuular de 1938

Director a ia 1. Secequa

Vermo de luntada

Veita data, finto a lla. 115 e

segunites dectes autos, of documentos protocolados sob os $\mu^{2} 9.829$ e 9.901, de 1938.

$$
h_{\text {io, }} 28 / 6 / 938
$$

Waria Aleina Cla detá Mirauda Of. Adur. - Classe "g". 


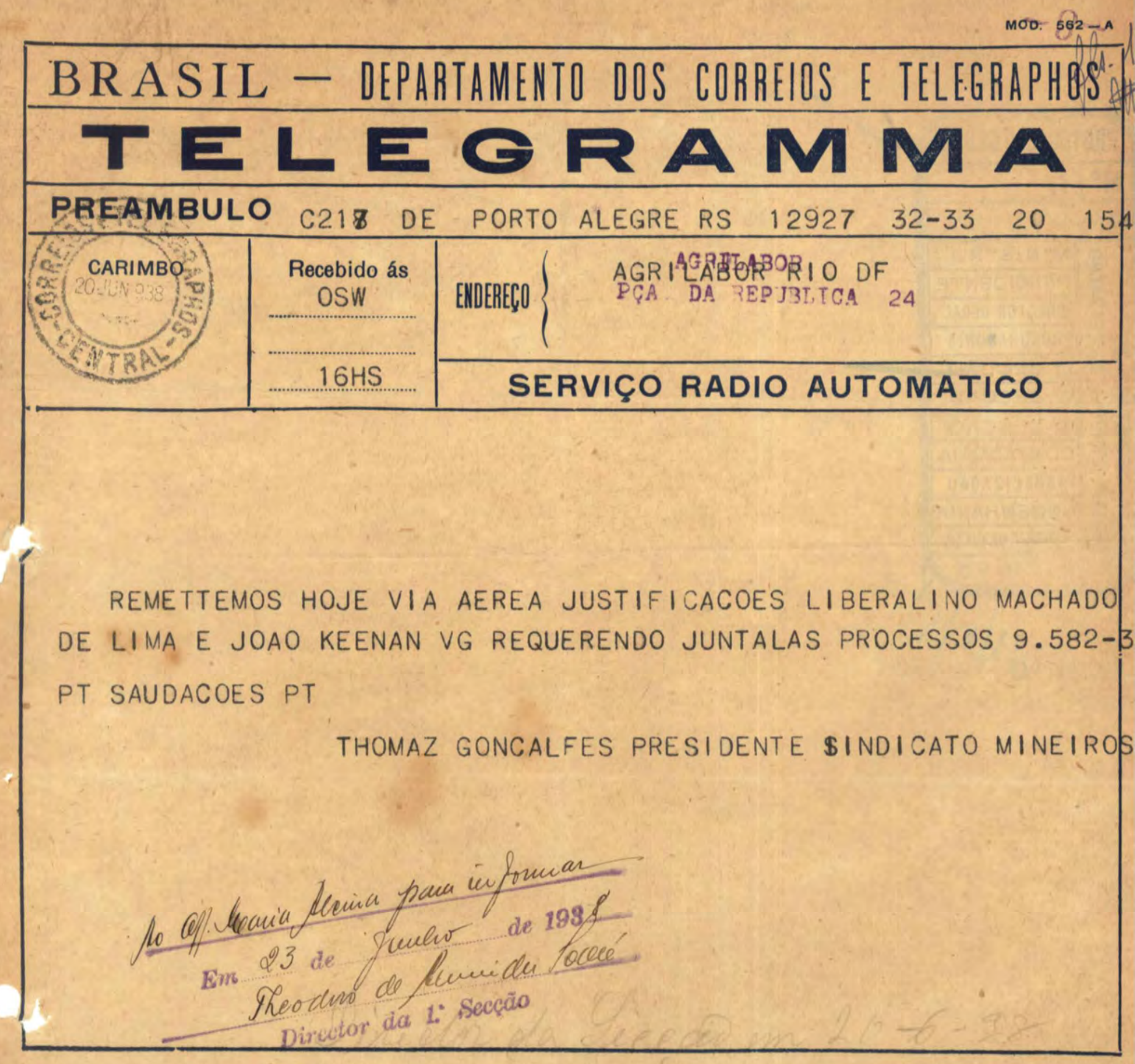



O SINDICATO DOS MINEIROS E CLASSES ANNEXAS DO MUNICIHUO DE SIO JERONYMO, Estado do Rio Grando do Sul, por seu procurador, abaixo assigna 0 , nos autos do processo n $9582 / 34$, om andrment o nesse Bgrog10 Conselho, reuquera V. Exa. a juntada das inclusas justif1cações do tempo do serviço, na Cla. Estradn de Ferro o Minas de S̃̃o Joronymo, do sous associndos Srs. JOÃO KEENAN O IIBERALINO MAchado de IIMA, este tendo trabalhado na alludida Cir, com o nome JANUARIO MACHADO DE LIMA - parr que os citrdos docume ntos produzam seus effoltos legaes. Annexa, outrosim, uma procuraçẽo.

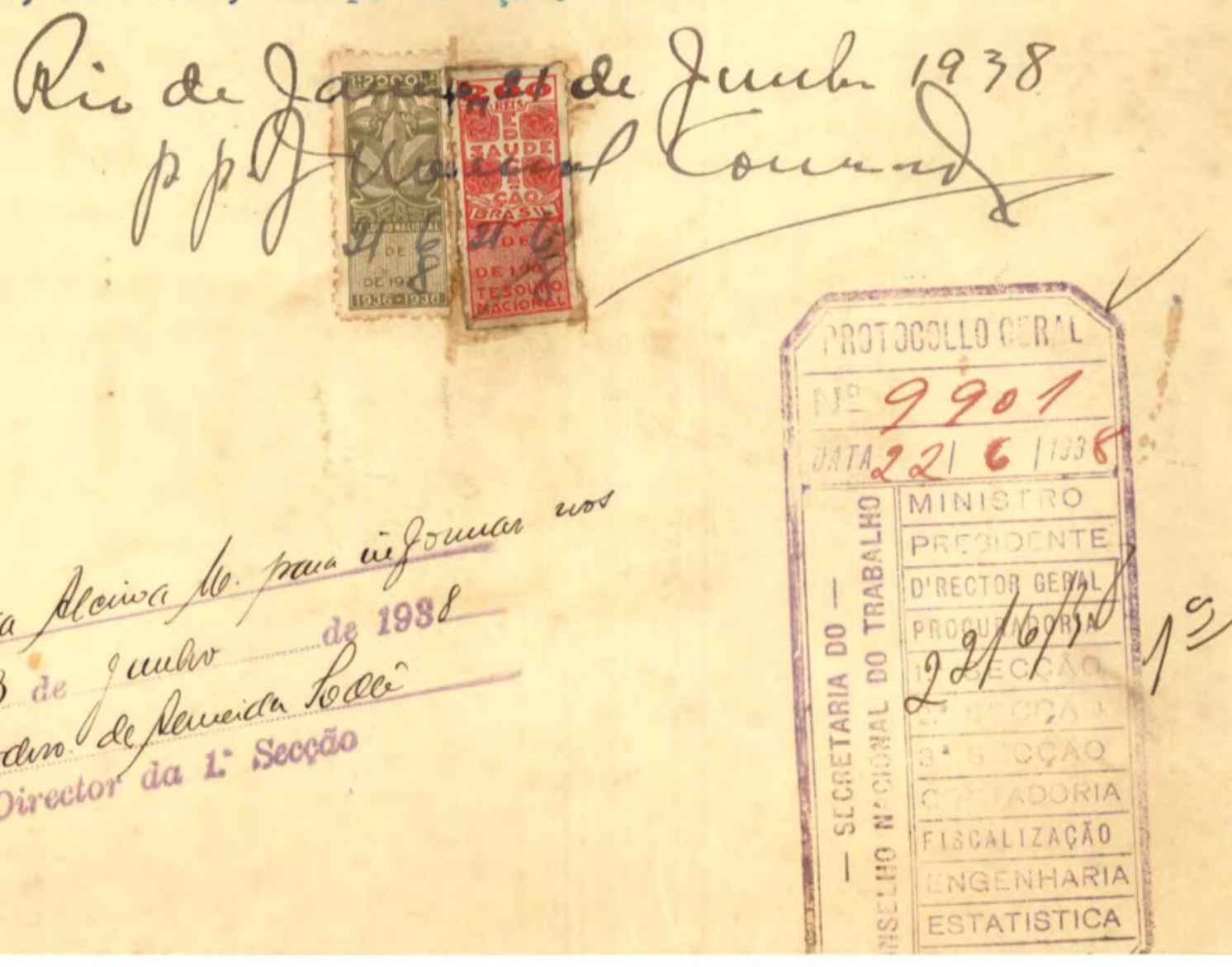




\section{TRASLADO}

\section{$L^{\circ}{ }^{\circ} .^{\circ} ?$ \\ Republica \\ dos Erstados Unidos \\ Fls. 98 \\ do Brasil}

ESTADO DO RIO GRANDE DO SUL

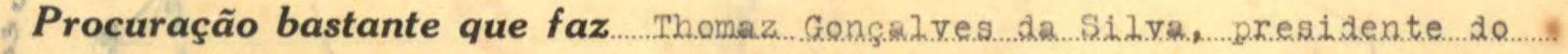
Syndicato dos uineiro.s. e Glas.s.e. Anexas de são Jeronimo.

Saibam todos quantos este publico Instrumento de Procuração Bastante virem

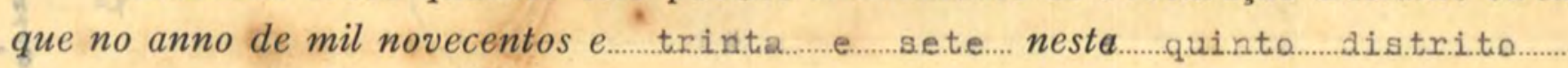
-...do raunicipio de .............s. o...... Teronimo,

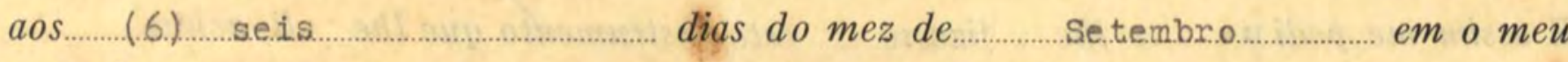

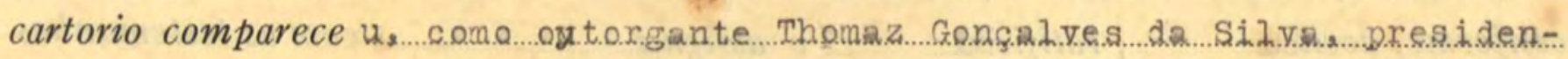

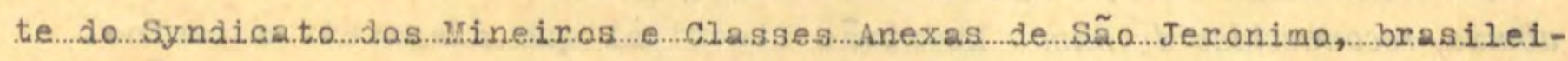
ro residente nes.te quinto dis.tri.t.o,

reconhecido pelo proprio ...... he mim escrivão dis.tri.tą e das testemunhas no fim assignadas, perante as quaes disse........... que fazia...... seu bastante procurador na cidade do Rio de Janeiro, o snr. Amaro Junqueira Saraiva brasileiro, s.ol.teiro, maior, ...esidente nes.te quinto dis.tri.to, a a quem concelle todos

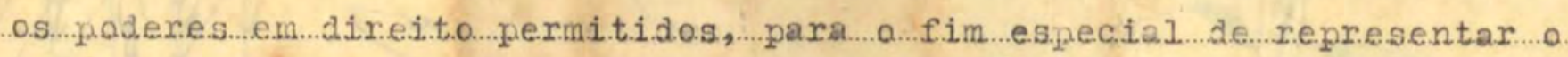

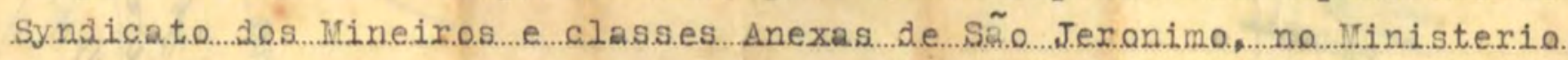

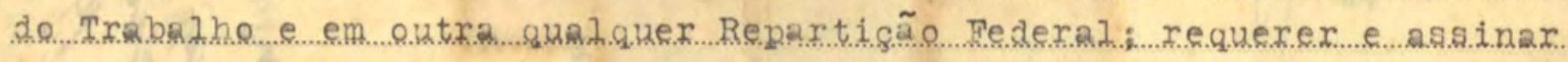
tudo que for necessario..... bem dos direi.to e interesses do referido syn-

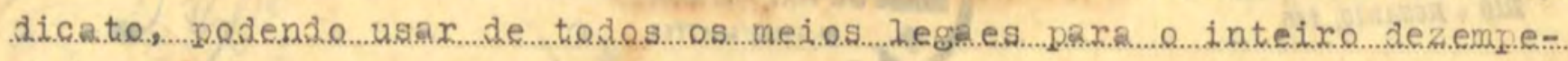
nho deate mandato e substabelecer. 
Estado do Rio Grande do Sul

Juizo Lisitedea Municipal

São Jeronymo

Cartorio do Civel e Crime

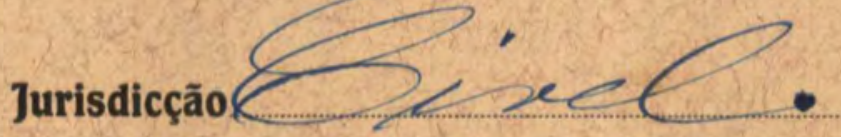

Escrivão: Oilanda Ganaies

L sotiotracoso.

(3).

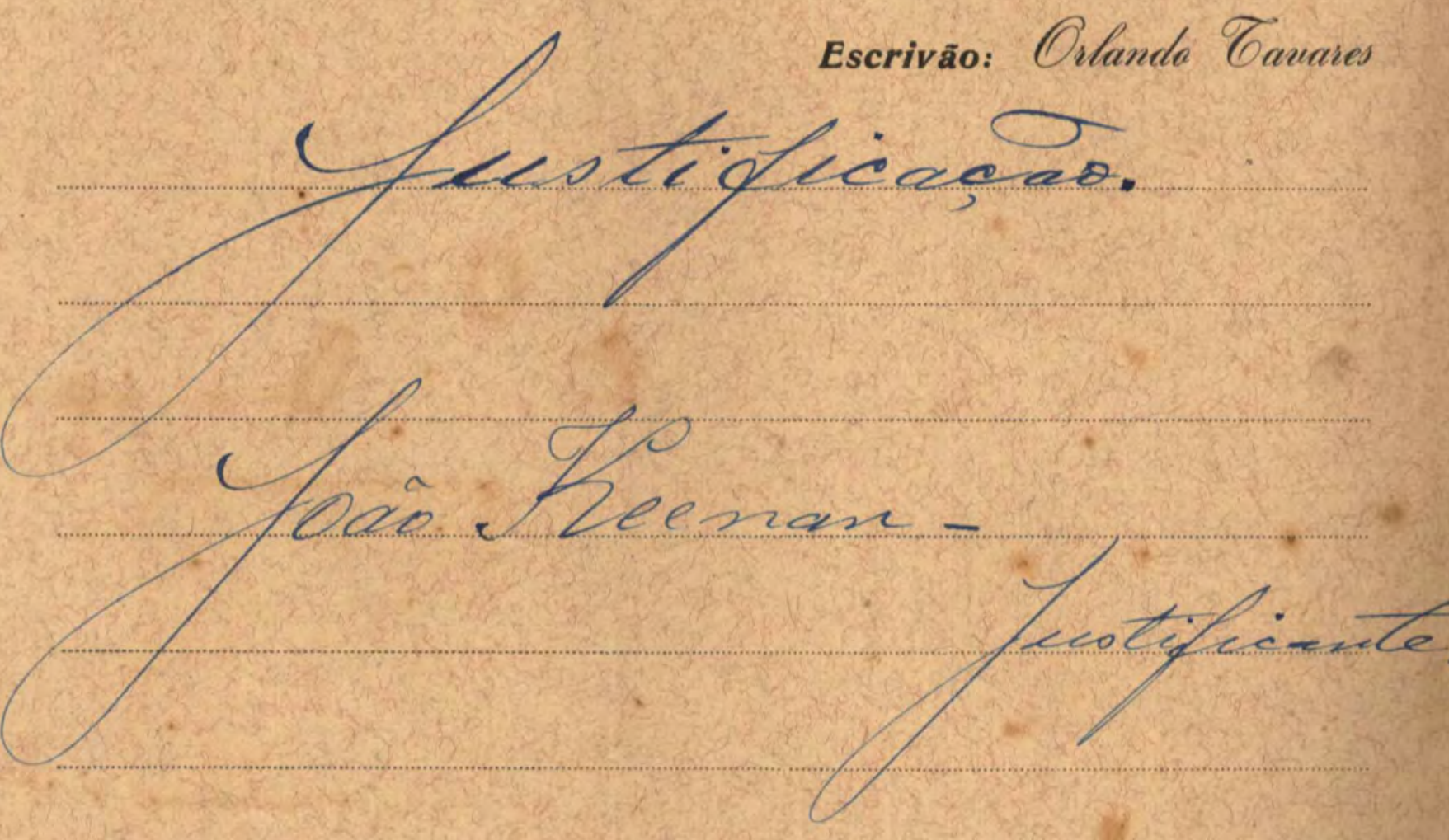

etutuacãa.

ass dias do mez de Detérer.bes de mil nove.

centos e trinta e sais, nesta villa de São Jeronymo, no meu cartorio autuo as pegas que se seguem do que, para constar fago este termo.

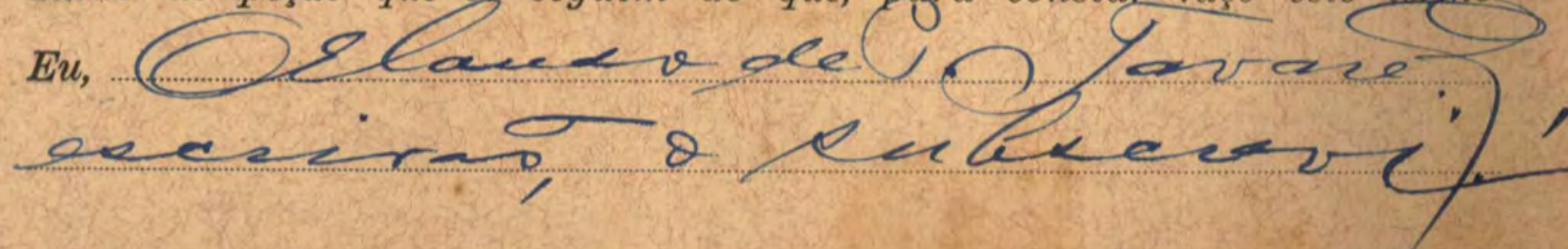


Exm•. Sr. Dr. Juiz MUnicipal

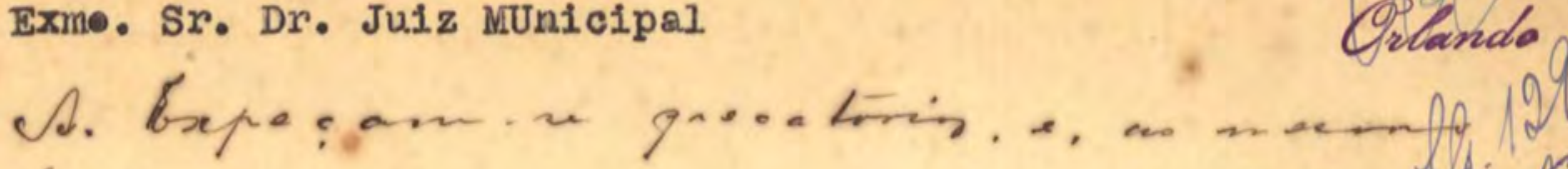

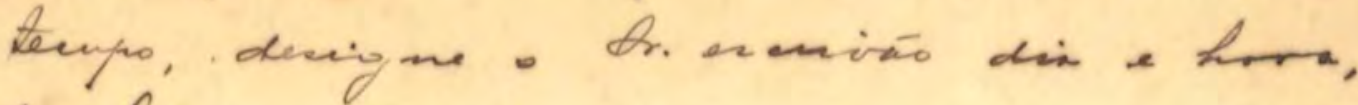

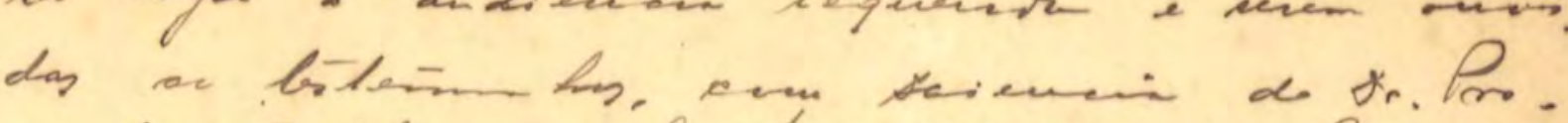

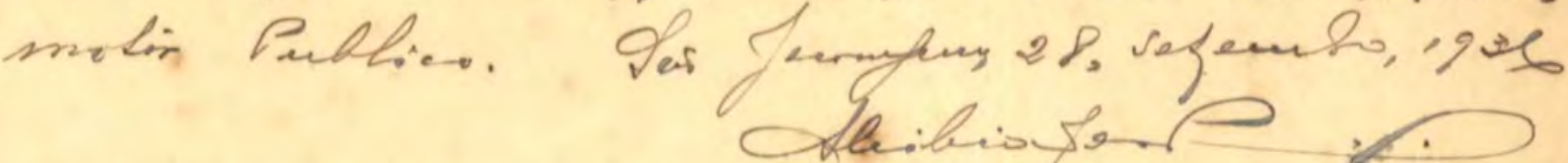

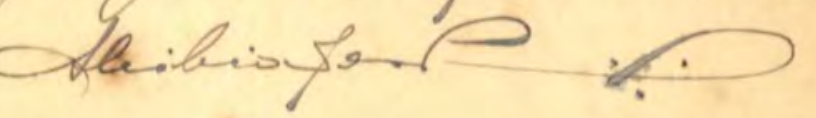

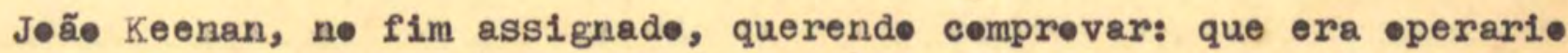
da Companhia Estrada de Ferr॰ e Minas de Sã॰ Jerønym, trabalhand• de 16 de Junho de 1888 até fins de Julhe de 1929, data em que fei victima de um accidente ne trabalho, continuand• - tratament•, desse dia, até quande teve alta, ne dia 31 de Outubre de 1933, data esta, em que apresentou-se á chefia da Mina para recomeçar a trabalhar; tend a referida Oompanhia

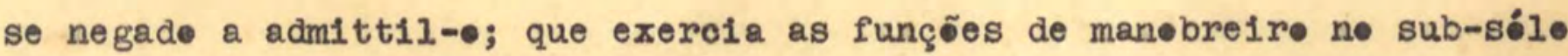
da mina, percebende - salarie de $9 \$ 000$ diaries; deseja fazer nesse Juize, uma justificaçã॰ de temp• de serviç॰ e de salarie, afím de que venha a preduzir esta, os seus effeites legaes; requer, pois, que V. Excia. determine ao Sr. Escrivão, a deslgnação de dia e hora, afim de serem •uvidas as testemunhas, as quaes - supp. se compromette a apresentar, independente de citaçãp, quande fôr designada a respectiva audiencia. Requer mais - supp., sejam Intimados a comparecerem nessa audiencia: - Exmo. Sr. Dr. Promotor Publice da Comarca e es representantes da Caixa de Aposentaderi-

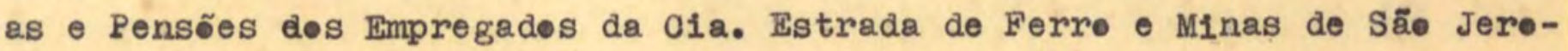
nym• e da Companhia. Estrada de Ferr e Minas de Sã Jerønym, hambas com. escripteries em Pert॰ Alegre, a rua Paysandú $\mathrm{n}^{2} 219$, Edif1ci• Hudsen-2e andar, expedindo-se para iste as respectivas precaterias. Outressim, pede ainda, que após a homølogaçãe, sejam-1hes és autos entregues, independente de traslade.

Nestes termes

P. D e f e r $1 \mathrm{~m}$ e $\mathrm{nt}$.

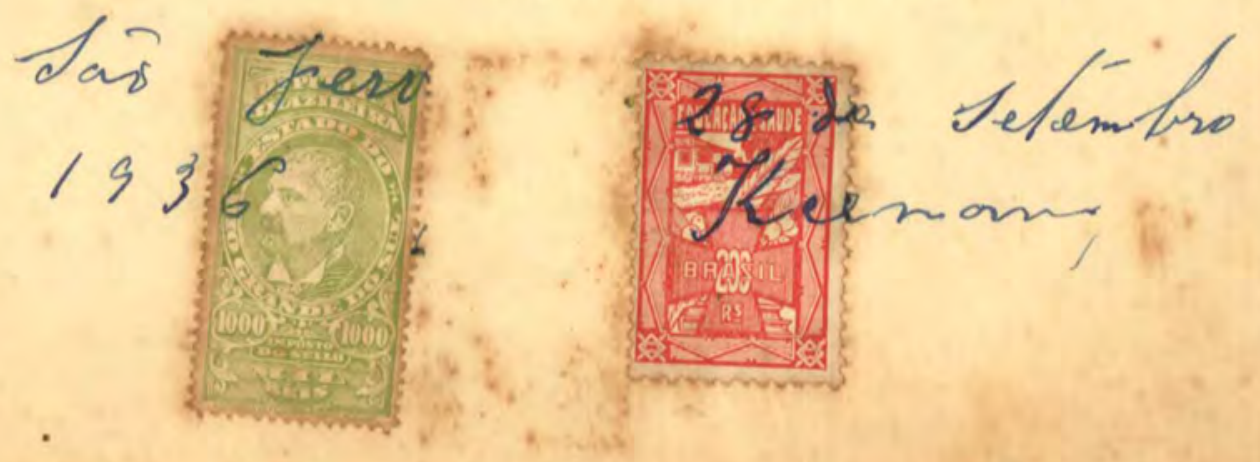


Certifico que, designei o dia seis de Outubro p.vindouro,ás déz e meia horas, na sala das audiencias, para a justiflcação requerida. Dou fó.

S.Jeronymo, 28 de Setembro de 1936.

o escrivão.

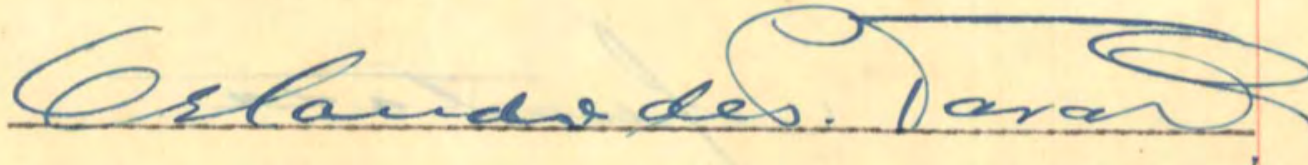

Certifico que, da designação supra intime1 nesta villa, - requerente. Sciente e dou fé.

S.Jeronymo, 28 de Setembro de 1936.

0 escrivão.

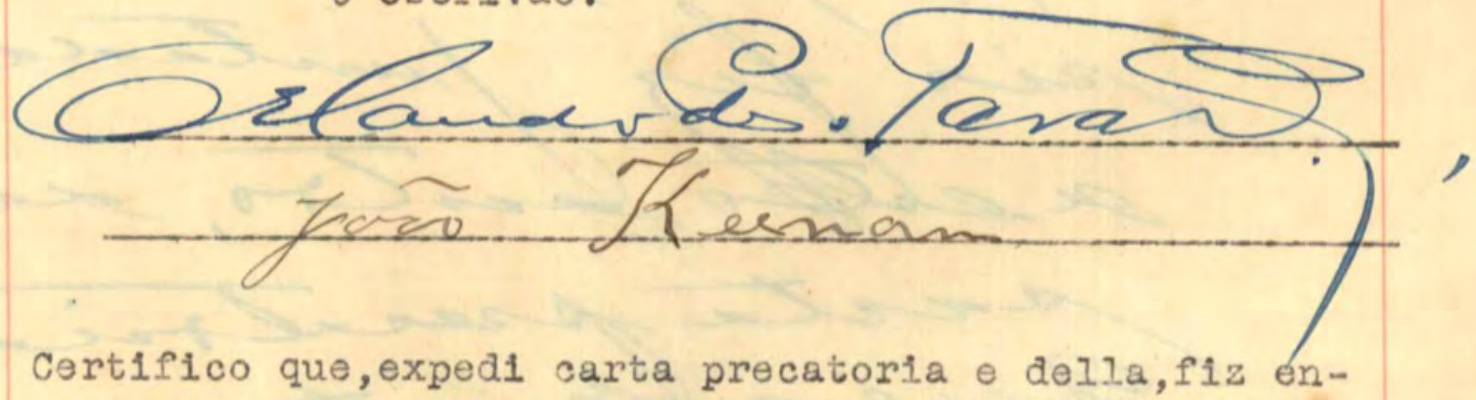

trega ao jusifficante, para o seu cumprimento. Dou fé.

S.Jeronjmo, 28 de Setembro de 1936.

0 escrivão.

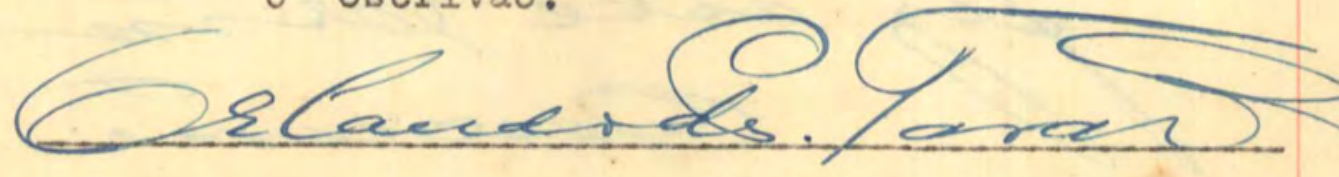

Certifico que, intimei nesta villa, o Dr. Emani Coelho, Promotor Publico, da petiç̃̃o de fs.2, respectivo despacho e designação supra.- Sciente e dou fé.

S.Jeronymo, 1: de Outubro de 1936.

o escrivão.

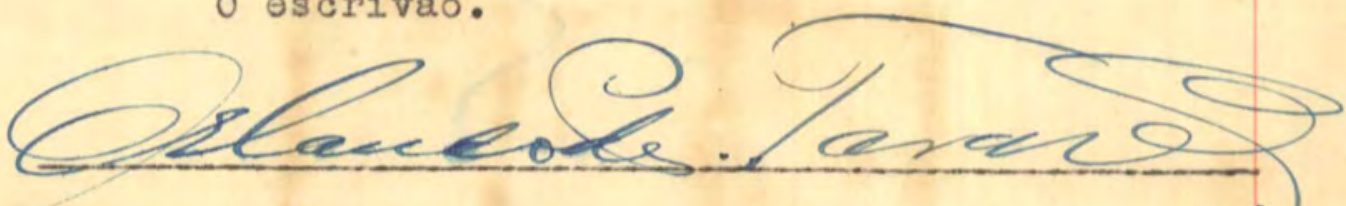

Sciente:

2 


$$
\text { №19-xix }
$$$$
1936
$$

Trav

शR. 1

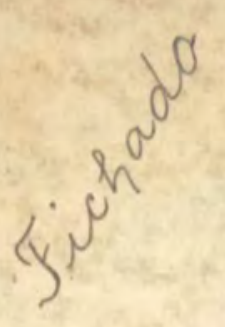

2: Semestre

Comarca

ESTADO DO RIO GRANDE DO SUL PORTO ALEGRE

H. Juizo Districtal da séde do municipio da Capital 5 aclosse

JURISDICCÃO DO CIVEL

1. Cartorio do Civil e Commercio

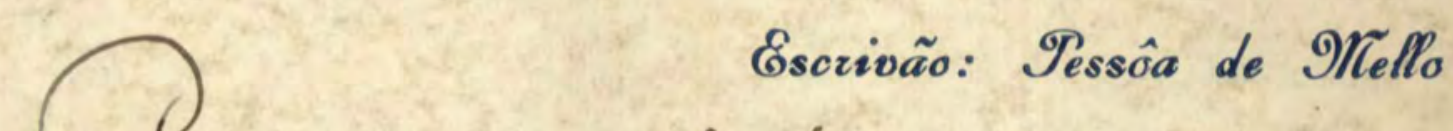

Srecatória

- Juiramunicipal de I. Jeronimo

Depte

Tuira municipal de Porto flegre Depdo

etutuasãa

aos triuta dias do mo detembro

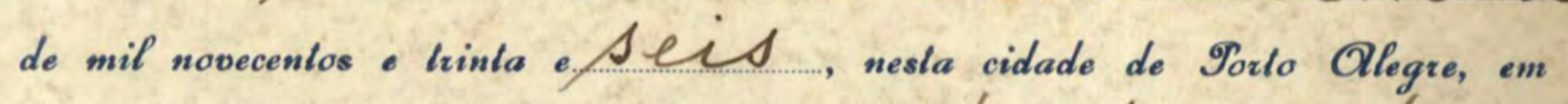
mian catorio, anthio as perasti a carta precato-

que se seguem, do que, para constax, faço este lermo.

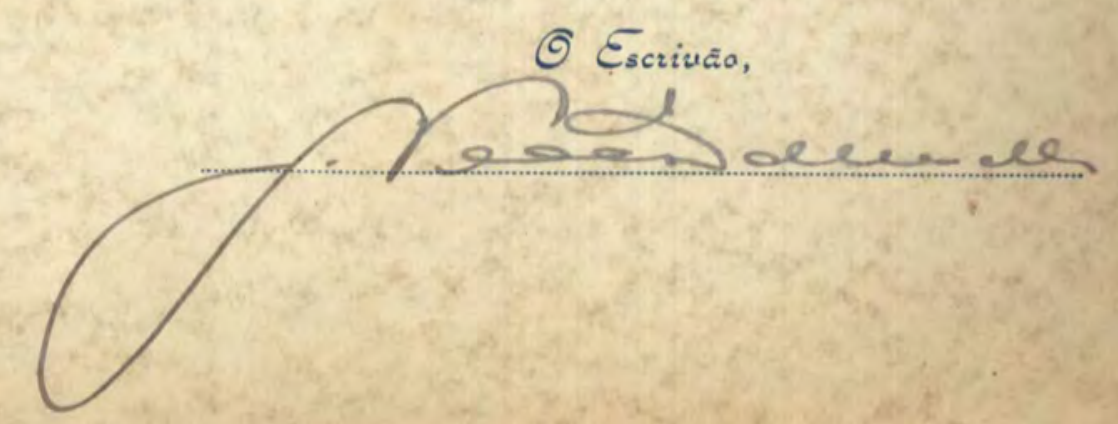




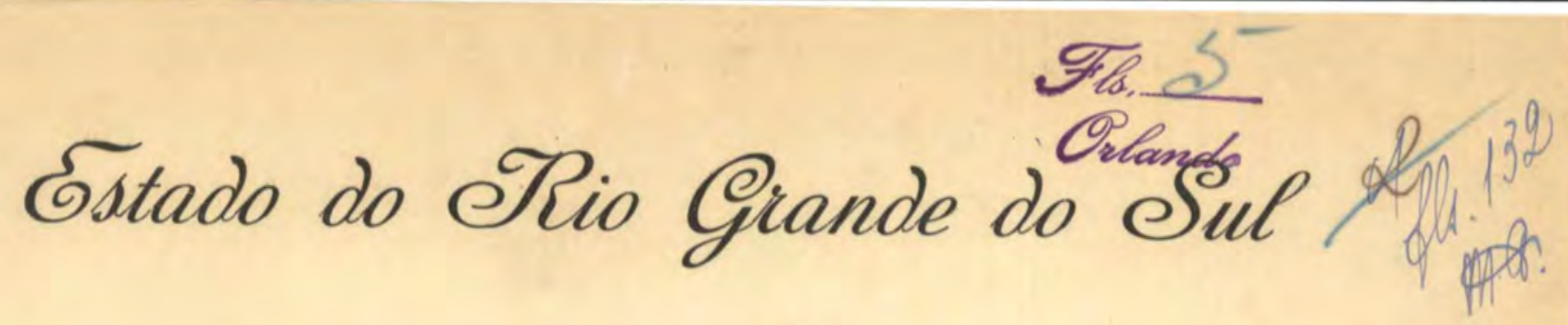

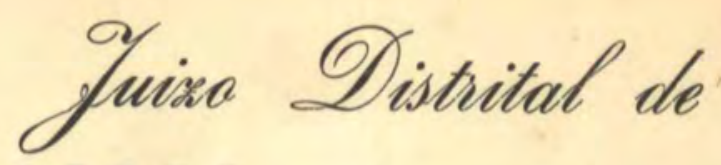

Ễa feranima, 28 de setembro de 1936

C. Prei

d) fistoifunest. 28.7 .896

A. 17. cumparderif.

in to. 1.46.

Pracedicta

Passada a requerimento do operaric João Keenan.

Dirigida ao Juizo linnicipal da Va. ra Civel de Porto Alegre Cap1tal do Estado do R1o Grande do Sul.

Pelo Julzo Munf́cipal da séde da Comarca de São Jeronymo.

Na forma aba1xo.

O Dr. Alc1biades Pereira, Ju1z Municipal da séde da Comarca de s. Jeronymo.

Faz saber que por parte do operario João Keenan the for derigida a seguinte:

$$
P E T I \& \tilde{A} 0
$$

To Jo Exmo Snr. Dr. Juiz lunicipal. da Companhia Estrada ass1 gnado, querendo comprovar:que era operar1o de 6 a viettra de 1888 até fins de Julho de 1929, data em que fol victima de un accidente no trabalho, continuando o tratamento, desse dia, até quando teve alta, no d1a 31 de outubro de 1933, data esta, em que apresentou-se á chefía da Mina para recomeçar a trabalhar, tendo a referida Companhia se negado a admitıl-o; que exercia as funções de manobre1ro no sub-solo da m1na, percebendo o salar1o de 9\$oódiar1os; deseja fazer nesse Juizo uma just1f1cação de tempo de serviço e de salario, afim de que venha a produzir esta, os seus effeltos legres; requer, pois, que V. Exc1a.detemine a. Snr. Escr1vão, a designa-ção de d1a e hora, af1m de serem ouvidas as testemunhas, as ques o supp. sejam intimados a comparecerem nessa audiencia:o Ermo Snr.Dr. Promotor Publico da Comarca e os representantes da Ca1xa de Aposentadorias e Pensões dos Empregados da Cia. Estrada de Ferro e Minas São Jeronymo e da Cia. Estrada de Ferro e M1nas de São Jeronymo, ambas com escriptorios em Porto Alegre,á ma Paysendú ne 219, Edifíc10 Hudson-2 2 andar, expedindo-se para 1sto as respectivas precatorias. outros1m, pede a1nda, que após a homologação, se jam-1hes os autos ontregues, independente de traslado.

Nestes termos P.Deferimento, Sũo Jeronymo, 28 de Setembro de 1936 (a) João Keenan

$$
\text { DIS P A C H O }
$$

A.expeçam-se as precatorıas, designando o Snr. Escrivão dia hora $\theta$ lugar, para procedor-se á audiencia requerida e serem ouvidas as testemunhas, com sciencia do Dr. Promotor Publico.S̃̃o Jeronymo,28, Setembro,1936. (a)Alcibiades Pereira. 
co je

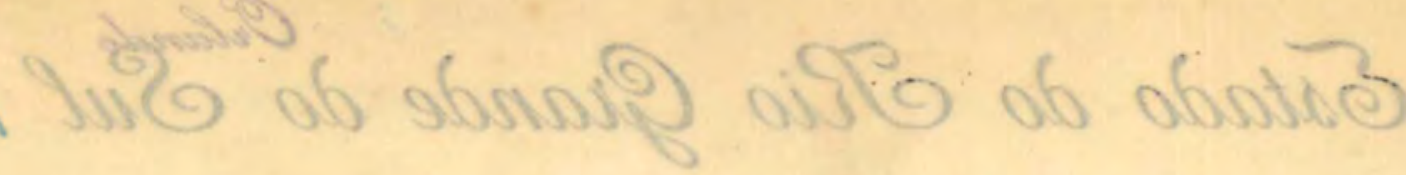

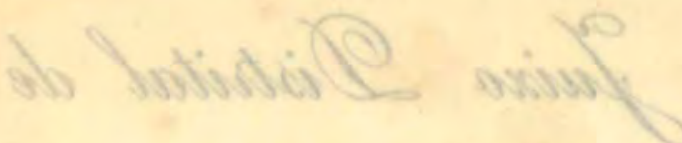

\section{DES I G N A \& $\widetilde{N}$ :}

Certifico que, designe1 o dia sels de outubro p.vindouro,ás dez Qel be meias horas, na sala das audiencias, para a justificação requerida.Dou fé.S.Jeronymo,28 de setembro de 1936.(a)0rlando de P. Tavares.

E, no cumprimento da presente fará V.S. serviço á parte e a mim espec1al mercs.

Dada e passada nesta villa de São Jeronymo, aos vinte e o1to a do mez de Setembro de mil novecentas e trinta e de1s.

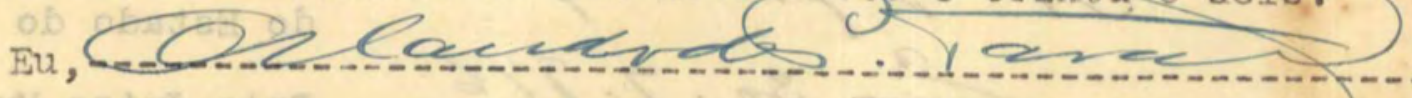

escrivão, a dactylographe1.

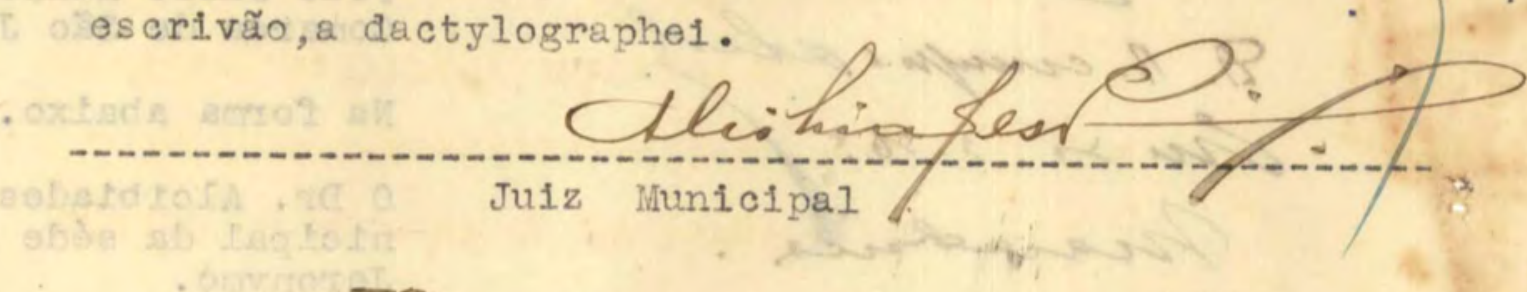

$\int \sim \operatorname{asse}$

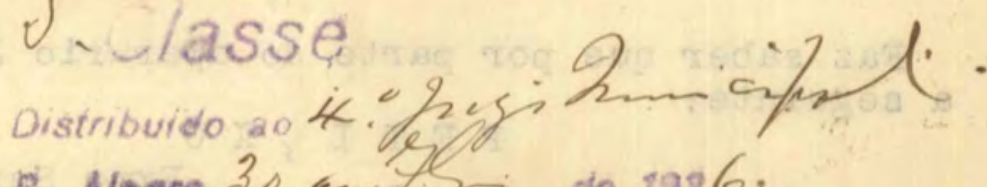
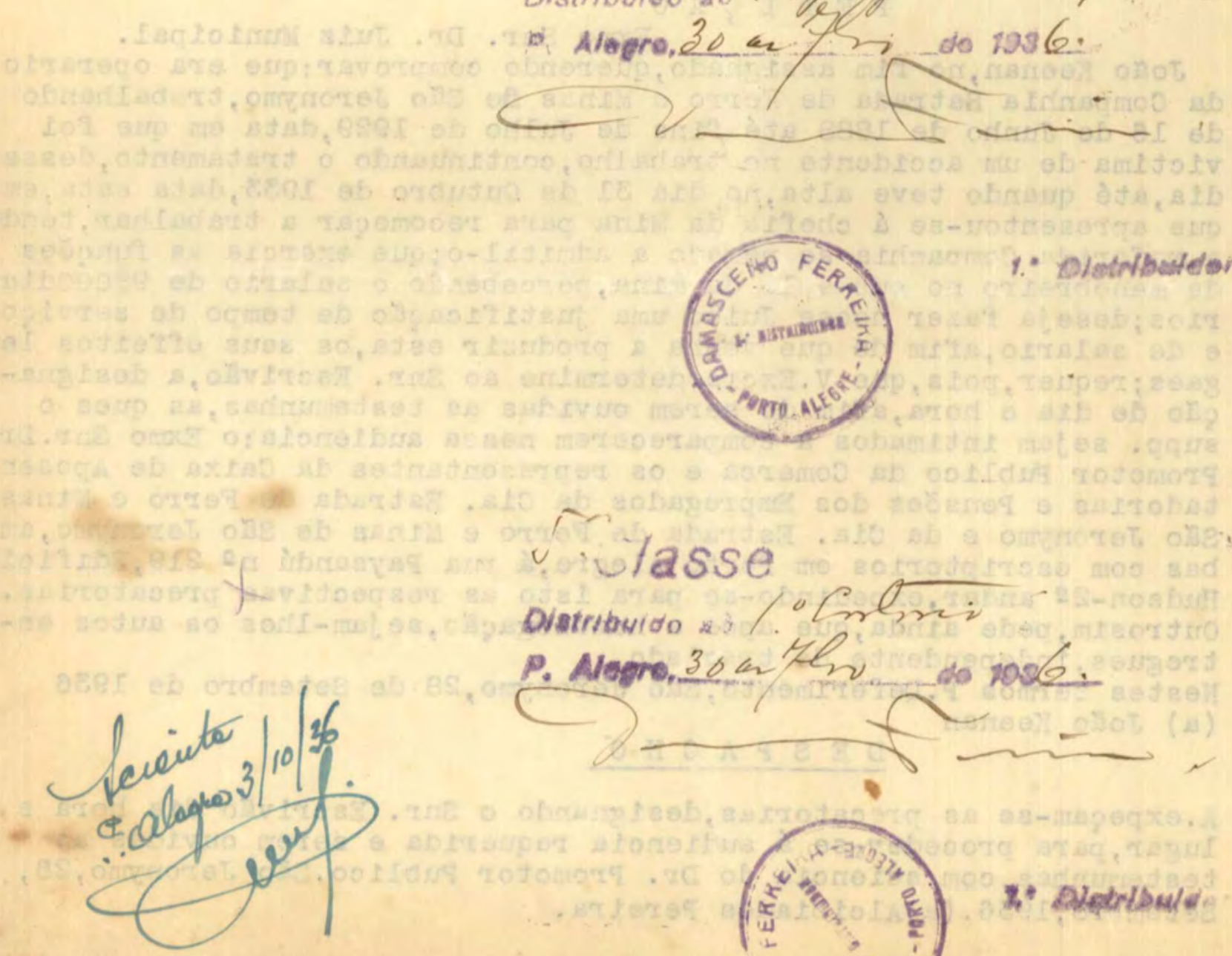

vivtasse

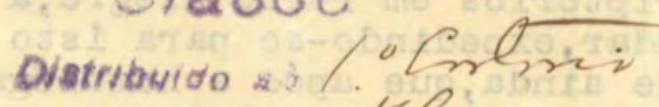

P. Nerer. 30 a the do 1006 .

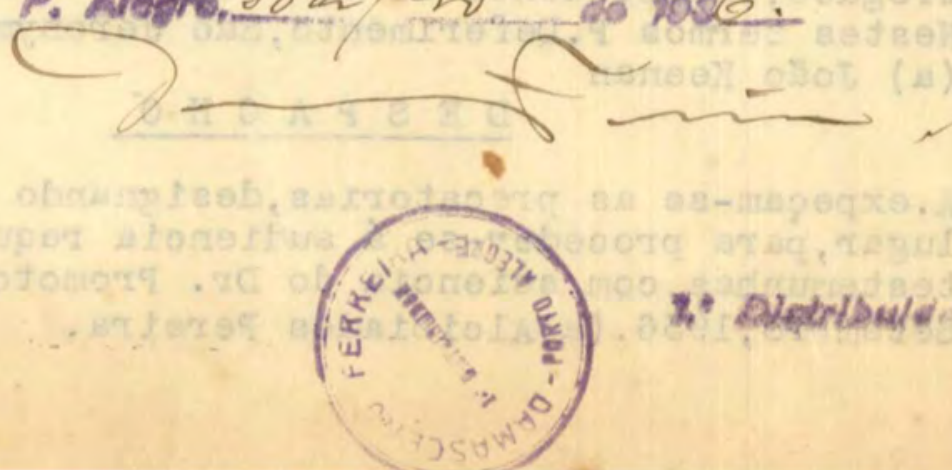


Ilmo.Sr.Dr.4 Juiz Munic1pal.
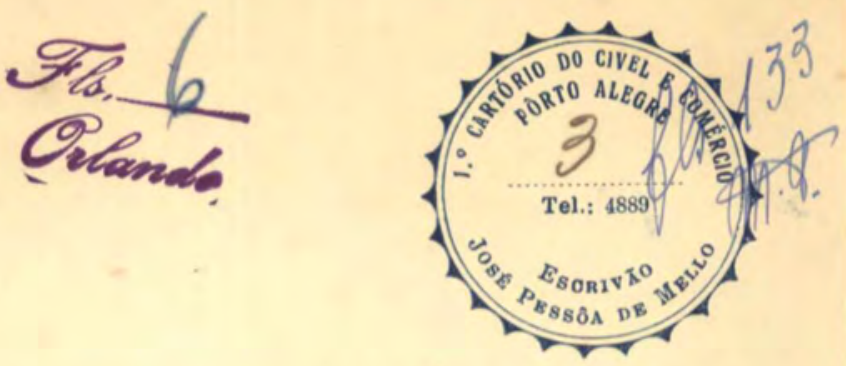

Solicito a VS, a necossaria per mi ssão para entregar estes autos a um oficlal de just1ça,ex-v1 do disposto pelo art. 128 alinea VIII \& unico da le1 de organisação judiclaria.

$\mathrm{E}$ para que V.S.agsim determine

vos faço estes autos conclusos.

Porto Alegre, 1: de outubro de 1936.

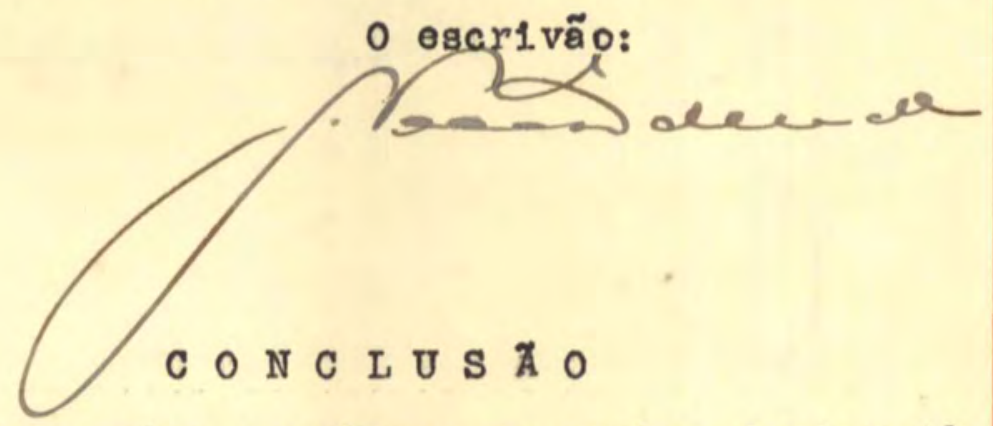

Faço estes autos conclusos ao senhor doutor $4^{\circ}$ Juiz Municipal.

Porto Alegre, 1: de outubro de 1936.

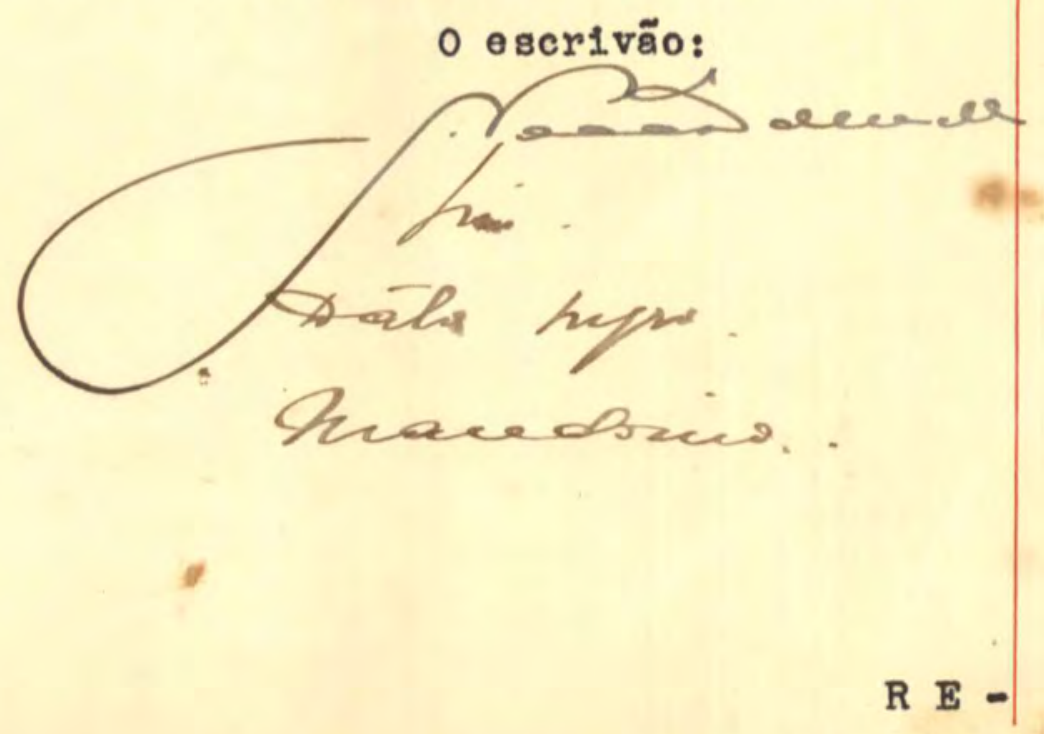


R E C E B I M E N T O Na data abaixo receb1 estes autos.

Porto Alegre, 1: de outubro de 1936.

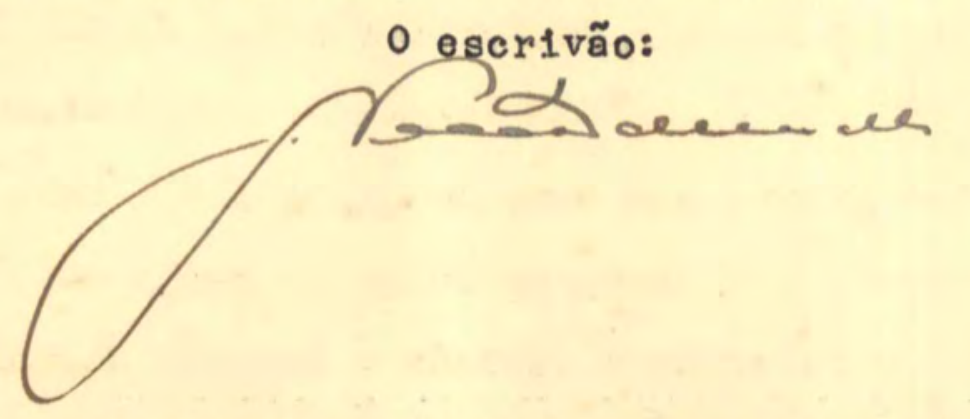

Certifico que, dovidamente autorisado, entrego estes autos ao oflcial de justiça Marlo Esteves de Abreu, afim de que o mesmo proceda a. Intimação deprecada. O referido é verdade, dou ก̊́.

Porto Alegre, 1: de outubro de 1936.

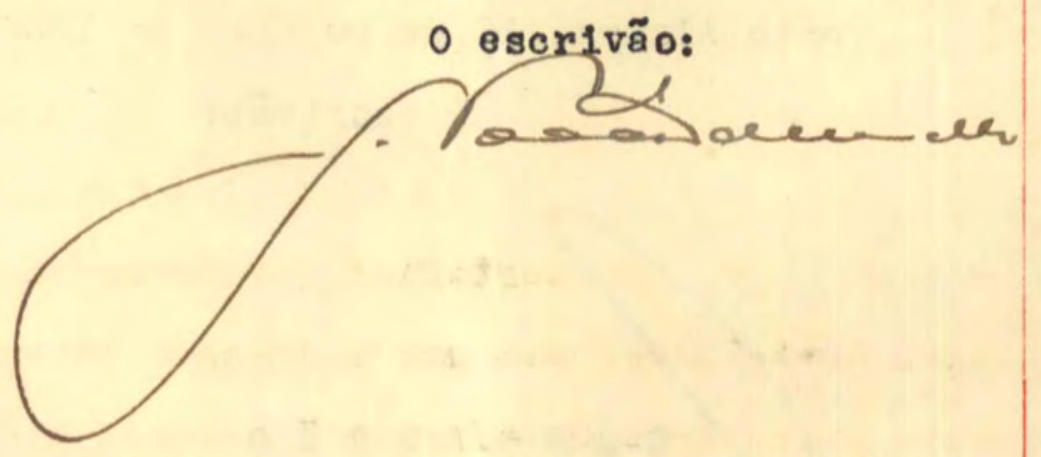




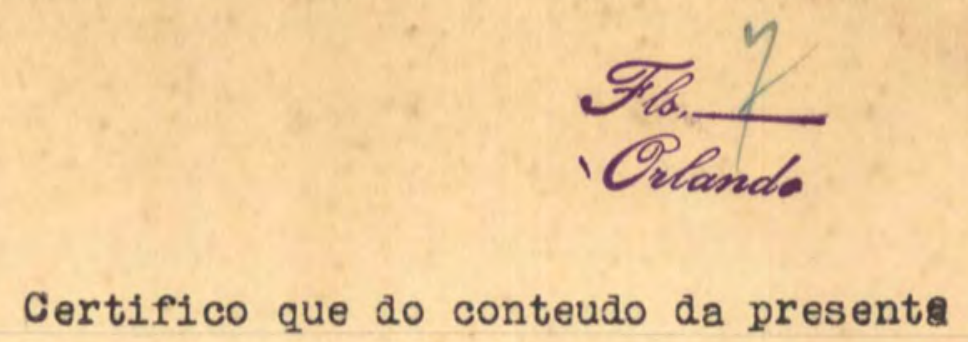

carta precatoria citatoria retro, intimei hoje, nesta cidade, á rua Paysandú, a Companhia Estrada de Ferro de Minas de São Jeronymo e a Caixa de Aposentadorias e Pensões dos Fmpregados da Companhia Estrada de Ferro e Minas de São Jeronymo, na pessôa de seu representante legal, senhor Gebrge Gougein, que ficou bem siente bem como do dia lugar e hora para comparecer na audiencia ordinaria do Juizo deprecante.

o referido é verdade e dou fé. P.Alegré, 3 de outubro de 1936; as 11 horas. O oficial de Justiça

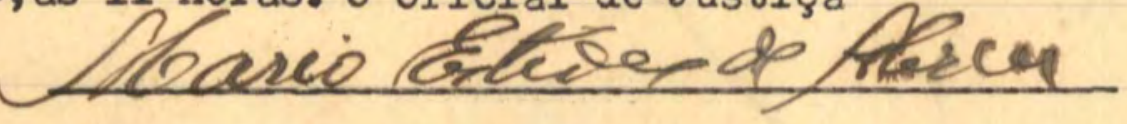

Recebimento

$\mathrm{Na}$ data abaixo receb1 estes autos

Porto Alegre, 3 de outubro de 1936. 0 escrivão:

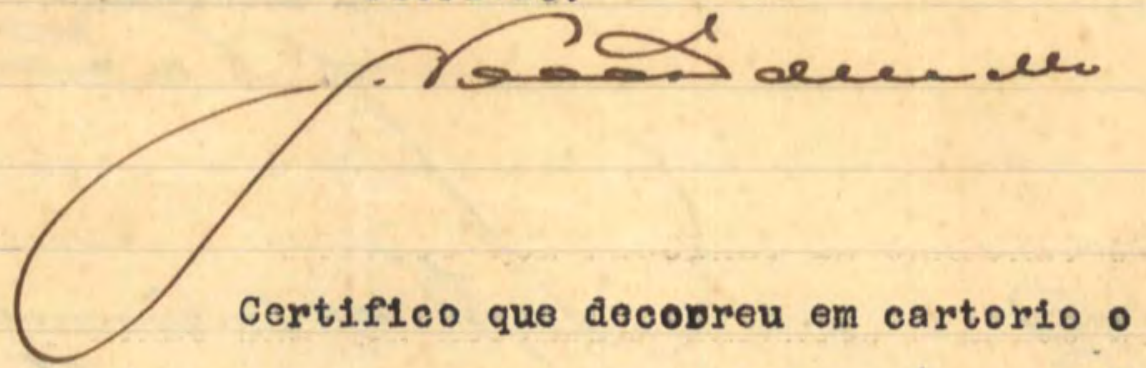

praso legal de 24 horas sem que houvessem embargos á execução da presente precatór1a.o reforido é verdado o dou fé. Porto Alegre, 5 de outubro de 1936.

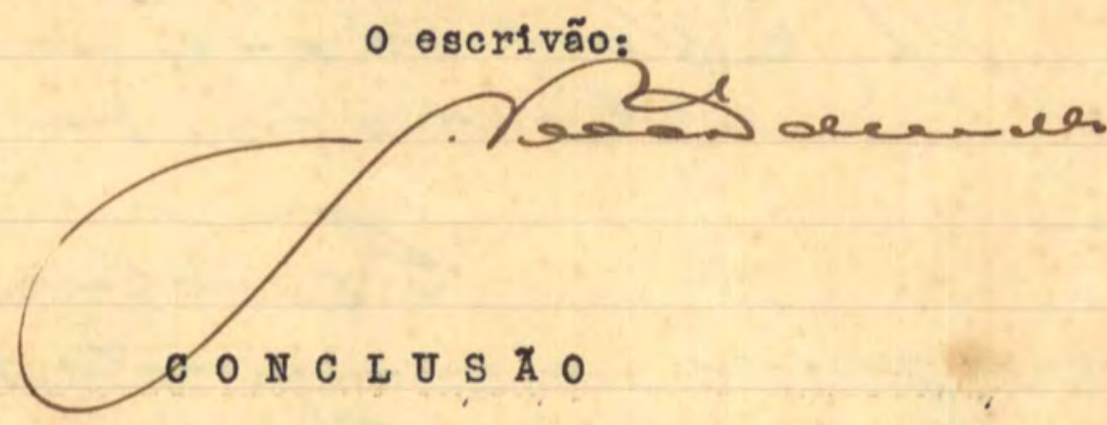

Faço estes autos conclusos ao sr.dr.4 Juiz Municipal.

Porto Alegre, 5 de outubro de 1936.

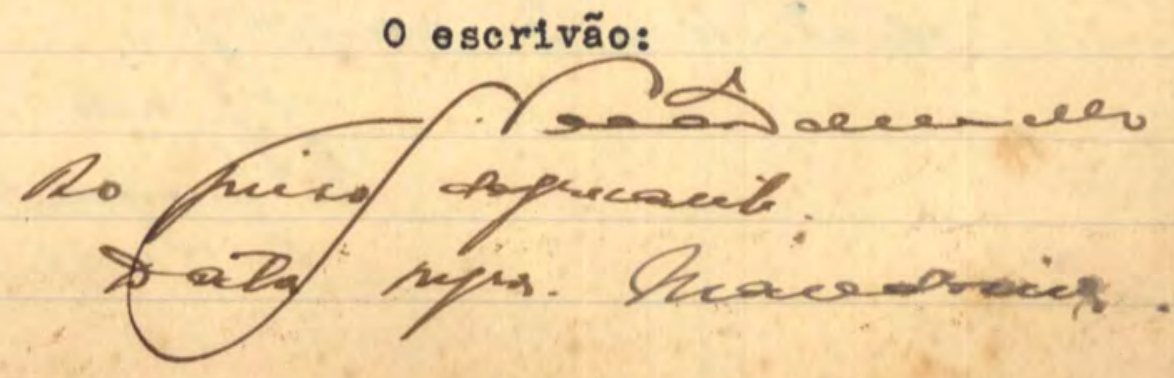


RECEBI M E N T O

Na databalxo recebi estes autos.

Porto Alegre,5 de outubro de 1936.

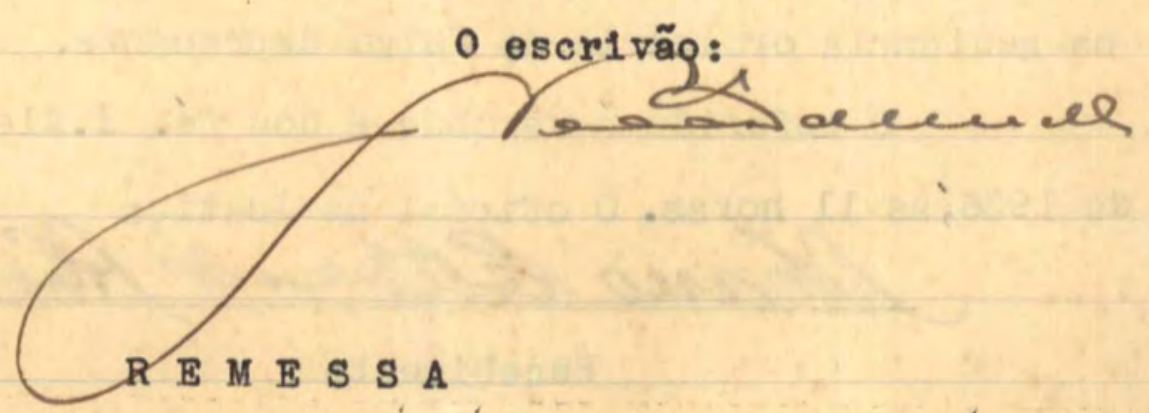

Faço remessa destes autos ao sr.dr.Jutz municipal de S. Jeronimo.

Porto Alegr c,5 de outubro de 1936.

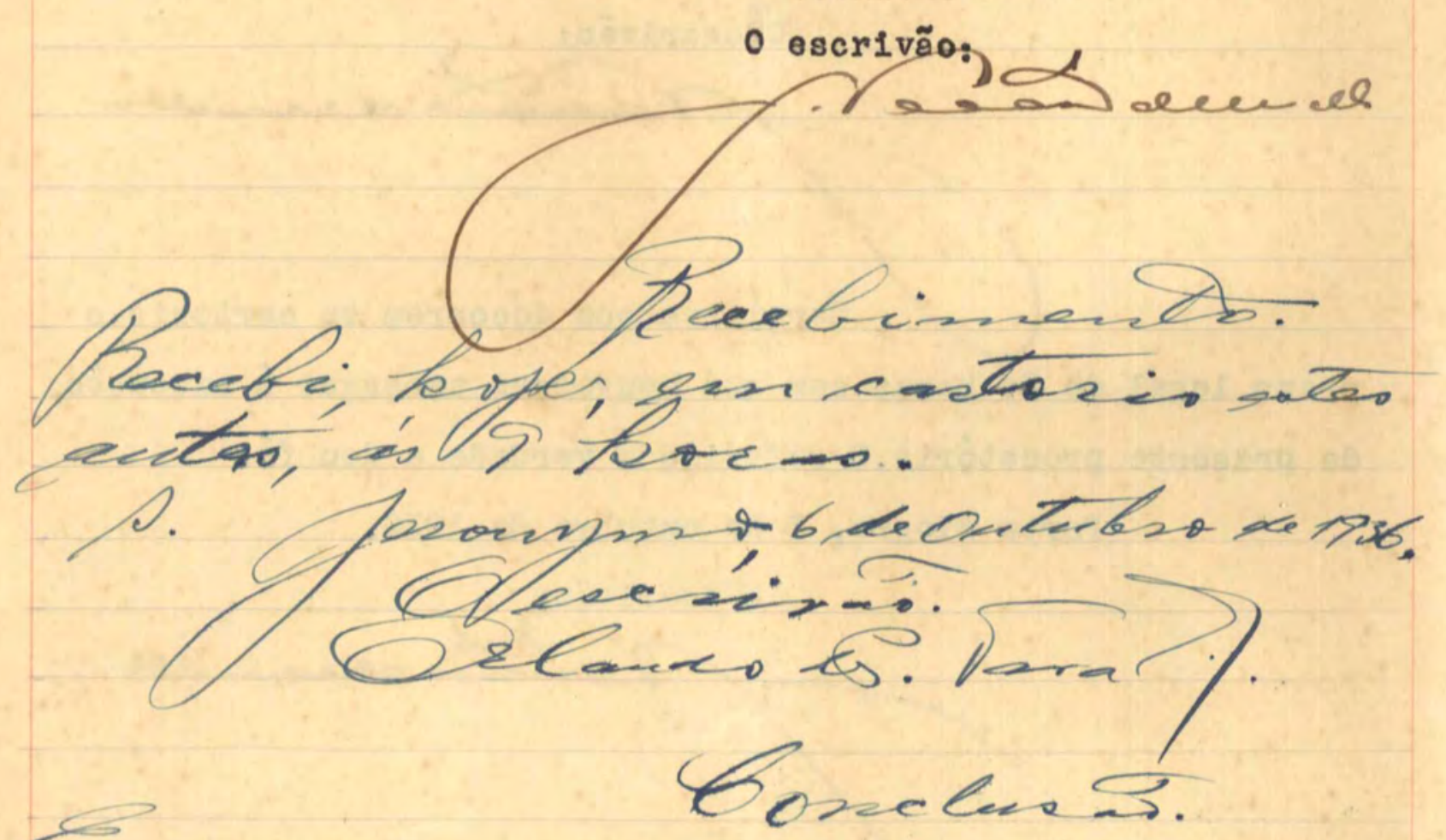

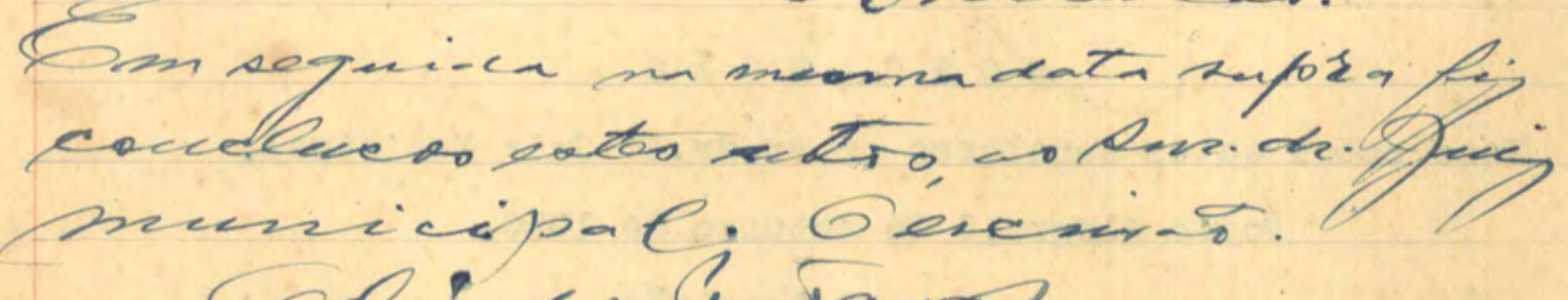

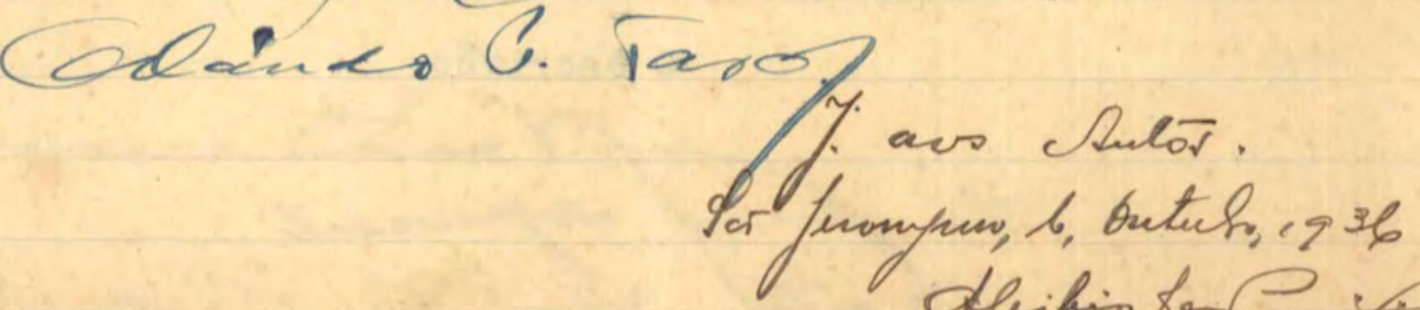

$$
\begin{aligned}
& \text { devibiagor } P \text {. }
\end{aligned}
$$


TERMO DE ASSENTADA.

Aos seis dias do mez de outubro de mil novecentos e trin ta e sois, nesta Villa de são Jeronymo, as dez e meia horas, nas salas das audiencias, onde se achava o Sr. Dr. Alciblades Perelra, Juiz Municlpal, commigo Escrivão no fim assignado, ahi presentos o justiflcante Jođo Keenan e o Dr. Ernani Coelho, Promotor Publico e ́́ revelia do representante da Caixa de Aposehtadoriase Pensões dos Empregados da Companhia Estrada de Ferro e Minas de são Jeronymo, e, desta, foram inquiridas as testemunhas Felippe Teixeira da Silva e João Thomaz Beardworth, que foram inquiridas pela maneira seguinte; do que fiz este termo.

Eu, Orlando Paula Tavares, escrivão o dactylographe1 e assigno.

- Escrivão

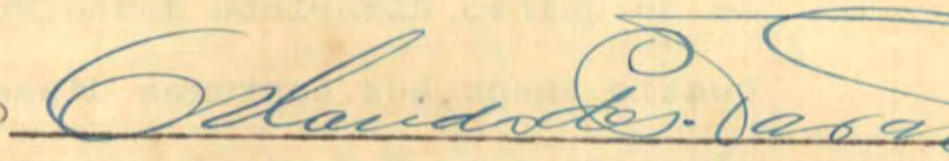

PRIMEIRA TESTEMUNHA :

João Thomaz Beardworth, com 72 (setenté e do1s) annos de 1dade, viuvo, natural da Inglaterra, mine1ro, residente no quinto districto deste Municipio ha sessenta e sels annos. Prestou o compromisso da le1. E sendo inquirida sobre a inicial de folhas dois que the fol lida, respondeu: que João Keenan era operario da Companhia Estrada de Ferro e Minas de São Jeronymo onde trabalhou de desesseis de Junho do anno de m1l oltocentos e oltenta e olto até o mez de Julho do anno de mil novecentos e vinte e nove, como manobrelro no sub-sólo do poço do1s, data em que roi victima de um accidente no trabalho;que depo1s que teve alta do accidente que soffreu o justificante no dia trinta e um de Outubro do anno de mil novecentos e trinta e tres, apresentou-se á chef1a da mina para recome- 
recomeçar a trabalhar, tendo a refertda Companhta se negado a admittil-o no serviço; que o justificante percebia o salario de nove mil réis diarios. - Dada a palavra ao Dr. Promotor Publico nada perguntou. E como nada ma1s disse e nemthe fo1 perguntado, lavre1 este termo. Eu, Orlando Paula Tavares, Escrivão o dactylographe1 e

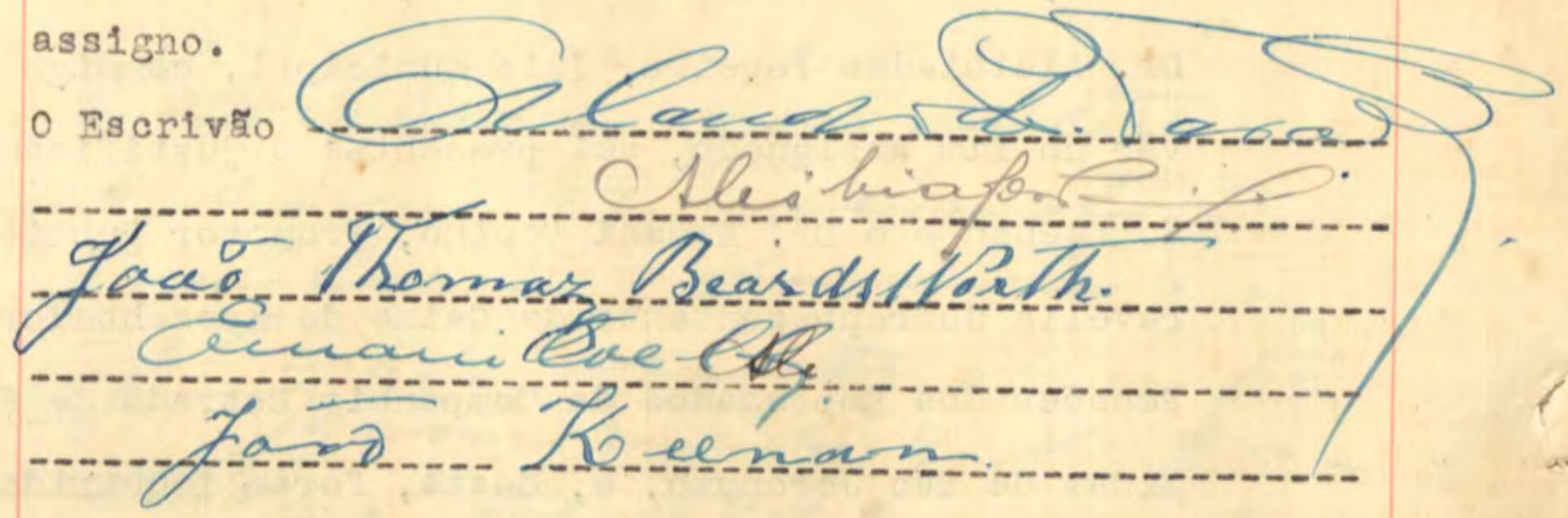

SEGUNDA TESTEMUNHA:

Felippe Teixeira da Silva, casado, com sessenta e olto annos de 1dade, natural deste Istado, mineiro, residente no quinto districto deste Municiplo ha cincoenta e quatro annos, aos costumes disse nada. Prestou o compromisso da 1e1. E sendo inquirta sobre a Infc1al de folhas dols que the fol Ilda, respondev: que Joa Keenan fol tocador de carros no sub-s6lo da Companhia Estrada de Ferro e Minas de são Jeronymo, deba1xo das ordens do depoente no año, de mil oltecentos e oltenta e olto; que continuando no serviço da Companhia, ainda, até Julho do anno de mil novecentos e vinte e nove, data em que fol victima de un accidente no trabalho; que a trinta e um de Outubro do anno de mil novecentos e trinta e tres, após ter alta do accidente que soffreu, apresentou-se o justiflcante á chefia da Mina para recomeçar a trabalhar - que foi por esta the negado a admittil-o no serviço; que do anno de mil novecentos e vinte e seis a mil novecentos e vinte e nove, o justificante exercia as funções de manobreiro no sub-sólo da mina, percebendo o salario de nove mil réis diario.- Dada a palavra ao Dr. Pro- 
Promotor publico, nada perguntou. $\theta$ como nada mals disse e hem the fol perguntado lavre1 este termo. Eu, orlando Paula Tavares, Escrivão, dactylographe1 e assigno.

Ora Escrivão:

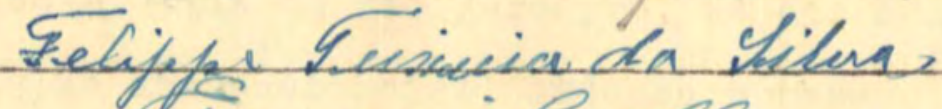

Emani bell

Janas reenoin.

ont
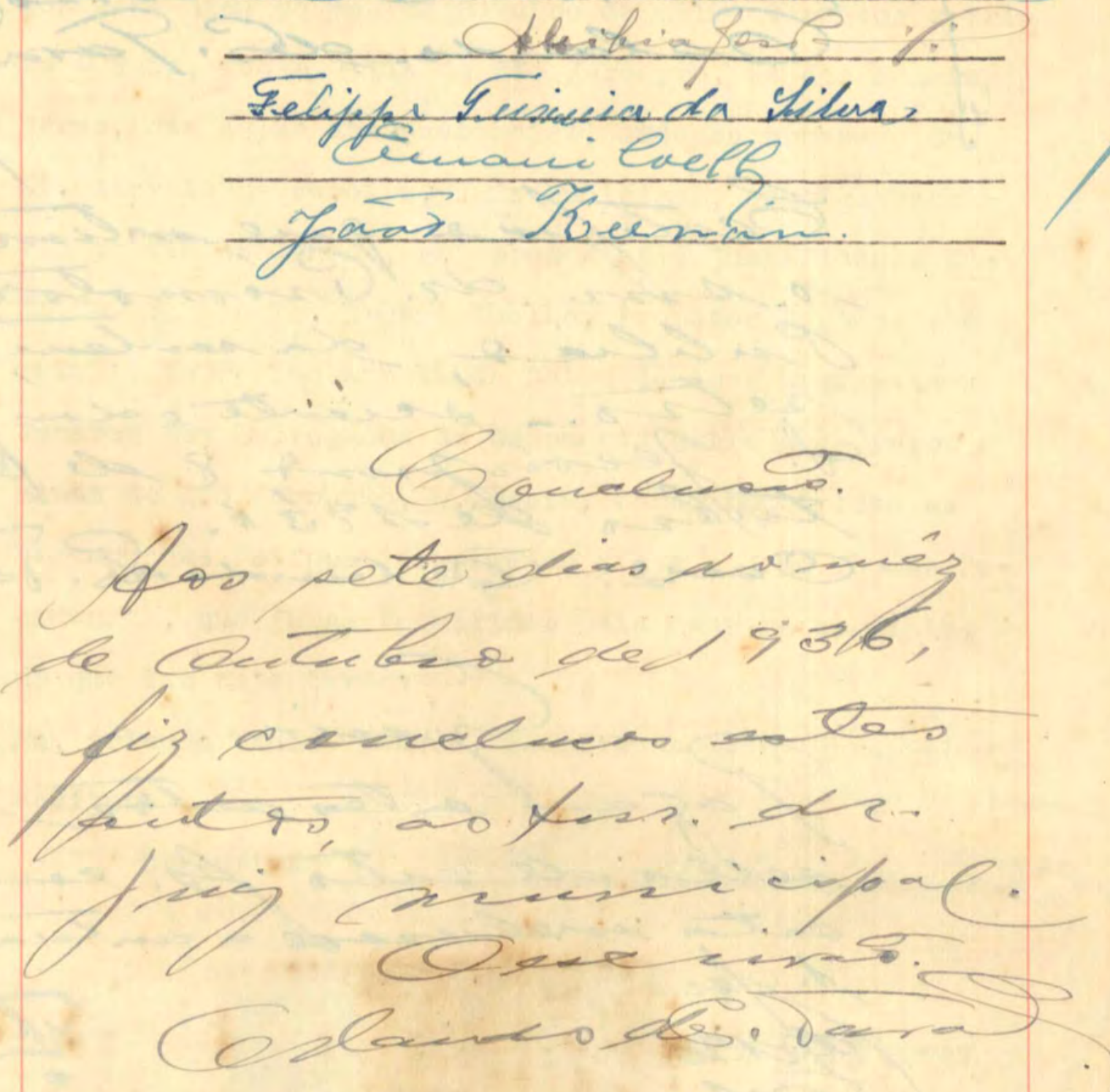

July: for tenteuce, a justificacas que fore foan Keerain, e, que, decone du, per 8"ucque, 9, para Que a mesma produra seus effectó de divectó.

Pelladose coutary, entieguarke. a' parte.

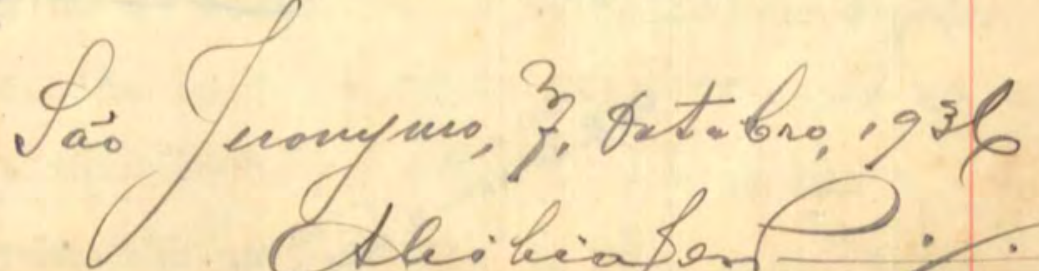

$$
\begin{aligned}
& \text { Cheikinger i. ist }
\end{aligned}
$$




\section{2.}

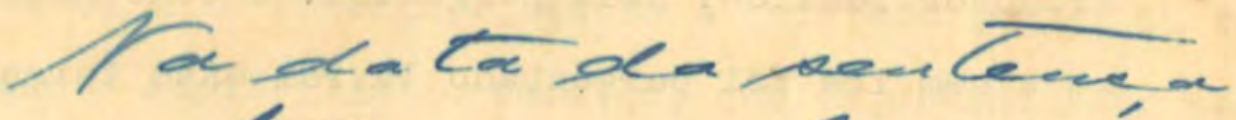

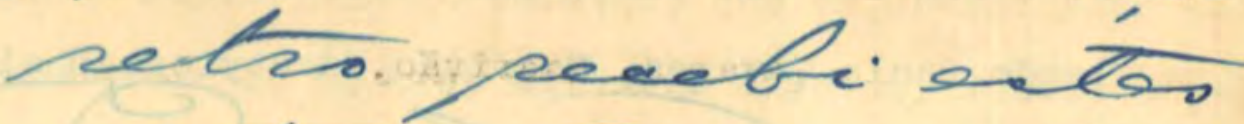

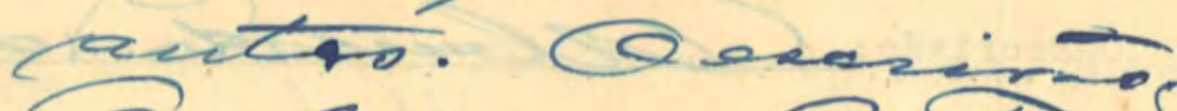

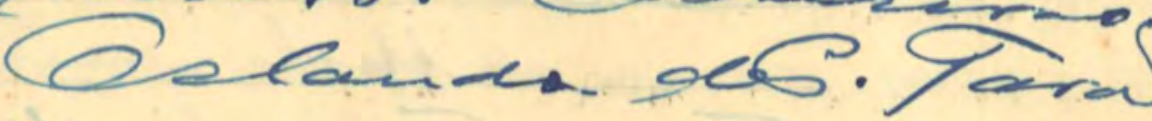

$\sum_{2}+2$.

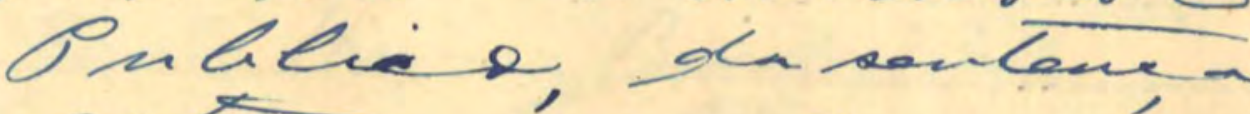

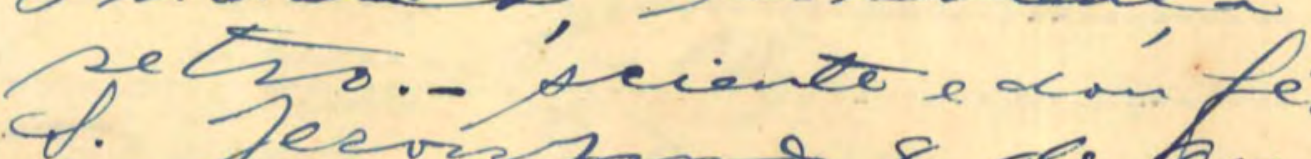

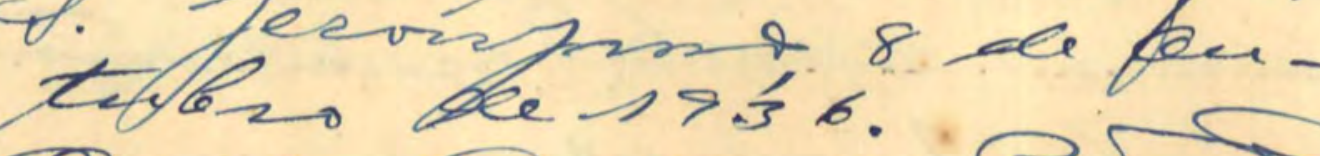

$105 x=-1$,

Q

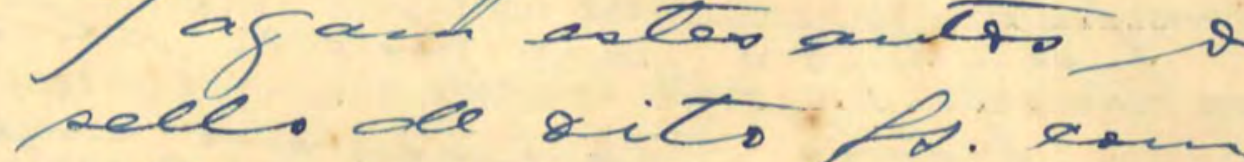

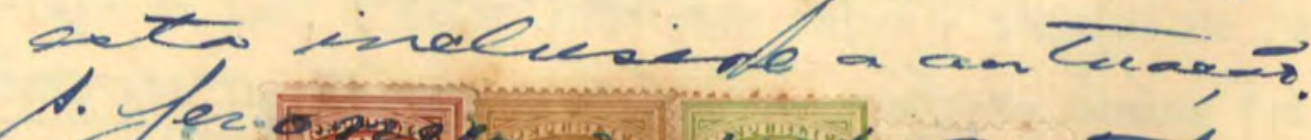

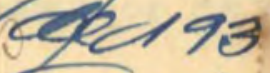

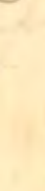
elac
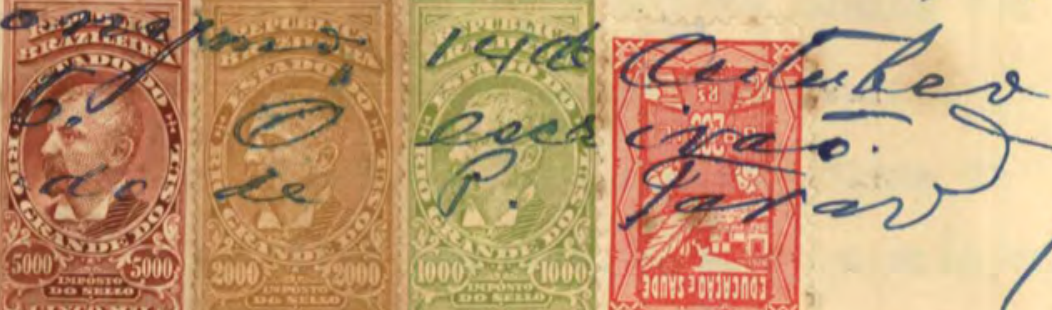

2. 2.000

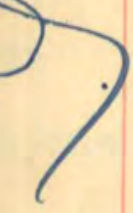

A.

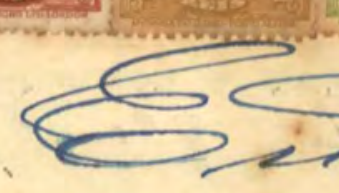
tos

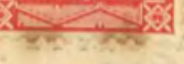


Rec. em $28 / 6 / 938$.

- INFORMAC $\tilde{A O}-$

- sindicato dos Mineiros e Classes Anéxas do Munic1pio de são Jeronimo, em telegrama de 11s. 115, comunica ter enviauo, por v1a aérea, as just1ficações jud1cia1s procedidas pelos seus assoclados L1beral1no Machado e João Keenan, af1m de serem juntadas aos autos do presente processo.

Em requerimento de 11 . 116, o sindicato dos $\mathrm{N} 1 \mathrm{ne} 1$ ros e Classes Anéxas de são Jeron1mo, por seu bastante procurador (1nstrumento de mandato a 1ls. 117), submete à cons1deração deste conselho as just1f1cações jud1c1a1s procedidas por Liberalino Machado e João Keenan, para prova de tempo de serv1ço na Companh1a Estradas de Ferro e M1nas de São Jeronımo.

F1cando estes autos em condições de voltarem à

douta procuradorıa ceral, em face da promoção pela mesma reque rida a Ils. 111 verso, passo o presenté processo ao sr. D1retor désta secção, para os devidos lins.

R10 de Jane1ro, 28 de junho de 1938

Charia Aloma l4. delá Pleranda of. Adm. - Classe "J".

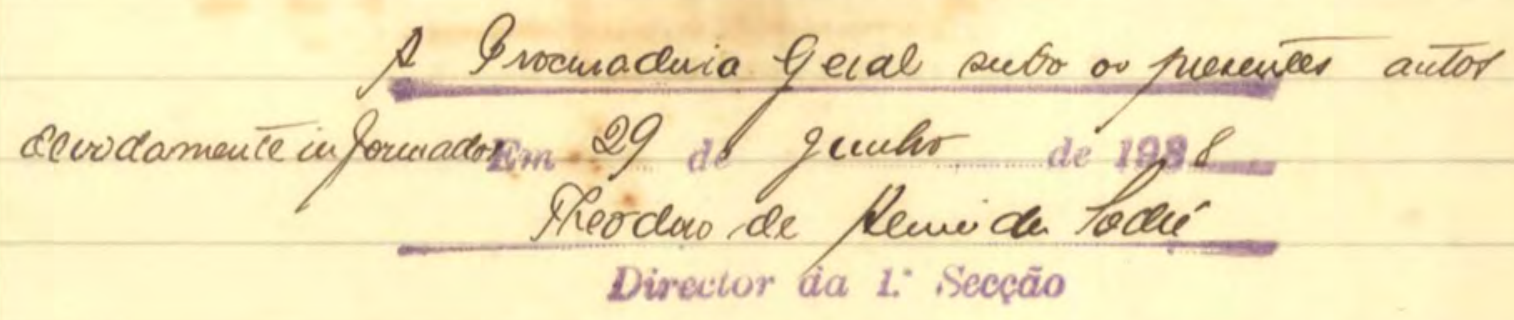

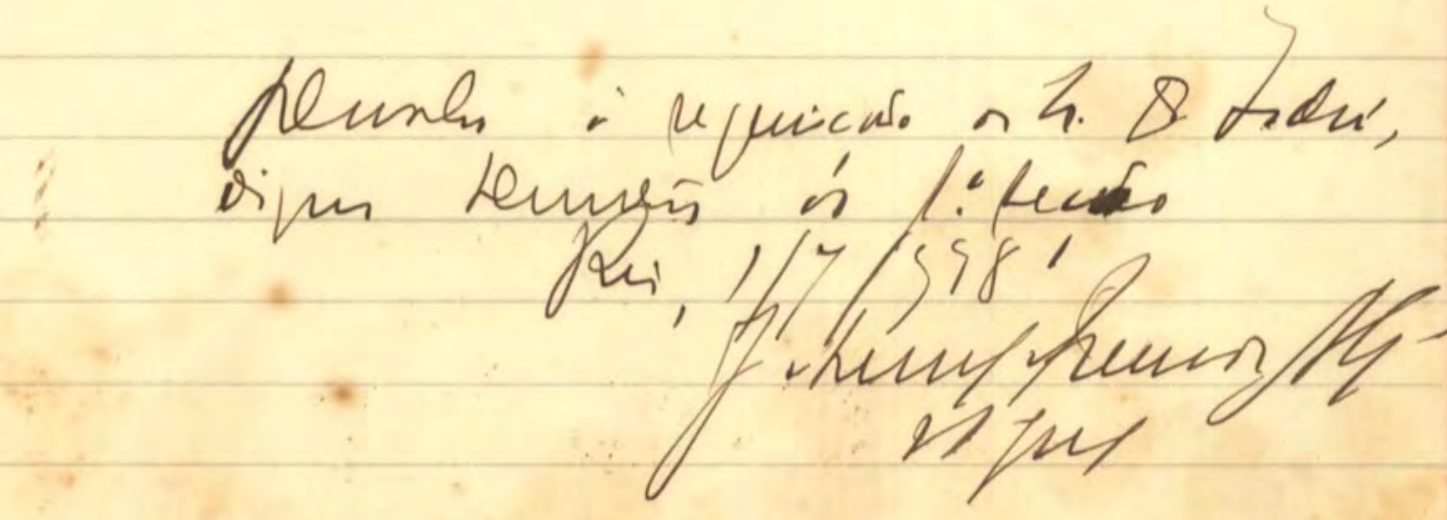


Sermo de funtada:

Innta necta data, a

fls. 138 e segunites dectes autos, duas

funtificacrés Indiciair procedidas for

Liberalinis Mochado de finna e Yoca

Reenan, frotocoladas sob of $n^{0 .} 10.182$

e 10.183, de 1938.

$$
\beta_{\text {io }} 7[7 / 938
$$

Aaria Cleina'AY delá Alvianda Of. Adur. - Cave "y". 
1938

F1s.

Estado do Rio Grande do Sul

Escrivania do Civel e Crime São Jeronymo

Jurisdicção bivel

Escrivão: Orlando P. Tavares

Tustificacás de teug/es de permice.

6 Sindicato dos vineinos i blasses snexas.

Soão Rréenaun

Pegrerrence

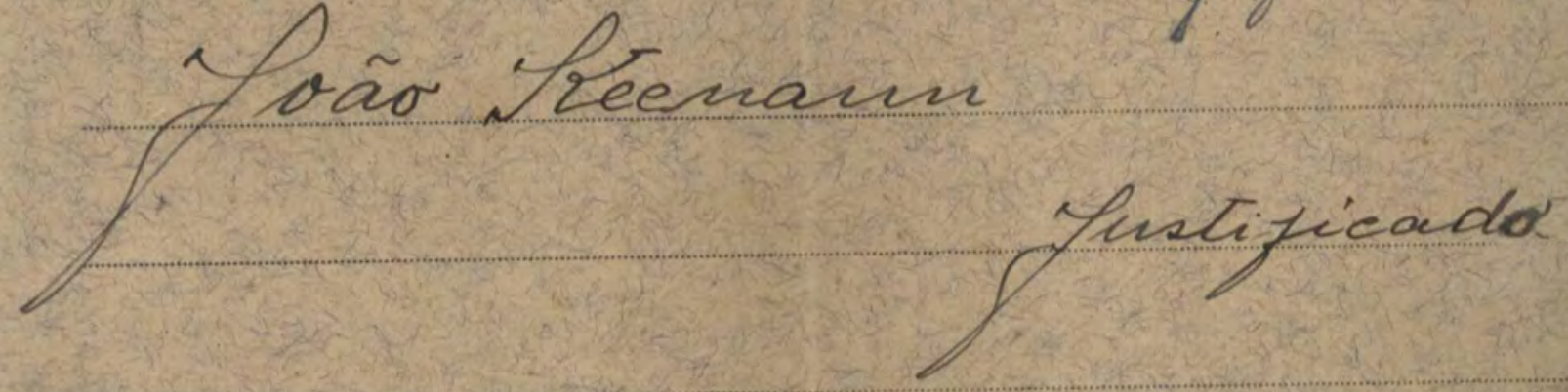

etutuacãa.

Aos Crese dias do mez de Jucih de milnovecentos e trinta e oito, nesta villa de São Jeronymo, no meu cartorio autuo as pegas que se seguem do que, paraconstar faço este termo. Eu, escrivano, of subscrevi:- 

IIm으. Smr. Dr. Ju1z Wunicipal.
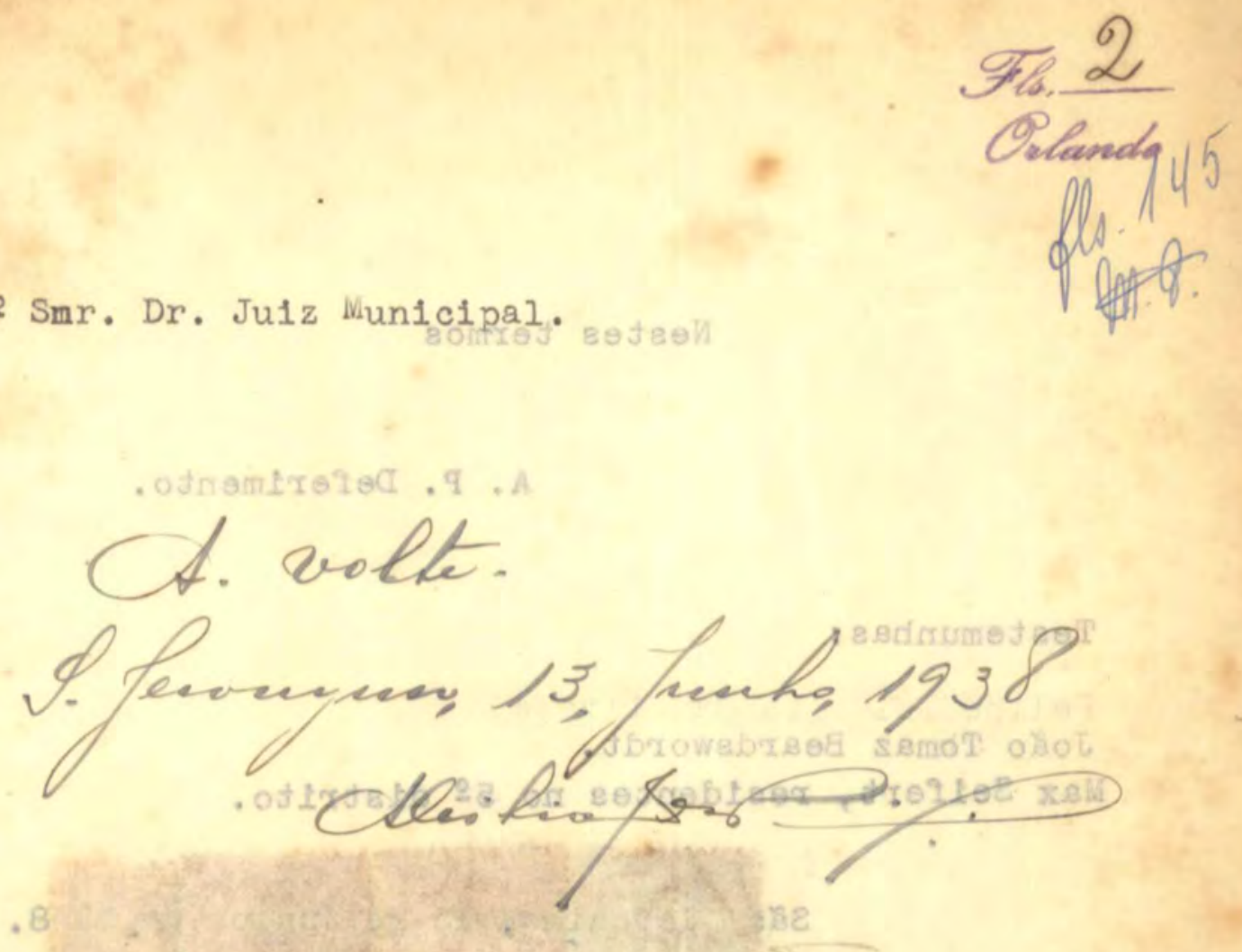

- Sindicata dos Mineiros e Classes Anexas, do. Whunicipio de São Jerônimo, representado por seu presidente no fim assinado, vem dizer a V.S. que, João Keenann, fo1 admit1do como operario da Companhia Estrada de Ferro e Minas de S.Jeronimo, no ano de 1888, trabalhando até o ano de 1929, quan do sofreu um acidente no trabalho; que dessa data até o ano de 1933 esteve em tratamento pelo acidente sofrido o d 1 to João Keenann; que ficando o justificado restabelecido, a presentou-se ao serviço da Empreza acima mencionada, tendo sido por essa, recusado os seus sérviços; que João Keenann era mineiro, trabalhando por empreitada, a principio,e mais tarde começou a perceber uma diaria de $12 \$ 000$.

Isto posto, o requerente precisan do para fins de direito, justificar esse tempo de serviço, do seu associado, o dito João Keenann,

V Sila e hora, afim de ser feita a justificação, cujastestemuWhas arrola e protesta apresentar, independente de citação. Outrossim, péde a intimação do Sr.Dr.Promotor Publico e do representante da Caixa de Aposentadorias e Pensões, residen te no 5 distrito deste municipio, e que julgada por senten ça a dita justificação, Thes sejam entregues os autos independentes de traslado. 


\section{Nestes termos}

\section{A. P. Deferimento.}

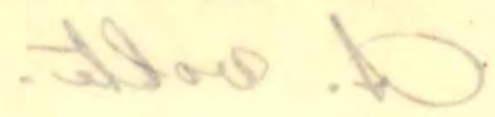

Testemunhas:

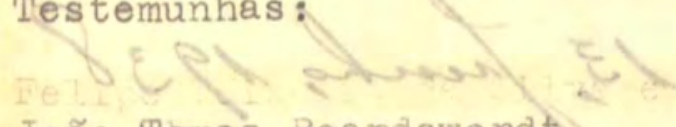

Joăo Tomaz Beardswordt.

Max Selfert, residentes no 52 distrito.

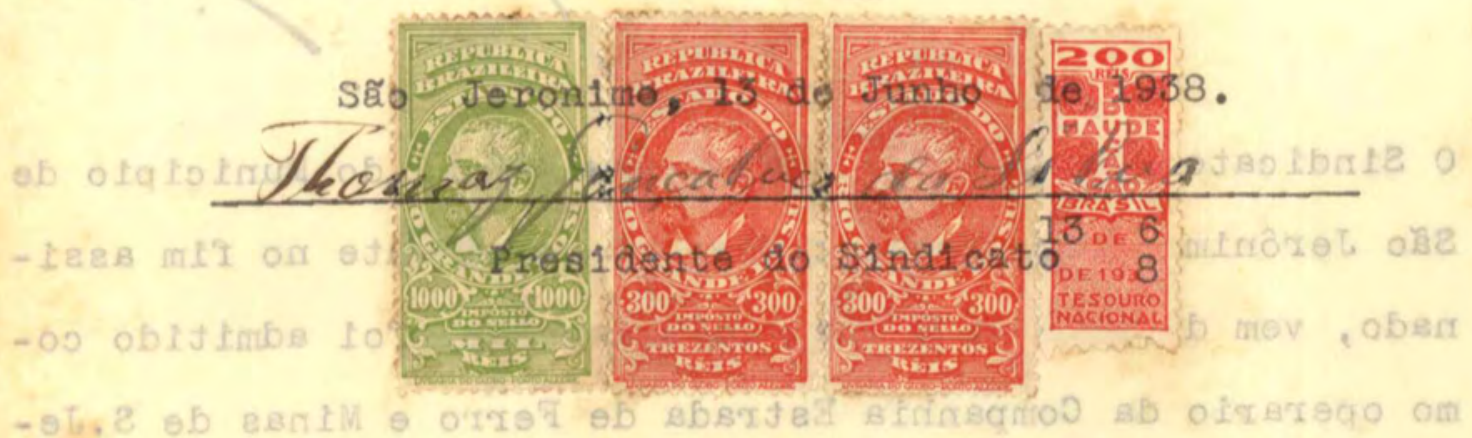

-

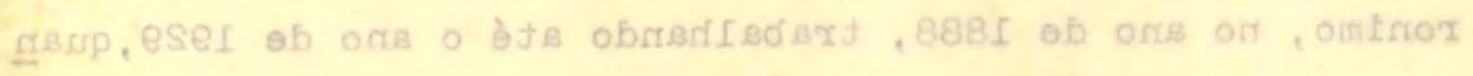

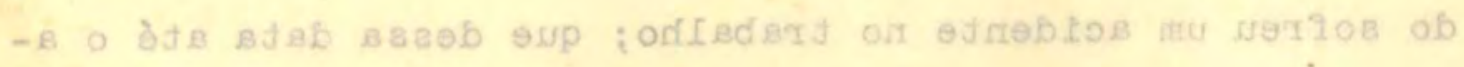

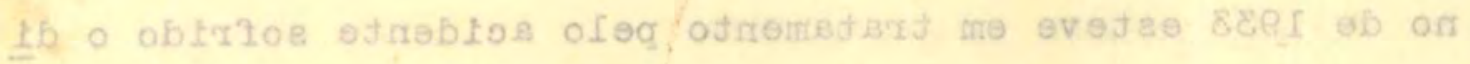

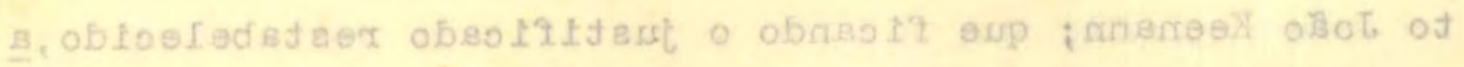

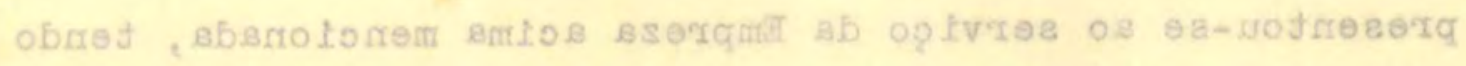

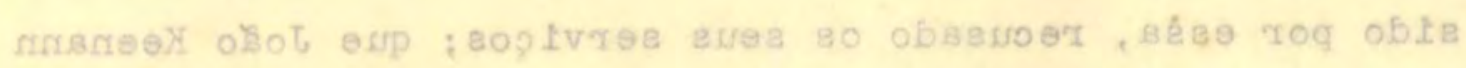

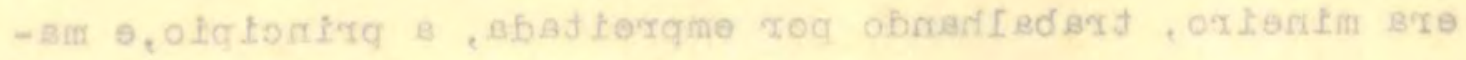

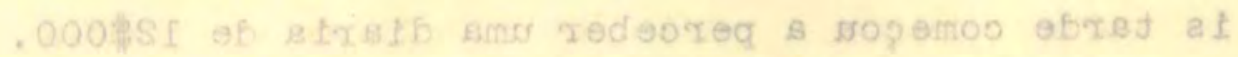

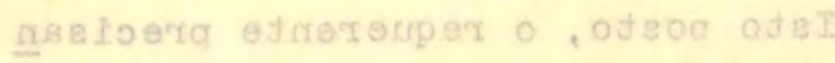

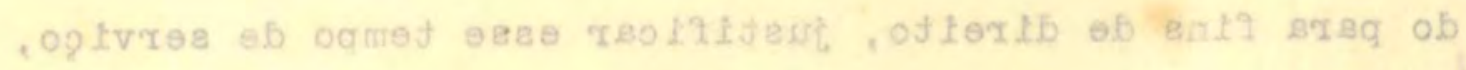
Ob olipangleeb, भIU⿴囗十

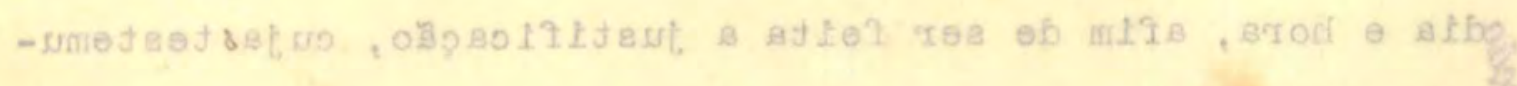

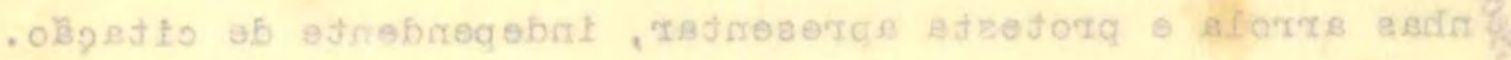

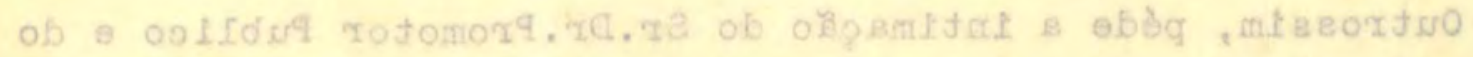

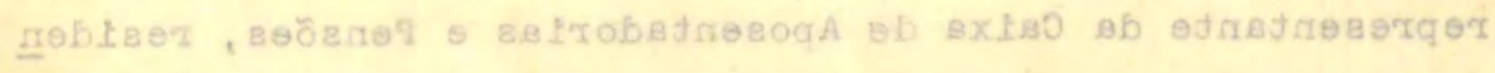

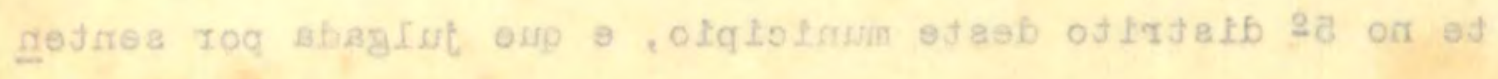

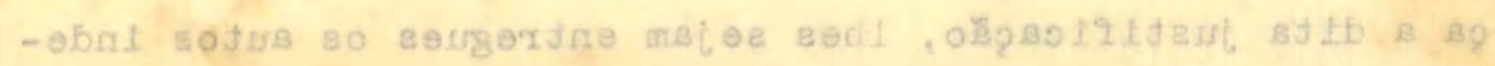

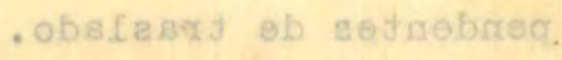




\section{CONCLUSÃO}
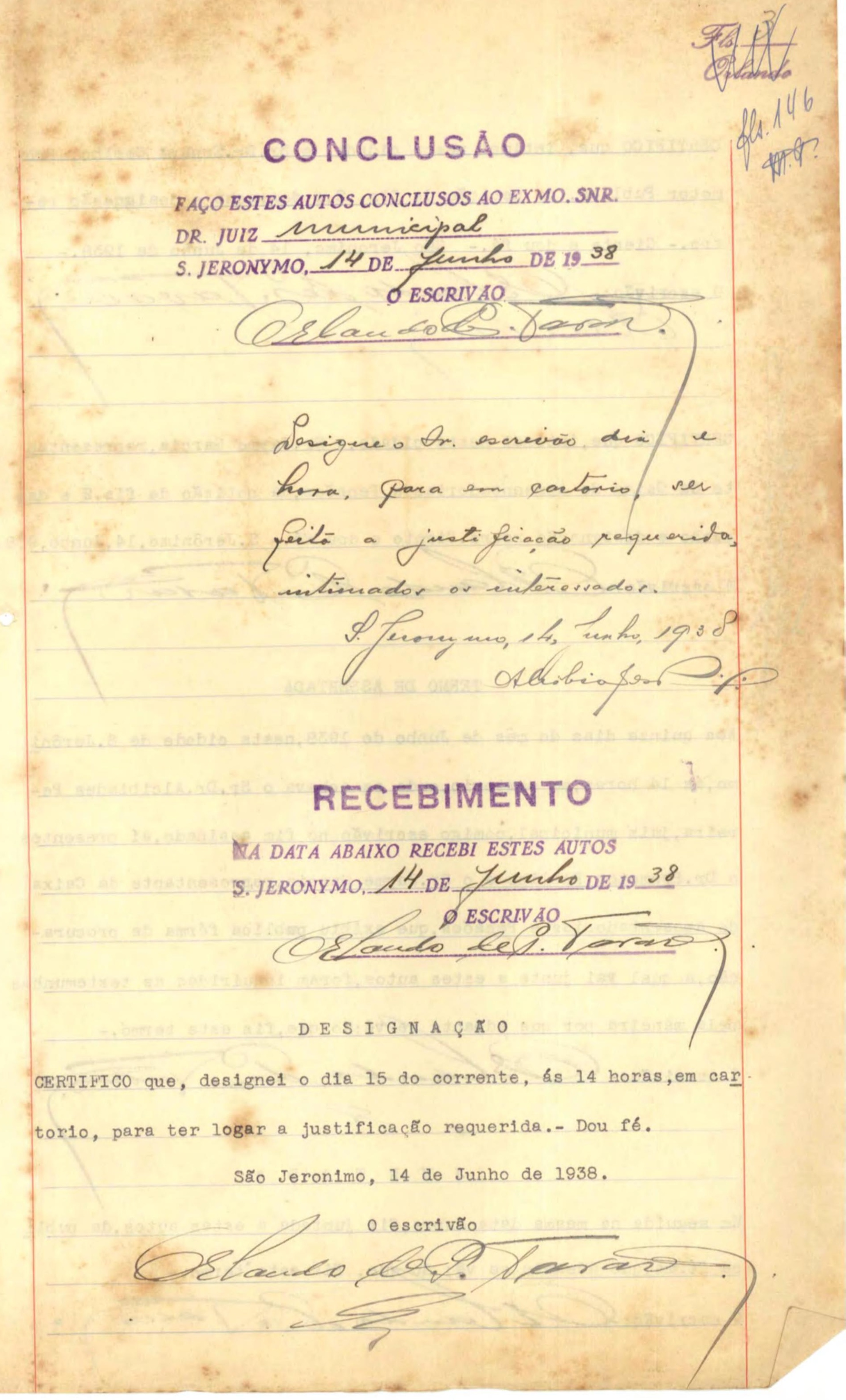
CERTIFICO que, intimei nesta cidade, o Sr.Dr.Ernani Coelho, Promotor Publico, da petição de fls. 2,e despacho e des1gnação retro.- Ciente e dou fé.- São Jeronimo, 14 de Junho de 1938.o scriyão:-

CERTIFICO que, Intime1 nesta cidade, o Sr.Jayme Garcia, representan te da Ca1xa de Aposentadorias e Pensões, da pet1ção de fls.2 e des pacho e designação retro.Ciente e dou fé.- S. Jerônimo, 14, Junho, 938. Q escrivão:

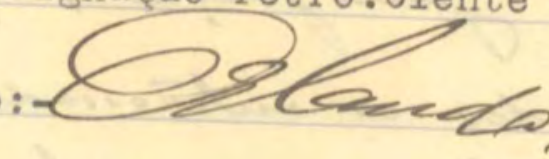

TERMO DE ASSENTADA

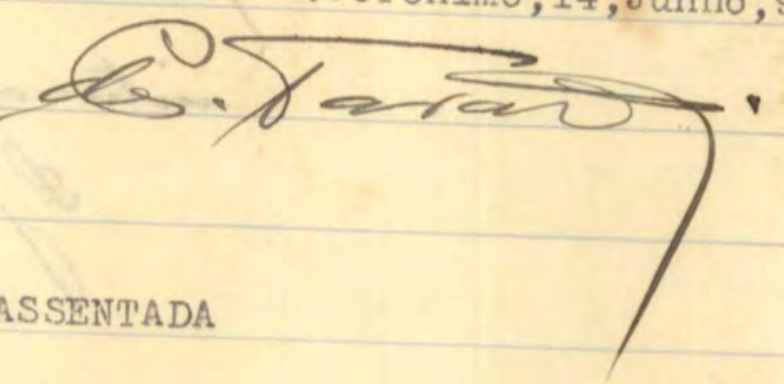

Aos quinze dias do mês de Junho de 1938, nesta cldade de S.Jerônt mo, 14 horas, em cartorio, onde se achava o Sr.Dr.Alciblades Pere1ra, juiz munic1pal, comigo escrivão no fim assinado, a1 presentes - Dr.Promotor Publico e o Sr.Jayme Garcia, representante da Calxa de Aposentadorias e Pensões, que exiblu publica fórma de procuração, a qual yal junta a estes autos, foram inquiridas as testemunhas pela mane1ra por que adeante 80/vê; do que, fiz este termo.-
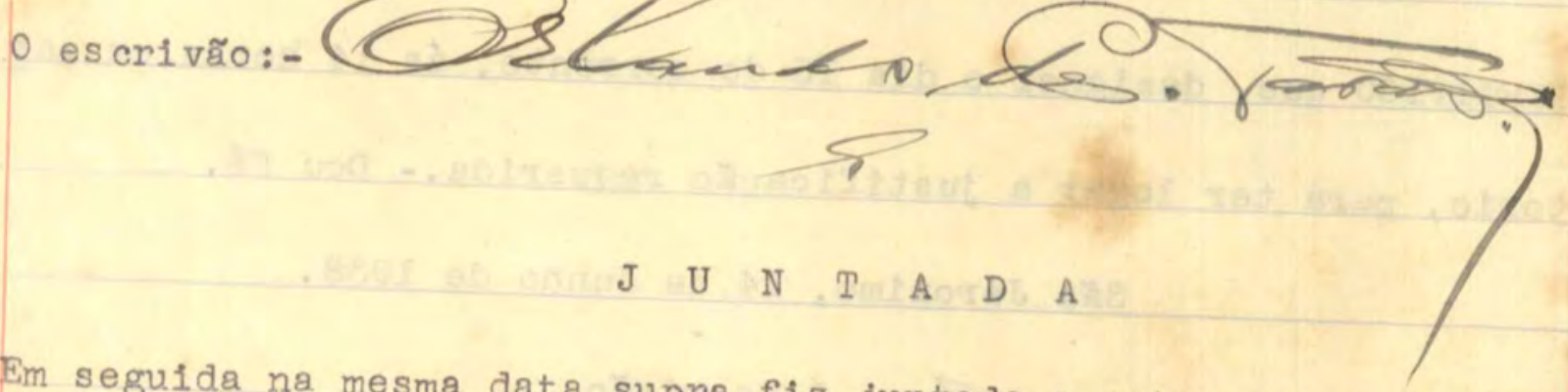

Em seguida na mesma data supra,fiz juntada a estes autos, da publ1 ca. fórma, que adeante se vê; de que, fiz este termo.o escr1vão:
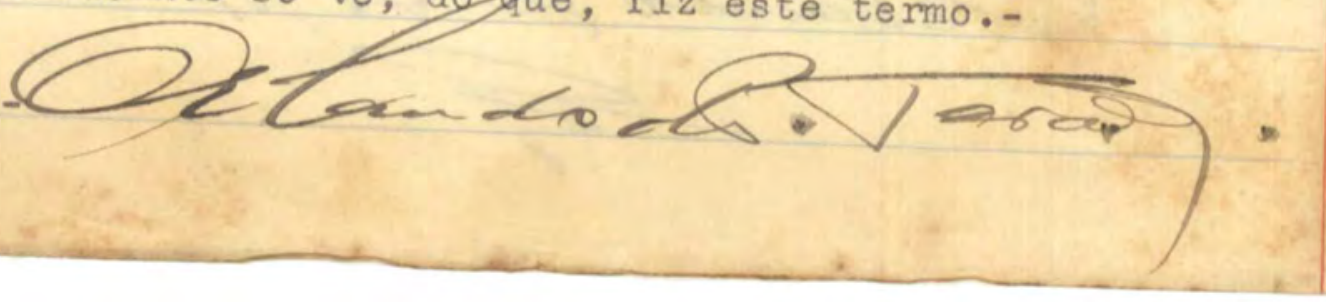


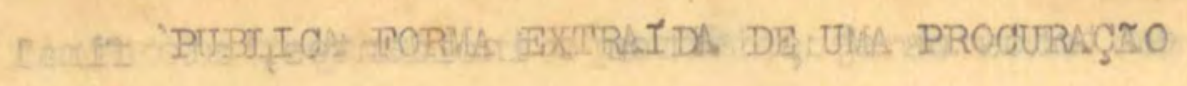

-Republicar dos Rstado Unidos de Brágit. Betado do Rio

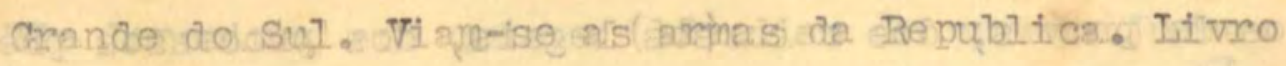
ITS 116. 10 Praslado. Flis. 46. Portio Alegrep pua ry de Setembro, 1101 - FPane, 4484 . Wia-se um on rimbo com- os

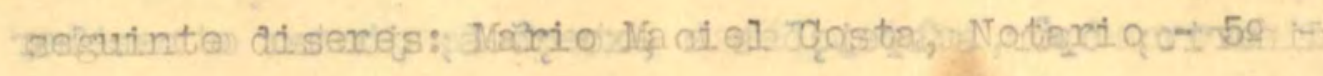

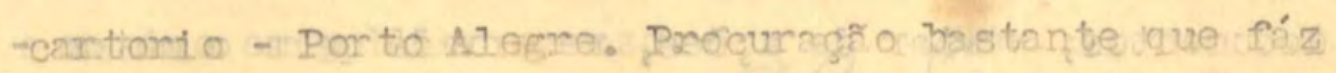
dariso Pinho dosi Santios. Satzem os cue viximem este pu blico instrminento dę procuração que, no a no dê mil novedentos xei trinta oito, nesta cidade de Fortio AIegre, tea pt tal z do Bstado do Rio Grende do SuI, aos 3 -(tres) dias do mer de Junho, neste quinto cartorio = compareceu Carlos Pinho dos Sentos; presileiro, casa -dd, arui residente, na qualidade de presidente da -Juntá Administrątiva de Caixa de Aposentaçoriąs $\theta$ Pen soẹs de Serviços dé Minerag̃̃o, ŗecophecido pel p proprio do Nótario, de mimgduannte e das testemunhas -adeainte nomeadek.e no flo ássinedas, perante as quaés dissé quề nomeava e constituie seu bestonte procurador.o Snr. ¿dayme Giroia; brasilezro, wai or, fum- cionerio de referidą Caixa, nas Minas de ș̃o Jeroni-mo, 50 alstrito do municipio de São Jeronimo, para o rim especial de representar á daixa citade nas justi. - Micaçres judiciaes que selprocessarem no Juizo deque

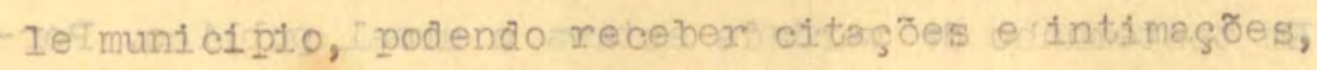
-inclusivel as primeiras, arecorrer de despachos, transigir, agrever, protestar, desistir, acôrdar, o pratichr ós denais átios necosgarios a p fim deste mandee to. (segue-se os poderes itmgressos:) conicede todos os

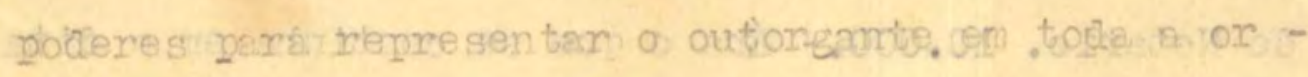
- orimi ce figura de juiro jon fórer dele p requerer, legar

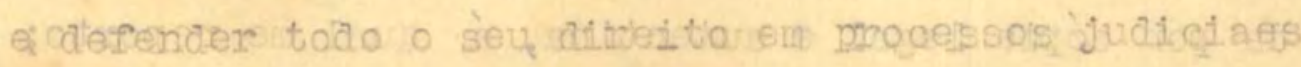
- de vqualcuér natureza, ein quiè for autor ou réo, essits tntente ou opcente, ou de qualquér modo interèssado, em

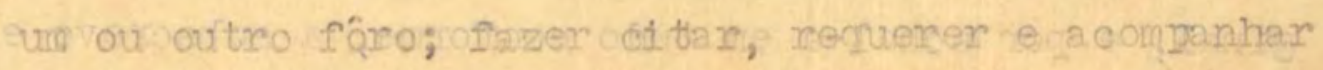




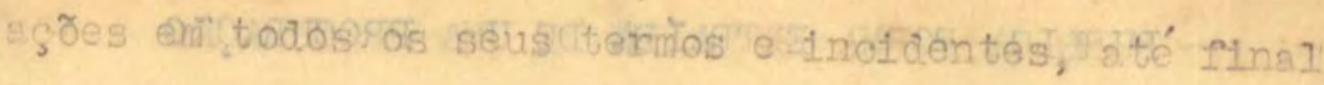

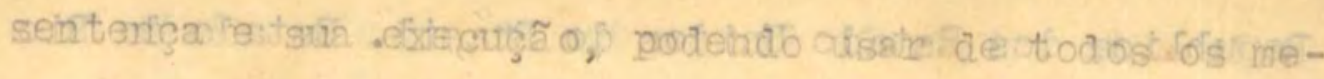

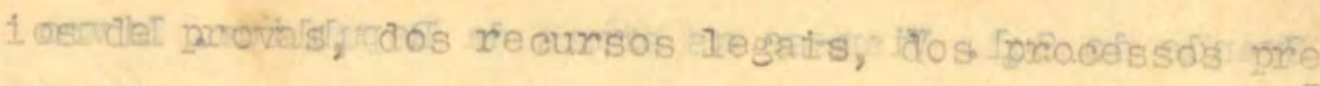

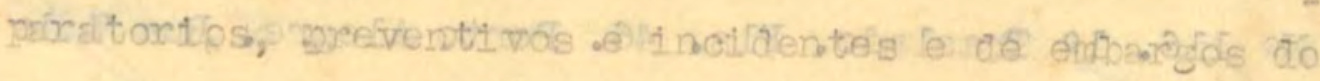

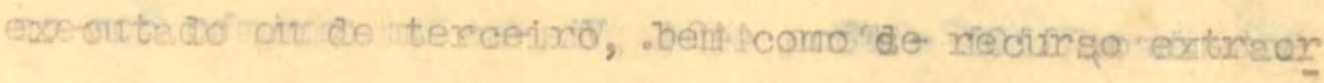

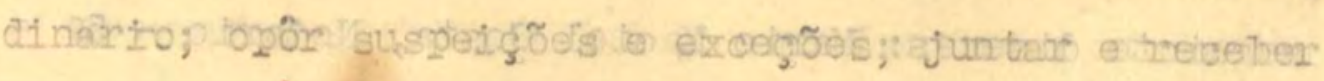

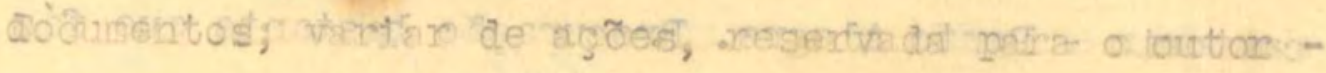

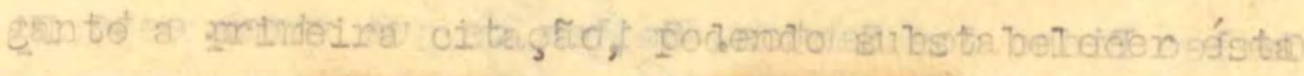

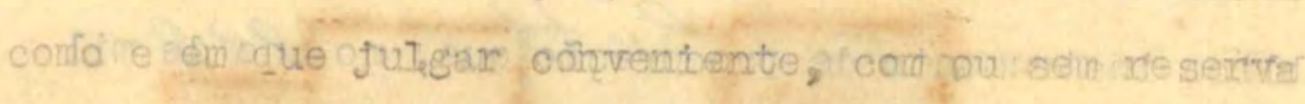

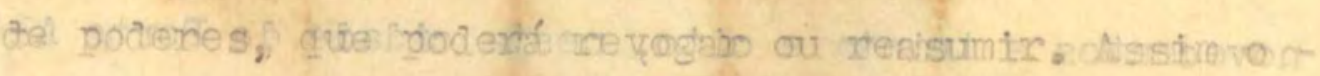

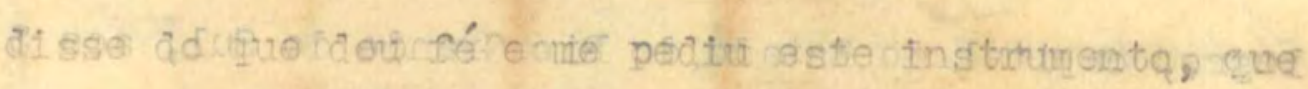

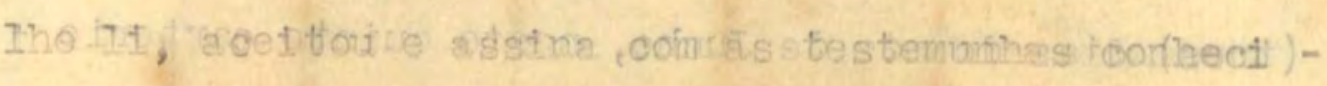

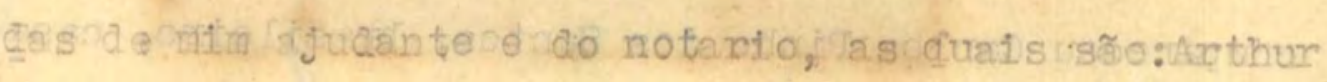

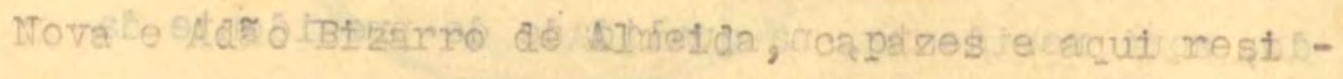

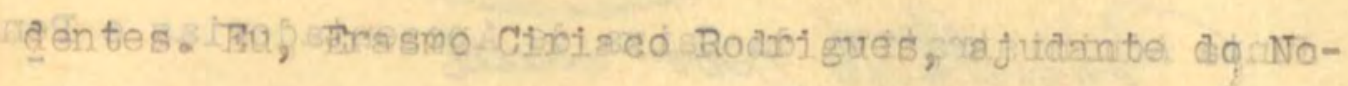

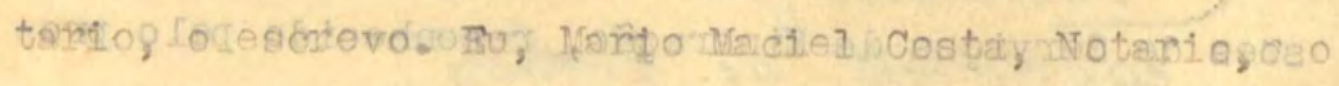
subscrewate àssino. O Notario, Mario, Miated un Coste :Tor

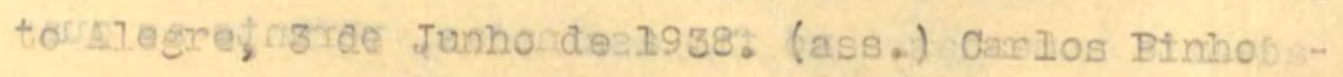

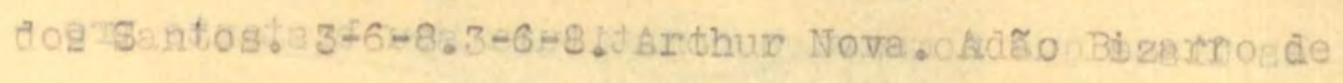
Alrieida. Com dois miz e duzentos réis, - बstampithas fe-

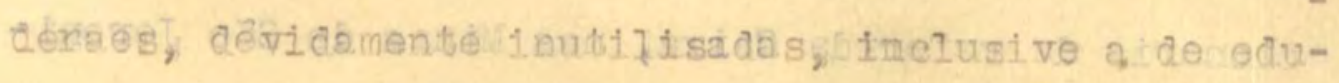

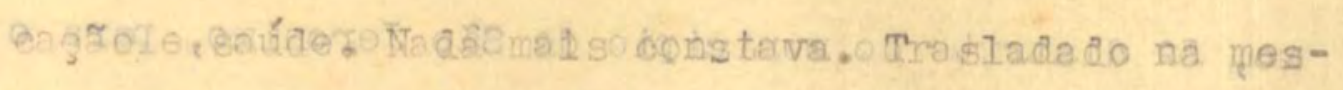

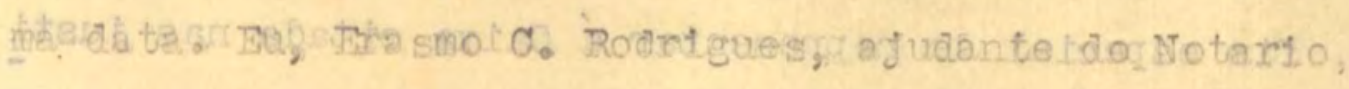

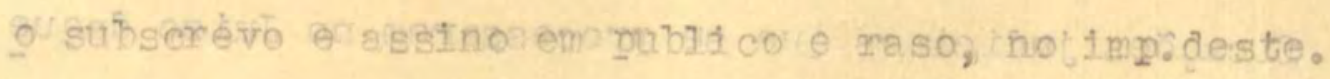

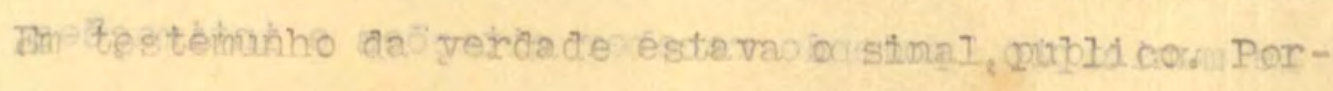

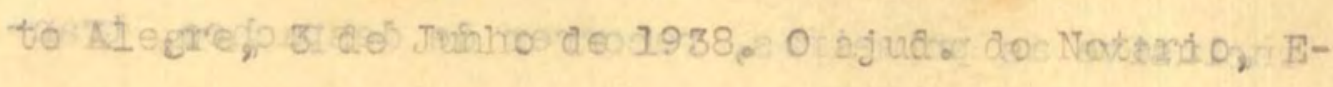

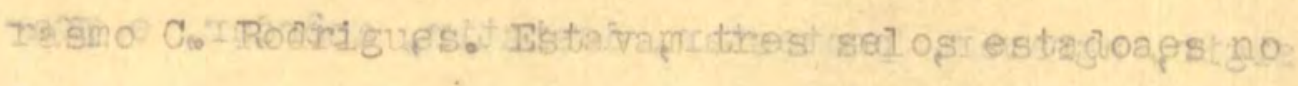

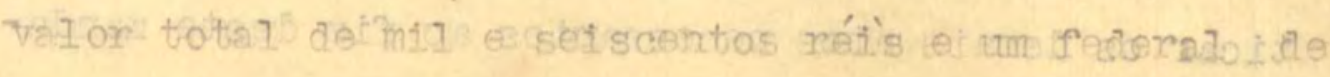

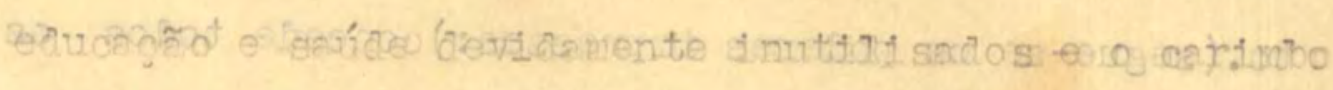

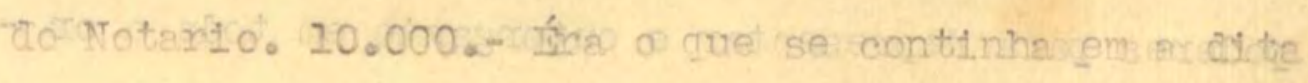

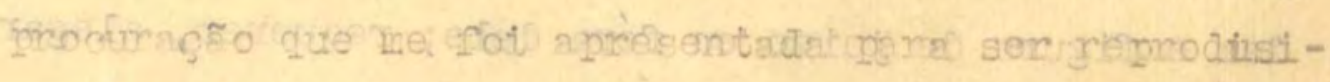

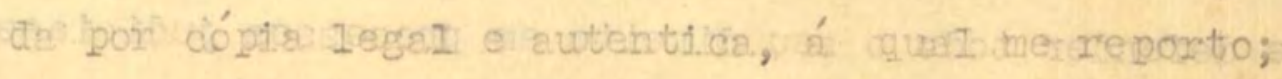

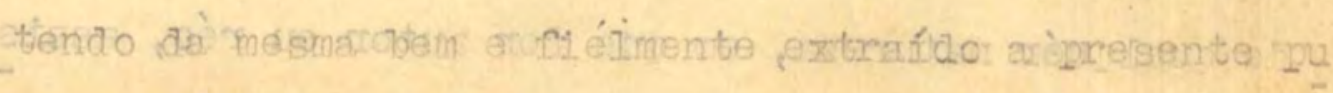

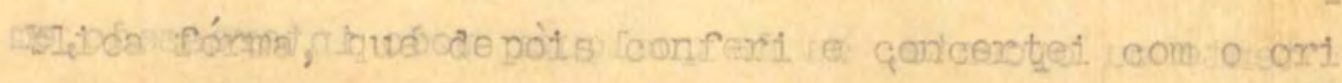

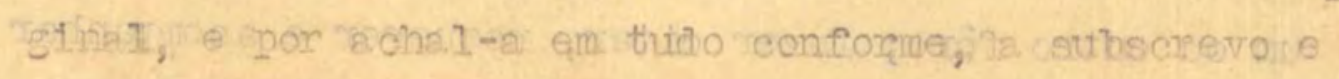


essino entredando-a 20 portador, juntamente com a quele dito original; do due dou fé, néste cidade de s̃o Jeronimo, a os quinze (I5) dias do mez de Junho

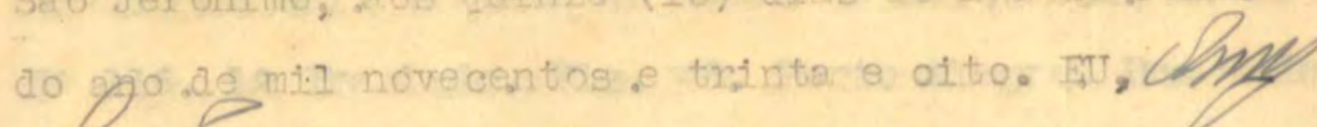
to. Seckeco, ajuante do Notario, no hm-

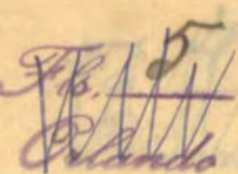

ofa. 148
affet?

pedimento oceisional deste, datilozmafel, subsomero

e assino am purbil do en raso.-

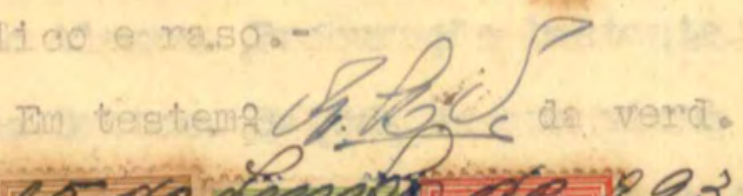

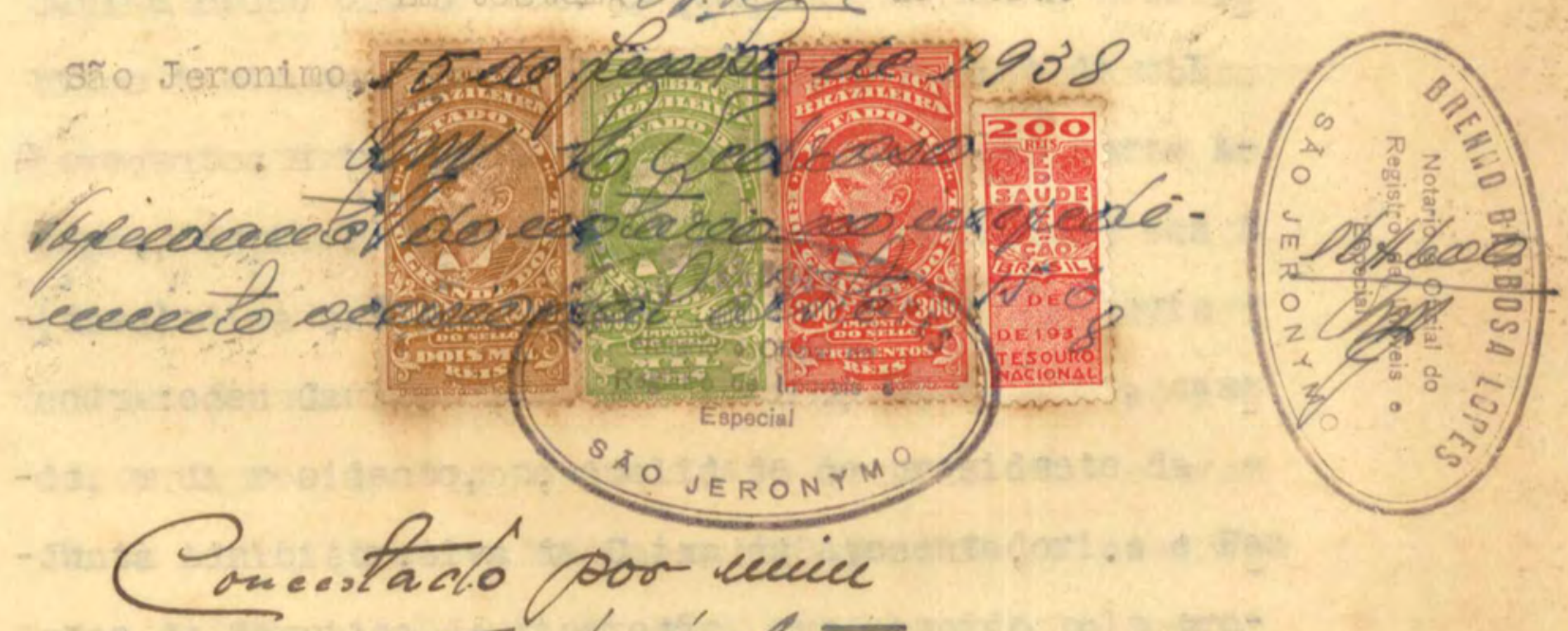

encrivas de ómpos.

Data oupra.

(O) Acizar,

Cunerf 3 ar-cellos. 
Primeira testemunha, ebruge8

- Obab MaX SEIFERT, com sessenta o ol to anos de ladade, casalo,

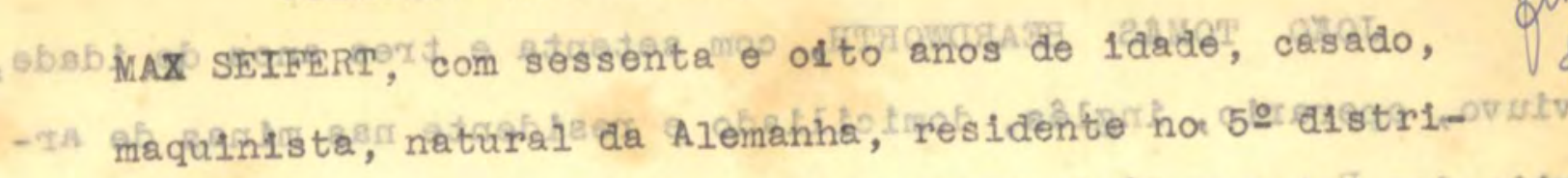

BbBr to deste muni cipio, aos costumes als'se hada. Prestou so olde

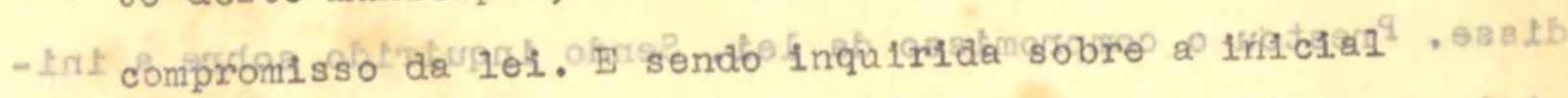

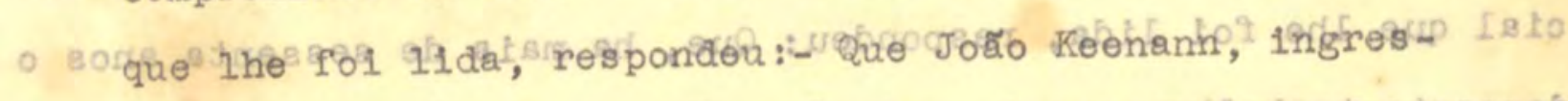

. 8 ob sou como minelro nos serviços de Compenhile tstrada de jueogeb

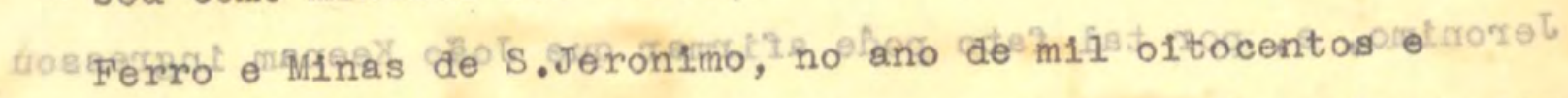

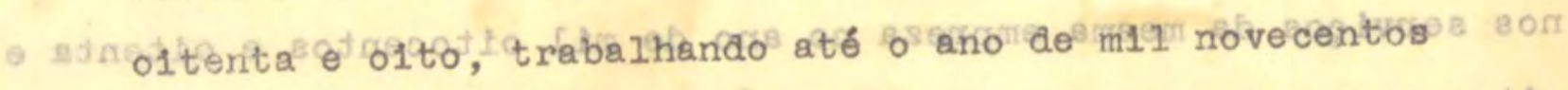

ab ervinte e nove, equando sofreu um acidente no trabalho; : of to

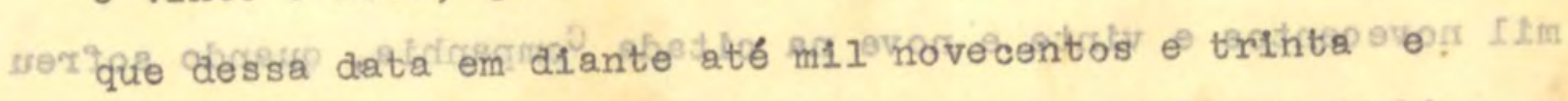

- reovtres ésteve em tratamento mealco; que após ter ele fi- to mis

marcado restabelecido, aprésentou-se a dita Empreza, ten- $\theta$ soj

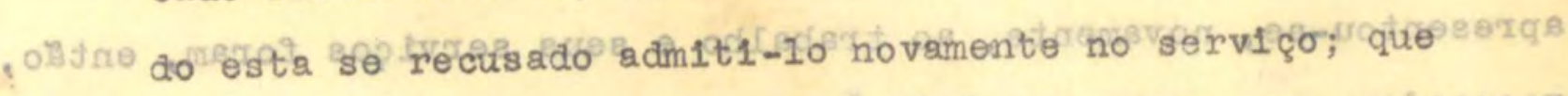

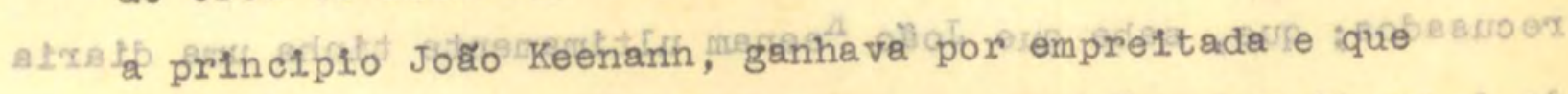

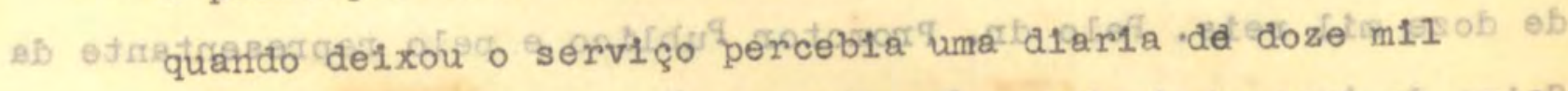

aber relis;"que o depoente sabo alsto, porque quando od to sxtal

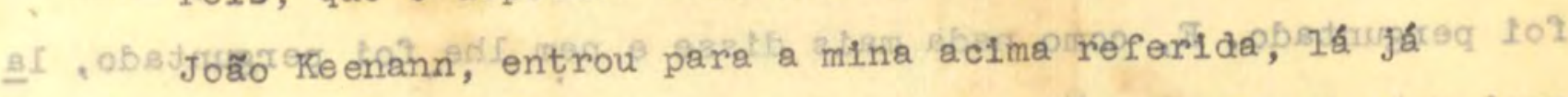

exgolltse oncontrava a depoente trabelhando; que quanto abo aos- ferv dente por ele sofrido, fol o depoente digo, viu-o doente le? em casa. Dada a palavra ao Dr. Promotor Publico e :ao vre- 80 presentante da Caixa de Aposentadorias e Pensões, por eles nada fal penguntado. Do que, oflzeste temo. Eu, orlando de Paula Tavares, escrivão, o datilograpel e as-

sino.

0 escrivå
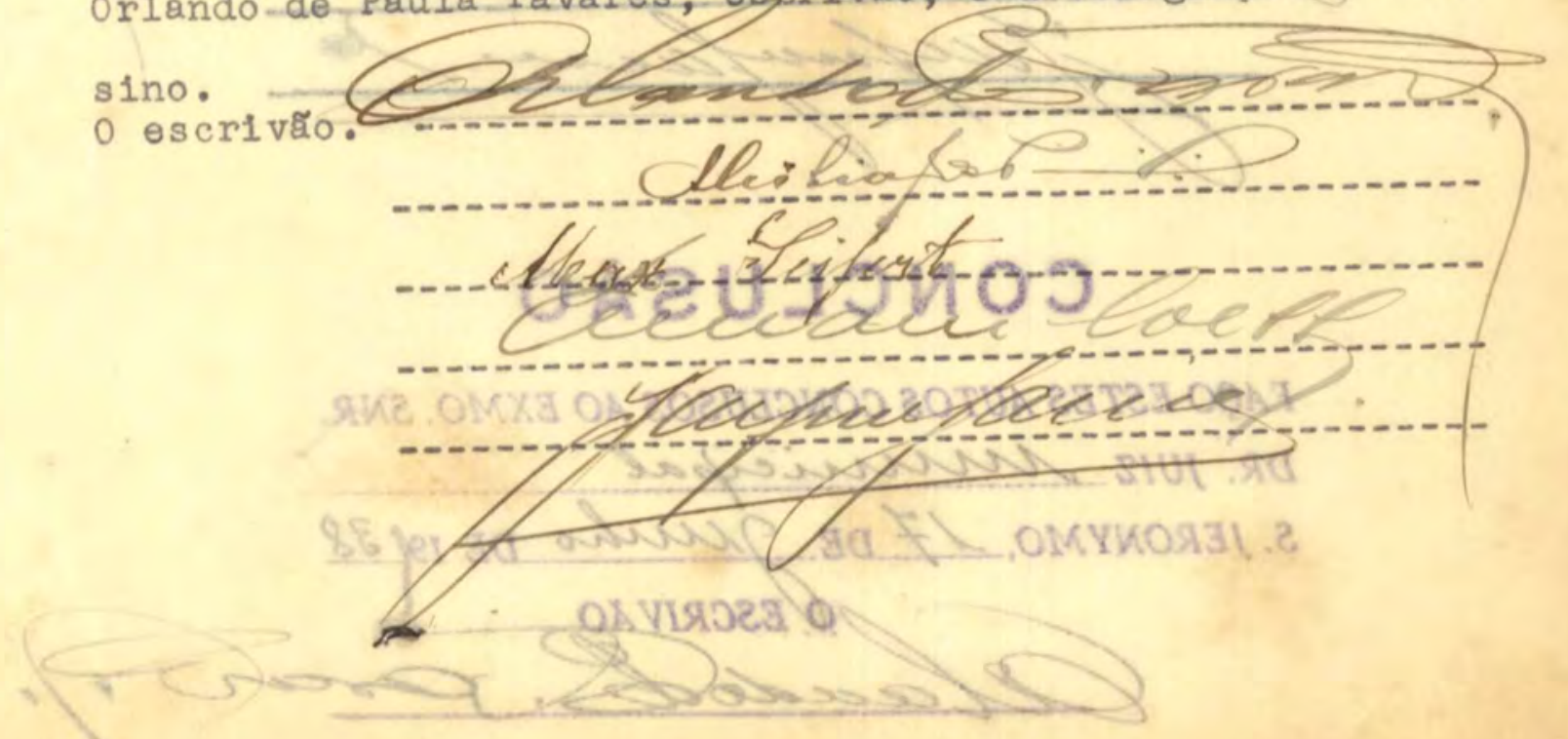


\section{Segunda estemunhas sriemLiq}

: JORO TOMAS BEARDWORTH, com, setenta e tres anos de 1 dade, viuvo, operarlo, inglês, tom1 clilido e residente nas minas de ArDilo dos Ratost $5^{\circ}$ distrito deste municipio - Aos costumes nada disse. Prestou a compromisso da le1. Sendo Inquirido sobre a inicial que the fot lida, respondeu: Que, ha mais de sessenta anos 0 depoente trabal ha nas minas da Cia. Estrada de ferro a Minas de S. Jeronimo, e, por tal fato pode afimar que. João Keenam ingressou nos senvicosodar mesma empreza no ano de mil oitocentos e oltenta $\theta$ o1to; que, sabe, tambem, que João Keonam traba thou até o ano de m1l navecentos e vinte e nove na cltada Companhia, quando spfreu um acidente of ficou em tratamento medico até 0 ano de m1 $l_{8}$ novecentos e trinta e tres; que, restabelec1do do acidente João Keenam apresentou-so, novamente, ao trabalho e seus servi cos foram, então, recusados; que, sabe que João Keenam ulifimamente, tinha pme diarla de dozer mlit nels. Pelo dr. Promotor Publico $\theta$ pelo representante da Ca1xa de Aposentadopias e Pensões dos Serviços de Mineração, nada fol perguntado. E. como nada mats disse e nem the fol perguntado, la vre1 exte termo. Eu, urlanda de Paula Tavares, escrivão, o dat1logra

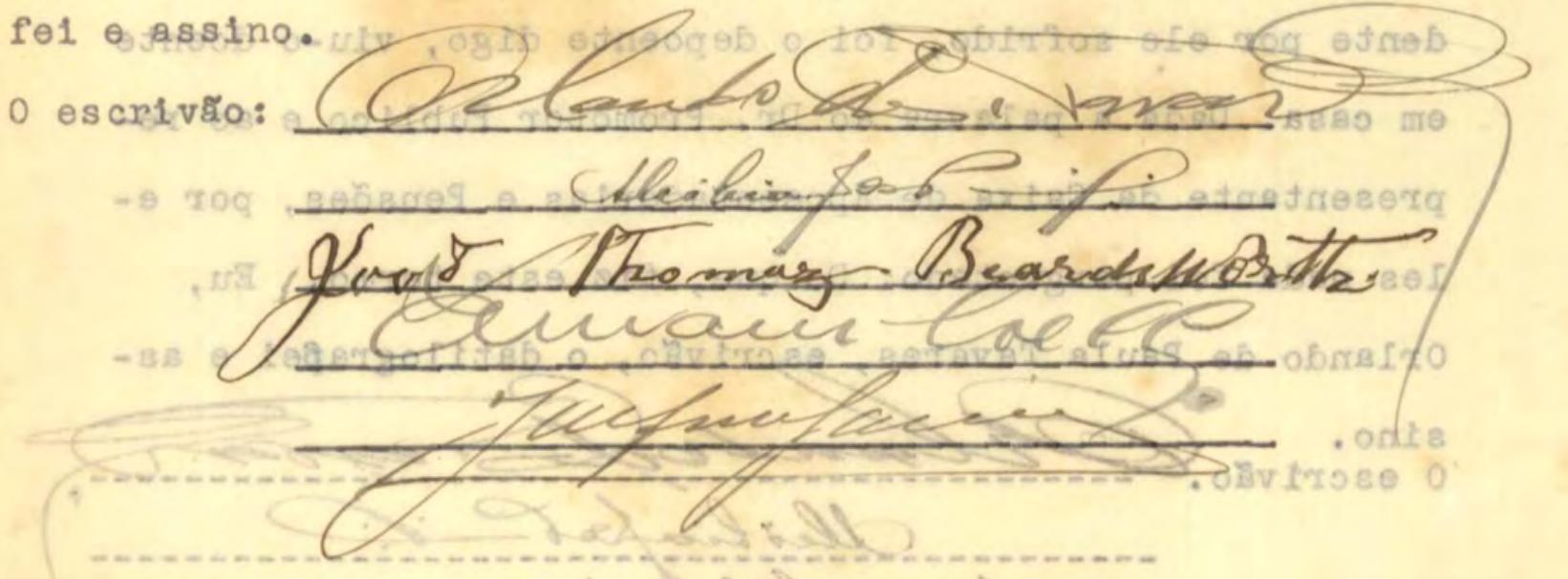

\section{CONCLUSAO}

FACOO ESTES AUTOS CONCLUSOS AO EXMO. SNR.

DR. JUIz Uivicya

S. JERONYMO, IF DE jWWho DE 19 I8

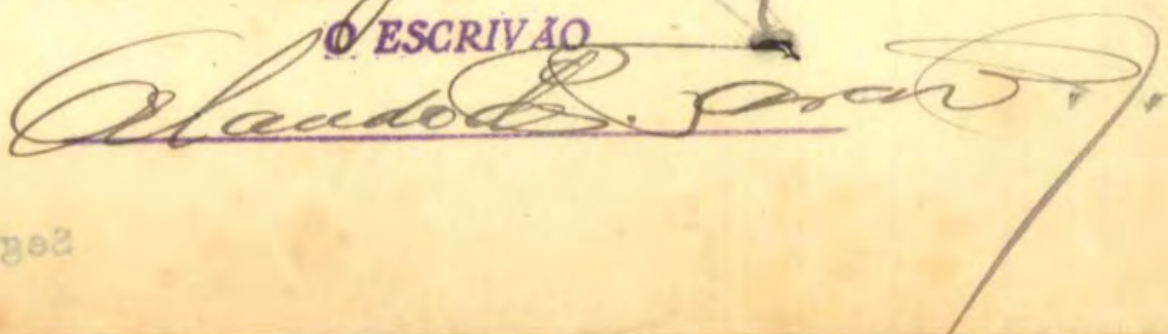




\section{RECEBIMENTO}

NA DATA 'ABAIXO RECEBI ESTES AUTOS

S. JERONYMO, $\angle Z$ DE Junho DE 1938

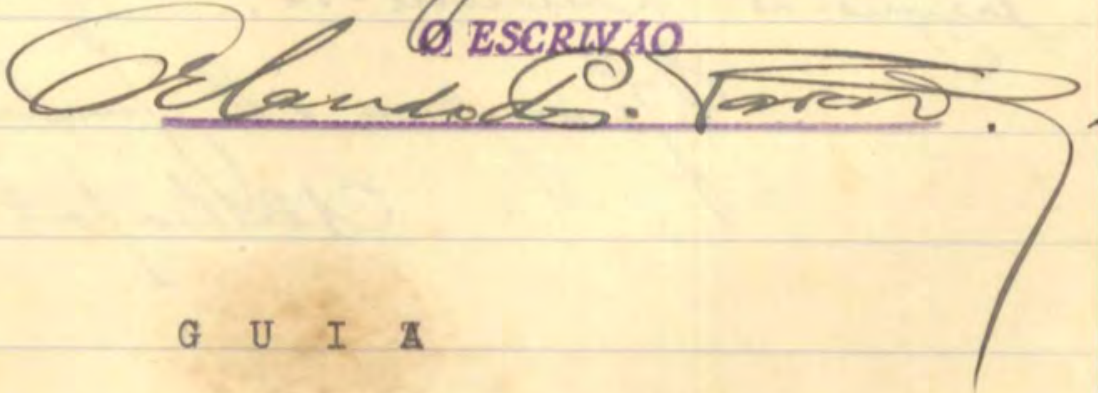

Pagam estes autos, o selo de quatro folhas com a seguinte, inclus1ve a autuação e de tres cert1dões.-

escr1vão:-
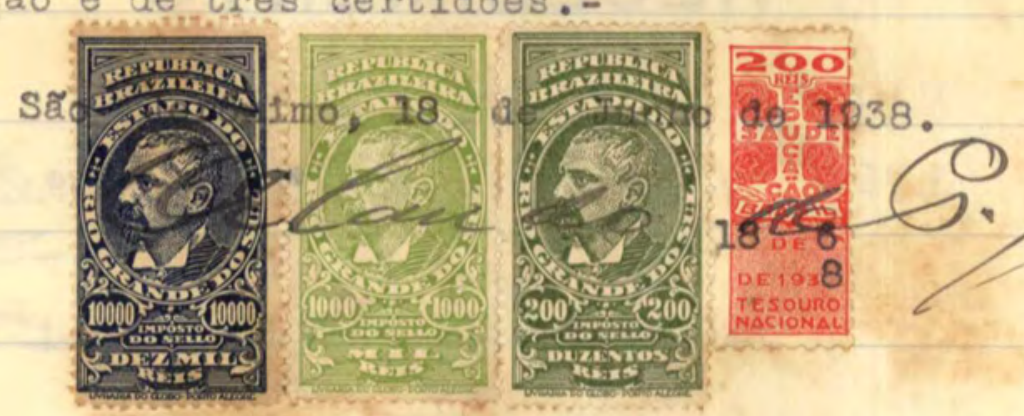

\section{CONCLUSẢO}

EACSO ESTES AUTOS CONCLUSOS AO EXMO. SNR.

DR.JUIR MUnvicipal

S. JERONYNAT, I DDE Junho $D E 1938$

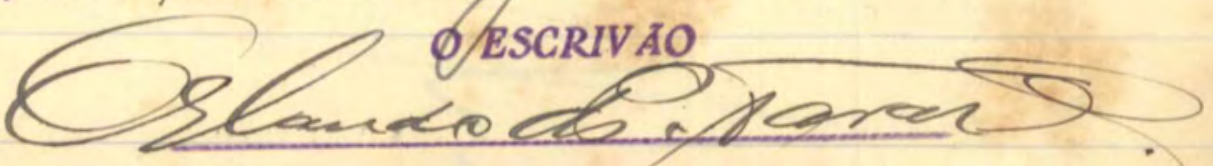




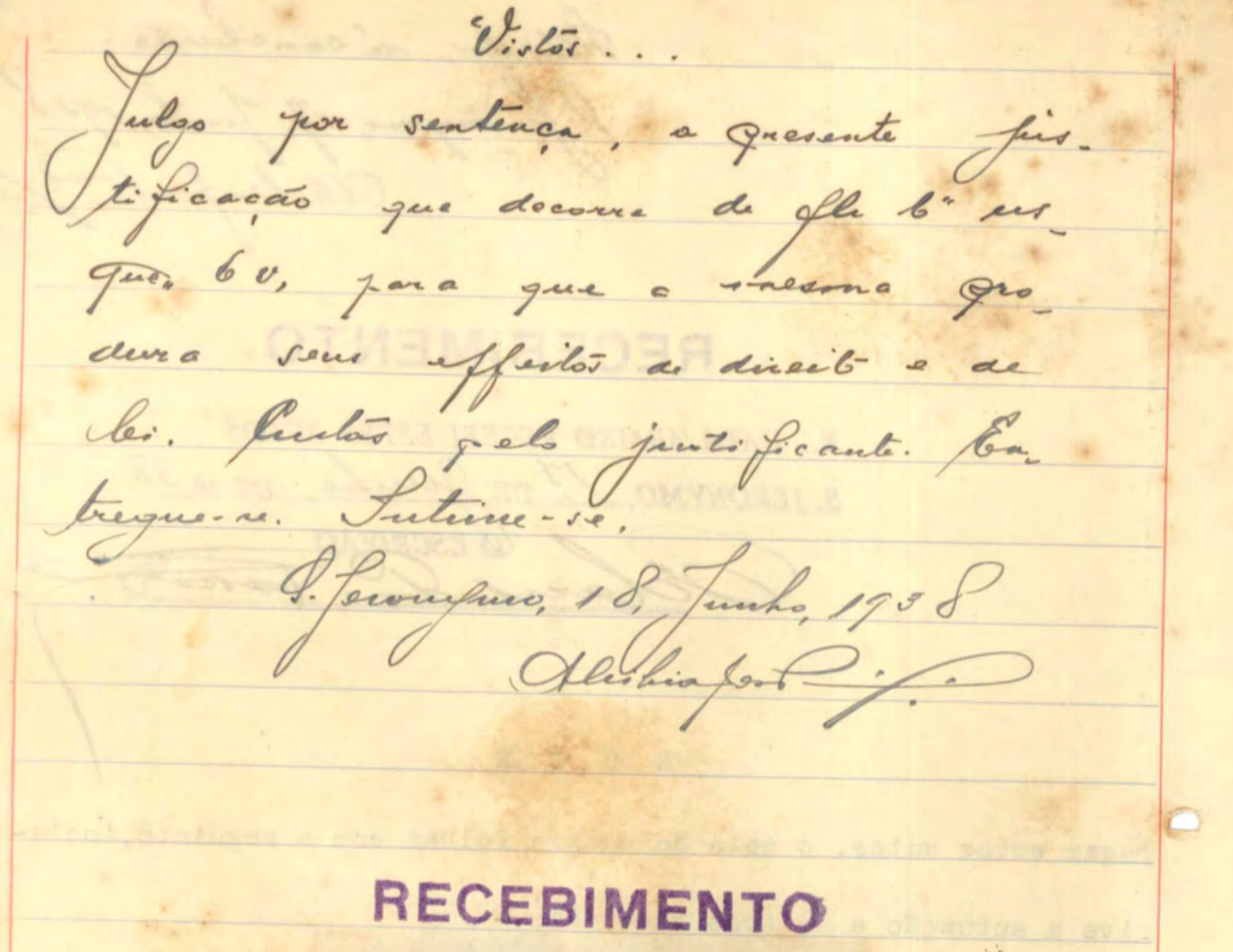

\section{NA DATA ABAIXO RECEBI ESTES AUTOS}

S. JERONYMO, 18 DE Jumho DE 1938

ENTRE G A

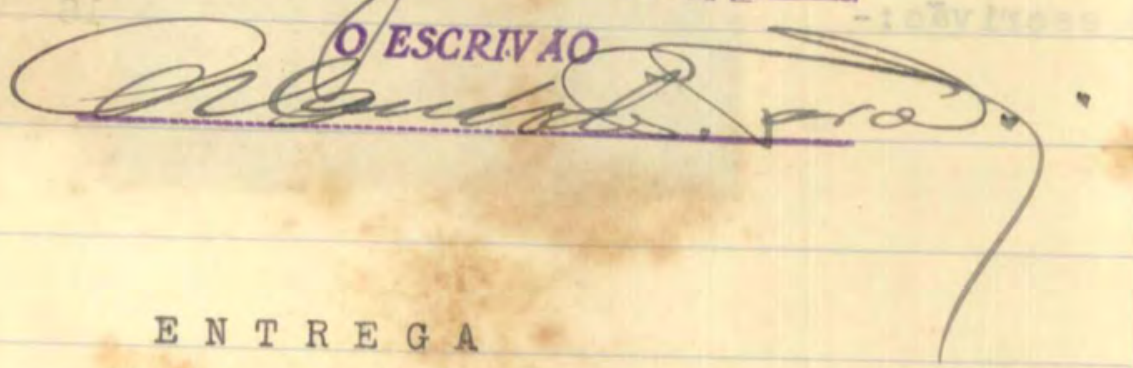

Aos dezo1to dias do mế de Junho de mil nóvecentos e trinta e o1 to, nesta cidade de São Jerônimo, em cartorio, fiz entrega destes autos, ao justificante,-dígo, ao requerente.-

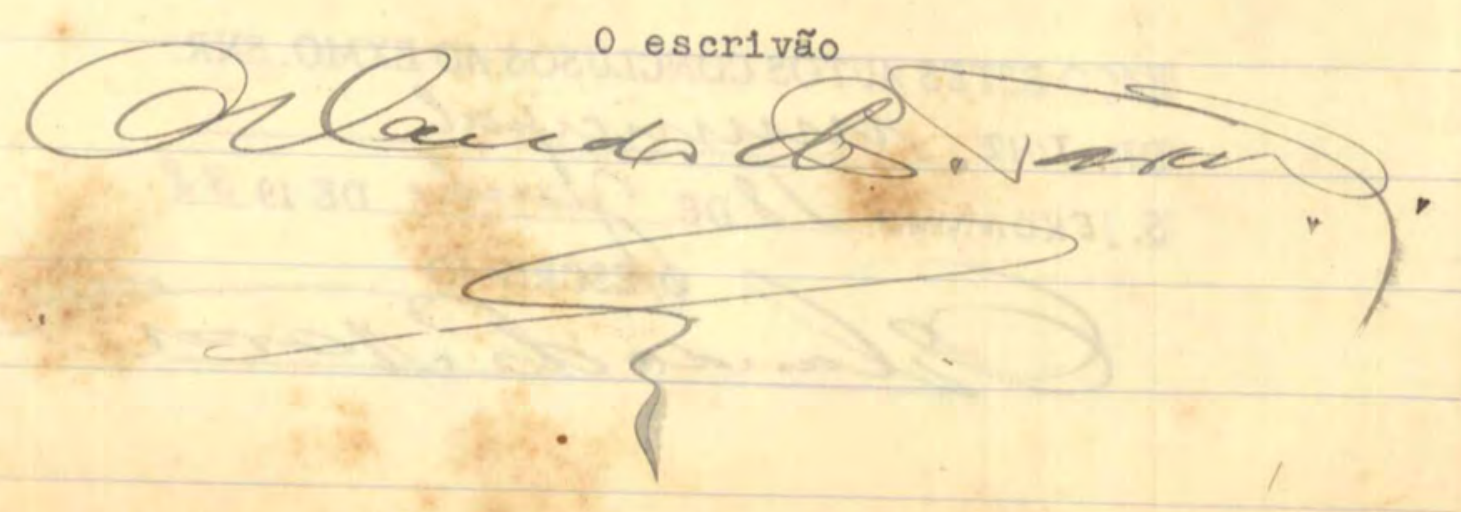


MINISTERIO DO TRABALHO, INDÚSTRIA E COMERCIO CONSELHO NACIONAL DO TRABALHO

Rec. em 5/7/938.

- INFORMACẼO

Procedida, nesta data, a 11s. 138 usque 150 destes autos, a juntada das duas just1ficações jud1c1a1s promov1das por Liberalino Machado de Lima e João Keenan para prova de tempo de serviço prestado à Companhia Estradas de Ferro e Minas de são Jeronimo, passo o presente processo ao sr. D1retor desta secção, propondo se ja o mesmo encaminhado novamente à consideração da douta procuradorıa Geral.

R10 de Jane1ro, 7 de Julho de 1938

Aaria Alcira M. dela Miranda of. Adm. - Classe "J".

A' Groundiria treval de acond com a cieforuacait surnaw bin 9 fullo do $198 \mathrm{~g}$ Meodero do Reurida todé.

Director dia L' Seopão

Procurador Geral

Pareser

C'. Pa Camana:

- Sirdicato dos Mímeiras e clases anescas do 
Mumicipic de Sac Aeromino emiva, par ren leastante pro. enradem. ( doe; de pobs 117); as firatipicacaies inaliciais pro. manidas par siberalíno machado de Sina e hoo Keteenan. Epls 118 "uzque" iso). Wuanto ao piriminimo, a deciraw dac c. 39 camaraía rándar de plos, 96 a99) que fir earr insprocedente a una reclamacae jón transitan en firlgíado, nae lhe asais tindo, eniderterirente, 0 direíto de pleiteor a sua reintegracie.

Unanto do requmale, a justipicaco apresentada wem cumperir é didigoncia elako. rada pela d.39 Camara. A reperiola jinstipicacer piredi. cíal pai pro-cedíála do acâr. do a sen aceita canvo do. amento probante do tem. No de rervicico do sumplicemte, pais a rua mancha pro. cesmal paí assistida pelas representantes $2 q$ C.F.P. das ermpregadas da Citrada de Ferro e thinas de Soid peromimo,e, da emprása redannada. 
NISTERIO DO TRABALHO, INDÚSTRIA E COMERCIO

CONSELHO NACIONAL DO TRABALHO

$(\pi)^{3}$

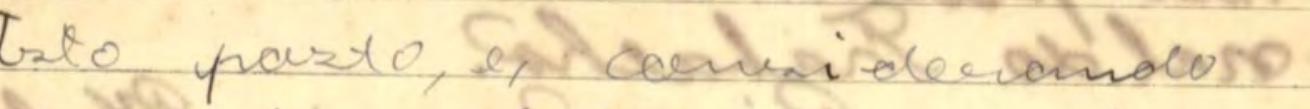

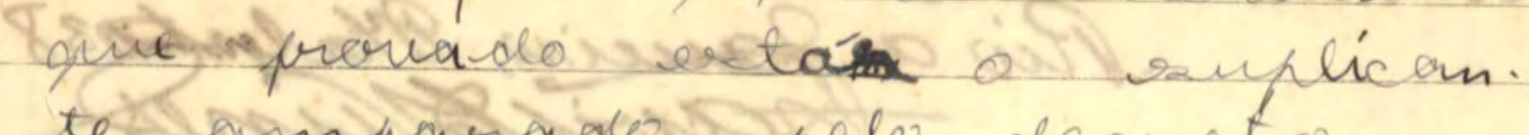
te ainparadio pele decueto nos 20 4 65, art 53 , de 19.31, e' procedente a reclamacas; tí cansideriando qué a pis. tipicacas apresertade ratis. paz a prelininar levantada pela C. ia camour;

apino, salvo methar püzo, pela protedentia da prerente re la nuaca.

aid, 16 de Aquret de 1938. Arnalotineshine.

Uuse. Or. na Deroe.

CONGTISÃO

17.8

Pesta data, fuca ..'; auís c nelusos no Oxma. Om. Cinden'.

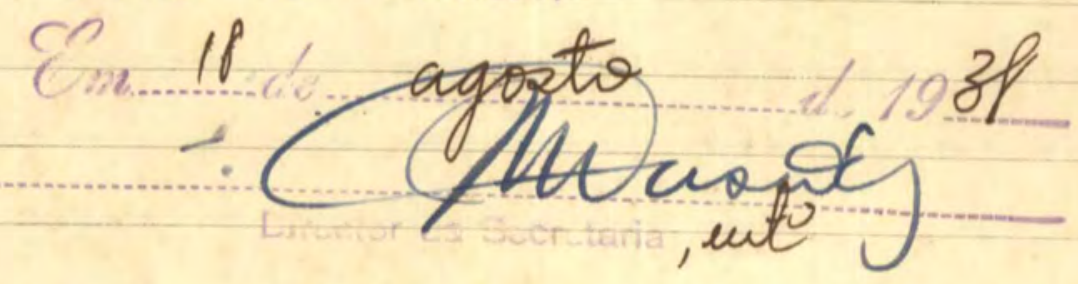

Reatididen $80 / 8 / 38$

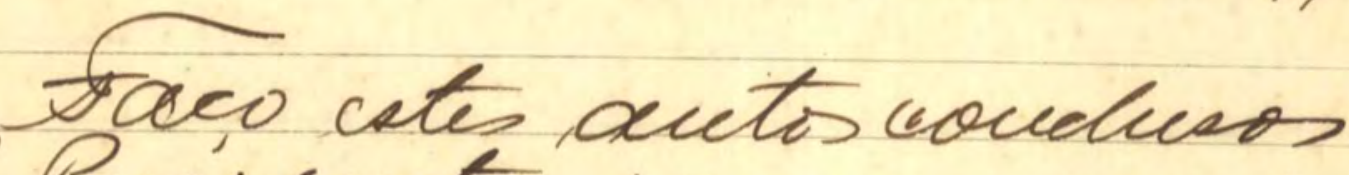
arf. Pusidut, para sur periar determinar a vulta dos messus - a' nono sorteris de celator wisti catar

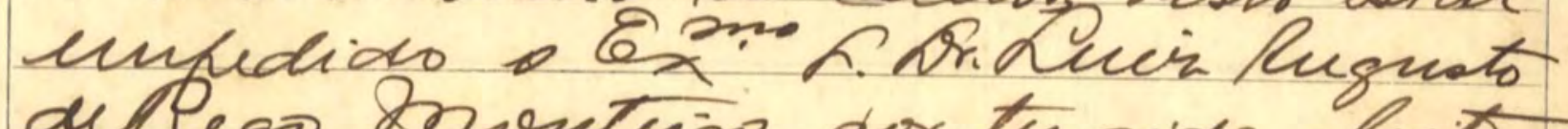
delego frvetuin, for turido eleito 
vice-freszdute -do E. Courechs baciot nal do Sighacho?

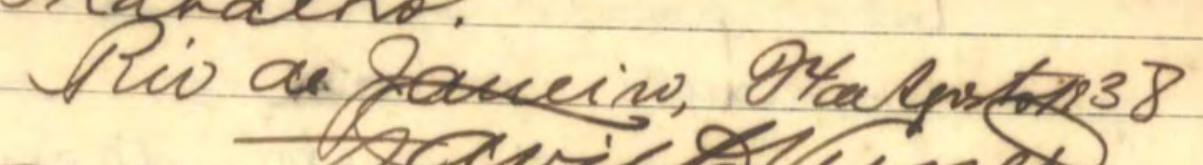

Lee. de 3.Carinana.

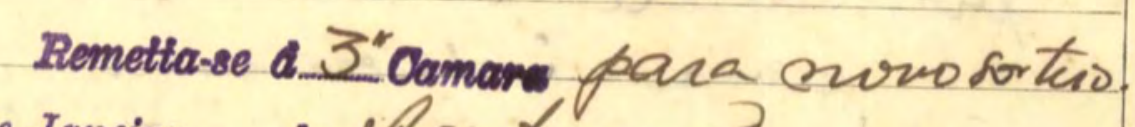

Rro de Janeiro, de Upers 198 -8

prrationary da 3 Fancara.

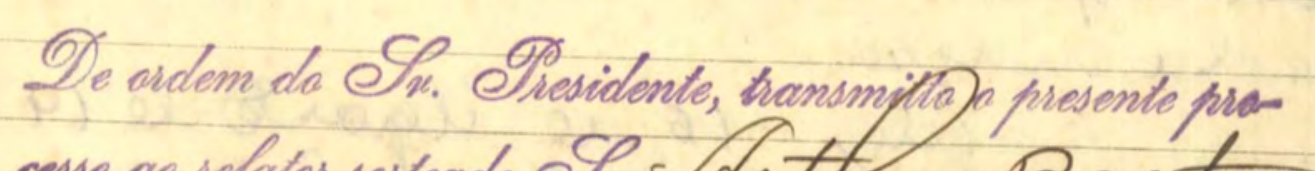

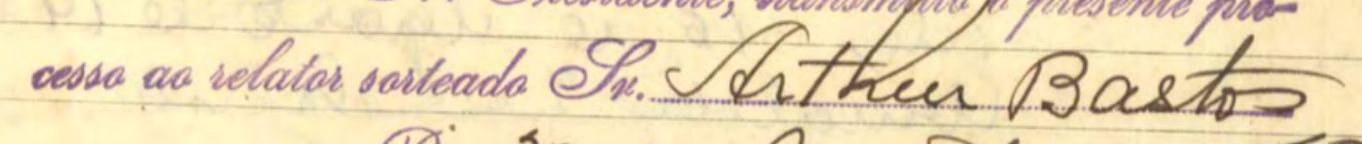

Qrie, so de Ngost te19 58

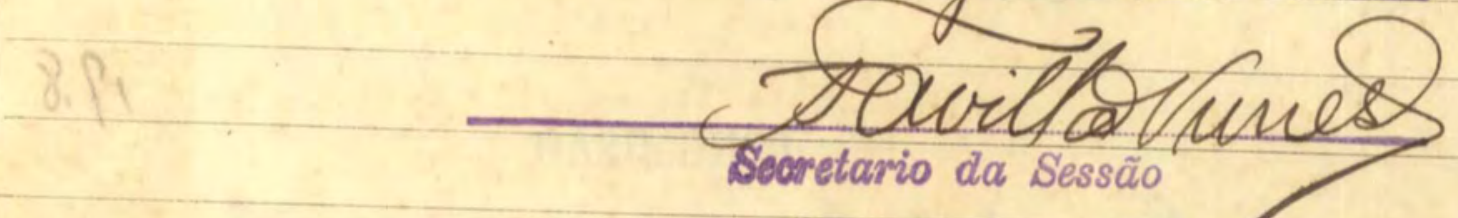


CONSELHO NACIONAL DO TRABALHO

(.......SECÇĀO)

V

N. $958 \mathrm{z}$

193.4

Ponningas Ubantiestha e oution, recluman

contra beri to. F e Memia a L ferouins

Arthur Basts

DATA DA DISTRIBUIÇÃO

$30 / 8 / 38$

DATA DA SESSAO

$e^{2}$

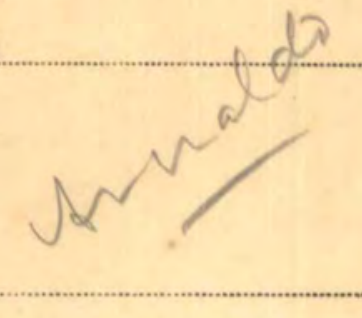

RESULTADO DO JULGAMENTO

helopon as frocidente a rid de

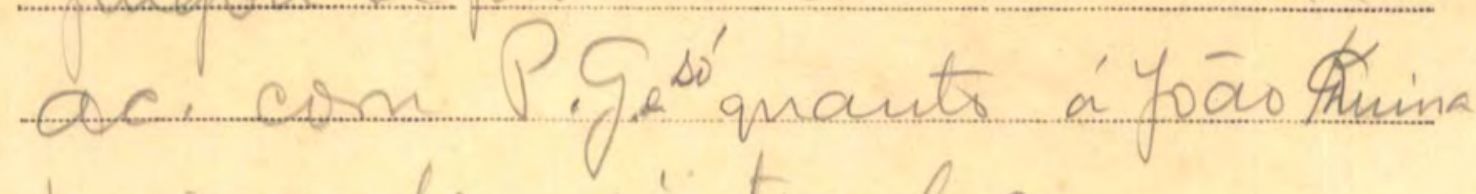
pare mandar reiritignal-o 
Secọăo

\section{CONSELHO NACIONAL DO TRABALHO}

ACORDÃO

\section{8}

VISTOS E RETATADOS os autos do presente processo referente á reclamação oferecida por Domingos Mantilha e outros contra a Companhia Estrada de Ferro e Minas de São Jeronímo:

Em virtude de terem sıdo dispensados do serviço, sem Justa causa, reclamaram perante este Conselho contra aquela Estrada os ferroviários Domingos Nantilha, Liberalino Machado de Lima, João Keenan, Raphael Mezza, Thomaz Gonçalves, Antonio Nunes das Pedras e Adalberto Azambuja dos Santos.

Feitas as necessarias provas do direito de estabilidade, e provado não terem respondido a inquerito, por falta grave, foram determinadas as reintegrações, com as van tagens lega1s, dos reclamantes Domingos Mantilha (Acórdão de 25 de Abril de 1.935), Thomaz Gonçalves e Rafael Mezza ( Acớdão de 2 de Junho de 1.936), e convertido o julgamento em diligenc1a, ouanto a parte de João Keenan, para que fizesse prova de contar mais de 10 anos de serviço. Quanto aos empregados Adalberto Azambuja dos Santos, Antonio Nunes das Pedras e Liberalino Machado de Lima fol julgado improcedente o ped1do de relntegração por falta de estabilidade funcional.

Segundo esclarece o oficio de fls. 105, da recla mada, os três primeiros funcionarios já foram reintegrados e indenizados, outrossim, dos salarios não percebidos durante o periodo em que estiveram afastados do serviço 1legalmente. 
Processo: $9.582 / 34$.

Resta, pols examinar, á vista da justificação judicılal ora oferecida por João Keenan, si a este está assegurado o direito de estabilidade funcional.

A Procuradoria Geral, em seu parecer, acentúa. que o documento em foco está regular e prova em favôr do suplicante (fls. 118/150).

Nessas condições, provado que João Keenan está amparado pelo art ${ }^{\circ} 53$ do Dec. 20.465, de 1.931;

Resolve a Terceira Câmara do Conselho Nacional do Trabalho julgar procedente a reclamação, para o fim de determinar a reintegração do referido ferroviário, com as vantagens legals decorrentes.

R1o de Jane1ro, 6 de Setembro de 1.938.

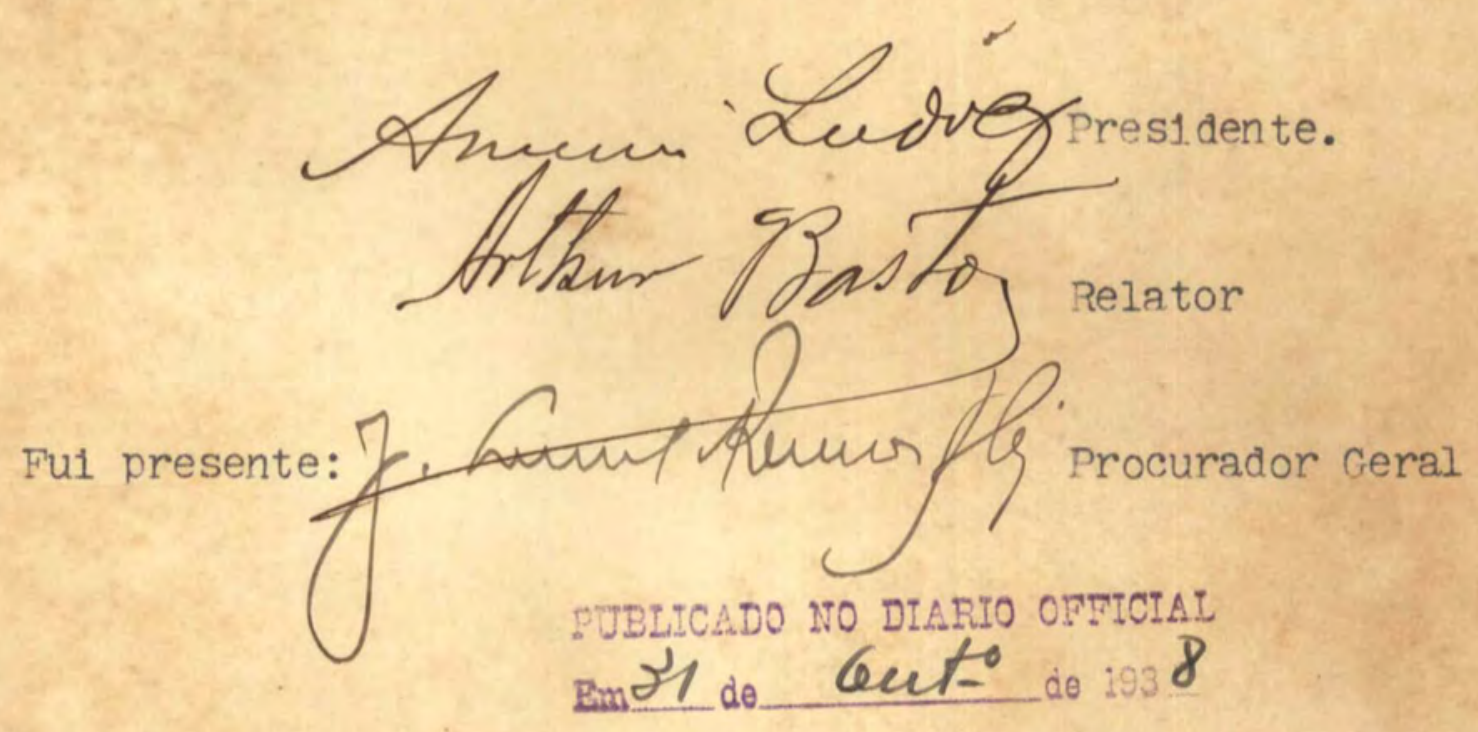


MP.

$1-2.176 / 38-9,582 / 34$
3 de Dezembro de 1938.

Sr. D1retor da Companhia Estrada de Ferro e Minas de S. Jeronimo.

Rua Paissandú, $219-2^{\circ}$ Andar.

Porto Alegre - Rilo G. do Sul.

Transmito-vos, para os devidos fins, copia autent1ca đo acórđão profer1đo pe 1a Terceira Camara do Conselno Nac1onal do Tra balho, em sessão real1zada a 6 de Setembro do corrente ano, nos autos do processo referente a reclamação formulada por Dom1ngos Mantilha contra essa Companhia.

Atenciosas Saudações

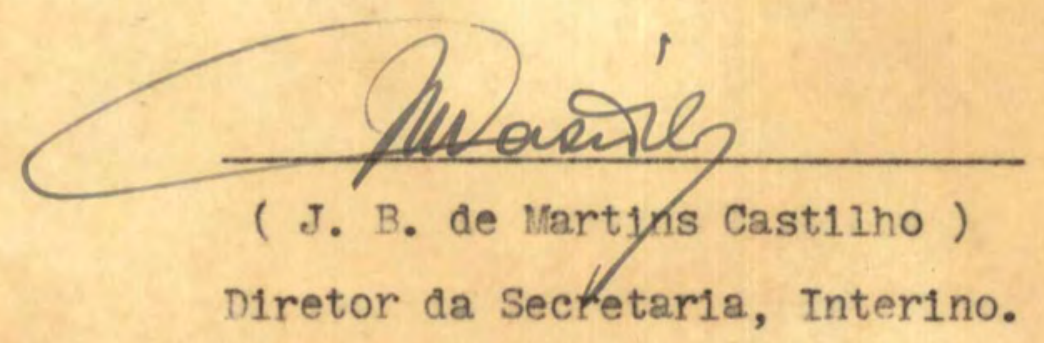


$\mathrm{MA} / \mathrm{MP}$.

$1-75 / 39-9.582 / 34$.
12 de Janeiro de 1.939.

Sr. Domingos Mantilha

A/C do Sindicíto dos Mineiros e Classes Anexas $5^{\circ}$ Distrito do Munic1p1o de S. Jeronimo.

R10 Grande do Sul

Levo ao vosso conhecimento, para os fins necessarios, que a Terceira Camara do Conselho Nac1onal do Trabalho, apreciando a reclamação que formulastes contra a Companhia Estrada de Ferro e Minas de São Jeronimo, em sessão real1zada a 6 de Setembro do corrente ano, resolveu pelas razões consubstanciadas no acórdão publ1cado no "D1ar1o oric1al" de 31 de outubro p. passado, julgar procedente a aludida reclamação, para o $\mathrm{flm}$ de deter m1nar a vossa reintegração nos serviços com as van tagens lega1s.

Atenciosas Saudações

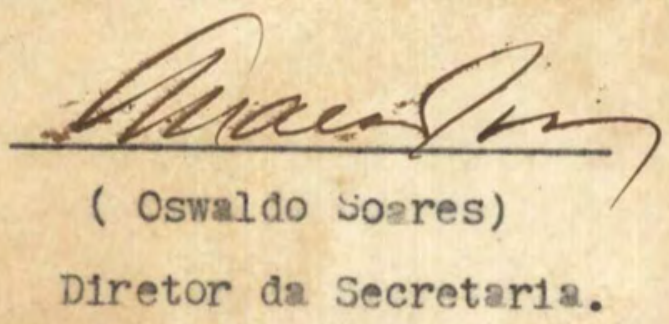


untada Nesta data, junto. ars prescerte, autos o documm. to aifes. 58, frotocelado sol. o n $5 / 1939 . \quad 1=5$ Seccéád, 18 aey ancion 1939

Aavilfrimis 
IIImo. Sr. Dr. J. B. de Vartine Castilho

D.D. Director Interino da Secretaria do

Conselho Nacional do Trabalho

RIO DE JANEIRO

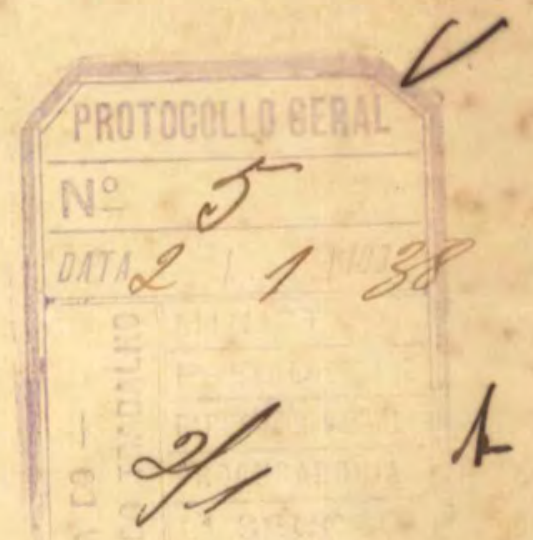

Accusamos o recebimento de vosso officio de 3 do corrente, sob ne 1-2.176/38-9,588//34, transmittindo-nos copia autentica đo accordão proferido pela Terceira Camara do Egregio Conselho Nacional do Trabalho, em sessão de 6 de setembro do anno em curso, que đetermina a reintegração đo operario João Keenan nos serviços da Companhia Estrada de Ferro e Minas de São Jeronymo, e, em resposta, cumpre-nos Informar que o operario em apreço, conforme certicão de obIto que mnexamos, falleceu em 14 de Janelro deste anno.

Valema-nos da opportunidade para reiterar-vos os protestos đa nossa elevada consideração e apreço, subscrevenđo-nos,

Attenciosamente.

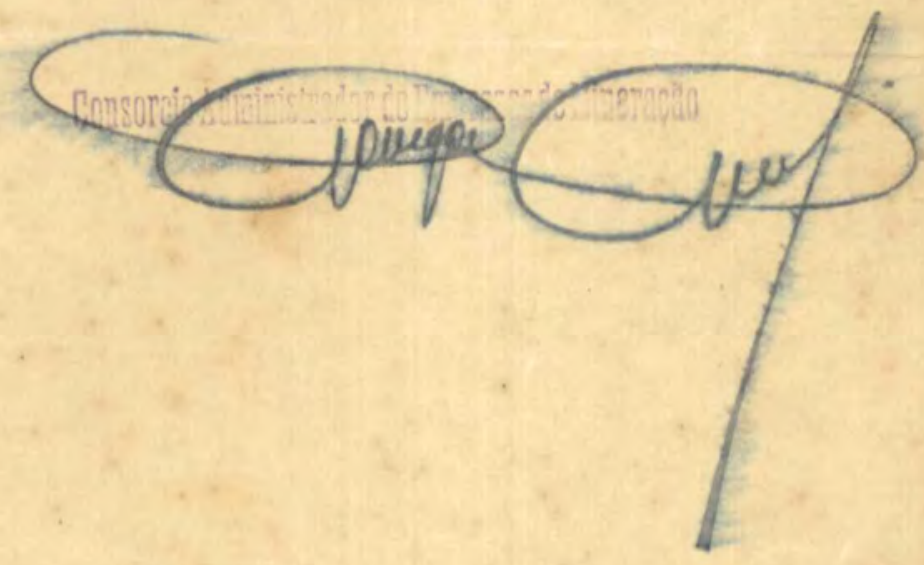




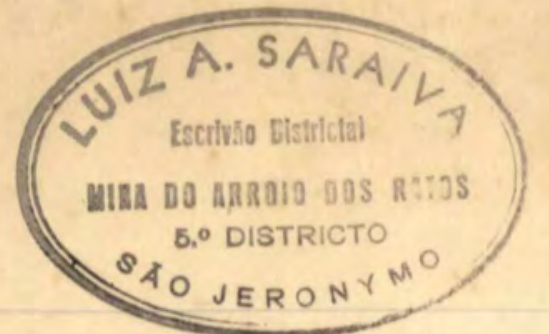

IUIZ ANDRADE SARAIVA, Escrivão do Registro Civil do quinto distrito do menicipio de São Jeronimo, Es tado do Rio Grande do Sul, etc.

\section{CERTIDÃO DE OBITO.}

Certifico, no uso das atribuig̃ões que me confere a lei, e por me ser verbalmente pedido, que revendo em weu cartorio o livro numero trez de registro de obitos, nelle á folhas 109, encontra-se o termo de obito do Snr. João Keenan, falecido em domicilio neste quinto distrito, no dia quatorze (14) de Janeiro de mil novecentos e trinta e oito (1938) as 4, 30 horas, to sexo mascolino, de côr branca, de profissão mineiro, natural deste Bstado, residente neste quinto distrito, com sessenta e quatro annos de idade, viuvo, filho legitimo de Patricio Keenan e de D. Margarida Davis, ja falecidos, sendo o atestado de obito firmado pelo Dr. Carlos Corrêa Rodri ues, que deu como causa da morte, Cancer gastro-durdenal.- o sepultamento foi feito no cemiterio deste distrito. Foi declarante Thomaz Keenan.- O referido é verdade e dou fe.

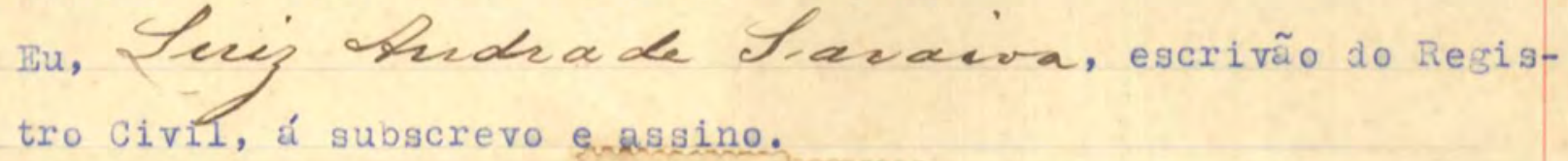

52 distrito de são Jeronimosi 24 de Dezembro de 1938.

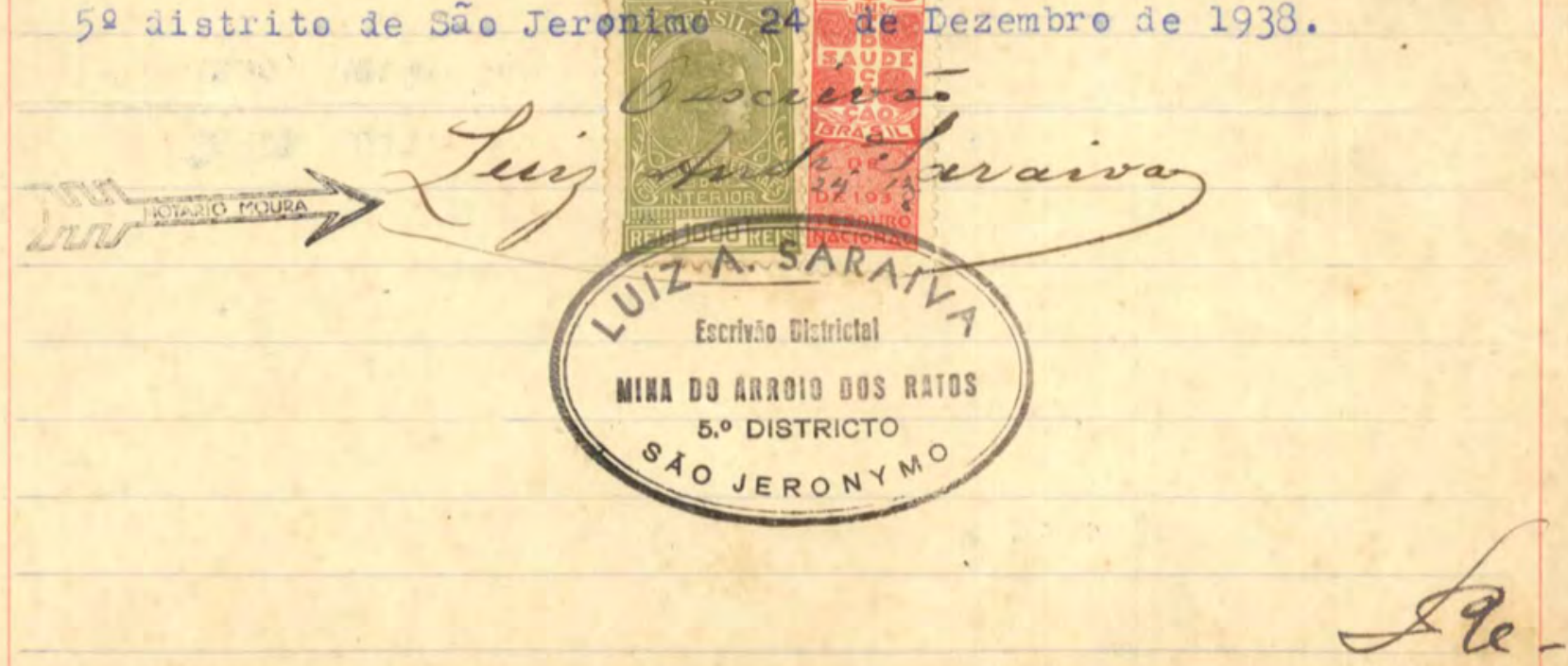




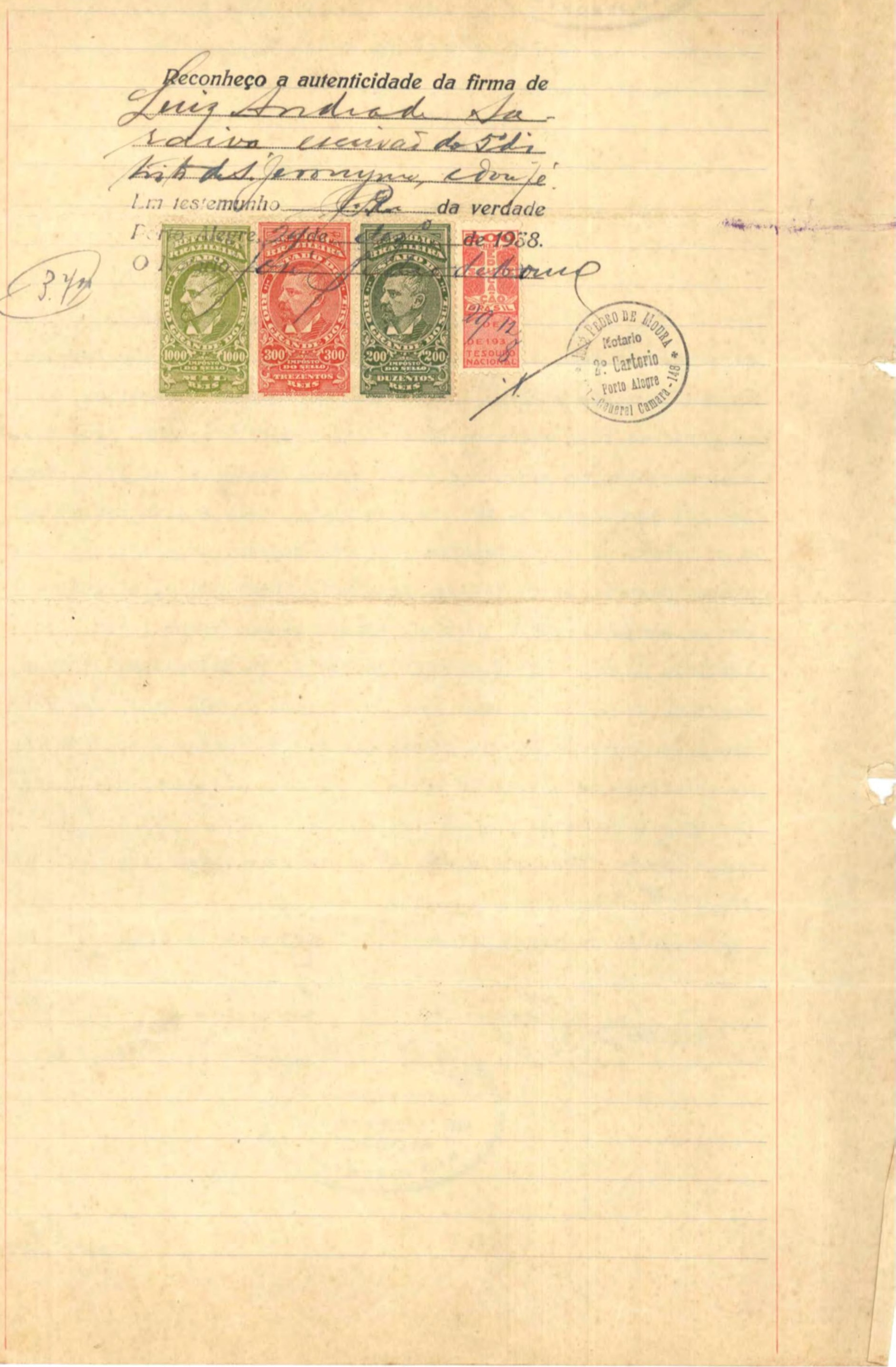


MINISTERIO DO TRABALHO, INDÚSTRIA E COMERCIO

CONSELHO NACIONAL DO TRABALHO

Prechidohofe.

(2)

$10 e^{62}$

- Sm ferctor da Cómpantia Estra. da de terros hinas de Sa feronimo. eur resposta an oficio, 1-2/76, desta Secntaria, tramponitindo eopia auten. trea deo acórdào mofonda pela Ter. clira Gamara do Consecho hacional do Ralacho, eur sessao de 6 ar Setemho. do correute digp, dei1938, iiforma jim. tando atestado de elito que o eqeranio Coào Xeenan pa lecer ecu 14 de fane: no de 1938.

lestas condicẽón qaco su Dir os presutes autos ácousiderarav supenior

li Seccão, 18 de lonunadins tevifolungs

Para os devidios fins, submeto epte prócesso á cons1deração do $\mathrm{Snr}$. Diretor Gera1.

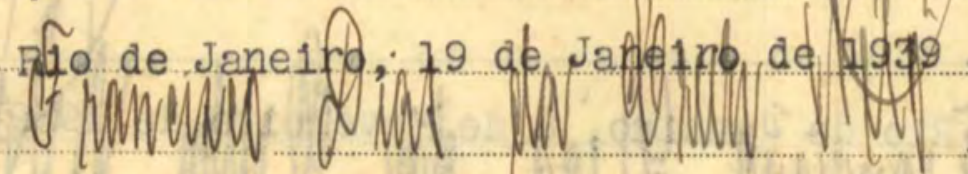

s. c. Diretor da 1a. Secção

YISTO-Ao Sur. Dr. Pr curraior Geral,

de ordem no Exritu. Ser. Fresidente.

Em 23 javeir de 10,39

Dire Neimeiso 
tho th Al Yivsteind

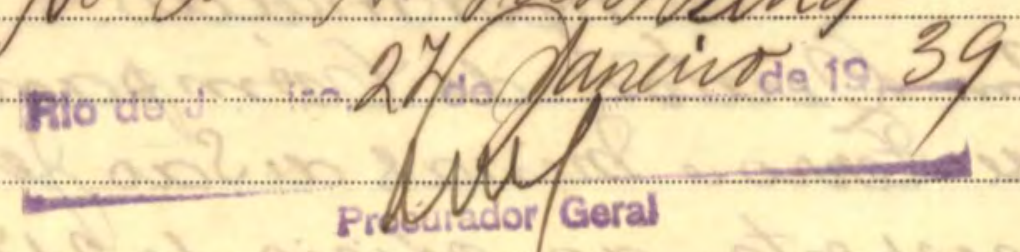

Cequeiro gure a Caíra informe si o Sr. nood zeman deizcan hordéveras:

Rio $27-1-39$

Armal a rivelaina

Assirt 6. da proe

4' 1" Seccís para Lageno ex. pebiente refuerido!

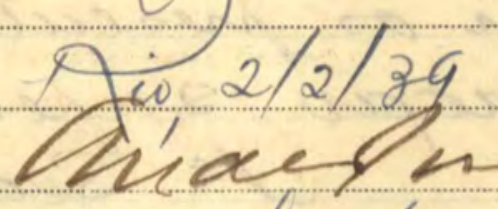

Rocobldo na 1:" Secçảo em $F=$ It-3/

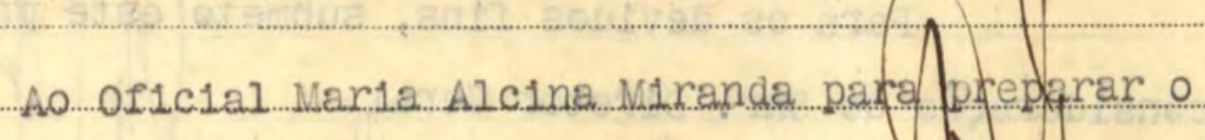
expediente.

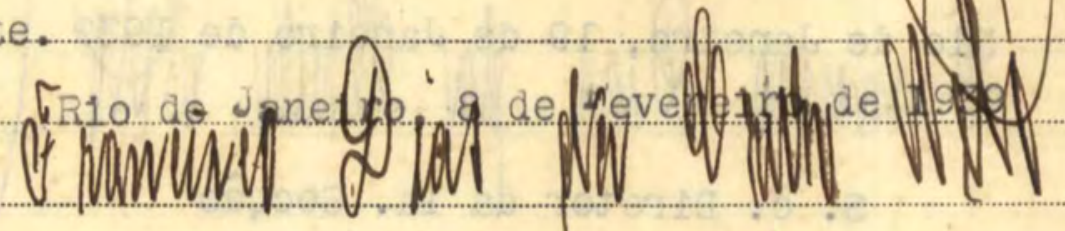

s. c. Diretor da la. Secção

Cunvbiido $\operatorname{San} 282 / 939$

Waria Oleina Mi dela Kurianda Q. Odim-Classe min:

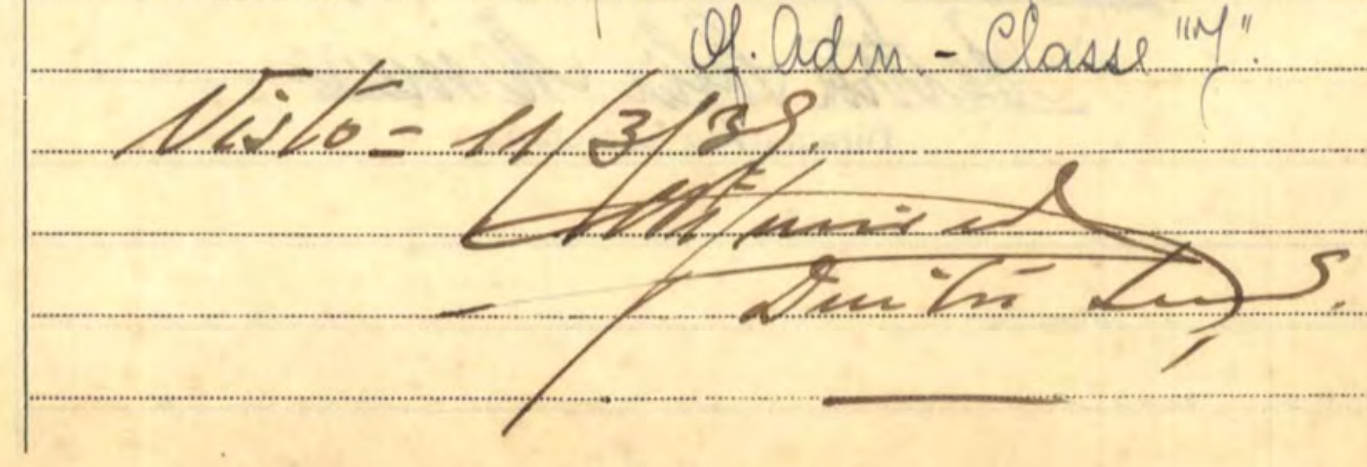


MA/MP.

Sr. Presidente da Ca1xa đe Aposentađoria e Pensões de Serviços de Mineração é porto Alegre. Rua S1cueira Campos - Ediflc1o do Banco Nacional. Porto Alegre - R10 G. do Sul.

En v1sta do processo em cue Domingos Mant1Iha e outros reclamam contra a Companh1a Estrada de Ferro minas đe Sâo Jeron1mo, solic1to-vos, đe acôrdo com o rerue mo pela Procurađorla Geral đêste Conselho, proviđenc1as no sent1do de ser 1nformado a esta secretar1a, dentro do prazo de 15 dias, s1 o func1onár1o João Keenan de1xou her de1ros.

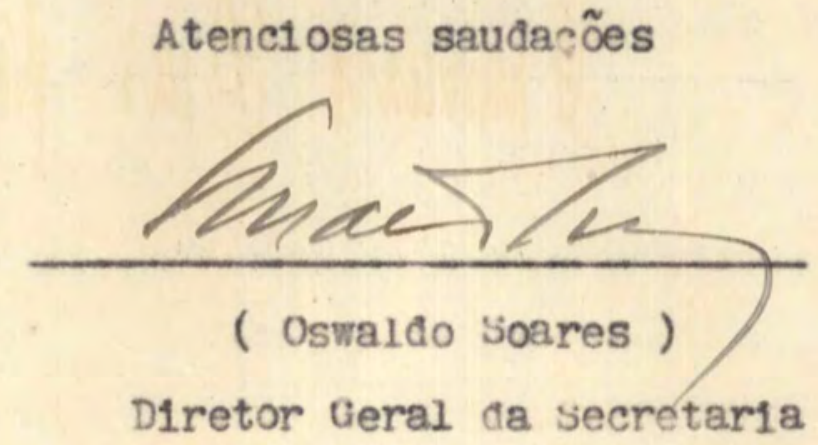




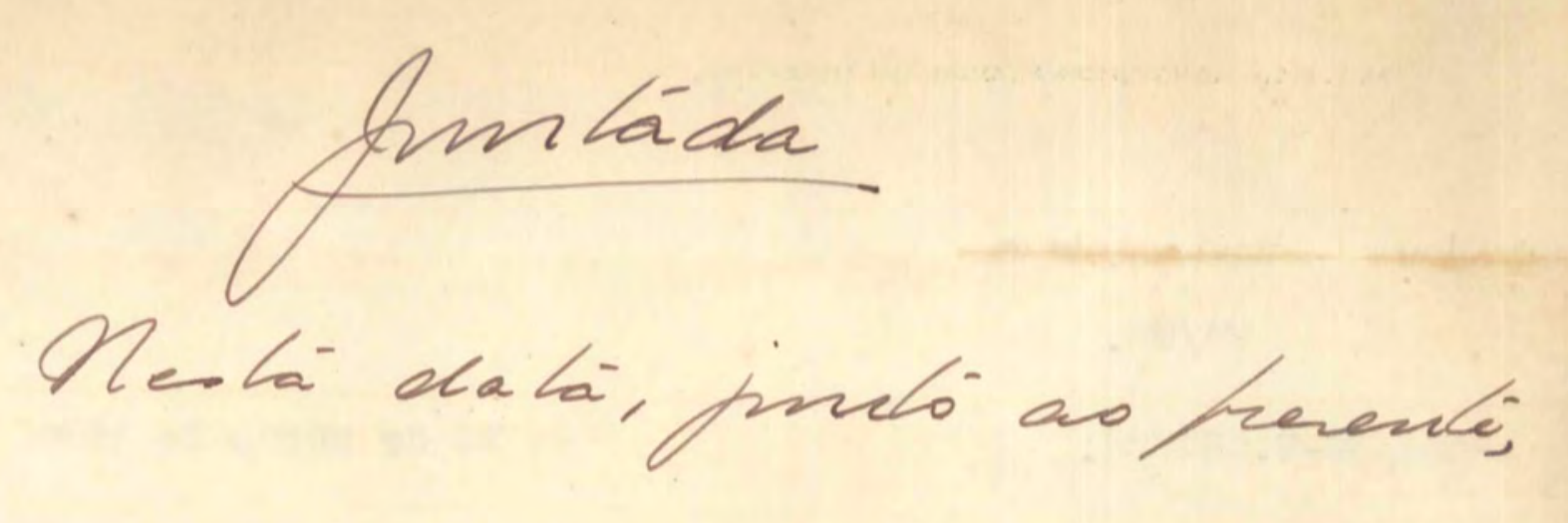

- dramento hotocollado ne

$$
\begin{aligned}
& =2.719 .39 \\
& 1 \div \text { Recén., } 29.3 .939
\end{aligned}
$$

buiburáa da but

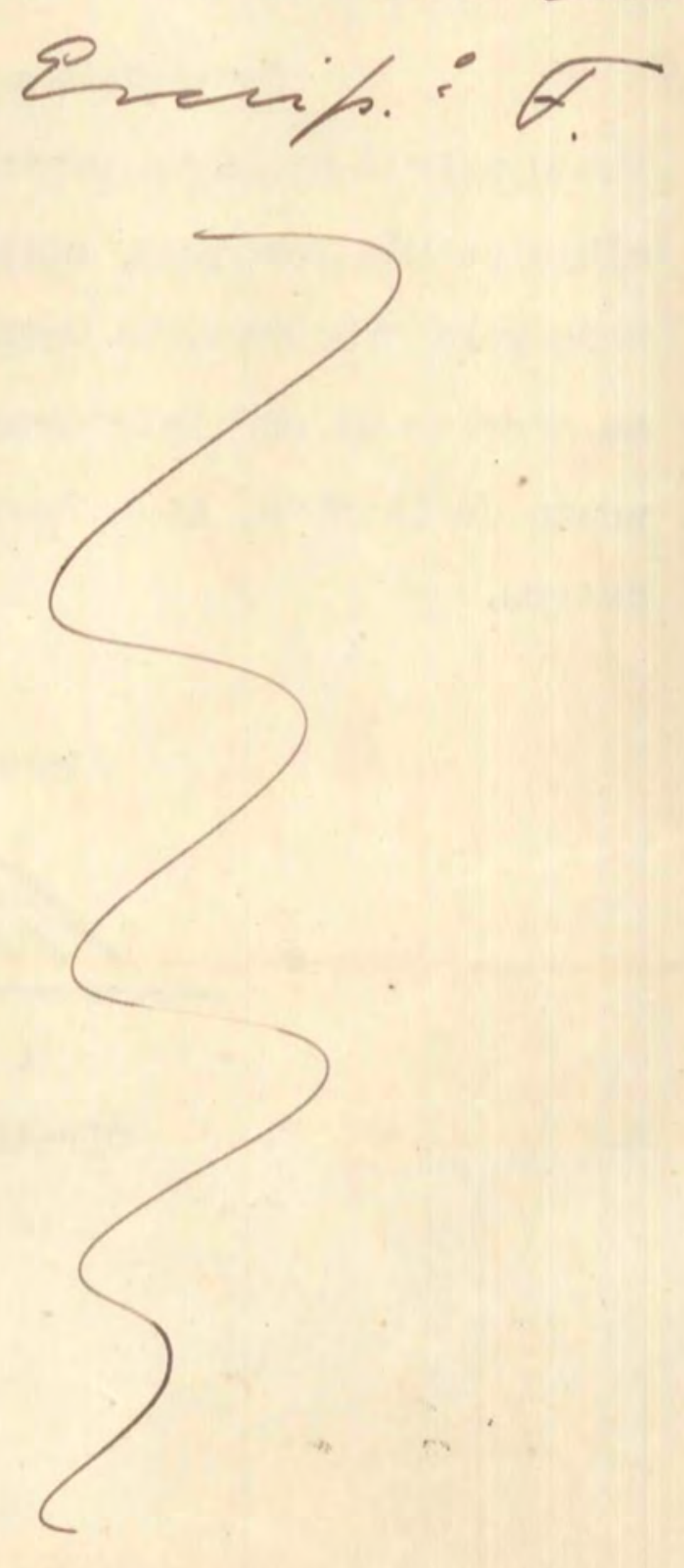



MINISTÉRIO DO TRABALHO, INDÚSTRIA E COMERCIO CONSELHO NACIONAL DO TRABALHO

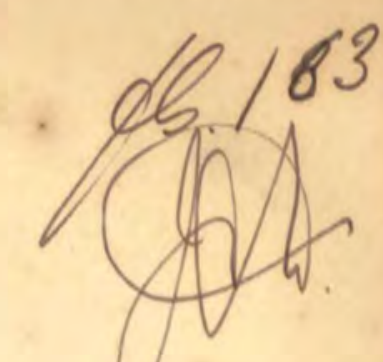

O Iyndicatio des Mincien e thas Mnnetas, a ecura o reet frimenti a officio n=1-75.39, - com refluercia as menos. dectara oue o velamankDomingo Mantilara já fri revirtigado e recelher a tirden. nipaleao enreshondentians drias im que estur afastado. In pace do etpuplojent.

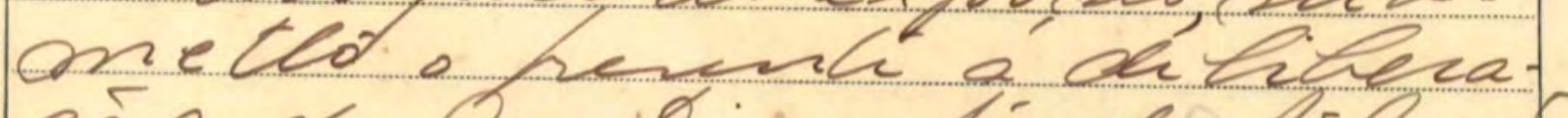
cais di h. Oiveotí de léreates, ropom do nepala siandada a

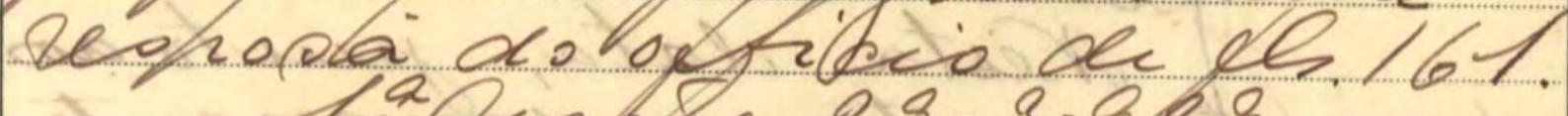
ta Decar, 29.8.989
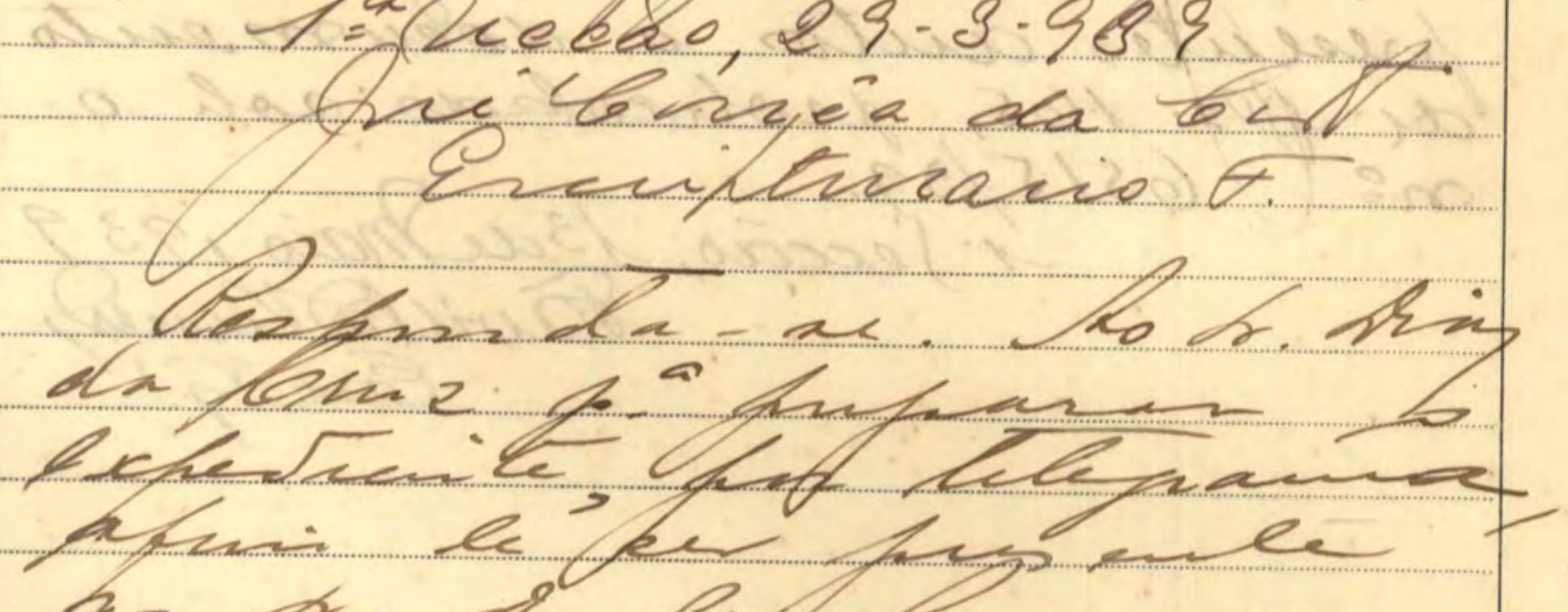
as $x$.
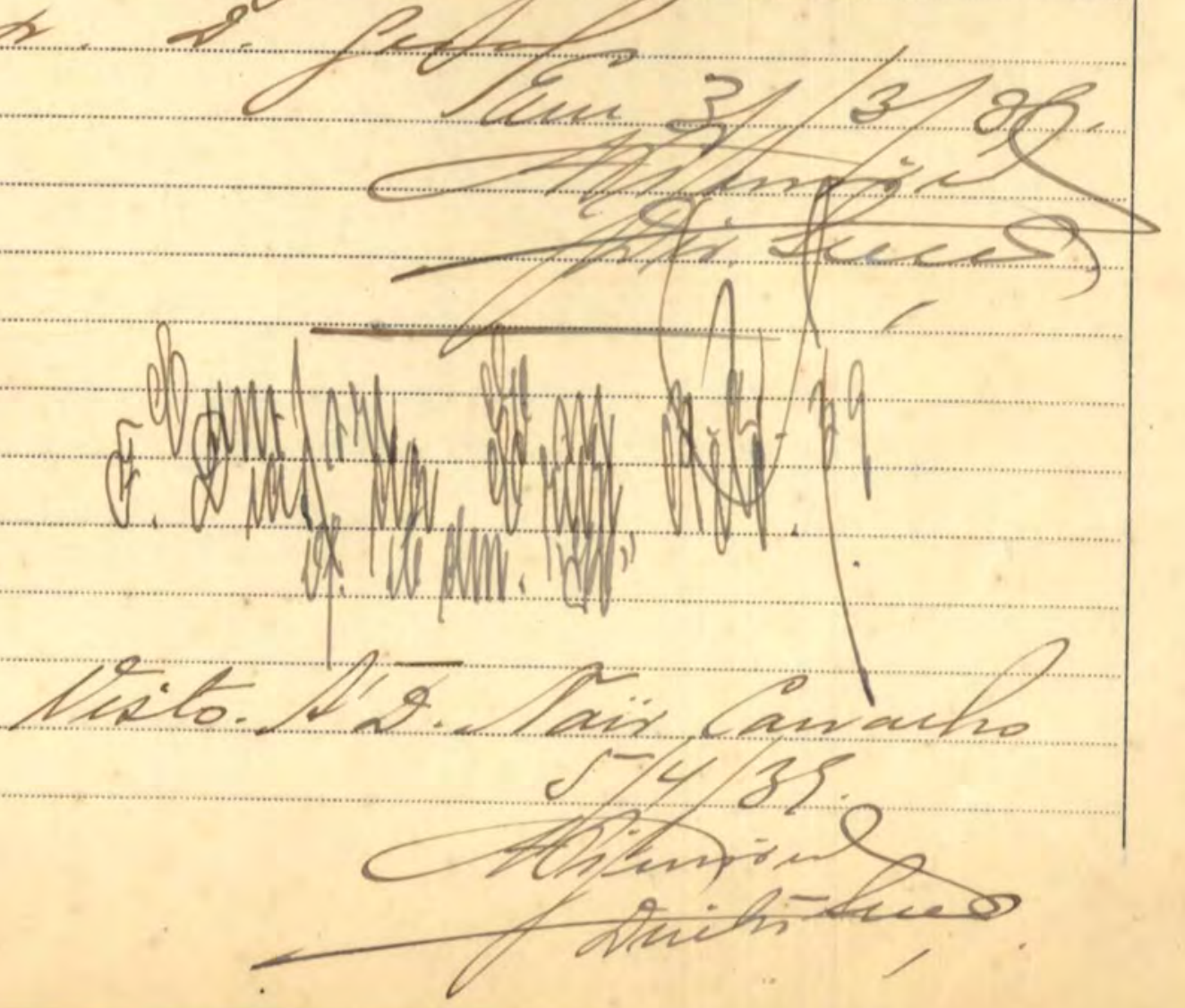


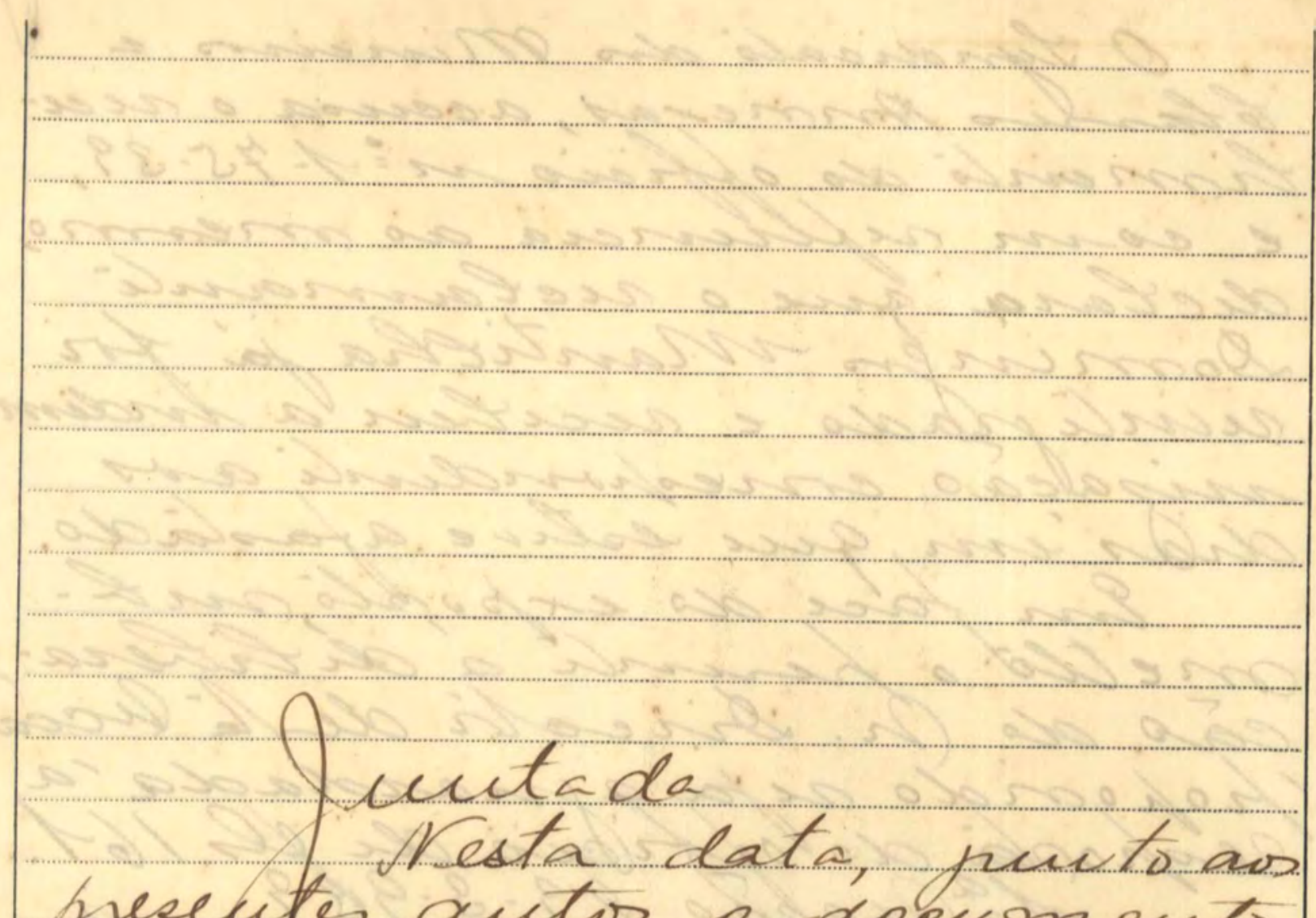
presuftes autos o désermento ar pe). 165, prolocolian sol o $n=6575 / 39$.

1. Seccão, 13de haís, 939 Aovildvans, ese $z$ 
MINISTERIO DO TRABAL D, INOÚSTRIA E COMERCIO CONSELHO NACIONAL DO TRABALHO

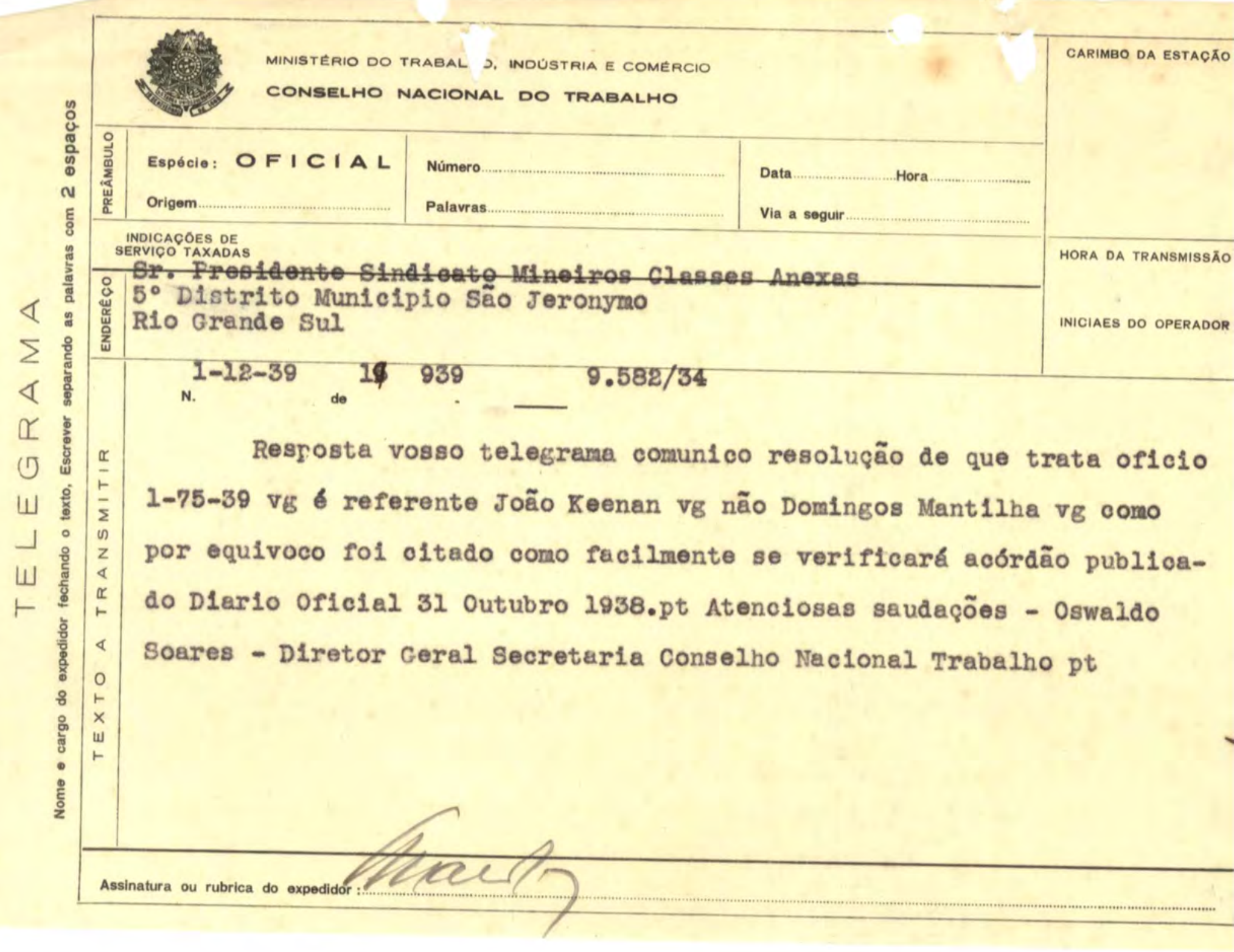


Caixa de Aposentadoria e Pensōes de Serviços de Mineração, em Porto Alegre PORTO ALEGRE

off. no?/260

IR/WPE
Porto Alegre, 10 de Abril de 1939.

Illmo Sr. Dr. Oswaldo Soares

DD. Diretor Geral da Secretarta do

CONSELHO NACIONAL DO TRABALHO

Rio de Janeiro.

Temos o praser de acusar o recebimento do ofício no 1-434/39-9.582/34, de 20 do mês pp., tendo dado antrada nesta Caixa á 4 do corrente, em que nos solicitais informar se o associado JOAO KEENAN deixou herdeiros.

Examinando os arquivos desta Caixa, nada encontramos com referência a êsse ex-associado, nem mesmo com relação a seus herdeiros, pois não se acha inscrito, razão pela qual deixamos de prestar outras informações que por ventura possa V.Sa. necessitar.

Com as expressões de elevada consideração e alto apreço, apresentamos a V.Sa.

Atenciosas Saudações.

CAIXA DE APOSENTABORIA EPENSỎES DE azavicos DE MINBEACIO, EM DORTO ALEORE

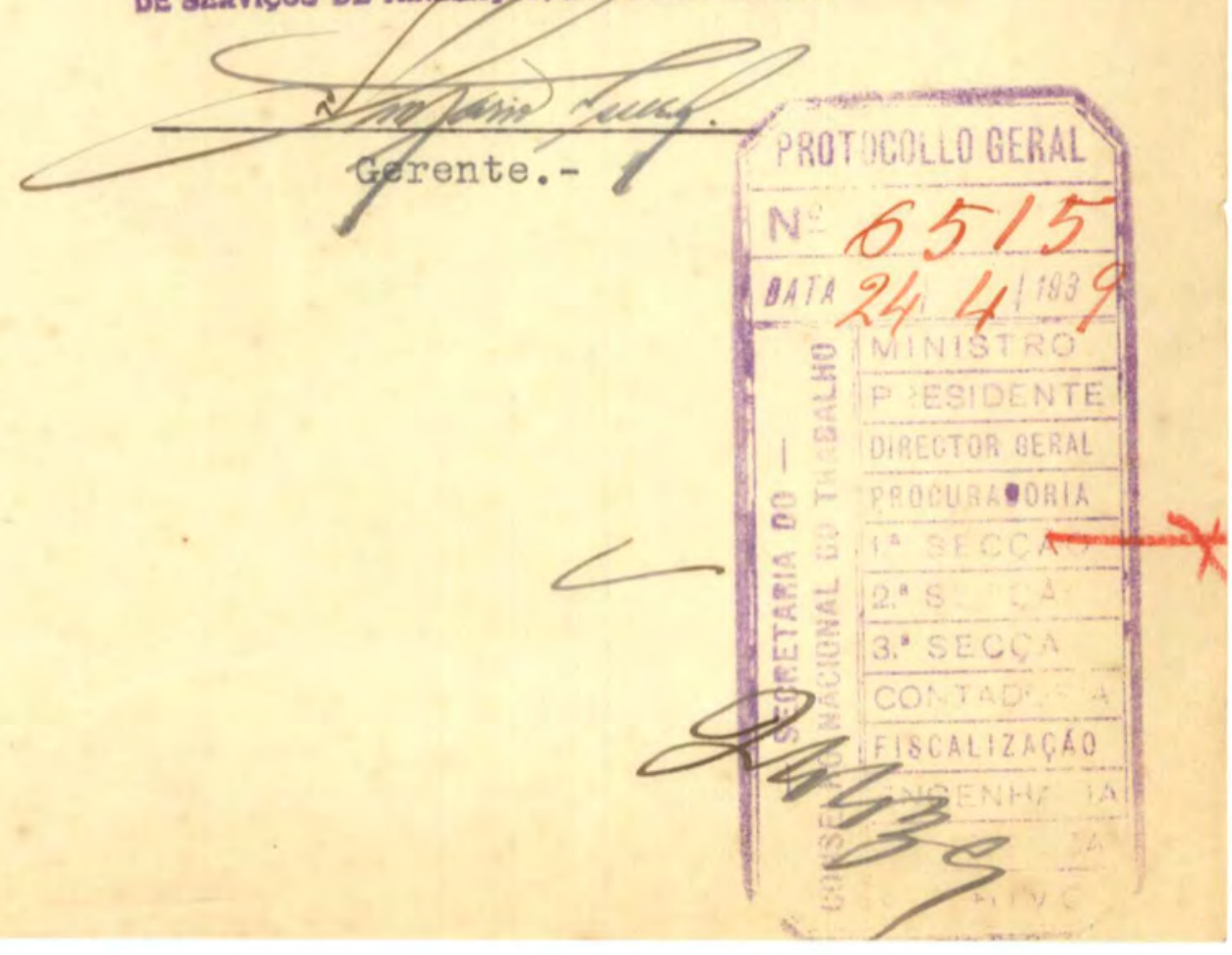


Recelido Roje if

ISTERIO DO TRABALHO, INDÚSTRIA E COMERCIO

CONSELHO NACIONAL DO TRABALHO

Orformaçã.

d Eavis a an posente dovia - Qeusoer der Serwidos de mineracão eun Gorto. Aleque, eu ceofvoita

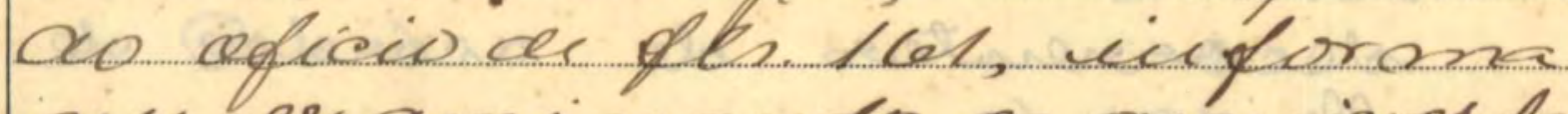
sier examinacudo os arguivos da Gouisa, mada eccoutrou comie. frencuciá a hercerinor defoñokeeman uño estaudo o mesmo visscrito.

Nestar condicioe, salinfeita a promosáo de pes. loo resso gacosu. his o preseute puncesso a'sutónda de superior, proponato o netornodo mesmo a Oouts Ro anzeric pial. x. Seceãd, 13armais arts's teviladenes

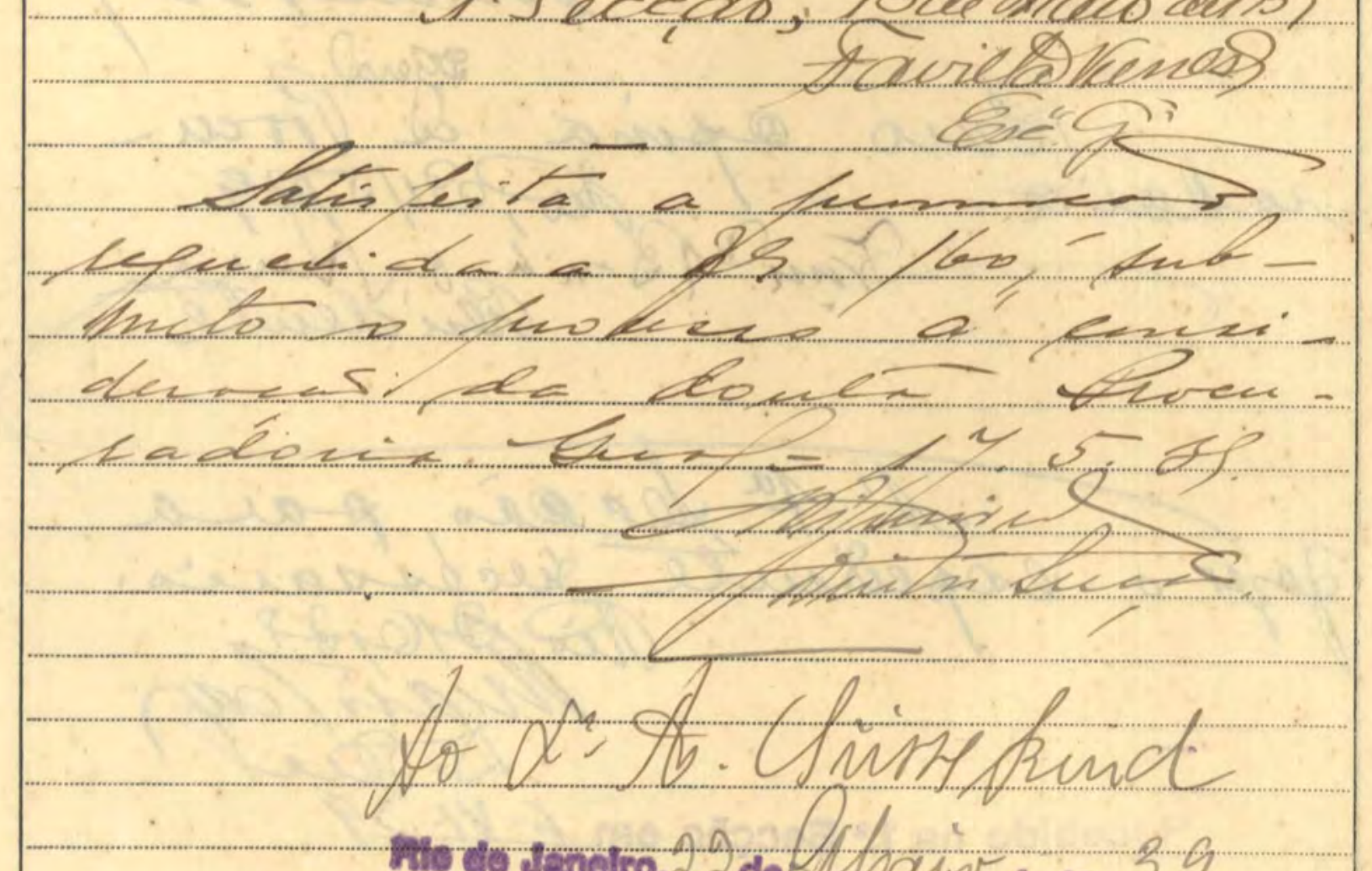

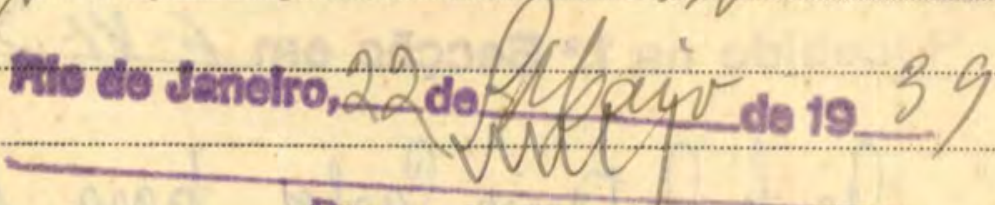

Pequévero que a Caisca fromóna a pulili- 
cacar de "ditais" corvocan. do des herdeveras do "de cujus "v a se Mahilistarem à pens sad e aas viencimentas decarrentas do acárda de fles 15415 .

Qve $23-5-39$ Cruat 2

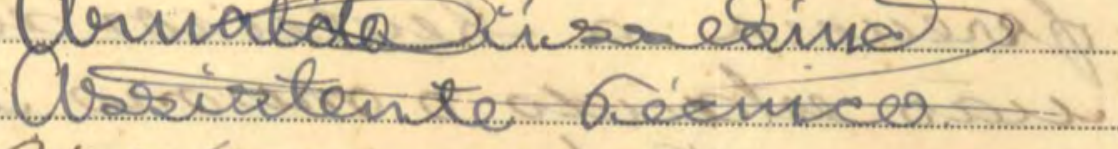

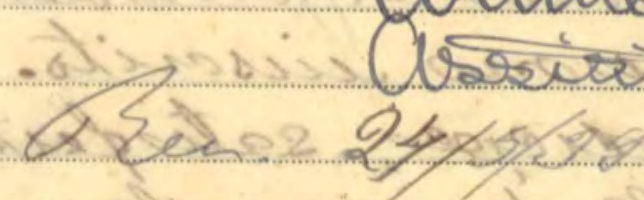

Latis Consuderacá dafs hesidente.

Q.

Piom $25 \cdot v \cdot 985$

ono oxina a prial ralaria. F ap $0,091 / 57^{2} 9$ residente

A' ja Lecoì par a

jojer expeciente diecésvario. D. Eerl

secebido na 1: secçäo ern $6-k-39$

Oo \&. Autoni Carlos para preparar expe. diente. Riv, 13 de Hunho de 1939

Maria Alemina hy delá CMvianda Of Adm. "Yy, no inip do Piretor de seccaí. 
.
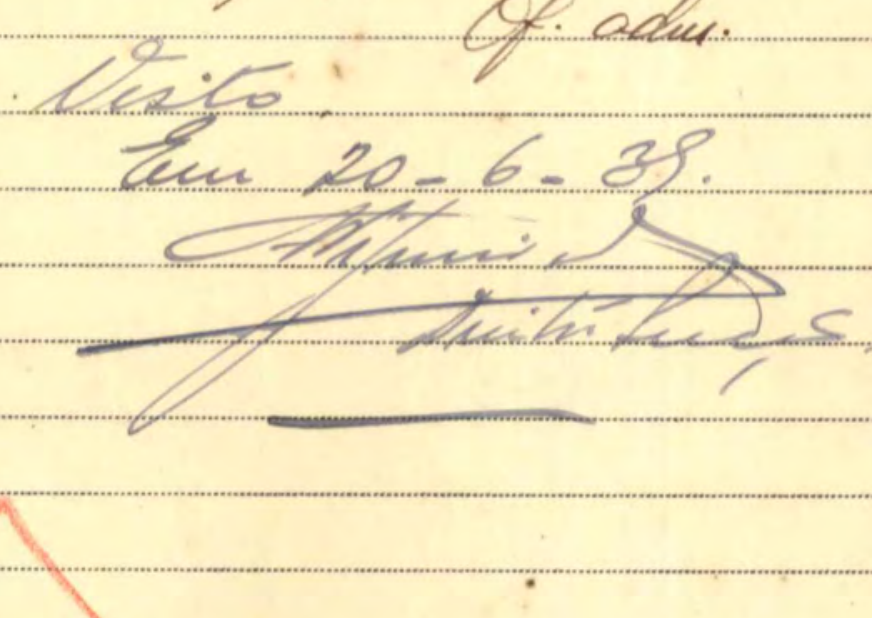
NSC

$$
1-1.248 / 39-9.582 / 34
$$

22 de Junho de 1939

Snr. Gerente da Caixa ae Aposentador1a

e Pensões de Serviços de Mineração

en Porto Alegre - RIO GRANDE DO SUL

De ordem dó Snr. Presidente e na fórna da promoçño de Procurador1a Geral deste Conselho, no processo en que João Keenan reclame contrs \&. Estrade de Ferro e M1nas de São Jeronymo, sollc1 to providencias no sent1do de serem publicados Ed1ta1s convocando os nerdelros do de cujus a se habilltarem a pensz̃o e aos vencimentos decorrentes do acórdão da Tercelra canara deste Conselho, de 6 de Setembro de 1938, publ1cado no "D1árlo of1c1al" de 31 de Outubro do referido ano.

Atenc1osas saudações

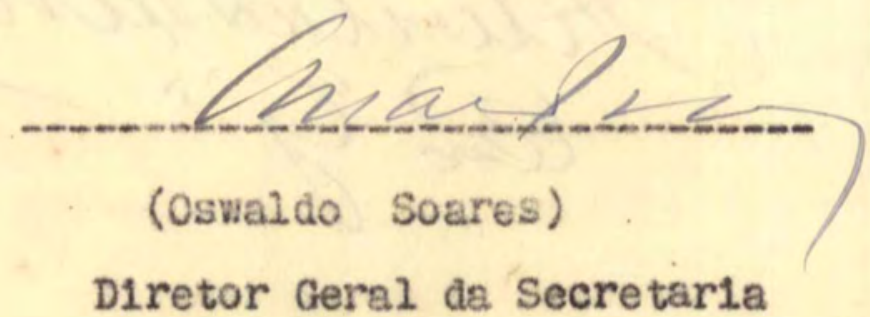




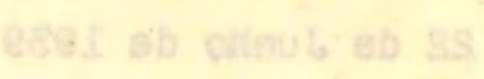

Astace. e-eolans. it-1

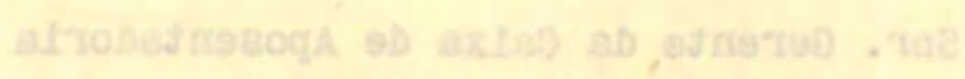

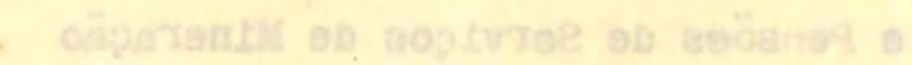

Cuntada

vesta cata, pucto aros

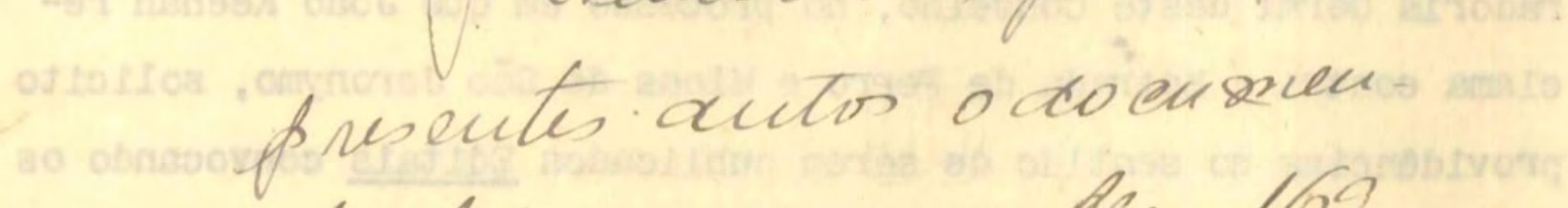

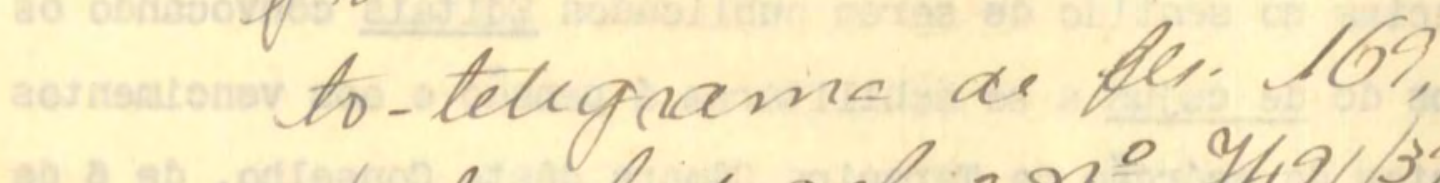
- a dutucolado vol o no 74913 .

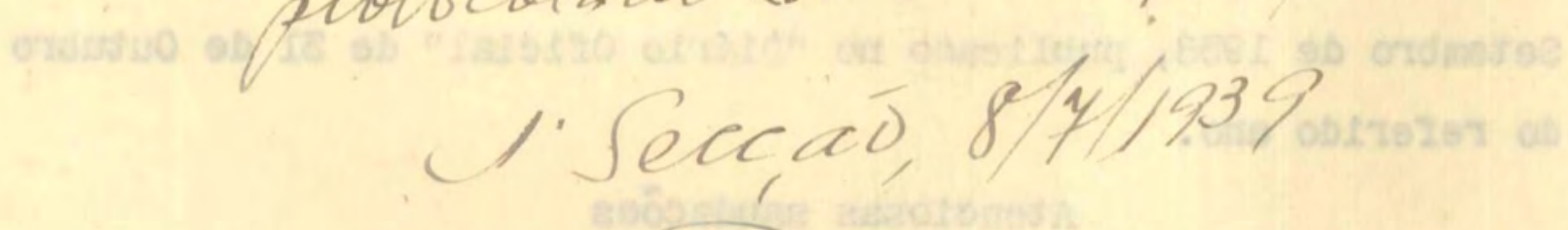
Savilostumes $8 x$

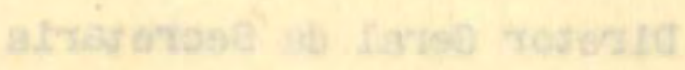




\section{BR ASIL - DEPARTAR: TO DOS CORREIOS E TELEgRAPHOS \\ T E L \\ PREAMBULO \\ C594 PORTQ ALEGRE R.S $972 \quad 61 \quad 821$ \\ R A M MA}

TIN

Sillogio

CHAERECO $\begin{aligned} & \text { OFF DOUTOR FRANCISCO BARBOSA } \\ & \text { REZENDE TRASELHO RIO } 10 \overline{6} \\ & \text { SERVIÇO RADIO AUTOMATICO }\end{aligned}$

I RN 27785939 SOLICITO VOS FINESA INEORMAR SOLUCAO PROCESSO 9582 TRACO 34 VG REMETIDO A ESSE CONSELHO EM 1934 SOBRE RECLAMACAO OPERARIO LIBERALINO MACHADO

DE LIMA CONTRA CIA ESTRADA DE FERRO MINAS SAO JERONIMO ESTA ESTADO PT OUTROSIM VG PECO VOS SOLUCAO LISTA AHI DEIXEI SOBRE PROCESSOS DESTA I NSPETORIA PT CORDEALMENTE DELMAR DIOGO TRASPETOR • 


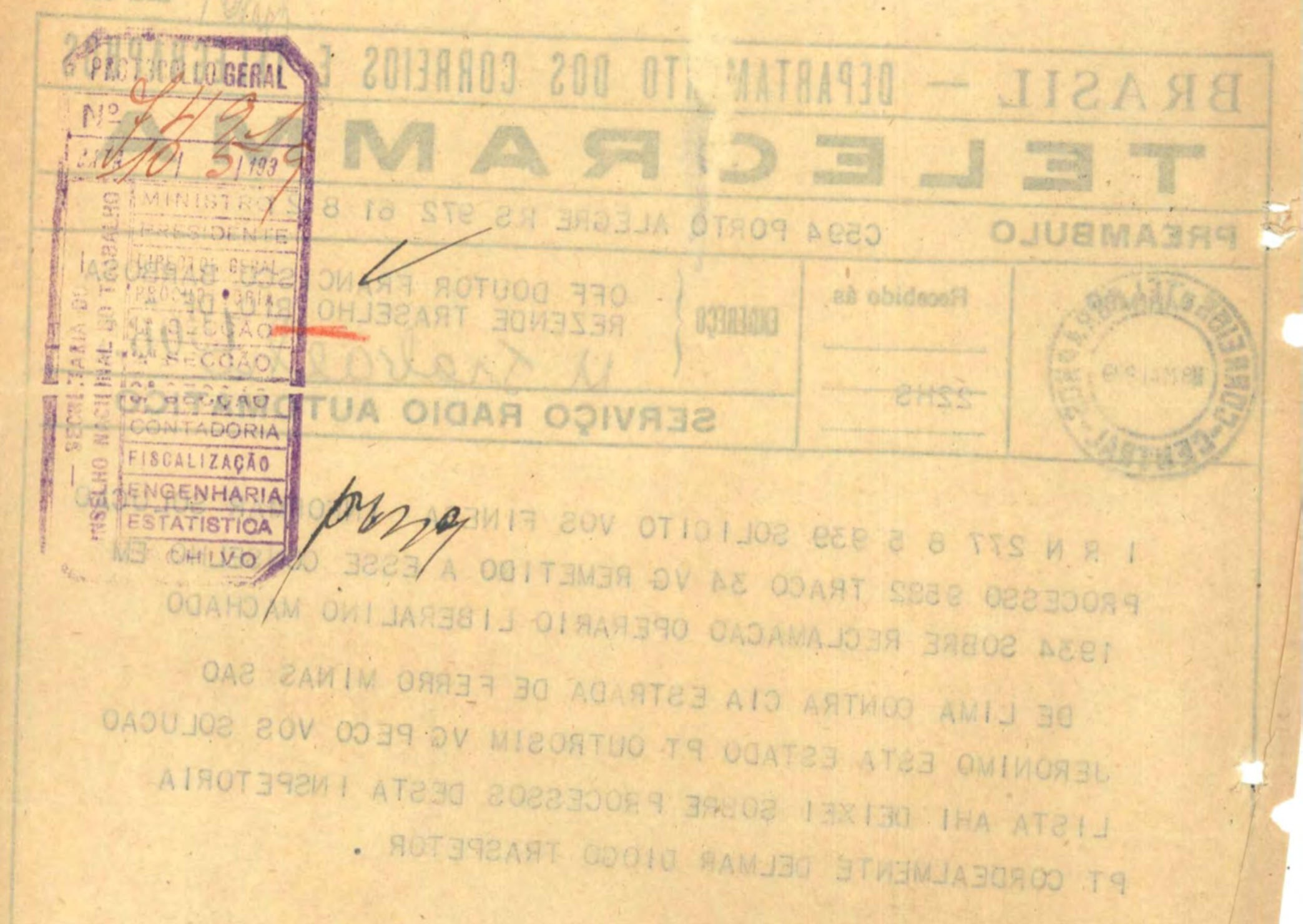


MINISTERIO DO TRABALHO, INDÚSTRIA E COMERCIO CONSELHO NACIONAL DO TRABALHO

Bue. hrofe

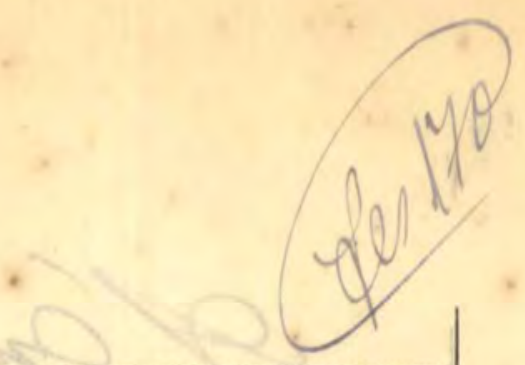

Conporemactoo

Gelman biogo, wisfrtón solieita eir formacias a neefpeito soluciás presesitipno.

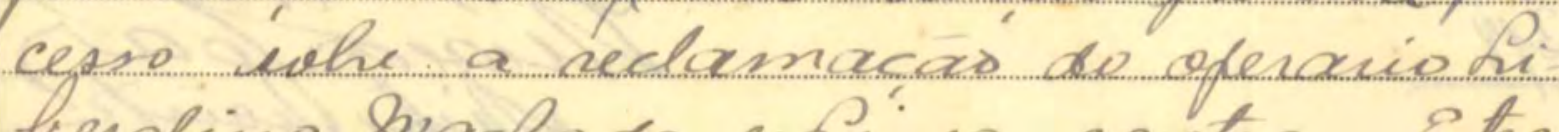
bralino brachace en fima contrs a eatra. la de Ferso huina vá̀ teronime.

Qufrosein, fece dallista que derson pohe o proesso da Inspeloria acolorto-blegre. Cumareme eselarecer gur ophesente procesn aquanda aesposta bo afieip de

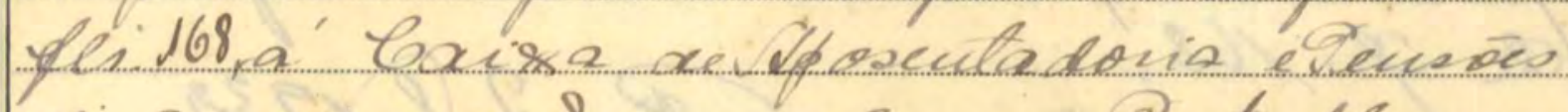
di sermices ar mimenacão ener Porto llegne. huacito a lista gar o omenno se refe. re, esta finita ros preecults duitos sohe o muaneso 3.

Mestar condiac̃es, passo es pre

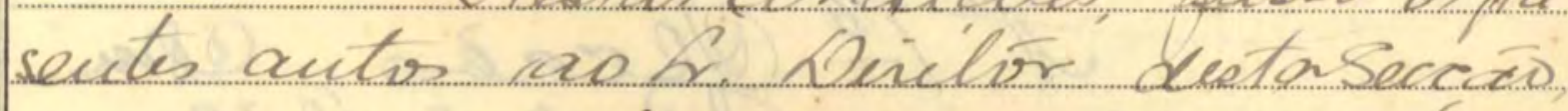

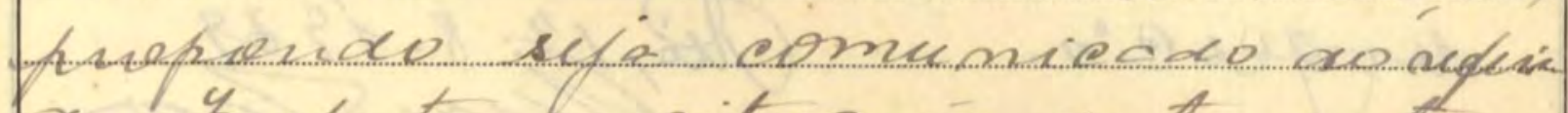

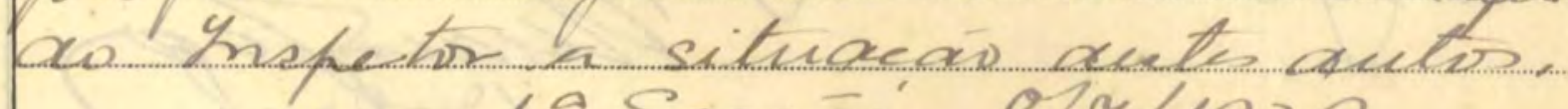

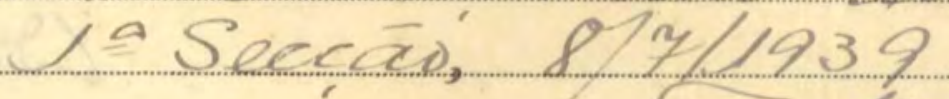
gavillonimas rein' $\mathrm{g}$.

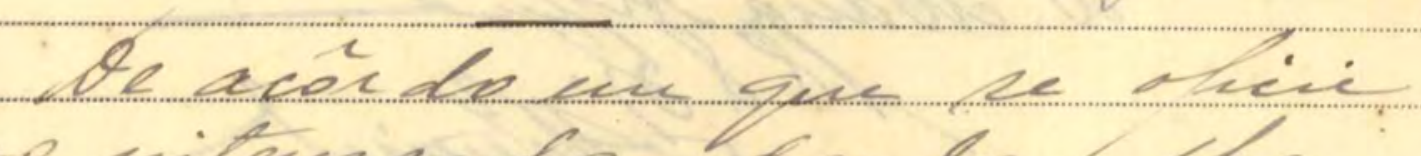
no witarisale danlo - Whe cieneria do udameto dus koderey antande da

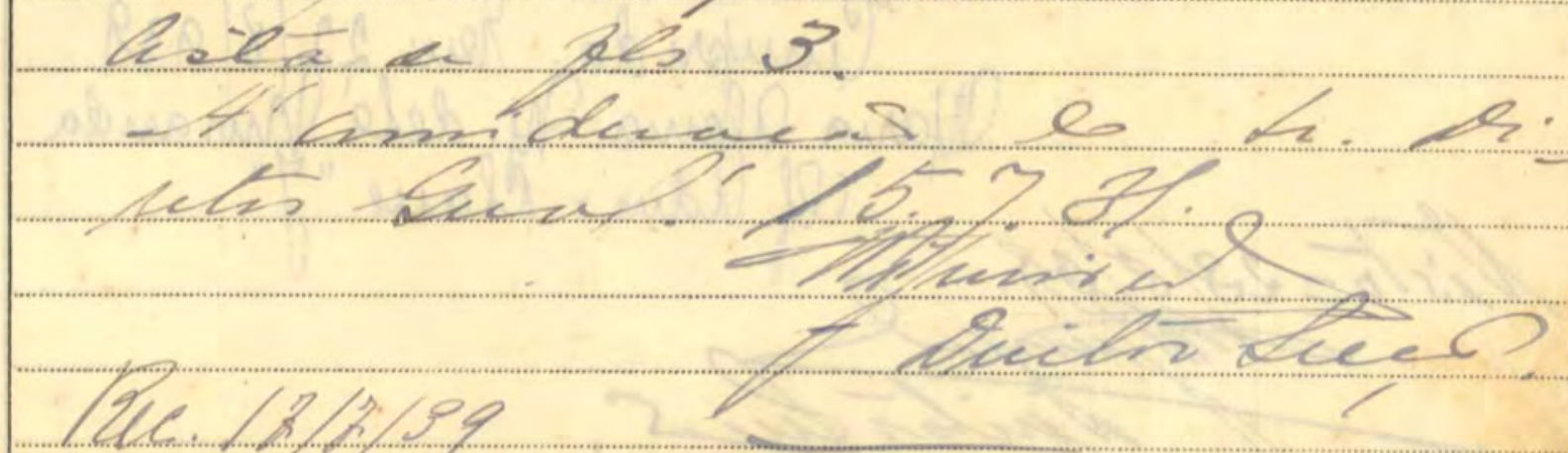




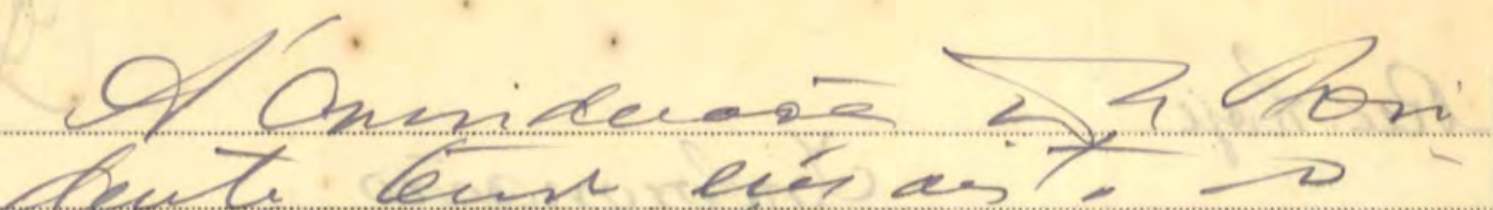

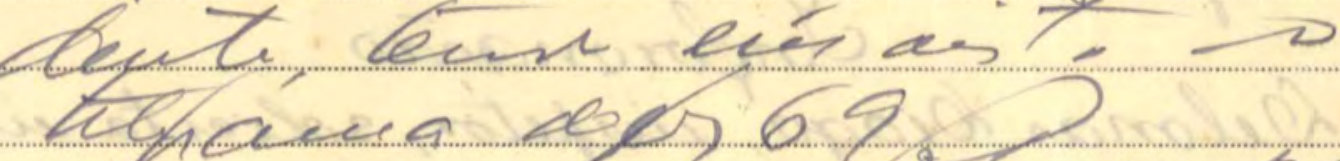

3/8

Tai 24BDS

Misurewas?

Oramscuita se av fuspetor

siquatái: do teleqrama de

P.169, or Delmar Diaq, opias ber acooroas de 7s. 96-99 e de B. 154-155, bem assin da oficio a 35.168 ?

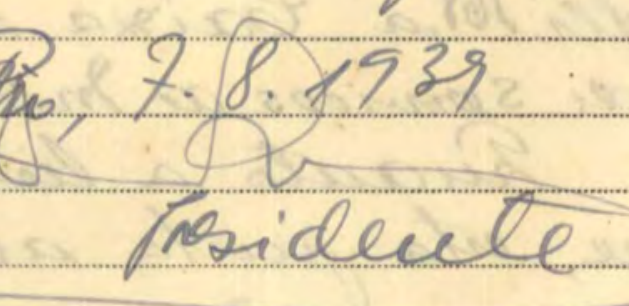

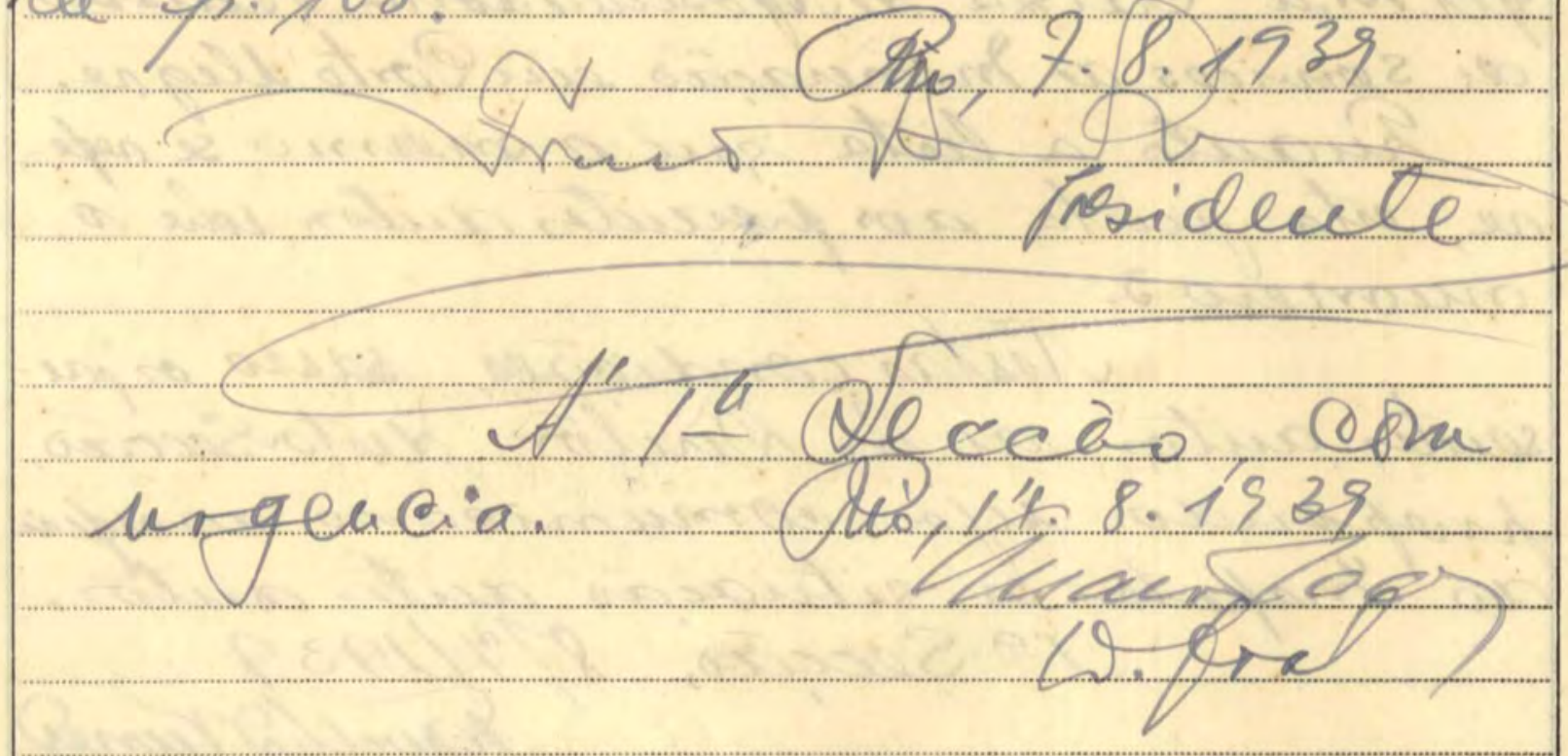

Rocebido na 1." Secção ern $/ 5=8-39$ A Alvaing fl.

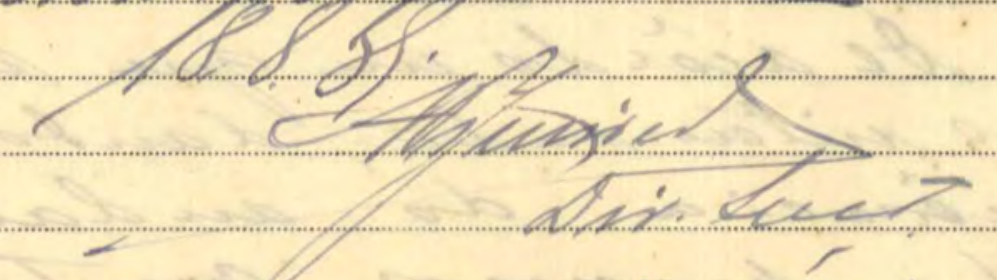

Tumprido, $\operatorname{ten} 228939$ Ularia Aberina Af deta Cuiranda Uf. Idm. Classe" I": 
MA/MP.

$1-1.626 / 39-9.582 / 34$
25 de Agosto de 1939

Snr. Inspetor

Em atenção ao assunto tratado no vosso telegrama de 8 de Malo p. I1ndo, Incluso vos remeto, de ordem do Sr. Presidente, cóplas, devidamente autenticadas, dos acóraãos proferidos pela Tercelra câmara dêste Conse Iho, em sessões de 2 de Junho de 1936 e 6 de Setembro de 1938, no processo em que Domingos Mant1lna e outros recla mam contra a Companhia Estrada de Ferro e Minas de São Je ronimo, bem como, do of1c1o dirigl do por esta Secretaria, ao gerente da Calxa de Aposentador1a e Pensões de Serv1ços de Mineração em Porto Alegre, sôbre o mesmo assunto.

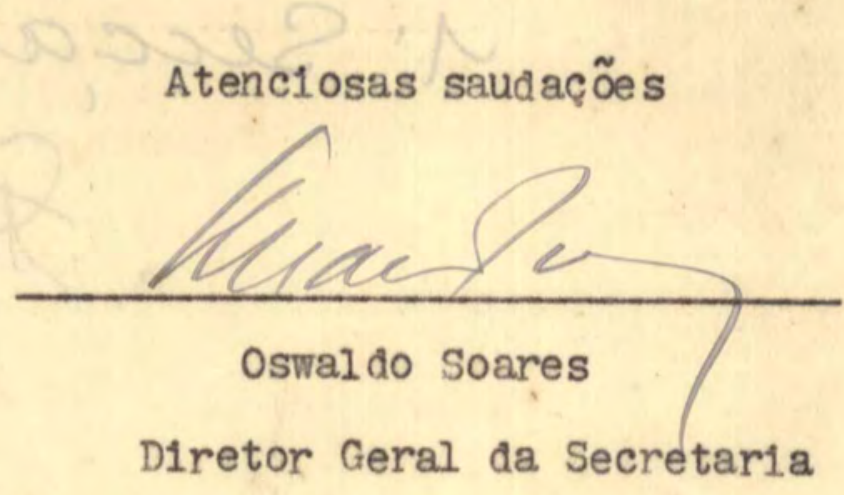

Ilmo. Dr. Delmar Dlogo

M.D. Inspetor Regional do Trabalno, em Porto Alegre 
SeL $9 D$ ofacha $9 b$ as

sejsea. 8-ec|asa. 1-

yojeqanI. Tre

- Deverutatada

Vesta data funto

ors prescutes cutos documents de fes. 172, protocolado sols o n: $14349 / 39$. 1. Seccáo, $4 / 9 / 39$ Tavillatures Exi'- 
CAIXA DE APOSENTADORIA E PENSÕES DE SERVICOS DE MINERAÇ̃̃O, EM PORTO ALEGREE PORTC $:$ :ECPE

Telefone n..$^{\circ} 5260$

ESTADO DO RIO GRA
- Caixa Postal n.o 816

Edificio do Banco Nacional do Comercio - Sala n.0 25 - 3.o andar - Caixa Postal n.o 816

off.n?ㅡ $7 / 632$

RNI/WPE
Pôrto Alegre, 9 de agosto de 1939.

Illmo Sr. Dr. Oswaldo Soares

DD. Diretor Geral da Secretaria do CONSELHO NACIONAL DO TRABALHO

Rio de Janeiro.

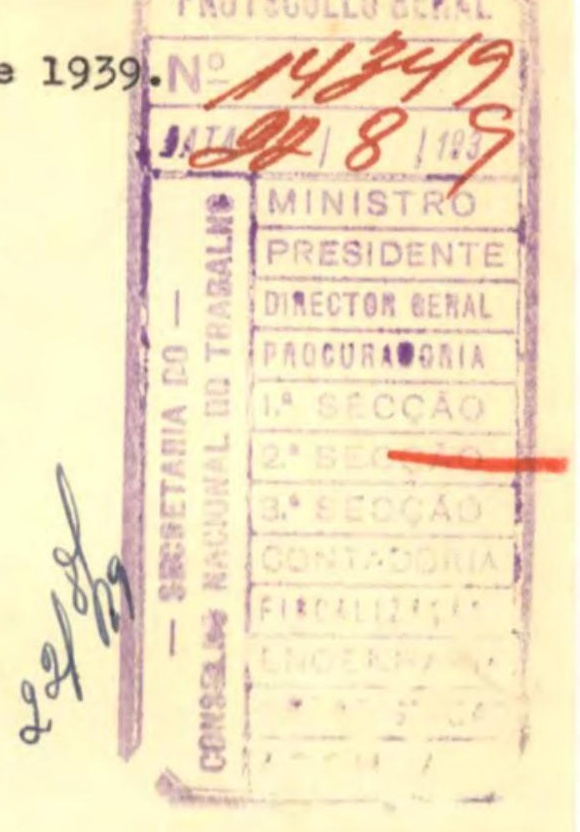

Respondendo aos termos constantes de seu oficio de 22 de junho pp., NSC 1-1.248/39-9.582/34, cumprenos informar V.Sa. que imediatamente providenciamos na publicação dos editais convocando os herdeiros te João Keenan a se habilitarem á pensão e aos vencimentos decorrentes do acordão da 3â Câmara desse Conselho, conforme poderá verificar pelo recorte do orgão da imprensa local " CORREIO DO POVO ", onde foi publicado em tres vezes alternadas.

Reafirmando a V.Sa. as expressões de elevada consideração e alto apreço, apresentamos-1he as nossas

Atenciosas Saudações.

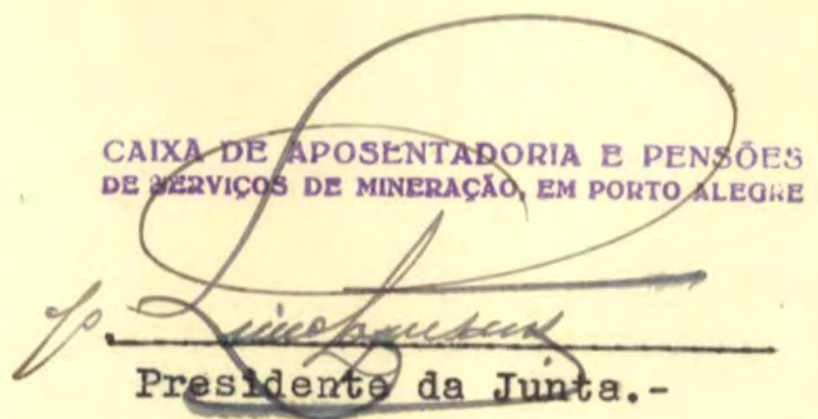




\section{CAIXA DE APOSENTADORIA E PENSÕES DE SERVIÇOS DE MINERAÇ̃̃0, EM PORTO ALEGRE PORTC ALet Ce

De conformidade com as determiną̧⿸厃s do CONSHLHO NACIONAL, DO TRABALHO, săo convocados os herdelros de

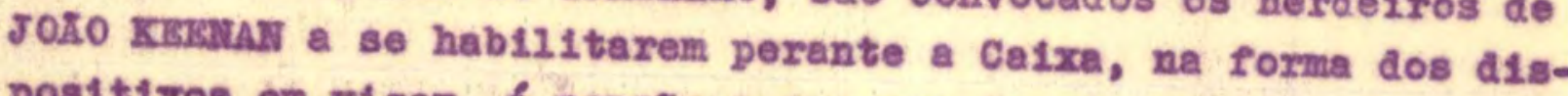
positivos en vigor, á pensâo o aos vencimentos decorrentes do acordăo da Tereelra Câmara do mesmo Conselho, de 6 de Setrembro de 2938, publicado no "Diario orielal " de 31 de Outubro do referido ano.

de 1939.

Becretarla da Calxa, Porto Alegre, 29 de Julho

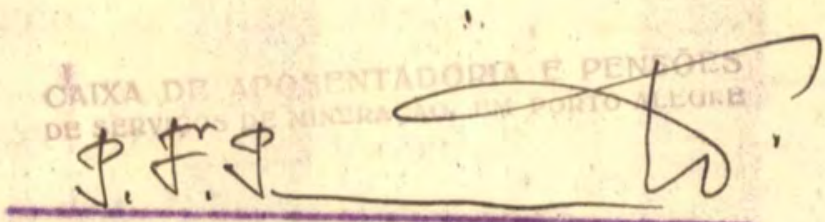

PRISSTDEANTE DA JUNVA.-

\section{EDITAL}

Paiva de Aneconiontio Apsen Services de

De conformidade com

NACIONAI

de JOÃO de JOAO KEEN a se habilitaremvocados os herdeiros

orma dos dispositivos em vigor, $m$ perante a Caixa

tos decorrentes do as en vencimen

Conselho, de 6 de Setema da Terceira Camara do men-

Official" de 31 de Outubro de 1938, publicado mo "D

referido anno.

Secretaria da Caixa, Porto Alegre, 29 de Julho de 1939.

$$
\begin{gathered}
\text { P. F. PINTO } \\
\text { Presidentc da Junta. }
\end{gathered}
$$


Pec hoje.

(11.

1 Cais de formacá.

Peusoes de de dpsentadonia e Borto. Slea serricos as bimeracas, om cobia as Ils 168 indendo oficio por inediatamerte providenciou ra publicacáo dos editais con rocaindo os hendeinos de foăofeenan a de halilitarenn á pursãos ow vencimeutos decorreutes do acórdão de fls. juitando recorte do orgão da limpreusa local "Correio do Ponv" - copia do referido edital.

Wessa'arte, cumprida a promo. fă defes. 166 , da Fouta Procurodo. ira Geral faco subir os presentes an tos a' diliheraçás superior.

1'Secçã 4/a/1939:

tavielariunes?

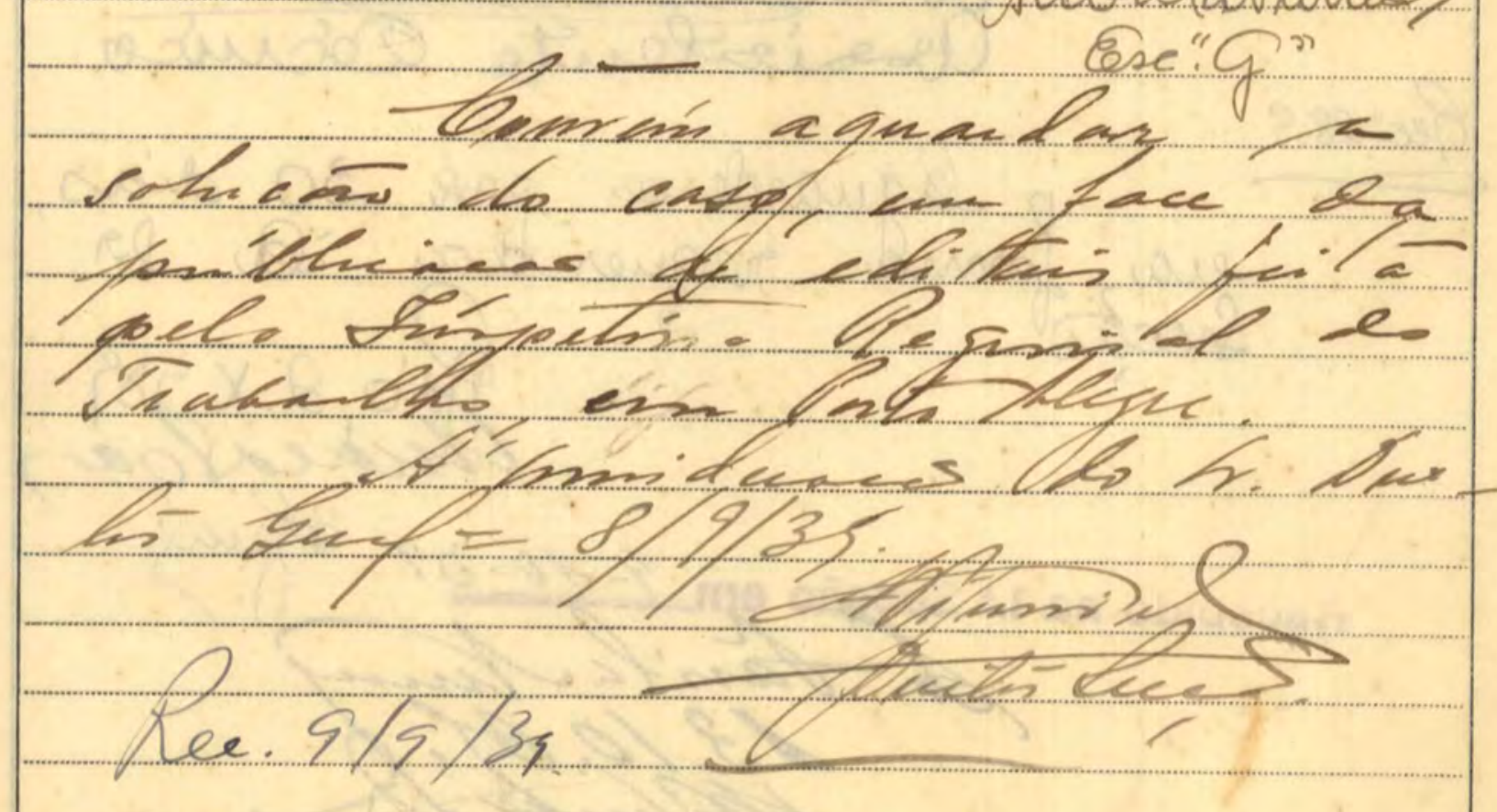




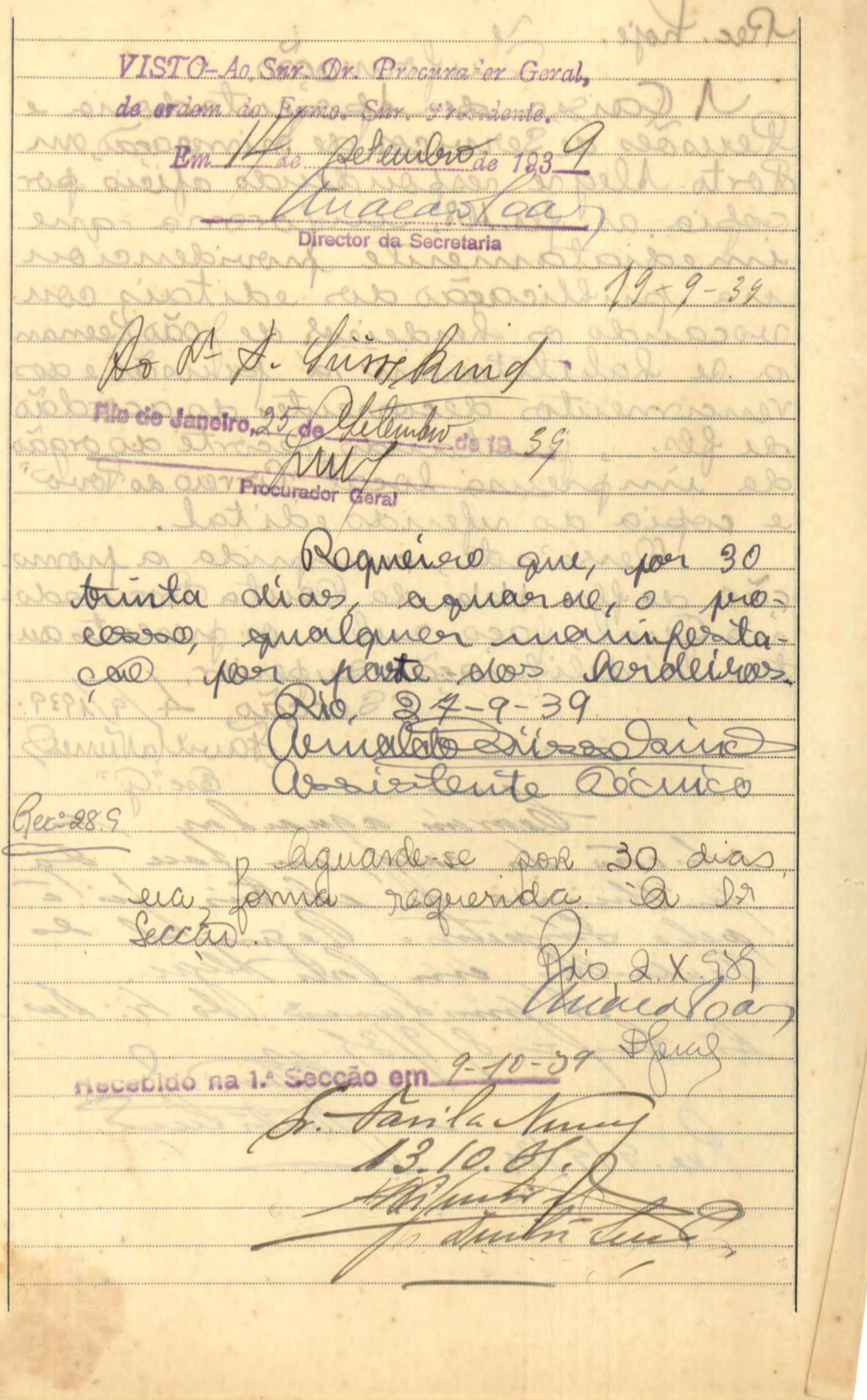


MINISTÉRIO DO TRABALHO, INDÚSTRIA E COMÉRCIO

CONSELHO NACIONAL DO TRABALHO

Tuformação

Cour relaceás a promocáo de fes netro, cimpre me esclarecer pre, ate a presuite data, segundo me for dado afurar uno Pro. tocolo Geral, nāo deu entrada qralquer manifestacóo por parte de herdecinos de foōo keenan Stssin, faco subir os peen. tes autos as sin. Firelor desta Seccarospoponas o netorono dis mes. nos a Procuradoria Geral, de wer one está expgota do o prano pela on esma concedido, di30 dian st' deliheraéás sufenior.

I' seccad, 21-11-1939

it Fowiltal kumes?

do $\mu$ Avirisstang

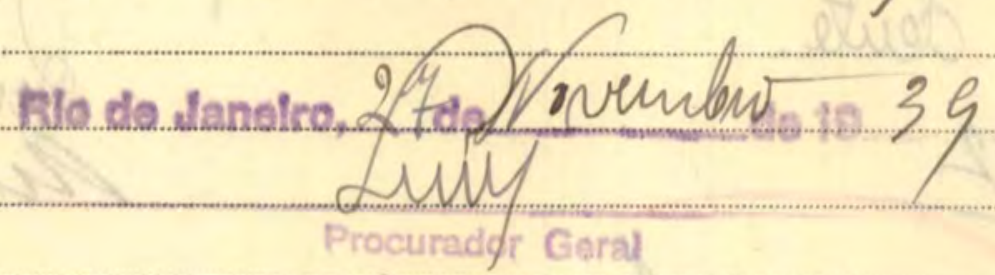

Paceoer

(4) 1 th 


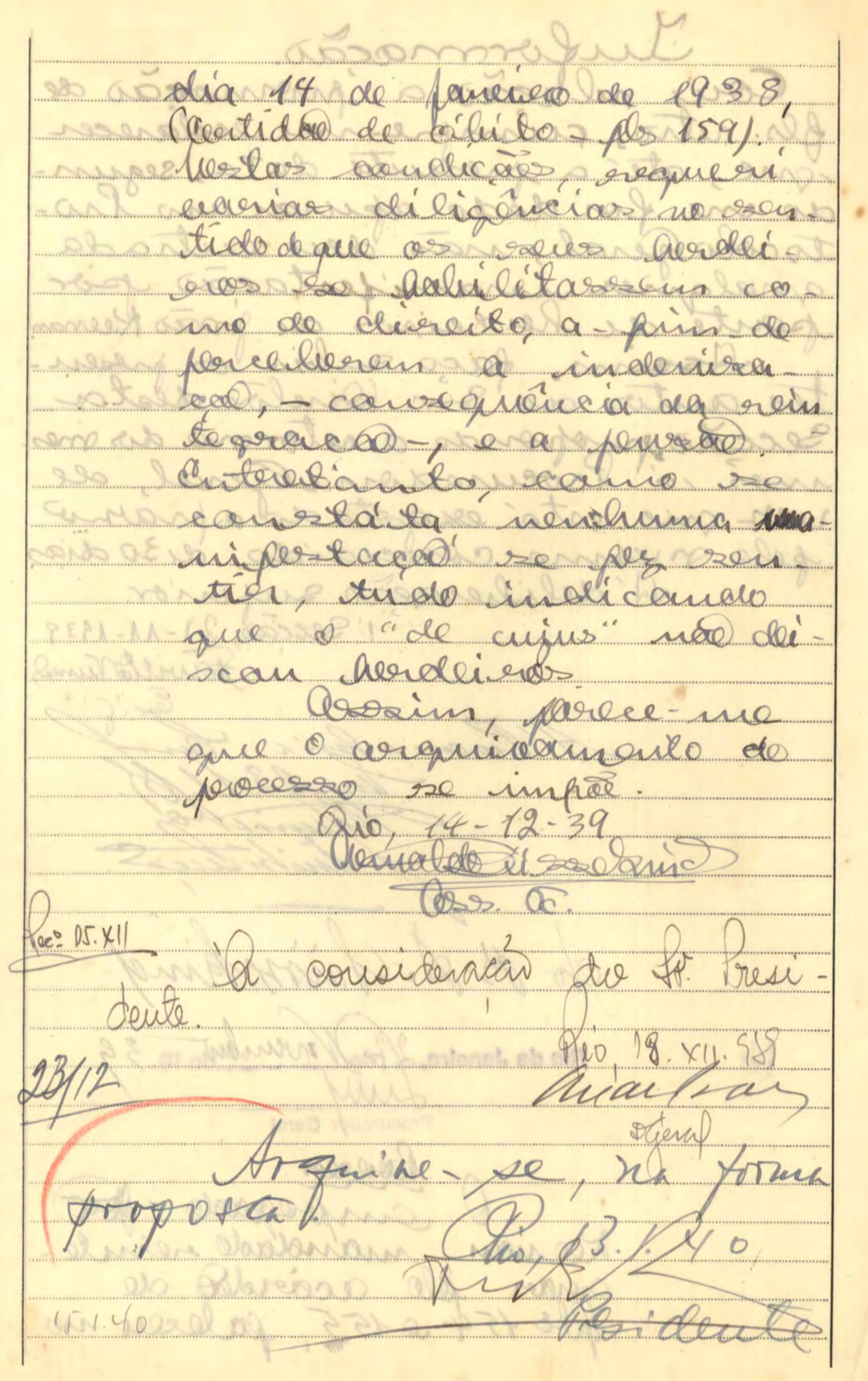


iff

CONSELHO NACIONAL DO TRABALHO

Sol

'b bisectâ.

hiois 104.940

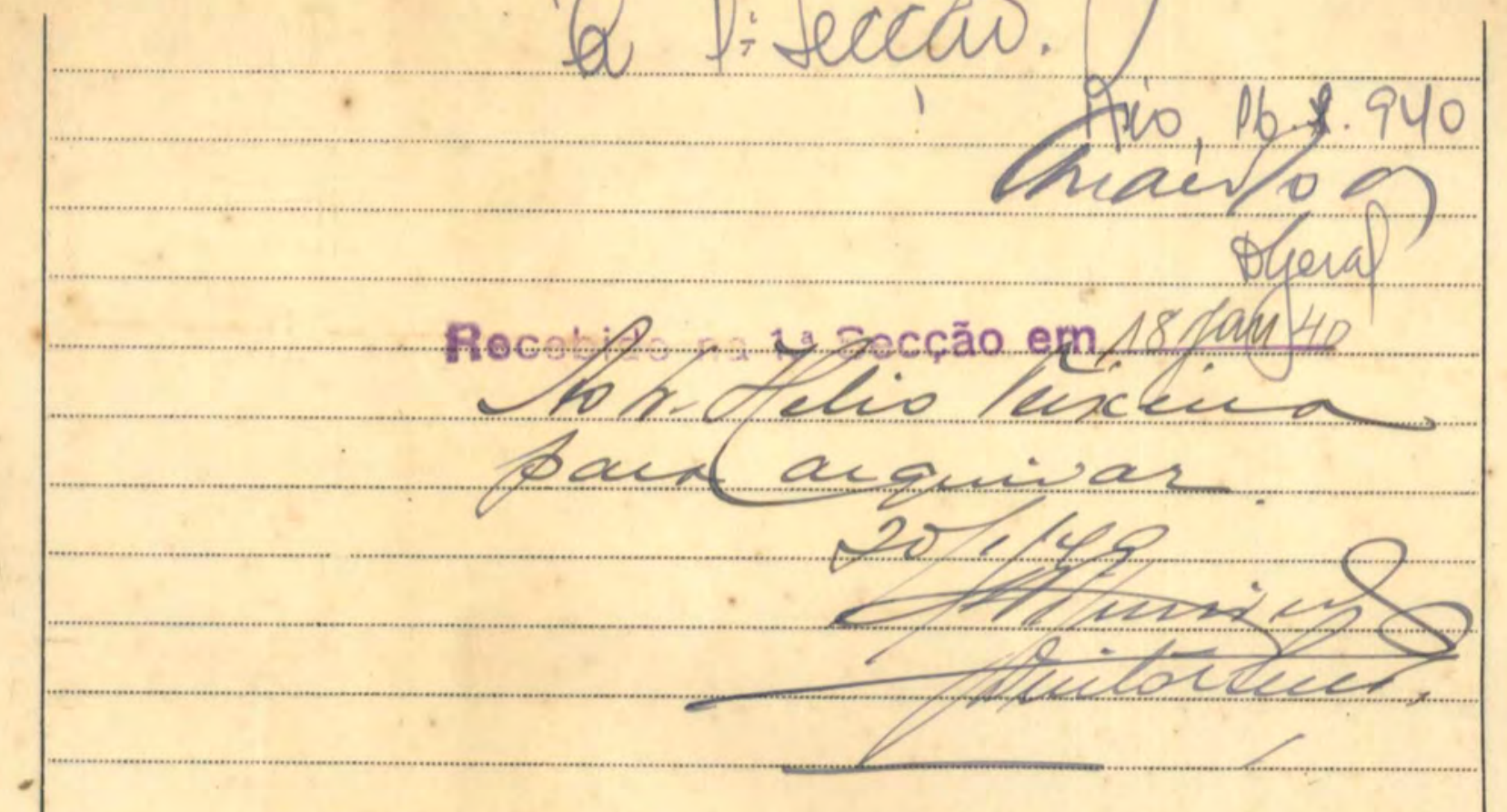

- Gumifir ensesfomito

Aleliodivents 


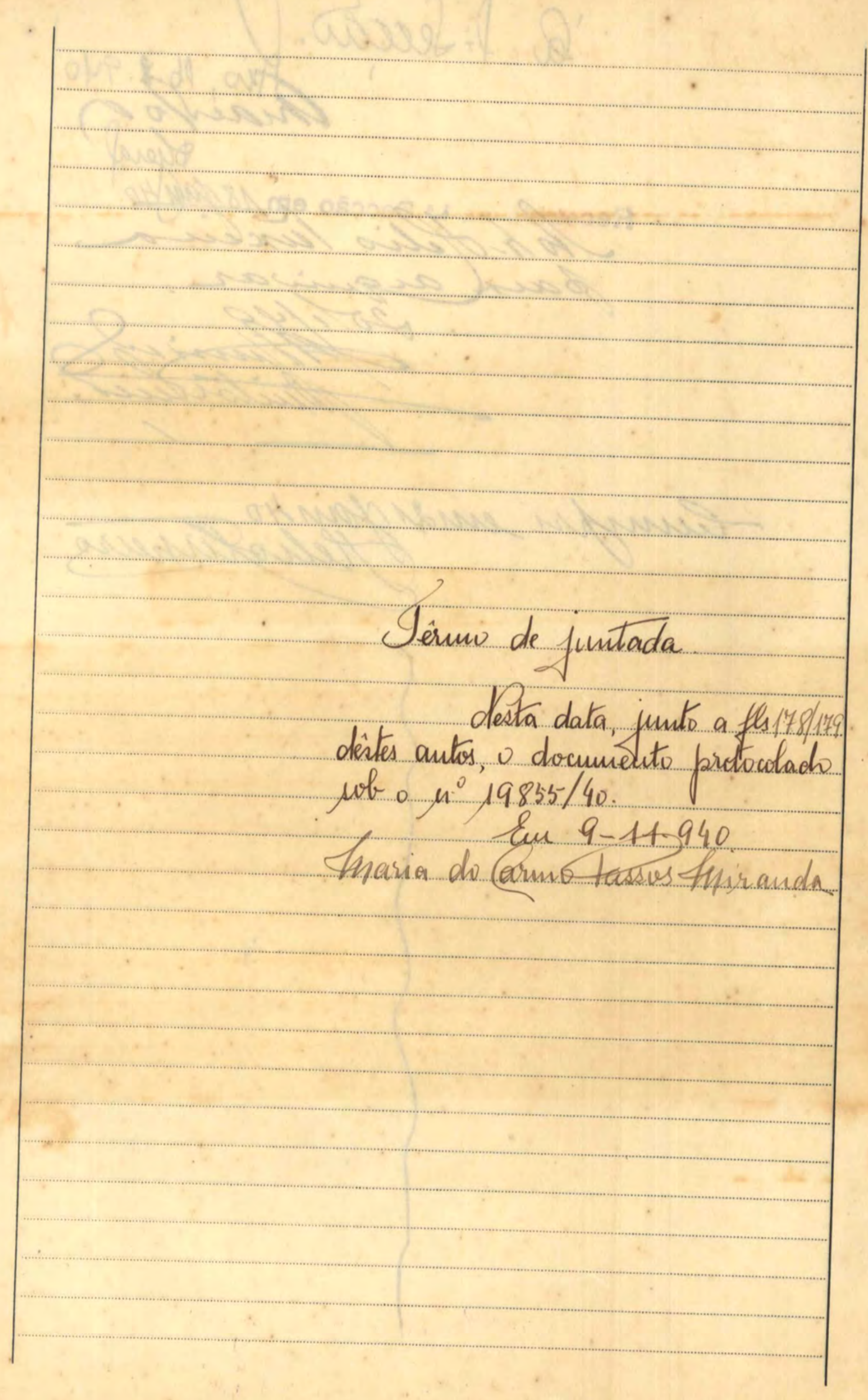


FHEANGOUO R 87 SJÉRONIMO RS $16,94 / 95,19,10=$

PÉCO VENIA SOLICITAR VOSSENCIA SEJA INFORMADA VG POSSIVEL BREVIDADE VG DATA FOI OPERARYO JOAO KLENAN | $\begin{aligned} & \text { I } \\ & \mid\end{aligned}$ DEMITIDO SERVICOS CIA ESTRADA DE FERRO MINAS I S JÉRONIMO VG CONFORME DEVE CONSTAR PROCÉSS.0 $9582: 134$ JULGADO COLENDU CONSELHO SEIS DE SETEMBRO ANO MIL HOTIVADA PROVAR JUIZO EXEUUCAO REFERIDO ACORDAO DATA EM QUE CY TADA DEMISSAO SE T.ORNOU EFETIVA PT 1 ATS SAUDS DR ERNANI COELHO PROMOTOR PUBLYCO. - COMARCA S JÉRONIMO VG ESTADO RYO GRANDE DO S.UL 
PROTOCOLO GERAL

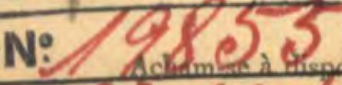

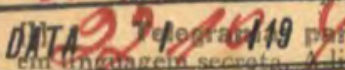

de ROIPRESIDENTE

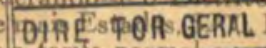

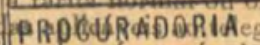

2] 1.ग

alares ordinários. São os telegramas comuns e de uso generalizado. Pb́dem ser redigidos em linguagem clara ov iagem secreta convencionada tambem se denomina de c5digo ou CDE. Tarifa no serviço interior: taxa fixa, por grup, icăo em cada telegrama, 1\$000; taxa de percurso, por palavra, em telegrama com percurso dentro do mesmo Estado, ederal incluido no Estado do Rio de fabeiro, \$100; taxa de percurso, por palavra, em telegrama com percurso entre

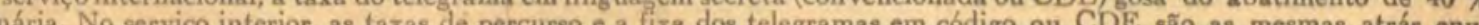
nária. No serviço interior, as taxas ce percurso e a txa dos telegramas em codigo ou CDE sấo as mesmas atrás enuma particular ordinario em linguagem clara. No serviço internacional, as taxas dos telegramas ordinarios são multifária. taçoes telegraficas possuem tarifas especiais para oricntaçấo do público neste particular.

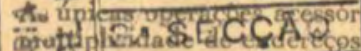

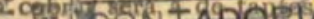

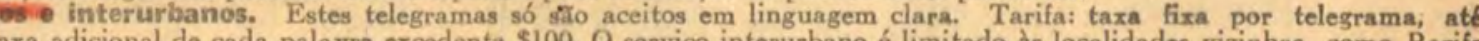
xa adicional de cada palavra excedente $\$ 100$. O serviço interurbano é limitado às localidades vizinhas, como Recife , Vitória e Vila Velha, mesmo que estejam em Estados diferentes, como Penedo em Alagôas e Vila Nova em Sergipe. admitidas nos telegramas urbanos e interurbanos são a resposta paga (RPx) e o expresso pago (XPx). Não é aceita a elo sistema de cópias (TMx). Nos telegramas urbanos e interurbanos de texto igual para diversos destinatários a taxa gramas quantos os enderêços. Não é, do mesmo modo, aceita a urgência ou $=\mathrm{D}=$ nos telegramas desta espécie. es ou $=\mathbf{D}=$. Os telegramas urgentes pagam o duplo da taxa de percurso, sem aumento da taxa fixa de $1 \$ 000$. própria

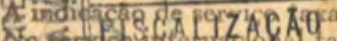

m está a urgência sujeita ao pagamento do duplo da taxa de percurso.

tama nos aparelhos para maior fidelidade de sus trans-

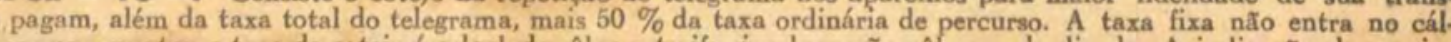
gramas urgentes, a taxa do cotejo é calculada sôbre a tarifa simples e não sôbre a duplicada. A indicação de serviço

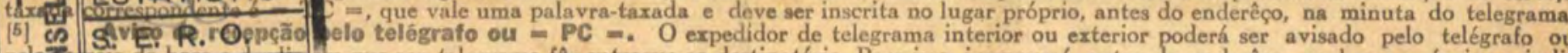

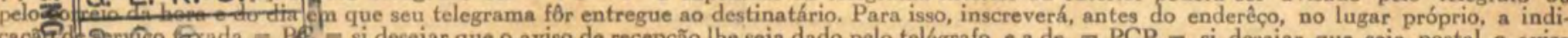

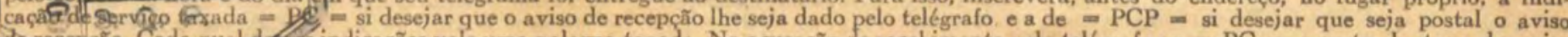
đe recepç̧̃o. Cada quel thoprs indicações vale uma palavra-taxada. Na acusação de recebimento pelo telégrafo ou $=$ PC $=$, o custo da taxa do aviso de recepçấo-serát Trunt åo de telegrama ordinário de seis palavras, sem taxa fixa, para o mesmo destino e pela mesma via do telegrama em que êse serviço acessório fôr pedido. A taxa do aviso de recepç̃o $=\mathrm{PC}=$ serí, em qualquer caso, a da tarifa plena ou ordinária, seja qual fôr a natureza do telegrama a que o aviso se refira (urgente, preterido, etc.).

[6] Aviso de recepção pelo correio ou $=\mathbf{P C P}=$. Si a acusıção de recebimento fôt dada pelo correio ou $=\mathrm{PCP}=$ (ver item anterior), a taxa do aviso de recepç̃o será a do porte e registro do correio.

[7] Telegramas a fazer seguir por ordem do expedidor ou $=\mathbf{F S}=$. O destinatário de qualquer telegrama póde encontrar-se ou não na localidade de destino dêsse telegrama. Na dúvida, póde o expedidor determinar que o telégrafo faça seguír o seu telegrama até encontrar o desti. natário. Para isso usará a indicação de serviço taxada = FS =, que vale uma palavra-taxada e é posta antes do enderêco, no lugar a isso destinad $\mathrm{O}$ expedidor pagará as taxas do primeiro percurso. A taxa da reexpedição (segundo ou terceiro percurso) será paga pelo destinatário. Si êste na

a pagar, deverá indenizá-la o expedidor. ficaçōes necessárias (identidade, residència, etc.), que ihe sejam reexpedidos telegraficamente para novo enderếço, que indicará, os telegramas a éla dirigidos que chegarem a qualquer estaçăo telegráfica. Os pedidos de reexpedição deverão ser leitos por escrito, por aviso de serviço taxado ou pelo correio. Serão formulados ou pelo próprio destinatário gu em seu nome por pessôa autorizada a receber os telegramas em sua vez. A taxa desta reexpedição póde ser paga no lugar da reexpedição ou no novo destino do telegrama. As estações telegrálicas inserirão, nas reexpediçõex desta espécie, a indicação de serviço taxada $=$ Reexpedido de $\ldots=$, que vale uma palavra-taxada.

[9] Telegramas a guardar na posta restante ou no telégrafo restante. O expedidor póde pedir que seu telegrama fique na posta res. tante ou no telégrafo restante de qualquer localidade, conforme haj « combinado com o respećtivo destinatario. Para isso. usará as expresš̉es - $\mathrm{GP}=$ ou posta restante $0=\mathrm{TR}=$ ou telégrafo restante, que escreverá na minuta de seu telegrama, antes do enderêco, no lugar destinado à inclicações de serviço taxadas, valendo cada qual délas uma palavra-taxada. Além dessa taxa de uma palavra, não ha, neste caso, outra contribuiç̃ adicional pela operação acessória prestada, a não ser a da taxa de $\$ 200$ que será pagn pelo destinatário no caso de posta restante. 
MINISTERIO DO TRABALHO, INDÚSTRIA E COMERCIO

CONSELHO NACIONAL DO TRABALHO

$$
\text { sine }
$$

Pecelido an 29/10/40

Com o le.dPG. 19855/40, thomotar Anblico da Connarea de plaw jeromimo solicita sefa informado a data da demistav do Sh Joaro Aruan para fazer prova un juizo na occasias da execuçán do referido acoirtas.

A respeits cumpre me infor. mar que ch goow Mfenan foi dispenzacto dos servicos da Companhia Estrada be Terro e cllinas de

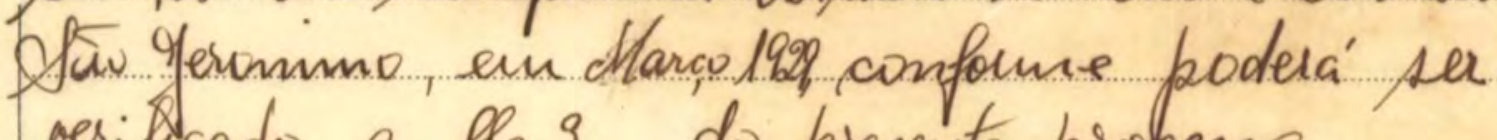
perificado a fls 3 , do preance processo.

Assim priponho refa oficia. do av Drx. Imani Coetho cintificando-o da data da demisiás do ferroriálio en questa.

Q' comsidera cás supeinot. Petardado por acumusto de serrico a men cargo

Inaria do amo tassos Anirauda. Qursesenit If
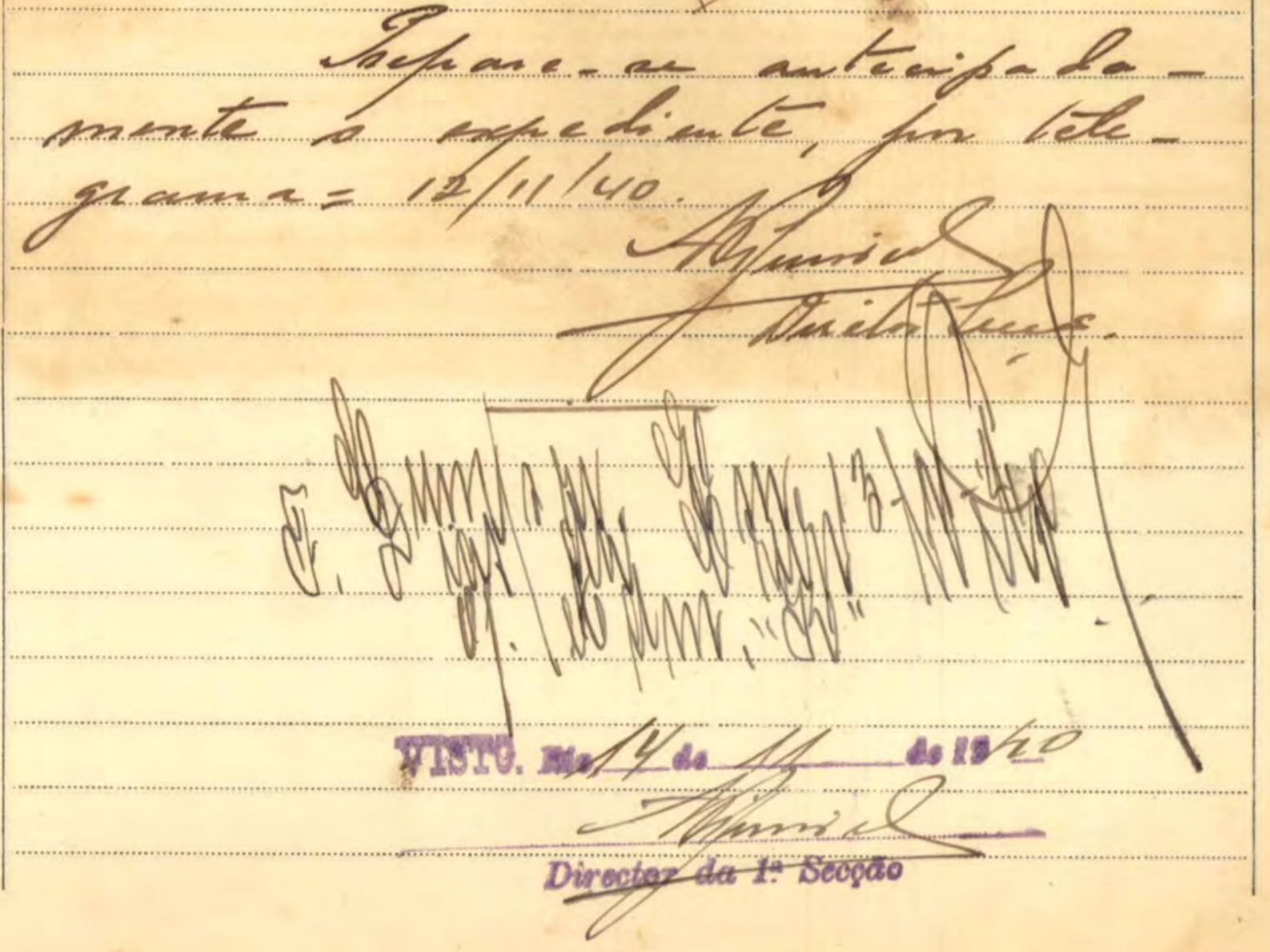
MINISTERIO DO TRABALHO, INDÚSTRIA E COMERCIO CONSELHO NACIONAL DO TRABALHO

CÓPIA PARA ARQUIVAMENTO EM ORDEM CRONOLOGICA

Snr. Ermani - Promotor Público

Comarca de São Jeronimo - Rio Grande do sul

$1-37 / 40 \quad 9-12-940-$

Resposta vosso telegrama vg cabe-me informar vg ordem Snr Presidente vg que João Klenan foi afastado serviços Companhia Estrada Ferro Minas São Jeronimo vg em Março de 1929 vg segundo justificação judiclal vg constante processo no $9.582 / 34$ pt Atenciosas Saudações pt Oswaldo Soares pt Diretor Geral da Becretaria do Gonsel ho Nacional do Trabalho 
<smiles>CCCCCCCO</smiles> 
Sêmus de funtade

Qesta data, junto a fl.

199 distes autos, 0 doenmento protocolads ob : $n: 23.84340$

Maria Oleina 44 dela

Uf Adur detá huranda 

Syndicato dos Mineiros e Classes Anexas do Municipio de São Jetronymo

Séde Central: 5. DISTRICTO DO MUNICIPIO DE SÃO JERONYMO ESTADO DO RIO GRANDE DO SUX - BRASIL

Syndicato de Classe reconhecido pelo Ministerio do Trabalho, de accordo com o Decreto n. 24.694 de 12 de Julho de 1934

Minas do Arroio dos Ratos, 29 de novembro de 1940

Illmo. Snr. Presidente dow. Consetho Nacional do Trabaltho D. D.

Officio $N .125 / 40$

Rio de Janei ro

Tem o presente por tim este Sindicato requerer a $V . S$. - desentranhamento da justificação de nome de tempo de serviço, certidå de nascimén to e atestado de saude do Coronel Alipio Bandeira, que se acham no rocesso 8295-34, reterente ac nosso associado Liberalino ou Januario Machado de Lima.

Estes documentos poderão serem enviados para a 17a. Delegacia Regional do Trabalho, que ali os receberemos medidnte recibo.

Nestes termos

E. Deterimento

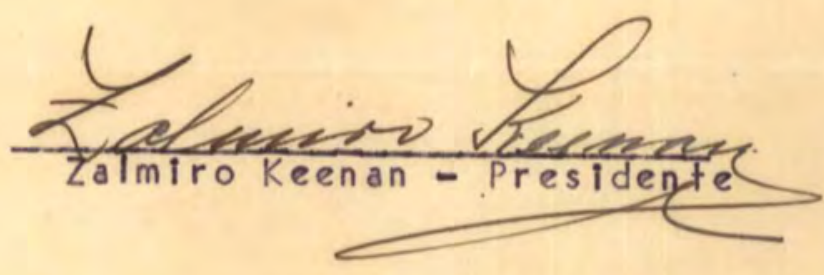

P.JTOGOLE GERAL

N.23843 DATA $181 / 2119 Y$

Cᄋ PRESIDENTE

DIRE TOR GERAL

$29-11-40-29-11-40$

PROCURADORIA
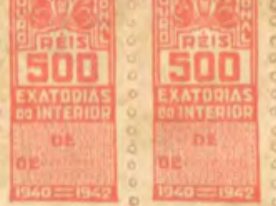

500 


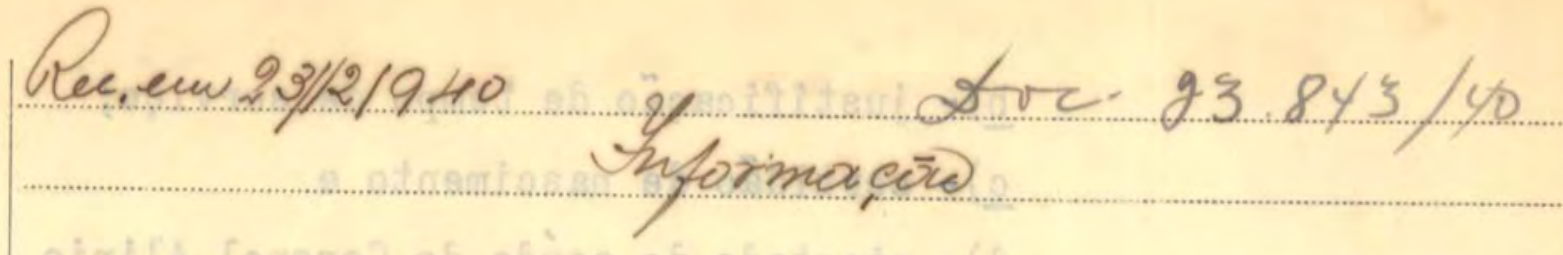

Gossuntorfuente ao gicio do Sina: cáto dos muires e flases aucas do muni:

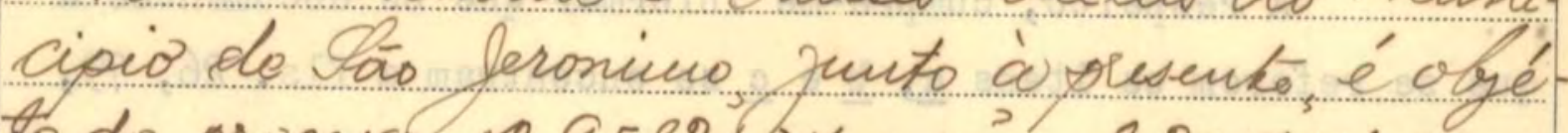
to do processo p. 9582104 e nav 8.295754 cono or equive co foi datílográfavo, sertenceuvo

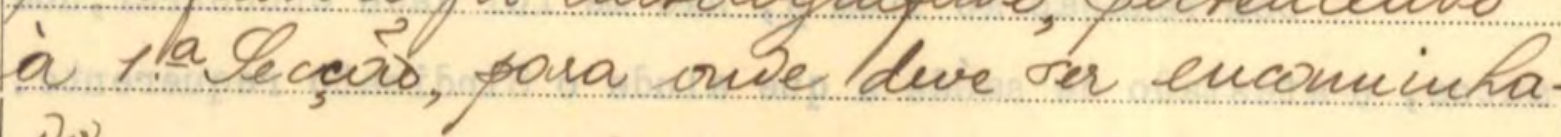
No.

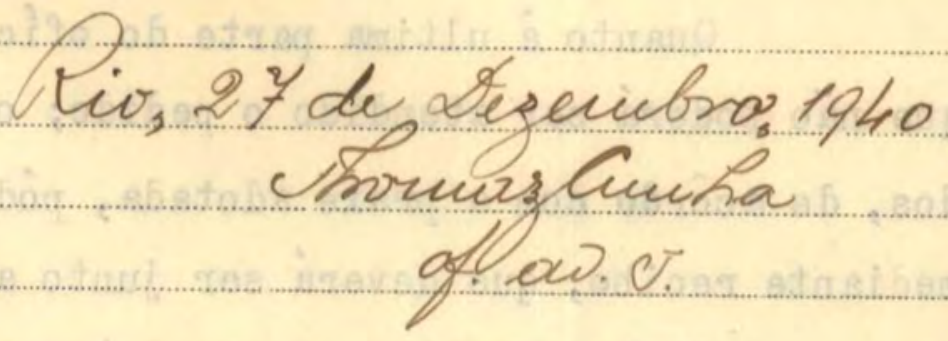

(

Sare.

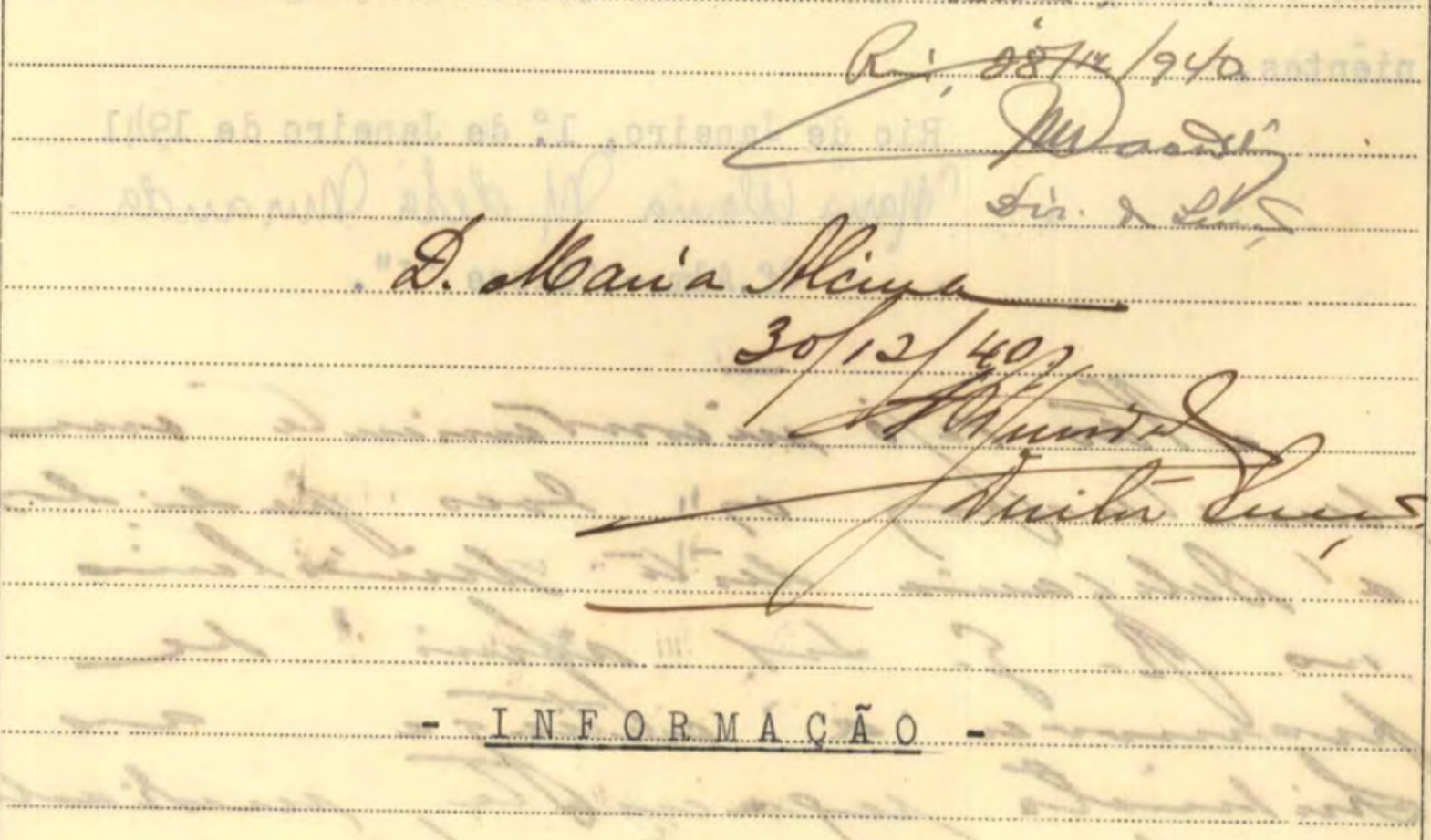

O... Sindicato dos Mineiros e Classes Anexas do Municipio de São Jeronimo, no documento de fls. , , requer a êste Conselho, the sejam restituidos os seguintes documentos, referentes ao seu associado, Liberalino ou Januário Machado do lim ma:-

a)- justificação do nome do aludido enpregado; 
b)- justificação de tempo de serviço;

c)- certidão de nascimento e

d) - atestado de saúde do Coronel Alipio

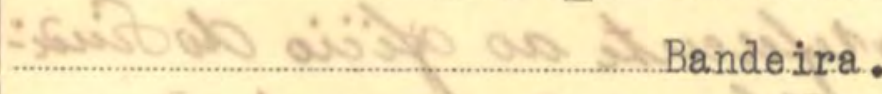

A respeito, cumpre-me informar que os documentos a que se referem os itens a , $b$ e $c$ se oncontram a fls. 26,79 . 118 e 27, respectivamente.

- Gu Com relação ao item d, não me foi dado encontrar, nos autos, o atestado de saúde a que alude o Sindicato requerente. Quanto à ultima parte do ofício de fls., parece-me que não poderá ser atendido o pedido; os documentos solicitados, de a côrdo com a praxe adotada, póderão ser restituidos mediante recibo, que deverá ser junto ao processo.

Contudo, passo os presentes autos às mãos da autoridade superior, para as providências que forem julgadas conveniêntes.

Rio de Janeiro, 1: de Janeiro de 1941

Maria Alania Cy delá Churanda Of.Adm.- Classe. "J".

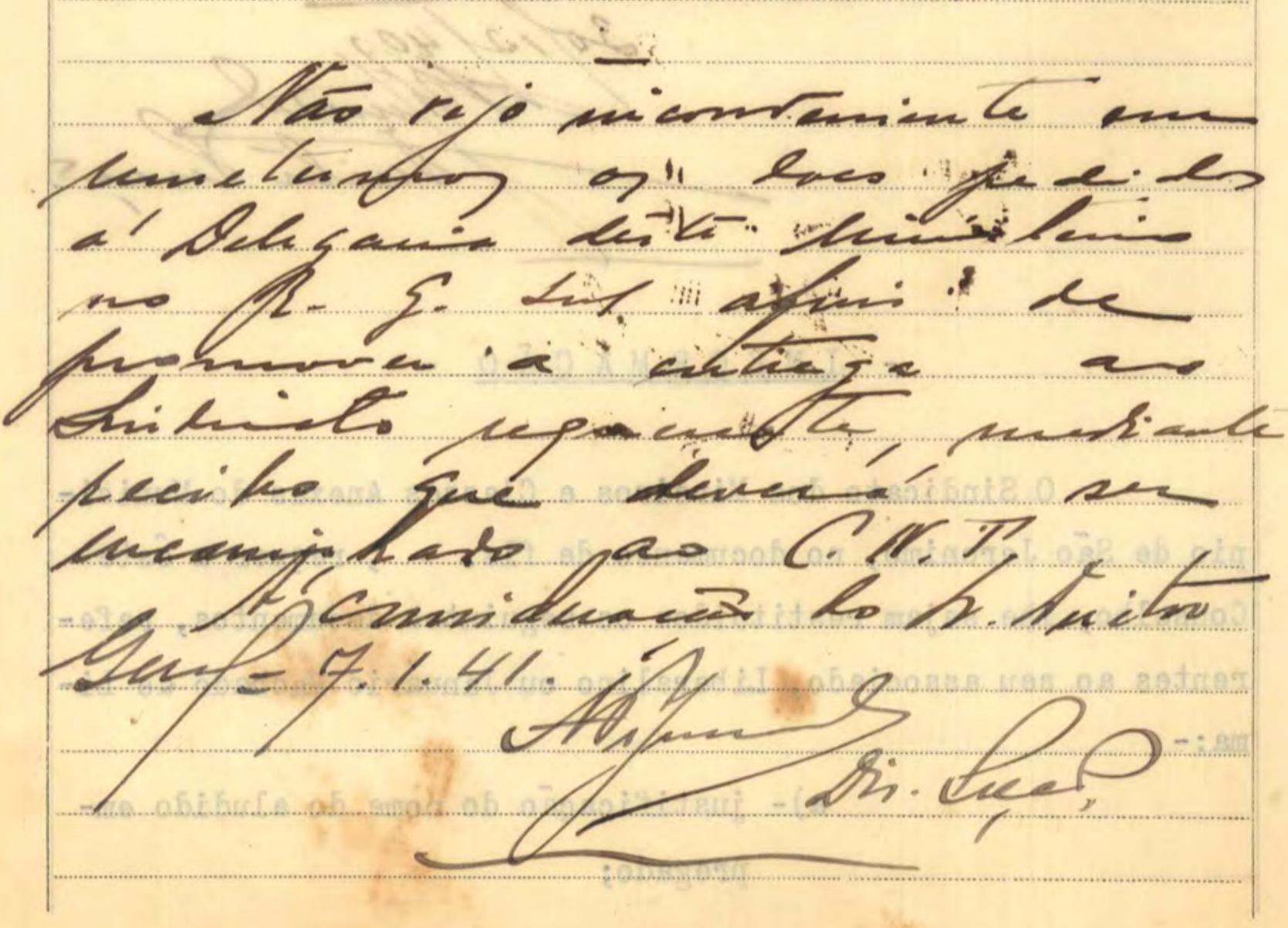


MINISTERIO DO TRABALHO, INDÚSTRIA E COMERCIO

CONSELHO NACIONAL DO TRABALHO

fis4

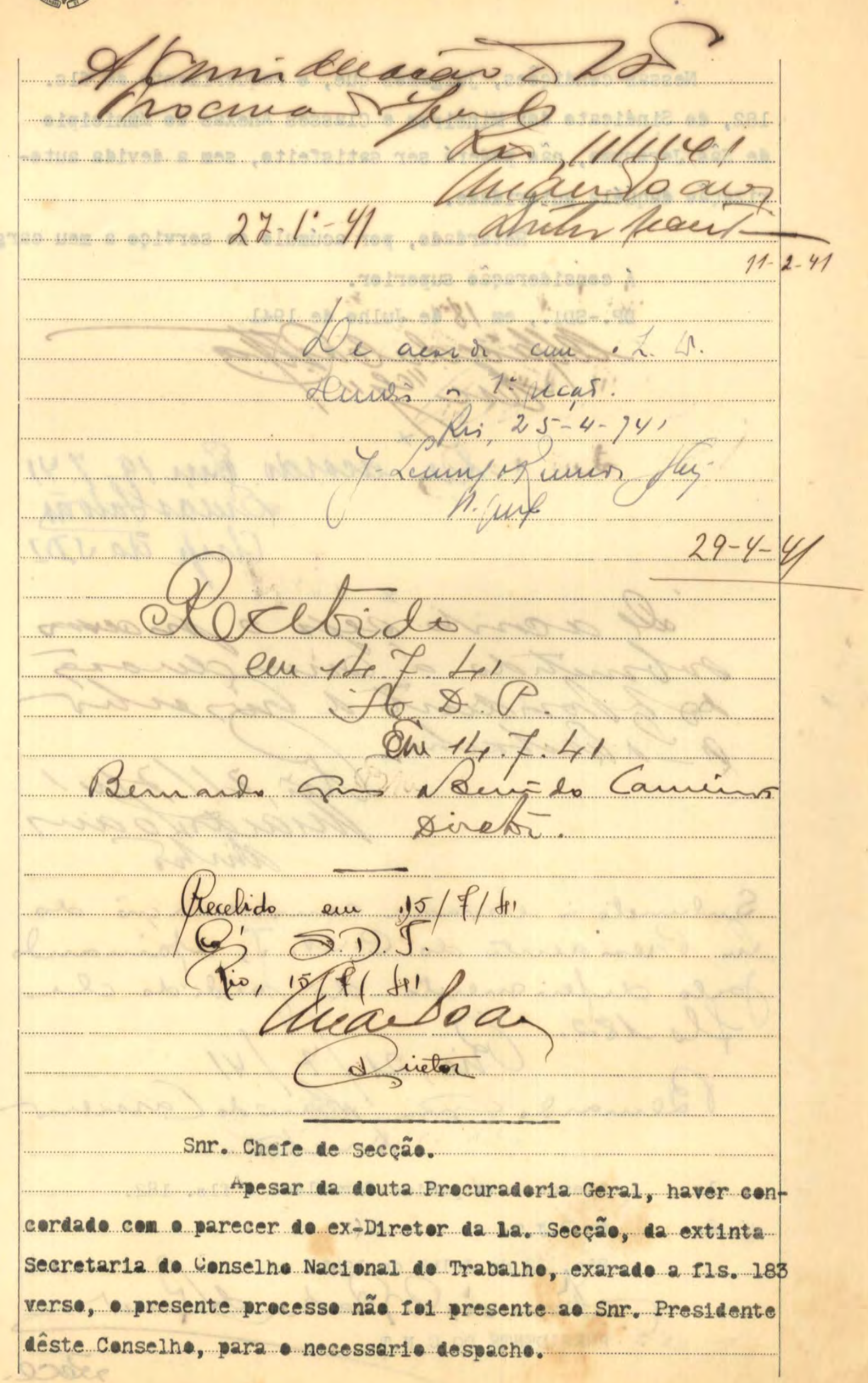


Nessas condiçées, julgamos que, $\bullet$ requeriment de ils. 182, do Sindicat dos Minè ros e classes Anexas do Manic1pic

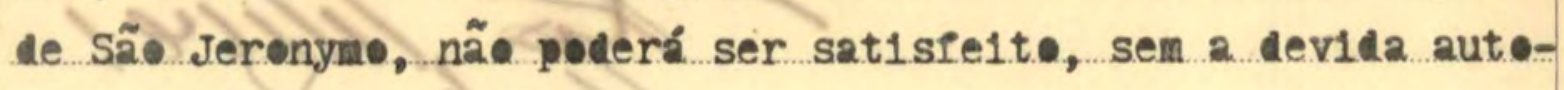
rização daquéla autoridade.

Retardade, por acúmul de serviç a meu carg॰ A copsileração superior.

DP. -SDI.", en $18^{\circ}$ ke Juin de 1941

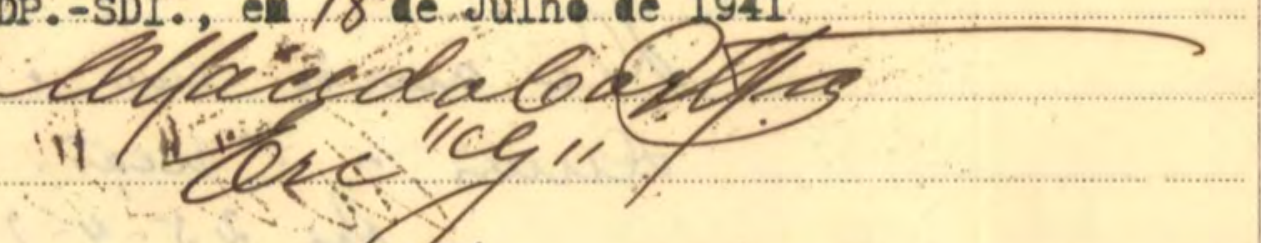

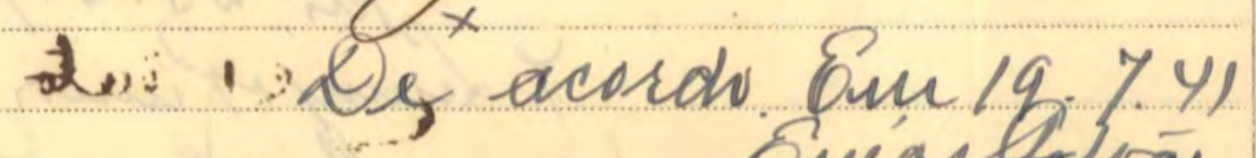

oncuastatóns

Chepe da vDI.

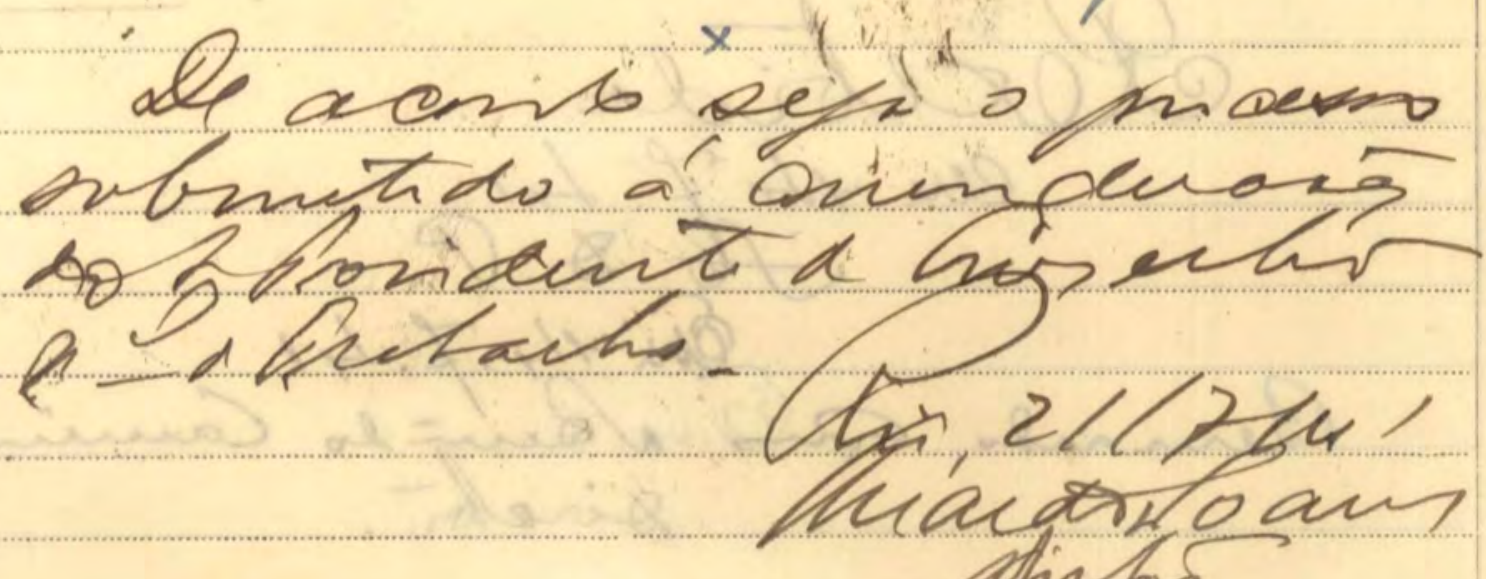
din tor

Sulmueto a eleviadia consbourlasn do In Presidentis do Pter. I, Aataimanto toyes deferimento do foildids ce flo 182.
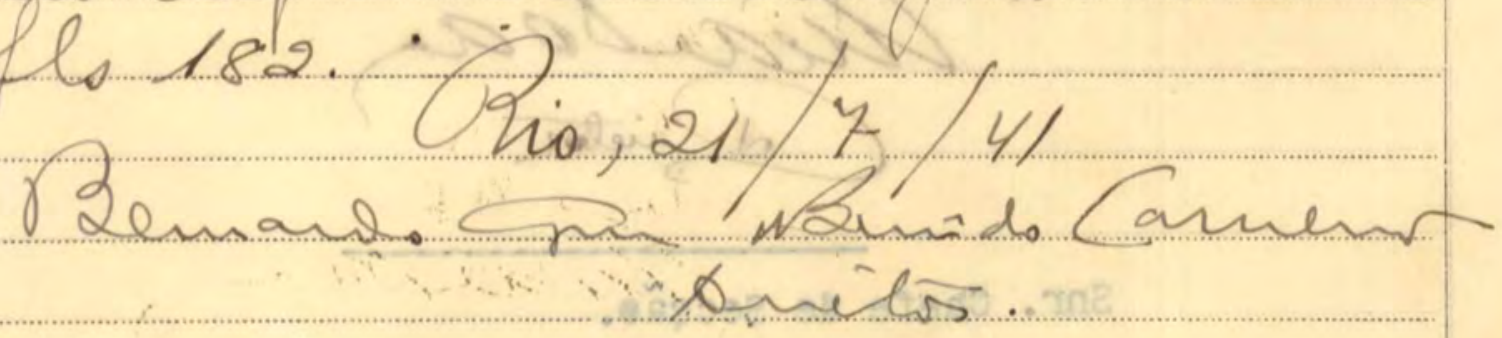

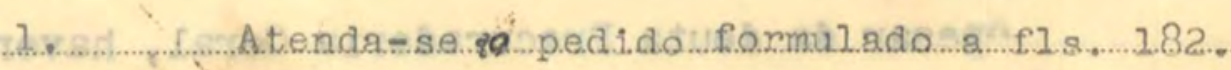

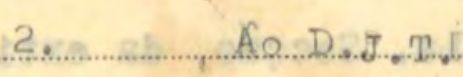

Rio, 22 de Julho de $19 / 1$.

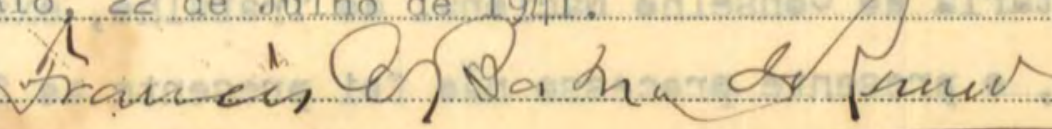
$\therefore$ PRESTDENTE DO C.N.T.

vece. 


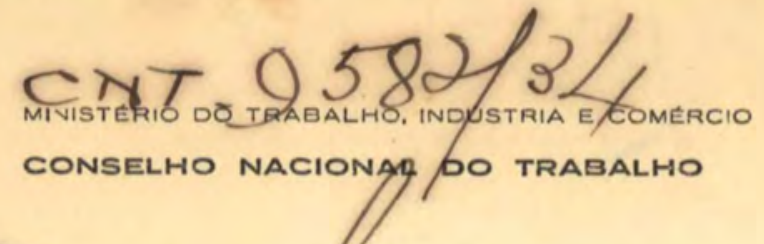

180

ben.

Lacefido en 2s/7/4.

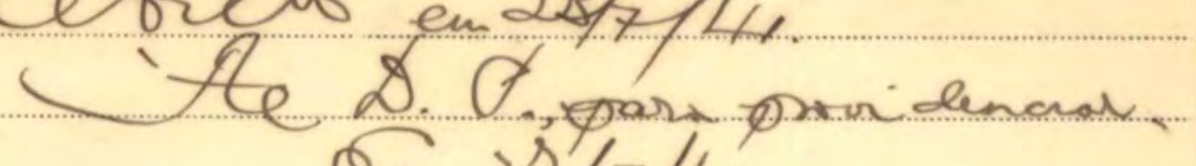

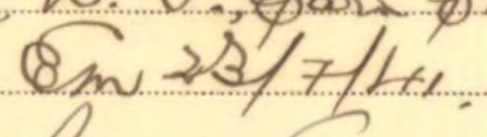

Bemando arm Benses Fameins.

Sirefor.

Recelide ene 2t. F. It Q. S. D. .

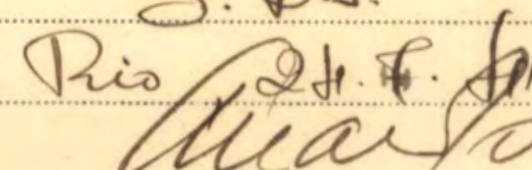

Diuter

Apresento, desta ata, Projéto de expediente.

DP.-SDI., en 29 de Juhno de 1941

leflacedaboly

tenercy

Vist. Em $00 \%$ YI Puíaslatias chep da $\cos$

tosinger enfe diente

$6 i_{i}, 4 / 8 / v 1$

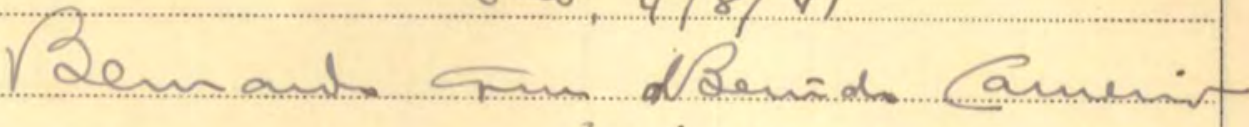

Reculido, en 5.8. \%'

Q' $\$ .5 .8$.

$$
\text { Reo, 5.8. fil }
$$

$\frac{\text { Auado. }}{\text { Dinto }}$

Linge 8161

Anadedoue dustu 
M. T. I. C. - J. T. - CONSELHO NACIONAL DO TMABALHO

LRFL

DEPARTAMENTTO DE JUSTIÇA DO TRABALHO.

CNT-9.582/34-DJT- $133 / 41 \quad$ Bm 5 de agosto de 1941 .

Sr. Delegado Reglonal.

De acordo com o despacho do Sr. Presidente do Conselho Nacional do Trabalho, exarado no processo em que Domlngos Mantitha e outros reclainam contra a Companhia Estrae de Ferro e MInas de São Jeronimo, incluso vos transmltó a justifıcação judic1al de nome e de compo de serviço, bem como a cert1dão de 1dade e atestado de saude, pertencente a ferroviário ilberalino ou Januárío Machado de Lima, afim de ser entregue, meâlante recibo, a SIndieato dos Mineiros e Classes Anexas do Municlplo de São Jeronimo, conforme requerimento de 29 de novembro do ano passado. Outrossim, solicito vos dignels enviar a este Departamento o citado recobido, com a possivel urgênela.

\section{Saude e fraternidade}

(Bernardo Cezar de Berrêdo Carne1ro) Diretor.

Ao Sr. Delegado Regional do Ministério do Trabalho, Indústria e Comércio. - Porto Alegre - Estado do Rlo Grande do Sul. 
$18^{74}$

CONSELHO NACIONAL INDÚSTRIA E COMERCIO CONSELHO NACIONAL

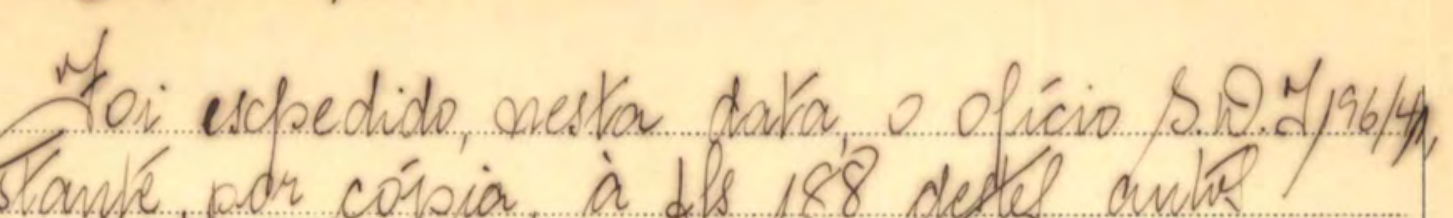
conslanne, par cópia, à fls 188 delles an

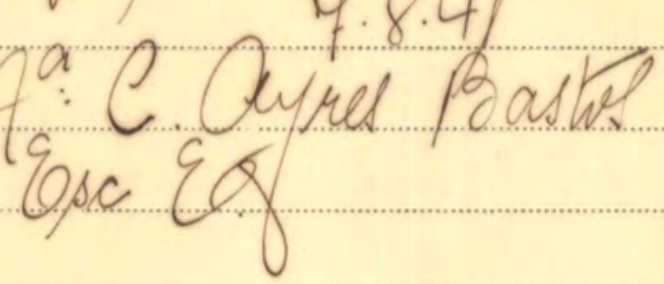




$$
\text { CNT- } 0.582 / 34-S D I-/ 96 / 4 / \quad \text { Em } f \text { de agosto de } 1941 .
$$

\section{Sr. Presidente.}

Conunico-vos, para os devidos fins, que este Departamento, pelo offc1o ne $133 / 41$ de 5 do corrente mês, encaminhou ao Delegado Regional do Trabelho, nesse Eatado, os documen tos pertencentes a ferroviár1o Ilberalino ou Január1o llachado de Lima, conforme despacho do Sr. Presidente do Conselho Naclonal do Trabalho, exaraco no requerimento que the fez esse sindi cato, datado de 29 de novembro do ano próximo findo.

\section{Atenc1osss saudaçōes.}

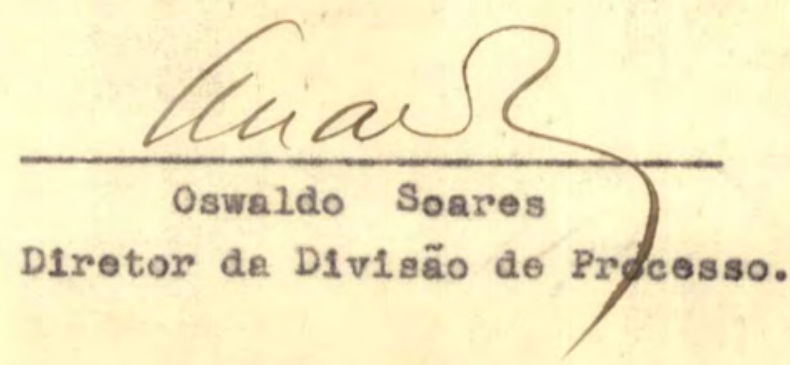

Ao Sr. Presidente do Sindicato dos Minelros o Classes Anexad do Itunic1plo de São Jeronlmo. São Jeronimo - Estado do Rio Grande do Sul. 
Ministerio ó trabayHo. IndUSt CONSELHO NACIONAL DO TRABALHO

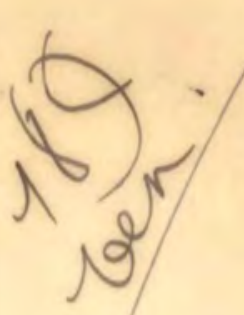

Nâ terdo equido coni

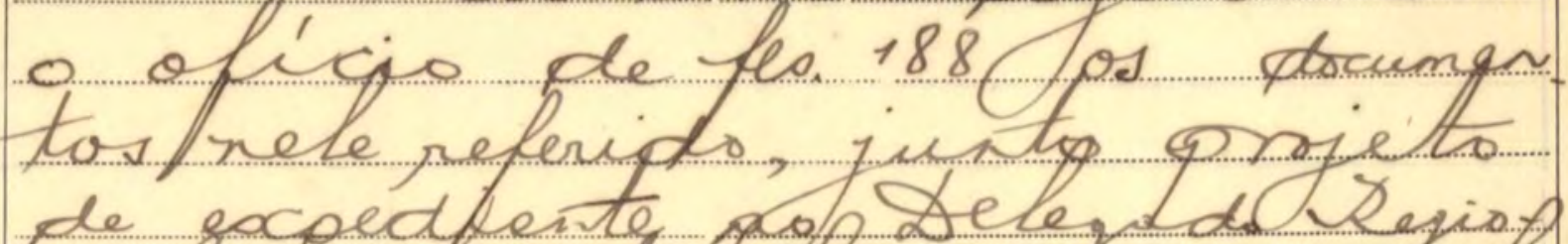
de expedfonte Prop Seley as tejiop nal em Oorta Itene ehuionds-he a juateficará. de nome a a de tem

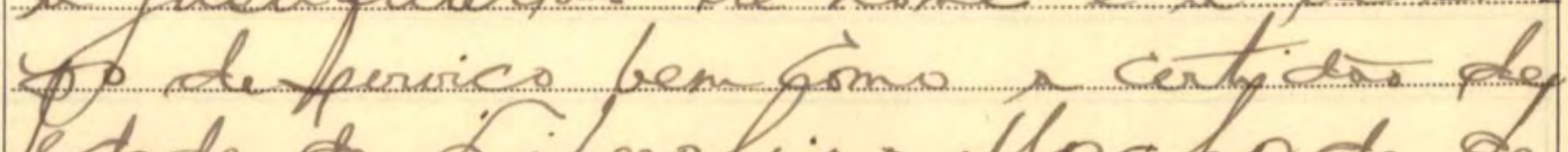
edade de Liberalino Ifpachado Le hima, e commiciando - the que ro.

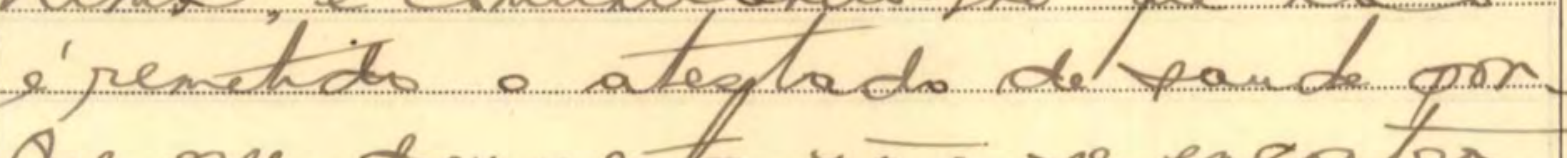

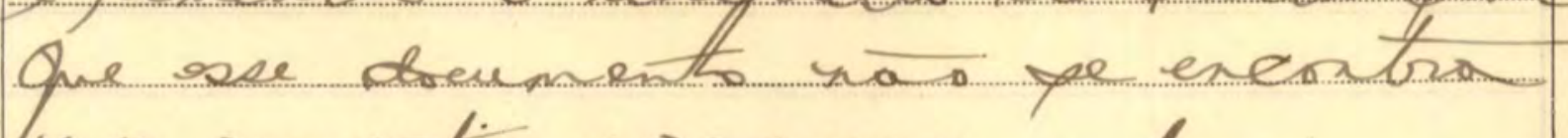

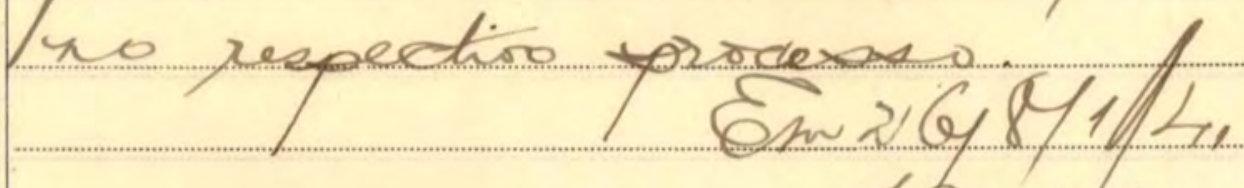

toenerr.

$$
\text { Secrataí. }
$$

Assiner o aficio

$$
\text { Qi } i_{i, 2} / d / 41
$$

Bemant on BeradoCamem

Reulido ari 28.8 .4

Qne, $8.8 \cdot 8 \cdot 4 y$

Acraconfower

(1) wils 
M. T. I. C. - CONEELHO NACIONAL DO TRAEALHO

DBPARTAMENTO DE JUSIICA DO TRABALHO

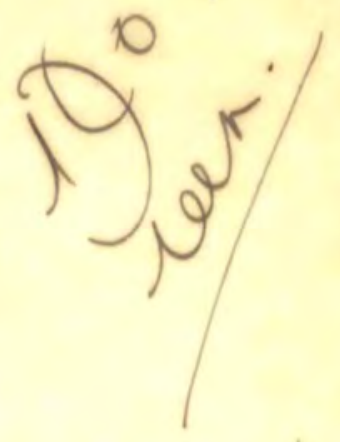

$C N T-9582 / 34-D J T-251 / 42$

Em 26 de agosto de 2942

Sr. Delegado Fieglonal.

Dim aditamento ao meu offolo n. CN2 $-9582 / 34-D J T-133 /$

41, de 5 do mês corrente, Junto vos remeto a just1f1cą̧äo jud1c1al de nome o a de tempo de serviço assim como a certidão de edade do fer roviár1o Liberalino Machado de Lima, documentos esses que delxaram de acompanhar o offelo acina referido.

Quanto ao atestado de saude, comunico-vos que esse documento delxa de ser remet1do porque não fol encontrado no processo CNT-9582/34, em questão.

\section{Saúde e fraternidade}

(Bernardo Cezar de Berrêdo Carne1ro) D1retor.

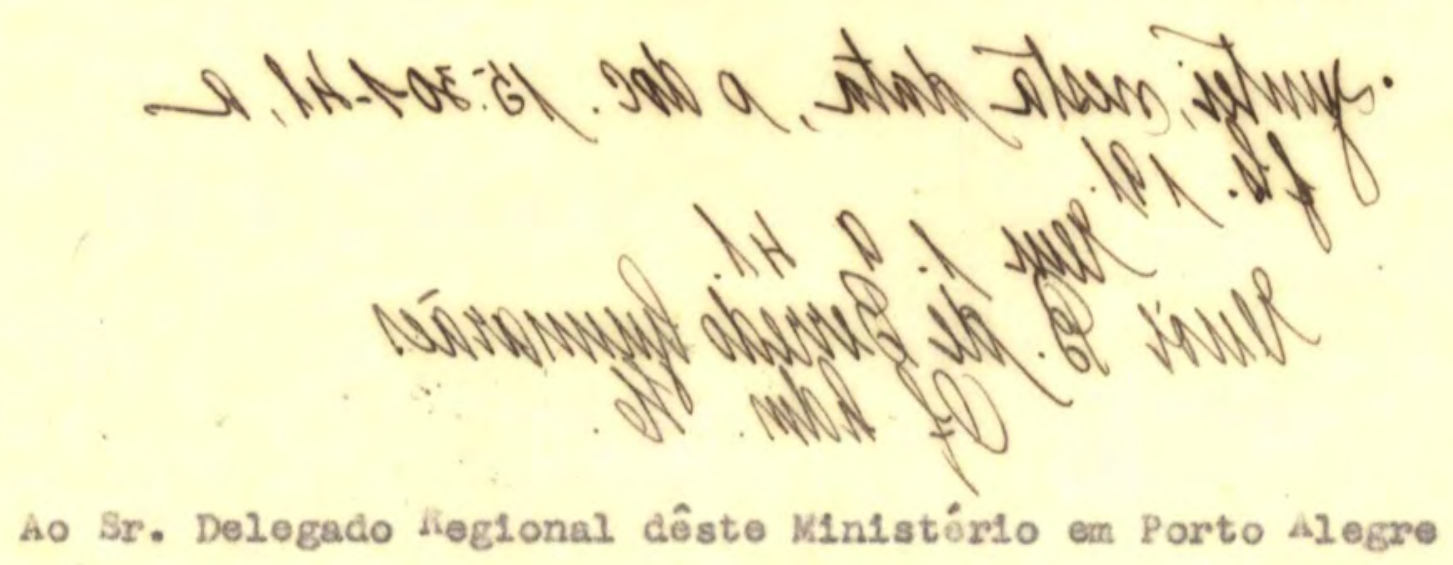



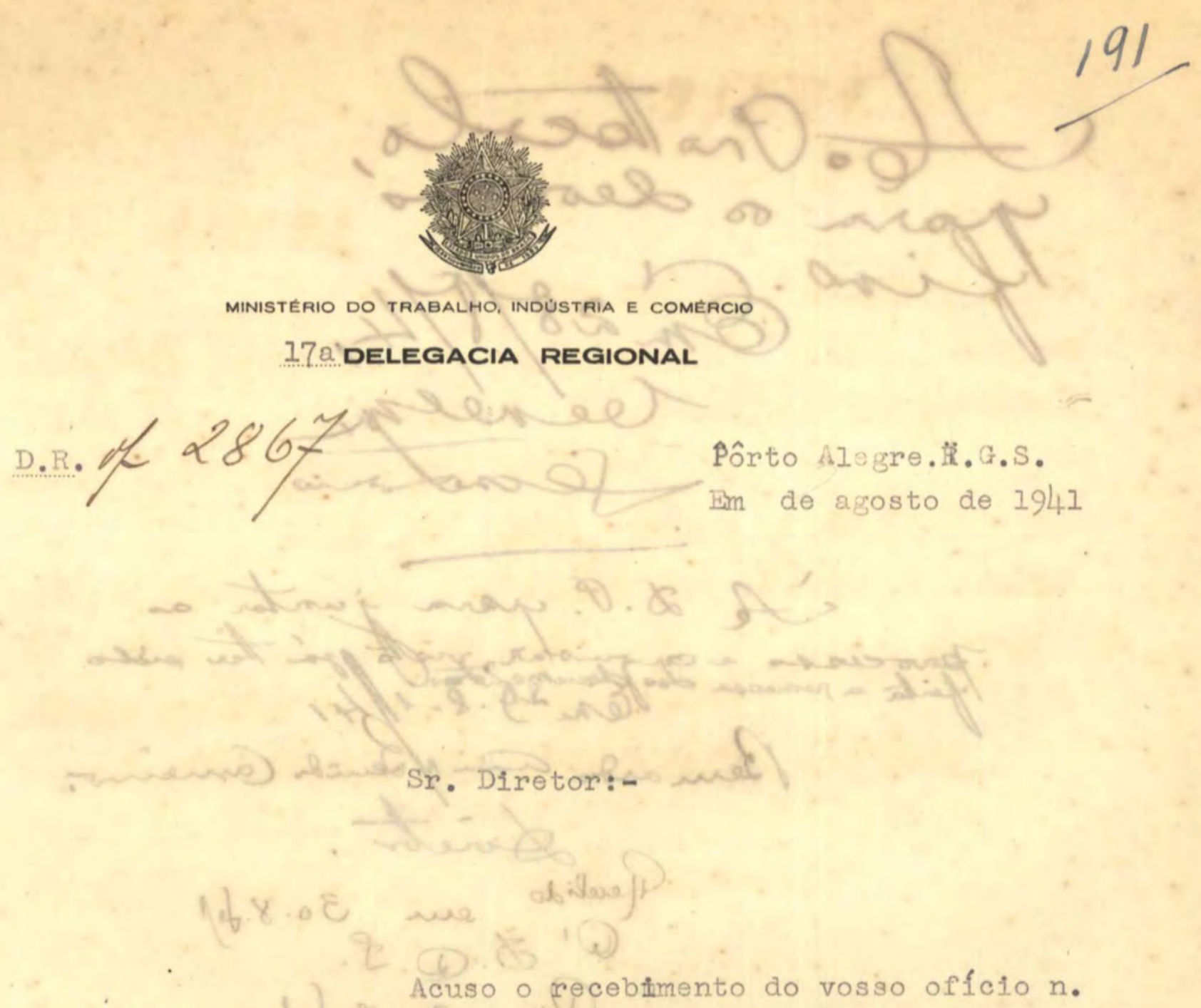

CNT-9.582/34-DJT-133/4I, datado de 5 do mês em curso, e comunico-vos, pars as pravidênoies necessárias, não ter acompanhado - refenido ofício, a documentação nele mencionada.

Saúde e fraternidade

Ilmo. Sr. Bernardo. César de Berrêdo Carneiro DD. Diretor do Dep. de Justiça do Trabalho RIO DE JANEIRO, D.F.

Ref.:- 5827/41.JOD/. -

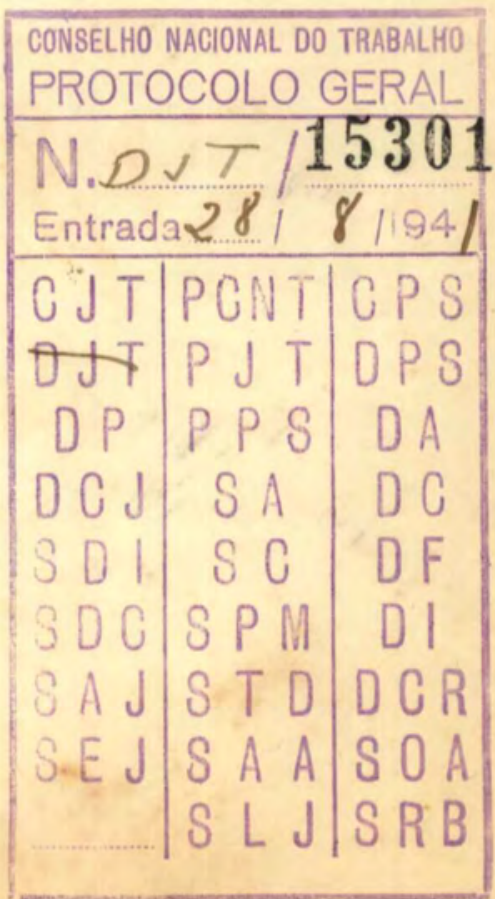



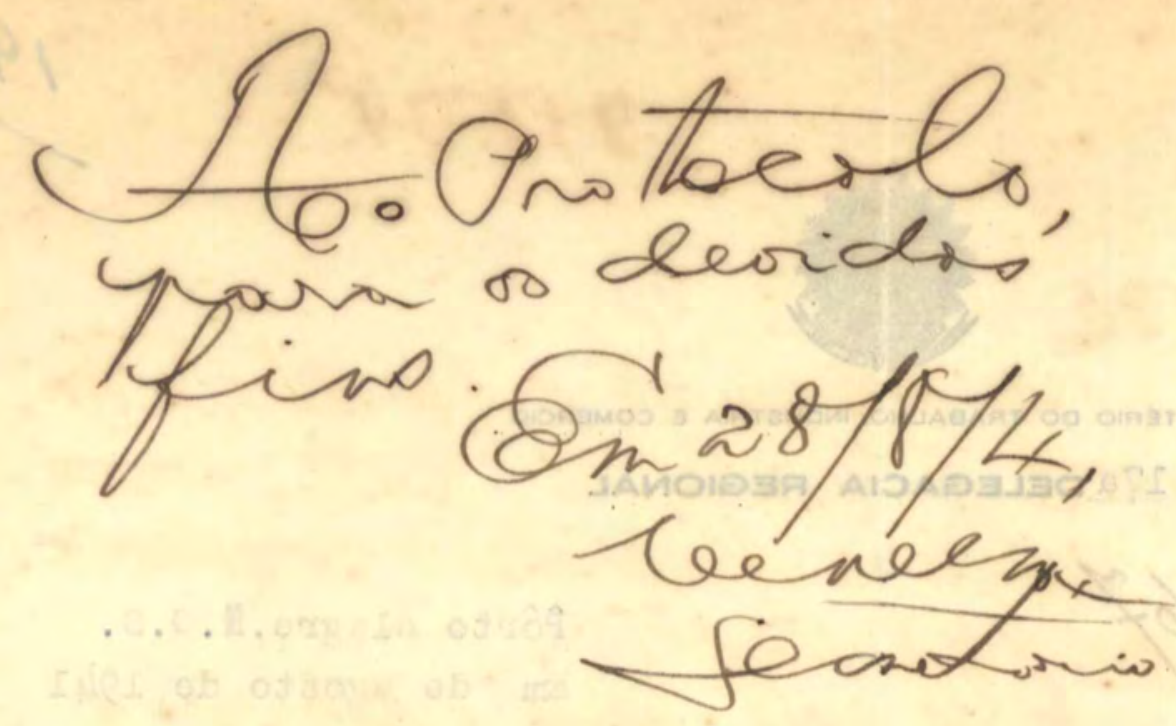

If D.P. yera juntar as

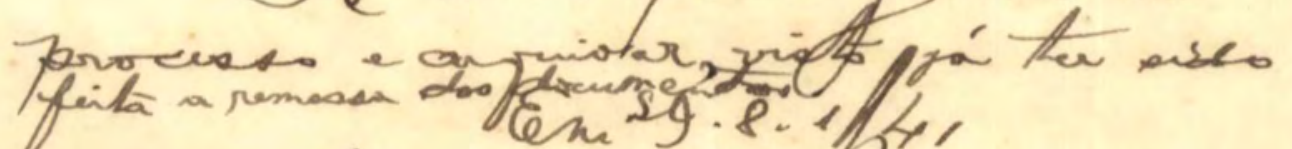

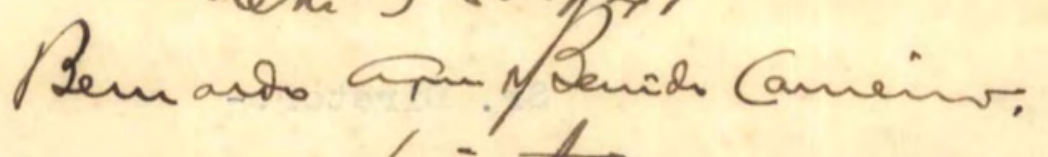
Q Decelido Q. D. D. S. $30.8 \cdot \mathrm{d}_{1}$ Rio, go. 8. $\mathrm{f}_{1}$ Divetor 


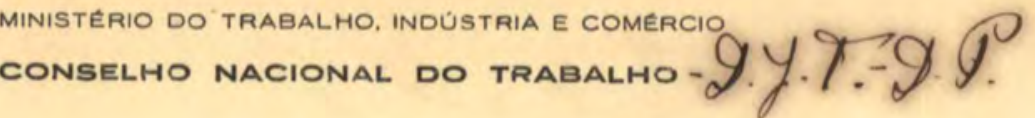

192

$202 \div-9582-34$

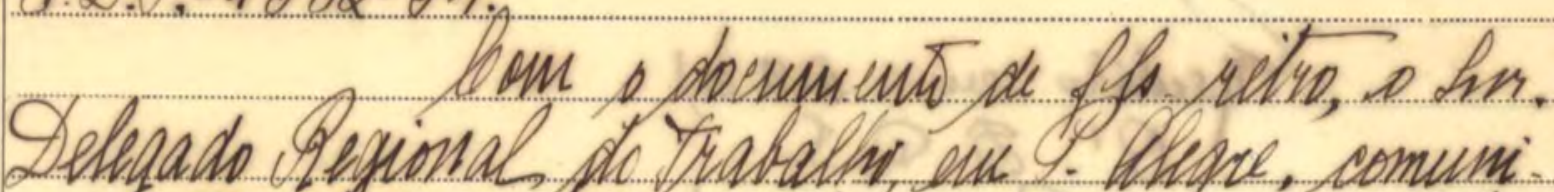

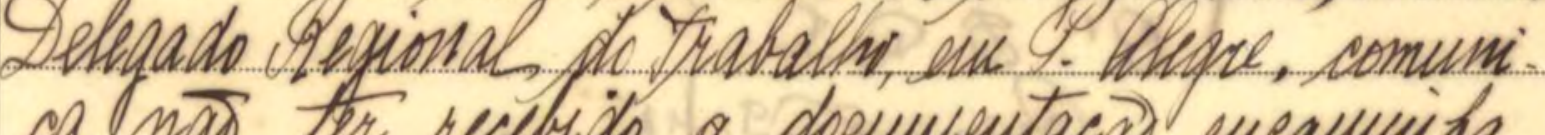

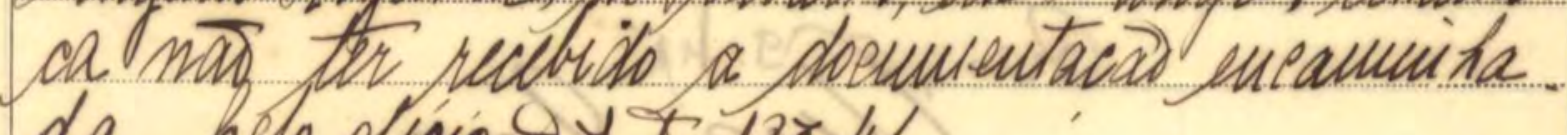
da holo ofisin 2 y. T.135-k1.

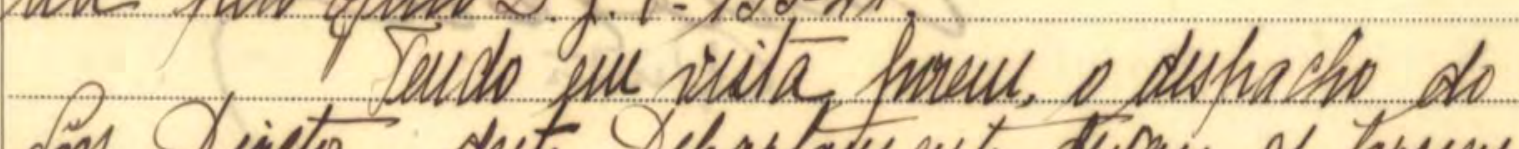

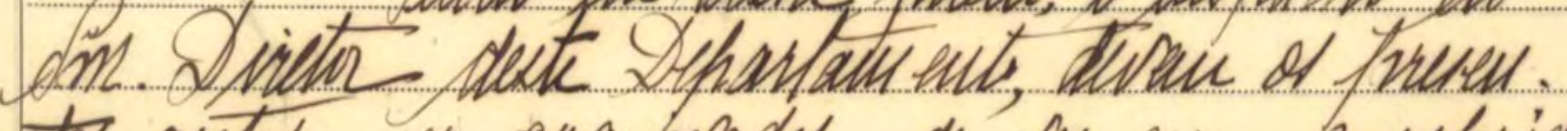

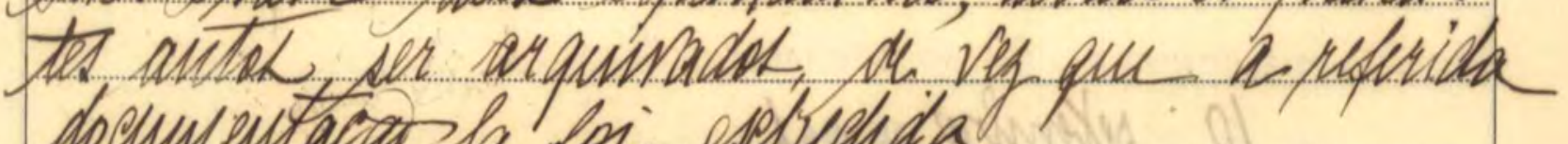

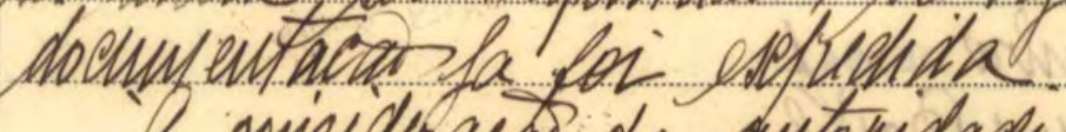

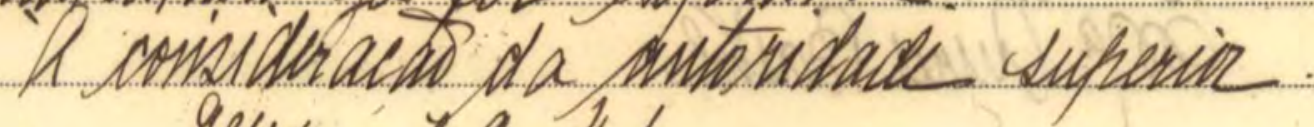

geu 19.21

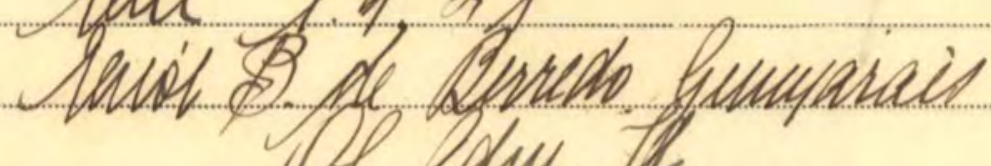

We aconde, twoh em vista a duclanaças é fle. 189 am 2. 9. 41 Eniastyatios chife da oDI

Aara onvenier bi opiarsar or jo kes vezonti. L Alelepar Efinif om a dedar S P recubinum \& As 6 aunents uniats a fui dever ewhores do mibresades $3 /$ siced maidstod Brek Shquim-se. Phi, 4/9/41 Bemanto Crm Bemid Comenir 
Terte

AE-8800-K.64

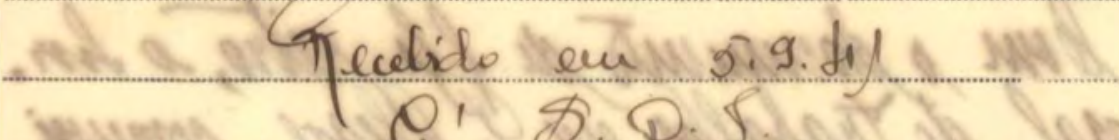

10 seternbribe 194 L

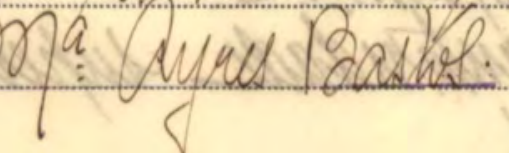

Junstàda

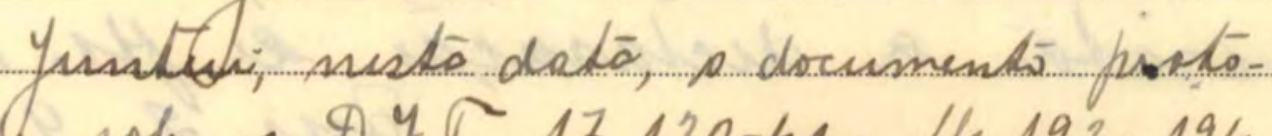

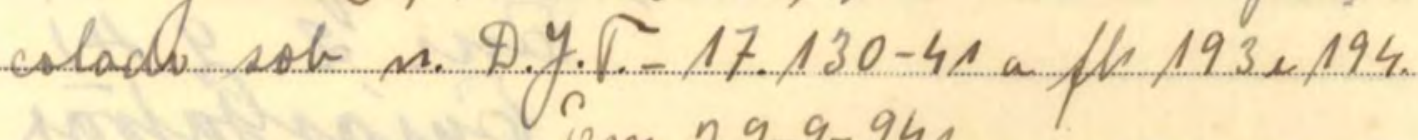

on $29-9-941$

Pucilia Yannari Biapa.

aux ess. IX 
MINISTERIO DO TRABALHO, INDÚSTRIA E COMERCIO

\section{2.DELEGACIA REGIONAL}

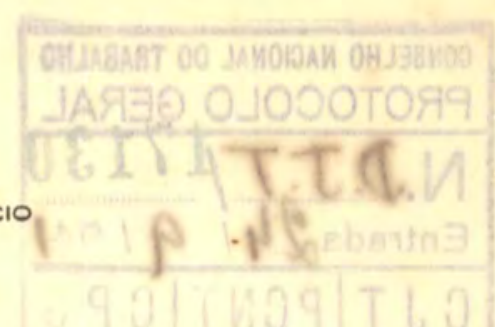

D.R. 30 t/ 8

Pôrto Alogro, R.G.Sul

$\mathrm{Em} / 6$ de setembro de 1941

Ilmo. S*. DIretor:-

Com referência ao vosso offcio $n$. DJT-151/41, junto vos remeto o recibo dos documentos c1tados om vosso oficio supra.

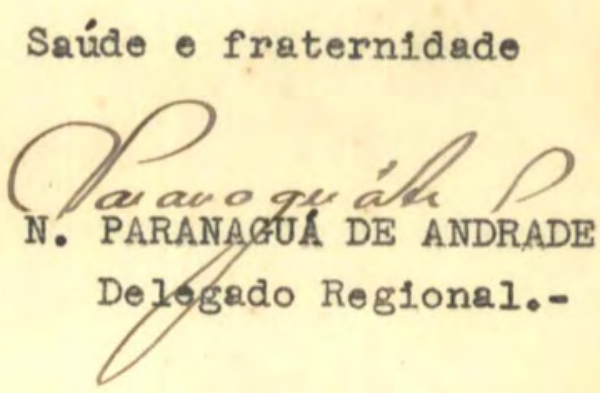

Ref.::- 6490/41.-

JOD/.-

Ilmo. Sr. Diretor do Departamento de Justiça do Trabalho Ministér1o do Trabalho, Indústria e Comércio

RIO DE JANEIRO,D.F. 


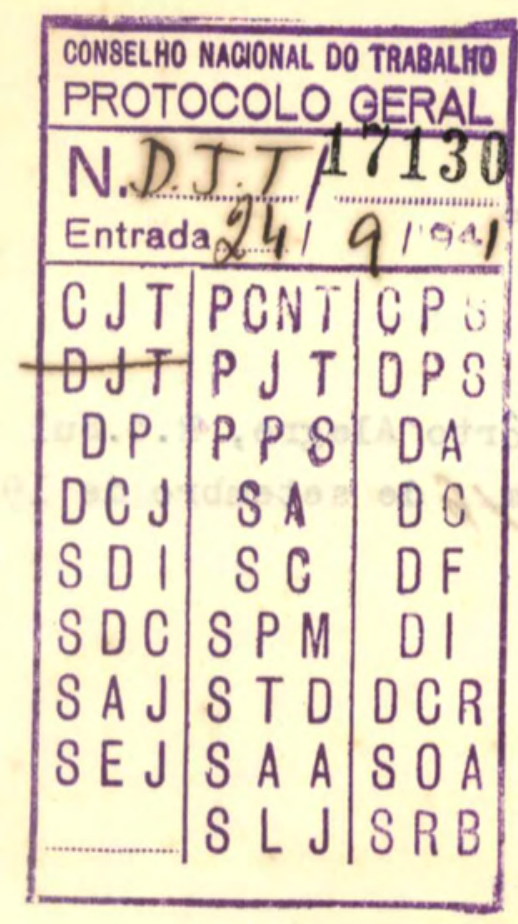




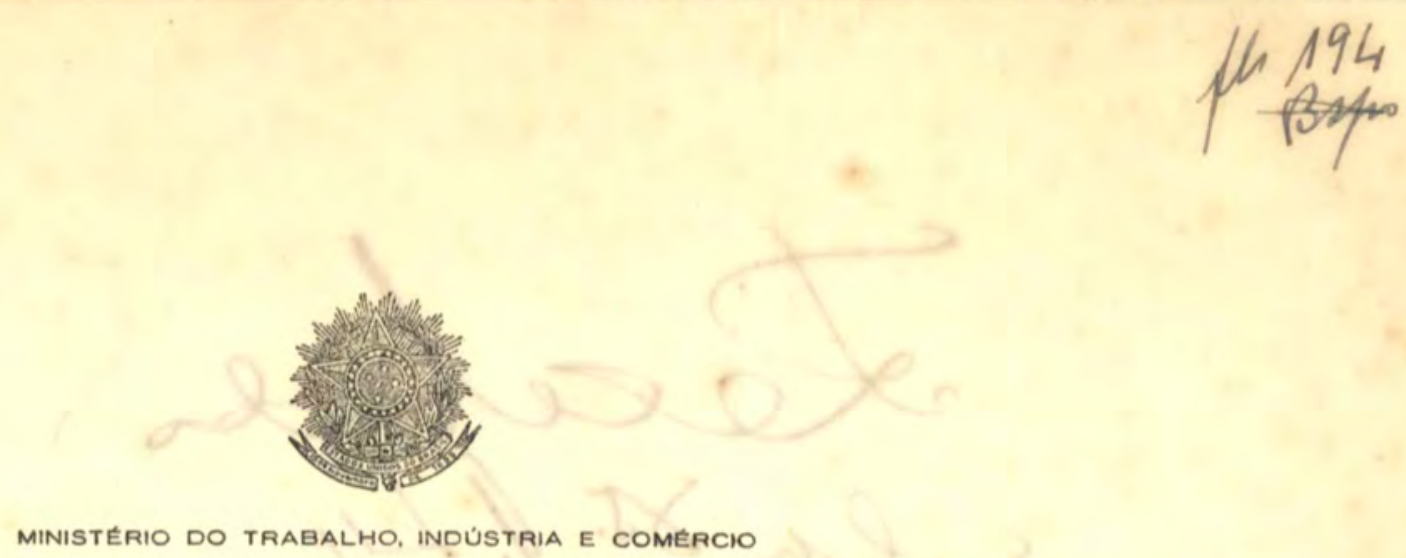

DELEGACIA REGIONAL

Nesta data, recebi da 17a. Delegacia Regional do Trabalho os documentos enviados pelo Departamento de Justiça do Trabalho por or1e10 CNT-9582/34- DJT 151/41, om aditamonto ao de No CMT-9582/34 DJT 133/41, de 26 de Agosto -5 do mesmo, referente ao operar1o IIboralino Machado de Lima ou Januario Machado de Lima pertencente a sindieato dos Minelros e Classos Anoxas, de Saõ Jeronimo.

Porto Alegre, 10 de Setembro de 1941

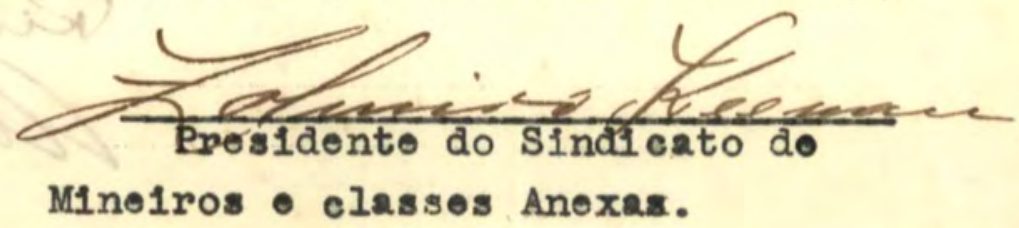




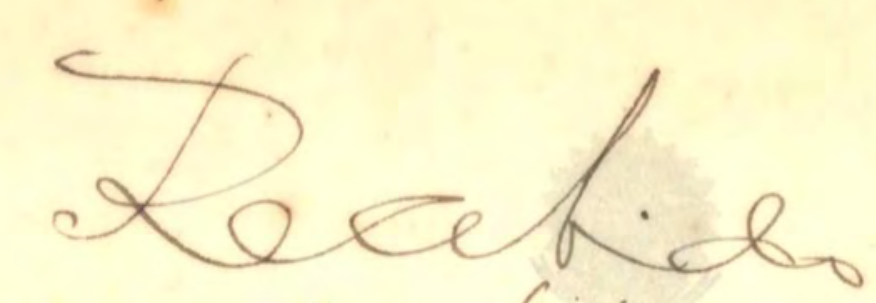

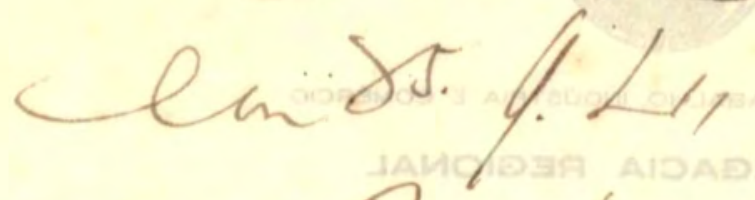

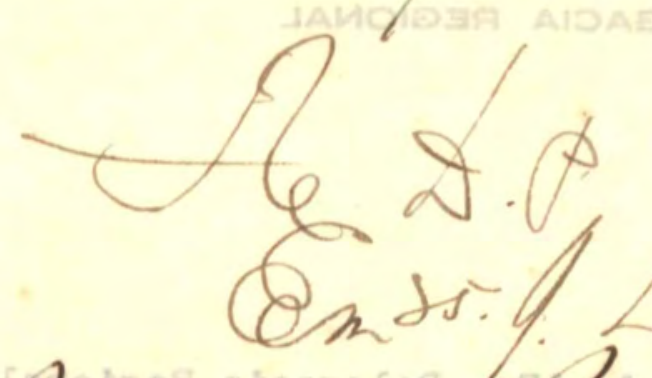

Qmsi.

Semants Cring anido aminos.

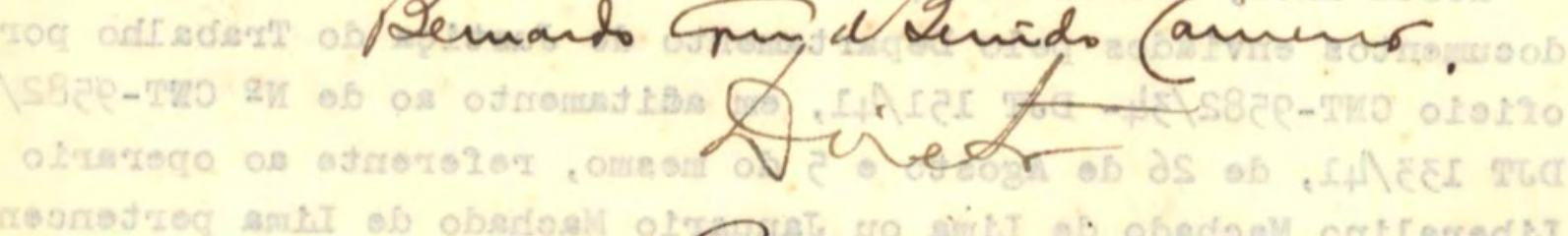

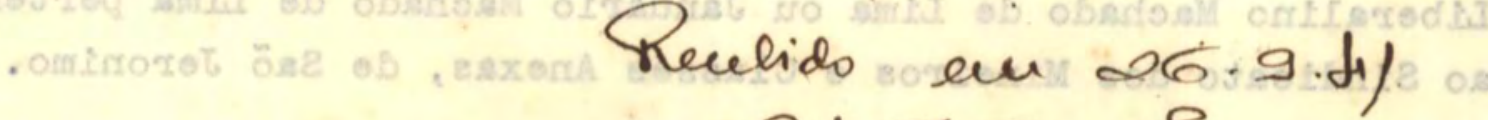
Q'8. D. I. Aliawis Cinetos 
195

MINISTERIO DO TRABALHO, INDÚSTRIA E COMERCIO

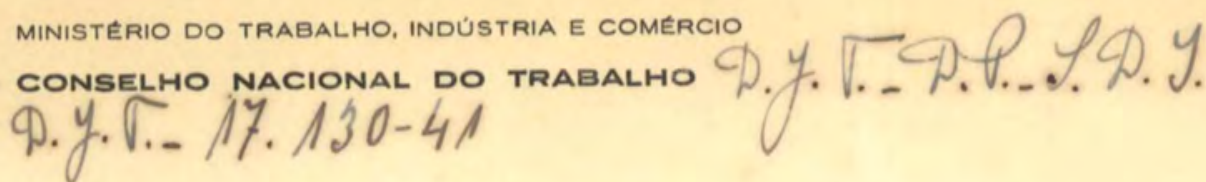

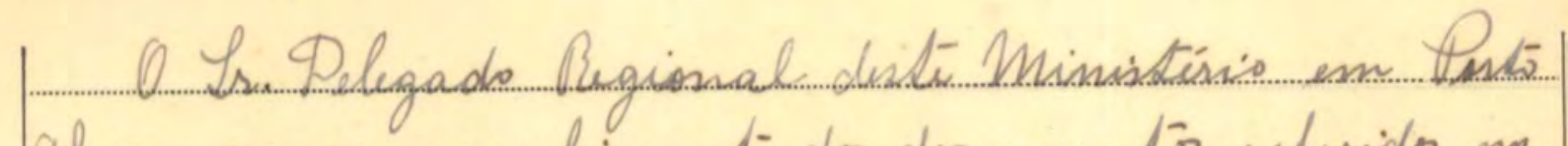

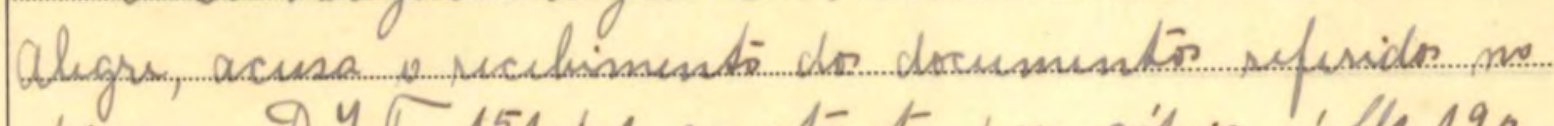

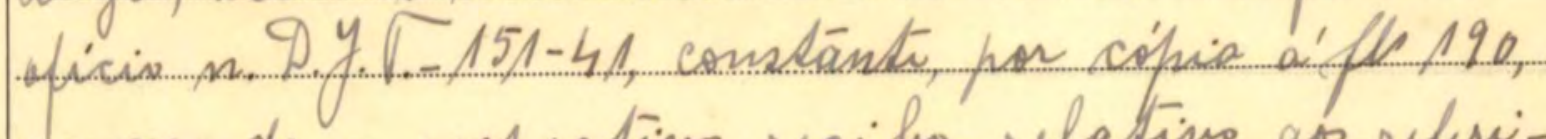
anvando pespuctive recilo, selativo as refessi-.. dos dransmentis.

inar face do já combantí de fls 192, paruce-mo qun ss presentis andis desum sel arqunivads.

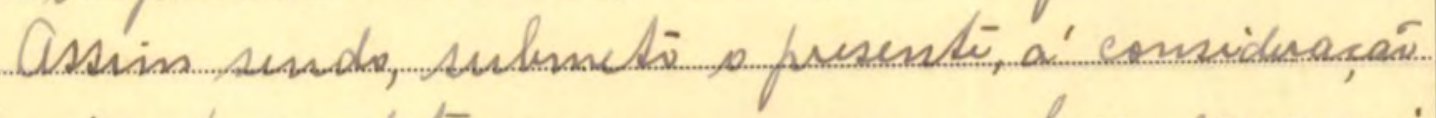

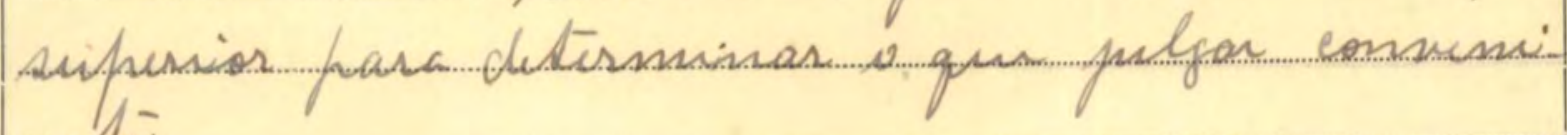
im 29-9-941

Pucilis Yammanis Bispo anx esc. IX

Volte as Arquins.

Em 2q o. 4)

Ouísttahios - Chife da soi 